\title{
Likovi dekadenata u hrvatskoj književnosti na kraju XIX. i početku XX. stoljeća
}

\section{Kokolari, Martina}

Doctoral thesis / Disertacija

2020

Degree Grantor / Ustanova koja je dodijelila akademski / stručni stupanj: University of Zagreb, University of Zagreb, Faculty of Humanities and Social Sciences / Sveučilište u Zagrebu, Filozofski fakultet

https://doi.org/10.17234/diss.2020.130245

Permanent link / Trajna poveznica: https://urn.nsk.hr/urn:nbn:hr:131:340133

Rights / Prava: In copyright/Zaštićeno autorskim pravom.

Download date / Datum preuzimanja: 2023-04-26

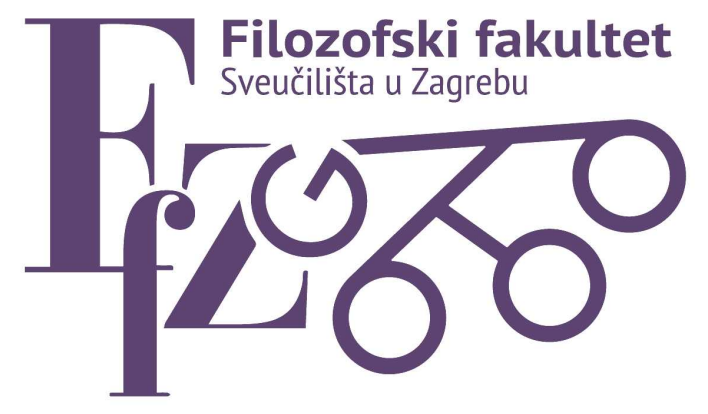

Repository / Repozitorij:

ODRAZ - open repository of the University of Zagreb Faculty of Humanities and Social Sciences
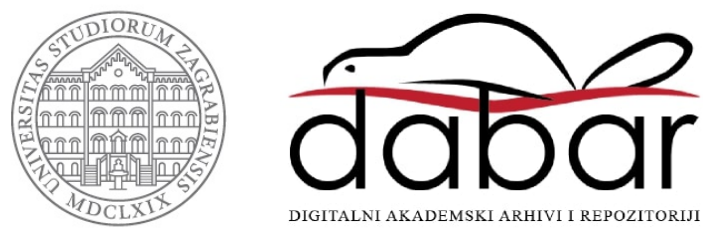


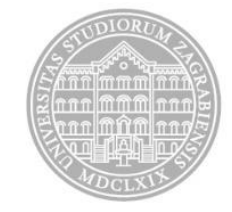

Sveučilište u Zagrebu

Filozofski fakultet

Martina Kokolari

\section{LIKOVI DEKADENATA U HRVATSKOJ KNJIŽEVNOSTI NA KRAJU XIX. I POČETKU XX. STOLJEĆA}

DOKTORSKI RAD

Zagreb, 2020. 


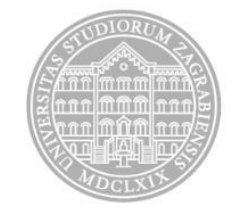

Sveučilište u Zagrebu

Filozofski fakultet

Martina Kokolari

\title{
LIKOVI DEKADENATA U HRVATSKOJ KNJIŽEVNOSTI NA KRAJU XIX. I POČETKU XX. STOLJEĆA
}

\author{
DOKTORSKI RAD
}

\author{
Mentor: \\ prof. dr. sc. Tvrtko Vuković
}

Zagreb, 2020. 


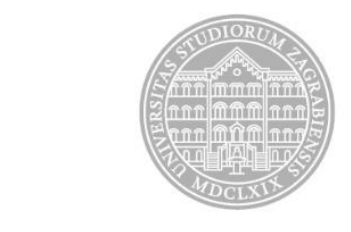

University of Zagreb

Faculty of Humanities and Social Sciences

Martina Kokolari

\title{
DECADENT CHARACTERS IN CROATIAN LITERATURE AT THE END OF THE $19^{\text {TH }}$ AND THE BEGINNING OF THE $20^{\text {TH }}$ CENTURY
}

\author{
DOCTORAL THESIS
}

Supervisor:

PhD Tvrtko Vuković, full professor 


\section{O MENTORU}

Tvrtko Vuković rođen je u Slavonskom Brodu 1969. Na Filozofskom fakultetu Sveučilišta u Zagrebu završio je studij kroatistike te doktorirao 2004. tezom Modeli prikazivanja kvorumaškoga pjesništva: Subjekt, svijet, tekst kao interpretativno iskustvo. $\mathrm{Na}$ Odsjeku za kroatistiku Filozofskoga fakulteta Sveučilišta u Zagrebu zaposlen kao asistent na Katedri za noviju hrvatsku književnost od 2000. U suradničko zvanje višeg asistenta izabran 2005. Od 2005. do 2007. radio je kao viši lektor i predavač za hrvatski jezik i književnost na Sveučilištu Sorbona u Parizu. U znanstveno-nastavno zvanje docenta izabran je 2008, u znanstveno-nastavno zvanje izvanrednoga profesora 2013, a u znanstveno-nastavno zvanje redovitoga profesora 2019. Radove je izlagao na mnogobrojnim međunarodnim znanstvenim skupovima i skupovima s međunarodnim sudjelovanjem. Kao gost predavao je na Sveučilištu Adam Mickiewicz u Poznanju, Šleskom sveučilištu u Katovicama, Jagelonskom sveučilištu u Krakovu i Masarykovu sveučilištu u Brnu. Bio je pozvani predavač na seminarima Zagrebačke slavističke škole 2009-12, 2016. i 2018. Surađivao je u izradi Leksikona hrvatskih pisaca, Leksikona hrvatske književnosti - Djela te Hrvatske književne enciklopedije i Leksikona Antuna Gustava Matoša Leksikografskoga zavoda Miroslav Krleža. Radio je kao istraživač na znanstvenim projektima Modeli hrvatskoga pjesništva 20. stoljeća, Hrvatsko pjesništvo od romantizma do postmodernizma i Odnos kultura-društvo u hrvatskoj modernizaciji. Bio je voditelj znanstvenoga projekta Hrvatsko pjesništvo od romantizma do postmodernizma, istraživačkoga sveučilišnog projekta Nenormalni u hrvatskoj kulturi i književnosti na prijelazu 19. i 20. stoljeća, voditelj književnoga smjera Poslijediplomskoga sveučilišnoga doktorskog studija kroatistike, predstojnik Katedre za noviju hrvatsku književnost te voditelj Zagrebačke slavističke škole u dvama mandatima. Bio je također predsjednik Goranova proljeća, središnje nacionalne pjesničke manifestacije. Objavio je četiri samostalne znanstvene knjige, priredio i uredio desetak znanstvenih zbornika i pjesničkih panorama, u suautorstvu školske udžbenike i kritička izdanja djela kanonskih autora. Trenutno je zamjenik voditelja poslijediplomskoga sveučilišnog studija Hrvatska filologija u interkulturnom kontekstu te urednik teorijske edicije Drugi smjer u izdavačkoj kući Meandar. Znanstvene i stručne članke te recenzije redovito objavljuje u periodici.

Objavio je knjige:

- Svi kvorumaši znaju da nisu kvorumaši. Aporije reprezentacije u kvorumaškome pjesništvu, Disput, Zagreb 2005, str. 283. 
- Ljubi Žižeka svoga! Je li teorijska subverzija zapravo kapitalistička perverzija i druge nedoumice o etičko-političkom čudovištu Žižekove misli, Meandar, Zagreb 2009, str. 91.

- Bajke i basne. Sabrana djela Ivane Brlić-Mažuranić. Kritičko izdanje [Supriređivačica Ivana Žužul], Ogranak Matice hrvatske Slavonski Brod, Slavonski Brod 2011, str. 511.

- Tko je u razredu ugasio svjetlo? Predrasude, stranputice i moguće promjene u poučavanju i proučavanju lirike na primjerima Cesarićevih pjesama Voćka poslije kiše $i$ Pjesma mrtvog pjesnika, Meandar, Zagreb 2012, str. 167.

- Na kraju pjesme. Studije o modernoj hrvatskoj lirici i njezinim politikama, Meandar, Zagreb 2018, str. 322. 


\section{SAŽETAK}

U ovom se doktorskom radu bavimo dekadencijom u hrvatskoj književnosti na kraju XIX. i početku XX. stoljeća, odnosno likovima dekadenata u izabranim proznim djelima, koje prepoznajemo kao jedan od najčešćih karaktera u našem findesiècleovskom književnom diskursu. Da bismo na konkretnim primjerima što kvalitetnije demonstrirali na koji su način pisci fikcionalizirali dominantna duševna raspoloženja vremena, u prvim trima cjelinama, svojevrsnim uvodnim dijelovima kojima kontekstualiziramo korpus djela, predstavljamo duhovnu i kulturnu klimu u kojoj se dekadencija razvijala, njezine filozofske temelje i društveno-političke okolnosti. U prvoj cjelini iznosimo definicije dekadencije, povijest termina i kulturni kontekst, prezentirajući kao jedan od temeljnih znakova epohe raspad vrijednosti te slabljenje ili potpuni nestanak autoriteta bilo koje vrste. U drugoj se cjelini osvrćemo na osnovne postavke Schopenhauerove $i$ von Hartmannove filozofije pesimizma te Kierkegaardove psihologije očajanja, koje držimo najcjelovitijim izrazima prevladavajućega devetnaestostoljetnog uvjerenja da je svijet izgubio svaki smisao. Društvene i političke okvire toga doba duhovne depresije postavljamo u trećoj cjelini, u kojoj upozoravamo da je AustroUgarska Monarhija bila rastrgana između tradicionalizma i liberalizma te da je kao takva snažno utjecala na hrvatski kulturni prostor, u posljednjim dvama desetljećima XIX. stoljeća bitno određen banovanjem Khuena Héderváryja i nezadovoljavajućim položajem unutar dvojne države.

U središnjoj cjelini, analitičkom dijelu disertacije - kojim smo obuhvatili glavne likove Prijana Lovre A. Šenoe, Janka Borislavića i Radmilovića K. Š. Gjalskoga, Pavla Šegote i Dvaju svjetova V. Novaka, Velikoga grada, Zelenoga mora i Bijega M. Cihlara Nehajeva, Misli na vječnost, Jesenskih cvijetaka, Katastrofe, Poslije nesreće i Sjena ljubavi J. Leskovara, Tuđinca D. Šimunovića i Isušene kaljuže J. Polića Kamova - pokazujemo na koji način neuroza, posebno kroz abuliju kao jedan od njezinih glavnih simptoma, te s njom povezani patološki oblici tjeskobe i melankolije onemogućuju uspostavu identiteta. Zaključno iznosimo kako je dekadencija u svim tim likovima specifična svijest o egzistencijalnoj propasti i besmislu svijeta, osobito čuvstvo inferiornosti koje paralizira svaku mogućnost aktivnoga života.

Ključne riječi: dekadencija, fin de siècle, hrvatska književnost, lik, pesimizam, identitet, melankolija, tjeskoba, neuroza, volja 


\section{SUMMARY}

The topic of this dissertation is decadence in Croatian literature on the turn of the century, more specifically decadent characters in prose in the late $19^{\text {th }}$ and early $20^{\text {th }}$ centuries. Aware of the complexity and heterogeneity of the term 'decadence', and without pretence that it is possible to encompass and define it in a stable and unproblematic manner, we examine the ways in which the decadent sensibility so characteristic of the European fin de siècle manifested in the works analysed herein. We examine decadence as the awareness of existential decline and the meaninglessness of the world, a latent or openly expressed state of mind, a distinctive feeling of inferiority, and assert that the decadent character, who embodies decadence in various forms - physical and spiritual weariness, melancholic apathy and blasé attitude, nervous tensions and neuroses, etc. - is among the most common character types in the Croatian prose of the fin de siècle. Therefore, this dissertation is focused on characters as literary constructs and often the most important structural elements of a work of literature. Believing that it is important, perhaps even essential, to interpret literature within the context in which it was created, we strive to show how decadence in its specific manifestations was of decisive importance regarding the typology of male characters, who are the key methodological element of this doctoral thesis.

Structurally, the thesis is divided into four chapters. These are preceded by a brief introduction presenting the analysed works, followed by a description of the goal, hypothesis, methodology, and methods of analysis used in this thesis. Since we have detected that the manifestations of decadence in Croatian literature on the turn of the century reflected the spiritual climate in Europe, the first chapter presents the physiognomy of decadence. This includes definitions of decadence, the history of the term, and the cultural context, presenting the collapse of values as one of the defining characteristics of that period. Namely, even though the idea of historical decline is by no means characteristic of the $19^{\text {th }}$ century, no other period had such a reputation for pessimism as the fin de siècle. In the West, the fin de siècle indicated much more than just a period of time. Closely linked to the closing of one century and the onset of another, it encompassed the characteristic mind-set of the time, a series of spiritual, moral, and cultural aspects that can be linked to decadence. In art history and literature, the term came to signify various pathological conditions, i.e. a break with old stylistic tendencies and aesthetic categories. The term spread from French to other languages and came to encompass the technological, industrial, economic, cultural, and scientific progress of modern society and the prevalent feeling of pessimism and unease that burdened modern man. 
Decadence is the main and, at the same time, most complex term in this thesis and is therefore in the focus of our interest. As a general term, it stems from social and cultural history, in which it signified the decay of values, gradual loss of creative energy, and the decline, fall, and/or collapse of some political or social system (e.g. it often pertained to the collapse of great civilisations, especially the Roman Empire). However, from the end of the $19^{\text {th }}$ century, and especially following Nietzsche's stressing of the importance of the revaluation of values, it no longer signified only decay, but also the awareness of it, with the important difference that it now became a way out of that decay. It grew into an awareness that leads towards nihilism as the final point from which a different world is built, into an awareness of decay as a renewed existence. As an exceptional form of emotionality within the frame of the mal de vivre phenomenon, decadence simply had to manifest so that the human spirit could try to reject being conditioned by grand narratives, be they intellectual, scientific, or socio-political. In support of this interpretation, we highlight that Nietzsche characterised $19^{\text {th }}$-century European culture as a whole as the awakening of a feeling of a certain form of décadence. This feeling was a reaction to the collapse of European values based on two edifices that were pressuring the fin de siècle man. Mutually opposed, they both eroded the spirit of the people of that time. One of them was metaphysics, which, proclaiming the principles of Christian morality and human immortality, deprived the individual of his orientation towards the mundane world. The other was science, which used abstract and objective principles to exclude from the world all that is subjective, human, promoting principles of rational objectivity as opposed to metaphysical moral principles. Both influences made humans into weaklings who, through a decadent consciousness, raised their voice against morals and rationalism. Thus, the characters we examine here are aware that a certain world order is collapsing, disappearing, and of their frustrating helplessness to prevent this collapse or to build a new world - what they all have in common is a resistance, usually completely passive, towards imposed norms, social conventions, and a priori assigned roles. Decadent consciousness is affirmed as something that tears people up from the inside.

A special place within the complex of decadence is devoted to the problem of fatigue, i.e. the weakening of the body and spirit, and degeneration and neurasthenia, two phenomena that left a powerful mark on the end of the $19^{\text {th }}$ century and its atmosphere of decay. In addition, we underline the importance of the Russian 'superfluous man', i.e. the Slavic heritage in the creation of Croatian decadent characters.

Keeping in mind that all the mentioned spiritual dispositions were mostly built on the basis of philosophical-conceptual developments, in the second chapter we encompass the 
philosophical groundwork and the crisis of culture through the basic principles of Schopenhauer's, von Hartmann's, and Kierkegaard's philosophy. The most complete expression of the predominant $19^{\text {th }}$-century belief that the world had lost all meaning and that life is constant suffering was Schopenhauer's pessimism, which was further developed by his 'pupil' Eduard von Hartmann, who suggested that it would be better had this world never existed because life is a fraud that nobody should experience, and Kierkegaard, who posited anxiety as that which determines every existence, explaining that we undeniably live in a time of spiritual depression.

In the third chapter, we examine the broader socio-political and cultural context of Austria-Hungary and Croatia as its constituent part. Decadence in Croatia was built on the firm foundation of national psychology, and the reception of European spiritual currents was in many ways determined by the political situation. Namely, in the Schopenhaueresquely hopeless years of Ban Khuen Héderváry's governorship, Croatian writers were also dismayed due to their country's position within the Dual Monarchy, in which they felt as frustrated subjects, exhausted by their lack of freedom as well as their political, economic, and social inferiority.

Applying the set theoretical and methodological framework to the prose of the Croatian fin de siècle, the fourth chapter encompasses manifestations of decadence in the analysed works, showing on concrete examples how Croatian literature was affected by the contemporaneous social, political, and cultural environment. In the centre of our interest are works of prose focused on the formation of psychologically prominent individuals, in which we have identified decadent characters created in that distinctive spiritual climate. The decadence that we examine is specifically Croatian; unlike Western decadence or the decadence of the Russian 'superfluous man', it is not inherent to members of the upper classes who live in wealth and, in their idleness, indulge in analysis and rumination, but is instead usually tied to 'common' people, teachers, fallen priests, writers, or (semi-)intellectuals who, often also pressed by material worries, collapse under the weight of frustrating melancholia and anxiety. According to our interpretation, these dispositions are two sides of the same phenomenon: symptoms of neurosis as the starting- and end-point of all decadent identities. All characters from the analysed texts are burdened with the historical heritage of melancholia, a yearning for the unattainable and lost as well as an all-pervading sorrow, and anxiety, some unclear paralysing fear that prevents them from actively participating in their own lives.

We begin the analytical part of the dissertation with Šenoa's Lovro (1873), whom we have identified as the predecessor of all decadents, who paved the way for the full development of that type of character, and Gjalski's Borislavić (1887) and Leskovar's Ivanović (1894), 
sensitive decadents preoccupied with mystical-philosophical problems, especially Schopenhauer's will, which precludes them from actively living their life. We have devoted separate subchapters to characters determined by their environment - Novak's Šegota (1888) and Nehajev’s Mirković (1902) and Grančarić (1903), who are torn between their homeland and the world abroad, the country and the city, and therefore formed so that they constantly, neurotically feel they belong neither here nor there - and those whose fate is decisively influenced by the futility of the situation in Croatia - Gjalski's Radmilović (1894), Novak's Zlatanić (1901), and Nehajev's Andrijašević (1909), whose tragic fates are related to their alienation from both themselves and others. A prominent place is given to Leskovar's modern decadents, whom we encompass in two subchapters: we examine Martić (1891) and Imrović (1897) through the complex problems of melancholic attachment to object-loss, and, through exceptional aesthetic sophistication that prevents one from living life 'properly', Bušinski (1898), an archetypal example of a passive decadent whose clinical image is grounded in philosophical and historical pessimism, a hopeless feeling of ennui. A prominent position in the gallery of characters is also given to Šimunović's Lukavac (1911), a radical decadent without an identity in a failed quest to find his own roots. The final subchapter is devoted to Leskovar's Ljubić (1892) and Kamov's Toplak (1906-09), whose decadence is built around tuberculosis as the starting point for the collapse of all values.

In the conclusion, we summarise the theses put forward in this dissertation and refer to its analytical part, in which we identified decadence as a privileged state thanks to which an individual comprehends the foundations of their culture and society, seeing their meaninglessness and corruption. We have therefore singled out protagonists styled as neurotic decadents, whose decadence is detected as one of the dominant topoi of the time, and analysed the factors that decisively influenced their creation. Read within the frame of fin de siècle historical scepticism and the mal de vivre phenomenon, the analysed works reveal anxious, lost, paralysed characters, who in various ways face the nothingness of the world and the consequent inability to establish one's own identity.

Key words: decadence, fin de siècle, Croatian literature, character, pessimism, identity, melancholy, anxiety, neurosis, will 


\section{SADRŽAJ}

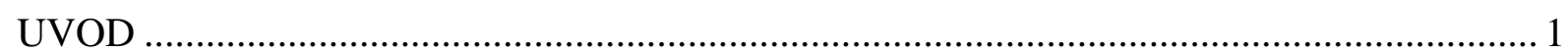

Cilj, hipoteza, metodologija i raščlamba rada .......................................................... 2

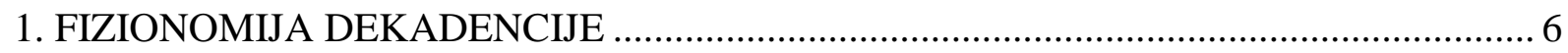

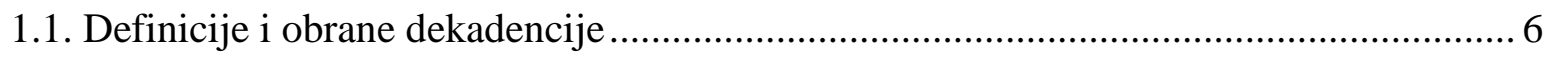

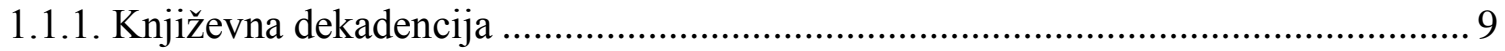

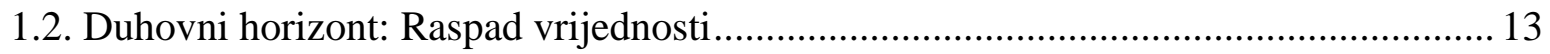

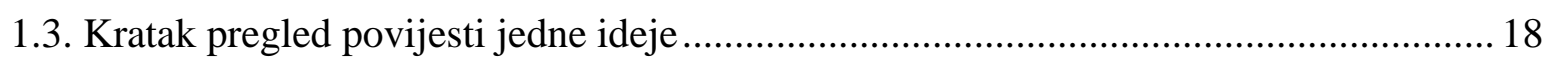

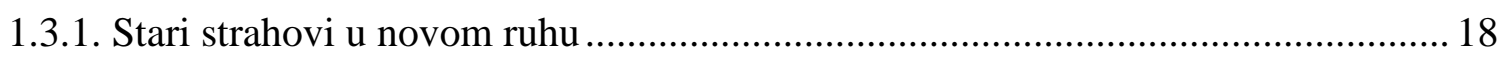

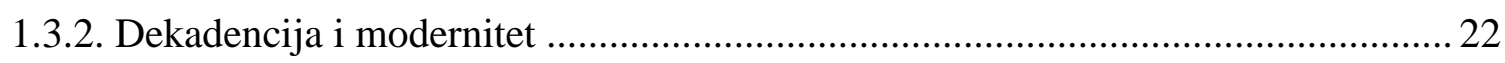

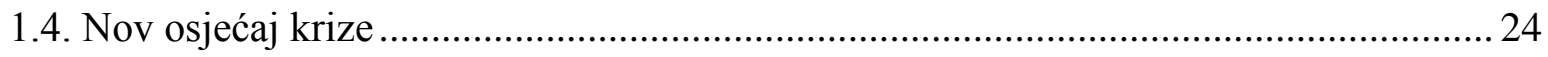

1.4.1. Devetnaestostoljetna francuska dekadencija ..................................................... 24

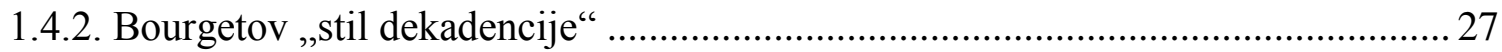

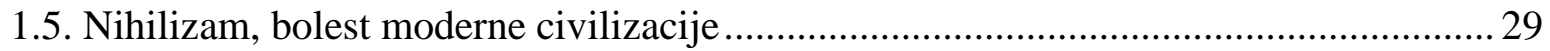

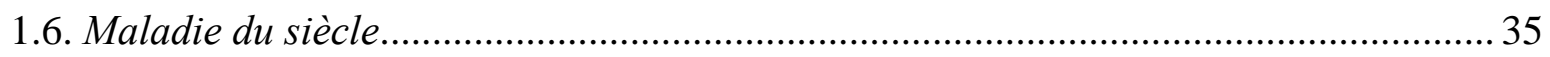

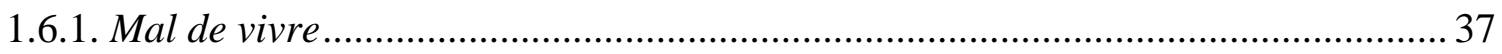

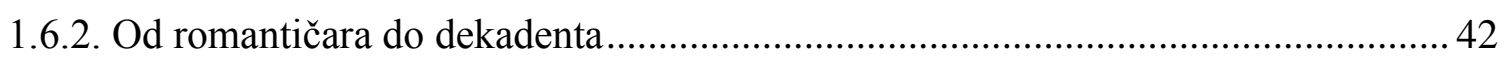

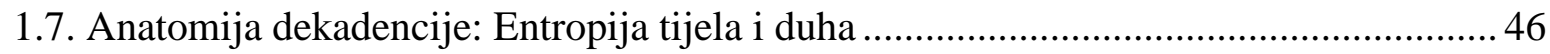

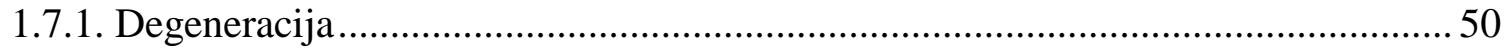

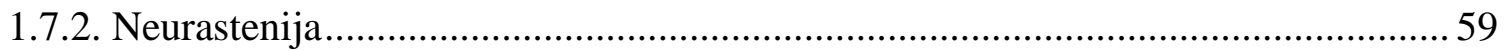

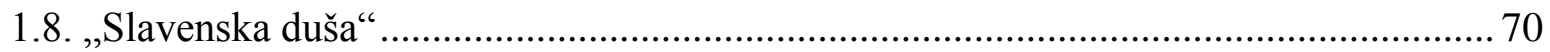

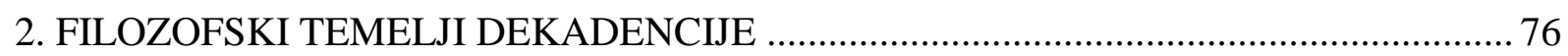

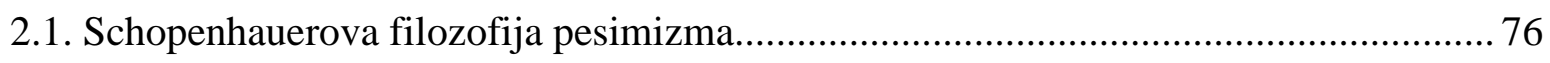

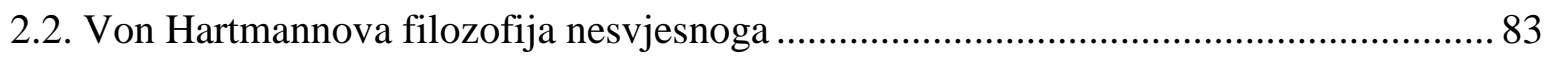

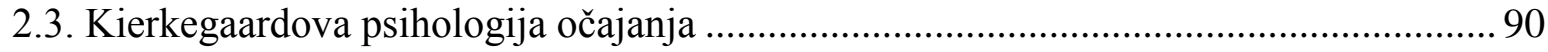

3. DRUŠTVENO-POLITIČKI I KNJIŽEVNOPOVIJESNI OKVIR DEKADENCIJE ......... 95

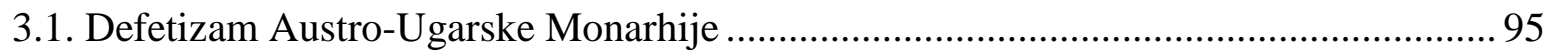

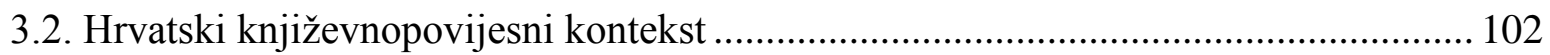

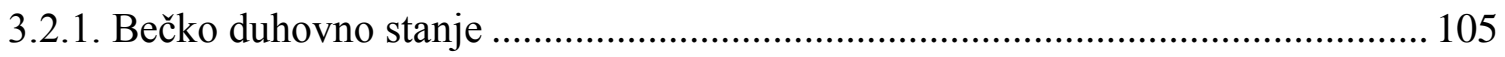

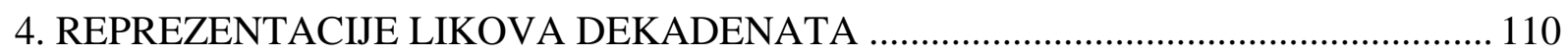

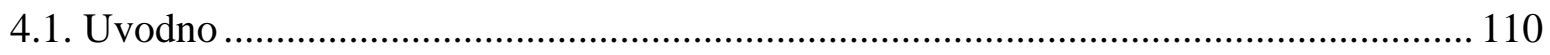

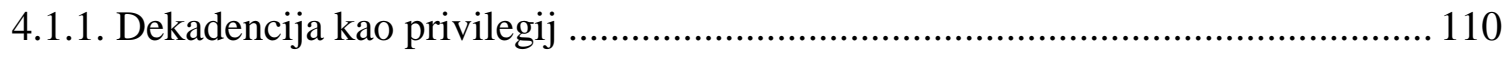

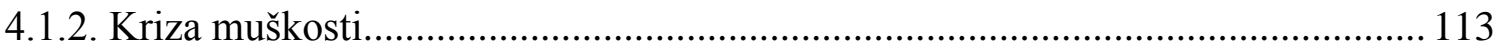




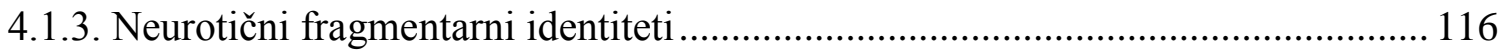

4.1.4. Tjeskoba i melankolija, dva lica hrvatske dekadencije ..................................... 120

4.1.4.1. Melankolija: Od patološke forme do teorije subjektiviteta .......................... 120

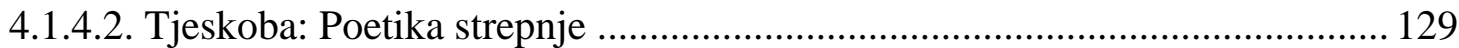

4.2. Tjeskoba u nastajanju: Priča jednoga protodekadenta ............................................. 141

4.3. Šopenhauerizacija tjeskobne muškosti: Borislavić i Ivanović .................................. 149

4.4. Na putu u otuđenje: Šegota, Mirković, Grančarić.................................................... 165

4.5. Između prirode i društva: Radmilović, Zlatanić, Andrijašević ................................ 187

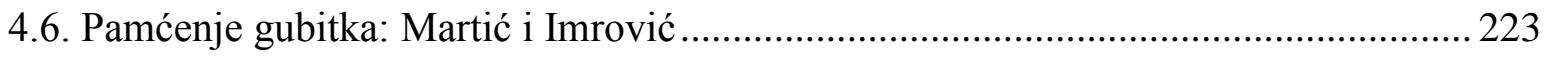

4.7. Marcel Bušinski, dekadent bez opravdanja ............................................................ 232

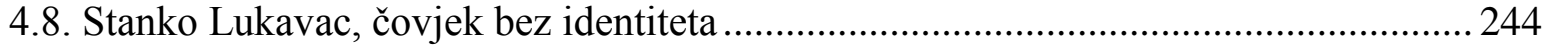

4.9. Dekadentno tijelo u raspadu: Ljubić i Toplak ........................................................... 253

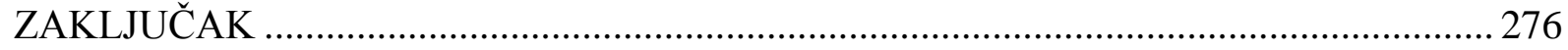

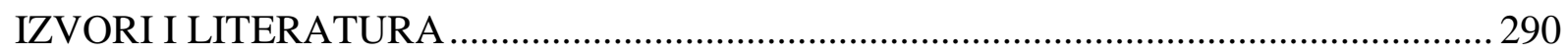

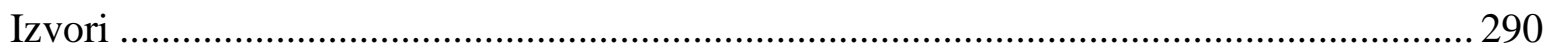

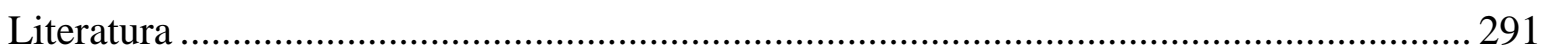

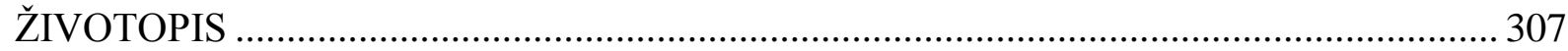




\section{UVOD}

Ne postoji književno djelo koje ne bi bilo „opterećeno“ proturječnostima vremena u kojem je nastalo. Ono svoje pune potencijale realizira, smatramo, tek kad se u obzir uzmu različita značenjska žarišta koja u književnost prodiru iz izvanknjiževne zbilje. Zato u disertaciji želimo pokazati na koji je način povijesni kontekst oblikovao literarnu fikciju te osvijetliti temelje dekadencije na kraju XIX. i početku XX. stoljeća, izvore tjeskobe i melankolije koje smatramo osnovnim dispozicijama neurotičnih dekadentnih likova, a koje ih priječe u uspostavi vlastite cjelovitosti. Izbor je proza u ovom radu, u to nema sumnje, posve proizvoljan $\mathrm{i}$ subjektivan. Lista iscrpljenih, duševno i tjelesno malaksalih likova u našoj književnosti neiscrpna je te bi se, s obzirom na djela u našem interesu, mogla uvelike proširiti (primjerice Kozarčevim suvišnim ljudima i Kovačićevim Kičmanovićem) i protegnuti sve do Krležinih Leonea Glembaja i Filipa Latinovicza, pa i dalje, duboko u polovicu XX. stoljeća. Usto mogla bi se i žanrovski dopuniti, nedvojbeno naprimjer Vojnovićevom Dubrovačkom trilogijom. No s obzirom na to da je korpus opsežan te da mu se može pristupiti iz različitih perspektiva, bilo je potrebno postaviti granice. Odabrali smo dakle djela koja držimo reprezentativnima za ovu tematiku, prema problemskom kriteriju te neovisno o pripadnosti stilskoj formaciji, kako bismo kontekstualnim čitanjem na primjerima likova istražili pogubne posljedice rastakanja identiteta.

Korpus proza, prema srodnim svojstvima grupiran u osam poglavlja, obuhvaća romane Janko Borislavić i Radmilović K. Š. Gjalskoga, Pavao Šegota i Dva svijeta V. Novaka, Sjene ljubavi J. Leskovara, Bijeg M. Cihlara Nehajeva, Tuđinac D. Šimunovića i Isušena kaljuža J. Polića Kamova te pripovijetke Prijan Lovro A. Šenoe, Misao na vječnost, Katastrofa, Poslije nesreće i Jesenski cvijetci J. Leskovara i Veliki grad i Zeleno more M. Cihlara Nehajeva. U svakoj smo od njih dekadenciju prepoznali kao odstupanje od uobičajenoga, od „,normalnoga“ poretka stvari, kao svojevrsnu bolest koja sa sobom uvijek nosi tjeskoban osjećaj praznine. Dekadencija je naime istovremeno prednost i nedostatak: prema uvriježenom mišljenju poremećaj pretjerano osjećajnih pojedinaca, prema našem sudu privilegij koji, premda najčešće s tragičnim ishodom, pojedinca tjera da osvijesti svijet oko sebe i spozna mu korumpirane temelje. Vrednovanje dekadentnih likova kao nenormalnih, nepoželjnih, nemoralnih, zazornih zrcali zapravo našu anksioznost koja se projicira na drugoga, eksternalizirajući naš osjećaj gubitka kontrole. Budući da je drugi, kojega imamo potrebu uvijek postaviti u stereotipne okvire, antiteza našega ,ja“, on u sebi već sadržava osnovne kategorije koje to isto ,ja“ definiraju. Pritom je razumijevanje patološkoga, kako iznosi Gilman, ukorijenjeno u svijesti o krhkosti ljudskoga organizma, i to ne u smislu njegove smrtnosti nego 
podložnosti propadanju, bolesti i najrazličitijim malformacijama (1985: 23). Ideja patološkoga, općenito gledano, jest središnja oznaka za različitost. A među njegovim mnogobrojnim modelima kao najčešći se izdvajaju duševne bolesti. Budući da su red i kontrola antitetični patološkomu, patologija se može protumačiti kao ne-red i gubitak kontrole, odnosno prepuštanje silama koje leže izvan sebstva. Prema tome s obzirom na to da identificiranje „bolesti“ u fikcionalnih karaktera traži široko iskustvo, posegnuli smo za raznolikom interpretativnom paradigmom koja osvjetljava ono što nam se činilo ključnim za razumijevanje dekadencije odabranih likova. Jer, možda je najbolje razotkrio Arsen Toplak:

Dosadna je čitava literatura bez propalica, luđaka i zločinaca. Život je interesantan, ako ga žive ljudi, a ljudi, ako spadaju u psihopatologiju. Psihologija počinje tamo, gdje zdravlje prestaje! (Polić Kamov, 2004: 145)

\section{Cilj, hipoteza, metodologija i raščlamba rada}

U doktorskom se radu dakle bavimo dekadencijom u hrvatskoj književnosti na prijelazu stoljeća, točnije muškim likovima u proznim djelima s kraja XIX. i početka XX. stoljeća. Svjesni složenosti i heterogenosti pojma dekadencija, bez pretenzija da ga je moguće posve cjelovito obuhvatiti te stabilno i neproblematično odrediti, proučavamo načine na koje se dekadentni senzibilitet toliko karakterističan za europski fin de siècle, u različitim svojim formama, očitovao u izabranom korpusu djela. Kako bismo zahvatili cjelinu duha uz koju se dekadencija veže te doprli do različitih silnica pomoću kojih su autori strukturirali likove, uključili smo različite aspekte teme.

Dekadenciju u radu promatramo ponajprije kao svijest o egzistencijalnoj propasti i besmislu svijeta, latentno ili jasno izraženo stanje duha, osobit osjećaj inferiornosti te kao osnovnu tezu ističemo činjenicu da je lik dekadenta, u kojem se dekadencija iskazuje na najrazličitije načine - od tjelesne i duševne onemoćalosti i bolećivosti preko melankolične bezvoljnosti, apatije i blaziranosti do živčanih trzavica i neuroza - među najčešćim karakterima $\mathrm{u}$ hrvatskom proznom diskursu fin de sièclea. Prema tome cilj nam je izdvojiti likove u kojima se ona prepoznaje kao jedan od glavnih toposa vremena te analizirati raznovrsne poticaje koji su na njihovo kreiranje presudno utjecali. Dekadencija koju razmatramo specifično je hrvatska: ona nije, za razliku od dekadencije na Zapadu, inherentna pripadnicima viših staleža, koji žive u bogatstvu te se u dokolici prepuštaju analiziranju i umovanju, nego se najčešće veže uz 
„obične“ ljude, učitelje, propale svećenike, male plemiće, književnike, (polu)intelektualce koji, nerijetko pritisnuti i materijalnim brigama, posrću pod teretom frustrirajuće melankolije i tjeskobe.

Rad se temelji na metodama analize, interpretacije, hermeneutičkoga i problemskoga pristupa te na kritičkoj metodi. Strukturno, podijeljen je u četiri temeljne cjeline. S obzirom na to da smo prepoznali da su u hrvatskoj književnosti manifestacije dekadencije, koje detektiramo u psihologiji iscrpljenih, egzistencijalno malaksalih likova, reflektirale i duhovnu klimu u Europi, u prvoj cjelini iznosimo fizionomiju dekadencije, koja obuhvaća njezine pojavne oblike. Svjesni pak da su se te manifestacije uvelike gradile i na filozofsko-idejnim kretanjima te društveno-političkom i kulturno-književnom kontekstu, u drugoj cjelini zahvaćamo filozofske temelje navedene krize voluntarizma i decizionizma, kroz neke osnovne postulate Schopenhauerove, von Hartmannove i Kierkegaardove filozofije, a u trećoj propitujemo izabrane detalje širega društveno-političkog i kulturnog kontekst Austro-Ugarske i Hrvatske kao njezina sastavna dijela. Pritom se naročito osvrćemo na hrvatski književnopovijesni kontekst, na modernu koja je, implicirajući izmijenjenu kulturnu svijest, pred umjetnika postavila nove artističke zahtjeve. Primjenjujući postavljene teorijske i metodološke okvire na prozu hrvatskoga fin de sièclea, u četvrtoj se cjelini bavimo očitovanjima dekadencije u odabranom korpusu tekstova, pokazujući da je i hrvatska književnost bila u dosluhu s aktualnim društvenim, političkim i kulturnim strujanjima. Najkraće rečeno, u središtu su našega interesa djela kojima je u fokusu oblikovanje psihološki istaknutoga pojedinca, a u kojima smo pronašli likove dekadenata kreirane u toj osebujnoj duhovnoj atmosferi.

Što se očekivanoga znanstvenog prinosa tiče, rad će - s obzirom na to da se na temelju proučavanja literature može zaključiti da ova tema u povijesti naše književnosti nije cjelovito obrađena, odnosno da postoji tek manji broj priloga koji se navedene problematike ili jednoga njezina segmenta dotiču usputno - kroz raznovrsne aspekte dekadencije, ponajprije kroz melankoliju i tjeskobu kao stanja koja snažno utječu na te dezintegrirane, neurotične identitete, ponuditi drukčiji pogled na muške likove u hrvatskoj prozi na prijelazu stoljeća, obuhvaćajući raznolikom interpretativnom mrežom njihove svjetonazorske, filozofske i motivske dimenzije.

Temeljni su pojmovi disertacije dekadencija, fin de siècle i lik. Dekadencija je glavni i ujedno njezin najsloženiji pojam te je i zato u najvećoj mjeri predmet našega interesa. Kao općenit pojam, svoj je diskurzivni put imala u zapisima mnogobrojnih stručnjaka, uglavnom iz društveno-humanističkoga područja. Nastala iz srednjovjekovne latinske riječi decadentia, tj. od latinske cadere (pasti), potječe iz društvene i kulturne povijesti u kojoj je označavala propast vrijednosti, postupan gubitak stvaralačke energije, pad, slom i/ili urušavanje nekoga političkog 
ili društvenog sustava (primjerice vrlo se često određivala prema propasti velikih civilizacija, posebno Rimskoga Carstva). No od kraja XIX. stoljeća, a osobito od Nietzscheova isticanja nužnosti prevrednovanja svih vrijednosti, dekadencija više ne označava samo propast, nego nužnu svijest o njoj, s bitnom razlikom što ona sad postaje i izlaz iz te propasti. Prerasta u svijest koja duh dovodi do nihilizma kao krajnje točke na temelju koje se izgrađuje drukčiji svijet, u svijest o propadanju kao ponovnom postajanju. Dekadencija se kao izniman oblik osjećajnosti jednostavno morala dogoditi da bi ljudski duh odbacio uvjetovanost velikim sustavima, kako misaonim, znanstvenim, tako i političko-društvenim. Kao potporu ovomu tumačenju istaknimo da je Nietzsche u svojim radovima cjelokupnu devetnaestostoljetnu europsku kulturu okarakterizirao kao buđenje svojevrsnoga osjećaja décadence. Taj je osjećaj bio odgovor na propadanje europskih vrijednosti utemeljenih na dvjema ,zgradama“ koje su pritiskale modernoga čovjeka. Međusobno suprotstavljene, obje su jednako nagrizale čovjekov duh toga doba. Riječ je s jedne strane o metafizici koja je, proklamirajući načela kršćanskoga morala i čovjekove besmrtnosti, oduzela biću njegovu okrenutost životnom svijetu. S druge je pak strane znanost koja je apstraktnim i objektivnim principima iz svijeta pokušala isključiti sve ono subjektivno, ljudsko, promovirajući načela racionalne objektivnosti. Oba su utjecaja čovjeka učinila slabićem koji dekadentnom sviješću podiže glas protiv morala i racionalizma. Okretanje ljudskomu, životnomu, intuitivnomu i subjektivnomu, kao odraz aktualnih duhovnih stanja, bit će jedini put zadobivanja autentične slobode. Budući da je u ovom radu pojam dekadencije, umjesto objektivističkoga razumijevanja, izraz krajnje subjektivnosti, analiza likova i njihovih unutarnjih previranja dobila je prednost u odnosu na objektivne fenomene vremena. Nastojimo dakle demonstrirati da su psihološka stanja naših likova odraz rastrganosti findesiècleovskoga čovjeka između slobode, koja se daje sa subjektivnošću, i neslobode tj. osjećaja besmisla, postavljenoga na razini objektivnoga sustava. Karakteri koje obrađujemo svjesni su da se određen oblik svijeta urušava, nestaje, i svoje nemoći da takvo propadanje spriječe ili da izgrade neki novi svijet - svima im je zajednički otpor, najčešće ipak posve pasivan, prema nametnutim normama, društvenim konvencijama, apriorno postavljenim ulogama. Na taj se način dekadentna svijest potvrđuje kao razdiruća karakteristika. Šire gledajući, možemo ustvrditi da i umjetnost s kraja odnosno početka stoljeća nastoji sebe uspostaviti kao novu, avangardnu umjetnost koja će takva biti baš zato što traži pravo subjektivnoga izraza koji je stoljećima bio nepoželjan u odnosu na kanonski postavljen objektivistički pristup umjetnosti. Tako su krajem XIX. stoljeća sve dominantniji umjetnički izrazi koji na vidjelo iznose unutarnja stanja koja traže izlaz iz situacije društvenoga i političkoga besmisla. Možemo zato zaključiti da je upravo dekadencija na prijelomu stoljeća bila temeljno polazište umjetničkih pravaca prve polovice 
XX. stoljeća. Kao specifična svijest o aktualnoj ili nadolazećoj propasti i padu, pesimizmu i nihilizmu koji prodiru u sve pore društva, prijelomno je utjecala na subjektivistički senzibilitet presudan u narednim razdobljima.

Što se termina fin de siècle tiče, napomenimo da se njime najčešće označava kraj XIX. i početak XX. stoljeća. No ta je sintagma na Zapadu puno više od puke vremenske oznake; usko povezana s krajem jednoga stoljeća i rađanjem novoga, ona podrazumijeva i jedinstven mentalitet vremena, cijeli niz duhovnih, moralnih, društvenih i kulturnih aspekata koji se mogu dovesti u vezu s dekadencijom, a nazvati nešto findesiècleovskim fenomenom implicira raskid sa starim i osjećaj novoga. S vremenom se dakle taj pojam u povijesti umjetnosti i književnosti utvrdio kao znak dekadentnosti, različitih patoloških stanja, duševnoga zamora. Ukratko, kao oznaka prekida sa starim stilskim tendencijama i estetskim kategorijama. Imajući to na umu, mogli bismo poentirati kako nijedno razdoblje nije imalo reputaciju pesimističnoga kao fin de siècle. Taj je francuski pojam, proširivši se jednakovrijedno i na druga govorna područja, istovremeno obuhvaćao tehnološki, industrijski, znanstveni i svaki drugi napredak građanskoga društva te prevladavajući osjećaj pesimizma i nespokoja koji je opterećivao suvremenoga čovjeka. Stoga je on razumljiv i obuhvatljiv tek sa sviješću o tom dualitetu, o procesima modernizacije u drugoj polovici XIX. stoljeća i duhovnim stanjima modernoga čovjeka koji na te procese reagira povlačenjem u sebe.

Likovi su pak, kao književni konstrukti te vrlo često najvažniji strukturni elementi književnoga djela, nositelji ovoga rada. Smatrajući da je književnost bitno, možda čak i prijeko potrebno tumačiti unutar konteksta u kojem je nastajala, pokazat ćemo da je dekadencija u svojim specifičnim očitovanjima bila odlučujuća u tipologiji muških karaktera koji su, kako smo i upozorili, ključan metodološki put naše doktorske disertacije. 


\section{FIZIONOMIJA DEKADENCIJE}

\subsection{Definicije i obrane dekadencije}

Ne postoji pojam koji bi se mogao oteti kontekstu iz kojega izrasta kao posljedica, bilo kao potvrda, bilo kao negacija, ili samo kao dijagnoza vremena u kojem nastaje. Dekadencija obuhvaća sva ta značenja jer je riječ o iznimnom, specifičnom senzibilitetu koji je, kako piše Nietzsche, bolest i lijek istodobno. Da je definirati dekadenciju prilično nezahvalno, pokazuju mnogobrojni varijeteti njezina značenja. Neuhvatljivost je toga koncepta upravo simptomatična jer „neuhvatljivost podrazumijeva značenje“ (Weir, 1995: 10). Svjesni mogućih prigovora da je termin poprilično potrošen, pokušat ćemo demonstrirati da o njemu ipak nije sve rečeno jer, „ukratko, dekadencija znači gotovo sve i baš zbog toga ne znači gotovo ništa“ (Drake, 1982: 71). Nasuprot Gilmanovoj procjeni da je taj „oštećeni““ pojam, s obzirom na mnogobrojne oscilacije, divergencije i izmjene u značenju, ,izabran da popuni prazno mjesto“ (1979: 159), ${ }^{1}$ nastojat ćemo pridonijeti rasvjetljavanju njegove srži i okolnosti koje ga prate te mu opravdati primjenu u hrvatskoj književnosti. Moglo bi se reći da je dekadencija jedan posve subjektivan, raspršen termin koji kritičari upotrebljavaju kako im odgovara, a upravo joj je to opiranje sistematizaciji jedan od glavnih značenjskih elemenata. O njoj se naveliko raspravljalo kao o povijesnom, društvenom i estetičkom fenomenu te ćemo u ovom kraćem ekskursu, koji će poslužiti kao predstavljanje okvira unutar kojega smo izgradili vlastito viđenje, iznijeti najkonstruktivnija kritička mišljenja koja prikladno pokazuju kako problem definiranja dekadencije ujedno osvjetljava njezino značenje. Naime respektabilan se broj kritičara zalagao za uklanjanje te neodređenosti koja kao sjena prati i termin i činjenicu dekadencije. Budući da je literatura o njoj pozamašna, nemamo pretenzija iscrpiti je dokraja i obuhvatiti cjelovito, već pokazati koje su nam bile polazišne točke za povijesno bavljenje tim fenomenom u hrvatskoj književnosti.

Kao pokušaj etiološkoga objašnjenja dekadencije naročito je vrijedna Swartova studija The Sense of Decadence in Nineteenth-Century France (1964), zasigurno jedna od najcjelovitijih knjiga o tom konceptu. Ne ograničavajući se sadržajno samo na područje

\footnotetext{
${ }^{1}$ Govoreći o problematici samoga naziva, koji mu je posebno dvojben, Gilman se pita postoji li uopće objektivna realnost na koju se pojam odnosi te pojašnjava: „Određene riječi koje se odnose na moral ili ponašanje, osuđujuće riječi, nastavljaju se uvlačiti u kontekste u kojima dovode do zbrke jer sa sobom nose prethodnost, nešto što je nekad vrijedilo kao istinito, nešto nekad upotrebljivo. Postoje riječi koje se upotrebljavaju iako se više ne mogu ni na što primijeniti.“ (1979: 5) Dekadencija je dakle za njega isključivo dio atmosfere vremena u kojem se kao pojam rabila (posebno se osvrće na Francusku posljednjih desetljeća XIX. stoljeća) te zato nema razloga i dalje se njome koristiti. Ona uvijek iskrsava kao logička dopuna nekoga drugog termina te joj je danas upotreba krajnje promašena.
} 
sugerirano u naslovu, Swart poistovjećuje dekadenciju s pesimizmom koji je najčešće bio odgovor na povijesna zbivanja, a književnu pak dekadenciju drži nekom vrstom kasnoga romantizma. Na sličan je način promatra i Praz u svojoj Agoniji romantizma (1974), ${ }^{2}$ tumačeći je na pozadini specifičnoga motivskog kompleksa kao odvjetak romantizma, tj. kao perverzni i morbidni kasni romantizam, čijim bi se prototipom mogao smatrati erotski senzibilitet Marquisa de Sadea. Negdje između tih dvaju viđenja smjestila se Carterova The Idea of Decadence in French Literature 1830-1900 (1958), u kojoj je dekadencija reakcija na romantizam, posebno na njegov kult prirode, pri čemu joj je artificijelnost vrlo bitno svojstvo. Pierrotovo pak tumačenje dekadencije kao modernističke estetike s antimimetičkim temeljem u studiji The Decadent Imagination 1880-1900 (1981) i Fletcherovo kao vremena tranzicije k modernizmu u knjizi Decadence and the 1890s (1979) izvrsno najavljuju Calinescua (1988), prema kojem je dekadencija - za razliku od dosad apostrofiranih autora koji je vide kao književno razdoblje čije se granice protežu od polovice stoljeća do njegova kraja - jedno od „lica moderniteta“, priprema za ono što će u književnosti tek slijediti. Pynsent u svom završnom eseju u knjizi Decadence and Innovation (1989) ističe sličnosti naturalizma i dekadencije s dominantnom pesimističnom koncepcijom života: dok naturalizam pod mikroskopom proučava segmente čovjekova materijalnoga, fizičkoga života, dekadencija to čini s njegovom psihom. A dok se u francuskoj kritici taj pojam upotrebljava mahom za književni pokret započet u prvim godinama 1880-ih, talijanski ga kritičari, preferirajući pojam dekadentizam (decadentismo), rabe kao širu povijesnu kategoriju koju također dovode u izravan odnos s modernizmom. Pa tako naprimjer Gioanola (1999) kao bitnu odliku dekadentizma izdvaja podsvjesno, koje će biti polazišna točka niza dvadesetostoljetnih tendencija i disciplina (poput ekspresionizma, nadrealizma i psihologije). ${ }^{3}$

Budući da je po nama dekadencija u izabranim prozama upravo kombinacija tih dviju kategorija - ona je u isti mah po nekim svojim aspektima nastavak i hipertrofija romantizma, a po drugima reakcija na modernitet - blizak nam je Weirov stav (1995), kojem se priključuje i Downes (2010), prema kojem se o njoj može govoriti kao o ključnoj točki koja povezuje romantizam i modernizam. Weir smatra da se dekadenciju može tumačiti kao tranziciju te zastupa tezu da se devetnaestostoljetni umjetnički pokreti trebaju promatrati upravo na podlozi koncepta dekadencije. Dekadencija je ,zajednički nazivnik koji pokriva izrazito složene i raznolike književne aktivnosti oko sredine i s kraja stoljeća“ (Weir, 1995: xvii) te ujedno kamen

\footnotetext{
${ }^{2}$ Prvi put tiskanoj puno prije, 1930.

${ }^{3}$ Za pregled pojma i činjenice dekadencije u talijanskoj književnosti i kulturnoj povijesti usp. npr. Binni (1936), Seroni (1970) i Moroni (2004).
} 
temeljac suvremenoga dvadesetostoljetnog romana (Mann, Gide, Joyce, Proust). Ako se stvari mogu tako postaviti, tad bi bilo jasno zašto se dekadencija doista najčešće promatra kao svojevrsni predznak, najava. Nietzsche u Sumraku idola i pojašnjava kako „mi moderni“ živimo u vremenu propasti i slabosti u odnosu na „snažnija“ prethodna razdoblja. Svjestan je međutim da je retrogresija nemoguća; jedino dakle što preostaje jest još korak dalje u dekadenciju. Prema Poggioliju (1975) dekadentno je nezadovoljstvo sadašnjošću, kao rezultat negativnih posljedica civilizacijskoga napretka, moguće izjednačiti s antipovijesnom perspektivom avangarde. Jer kao dvije strane istoga modernističkog nezadovoljstva buržoaskim pozitivizmom „obje nastoje épater le bourgeois ${ }^{64}$ (Downes, 2010: 31-32).

To je Poggiolijevo stajalište prilično blisko Calinescuovoj razlici društvene i estetičke koncepcije moderniteta, prema kojoj ova posljednja podrazumijeva „odbacivanje buržoaskog moderniteta, njegove potrošačke negativne strasti““ (1988: 49). Na njegovu tragu držimo da se dekadencija kao stanje duha može čitati kao pobuna protiv buržoaskoga, filistarskoga društva, odnosno kao pokušaj nadilaženja „običnoga“ građanskog čovjeka. U osjećaju krize njezin je primarni cilj bila kritika povjerenja u progres, pozitivističkih ideja i jedinstva kroz narušavanje cjelovitosti i promoviranje svega onoga što na bilo koji način iskače iz poretka. „Radnu etiku i nadu u vlastito poboljšanje zamijenila je provokativna poza hedonista, zadovoljstva ennuija i zamora te perverzne satisfakcije samoponižavanja.“ (Downes, 2010: 1)

Takav otuđen život, prezren u očima (malo)građanstva, dekadenta oslobađa od svake odgovornosti i potrebe da društvu polaže račune o svom životu. „Pokazati vlastitu izopačenost kao izraz ljudske prirode uopće, znači zbaciti sa sebe odgovornost za društvene akcije, zatvoriti se u vlastitu ravnodušnost.“ (Supek, 1950: 142) Zato primjećujemo da se krajem XIX. stoljeća svjedoči radikalnijemu rezu u tretiranju dekadencije, kad se ona počinje razumijevati kao simptom zastranjenja intelektualne elite $u$ odnosu na dominantne društvene tijekove, što je rezultiralo estetskim konceptom dekadencije. Ona je zapravo bila svjestan izraz udaljavanja od uvriježenih društvenih normi i očekivanja. Prividnoj normalnosti građanskih kodova suprotstavljale su se različite forme duhovne, moralne i fizičke dekadencije, pa tako i sam pojam dekadencije počinje odražavati vrijednosnu inverziju, u kojoj se ona sve jasnije shvaća kao privilegij.

\footnotetext{
${ }^{4}$ U slobodnom prijevodu ,šokirati buržoaziju“.
} 


\subsubsection{Književna dekadencija}

Dekadenciju u ovom radu prepoznajemo kao jedan od najistaknutijih kulturnih fenomena u intelektualnoj povijesti Europe fin de sièclea, kao životnu filozofiju modernoga čovjeka koja je svoju punu afirmaciju doživjela u tadašnjoj književnoj produkciji.

U povijesti književnosti dekadencija se najčešće shvaća kao neka osobina književnosti na prijelazu stoljeća (tzv. fin de siècle) i/ili književnosti prvog većeg razdoblja našeg stoljeća (modernizam ili avangarda). Pojam dekadencije pri tome se povezuje s određenim idejama ili raspoloženjima koja se korijene u svijesti o propadanju, krizi i „kraju civilizacije“. Takva je svijest - smatra se - prisutna kako u refleksiji o književnosti tako i u samim književnim djelima, a ona se može razumjeti kao posljedica stanovitog mentaliteta koji se povremeno naročito ispoljava barem u nekim razvojnim tokovima književnosti od druge polovine prošlog stoljeća do danas. (Solar, 1985: 41)

Međutim ne tvrdimo da je književnost kojom se ovdje bavimo dekadentna, nazadna ili neuspjela te, suprotno izjavi da dekadentna djela „ne samo da svjedoče o krizi cjelokupne kulture nego tu krizu i potiču jer je izražavaju; ona su simptomi bolesti ili su 'krivi lijekovi'“ (ibid.: 21), nemamo uopće namjeru vrijednosno je određivati. U razdoblju u kojem se javlja kao društveni fenomen i misaona konstrukcija dekadencija je bila praćena negativnim vrijednosnim sudovima te određivana pejorativno, kao amoralna i iskvarena senzibilnost, a značenje joj je primarno ovisilo o moraliziranju onoga koji o njoj piše. Na prijelomu stoljeća tim se pojmom koristilo kao osudom za sve novo. Budući da se dekadentno pismo neizbježno smješta na stranu patologije, paljbu s polja onoga što se smatralo normalnim gotovo da i možemo razumjeti. Napadi su ipak manje govorili o književnom tekstu kojim su se bavili, a puno više o oprečnoj ideologiji koju su zastupali. Arhetipski su primjeri takva pristupa Nordauova opsežna summa dekadencije, u kojoj se autor na čak 600 stranica prezentira kao njezin najvjerniji dijagnostičar, ili pak Symonsova sugestija da je dekadencija perverzan proizvod „manje vrijednoga čovjeka“ koji se polagano odmiče od „glavnoga književnog smjera“ (1919: 6-7). Primjeri takvih podcjenjivačkih ocjena mogu se nasumce izvući iz niza studija. Ne čudi što iz takvih sudova iskače Baudelaire, koji kao umjetnički arbitar prvi reinterpretira uvriježeno moralističko viđenje, označavajući terminom literarne dekadencije, koja poprima pritom nov, objektivan smisao, književnost s temama propasti i disolucije u središtu (Rasch, 1982: 207). Naime prije nego što je raspad uopće mogao postati relevantnom književnom temom, valjalo je iznova evaluirati koncept dekadencije. Iako se tom idejom nikad 
nije sustavno bavio, teme književne dekadencije, pionirski joj ističući pozitivne aspekte, Baudelaire je ujedinio u metafori očaravajućega zalaska sunca, kao zajedničkoj sintagmi za najraznovrsnija očitovanja nazadovanja i propasti:

U promjenjivu sjaju ovoga umirućeg sunca neki će pjesnički umovi pronaći nove radosti; otkrit će blistave kolonade, kaskade rastaljenoga metala, rajeve vatre, melankolično blještavilo. (...) I zalazak sunca pojavit će im se kao čudesna alegorija duše, prožeta životom, koja se spušta izvan horizonta, s veličanstvenim bogatstvom misli i snova. (cit. prema Downes, 2010: 3)

$\mathrm{Na}$ taj je način reinterpretacija dekadencije bila dovršena: ona prestaje biti isključivo oznaka inferiorne književnosti, a iako termin zadržava stare, pogrdne konotacije, novi smisao sve više pušta svoje korijenje. Tako je upravo sam Baudelaireov opus poslužio kao uzor njezinim različitim definicijama, od Gautiera, koji se zahvaljujući predgovoru Cvjetovima zla (1868) može nazvati jednim od prvih kritičara književne dekadencije, do Bourgeta i mnogih drugih autora. Baudelaire naime zbog utjecaja koji je imao na generacije „pravih“ francuskih dekadentnih pjesnika, ali i zbog svoga životnog stila koji se smatra prototipom stila dekadencije, uživa golemu važnost u povijesti toga pojma te se beziznimno drži jednim od otaca dekadentnoga pesimizma. Smatrajući stil dekadencije radikalno inovativnim stilom u kojem riječi iz najrazličitijih registara izražavaju suptilne, rafinirane misli i kratkotrajne senzacije, Gautier u predgovoru piše:

Stil netočno nazvan stilom dekadencije, zapravo je umjetnost u točki posvemašnje zrelosti, plod zalazećeg sunca starih civilizacija; vješt, kompliciran stil, pun kontrasta i istraživanja, neprekidno promičući granice govora, pozajmljujući iz rječnika svih umijeća, boje sa svih paleta i note iz svih klavijatura kako bi umjetnički prikazao ono što je najneizravnije u duhu, uobličio nejasno i najneuhvatljivije, preveo suptilne natruhe neuroza, zamiruću ispovijed izopačene strasti i neobična priviđanja opsjednutosti što prerasta u ludilo. (cit. prema Calinescu, 1988: 157)

Za razliku od kritike koja dekadenciju u europskim zemljama smatra tendencijom nadređenom umjetničkim strujama iskrsnulima u posljednjim dvama desetljećima XIX. stoljeća, u hrvatskoj je književnosti ne držimo ni pokretom ni stilom u onom najužem smislu. ${ }^{5}$

\footnotetext{
${ }^{5}$ Nerijetko se u svjetskoj književnoj povijesti na dekadenciju odnosno dekadentizam - čime se jasno aludira na pred- ili postromantičarske škole, tj. ,izme“ - referira kao na umjetnički stil i književni pokret te se detektira ponajprije u francuskoj, talijanskoj i engleskoj književnosti (usp. npr. Ridge, 1961; Thornton, 1979, 1983; Pierrot, 1981). Najkraće rečeno, očituje se u mazohističkom motivskom registru sa željom za šokiranjem, u zazornom, umjetnom i ezoteričnom te u stilističkim pretjerivanjima. Pa se primjerice, kako ističe Morazé, u engleskoj
} 
Iako se dominantno javlja, kako je istaknuto, krajem XIX. i na početku XX. stoljeća, opire se vremenskim klasifikacijama i književnim periodizacijama. $\mathrm{Na}$ tragu Croceova razlikovanja termina decadenza i decadentismo (ibid.: 200) - prema kojem je decadenza općenit pojam koji označava propast, a decadentismo ima estetičko-povijesno značenje - u izabranim prozama dekadenciju ćemo promatrati kao zajednički nazivnik za propadanje u svim životnim područjima. Naime koncept literarne dekadencije obuhvaća specifičan kompleks tema te je, barem načelno, ,percipiramo uvijek ondje gdje je nešto morbidno - mračno - beznadno i etički upitno upućeno na propadanje“ (Grizelj, 2016: 151). I u Raschevoj je interpretaciji ona kao književni fenomen na kraju XIX. stoljeća primarno fokusirana na „teme propadanja i urušavanja u svim njihovim varijantama“ (1986: 21). Bauer (2002) pak, imajući na umu ove konstatacije, sugerira da se termini décadence i dekadencija u upotrebi trebaju jasno odvojiti: décadence valja upotrebljavati kao oznaku kulturno-povijesnoga razdoblja posljednje trećine stoljeća (Nietzsche, Baudelaire, Barrès, Huysmans, Wilde, Altenberg, Bourget, Freud, Bahr, Hofmannsthal, Schnitzler), a dekadenciju kao oznaku za prepoznatljiv motivsko-tematski repertoar koji se može pronaći i u drugim umjetničko-povijesnim razdobljima.

Sa svim navedenim postulatima na umu u radu ćemo pokazati na koji se način dekadentni senzibilitet toliko karakterističan za europski fin de siècle očitovao u odabranom korpusu hrvatske književnosti na prijelomu stoljeća. Da bismo zahvatili cjelinu duha uz koju se dekadencija veže, odnosno doprli do različitih poticaja pomoću kojih su autori kreirali likove, propitat ćemo i širu društveno-kulturnu klimu. Prema tome kad opsežnije govorimo o fenomenu u njegovu povijesnom okruženju, radimo to s namjerom da predstavimo kontekst prema kojem su hrvatski autori literarizirali fundamentalne misaone preokupacije vremena. Ne kvalificiramo autore kao dekadentne, nego se primarno osvrćemo na njihove likove, te ne tvrdimo da je dekadencija u književnosti u vrijednosnom smislu zrcalila dekadenciju društva, nego u njoj pronalazimo različita dekadentna stanja koja se mogu dovesti u blisku vezu s društvenopolitičkim konstelacijama. Upravo se naime u to vrijeme naša književnost, iako se razvija u zemlji koja je na marginama svijeta, uključuje u suvremene europske umjetničke tokove preuzimajući najraznovrsnije duhovne manifestacije.

Zajedničko je mjesto dekadencije, neovisno o konkretnom imaginariju kojim se artikulira, raspad. Propast pojedinaca i cijelih obitelji kroza smanjenje vitalnosti, gubitak energije i paralizu volje, disolucija društveno-političkih struktura. Imajući u vidu činjenicu da

književnosti dekadencija prepoznaje u djelima Charlesa Swinburnea, Waltera Patera, Jamesa Thompsona, Thomasa Hardyja i Oscara Wildea, a najosebujniju je ličnost dekadentnoga pokreta, Gabrielea d'Annunzija, iznjedrila Italija (1976: 189-192). 
zbog širokih raspona svojih značenja sam pojam prijeti banalizacijom, u odabranim je tekstovima interpretiramo kao manje ili više latentno stanje duše, specifično osjećanje slabosti i egzistencijalne propasti, koja se u klimi mal du sièclea može razumjeti kao konačan izraz stoljetnoga pesimizma, kondenziran u različitim očitovanjima melankolije i tjeskobe kao referentnih točaka dekadentne ličnosti: živčanim nemirima, rezignaciji, apatiji, izmučenosti, tjelesnoj i duhovnoj degeneraciji. Temelji se prije svega na pesimističnom pogledu na ljudsku egzistenciju, na ideji čovjeka kao objekta društvenoga determinizma, nerijetko i sudbinskoga fatalizma.

S neizostavnim simptomima boležljivosti civilizacije koji su se osjetili u svim europskim kulturama, umjetnost za navedenoga razdoblja postaje vizija egzistencijalnoga stanja suvremenoga čovjeka, poremećene aktualnosti, ali istovremeno i simbol atemporalnosti ljudske tjeskobe. Potaknuta intuicijom da se iza civilizacijskih zakonitosti građanskoga društva kriju proturječja koja vode u besmisao, rođena je iz krize vrijednosti. Prema tome motivira je svijest da nijedan društveni, estetski ili moralni standard nije siguran. Razvijajući se u percepciji polaganoga iščezavanja svijeta koji se donekle održavao zahvaljujući vjeri u razum i znanost, u skladu s koncipiranjem nove realnosti koja je podrazumijevala odustajanje od strogoga racionalizma i odbacivanje njegovih pretpostavki, umjetnost se okreće subjektivnomu i intuitivnomu te u središte svoga interesa postavlja labilni, slabi, rasipajući subjekt. I dok je tradicionalna estetika određivala lijepo kao ono što se može postaviti objektivistički te se zalagala za klasični model ljepote (što je pak značilo da čovjek razumom može spoznavati lijepa djela), umjetnost se na prijelomu stoljeća, dovodeći u pitanje racionalno-znanstveno postavljanje svijeta, svela na iznošenje unutarnjih ekspresija koje svijet ne prikazuju u njegovu totalitetu. Propitujući dakle njegov monologocentrični model, ona počinje sumnjati u mogućnost ovladavanja realnošću uopće. U uvjetima poljuljane duševnosti, u kojima se ideja kraja u temporalnom smislu povezala s idejom kraha čovjeka i civilizacije, stara se estetika zamjenjuje estetikom imanencije. Njome na tron dolazi subjektivizam kao osnovni ideologem razdoblja, a središnja kategorija postaje subjekt, njegove emocije i impresije kao „nevidljiv i razumski neuhvatljiv fluid kojemu se čovjekova volja teško može suprotstaviti““ (Posavac, 1986: 182). Zbilja se strukturira čovjekovom subjektivnošću te u središte pozornosti dolazi umjetnost nerva i duše. Ne iznenađuje stoga što Bahr u eseju Die Décadence iz 1891. piše upravo o umjetnosti živaca, tumačeći kako pisci koji se dekadencijom bave ili od nje pate „ne mare previše za razmišljanje, osjećanje i htjenje, a žele izraziti samo zalihe koje pronalaze u svojim živcima“" (2005: 25). Kao što je elaborirao Nietzsche u svojoj knjizi Ljudsko, odviše ljudsko, izravno spajajući modernitet i neurotične poremećaje, nervoza postaje moderna bolest 
par excellence, nužna stepenica na putu do moguće renesanse. ${ }^{6}$ Ili, kako će zapisati Schorske, potaknut činjenicom da svi na prijelomu stoljeća govore o živcima, ,racionalni je čovjek morao ustuknuti pred bogatijim, ali opasnijim i nepostojanijim stvorenjem psihološkim čovjekom“, koji se postavlja primarno kao biće „osjećaja i instinkata“ (1997: 24). U okolnostima niza kulturnih i društvenih promjena, na temeljima filozofija koje propituju racionalnu sliku svijeta, pisci napuštaju realistički kategorijalni sustav, zaokreću prema čovjekovu mikrokozmosu te svijet prikazuju kroz njegova unutarnja doživljavanja i borbe, istražujući ono što mu iracionalno upravlja životom. Dok pojedinac gubi nekadašnja čvrsta svjetonazorska uporišta, jedno od osnovnih epistemoloških obilježja moderniteta postaje njegova potreba da materijalnoj zbilji nametne „svoj subjektivitet kao strukture njezine pojavnosti“(Gjurgjan, 1995: 30).

\subsection{Duhovni horizont: Raspad vrijednosti}

Povijesno gledano, dekadencija je, složit ćemo se s Weirom, ,jednostavna riječ, ali složen koncept“" (2018: 1). Koncept koji uvelike premašuje granice umjetničkoga područja te izvrsno demonstrira opravdanost teze da je književnost toga vremena neophodno kontekstualno interpretirati, „u ustrajnom isprepletanju s dominantnim društvenim i kulturnim kretanjima u različitim zonama ljudskog djelovanja“ (Vuković, 2016a: 445). Dekadencija je zato istovremeno društveni fenomen i estetska kategorija. U svakidašnjem rječniku definirana kao nazadovanje, propadanje, opadanje stvaralačkih snaga i urušavanje tradicionalnih vrijednosti, sredinom XIX. stoljeća te napose na prijelazu dvaju stoljeća usko se veže za društveno-političke i duhovne procese. Devetnaestostoljetna je Europa, najkraće rečeno, u krizi, a dekadencija fin de sièclea simptom je te krize društva te je postala nešto što bismo mogli označiti kao kultura krize. Duhovna pak kriza, koju držimo ključnim simptomom dekadencije odabranih likova, zapravo je rezultat krizâ svih prethodnih epoha, a iako joj se uzroci pronalaze u nizu čimbenika, može se reći da je ona ishod jedinstvenoga civilizacijskog procesa: oslobađanja od autoriteta svake vrste (Bobbio, 1944: 14-15). U temelju joj je slabljenje ili potpuno nestajanje autoriteta, koji se postavlja kao konstitutivni princip duha, kao središte svake njegove manifestacije. Vrhovni princip koji bi bio postavljen kao autoritet prestao je postojati. Onoga trenutka kad je kantovska kritika prekinula prevlast spekulativne metafizike, a kartezijanska sumnja teološku

\footnotetext{
${ }^{6}$, ,...) ukupnost senzacija, znanja i iskustava, tj. čitavoga tereta kulture, postala je toliko golemom i teškom da postoji generalna opasnost prekomjerne stimulacije živčanoga i misaonoga kapaciteta, tolika da su obrazovane klase u europskim zemljama posve neurotične; gotovo svi u svojim obiteljima imaju nekoga tko je na rubu ludila." (Nietzsche prema Le Rider, 1993: 38)
} 
metafiziku te čovjek više nije mogao pronaći odgovore na svoje teorijske i praktične neodlučnosti, pred njim su se našla dva smjera: idealizam i pozitivizam. Kako obrazlaže Bobbio, u prvome misao nastoji izbjeći podvrgavanje načelu autoriteta, konstruirajući (ili barem to pokušavajući) sustav koji ne bi imao autoritet izvan uma samoga koji ga kreira; drugi pak podrazumijeva autoritet koji bi proizlazio iz materijalnoga svijeta prirodnih i društvenih zakona koji se suprotstavljaju duhu. Jedan dakle znači apsolutnu slobodu uma, drugi podčinjenje uma prirodi. Međutim kad je kriza eksplodirala, između toga se dualizma kristaliziralo posve novo stajalište koje se prezentiralo kao jedino ispravno i autentično:

(...) pozicija onoga koji se odriče svakoga autoriteta i prihvaća nesustavnost, preuzimajući na sebe krizu kao teret koji mora dovesti do potpunoga poništenja, poput kazne za iskupljenje koja vodi sve do autodestrukcije; onoga koji krizu ne smatra kaznom ni odskočnom daskom, već osobnom sudbinom, posljednjim utočištem, te u toj degradaciji pronalazi zadovoljstvo, gotovo entuzijazam zbog izostanka svake potpore. (ibid.: 20)

Nije teško u ovim rečenicama prepoznati i tezu o složenosti fenomena dekadencije upravo zbog njezinih kontradiktornih pozicija. Istovremena odanost i odbojnost, privrženost propadanju i urušavanju, ključna je pozicija književne dekadencije, a najbolje ju je formulirao Mallarmé: „Čudno i neobično, volio sam sve što je sadržano u toj riječi: propast.“ (cit. prema Rasch, 1986: 7) Ona dakle ne implicira samo propadanje kao takvo nego propadanje koje je istovremeno pokvareno i primamljivo. Odnosno, kako će postaviti Nietzsche govoreći o stvarnoj bolesti i izabranoj bolećivosti, ona postaje odabrana zadaća. „Od relativno benigne melankolije na početku XIX. stoljeća do tjeskobnoga milenijalizma na kraju stoljeća, od mal du siècle do fin de siècle“ (Weir, 1995: xii), dekadencija je nerijetko bila popraćena oduševljenjem, izazivajući u najmanju ruku znatiželju.

Propitivanje temeljnih postavki novoga vijeka, tj. ono što Weber promatra kao napuštanje statičkoga, nepromjenjivoga poimanja tradicionalnih vrijednosti (1982: 10), otvorilo je krizu koja je Zapadu „razbila sve nade u 'ozdravljenje' dotrajalog svijeta, i zapravo je tek izvanjski simptom preživjelosti njezinih temelja“ (Pejović, 1979: 10). Drugim riječima:

Ako su apokalipsa i melankolija simptomi duhovne situacije vremena kao radikalne krize vrijednosti u Brochovu smislu, onda nisu posrijedi tek pojmovi koji zadiru s onu stranu zapadnjačke filozofije, nego poglavito stanje svijesti i odnos čovjeka spram povijesnoga svijeta 
u kojem ništa više nije osigurano od propasti i propadanja, pa tako ni tzv. vječne istine. (Paić, 1999: 531; isticanje naše)

Upravo sumnja u vječne, transcendentne istine, ponajprije u kršćanski moral i svjetski duh odnosno Boga, postaje bitan biljeg dekadencije. Već je, istaknimo kao primjer, Schelling upozorio „da se kriza našega doba ne sastoji u manjkavoj ozbiljenosti ćudorednih i duhovnih načela što održavaju ljudski život, nego u njihovoj povijesnoj istrošenosti i dotrajalosti“ (cit. prema Kopić, 2001: 14). Zato i Croce govori o dekadenciji kao odbacivanju moralnih i intelektualnih standarda koji su Zapad učinili predvodnikom svijeta, izjednačujući je s kulturnim pesimizmom (prema Drake, 1982: 81). Iz toga se razloga na drugu polovicu stoljeća te napose na fin de siècle može primijeniti Brochova refleksija o raspadu vrijednosti u suvremenoj zapadnoj kulturi. Ona je postala jedna od sintagmi koja je, uz Nietzscheovu volju za moć, Bergsonov élan vital i Freudovo Nad-Ja, presudno obilježila kulturnu atmosferu XX. stoljeća. „Jer i slom materijalno-gospodarskog vrijednosnog područja treba shvatiti tek u povezanosti sa slomom sveobuhvatnog i ukupnog sustava vrijednosti““(2007: 26), opaža Broch, što je i naša misao vodilja u ovom pregledu dekadencije. Prema njemu dekadencija je završna točka u razumijevanju krize moderne civilizacije, a cijela druga polovica XIX. stoljeća može se okarakterizirati kao epoha laži, lažnih tendencija i ne-stilova, kao vrijeme vrijednosnoga vakuuma koji je rezultat propasti vrijednosti, odnosno raspada metafizičke cjeline duha iz kojega potječe „doba tragike svijeta bez duha“ (Paić, 2007: 207). Prisjetimo se zato na koji je način slom jedinstva čovjeka i svijeta utjecao na rađanje osjećaja dekadencije.

U filozofskom smislu, kao što smo već upozorili, novovjekovnim je svijetom dominirala napetost između idealizma i materijalizma, s nekim slabijim pokušajima njihova pomirenja (usp. Pejović, 1979). Za tradiciju idealizma um kreira čitavu zbilju, dok je za tradiciju materijalizma um samo nadgradnja materijalnomu, već postavljenomu svijetu, koji razum može samo dobro ili loše razumijevati. Oba su se ta velika filozofska sustava nastojala legitimirati apsolutnom znanstvenom istinitošću, najčešće ne priznajući jedna drugu, a iz toga je dualizma bio izostavljen pogled koji bi upućivao na to da postoji svijet onkraj tih sustava, svijet koji se ne da podvesti pod njihove apsolutne zakonitosti. Kao reakcija na navedeno krajem XIX. stoljeća razvija se filozofija egzistencije, koja nastoji opisati pojedinca neuhvatljiva tim apsolutizirajućim filozofskim istinama. Shvaćajući kako je njegov položaj u krizi baš zbog toga što se on razumijeva ili kroz idealizam ili kroz materijalizam, za filozofe egzistencije pitanje čovjeka postaje pitanje egzistencije te oni, nasuprot strogo znanstvenoj i determinističkoj perspektivi, ,ističu, u prirodnom i društvenom zbivanju, odlučujuću ulogu iracionalnih, 
metafizičkih i subjektivističkih faktora“ (Supek, 1950: 9). Budući da se čovjek ne može reducirati ni na idejni ni na materijalni svijet jer je on i jedno i drugo, napominju da su ga te pozicije i dovele u krizu, iz koje se može izbaviti tek kad se zapita o vlastitoj egzistenciji u svijetu koji sve više shvaća otuđenim. Zato je temelj filozofije egzistencije, ali i originalnih filozofija koje su mu prethodile (poput Kierkegaardove), pesimistički i nihilistički pogled na svijet: pojedinac jest dio svijeta, ali ga razumijeva sebi udaljenim. Da bi se takvomu svijetu odupro, čovjek mora ovladati vlastitim bitkom. Iako se u svojim pozicijama filozofi egzistencije međusobno razlikuju, jedna je odlučujuća odlika kojoj se uvijek vraćaju: svi naime govore o slabosti, nevoljkosti, pa i nemogućnosti čovjeka da ovlada vlastitom egzistencijom. Takva je nastojanja Tillich vidio kao očajničku borbu da se životu dade novi smisao, jer su ,posljednjih stotinu godina implikacije sustava postajale sve jasnije: logički ili naturalistički mehanizam koji uništava slobodu pojedinca, osobne odluke i organske zajednice, analitički racionalizam koji iscrpljuje životne snage i sve pretvara, uključujući čovjeka samoga, u objekt kalkulacije i kontrole“ (cit. prema May, 1977: 31). Vjerujući da je upravo subjektivnost put do istinske objektivnosti, u smislu one „prave“ nasuprot umjetnoj objektivnosti racionalističkih sustava, filozofi su se egzistencije okretali čovjekovu neposrednomu iskustvu. „Nema i ne može da bude neke 'objektivne' istine nezavisne od pojedinačne egzistencije, jer samo ono shvaćeno sa strašću kao moje i samo moje može biti istinito.“ (Pejović, 1970: 93)

Prema tome uzroke devetnaestostoljetne duhovne krize o kojoj govorimo, a koju prepoznajemo u likovima kojima ćemo se u središnjem dijelu rada baviti - a to je jedinstvena konstelacija društvenih i političkih čimbenika u Hrvatskoj (ponajprije šopenhauerovski bezizlazne godine Khuenova banovanja) te umjetnost obilježena estetikom imanencije i subjektivizmom kao novim ideologemom - pronalazimo u činjenici da je povijesno mišljenje opterećeno metafizikom i idealizmom te transcendentnim smislom istine, koje je pojedinca razumijevalo kao dio nadređene mu cjeline. Takva je pozicija sve više onemogućavala za slobodu nužno identitetsko razdvajanje pojedinca i cjeline, čovjeka i svijeta, subjekta i objekta. Moderni je svijet naime od čovjeka učinio biće koje ne misli vlastitu egzistenciju, biće koje uočava da je dio toga svijeta, ali mu on spoznajno i vitalno izmiče, izazivajući u njemu upravo otuđenje od svijeta kojega je dio, a istodobno mu je potpuno stran. Stoga se pesimizam i nihilizam nameću kao jedine moguće egzistencije u svijetu.

Dekadencija je, zato možemo reći, ono „drugo“ metafizici i teleologiji, odnosno idealiziranim normama koje se nadaju tek kao iluzorne projekcije. Kraj je XIX. stoljeća prema tome obilježio već poznati mehanizam razumijevanja povijesti: 
(...) neograničena novovjekovna subjektivnost (Descartesov Cogito, ergo sum) postavlja neku tezu o apsolutnoj slobodi (pojedinca, građanina, nacije, klase, umjetnosti), želi tu ideju ostvariti u zbilji, ali kako je ta ideja metafizička transcendentna konstrukcija (sekularizirani Duh Sveti, Kantov Ding an sich koji se ne može ostvariti u zbilji, jer je s onu stranu svakoga mogućega iskustva), ta se ideja pokušava provesti nasilno (...), pa kada se ustanovi da se ideja ni nakon svih pokušaja nije ostvarila u zbilji, da carstva apsolutne slobode nema ili da ga čak ne može biti, sama se ideja odbacuje, a povijest započinje iznova - stvara se nova ideja, novi eksperimenti, nove revolucije i novi ratovi, novi umjetnički pokreti. (Oraić Tolić, 1996: 168169)

Premreženost dekadencije s pojmom fin de sièclea, kojim se označava kraj XIX. i početak XX. stoljeća, ali i specifičan mentalitet vremena, toliko je intenzivna da se oni rijetko pojavljuju odvojeno. Fin de siècle naime ne samo kao temporalna nego i kao društvena i kulturološka oznaka implicira niz aspekata koji bi se, najkraće rečeno, mogli podvesti pod dekadenciju. Kako iznosi Oraić Tolić, „smisao pojma kristalizirao se u povijesti književnosti i teoriji umjetnosti kao oznaka za raskid s tradicijom, dekadenciju, iscrpljenost i bolećiva stanja u duhovnosti i umjetnosti toga vremena“ (ibid.: 167). Njegova se prava kulturološka konfiguracija ostvaruje prenošenjem koncepata linearnosti i progresa na ideju civilizacije, koji se nadovezuju na strahove o ispraznosti težnji te iste civilizacije te rađaju jedinstvenu svijest o jazu između običaja i morala, teorija i praksi, smanjujući pouzdanje u čvrsto zaleđe. Jer i Zapad je samo civilizacija i sve njegove pretenzije na univerzalnost i vječnost ne mogu poništiti tu temeljnu istinu: i on je osuđen na neprestano ponavljanje uzoraka života, postupno propadanje i smrt (Jervis, 2015: 60). U tom je smislu fin de siècle oznaka duhovne klime na prijelomu stoljeća.

„Od Francuske je revolucije čovječanstvo živjelo u nepromijenjenom stanju političke, ekonomske i kulturne krize. U najmanju ruku možemo reći da osjećaj življenja u prijelaznom dobu revolucionarnih i radikalnih promjena nikad nije posve izostao iz zapadnoeuropske svijesti posljednjih stoljeće i pol“ (1964: 44), iznosi Swart, ističući kako je osjećaj življenja u tom nestalnom razdoblju, na razmeđu dvaju svjetova, postao osnovom dekadentnoga senzibiliteta. Nemoguće je ne primijetiti opsesiju intelektualnih elita destrukcijom svijeta, tj. „sumrakom nacija“ (Nordau, 1895: 1) za koji se vjerovalo da dolazi s krajem stoljeća. Nordau, koji je poput mnogih svojih suvremenika nastojao izolirati temeljne konstituense duha vremena, spominje da je sličan predosjećaj anulacije svijeta bio prisutan u kršćanskoj tradiciji kad se približavala 1000. godina. No dok su beznađu pred to novo tisućljeće prethodili zadovoljstvo i 
punina života, raspoloženje je devetnaestostoljetnoga fin de sièclea „nemoćan očaj bolesnoga čovjeka koji osjeća da polagano umire u prirodi koja vječno cvijeta“"(ibid.: 3). Dakle pesimizam u različitim formama i intenzitetima postaje glavna odlika.

Nije li Baudelaire vidio stvari jasnije kad je neku vrstu melankolije smatrao neizbježnim proizvodom podjele između naših potreba kao civiliziranih bića i realnosti vanjskih uzroka i uvjeta? Dokaz da je to bilo upravo tako, od jednoga kraja Europe pa sve do drugoga, jest činjenica da suvremeno društvo, neovisno o naciji, pokazuje iste simptome melankolije i disharmonije. Univerzalna mučnina izazvana neadekvatnostima svijeta utječe na srca Slavena, Nijemaca i Latina. Kod prvih preuzima oblik nihilizma, kod drugih pesimizma te kod nas samih simptome osamljene i neubrojive neuroze. Ne dijele li ubilački bijes urotnika u Sankt Peterburgu, Schopenhauerova djela, gnjevni požari Komune i mizantropija naturalističkih romanopisaca (...) isti negativan stav prema životu koji svakim danom baca sve više mraka na zapadnu civilizaciju? (Bourget, 1920: 13)

\subsection{Kratak pregled povijesti jedne ideje}

\subsubsection{Stari strahovi u novom ruhu}

Budući da je dekadencija kao općenit pojam svoj diskurzivni put imala u zapisima mnogobrojnih autora, povjesničara, povjesničara kulture i književnosti, sociologa i filozofa, ovo je poglavlje malen prinos njezinu razumijevanju kroz pokušaj sistematizacije toga temeljnog pojma našega rada i nekih pojavnih oblika koji su mu inherentni. Ono nam omogućuje bolje zahvaćanje njezina smisla te shvaćanje razloga i motivacije intenziviranja baš za fin de sièclea.

Nastala iz srednjovjekovne latinske riječi decadentia, tj. od latinske cadere (pasti), potječe iz društvene i kulturne povijesti u kojoj je označavala slom, propadanje i/ili urušavanje nekoga političkog ili društvenog sustava, propast vrijednosti, postupan gubitak stvaralačke energije. Dekadencija je po svojoj definiciji vrijeme promjene, u najširem smislu opća ideja zasnovana na uvjerenju o propasti civilizacija, čovječanstva, svijeta uopće, a tumačenju joj je najčešće inherentan biološki predznak. U okviru modela organicizma opisuje se kroz metaforu organizma i njegova životnoga ciklusa te se pritom kao najvažnija izdvaja teza da životni ciklus svakoga organizma uključuje neminovnu sukcesiju: rođenje, odrastanje, dekadenciju i smrt. 
Sve što postoji po sili prirodnoga zakona jednom mora završiti. Upravo na toj biološkoj analogiji počiva opći koncept dekadencije.

Iako se naše zanimanje za dekadenciju pozicionira primarno u drugu polovicu XIX. stoljeća, vrijedi se osvrnuti i na „stari“ pojam, koji je rezultirao devetnaestostoljetnim shvaćanjem i kulminacijom dekadencije kao povijesno-estetske kategorije. Dekadencija nije mimezis nekoga povijesnog trenutka, nego čovjekova refleksija o njemu; nije objektivna povijesna činjenica, nego epistemološko sredstvo koje uočava fazu propasti u odnosu na prethodne epohe. Kako Herman procjenjuje, ideja propasti u zapadnoj civilizaciji, tijesno povezana s kulturnim pesimizmom, o kojem će još biti riječi, mračna je strana misli XIX. stoljeća te najutjecajnija tema u politici i kulturi XX. stoljeća (1997: 7). S obzirom na to da povijest pojma dekadencije seže daleko u prošlost - tragove mu nalazimo gotovo posvuda $u$ povijesti zapadne misli - prilično je jednostavno zaključiti da ta ideja nije nastala u XIX. stoljeću te da dojam življenja u vremenu društvenoga i kulturnoga raspada nipošto nije izvorno devetnaestostoljetni. Usto povijesna priča o progresu gotovo je uvijek u društvenopovijesnim analizama popraćena pričom o nazadovanju ili propasti: pojam zlatnoga doba nakon kojega slijedi doba regresije ili propasti te destruktivna snaga vremena prisutni su u gotovo svim kulturama.

Mit o dekadenciji poznavali su gotovo svi stari narodi u ovom ili onom obliku. Rušilačka moć vremena i sudbina propasti među glavnim su motivima svih velikih mitsko-religijskih tradicija od indijskog shvaćanja vladavine božice Kâlî, do zastrašujućih vizija izopačenosti i grijeha koje nagovještavahu židovski proroci (...). (Calinescu, 1988: 145)

Dakle koncept dekadencije kao univerzalni princip rasapa susreće se već u ranim civilizacijama, gdje je on doista funkcionirao poput mita, gotovo deluzije koja se proširila među ljudima jer su se bojali zala za koja su vjerovali da vladaju svijetom. Sve su stare kozmologije zdravo za gotovo uzimale činjenicu da žive u nepovoljnijem vremenu u odnosu na prošlost, a sadašnjost se ocjenjivala posve beznačajnom u odnosu na prethodna razdoblja. No shvatiti modernu, findesiècleovsku dekadenciju nemoguće je bez poznavanja judeo-kršćanske tradicije, slaže se kritika. Ona se u toj tradiciji, unutar vitalnoga koncepta milenijalizma, tj. vjerovanja u tisućgodišnje carstvo, u posljednji dan nakon kojega slijedi vječna radost za jedne, odnosno paklene muke za druge, doživljavala kao duboka iskvarenost i moralna izopačenost. Dekadencija na taj način postaje najava propasti svijeta, a novost joj je u kršćanskom 
razumijevanju dramatična svijest o vremenu, odnosno „oštar i grozničav osjećaj urgentnosti“"(ibid.: 147).

Počevši od Hezioda, koji je tumačio kako je svemir podložan procesu raspada, i Platona, čije je stajalište da povijest i društvo nisu ništa drugo nego kontinuirano propadanje prilično blisko našoj ideji dekadencije, ${ }^{7}$ preko sumnje u mogućnost preživljavanja svijeta dominantne u europskoj misli od pada Rimskoga Carstva do renesanse, do Rousseaua, koji je držao da je dekadencija rezultat protivljenja prirodnim zakonima te tvrdio da je sve proizašlo iz čovjekove ruke kvarno i podložno degeneraciji, različite se varijante povijesnoga i filozofskoga pesimizma mogu detektirati u svim epohama zapadne civilizacije. ${ }^{8}$ Premda bi se moglo prigovoriti da su „moderne forme koje je smisao dekadencije poprimio u XIX. stoljeću često bile tek nove varijacije nekih osnovnih stavova i vjerovanja koji se mogu pronaći već u antičkoj i srednjovjekovnoj književnosti““ (Swart, 1964: xi), neosporno je da se od XIX. stoljeća prvi put sustavno javlja vizija konačnoga i potpunoga kraja čovjeka (Friedländer, 1985: 61). Naravno, s obzirom na dugu povijest pojma, podrazumijeva se da se kulturni i filozofski koncept dekadencije ne zaustavlja na početku XX. stoljeća. Baš naprotiv, neka od najutjecajnijih djela s tim konceptom u središtu tek će nastati, poput Spenglerova i Toynbeejeva.

U naracijama o propastima civilizacija najživlje su bile usporedbe s padom Rimskoga Carstva. One najbolje svjedoče o širokom semantičkom polju ovoga pojma, u kojem ponajprije označuju postupno urušavanje nekoga političkog i društvenog poretka. Pad toga najvećeg carstva stoljećima je bio izvor mnogobrojnim refleksijama o propasti općenito i njezinim mogućim uzrocima. U pričama o padu pojam se transformirao iz područja narušenih moralnih i intelektualnih vrijednosti u područje širih društvenih i političkih promjena. Kao najrazvidniji se simptom političke regresije apostrofirao društveni nazadak koji se identificirao s korumpiranošću državnika i sklonošću ekscesivnom hedonizmu, a ova prva dva smisla dekadencije u deskripciji pada vodila su do trećega, estetske inferiornosti. Naime sva su se umjetnička i književna djela nastala za procesa propadanja ocjenjivala neuspjelima u odnosu na ona iz prethodnih razdoblja. Imajući na umu sve navedeno, mnogi su autori, pa i prije XIX. stoljeća (među njima su svakako najzvučnija imena Montesquieu i Gibbon), analizom političkih, društvenih i moralnih uzroka koji su doveli do propasti Carstva nastojali odgonetnuti kako njihovo društvo može izbjeći takvu ili sličnu sudbinu, a nerijetko su na kasnije koncepcije dekadencije utjecale spoznaje o moralnoj iskvarenosti rimskoga društva. Tako je u dugom nizu

\footnotetext{
${ }^{7}$ Moroni upozorava da već Platonova teorija ideja, prema kojoj je sve podložno nekim oblicima propasti, tj. pokvarenosti vremena i promjeni, implicira „metafizički koncept dekadencije (ili degeneracije)“ (2004: 66).

${ }^{8} \mathrm{Za}$ informativniji povijesni pregled pojma posebno usp. Swart (1964).
} 
godina Rimsko Carstvo „ostalo paradigma dekadencije te istovremeno uzorak za neraskidiv spoj dekadencije i obnove“ (Weir, 2018: 2).

Iako je teško odrediti kad je pojam evoluirao u značenju, može se definitivno istaknuti da grozničav dojam hitnosti, akutan predosjećaj kraja jednoga vremena, koji se poistovjećivao s urušavanjem svih vrsta vrijednosti, nikad nije bio tako snažno izražen kao na prijelazu XIX. u XX. stoljeće. Koncept dekadencije svoju kulminaciju doživljava upravo u posljednjim desetljećima stoljeća, o kojima se često govori kao o izgubljenim godinama (Fletcher, 1979), u kojima su se generacije suočile s jasnim znakovima „duboke tjeskobe, sviješću o slabosti, strepnjom zbog dekadencije, opsesijom propašću“ (Nye, 1984: 140). Nikad prije umjetnici nisu bili toliko opsjednuti manifestacijama propadanja i nazadovanja iz kojih su, paradoksalno, izvlačili obilje kreativne energije. Iako smo već upozorili da pesimizam kao beznadnost u mogućnost iskupljenja ovoga svijeta dominira zapadnoeuropskom misli od pada Rimskoga Carstva do renesanse, treba naglasiti da nijedno razdoblje nije imalo reputaciju pesimističnoga kao fin de siècle.

Životna bol postala je autonomno, endemsko depresivno stanje koje je pogađalo pojedince neovisno o kulturnom ili društveno-političkom kontekstu, od carske Rusije do Amerike, prelazeći preko viktorijanske Engleske i imperijalne Francuske. Nije više bila riječ o „bolesti stoljeća“, o nemirima mladih koji se dosađuju i inspiriraju životnom mahnitošću, nego o bolesti moderniteta, jačoj i persistentnijoj. (Minois, 2005: 225)

Mišljenje da je Europa „stari svijet“ postalo je gotovo opće mjesto u kulturi druge polovice XIX. stoljeća. Budući da se čovjek suočio s činjenicom da je epoha dinamičnoga rasta prošla, ,,počelo se sumnjati čak i u dotad neospornu moć i utjecaj Europe diljem svijeta; jedino što je u budućnosti preostalo jest zrelost koja je polagano klizila u pretjeranu zrelost $\mathrm{i}$ raspad“ (Herman, 1997: 44). Pod pritiskom povijesnih iskustava i suvremene zbilje dekadencija se nametnula kao neizbježna forma umirućega društva u vremenu oslabljene pozitivističke sheme. Osjećaj onemoćalosti u kombinaciji sa zamorom i degeneracijom prepoznaje se kao conditio humana modernističkoga razdoblja. 


\subsubsection{Dekadencija i modernitet}

Možda više od tih konstatacija intrigira činjenica da priča o regresiji ide ruku pod ruku s pričom o progresu. XIX. je stoljeće epoha kompletnoga civilizacijskog razvoja (industrija, tehnologija, gospodarstvo, građansko društvo). Vrijeme od 1848. do 1875, kad su već uspostavljeni društveno-gospodarski procesi doživljavali svoje stabilizacije ili klimakse, doba je ,velikog napredovanja svjetske privrede industrijskog kapitalizma, društvenog poretka koji ona donosi, te ideja i vjerovanja koja odobravaju i ozakonjuju taj poredak, tj. vjerovanja u razum, znanost, napredak i liberalizam“ (Hobsbawm, 1989: 10). Prema Le Rideru modernitet je „način života, mišljenja i stvaranja koji se ne boji promjene i inovacije te posjeduje kritičku svijest o modernizaciji“ (1993: 27), a karakterizira ga znanstveni i tehnološki napredak koji rezultira krupnim društvenim promjenama, nestankom određenih kulturnih tradicija, ekonomskim rastom i porastom stanovništva, urbanizacijom i novim modelima komunikacije. No visok se stupanj civilizacijskoga razvoja, kako primjećujemo, odlično slagao s ozbiljnim osjećajem dekadencije jer se na rezultate napretka reagiralo otuđenjem i gubitkom. Ono što se smatralo pozitivnim učincima progresa bio je znak posljednjih sati čovječanstva, a civilizacijski je napredak postao okidač za sociološke i psihološke patologije. Prekretni politički događaji, brza i intenzivna industrijalizacija, trka za imovinom, migracije, istodobnost bogatstva i siromaštva, luksuza i bijede, privlačnosti buržoaskoga života i oskudice radničke klase te iznad svega moć novca - u čovjeka svjesnoga tih mijena, pritisnutoga razmišljanjima o svrsi postojanja, stvara se dojam da je život u isti mah ugodan i oduran te da ga nije moguće uživati bez gadosti. Uhvaćen u koloplet hektičnih promjena, u kaotičnim uvjetima intenzivne svakidašnjice, pojedinac se počeo pribojavati da će izgubiti kontrolu u svim područjima. Odnosno:

(...) ti u 19. stoljeću razvijeni mehanizmi, ideje i prakse, proizvodeći ubrzano mrežu stabilnih građanskih normi, proizvode i neku čudnu stranost u središtu vlastite intimnosti: ludilo, tjeskobu, siromaštvo, nepravdu, granične identitete i različite psihosomatske oblike bolesti. (Vuković, 2014: 319)

Dakle iskustvo moderniteta kao etape ${ }^{9}$ rađa tjeskobu i otuđenje te se zato on određuje kao prijelazno razdoblje obilježeno ,dvostrukim procesom rasapa i obnove te prema tome i kao

\footnotetext{
${ }^{9}$ Referiramo se na Calinescuovu distinkciju moderniteta kao etape, koju obilježava doktrina napretka, kult razuma i ideal slobode te zaokupljenost mjerljivim vremenom, za razliku od moderniteta kao estetičkoga pojma koji karakterizira sklonost ,radikalnim antiburžoaskim stavovima“ (1988: 48), a iz kojega će se razviti avangarda.
} 
vrijeme sumnje prema ishodima“" (Downes, 2010: 33). Kad govorimo o uzajamnosti napretka i dekadencije, a za potkrepu te konstatacije, valja podsjetiti i na Calinescuovu tezu koja dobro svjedoči o paradoksima fin de sièclea: ,progres je dekadencija, dekadencija je progres“ (1988: 149). S jedne strane anksiozan dojam življenja u posljednjem stupnju civilizacije, s druge pak vjera u dolazak novoga vijeka. Optimističnoj se viziji napretka direktno suprotstavljao osjećaj nesigurnosti i bespomoćnosti, a povjerenje u znanost, koja bi trebala odgovoriti na sva pitanja koja muče suvremenoga čovjeka, koincidiralo je sa slomom filozofskoga i političkoga idealizma. S obzirom na navedeno mogli bismo poentirati da ta dva termina, budući da nikad ne možemo govoriti o njihovim apsolutnim vrijednostima, uvijek valja razmatrati $u$ mnogobrojnim nijansama. Možda je tu nevjerojatnu kombinaciju optimizma i pesimizma ponajbolje opisao Dickens u uvodnim rečenicama svoje Priče o dva grada iz 1859, koje se mogu protegnuti na cijelu drugu polovicu stoljeća: „Bila su to najbolja vremena, bila su to najgora vremena (...), bila je to epoha vjere, bila je to epoha nevjerice (...).“

Dekadencija se u književnosti, primjećuje Gagnier, javlja upravo u onim društvima u kojima je u kontaktu, tj. u sukobu sa silnicama modernizma (2015: 11). Kao etapa u razvoju zapadne civilizacije modernitet je počivao na osjećajima tjeskobe, nelagode i straha te je istodobno nastojao učiniti sve da ih ,izgradnjom složene mreže institucija i regulirajućih praksi“ (Vuković, 2016a: 438) zatomi te tako zadrži relativnu i barem prividnu stabilnost svojih konstitutivnih elemenata. Tu njegovu unutarnju napregnutost i ambivalentnost kroz metaforu juggernauta, ${ }^{10}$ „,motora goleme moći koji, kolektivno kao ljudi, možemo pokretati do određene mjere, ali on prijeti izmicanjem iz naše kontrole i cijepanjem napola“" (1990: 139), izrazio je Giddens na sljedeći način:

Juggernaut slama sve one koji mu se odupiru te se, iako se čini da slijedi uvijek isti put, ponekad pomiče u smjeru koji ne možemo predvidjeti. (...) No sve dok institucije moderniteta ustraju, nikad nećemo biti kadri posve kontrolirati ni smjer ni ritam toga putovanja. To znači da nikad nećemo osjećati potpunu sigurnost jer je teren preko kojega se kreće pun rizika dubokih posljedica. Osjećaji ontološke sigurnosti i egzistencijalne tjeskobe ambivalentno će supostojati. (ibid.)

Ta Giddensova slika golemoga modernističkog stroja sugerira da više nema drugih, onih koji bi bili izuzeti iz njegova djelokruga te, dok zahtijeva aktivno sudjelovanje, proizvodi

\footnotetext{
10 Tom je metaforom Giddens zamijenio dvije konstrukcije moderniteta prisutne u sociološkoj literaturi: Weberovu, prema kojoj snažne veze racionalizma zarobljavaju čovjeka u birokratskoj rutini, i Marxovu, u kojoj se modernitet odnosno kapitalizam eo ipso doživljava kao čudovište (1990: 138-139).
} 
ontološki strah zbog mogućega gubitka kontrole u svim područjima. Dekadencija zato, prema viđenju tendencioznih kritičara, i jest opasna - omogućili su je modernizacijski procesi protiv kojih se zatim okrenula. Modernitet se urušava sam u sebe. Tu njegovu imploziju problematizirao je i Pick, sumirajući problem degeneracije u XIX. stoljeću na sljedeći način: ,je li se degeneracija odvojila od povijesti napretka (kodirana kao 'regresija', 'atavizam' ili 'primitivizam') ili je samo otkrila grad, napredak, civilizaciju i modernitet, paradoksalno, upravo kao čimbenike propasti““(1989: 106).

Kako pak pobliže opisuje Jervis, kultura postaje moderna onoga trenutka kad shvati na koji način njezini procesi interveniraju u svijet (2015: 59). Modernitet se stoga nadaje kao inherentno refleksivan, a ta se svijest za fin de sièclea okreće prema njemu samom, „stvarajući rastući osjećaj krize“ (ibid.). Samopropitivanje prijeti destruiranjem vlastitih temelja.

\subsection{Nov osjećaj krize}

\subsubsection{Devetnaestostoljetna francuska dekadencija}

Već smo spomenuli kako je umjetničke tendencije nemoguće razumjeti i tumačiti bez poznavanja političkih, gospodarskih, kulturnih i društvenih trendova, „osjećaja opće ekonomske i, posljedično, društvene slabosti“ (Hobsbawm, 1987: 35). Zato kao jedan od ključnih faktora intenziviranja dekadentnoga senzibiliteta u XIX. stoljeću prepoznajemo one političke. Naime veliki su povijesni događaji u europskim zemljama proizveli osjećaj krize i tjeskobe, a razočaranost razvojem „velikih“ događaja i slom političkih iluzija prigodno su se poklopili s uvjerenjem o kraju civilizacije.

Kao kraće razmatranje stanja „na terenu“ iznijet ćemo osnovne crte situacije u Francuskoj, paradigmatskoga primjera za razumijevanje koncepta dekadencije u jednoj europskoj zemlji. Francuska se naime s razlogom smatra ishodištem dekadentnoga osjećanja. Premda se tamošnje političko stanje, pa tako ni duhovnost, ne mogu preslikati na ono u Hrvatskoj, taj nam uvid služi kao širi pogled na povijesne pesimizme u drugim zemljama te pomaže u stjecanju dojma o razvoju i rasprostranjenosti dekadentne senzibilnosti, koju su baštinili i pripadnici hrvatske intelektualne i kulturne elite.

Nije nebitna činjenica da je baš Rimsko Carstvo, procjenjuje Weir, imalo veliko značenje za Francuze (2018: 23). Nemali broj povjesničara smatra da su tvorci Francuske revolucije imali pred sobom republikanski Rim kao primjer vladavine te da je Francuska u samo 
dvama desetljećima - Prvoj Republici i Napoleonovoj vladavini (1792-1815) - prošla ono što i Rim u nekoliko stoljeća. ${ }^{11}$ Kako detaljno iznosi Swart (1964), snažniji se zamah pesimističnih preokupacija u svim područjima ljudske djelatnosti ondje može detektirati nakon revolucionarnih zbivanja 1848, kad se stvorio nov, urgentniji osjećaj krize s dominantnim vjerovanjem da civilizacija srlja u propast. ${ }^{12}$ No pesimizam se ipak najjače očitovao nakon korjenitih političkih, gospodarskih i društvenih promjena oko polovice XIX. stoljeća te u razdoblju fin de sièclea, za „vrtoglavih godina“, da se poslužimo Blomovim riječima, kad zemlja gubi vjeru u vlastitu grandioznost i nekadašnji međunarodni ugled. Nisu ga motivirali samo ekonomski i politički potresi nego i vojni porazi te drugi nepovoljni događaji ponajprije vezani za odnose s neprijateljskim zemljama. Dakle pod utjecajem triju odlučujućih događaja s kraja XVIII. i u XIX. stoljeću - Francuske revolucije, industrijske revolucije te opadanja državne moći i autoriteta - ideja kulturne dekadencije i nacionalne degeneracije nezaustavljivo se širila. Središte svijeta premjestilo se drugdje, a Francuska je postala „nacijom koju progone sablasti poraza, gubitka teritorija, propasti i dekadencije pod prijetnjom fizičkog izumiranja“(Blom, 2015: 26). Ili, kao što sažima Pynsent:

Prema Mussetu politički i vojni poraz, giljotiniranje Luja XVI, Napoleonova abdikacija i progon na Elbu te pad apsolutizma i carstva bili su pokretači toga svjetskog umora, nihilističkoga skepticizma i potencijalno destruktivnoga solipsizma koji tvore dekadentno odbacivanje pojma napretka i dostignuća civilizacije. (1989: 117)

Prema tome različiti fenomeni dekadencije svoj vrhunac doživljavaju upravo $\mathrm{u}$ Francuskoj. Nordau procjenjuje da se nakon uspjeha Francuske revolucije, koja je pojedinca uvjerila u primat francuske nacije, urušilo povjerenje u tradicionalne vrijednosti, a osjećaj tjeskobnoga razočaranja rezultirao je živčanim poremećajima i problematičnim duševnim stanjima u XIX. stoljeću. Stoga je sasvim jasno zbog čega su se baš tamo „pojavile najluđe tendencije u umjetnosti i književnosti“: ondje se naime „morbidna iscrpljenost po prvi put jasno

\footnotetext{
${ }^{11}$ Thomas Couture 1847. u Parizu izlaže svoju veliku kompoziciju Rimljani u doba dekadencije, u kojoj prikazuje orgije u grandioznoj palači. Dok hedonistički uživaju u tjelesnosti, njihova lica otkrivaju dosadu, duhovnu i moralnu prazninu. Povjesničarima umjetnosti nije dugo trebalo da na platnu uoče Francusku u aktualnom dobu dekadencije.

${ }^{12}$ Gottfried drži da se to pesimistično nepovjerenje u Njemačkoj afirmiralo kao izravna posljedica deziluzija nakon revolucija 1848. i 1849. Postojala je naime neka tajna veza između propasti europske liberalne misli i difuzije pesimizma u drugoj polovici stoljeća. „Propasti revolucija ostavile su mnoge Nijemce politički frustrirane. (...) Štoviše, francuski kapitalisti preplašeni radničkim pobunama u lipnju 1848. pomogli su da pesimizam stekne 'međunarodni ugled'." (Gottfried, 1973: 193)
} 
predstavlja, dopuštajući da se upravo za nju stvori novi koncept, koncept fin de sièclea“"(Nordau, 1895: 43). Osjećaj dekadencije koji se ondje očitovao imao je dvostruk razvoj koji se ni u jednoj drugoj zemlji nije prezentirao istovremeno u istom stupnju: „propadanje nacionalne moći i kompleksni problemi proizašli iz demokratskoga i ekonomski snažno razvijenoga društva“" (Swart, 1964: 254).

Dobro je poznato da je Francuska revolucija bila prijeloman događaj ne samo u povijesti te zemlje nego i izvan Europe. U drugim se zemljama od prvotnoga oduševljenja došlo do uvjerenja kako Francuska postaje prava „europska noćna mora“ (ibid.: 217), a očaj i strah sve su snažniji među intelektualcima oko sredine XIX. stoljeća. Nemali je broj mahom konzervativnih povjesničara, kako tumači Swart, njegovao fatalistički pesimizam, smatrajući da je revolucionarni duh utjecao na cjelovitost političkoga tijela, te podupro sebične interese i mentalitete koji bi se mogli označiti kao individualistički, anarhistički ili atomistički. No u drugoj polovici stoljeća to raspoloženje slabi, a intelektualci postaju svjesni da pravi problem ne predstavlja samo politička (ne)jednakost i sloboda nego i nezaustavljiv proces industrijalizacije s nemjerljivim reperkusijama na gospodarski razvoj zemlje.

Uza sve to Francuska je za koncept dekadencije vrijedna i zbog još jedne činjenice: upravo se ondje on prepleo s idejom moderniteta kao kompleksom društvenih, gospodarskih i tehnoloških promjena, dobivši priliku kulturnoga potvrđivanja u pravoj estetici dekadencije, koja je u tamošnjoj književnosti najpoznatija kao décadisme ili décadentisme, a koju ovom prilikom iznosimo tek u kraćim crtama. ${ }^{13}$ Dok Verlaine 1883. u časopisu Le chat noir sonetom Slabost, u kojem manifestno izjavljuje „Ja sam Carstvo na kraju dekadencije“, najavljuje dekadentizam kao književni pokret, Huysmans 1884. objavljuje Protiv struje, roman koji se zahvaljujući živopisnomu portretu protagonista Jeana des Esseintesa unisono određuje kao „summa dekadencije, enciklopedija dekadentnog ukusa i idiosinkrazija“ (Calinescu, 1988: 163) te vrhunac njezine estetizacije. Koju godinu poslije, pokretanjem časopisa Le Décadent (1886), dekadencija u Francuskoj postaje pomodna tema, gotovo poza, te utire put simbolizmu. Međutim i prije toga korijeni su se dekadencije učvrstili u pojedinim djelima Baudelairea, braće

\footnotetext{
${ }^{13} \mathrm{Ne}$ bi li potvrdio kako je svijest o propadanju u većoj ili manjoj mjeri razdirala gotovo svaku književnost, Morazé, govoreći o Francuskoj, podsjeća na veliko zanimanje za Schopenhauerovu filozofiju od 1880-ih, na trijumfalno uvođenje ruskoga romana te na činjenicu da je i impresionističko slikarstvo veliku pozornost posvetilo ,promjenljivom aspektu stvari, njihovu stanju gibanja i prolaženja, i u svakom živom biću vidjelo samo susljedni niz stanjâ, promjenjivu igru njegove pojavnosti“ (1976: 184). Takva je atmosfera, sasvim je jasno, pridonijela produbljenju ionako poljuljane vjere u izvjesnost kozmosa i stabilnost društveno-političkih sustava: „,Stjecaj tih različitih strujanja pridonio je stvaranju atmosfere 'fin de sièclea' sugerirajući teme i načine izražavanja simbolističkoj i dekadentnoj književnosti, koja je, u nekim svojim aspektima, predstavljala obnovu romantizma.“"(ibid.: 184-185)
} 
Goncourt, de Maupassanta i Flauberta, ${ }^{14}$ u njihovu inzistiranju na bolećivim temama, autonomiji umjetnosti, gađenju prema buržoaskom utilitarizmu i filistarstvu, fascinaciji umjetnim, morbidnim i perverznim te u potrazi za doživljajima koji bi otklonili osjećaj prazne dosade. Odnosno, kako kritika uglavnom jednoglasno ocjenjuje, dekadenti i simbolisti otvoreno su polemizirali s

pozitivizmom, racionalizmom, materijalizmom, vjerom u napredak i vrednote buržoaskoga konformizma, odbacujući opise prirode u korist estetske artificijelnosti, indulgencije u carstvu osjetila, imaginacije i individualnoga iskustva. Ako su se na jednoj strani kao rezultat svega navedenog našli ljepota i sebstvo, na drugoj su pak bili izrazi dubokoga pesimizma te usmjerenost na slike propasti i nazadovanja, odnosno na društvo u procesu pada (Nissen i Härmänmaa, 2014: 4).

\subsubsection{Bourgetov „stil dekadencije“}

Uzimajući dosad navedene činjenice u obzir, napose francuski društveni i umjetnički kontekst, ne čudi što su napetosti i tjeskobe koje su mučile devetnaestostoljetnoga čovjeka rezultirale definicijom dekadencije Paula Bourgeta - nije slučajno da je iznosi baš nakon poraza u Francusko-pruskom ratu, proglašenja Treće Republike i osnivanja pariške Komune - koja je poslužila kao ishodišna točka možda najpoznatije, Nietzscheove.

Bourget je prvi odlučno usvojio i termin i činjenicu dekadencije u svojim Esejima $o$ suvremenoj psihologiji (1883) te ih razradio „u zreloj, filozofijskoj i estetičkoj teoriji dekadencije kao stila“ (Calinescu, 1988: 161). Dekadencija za njega ima dvostruko značenje: odnosi se i na društvo i na književnost. U zaključnim stranicama rada o Baudelaireu naslovljenima Teorija dekadencije opisao ju je, uz metaforu društva kao živoga organizma, kao suvremeno stanje društva u kojem neovisni pojedinci ne pridonose njegovim naporima i općoj energiji te tako vode društvenoj anarhiji (Bourget, 1920: 19-20). U analogiji s tom tezom komentirao je i dekadenciju u književnosti, objasnivši da se sličan zakon može primijeniti i na jezik: postajući neovisnima, manji elementi dezintegriraju cjelinu.

\footnotetext{
${ }^{14}$ Flaubert i Baudelaire stoje „kao dvije glave dvostruke Hermesove biste na raskršću, čvrsto usađene usred stoljeća, koja označava granicu između romantizma i dekadencije, između razdoblja kobnog junaka i razdoblja kobne žene, između doba Delacroixa i doba Moreaua“ (ibid.: 162). Baudelaire koji, inaugurirajući „nov drhtaj“, na scenu izvlači teme neobičnoga, jezivoga, morbidnoga, upakirane u celofan psihološke tematike, i Flaubert koji Gospođom Bovary i Sentimentalnim odgojem predstavlja dekadentne likove koji upravo uzorno propadaju u turobnoj realnosti.
} 
Stil je dekadencije onaj u kojem se rastače jedinstvenost knjige da bi se zamijenila neovisnošću stranice, stranica se pak rastače da bi ustupila mjesto neovisnosti rečenice, a rečenica da bi svoje mjesto ustupila riječi. (ibid.: 20)

Književni i kulturni povjesničari suglasni su da je termin style de décadence Bourget preuzeo od Désiréa Nisarda, koji čak nekoliko desetljeća prije u opsežnom pregledu Studije običaja i kritike latinskih pjesnika dekadencije (1834), izjavljujući da je bizarna dekadencija moderne književnosti romantizma odraz dekadencije društvenih i moralnih vrednota $u$ suvremenom društvu, govori o „stilu dekadencije“ te važnosti detalja nauštrb cjeline i imaginativne moći nasuprot razumu (Calinescu, 1988: 154; usp. i Herman, 1997: 43). Tu Nisardovu ideju spojio je zatim s idejom dekadencije Théophilea Gautiera, koju smo spomenuli na početku ovoga rada, iskoristivši pritom ponajprije Gautierovu konstataciju kako je stil dekadencije neophodan za opisivanje egzistencije u društvu u procesu regresije (Weir, 2018: 44). Tako je Bourget u specifičnom pozitivističkom pristupu napravio razliku između homogenih, organskih, i dekadentnih, individualističkih, društava koja odlikuje opiranje svakomu tradicionalizmu, odnosno slabljenje funkcionalnih veza među elementima socijalnih struktura. Drugim riječima, dekadentna senzibilnost izgrađena na tjelesnoj i živčanoj malaksalosti proizvodi disharmonično stanje u kojem je naglasak na detalju, trenutku. Znakovito je što on pritom, suprotno uobičajenim kritikama dekadencije kao estetski i kulturno inferiornoga razdoblja, iz „psihološkoga“ gledišta neutralizira njezino dotadašnje negativno ocjenjivanje te je kvalificira kao svojevrstan privilegij:

Ako su građani neke dekadencije inferiorni kao radnici u odnosu na veličinu neke zemlje, nisu li kao umjetnici superiorniji u odnosu na unutrašnjost vlastite duše? Ako nisu prikladni za privatno ili javno djelovanje, jesu li možda previše prikladni za samotnjačko mišljenje? Ako su loši u reproduciranju budućih naraštaja, nije li to možda zato što su obilja rafiniranih doživljaja i izvrsnost rijetkih osjećaja, užitaka i boli od njih učinili virtuoze, jalove, ali profinjene? (Bourget, 1920: 21-22)

Bourget dakle ostavlja mogućnost da dekadencija pozitivno djeluje na razvoj književnosti te među prvima spaja patologiju dekadencije s visokim umjetničkim postignućima, što je pak otvorilo mogućnost da se dekadentni umjetnik smatra nekom vrstom žrtve, figure koja djeluje za umjetnost (Burrow, 2000: 184). Na taj je način, uspostavivši analogiju između evolucije društva prema individualizmu i individualističkih jezičnih izričaja karakterističnih za 
stil dekadencije, nadišao raskorak između općenitoga razumijevanja dekadencije i njezina estetičkoga modela „kao oblika radikalnog antitradicionalizma“ (Calinescu, 1988: 169) te postavio individualizam kao referentnu točku svake definicije dekadencije.

\subsection{Nihilizam, bolest moderne civilizacije}

Sintagmu „stil dekadencije“ preuzeo je zatim Nietzsche te kreirao možda najpoznatiju teoriju dekadencije, koju je izravno povezao s nihilizmom, modernitetom i stanjem suvremene civilizacije. Kako je sam priznao, ništa ga nije okupiralo više od te teme ${ }^{15}$ te joj je, svjestan njezine dominacije u europskom duhovnom prostoru, pokušao dati filozofsku dijagnozu. Odbacio je općeprihvaćenu ideju dekadencije kao kolapsa i propasti Rimskoga Carstva te je „pomaknuo iz krajnje marginalnosti u ambivalentnu istaknutost u modernitetu“ (Downes, 2010: 5). Za njega su naime opisi „dekadentan“ i „moderan“ vrlo često sinonimi. Zato i primjećuje da „ništa nije modernije od te sveukupne oboljelosti, od te kasnoće i prenadraženosti nervozne mašinerije“ (Nietzsche, 2006: 510). Iako se refleksije o nihilizmu i dekadenciji mogu pronaći u njegovu kompletnom opusu, Nietzsche se tim dvjema temama najsustavnije i najizričitije bavio u Slučaju Wagner (1888) i Volji za moć (1901). Njegova se teorija nihilizma, u kojoj pokazuje kako pojedinac pod utjecajem kulture postupno gubi svoj individualizam u metafizičkom i etičkom poretku te time i volju za moć, pritom postavlja kao „'zaglavni kamen’ u arhitekturi kulturnoga pesimizma“ (Tafra, 2008: 63).

Prema Nietzscheu nihilizam je glavna dijagnoza suvremene civilizacije: rastakanje i nestanak tradicionalnih uporišta, stanje lišeno svrhovitosti i odgovora na pitanje „Zašto“, konačna spoznaja „da se bivanjem postiže ništa, dopire do ništa“ (2006: 17). To raspadanje, odnosno obezvređivanje vrijednosti dio je cjelokupne povijesti Zapada, koja se dakle treba tumačiti u smislu nihilizma, tj. dekadencije. Posve sažeto, povijest europske misli povijest je dekadencije. A nihilizam je termin kojim označava duhovnu situaciju modernoga čovjeka, „disolutivno kretanje kojim se skončava više negoli dvijetisućegodišnja vladavina metafizike, apsolutne istine, autoritarne objave sveukupna smisla življenja“ (Kopić, 2001: 12-13). On je rezultat dugogodišnjega, tipično europskoga opadanja volje za moć, a za taj su fenomen

\footnotetext{
${ }^{15}$ Nietzsche je nedvojbeno iskusio ono što je tako kategorički odbacivao. I sam priznaje da je ,dijete ovoga vremena, što će reći décadent: samo što sam ja to shvatio, i što sam se tomu opirao. Opirao se u meni filozof" (2006: 501). Uz to manifestno priznanje, za njegovu poziciju nipošto nije nevažna činjenica da i on živi „životnu bol““. Pa tako primjerice 1883. piše Franzu Overbecku: „Ne zanima me više baš ništa. U intimi moga bića crna i nepromjenjiva melankolija (...). Najgore je pak što ne mogu nikako razumjeti zašto nastaviti dalje živjeti. (...) Sve mi se čini neugodno, bolno, odurno."(cit. prema Minois, 2005: 244; isticanje naše)
} 
odgovorni veliki metafizički sustavi koji su se oslanjali na idealizirani svijet, nastojeći izbjeći sve ono ljudsko, tjelesno, strastveno, agonalno - jednom riječju, dionizijsko. Najveći neprijatelj takva pogleda bila je metafizika, odnosno kršćanstvo koje je pojedincu propisivalo pravila o ponašanju da bi zaslužio vječni život, čime se u njemu slabilo ono pojedinačno, pa i volja za vlastitim progresom. U svijesti europskoga čovjeka, koji se pokazivao rastrgan između idejno postavljenoga svijeta i konkretnoga, realnoga svijeta svakidašnjice, sve se više otkrivao nihilizam - bezvoljnost za životom u takvom svijetu. „Vidimo da ne dopiremo do sfere u kojoj smo pohranili svoje vrijednosti - time pak ona druga sfera, u kojoj živimo, još nipošto nije dobila na vrijednosti: naprotiv, umorni smo, jer smo izgubili glavni poticaj.“ (Nietzsche, 2006: 16)

Slabljenje pojedinca i njegovih vitalnih snaga rezultat je višestoljetnoga inzistiranja na dominaciji objektivne istine pod koju je potpadao svaki individualitet. Čovjek je postao svojevrsna životinja „stada“ kojoj je ugodnije prepustiti se kolektivnim identitetima nego izgraditi vlastitu autentičnost. Velike filozofske i znanstvene paradigme bile su postavljene tako da je svijest pojedinca bila usmjerena općenitosti i objektivnosti koje nisu polazile od konkretnoga životnog svijeta. Zato su sve vrijednosti koje su pojedincu izvana dane konzekventno završile u nihilizmu kao ništenju objektivnoga svijeta kojemu se ne nazire smisao. Kako piše:

Nihilizam će kao psihološko stanje morati nastupiti, prvo, ako smo u svekolikom zbivanju tražili neki „smisao“ koji nije u njemu: tako da tražilac na kraju gubi hrabrost. Nihilizam je tu osvješćivanje o dugom rasipanju snage, muka s onoga „uzalud“, nesigurnost, manjak prigode da ćemo se igdje oporaviti, igdje zbog toga još smiriti - sram pred samima sobom, kao da smo se odviše dugo zavaravali... (ibid.: 17)

Pokušaj povijesnih sustava koji su se metafizički uspostavljali, pokazuje Nietzsche, bio je pokušaj uspostave jednoga nad-realnog svijeta kojega nema, no koji je imao snažnu očaravajuću moć. Umjesto svijeta koji jest stvaran, metafizika je nudila transcendentnu realnost koja se odmiče od konkretnoga čovjeka, udaljavajući ga i od njegovih ljudskih obilježja, tjelesnosti, požuda, strasti, volje, tj. od svega onoga po čemu on i jest čovjek. Razapet između svijeta i transcendencije, europski je duh, posve očekivano, klonuo u nihilizam u kojem se pojedinac predaje vlastitoj slabosti. Zaključivši da su sve tradicionalne vrijednosti koje su davale odgovore na pitanja (Bog, istina i dobro) izgubile svoju valjanost, a tražeći pritom izvore moderne dekadencije još u naukama o dvama svjetovima Platona i Sokrata - idealnoga svijeta 
koji postoji po sebi i osjetilnoga koji se smatra prividom - Nietzsche osuđuje ne samo propadanje ideala koji su inspirirali glavninu zapadne kulture nego i ideale same. Stoga bi se moglo reći da je svojim tumačenjem nihilizma, kojim ga je proglasio ključnim simptomom bolesti moderne civilizacije, a koje nas je i navelo da se na početku poglavlja referiramo na kulturu krize, doista najkonstruktivnije od svih pokušao detektirati u čemu se sastoji duhovna kriza koja je dovela do raspada metafizike (Pejović, 1979: 9-10).

Eksperimentirajući, moderan čovjek vjeruje sad u ovu, sad u onu vrijednost, da bi je potom ostavio da propadne; krug prevladanih i napuštenih vrijednosti sve je veći; sve se više zamjećuje praznina i siromaštvo vrijednosti; to je kretanje nezadrživo - iako postoje silni napori da ga se zaustavi. Na kraju čovjek smjelo upućuje kritiku vrijednosti uopće; prepoznaje im podrijetlo; ima dovoljno spoznaje da ne vjeruje više ni u jednu vrijednost; otud pathos, nov drhaj... To će biti povijest narednih dvaju stoljeća... (Nietzsche, 1971: 266)

Za razumijevanje nihilizma bitno je također istaknuti da za Nietzschea on postaje nužnost kojom se svijet najprije dovodi do vlastita obezvređivanja. Pa je nihilizam i uzrok i posljedica kojima se svijest dovodi do vrhunaca samopreispitivanja, što je, dakako, najizraženije u umjetnosti. $\mathrm{Na}$ taj način razlikuje pasivni nihilizam (bolest), kao propadanje, nazadovanje i slabljenje moći duha, te aktivni (lijek), kao znak povećane moći duha koji pritom figurira i kao oružje protiv svijeta koji je zapao u krizu.

Nihilizam vodi izravno u dekadenciju koja je znak propadanja, ali znak nužnoga propadanja kao ponovnoga postajanja. Budući da je u razumijevanju dekadencije dijametralno suprotan njezinim uvriježenim tumačenjima kao propasti, kraja, svršetka, Nietzsche je i svojom teorijom dekadencije postao referentna točka. ${ }^{16}$ Također je bitno napomenuti da on zamjenjuje pozicije uzroka i posljedice opominjući da nihilizam nije očitovanje dekadencije, nego metafizički razlog njezina pojavljivanja. Zato jednostavno, a efektno formulira: „Nihilizam nije uzrok, nego tek logika décadence.“ (Nietzsche, 2006: 31) ${ }^{17}$ Otišavši u interpretaciji puno dalje od Bourgeta, spoznaje joj destruktivno djelovanje prema kojem slabost postaje primarna zadaća. Filozofija samosažaljenja, umor i egzistencijalna iscrpljenost, gubitak energije, instinktivan strah od života, nesposobnost ili izgubljena vještina za borbu i otpor - to je stanje modernoga čovjeka. Umjesto da jednostavno kaže da on sam više ne vrijedi, dekadent kaže da

\footnotetext{
${ }^{16}$ Uvijek je piše u francuskoj ortografiji, kao décadence.

${ }^{17}$ Ili, kako na drugom mjestu bilježi: „,...) sve što se dosad držalo uzrocima degeneracije njezine su posljedice. (...) Posljedice décadence: grijeh - grešnost; bolest - boležljivost; zločin - kriminalitet; celibat - sterilnost; histerizam - slaboća volje; alkoholizam; pesimizam; anarhizam; libertinage (i duhovnost).“ (Nietzsche, 2006: 30)
} 
ništa više ne vrijedi, pa ni život. Prema tome dekadencija za Nietzschea jest prije svega fenomen volje, koja je, vidjeli smo, odsudna kategorija i u Schopenhauerovoj dijalektici.

Za naš je rad presudna i činjenica da dekadencija za njega nije propast, nego svijest o propasti. Kroz dekadenciju pojedinac na svojoj koži osjeća proturječnosti svijeta te joj izlazi ususret kao lijeku od bolesti propasti. „Otpad, propalost, izmet nije ništa što bi po sebi bilo za osudu: on je nužna konzekvencija života, rasta života. Pojava décadence nužna je koliko i bilo koji ishod i napredovanje života: nije u našim rukama da je uklonimo.“ (ibid.: 29)

Stoga ona nije nešto protiv čega bi se trebalo boriti jer je nužna i svojstvena svakomu dobu i narodu: ona nije uzrok nego posljedica određenoga stanja, nije degeneracija nego njezin simptom koji jasno kazuje da je sazrelo vrijeme za promjene. ${ }^{18}$ Za Nietzschea je najizravniji neprijatelj prevladavanja svijeta kroz dekadenciju pesimizam: budući da zaklon pronalazi u objektivnim, filozofskim, religijskim ili znanstvenim porecima svijeta, on slabi volju i svijest o svijetu. Zato se u Volji za moć bavi i kritikom Schopenhauerova razumijevanja volje. Za njega je naime šopenhauerovski put prevladavanja volje pogrešan: nju ne treba umrtviti jer ona nije metafizička, nego subjektivna, ljudska kategorija. Schopenhauerovo je fundiranje pesimizma na principu odricanja, tj. ne-htijenja, ne-volje, priznanje individualne iscrpljenosti, odnosno ,još uvijek posljedica onog istog ideala koji je stvorio kršćanski teizam“ (ibid.: 20). U tom kontekstu pesimizam razumijeva kao simptom nesposobnosti da se život prihvati dokraja, onakav kakav jest. A pokušaj njegova moralnoga nadvladavanja izraz je slabosti zato što moral, kao dio kolektivističkoga uređenja poretka, iscrpljuje pojedinačnu egzistenciju. Jer „,svaka čisto moralna uspostava vrijednosti (npr. budistička) završava s nihilizmom: valja to očekivati i u Europi““ (ibid.: 21). Nasuprot nadčovjeku koji je, kao autentičan pojedinac, kadar izaći iz začaranoga kruga i prevladati takav svijet, u pesimista iscrpljena volja i zloslutna svijest poručuje „ne činiti ništa“ (ibid.: 32). Slabić kojega Nietzsche ima pred očima trajno je rastrgan između moći i nemoći, aktivnoga i pasivnoga nihilizma, te se nakraju pokazuje kao nesposoban prevladati antagonizme.

I zato je dekadencija, preciznije rečeno, gubitak volje za životom, specifičan oblik razaranja samoga sebe, „osiromašeni život, volja za kraj, velika umornost“ (ibid.: 501). U dekadenciji je slabljenje zadaća, izraz odsustva volje za moć, odnosno težnje pojedinca da se vlastitim snagama odupre instinktu ,stada“. Iscrpljenost životom u kojem se čovjek bori protiv

\footnotetext{
${ }^{18}$ Jer svim je velikim epohama u vremenu rasta svojstveno i ,silno drobljenje i uminuće“ pa se tako, na tragu naše prijašnje konstatacije kako dekadencija ide ruku pod ruku s progresom, može sumirati da ,patnja, simptomi propadanja spadaju $u$ vremena silnog napredovanja; svako je plodno i moćno gibanje čovječanstva istodobno stvorilo i stanovito nihilističko gibanje“ (ibid.: 65).
} 
svoga vremena rezultira pasivnim nihilizmom u kojem opstaje još samo vjera u ništa, a iz takva beskonačna kruga teško može izaći jer ,siromašan životom, slabić, još više osiromašuje život" (ibid.: 34). No kao pitanje volje dekadencija je više od nazadovanja kao takvoga prihvaćanje toga nazadovanja. Dekadentan je onaj, može se reći, koji želi biti slab i jadan. Prema tome razlika se postavlja, kako ćemo vidjeti i u našim primjerima, između stvarne bolesti i odabrane bolećivosti:

Propadanje se prezentira kao samoosuđivanje na propadanje, kao instinktivno izabiranje onoga što mora razarati. Simptomi tog samorazaranja u onih prikraćenih: samovivisekcija, otrovanje, pijanstvo, romantika, prvenstveno pak instinktivna prisila na radnje kojima se moćnike čini smrtnim neprijateljima (- uzgajajući tako reći svoje krvnike), volja za razaranje kao volja nekog još dubljeg instinkta, instinkta samorazaranja, volje u ništa. (ibid.: 40)

Popularizirajući Bourgetovu ideju o dekadenciji kao fiziološkomu raspadanju organizma, raspadu nečega što je svojedobno bilo jedinstveno i koherentno, referira se na Wagnera, prototipa dekadentne moralnosti i stila, modernoga umjetnika par excellence, te pojašnjava:

Pa to, da život više ne stanuje u cjelini. Riječ biva suverena te iskače iz rečenice, rečenica preseže te potamnjuje smisao stranice, stranica zadobiva život nauštrb cjeline - cjelina više nije cjelina. Poredba je to međutim za svaki dekadentni stil: uvijek anarhija atoma, disgregacija volje, „sloboda individuuma“, govoreći moralno, - ,jednaka prava za sve“, proširena do bilo kakve političke teorije. Život, jednaka životnost, vibracija i egzuberancija života stisnuta na najmanje likove, ostatak pak siromašan življenjem. Posvuda osakaćenost, zlopata, ukočenost ili neprijateljstvo i kaos: a oboje upada u oči to više što je veći uspon u više oblike organizacije. Cjelina više uopće ne živi: ona je neki sklepan, sračunat, umjetni artefakt. (ibid.: 514; isticanje naše)

Međutim dok prve zapisane rečenice neodoljivo podsjećaju na Bourgetove, Nietzsche za razliku od njega ne smatra da dekadencija proizvodi nove estetske vrijednosti, nego da ponovo valja zadobiti cjelinu. Uzimajući u obzir taj sud o dekadenciji, koja se i inače ocjenjivala kao inferiorna, neosporan je njegov utjecaj na kasnije tumače. „Sve to baca svjetlo na povijesni kontekst idejâ i iskustava u koji Nietzscheova teorija dekadencije pušta svoje korijene, i pokazuje do koje točke ona o njemu ovisi.“ (Volpi, 2013: 67) 
Dakle u Slučaju Wagner Nietzsche kroz vizuru svoga odnosa s tim skladateljem iznosi vjerojatno svoju najcjelovitiju definiciju dekadencije. Problem dekadencije vidi u odnosu vremena prema Wagnerovoj glazbi, koja s jedne strane utjelovljuje velike epske naracije koje treba napustiti, a s druge pak čistu snagu i uzvišenost koje ga fasciniraju. Moral vremena osiromašuje i slabi, sve do uspostave neke nove snage koja će se uspostaviti kao volja za moć. Zato valja opredijeliti se ,protiv svega što je u meni bolesno, uračunavši tu i Wagnera, uračunavši i Schopenhauera, uračunavši ma svekoliku modernu 'čovječnost'“ (Nietzsche, 2006: 501). Wagner tako postaje metom Nietzscheove kritike - u njega je utkan šopenhauerovski duh patnje i pesimizma. On je prototip dekadentnoga izričaja jer je glazbu učinio bolesnom te se zato i obožavanje Wagnera može držati odrazom europske dekadencije. ${ }^{19}$ Njegov slučaj u toj elaboraciji izvrsno pokazuje već zabilježenu činjenicu da su moderan i dekadentan za Nietzschea sinonimi: „Koliko li Wagner mora biti srodan sveukupnoj europskoj décadence kad ga ona još ne osjeća kao dekadenta! On spada u nju: njezin je protagonist, njezino najveće ime... (...) Jer to što se od njega ne brane već je znak dekadencije.“ (ibid.: 510) Wagnerova je umjetnost, u svom ujedinjenju brutalnoga, umjetnoga i nedužnoga, bolesna. Ona iritira najsuptilnije duhove vremena, pobuđuje osjetilnost do bolesnih razmjera, izazivajući umorne živce. Kako efektno zaključuje:

(...) ona konvulzivnost njegova čuvstva, njegova prenadražena senzibilnost, njegov okus koji je tražio sve oštrije začine, njegova nestalnost koju je preodijevao u načela, nipošto na kraju izbor svojih junaka i junakinja, a promatra ih se kao fiziološke tipove (- kao nekakvu galeriju bolesnika! -): sve to skupa predstavlja sliku bolesti koja ne dopušta nikakve dvojbe. Wagner est une nérvose. (ibid.)

Za njega je on istinski degenerik, nipošto nekakav unesrećeni genij kakvim su ga proglašavali, „tipični décadent, kojemu nedostaje svaka 'slobodna volja'“ (ibid.: 513). I baš zato, bilježi Nietzsche gotovo na Nordauovu tragu, njegova glazba izaziva tipične urbane neuroze, psihičku rastrganost čovjeka. Bolest živaca - bolest umjetnosti:

\footnotetext{
${ }^{19}$ U svojoj kritici njemačkoga duha Nietzsche se često okreće francuskomu jeziku (što smo vidjeli i u korištenju francuske ortografije), koji je za njega izražajniji, avangardniji, hrabriji. Wagneru tako, nimalo slučajno, suprotstavlja Bizeta te navodi: „Ova mi se glazba čini savršenom. Nailazi lahka, gipka, udvorna. Ljubežljiva je, ne znoji.“ (ibid.: 503)
} 
Najneugodnija je izopačenost živaca. Prođite noću kroz kakav veći grad: posvuda je čuti kako se uz svečani bijes siluju glazbala - pa se tu umiješa i kakav divlji urlik. Što se tu zbiva? Mladež se moli Wagneru... (ibid.: 526)

Na stranu sve vrijednosne procjene, Nietzsche je dijagnozom raspada i nehomogenosti cjeline postavio ponajbolju definiciju dekadencije koja izvrsno odgovara našoj tezi o likovima dekadenata, u kojih primjećujemo različite manifestacije dezintegracije ličnosti. Uviđa se da cjelina (kulturna, politička, društvena) ne nosi više nikakav smisao, a još se uvijek ne pronalazi hrabrosti za biti individuom. Uz te konstatacije možda je najvažnija činjenica da od Nietzscheova isticanja nužnosti prevrednovanja tradicionalnih vrijednosti, odnosno stvaranja novih, dekadencija postaje i nešto više od same propasti: ona postaje nužna svijest o toj propasti.

\subsection{Maladie du siècle}

Osvrnemo li se pozornije, primijetit ćemo da XIX. stoljeće već započinje mračnom perspektivom u kojoj se čuju glasovi ideoloških neprijatelja revolucije, romantika koje je ta ista revolucija oduševila i zatim razočarala te onih koji su se pribojavali novoga duha koji se stvarao u početnim desetljećima stoljeća. Nećemo stoga pogriješiti ako postavke na kojima se zasnivala duhovnost na kraju stoljeća stavimo pod zajednički nazivnik maladie du siècle, tj. „bolesti stoljeća“. Neporeciva je činjenica da je tadašnja europska umjetnička produkcija bila opterećena raznovrsnim psihičkim stanjima, koja su se kretala od blagih izraza duševne i fizičke iznemoglosti, preko nespokoja, paralizirajućega straha i ozbiljnijih poremećaja duha, do ekstremnih patoloških stanja. Već smo spomenuli, posljednja su dva desetljeća XIX. stoljeća bila vrijeme prave plime melankolije i tjeskobe koja je, slažu se kritičari, bila krajnji izraz disharmonije svijeta i umjetnika, cjeline i pojedinca, jednom riječju, pesimizma karakterističnoga za romantizam (usp. Pierrot, 1981: 45; Hanson, 1997: 10). Rastuća svijest o tom fundamentalnom nesuglasju između svijeta i čovjeka, koje razvoj civilizacije samo dodatno pogoršava. Ako se čovjek toga doba globalno, neovisno o kulturnom prostoru u kojem je živio i stvarao, tako smiono, nerijetko očajnički, prepuštao sjetnim preokupacijama, razlog je ležao u njegovu nezadovoljstvu realitetom. Dekadencija, kako je mi razumijevamo, počiva na dvjema osnovnim emocijama: na patnji i očaju zbog svijeta i vlastitoga ,ja““ u njemu (von Sydow, 1922: 28). Zato bi se ona bez pogreške mogla obuhvatiti pojmom Weltschmerza, odnosno mal du sièclea. 
To pak priziva romantizam koji je snažno utjecao na rađanje osjećaja findesiècleovske dekadencije. Sjetno i turobno raspoloženje opterećivalo je mnoge osjetljive umove koji su se zgražali nad razvojem političkih i društvenih događaja te se njihovo nezadovoljstvo djelomice može protumačiti kao snažna reakcija na industrijsku i političku revoluciju. Ogorčenost principima vremena bila je izoštrena do krajnjih granica. A nezadovoljstvo je osobito snažno bilo u Njemačkoj krajem XVIII. i početkom XIX. stoljeća, kad su književnici romantizma, uvevši kult genija i originalnosti, „,bolno otkrili da su se, potičući subjektivnost i štujući 'genija', odbacujući sva društvena ograničenja te kultivirajući samoću, još više udaljili od društva svoga vremena" (Swart, 1964: 245). Weltschmerz je svoju najbolju potvrdu dobio u Schopenhaueru, koji je svaki pokušaj poboljšanja svijeta proglasio uzaludnim. Njegov je kozmički pesimizam postao temelj kulturnoga, baš onako kako to postavlja i Friedländer (1985: 62).

Činjenica da možemo naglasiti da je romantičarska „,svjetska bol“, primarno razvijena u njemačkoj književnosti, presudno odredila dekadenciju na prijelomu stoljeća, potiče i da sasvim jasno utvrdimo da Francuska nipošto nije bila jedina zemlja u kojoj se razvio osjećaj zle kobi i strepnje. Naime duboka je melankolija fin de sièclea bila europski fenomen koji se osjetio čak i više u zemljama koje se tradicionalno ne drže polazištem dekadencije (poput Njemačke, Austro-Ugarske, Rusije, Italije, Španjolske). I dok je književna dekadencija u Francuskoj imala malo veze s tragičnim osjećajem života ili pesimističnim viđenjem povijesti te je ondje, kao, uostalom, i u Engleskoj, Španjolskoj i Italiji, bila ponajprije estetska poza, u Rusiji i Njemačkoj „brojni su dekadenti bili vrlo ozbiljno zabrinuti zbog kulturne i društvene propasti moderne civilizacije“ (Swart, 1964: 249). U uvjetima političke i duhovne regresije mnogi su njemački i ruski pisci u opsesiji dekadencijom otišli puno dalje od svojih francuskih kolega, baštineći metafizičku tjeskobu i duh apokalipse. Iako je dekadencija u središnjoj i istočnoj Europi znatno rjeđe zaokupljala kritiku i književnu povijest, pa je prema tome i slabije istražena, ne može se osporiti da je ona krajem stoljeća u drugim zemljama poprimila nove silnice koje su snažno interagirale. Kao potvrdu te teze istaknimo da su primjerice Schopenhauer, ${ }^{20}$ von Hartmann i Nietzsche te Dostojevski i Tolstoj svojim djelima izvršili snažniji utjecaj na formiranje različitih oblika pesimizma od bilo kojega drugog francuskog autora (ibid.). Premda bi se moglo prigovoriti da je bila riječ tek o pukom širenju i pomodnoj popularizaciji koncepta dekadencije, treba istaknuti da se dekadencija rađala kao upečatljiv odgovor na promjene i krize unutar

\footnotetext{
${ }^{20}$ Kako pokazuje većina povjesničara (usp. Gottfried, 1973: 196), moglo bi se reći da su se francuska književnost i znanost doslovno inficirale Schopenhauerom.
} 
pojedinih zemalja. ${ }^{21}$ Jednostavno rečeno, povijest je definirala dekadenciju. Nezadovoljstvo se u različitim zemljama napajalo na sličnim izvorima, rezultiravši specifičnim proizvodima. ${ }^{22}$ Dok je mnogim piscima koji su se izjašnjavali kao dekadenti bila dobro poznata europska situacija, drugi su očigledno na slične socioekonomske probleme odgovarali sličnim književnim strategijama. Kako piše na tom tragu Gagnier, posve u skladu s našom tezom o jedinstvenosti hrvatske dekadencije:

Premda su pisci često bili svjesni europskih dekadentnih književnosti, književna se dekadencija nije tek širila iz Francuske, Britanije ili drugih zemalja kao kulturni pokret, nego je kontinuirano iskrsavala kao odgovor na promjene i krize unutar različitih nacija i kultura - te su formalne sličnosti jednostavno prešle u prvi plan. (2015: 25)

\subsubsection{Mal de vivre}

Iako je Weltschmerz jedan od najpopularnijih pojmova romantizma, u kojem je zakukuljena i popularizirana tadašnja koncepcija melankolije, on je zapravo prilično stara pojava. Naglašen pesimizam u filozofiji, književnosti, kulturi, u životu uopće, izraz je pojedinca izmučena nepodnošljivim događajima u vremenu raspada načela i vrijednosti.

Pesimizam ili ono što je Maupertius nazvao mal de vivre (,„̌ivotna bol“) zajednička je točka, dosad je već evidentno, svih priča o dekadenciji. Fenomen koji se može povezati s cjelokupnom kulturnom poviješću. Postoji otkad je čovjek vlastitoj egzistenciji pokušao dati smisao te je kroza stoljeća poprimao najrazličitije forme, a temeljna mu je karakteristika negativno viđenje realiteta u njegovoj cjelokupnosti ili pak nekih njegovih aspekata. U takvoj je perspektivi najčešće korišten motiv ideja da je čovjek nesretan, a njegov život pun boli. Mal de vivre nije tek znak patološke neravnoteže, on je jednostavno cijena koju čovjek mora platiti nakon što shvati da bezuspješno pokušava osigurati smisao vlastitomu životu. Misao se pozicionira u slabosti, a svaki njezin napredak ojačava spoznaju o tragediji egzistencije. Prema vrlo jednostavnoj jednadžbi, ako su sreća i ispunjenje smisao života, život tad nema ni smisla

\footnotetext{
${ }^{21}$ Za informativniji uvid u dekadenciju u nekim rjeđe tematiziranim zemljama, poput Kine, Japana, Španjolske i Rusije, usp. Gagnier (2015).

${ }^{22} \mathrm{U}$ Njemačkoj je naprimjer dekadencija integralni dio preusmjerenja društva iz tradicionalnih, poljoprivrednih paradigmi prema industrijskoj, znanstvenoj matrici (Rabinbach, 1992: 22), u Rusiji pak dubok osjećaj krize među pripadnicima inteligencije primarno potječe iz nezadovoljstva političkim strukturama i svijesti o kulturnoj inferiornosti (Swart, 1964: 235).
} 
ni svrhe. To negativno stajalište o prirodi postojanja, uvjerenje o nemogućnosti čovjekova moralnoga razvoja i poštivanja tradicionalnih načela dobra, u XIX. stoljeću učvršćuju i neke osobine koje se prepoznaju kao dominantne, poput bezobzirnosti, surovosti i neosjetljivosti te nezasitne žudnje za moći, novcem ili vlašću. Moralna erozija, relativizacija vrijednosti poretka i uspjeha, onoga što se držalo univerzalnim vrlinama, rađaju svijest o nužnoj reinterpretaciji svijeta. No čovjek šopenhauerovski shvaća da je ovaj svijet ipak najgori od svih mogućih. Ateleološka perspektiva, koja kreiranje svijeta promatra kao jednu veliku pogrešku koju može anulirati tek čovjek dovođenjem toga istog svijeta do nihilizma, sumira se u ideji prema kojoj je „ne-biti““ prihvatljivije od „biti“. Ta je ideja „radikalna negacija principa omne ens, in quantum ens, est bonum“" (Invernizzi, 1994: 4). Negativna vrijednost koju pesimizam pridaje različitim aspektima realiteta potječe od neprilagođenosti svijeta onomu zamišljenomu, onomu kako bi čovjek želio da on izgleda. Diskrepancija između pretpostavke o čovjekovim očekivanjima - da bi mu svijet trebao omogućiti ispunjenje, moralno uzdizanje, kolektivno i individualno zadovoljstvo, a koji bi iz njegova života trebali odagnati nesreću - i onoga što se doista može ostvariti temelj je filozofije pesimizma. Raskorak između ideala i realiteta. Taj apsurd ljudske egzistencije ne mogu razriješiti ni sloboda ni sreća jer su one „međusobno suprotstavljene kao rezultat ontološkoga raskida između svijesti o vremenu, koju ispunjavaju želje, ciljevi i uspomene, i vremenski određenoga svijeta koji neprestano uništava objekte želja“" (Dienstag, 2006: 35). Što čovjek više razvija svijest, to više u njemu raste nelagoda zbog njegova položaja u svijetu.

Dienstag upozorava kako bi o pesimizmu valjalo misliti isključivo kao o modernom fenomenu, jednako kao što naprimjer mislimo o ideji napretka (ibid.: 9). Iako pesimizam u takvoj interpretaciji proizlazi iz linearnoga koncepta vremena (koji je u zapadnoj misli poistovjećen s idejom progresa), pogrešno je izjednačiti ga s teorijama propasti i nazadovanja jer je on negacija progresa, a ne njegov antipod. Primjećujući da Dienstagovo razmišljanje o teretu vremena kao jednom od fundamentalnih osnova pesimizma možemo dovesti u vezu sa spomenutom sviješću o kraju vremena na kraju stoljeća, vrijedi istaknuti da je posrijedi izjednačenje između svijesti o vremenu i svijesti per se: „za pesimiste svijest o sebi jest svijest o vremenu u smislu da je svijest o vremenu temeljan, neophodan atribut svijesti o samom sebi““ (ibid.: 21). I zato ta svijest opterećuje pesimista - ona naime podrazumijeva i spoznaju smrti, koja se može označiti upravo kao pravi teror čovjekove spoznaje. Ta je konstatacija ipak jedan od pogrešnih putokaza u razumijevanju pesimizma. Jer „reći da su naši životi uvijek na putu prema smrti ne znači reći da su posve besmisleni, nego jednostavno znači da pesimizam postavlja moguće parametre naše egzistencije“ (ibid.). Stoga je spoznaja o stalnoj mijeni 
čovjekova života jedan od središnjih problema tereta vremena. Ništa nije toliko stabilno da ne bi iščeznulo. Netom istaknuta konstatacija, šopenahuerovski rečeno,

implicira da su sva ljudska nastojanja na neki način uzaludna. Štogod da si postavimo kao cilj u životu, sve i ako se on postigne, nestat će u trenutku ispunjenja. Ništa nije vječno i mi patimo upravo zato što ne vidimo trajnost u ljudima i stvarima do kojih nam je stalo. Doista, što nam je više stalo, to više patimo (ibid.: 22-23).

Kao što smo vidjeli, teorijski filozofski pesimizam temelji se na postavci da je ovaj svijet, budući da na njemu ima više zla nego dobra, najgori od svih mogućih svjetova. Premda većina teoretičara pravi razliku između filozofskoga i kulturnoga pesimizma, ta nam distinkcija u radu nije od presudnoga značenja te slobodno zaključujemo da je filozofski utemeljen pesimizam bio plodno tlo za stabilizaciju kulturnoga pesimizma koji svoju zrelost, mada mu se elementi mogu naći još u drevnoj povijesti, doživljava u XIX. stoljeću (usp. Tafra, 2008). ${ }^{23}$ Može se reći kako su pojedine teze filozofije pesimizma, naročito Schopenhauerove i von Hartmannove, i uopće generalni smisao koji se može izvući iz njihovih djela, rezultirale karakterističnim beznadnim ,štimungom“. Kulturni se pesimizam veže uz određenu prijelomnu točku koja označava odmicanje razvoja kulture u odnosu na tradiciju, a većina je filozofa $i$ povjesničara smješta u XIX. stoljeće. Možemo s Tafrom govoriti upravo o njegovoj devetnaestostoljetnoj radikalizaciji, koja je reakcija na nezadržive promjene koje dolaze $\mathrm{s}$ modernitetom: „Kraj je to povijesti koja je čovjeku davala mjesto i zadaću.“ (ibid.: 36) Za kulturne su pesimiste moderni svijet $\mathrm{i}$ čovjek u njemu konstantno u stanju nazadovanja $\mathrm{i}$ iscrpljenja te su zato predisponirani za propast. Pesimizam je dakle neraskidivo vezan s idejom propasti i urušavanja, koju označava uvjerenje da je građansko društvo, neovisno o vremenu o kojem pričamo, uvijek osuđeno na propast. Nije pitanje hoće li propasti, nego kad će se to dogoditi (Herman, 1997: 7).

Prema tome do XIX. stoljeća u ,životnoj boli“ nema ništa sistematično jer je riječ tek o individualnim problemima u kojima se miješaju nade i očaji (Minois, 2005: 165). XIX. stoljeće inaugurira pesimizam, pa i nihilizam kao sustavne ideologije očaja. Alfred de Musset 1836, tad dvadesetsedmogodišnjak, u romanu Ispovijest djeteta jednoga stoljeća piše o maladie du siècle, predstavljajući je kao golemo razočaranje mladih, rođenih početkom stoljeća, kojima izmiče

\footnotetext{
${ }^{23}$ Oliver Bennett procjenjuje da je kulturni pesimizam čak neki oblik blage depresije. Znanstvene su studije naime dokazale da ,umjereno depresivni ljudi vide sebe i svijet s manjim udjelom kognitivne distorzije od ovisnika o kontaminiranju optimističkim iluzijama“ (Bennett prema Tafra, 2008: 31).
} 
svaka optimistična perspektiva o slobodi i političkoj važnosti. Kako analizira Minois, prva se generacija romantičara, razočarana prosvjetiteljskim razumom, okreće osjećajima koji se sintetiziraju u ljubavi, koja ipak uvijek završava nesretno i tragično. U potrazi za vječnim i univerzalnim arhetipski junaci romantizma na svom životnom putu pronalaze samo prolaznost i lažnost. No unatoč tomu pripadnici te generacije zadržavaju vjeru u bolju budućnost i „nadu da mogu promijeniti svijet te se u aktivno djelovanje bacaju s nevjerojatnom naivnošću“ (ibid.: 200), smatrajući se glasnicima novoga vremena. Bol njeguju kao izvor inspiracije i vrijednosti. Međutim druga generacija romantičara, pravih „prokletih pjesnika“ rođenih nakon 1820, suočena s grubom realnošću te bez ikakve nade da je može popraviti, gubi sve iluzije: središnje mjesto zauzimaju očaj te čama kao isprazno raspoloženje, nemoć dosade kao originalan predosjećaj ništavosti. Ona je, elaborira Minois referirajući se na Baudelairea, izvor spleena, mentalne i fizičke tjeskobe, osjećaja bezizlaza, gušenja i apatije:

Čama razara sve što dotakne, njegujući veliki svjetski umor, te se hrani vremenom čija je poetska relativnost prethodila znanstvenoj relativnosti, vremenom od kojega ne želi gubiti ni sekundu i koje se širi u vječnosti (...). (ibid.: 222)

Dakle u XIX. su stoljeću sva tradicionalna objašnjenja egzistencije pokazala svoje granice te se život percipira kao neprestana bol. Najpotpuniji izraz uvjerenja da je svijet izgubio svaki smisao te da je on tek pakleni stroj koji unedogled proizvodi jad i nevolju Schopenhauerova je filozofija, o kojoj ćemo nešto opsežnije još pisati. Tamo gdje drugi govore tek o „,bolesti stoljeća“, Schopenhauer govori o generalnoj „životnoj boli“: „Dakle čovekov se život, poput klatna, njiše između boli i dosade, koje su, u stvari, njegovi poslednji sastojci.“ (1984: 62) U tom je tumačenju čitav život samo neizbježna i nezaustavljiva izmjena boli i dosade; čovjek izbjegava bol kako bi se utopio u dosadi i obratno. Stoga se može sumirati da egzistenciji suštinski pripada samo patnja te je istinsko zadovoljenje nemoguće. „Posledica ove poslednje vrste razvoja jeste donekle melanholično raspoloženje, stalno nošenje jedne jedine, velike boli (...).“ (ibid.: 72) Prema tome Schopenhauer je svojim djelom ekstremnoga pesimizma $^{24}$ pripremio publiku za prihvaćanje sličnih životnih modela, koje su dalje razvijali njegov učenik von Hartmann, koji sugerira da bi bilo najbolje kad ovakav svijet uopće ne bi postojao jer je život prevara kakvu nitko ne bi trebao okusiti, te Kierkegaard, koji postavlja

\footnotetext{
${ }^{24}$ Zanimljivo je da to kapitalno djelo u vrijeme tiskanja nije bilo ni otprilike toliko popularno koliko u drugoj polovici stoljeća, pa i poslije, te da je na početku doživjelo popriličan čitateljski neuspjeh (Minois, 2005: 231232).
} 
tjeskobu kao vezivno tkivo svake egzistencije, tumačeći da je neporecivo da živimo u vremenu duhovne depresije. Jer suvremeni je svijet „zajednica individualiziranih objekata, izoliranih u prostoru, pokretanih 'zakonima prirode' koji su lišeni ikakve namjere i svrhe, slijepe prema posljedicama“ (Minois, 2005: 238).

Svjesni dakle činjenice da je pesimizam u tom razdoblju postao iznimno popularan kulturološki fenomen, teško se ne složiti s Voigtom koji govori o njemu kao o „svjetskoj moći“, koja se ne susreće samo u filozofiji nego i u svim drugim sferama ljudskoga djelovanja (prema Invernizzi, 1994: 513). Većina je autora odnos pesimizma i društva vidjela „u perspektivi bliskoj onoj hegelijanskoj: pesimizam je konceptualni izraz, sinteza duhovnoga stava dominantnoga u njemačkom društvu nakon 1848“ (ibid.: 514). I ne samo u njemačkom društvu, dodat ćemo. Unatoč razilaženju u mišljenjima o uzrocima širenja pesimističnoga raspoloženja $\mathrm{u}$ drugoj polovici stoljeća, ${ }^{25}$ može se rezimirati da su provodni motivi bili kriza ideala, nepovjerenje u progres i moralno siromaštvo. Pesimizam je bio prevladavajuće stanje duha.

A njegov je logičan nastavak bio nihilizam, koji smo već elaborirali kroz Nietzscheovu prizmu. Ili, drugim riječima, pesimizam je svojevrsni predoblik nihilizma. „Biti istovremeno razumski svjestan da svijet ne bi trebao 'postojati' i patiti zbog činjenice da se na takvom svijetu postoji rađa želju da ga nestane.“ (Minois, 2005: 237-238) Specifično mu je obilježje svijest o ishodu povijesnoga procesa u kojem se vrijednosne strukture polagano, ali neumoljivo urušavaju. ${ }^{26}$ Iako nije ekskluzivizam modernoga doba, nihilizam se počeo širiti upravo u XIX. stoljeću kroz njemačku književnost te je svoj ,pravi život““ započeo u Rusiji, u drugoj polovici stoljeća, poprimivši značenje u kojem ga poznajemo i danas, kao oznaku raspadanja vrijednosti te posvemašnjega očaja i pobune. Nakon što mu je definiciju utisnuo Turgenjev u Očevima $i$ sinovima iz 1862, kako se obično navodi, ${ }^{27}$ proširio se po Rusiji, postavši prava politička doktrina i vjerski izbor tamošnjih intelektualaca, način života kojim su aspirirali kompletnoj obnovi društva. Moglo bi se zato reći da iz Turgenjevljeva romana proizlazi nihilist kao istinski skeptik koji sumnja u postojanje svijeta, pesimist koji misli da svijet ni ne bi trebao postojati ili čak anarhist koji odbija svaku moralnu, političku ili društvenu vrijednost. Za to vrijeme na Zapadu Nietzsche uspostavlja nihilizam kao sustav, zahvaćajući ga u originalnijem i širem potezu nego itko prije i poslije. Minoisovim riječima, kao „ekstremno ispunjenje različitih

\footnotetext{
${ }^{25}$ Za detaljan pregled filozofije pesimizma u Njemačkoj usp. Invernizzi (1994).

${ }^{26}$ Prava je povijest termina, bilježi Vercellone, započela krajem XVIII. stoljeća u otvorenom pismu F. H. Jacobija Fichteu, u kojem kantovski transcendentalizam naziva nihilističkim (1992: 3).

${ }^{27}$ Turgenjevljeva je definicija nihilizma, kroz usta Arkadija Kirsanova: „Nihilist je čovjek koji se ne klanja ni pred kakvim autoritetima, koji ne prihvaća nijedan princip na vjeru, ma kakvo poštovanje inače taj princip uživao." (1991: 35)
} 
oblika 'životne boli', nihilizam ujedinjuje sve snage pojedinca, njegov intelekt i strast, u finalnoj i konačnoj eksploziji protiv bitka“" (2005: 240).

Malodušnost tako već odavno nije razlikovni znak nekoga iscrpljenog intelektualca, nego se širi u svim strukturama. Pridružujući tim osjećajima neurozu kao najočigledniji produkt moderne ere, a o čemu će također biti riječi, može se naglasiti da izrazi „životne boli“ nikad nisu bili brojniji i intenzivniji, ali i ekstremniji. Odnosi se to ponajprije na porast samoubojstava u drugoj polovici XIX. stoljeća, koje Durkheim naziva proizvodom društvenoga konteksta. Moderna zapadna civilizacija u svom prividnom napretku prolazi pravim patološkim putem na kojem mal de vivre doseže svoj klimaks, putem na kojem se otkriva

trijumf individualizma, odvajanje od velikih religijskih struktura u korist izoliranih sekti; raspad obiteljske zajednice; potop velikih vrijednosti; sumnja u izvjesnosti; slabljenje tradicionalnih struktura, udruženja, političkih stranaka; rastuća nesigurnost ekonomskoga života i zanimanja koja utječe na krhkost profesionalnih kontakata (ibid.: 259).

I Durkheim u kontekstu svoga proučavanja psihologije samoubojstva obrazlaže da svako vrijeme sa sobom nosi određenu količinu kolektivne ,životne boli“ te da se patološki simptomi s odmicanjem stoljeća pogoršavaju, što i potvrđuje apostrofiranu sumnju da je to doista normalan i neizbježan slijed događaja. Potrošačko društvo u kojem dominiraju ekonomski interesi umnožava frustracije, ne nudeći nikakve ciljeve i vrijednosti osim zadovoljenja vlastitih potreba.

Prema kraju rezimirajmo da fenomen o kojem u ovom poglavlju pišemo u XX. stoljeću postaje toliko intenzivan da ne bi bilo pretjerano govoriti o kulturi mal de vivre. Kroz umjetnost, književnost i filozofiju očituje se kao fundamentalan problem ljudske egzistencije, a dosada, mučnina i tjeskoba, kao spoznaja o egzistenciji i izostanku svakoga razloga da se egzistira, postaju pravi simboli modernoga života.

\subsubsection{Od romantičara do dekadenta}

Budući da nam je prethodno potpoglavlje poslužilo i da pokažemo kako dekadencija mnogo toga zahvaljuje čuvstvima kultiviranima kroz cijelo „dugo stoljeće“, valja poentirati da moderni dekadenti za fin de sièclea nasljeđuju mnoštvo karakternih crta junaka romantizma. Drugim riječima, likovi romantizma evoluiraju u dekadentne tipove. Senzibilan pojedinac 
ugrožen $\mathrm{u}$ dobu nestalnih standarda, izmučen očekivanjima, zadovoljenjem normi i metafizičkom tjeskobom zbog svijeta i njegova položaja u njemu, što rađa spoznaju o vlastitoj suvišnosti - nije teško prepoznati romantičarsko inzistiranje na subjektivnom, iracionalnom, transcendentnom te nezaobilazan osjećaj Weltschmerza. Prihvaćanje zaraženosti neizlječivom „bolešću stoljeća“ koja, najjednostavnije rečeno, podrazumijeva uvjerenje da se svijet prepun patnji i neiskorjenjivih zala ne može popraviti, postaje oznaka književnosti na prijelomu stoljeća. „Dekadenti su istovremeno vrhunac i iscrpljenje tradicije romantizma“ (Hanson, 1997: 10) te, dodajemo, mnogo toga duguju hipertrofiji osjećaja romantika. I u Binnijevoj je interpretaciji dekadencija radikalna transformacija dviju temeljnih karakteristika romantizma: kulta vlastitoga ,ja“ i misticizma (1936: 5).

Romantičarska patetika nošena je lavinom historijskog vremena, koje je, nakon što je raskinulo nepomičnu viziju kršćanske vječnosti i statičku sliku čovjeka kao mikrokozmosa, dalo čovjeku zadatak da sam odlučuje svojom sudbinom i da sam oblikuje historijski tok. Ona je prouzročena potresom i izbijanjem nove svijesti čovjeka kao historijskog bića, prepuštenog samom sebi, daleko od svakog teleološkog i teološkog determinizma. (Supek, 1950: 119-120)

To uzimanje sudbine u svoje ruke izraz je pobune ,protiv patrijarhalnog autoriteta predstavljenog simbolično u kršćanskom bogu“ (ibid.: 117), odnosno protiv svake vrste autoriteta. A u shvaćanju revolta, kao primarnoga očitovanja individualnosti u romantizmu, leži i shvaćanje razvoja osjetljivosti u umjetnosti. Dekadentna se osjećajnost razvila na teoriji da je civilizacija korumpirana i umjetna - ona je rezultat transformacije, gotovo bismo mogli reći izopačenosti dvaju likova romantizma: plačnoga mlitavca i dinamičnoga fatalista (Carter, 1958: 27). No budući da je dekadent u europskoj književnosti najčešće pripadnik bogatoga sloja, dobrostojeći čovjek plemenita roda, u njemu je romantičarski revolt izgubio svaku ispriku, evoluirajući u neurotičnu dosadu i taedium vitae, prelazeći iz aktivizma u spleen, karakteristični findesiècleovski ennui. Neovisno o tome nasljeđuje li više karakternih crta od malaksaloga romantičara ili dinamičnoga fatalista, jednako je prepoznatljiv: sterilan, indiferentan, pasivan, blaziran, nesretan, rezigniran. Zamor tijela i duha za Tardieua je među prvim uzrocima prepoznatljivoga koncepta praznoga raspoloženja, odnosno čame koja je ,psiho-fiziološki kompleks beskonačne raznolikosti““ (prema Rabinbach, 1992: 42), a glavna mu je karakteristika bol u svim mogućim metamorfozama. Upravo bi se zamorom kao fiziološkom osnovom rastakanja volje mogao objasniti ekstreman subjektivizam umjetnika fin de sièclea. 
Monotonija egzistencije uvjetovana uvijek istim okruženjem, nepromjenjiva banalnost prirode, duboka trivijalnost čovječanstva, osamljenost pojedinca vječno zatvorenoga u vlastitoj svijesti, varljivost ljubavi i drugih velikih kolektivnih iluzija i demokracije - sve su to bili izvori na kojima se dekadentna melankolija neprestano napajala. (Pierrot, 1981: 61)

Kult prirode i kult idealne ljubavi, dvije stvari koje su romantika sačuvale od najtežih mogućih posljedica njegovih unutarnjih konflikata, u dekadenta više ne postoje. Destruira se svaka mogućnost uspješnoga osmišljavanja egzistencije. Dekadencija s kraja XIX. stoljeća vukla je prema tome svoje podrijetlo iz romantičarskoga nezadovoljstva civilizacijom, a tjeskoba nije bila uvjetovana samo aktualnim društveno-političkim čimbenicima nego i saznanjem da tradicionalna objašnjenja zla i patnje više ne vrijede. Stoga se, s obzirom na to da je proizlazila iz duboke zabrinutosti za sudbinu čovječanstva te osjećaja frustracije i nesigurnosti, može konstatirati da je dekadencija proizvod uznemirenoga srca i kritičkoga uma. Devetnaestostoljetni je nemir posljedica aspiracije modernoga čovjeka k perfekciji. Osjetljivo srce, veliko znanje i razvijena sposobnost spoznaje svijeta čine ga nesretnim, omogućujući mu da vidi kako je ovaj svijet najgori od svih mogućih, te ga proždire neka nevjerojatna egzistencijalna dosada - otud njegovo slabljenje volje, sjeta, mučnina, pa čak i agresivna reakcija na kulturu koju je sam stvorio. Moderan je dekadent preskeptičan da bi vjerovao u stare ideale i nove vrijednosti koje tek treba stvoriti te, za razliku od romantičara koji je, okrećući se harmoniji prirode, donekle gajio nade u pozitivniju budućnost, ne vjeruje u bolje sutra, preuzimajući kao životnu filozofiju skepticizam i nihilizam, nijekanje svakoga prirodnog, društvenog i političkog poretka. Nije teško izvesti zaključak da je duhovna bolest findesiècleovskoga čovjeka neposredan rezultat pretjeranoga intelektualiziranja, analiziranja, razmišljanja; njegove su aktivnosti isključivo mentalne te se on s razlogom smatra cerebralnim junakom (Ridge, 1961: 25). Pomalo ekstremno tumačeći, moglo bi se reći da mu um ne da živjeti. I Bourget u studiji o Flaubertu piše o trima osobinama svojih suvremenika koje su isključivo posljedica razvijena analitičkoga duha: istrošenosti tijela, osjećaja i volje (prema Šoštarić, 2016: 78). To je svijet senzacije i dojma, ne akcije, pa se čovjek preplavljen stanjem bezvoljnosti mora prisiljavati na djelovanje. No svaki eventualni poticaj na djelovanje brzo zaustavlja njegov analitički demon, intelektualna skrupula, indiferentnost koja proizlazi iz posvemašnje zasićenosti. To neprekidno razmišljanje o životu i svijetu, kao temeljno svojstvo pesimizma, jest, kako se često tumači, posljedica slabosti volje jer „samo nepraktični karakteri imaju tendenciju iscrpljivanja svoje fizičke snage pukim teoretiziranjem“ (Kowalewski, 1904: 121). Dekadent se dakle, u različitim fazama i nijansama, portretira kroz dosadu, deziluziju, 
melankoliju, bolećivost, kukavičluk, izostanak reakcije, estetsku sofisticiranost (usp. Carter, 1958; Ridge, 1961; Pierrot, 1981). Ipak, najviše ga određuju pasivnost i letargija te manjak volje koji najčešće graniči s patološkim oblikom - abulijom, koja implicira i nesposobnost ili akutnu nemogućnost donošenja odluke. Doista, „činjenica je da je većina dekadentnih junaka očigledno abulična karaktera, nesposobna donijeti ikakvu odluku, progonjena sumnjom, izolirana od društva“ (Pierrot, 1981: 62).

Njegova je „mana“ što svijet promišlja te ga vidi upravo onakvim kakav on jest: zao, destruktivan, pokvaren, amoralan. To je svijet kojemu ne želi pripadati i zbog toga je nesretan. U takvim ga okolnostima bezuspješno osmišljavanje vlastitoga života čini suvišnim čovjekom. Zato je njegova tuga puno dramatičnija od tuge romantičara, a svijest o življenju u vremenu propasti potpiruje snažan osjećaj očaja: mnogi su dekadenti na kraju stoljeća očajavali puno dublje od svojih predaka, proglašavajući degeneraciju moderne civilizacije. Svijet su vidjeli u sumornim tonovima buržoaskoga društva i njegova urbanoga života.

No emocionalna se prenapregnutost i iznimna rafiniranost, $u$ odnosu na romantika, više ne opisuju samo kao aspiracija idealizmu, nego se objašnjavaju simptomima neuroze. Dekadent naime ne boluje samo od nekoga misterioznog fatalizma. On pati i od mentalnih poremećaja, koje je najčešće naslijedio od svojih iscrpljenih predaka - nerijetko je proizvod bolesnoga naslijeđa. Moderan je čovjek dekadentan jer je neurotičan:

Emocionalna hipertrofija romantizma, teorijskih perverzija Gautiera i Baudelairea, ne prezentira se više kao plod aspiracije vječnosti ili osujećena idealizma. To su, naprotiv, simptomi neuroze. Još uvijek se radi o dekadentnoj osjetljivosti - karakteristike joj ostaju iste. No one se sad pripisuju drugim uzrocima: čovjek je dekadentan jer je psihotičan. (Carter, 1958: 63)

Dakle u korijenima je dekadencije neurotično stanje koje korespondira sa zahtjevnošću moderne civilizacije. Stvorio se kulturni kontekst u kojem se neuroza združila s patologijom degeneracije, udaljujući se od svoje romantičarske baštine. Kako navodi Poggioli, nekadašnje Baudelaireovo oduševljenje prokletstvom i bolešću prepušta mjesto

rezignaciji i bogobojažljivosti upravo zato što se ta stanja ne smatraju više metafizičkim, kao mitovi ili figure, već kao fizičke i objektivne pojave, bukvalno kao slabosti. Ovo shvatanje uspostavlja nepokolebljivu vezu između umetnosti i neuroze, očigledno u skladu sa frojdovskim doktrinama i psihoanalitičkim teorijama (1975: 140). 


\subsection{Anatomija dekadencije: Entropija tijela i duha}

Kako smo već utvrdili, priča o dekadenciji neizbježno prati priču o napretku. „Buržoasko društvo u trećoj četvrtini 19. stoljeća golemo samopouzdanje u najvećoj mjeri crpe iz ideje znanstvenoga progresa te iz s tom idejom usklađenih filozofija, francuskog pozitivizma i engleskog empirizma.“ (Vuković, 2016a: 438) No raznovrsni modernizacijski procesi u svim domenama ljudske djelatnosti - politici, društvu, gospodarstvu, tehnologiji, znanosti - rađaju, utječući pritom i na izgradnju građanske kulture, neku začudnu malaksalost, onemoćalost duha i tijela. Manjak energije, koji postaje gotovo uobičajena abnormalnost, preplavio je europski duhovni prostor, a nad intelektualnom se elitom nadvila sjena fizičke i duševne degeneracije. „Grdoba napretka““ (ibid.: 437), umor i iscrpljenost - riječi kojima se opisuje findesiècleovska Europa, a koje su označile protutežu privrednoj utopiji, progresivističkoj iluziji o radnoj produktivnosti. Mogli bismo prema tome sugerirati da krizu moderniteta valja promatrati kao krizu energije u kojoj su se strahovi od degeneracije u najširem smislu te riječi povezali s radikalnom bojazni o snazi i usmjerenosti životnih sila. Moderna se civilizacija, kao što smo i prije konstatirali, okreće na neki način sama protiv sebe, proizvodeći svoj nestabilan poredak, što rezultira neurozama i sličnim poremećajima.

Odnos energije i zamora posebno je zanimao Rabinbacha (1992), koji je pokušao osvijetliti divergenciju između modernističkih procesa i koncepta zamora koji se paralelno rađa. Promatrajući kako je predodžba iscrpljenoga tijela evoluirala iz moralno-religijske u materijalističko-pozitivističku matricu, tj. kako se od pojma lijenosti došlo do pojma zamora, ideju iscrpljenosti u ranonovovjekovnoj Europi opaža još u kršćanskom pojmu acedia, koji se tumačio kao grijeh duhovne tuposti, bezvoljnosti i lijenosti. S vremenom je taj pojam, prešavši $\mathrm{u}$ svjetovnu upotrebu, razvojem društva i promjenom okolnosti prerastao u tromost kao opasnost efikasnomu, svakidašnjemu obavljanju posla te se osobito povezao s aristokratskim krugovima, s njihovom nesklonošću radu i potrebom očuvanja tijela. No u XIX. je stoljeću pojam lijenosti počeo uzmicati te su, u skladu s izmijenjenim modelima društvene ekonomije, kao nove koncepcije iskrsnuli zamor i energija. Zamor se tako izjednačava s modernitetom te istovremeno predstavlja sve njegove paradokse. On je u temeljima dekadencije.

Koncepti energije i zamora reflektirali su paradoks toga društvenog moderniteta, istovremeno afirmirajući bezgraničnu prirodnu snagu dostupnu čovjeku te otkrivajući tjeskobu ograničenja - bojazan da su tijelo i psiha ograničeni iscrpljenošću te da zato ne mogu odgovoriti na zahtjeve moderniteta. (Rabinbach, 1992: 12) 
U devetnaestostoljetnim naracijama zamor se veže uz materijalizam, tj. rekonceptualizaciju energije, te, najkraće rečeno, predstavlja prepreku radu. Naime iza kompleksnih procesa modernizacije krilo se umorno tijelo. Nasuprot industrijskoj fantaziji o radnoj snazi i čovjeku kao motoru rada, metafori koju su na noge postavili mislioci XIX. stoljeća unutar pozitivističkoga znanstveno-kulturnog okvira, te tijelu kao sredstvu rada postavlja se destrukcija tijela - dekadent. Tijelo koje ne podliježe zakonu zamora bilo je tadašnja utopija, a iscrpljenost konstantna prijetnja ideji napretka. Zamor tako postaje najočigledniji znak ograničenja tijela i duha, indikator potrebe da se sačuva kapital tijela. Energiju pojedinca, možemo reći s Nordauom i Freudom, isisava društvena i psihička organizacija za čije je održavanje uvijek potreban stanovit napor. „A kad su zahtjevi za održavanjem preintenzivni, prijeti nam fizički i kulturni kolaps.“ (Dollimore, 2001: 134) Drukčije rečeno, kad se iscrpe sve zalihe energije, civilizacija je ugrožena.

Mnogobrojne tvrdnje o slabosti čovjeka razasute po najrazličitijoj literaturi simptomatične su za strah za civilizaciju koja, kako se držalo, juri u propast na prijelazu stoljeća. Jer dok je razvoj tehnologije s jedne strane omogućavao sve veću produktivnost, s druge je snažno utjecao na čovjekovo zdravlje. Iako je prije 1860. gotovo nemoguće pronaći rad koji bi se bavio zamorom, kako pojašnjava Rabinbach, on se u posljednjim desetljećima XIX. stoljeća prepoznaje kao osnova niza duševnih i fizičkih poremećaja koji su se smatrali bolestima volje.

Iscrpljenost nije bila samo posljedica prekomjernoga tjelesnog napora nego i uzrok mnogobrojnih fizičkih i mentalnih patologija nastalih zbog slabosti i tromosti muškaraca, žena i posebno djece školske dobi. (Rabinbach, 1992: 20)

Ako je suditi prema brojnim znanstvenim prilozima, novinskim člancima i popularnim tekstovima, zamor je bio rastući europski problem među radnicima i, što je vrlo zanimljivo, školskom djecom. Naime velik broj medicinskih radova izvještava upravo o nevjerojatnoj učestalosti i intenzitetu iscrpljenosti kod srednjoškolske, osobito gimnazijske djece. U jednom izvješću o stanju školske djece u Francuskoj iz 1892. stoji:

Mišići bez energije bolno podupiru tijelo; lice je blijedo; stav tijela oslabljen; držanje pognuto; sve izvanjske karakteristike djeteta odaju dojam biljke koja žudi za zrakom ili suncem. Sve se tjelesne funkcije narušavaju u karakterističnom stanju propasti. (cit. prema ibid.: 6) 
U modernitetu se dakle zamor prepoznaje kao patologija, vrlo često kao metafora za slabost volje i inerciju. Ta je ideja najbolje izrazila već apostrofiranu bojazan za sudbinu svijeta, društvenu dezintegraciju, pa i za kozmičku smrt. Crna perspektiva naime nije zaobišla čak ni pozitivističke znanosti. Unatoč njihovu prevladavajućemu optimizmu, tumači Rabinbach, skepsa se zamjećuje i u znanstvenika i socijalnih filozofa koji u novim fizikalnim zakonima uočavaju apokaliptične znakove skorašnje smrti svemira. I razvoj fizike u XIX. stoljeću potvrdio je pretpostavku o neizbježnosti propasti kroz uvođenje pojma entropije i hipotezu o toplinskoj smrti svemira, koji su učvrstili ionako stabilno apokaliptično viđenje prema kojem priroda neminovno ide svomu kraju (ibid.: 3-4). „Makrokozmos svemira ponovo se ogleda u mikrokozmosu čovjeka: nastao je; to znači da će i nestati.“ (Tattersall, 2014: 20) Stoga se može reći da je specifičan modus pesimizma, suprotno uvriježenomu mišljenju, u nekoj mjeri bio prisutan i u prirodnim znanostima.

Findesiècleovska ideja toplinske degeneracije spojila je drevnu ideju o kraju svijeta s cijelim nizom starih i novih ideja: linearnost, korištenje i odbacivanje, energija, materijalizam, religiozne i mnoge druge brige stopile su se u mješavini tjeskoba koje će se s vremenom transferirati u dvadesetostoljetno otkriće nuklearnoga procesa, koji je proširio toplinsko vrijeme, istovremeno predočavajući nove strahove o koncu svijeta. (ibid.: 29)

Ne čudi prema tome što slika o skorašnjem kraju svijeta, koji bi bio rezultat bioloških, fizikalnih i/ili kozmičkih procesa, proganja modernoga čovjeka, ponajprije zbog spoznaje da bi taj kraj mogao biti slom uvjetovan i tehnologijom i znanošću. Kako piše Friedländer, „destrukcija čovjeka čovjekom“(1985: 71).

Zamor je dakle i tjelesni i duševni poremećaj - on je znak slabosti i manjka volje, slom tijela i duha. Kao fenomen doista je lako fluktuirao između znanosti i književnosti. Zaokupljenost tom idejom $\mathrm{u}$ znanosti te opsesija medicine i književnosti degeneracijom i propašću bila je, vidjeli smo, posljedica novih znanstvenih razvojnih tokova: brige za moralnu regeneraciju te fizičko i psihičko zdravlje pojedinca. Potvrđuju to mnogobrojni opisi u medicinskoj literaturi, pa kao primjer izdvajamo zapažanja Pierrea Révillioda koji u svojoj knjizi iz 1880. ovako opisuje jednoga umornog čovjeka te pritom savršeno uzorno i našega dekadenta: 
Glava je teška, duh postaje lijen, misao, sjećanje i volja malaksaju, a apatija koja iz toga proizlazi preuzima kontrolu nad zakonodavnom i izvršnom vlašću tijela. (cit. prema Rabinbach, 1992: 40)

Takve sugestivne deskripcije služe kao izvrsna ilustracija suočavanja s raspadanjem tijela i duha pod pritiskom moderniteta, što se posebno zapaža u ideji neprilagođenih. Naime devetnaestostoljetna Europa, uvjerena u svoje novoutemeljene liberalne institucije nakon prekretničkih političkih zbivanja, inzistira na osjećaju superiornosti i uspostavi radikalnoga reza između primitivnih početaka ljudske zajednice i moderne civilizacije. Kao primjere posljednjega, najvišega stupnja evolucije ljudske vrste uzima disciplinirane, vrijedne radnike koji poštuju norme i ustaljene principe te tumači kako se neki pojedinci i skupine brže i uspješnije prilagođavaju novim uvjetima. Međutim to uvjerenje pobija veliki broj neprilagođenih, koji se pojavljuju u svim vrstama javnoga diskursa. Bolest i tijelo, pišu Herzlich i Pierret, postaju uporišne točke findesiècleovske znanosti (1987: 28). Statistike, znanstveni radovi, pregledi i izvješća, pa i osobno iskustvo detektiraju ogroman broj devijacija različitih vrsta, kriminalaca, neurotika, luđaka - svih onih koji narušavaju liniju bezuvjetnoga vjerovanja u napredak moderne civilizacije. Kratko rečeno, drži se da su mnogi pojedinci ispali iz poretka. Sociokulturni kontekst proizvodi neprilagođene subjekte te ih istovremeno isključuje. Ta je kontradikcija korijen društvene nelagode te ujedno objašnjenje širenja i popularizacije fenomena ,životne boli““.

Zato ćemo u poglavlju što slijedi pokušati barem djelomice rekonstruirati napore društva da ponudi znanstveno objašnjenje abnormalnosti s kojima se suočavalo, a koje dovodimo u izravnu vezu s dekadencijom. Zanimajući se za iskliznuća iz poretka iz različitih perspektiva, liječnici i znanstvenici kroz teorijsko i praktično bavljenje problemom pišu o nepodobnostima svih vrsta, razlikujući vanjske i unutarnje faktore pokretanja devijacija. Moglo bi se reći kako su pojedinci klasificirani kao neprilagođeni onoga trenutka kad nisu mogli ili nisu htjeli udovoljiti društvenim normama, odnosno onomu što je građansko društvo odredilo kao normalno. Pojedinac koji ne može kontrolirati svoje tjelesne i mentalne reakcije bio je centralna figura građanske strepnje. Uočavajući opasnost od porasta degenerativnih poremećaja, talijanski liječnik Angelo Mosso apokaliptično prognozira:

Ako borba za život postane beznadnija, učinci toga fatalnog slabljenja katastrofalniji, a borba misli ubojitija, rodit će se legije nesposobnih, neurastenika i degenerika, zajedno s onima koji 
će pasti izbezumljeni zamorom i iscrpljeni slaboćom, poput izmoždenih vojnika koje velika vojska ostavlja za sobom tijekom svoga marša na putu do pobjede. (cit. prema Nye, 1982: 59)

I dok su mnoge kategorije neprilagođenosti bile poznate od davnina, poput kriminala, prostitucije te odnosa genijalnosti i ludila, XIX. je stoljeće iznjedrilo i neke nove, poput neuroze i seksualnih perverzija, koje su izazivale velik interes znanstvene zajednice. Fascinacija tim kategorijama abnormalnosti proizlazi i iz toga što one znače napretku društva. Možda su to pojedinci koje je takoreći evolucija ostavila iza sebe, a možda oni jezivo nagovještavaju jednu drugu budućnost: propast.

\subsubsection{Degeneracija}

Opisana mračna perspektiva, s metaforom o bolesti civilizacije u središtu, svoje je širenje zahvaljivala nekolicini faktora. Među njima kao odlučne Porter (2004) prepoznaje teoriju naslijeđa, odnosno teoriju degeneracije kao njezinu izvedenicu, društveni darvinizam, prema kojem opstaju samo najsposobnije nacije i rase, dok su one slabe osuđene na propast, te s njim združenu ideju da bi se sve osobine koje su se tradicionalno držale prihvatljivima (poput osjećajnosti, benevolentnosti i altruizma) u procesu opstanka mogle pokazati nepoželjnima. Dakle sve ono što bi se moglo nazvati konačnim izrazom stoljetne civilizacijske „,bolesti“ utjecalo je na fatalistički predosjećaj kraja svijeta, na findesiècleovsko ozračje propasti dodatno ojačano konceptom biološke selekcije, a svoju je „,medicinsku“ potvrdu dobilo u doktrini degenerativizma (Porter, 2004: 592-593). Najrazličitiji oblici delinkvencije i malformacija, tj. sve ono što odstupa od utvrđenih kriterija, dobivaju prestižno mjesto u javnom diskursu. Pitajući se o osnovnom impulsu disperzije dekadentnoga imaginarija u posljednjim desetljećima XIX. stoljeća, i Pierrot potvrđuje da je to specifično uvjerenje o biološkom stanju modernoga čovjeka, odnosno postavka o degeneraciji čovječanstva utjecala na fundamentalnu melankoliju epohe (1981: 46). Ideja o civilizaciji u stanju propasti koincidirala je s kulturnim trendovima koji su nagovještali apokalipsu XIX. stoljeća. Dominantan fatalizam, spomenut već u nekoliko navrata, opravdavao se astrološkim razlozima, kojima se proricala neizbježna kozmička katastrofa, i biologijom, tj. teorijom hereditarnosti, koja je počivala na uvjerenju da se defekti u pripadnicima nekoga naraštaja perpetuiraju u idućima. Kao što iznosi Dollimore, „kozmičko se sad urušava u biološko, u smislu da pojačava tjeskobu jer se propast radikalno interiorizirala“ (2001: 129). 
Pojam degeneracije u (pseudo)znanstvenim, medicinskim, antropološkim i psihijatrijsko-psihološkim studijama bio je donekle istovjetan pojmu dekadencije u društvenohumanističkoj paradigmi. Ili, preciznije rečeno, degeneracija je kao „dio naslijeđa izgubljene subjektivnosti“ (Gordon, 1979: 45) od velike važnosti i za fenomenologiju dekadencije. Prema Whiteovu razumijevanju ,teorija je degeneracije pronašla istaknuto mjesto u diskursu popularne kulture, postavši temeljem na kojem je konstruirana dekadencija kao umjetnički pokret“" (2014: 49). Degeneracija je njezin pojmovni blizanac, no ponekad i tek najobičniji semantički alter ego, upozorava pak Burrow te podsjeća da se dekadencija - kao termin iz povijesti kulture - u pravilu povezuje s pripadnicima viših klasa, posebno s obrazovanima i umjetnošću, dok se degeneracija u viših klasa smatra iznimkom, nekom vrstom oslobađajuće izopačenosti, a u nižih može doseći epidemijske razmjere (2000: 183). Za razliku od ideje dekadencije koja je, kako smo protumačili, postojala oduvijek, patološki je diskurs degeneracije formuliran u kasnom XIX. stoljeću (iako su se neke ideje biološke regresije javljale još u prvoj polovici stoljeća u sociologiji, biologiji, povijesti i filozofiji) te je ona kao (pseudo)znanost postala dominantnom etiološkom teorijom. Smjestivši se u središte paradigme o bolesti civilizacije, prometnula se u prevladavajući narativ: diskurs o tijelu pojedinca artikulirao je kolektivne tjeskobe o fizičkom i duševnom zdravlju nacija na prijelomu stoljeća. Iako bazirana na biološkim argumentima, ona je u biti patologizirala osobine i ponašanja koja je smatrala amoralnima, kriminalnima, (po)grešnima - jednom riječju, nepoželjnima. Progonila ju je ideja neprilagođenih. Zanimljivo je pritom da su degenerici, za razliku od neurastenika, bili prozvani antitezom razvijenosti civilizacije, tj. „talogom društva koji je biološki inferioran“ (Scull, 2018: 264), a pritom se nerijetko njihova inferiornost fundirala na tjelesnoj neprilagođenosti.

Umjesto na simptomima zasnovanim interpretacijama ludila kao melankolije, manije, demencije i raznih monomanija (nimfomanije, kleptomanije i tomu slično), koje je raniji naraštaj psihijatara nastojao legitimizirati, ovdje se ukazalo protejsko objašnjenje svih oblika ludila, od njegovih najblažih do najturobnijih oblika, koje je upućivalo na defekte u mozgu. To što se te defekte nije moglo promatrati u prirodi i nije bilo toliko važno. (ibid.: 265)

Uporišna točka diskursa o vitalnosti rasa i nacija, degeneracija je mračna strana progresa te se s vremenom u povijesti kulture počela tretirati kao jedan od odlučujućih pokazatelja kraja civilizacije. Međutim, unatoč sustavnim pokušajima sistematizacije, nikad „nije bila uspješno reducirana na fiksni aksiom ili teoriju“ (Pick, 1989: 7) jer se širinom svojih implikacija, baš poput dekadencije, opire usustavljivanju. Kako piše Bernheimer: 
Dok je cilj teorije degeneracije bio dijagnosticirati psiho-fiziološke simptome dekadencije i te dijagnoze organizirati u koherentan sustav znanja, dekadencija podriva taj projekt ne dopuštajući ikakvo razumijevanje izvan vremenskoga svijeta beskrajnoga propadanja i kontinuirane patologije. (2002: 162)

Degenerativizam je proizašao iz znanstvenoga okvira teorije evolucije vrsta, postavši joj sušta suprotnost, nešto što bismo mogli nazvati de-evolucijom. Ideji evoluiranja u više oblike života, iz jednostavnijih u složenije, suprotstavio se kao proces regresije, nazadovanje u primitivniji oblik koje se, za razliku od dugotrajne evolucije, moglo odigrati u samo nekoliko generacija (Hurley, 2004: 66). On je „negativna naracija koja obrće smjer meliorističkih inačica evolucionizma, a koje su prirodan tijek povijesti promatrale kao progresiju prema višem, rafiniranijem stanju civilizacije“ (ibid.: 65). Iako je nastao u okviru biološke psihologije, glavnu mu je znanstvenu potporu pružila evolucijska psihologija u kojoj se govorilo o regresiji kao o vraćanju na prethodni, niži stupanj razvoja. Razvoj medicine (posebno psihijatrije i neurofiziologije) pomogao je u brisanju dotad prihvaćenih granica između duševnoga zdravlja i bolesti, omogućivši degenerativnim teorijama da pokušaju riješiti različite psihopatološke probleme. Osim toga nije teško zamijetiti da je degeneracija, kao regresija svojstava, odnosno slabljenja ili pogoršanja tjelesnih i psihičkih osobina pojedinca iz generacije u generaciju, $u$ drugoj polovici XIX. stoljeća evoluirala u način na koji se razumijevalo ono društveno drugo. Iz kliničke slike slučajeva prerasla je u društvenu teoriju. Devijantni su se pojedinci, legitimirani kroz vizuru psihijatrije, percipirali kao opasnost za napredak društva, kao paraziti na društvenom tijelu koji iscrpljuju njegovo zdravlje. Degeneracija „kao povremena podstruja unutar širih filozofskih, političkih ili ekonomskih teorija ili kao priča o užasima Francuske i industrijske revolucije tako prerasta u središte znanstvenoga i medicinskoga istraživanja“ (Pick, 1989: 20).

Imajući na umu sve o čemu smo dosad pisali, osobito političke i gospodarske okolnosti u Francuskoj (u čijem je krilu teorija i nastala), lako se zaključuje kako su se nakon 1848. „problemi povijesti premjestili u problem naslijeđa“ (ibid.: 59), a teorija se degeneracije postavila kao briga za povijesni tijek civilizacije te je u sebi obuhvatila sve društvene tjeskobe o duševnim bolestima. Vjerovala je da može objasniti sve ono što je sama vrednovala kao zlo (od pojedinačnih oboljenja preko gospodarskoga i društvenoga nazadovanja do izumiranja ljudske vrste), proganjajući potencijalno opasne i ugrožavajuće pojedince ili skupine. Prema tome nema sumnje da je ona, neovisno o političkim elementima, bila rezultat vladajuće ideologije, odnosno kompleksnoga uvjerenja da se živi u vremenu krize. S obzirom na 
navedeno ne iznenađuje što su se kulturološki modeli medicinske reprezentacije devijantnosti razvili upravo u Francuskoj, u drugoj polovici XIX. stoljeća - ondje su se naime razmatranja kriminala, prostitucije, mentalnih bolesti, alkoholizma i drugih patologija iznimno uspješno povezala sa strepnjom za zdravlje nacije nakon uspostave Drugoga Carstva te osobito nakon Francusko-pruskoga rata, kad se francusko društvo suočilo s intenzivnim osjećajem nesigurnosti o uzrocima povijesnih promjena. ${ }^{28}$ Postavke teorije degeneracije, uspostavljajući kontinuum između sociologijske i biologijske misli, snažno su se prožele ,zajedničkim kulturnim značenjem za većinu pismenih Francuza i žena u vremenu belle époque, stekavši u tom razdoblju ideološki status“ (Nye, 1984: 119).

Dakle mehanizam je hereditarnosti bitno utjecao na ideju o kolektivnoj propasti čovječanstva kao završnom ishodu dezintegracije društva. Budući da su, prema organicističkom društvenom modelu, napredak i boljitak društva bili neraskidivo vezani za zdravlje pojedinaca, duševni su se poremećaji držali konačnom fazom u lancu degenerativnoga nasljeđivanja. Kao pokazatelja dvostrukosti paradigme degeneracije, moralnoga i fizičkoga aspekta kojim se zahvaćaju degenerirani, odabiremo Lombrosa, koji u knjizi Čovjek genij (1889) piše:

(...) Što se tiče duševnosti, apatija, gubitak morala, česta sklonost impulzivnosti ili sumnji, psihičke nejednakosti zbog prekomjernih senzacija (...), pretjerana šutljivost ili govorljivost, morbidna taština, pretjerana originalnost i zaokupljenost samim sobom, sklonost mističnim interpretacijama čak i najjednostavnijih činjenica (...). Što se tiče tjelesnosti, izražene uši, nepravilni zubi, velika asimetrija lica i glave, prerana seksualnost, malo ili disproporcionalno tijelo (...). (1891: 5-6)

S obzirom na crne slutnje kraja svijeta i ,bolesti“ civilizacije ne iznenađuje mnoštvo studija o tjelesnim i psihičkim poremećajima, seksualnim nastranostima, teoriji naslijeđa i srodnoj problematici od polovice XIX. stoljeća pa nadalje. Čak i prije nego što je Nordau objavio svoju iznimno popularnu studiju, ideja degeneracije već je bila naveliko raširena, postavši referentnim mjestom izvorima dekadencije. Vodeći su je psihijatri i neurolozi doveli u vezu sa seksualnim perverzijama, genijalnošću i kriminalom. Morelova Studija o fizičkoj, intelektualnoj i moralnoj degeneraciji ljudske vrste, Lombrosov Čovjek zločinac, Lankesterova Degeneracija, Krafft-Ebingova Seksualna psihopatija i Maudsleyjeva Tijelo $i$ volja, da se prisjetimo samo najpoznatijih. Svi su ti radovi potvrđivali strepnju onih koji su, uvjereni da

\footnotetext{
28 Za detaljniju analizu povijesnoga konteksta i uspostave medicinskoga koncepta devijantnosti u
} devetnaestostoljetnoj Francuskoj usp. Nye (1984). 
društvo ne može podnijeti zahtjeve moderniteta, potencijalnu društvenu propast promatrali kao izravnu posljedicu fizičke degeneracije. Pa tako Krafft-Ebing, koji je pojam degeneracije popularizirao u findesiècleovskom Beču, bilježi da je propast svih prijašnjih velikih civilizacija bila izravna konzekvencija raširene degeneracije i moralnoga propadanja:

Epizode moralne propasti uvijek se podudaraju s napretkom feminizma, bluda i bogaćenjem naroda. Ti se fenomeni jedino mogu pripisati višim i strožim zahtjevima koje društvene okolnosti postavljaju pred moždani sustav. Njegova prekomjerna napetost stimulira senzualnost, vodi pojedinca i kolektiv ekscesima, potkopavajući same temelje društva, moralnost i čistoću obiteljskoga života. Materijalna i moralna propast zajednice proizlazi iz razvrata, preljuba i luksuza. Grčka, Rimsko Carstvo i Francuska pod Lujem XVI. i XV. upečatljivi su primjeri navedene tvrdnje. (...) Veliki su gradovi žarišta neuroza i srozane moralnosti, kao što je vidljivo i u povijesti Babilona, Ninive i Rima te u misterijima modernoga velegradskog života. (cit. prema Bernheimer, 2002: 140-141)

Teorija naslijeđa, tj. teza da nasljedna svojstva čine pojedinca podložnim određenim duševnim bolestima u temeljima je degenerativizma. Hereditarnost je naime sredinom XIX. stoljeća postala nezaobilazno mjesto u francuskoj školi psihijatrije. Jacques-Joseph Moreau, cijeloga života obuzet tom problematikom, u svojim djelima 1850-ih ističe mnogostruku nasljednu predispoziciju za imbecilnost, epilepsiju i ludilo, kreirajući rani koncept degeneracije te uvodeći ideju „neurotičnoga naslijeđa“ (Pietikainen, 2007: 80). ${ }^{29}$ Degeneraciju je pak kao zaokruženu paradigmu osmislio Bénédict Morel 1857. u Studiji o fizičkoj, intelektualnoj $i$ moralnoj degeneraciji ljudske vrste. Za njega je degeneracija nasljedna devijacija, tj. odstupanje od svakoga „normalnog“ oblika vrste, koje međutim ne podrazumijeva samo reprodukciju anomalije iz osobe u osobu nego i široku mrežu poremećaja i bolesti te uzorke njihova pojavljivanja i promjena (Pick, 1989: 50). U njegovu je viđenju degeneracija nužno progresivan proces, koji započinje blažim poremećajima, a završava ludilom i izumiranjem. ${ }^{30}$ Dakle kroz nasljedne se patološke promjene tjelesno i mentalno zdravlje svakoga naraštaja u odnosu na prethodni pogoršava, preko histerije, neurastenije i ludila do idiotizma i sterilnosti te konačnoga

\footnotetext{
${ }^{29}$ O neurotičnim je oboljenjima Moreau pisao kao o vrstama ludila te je tvrdio da ona čine ,neuropatičnu obitelj“ (prema Pietikainen, 2007: 80).

${ }^{30}$ Za razliku od njega Maudsley u knjizi Tijelo i volja pojašnjava da degeneracija nikad nije povratak na primitivniji oblik, nego da je riječ o morbidnoj varijanti nekoga svojstva: „Od-čovječenje koje nazivamo degeneracijom nije regresija s višega stanja na niže normalno stanje, nego preobrazba višega svojstva u novo ili abnormalno (...).“ (1884: 241) Vodeći se za tezom o biološkoj vezanosti dekadencije kao morbidnoga iscrpljivanja i degeneracije, utvrdio je da organizam, kako bi barem donekle zadržao ravnotežu pred zamršenim utjecajima društva, postaje prekompleksan, a kompleksnost implicira i veći broj mogućih poremećaja.
} 
izumiranja obitelji (Hurley, 2004: 66). U svoju je nosografiju degeneracije Morel uklopio čitav niz potencijalnih uzroka, od fizičkih predispozicija preko socijalnih navika do pogubnih utjecaja društvenoga okruženja. Osobito zdušno zastupajući stajalište da upotreba narkotika i drugih stimulansa može rezultirati oboljenjima, na velika je vrata uveo tezu da je amoralnost degeneriranih pojedinaca i uzrok i simptom degeneracije. Jer kako je „teorija degeneracije postala sredstvo mjerenja moralnoga zdravlja društva i zdravlja pojedinca“ (ibid.: 71), tako su se simptomi počeli brkati s uzrocima.

Morelovu listu anatomskih deformacija degeneriranih tipova dopunio je Lombroso, stvorivši u krilu degeneracije, uz Nordauovu, možda svjetski najpopularniju teoriju. Potvrđujući europski trend detektiranja primitivnoga u civilizaciji, Lombroso, prema uvriježenom mišljenju otac moderne kriminologije, u knjizi Čovjek zločinac (1876) predlaže razlikovanje kriminalca od nekriminalca prema višestrukim fizičkim anomalijama. I za njega je naime tijelo pokazatelj moralne prirode pojedinca. Frenološkim je istraživanjima nastojao demonstrirati kako je sklonost kriminalu urođena: ona je nasljedna patologija, a zločin je kao primitivna forma, iako društveno neprihvatljiv, u smislu teorije naslijeđa zapravo posve prirodan (Pick, 1989: 122). Lombroso usto u svoju teoriju kriminaliteta uvodi koncept atavizma, procjenjujući da je kriminalac upravo atavizam, odnosno potomak primitivnijega oblika egzistencije. Premda je njegova prvotna upotreba, kao neočekivane i iznenadne pojave nekih fizičkih osobina neizravnih predaka koje više ne postoje, bila moralno neutralna, s vremenom se atavizam počeo promatrati kao patološki fenomen upravo zahvaljujući Lombrosu (Mighall, 1999: 144). U njegovoj teoriji kriminalna djela nisu definirana razumom, odnosno njegovim izostankom ili pak nekim vanjskim poticajima, nego su atavistička ostavština predaka.

Mogli bismo s obzirom na navedeno skrenuti pozornost na to da se, počevši od Pinela, koji je još početkom XVIII. stoljeća postulirao nasljednu predispoziciju za ludilo, pa preko konstituenata teorije Moreaua i Morela, teorija degeneracije temeljila na neolamarkističkoj tezi po kojoj su duševni i fizički poremećaji rezultat suodnosa urođenih osobina i patogenosti okoliša (usp. Nye, 1984: 119; Pietikainen, 2007: 79). Nasuprot Darwinovoj ideji prirodne selekcije, koja je inzistirala na važnosti slučajne mutacije, Lamarckov je model evolucije proučavao razvoj vrste kao postupnu prilagodbu na okoliš te prenošenje svojstava na potomke. Ta adaptirana i transformirana ideja o funkcionalnoj vezi pojedinca i okoline bila je ključna za razvoj koncepta degeneracije jer je, u jednoj krajnje beznadnoj perspektivi, omogućio povezivanje čimbenika u okolišu s patološkim promjenama u organizmu pojedinca koje se prenose s koljena na koljeno, sve do smrti posljednjega potomka i odumiranja loze. Dakle proces degeneracije u intelektualnim i znanstvenim krugovima bio je, uglavnom prema svim 
analitičarima, rezultat složenoga preplitanja nasljedno uvjetovanih specifičnosti, tj. urođenih potencijala za neku vrstu bolesti, i utjecaja miljea, odnosno kombinacija intrinzičnih i ekstrinzičnih čimbenika.

Krajnji izraz trendovskoga proučavanja degenerativnih tendencija i zabrinutosti za opće društveno, moralno i duševno propadanje bila je studija Maxa Nordaua iz 1892. Nijedan teoretičar nije bio uspješan u popularizaciji toga termina i ideje kao Nordau u svojoj Degeneraciji, koja je vrlo brzo postala globalna senzacija (premda je u medicinskoj zajednici dočekana s velikom skepsom), pa je već sljedećih godina prevedena na talijanski, francuski, ruski i engleski.

Njegov pseudoznanstveni kompendij, ocijenjen kao gnoseologija dekadencije (usp. Praz, 1974), denuncijacija je devetnaestostoljetnih umjetničkih i filozofskih strujanja i njihovih najistaknutijih predstavnika (Zole, Ibsena, Baudelairea, Nietzschea, Wagnera, Tolstoja te francuskih simbolista), koji se odmiču od tradicionalnoga poimanja svijeta, utvrđenoga reda i poretka te na taj način simboliziraju regresiju u svakom mogućem smislu. Dekadencija protumačena degeneracijom. Nordauova osuđujuća perspektiva obuhvaćala je sve ono što je on sam držao dekadentnom umjetnošću, koja je proizvod degeneriranih umjetnika. Takav je društveno-medicinski kriticizam, izlazeći izvan okvira psihijatrije, ujedinio biologiju, fiziologiju, psihopatologiju i moralnu filozofiju kako bi u jednom potezu diskvalificirao modernitet. Posvetivši je „učitelju“ Lombrosu, studiju je otvorio saznanjem da degenerici nisu samo prostitutke, kriminalci, luđaci; oni su često i umjetnici te pritom „manifestiraju iste mentalne karakteristike i uglavnom ista somatska obilježja“ (Nordau, 1895: vii). Degeneraciju je dakle transferirao u područje književnosti i glazbe, a dekadenciju je vrednovao kao epidemiju, pokretačku snagu koja vodi propasti moderne civilizacije, te konstatirao da je ona najraširenija u Francuskoj, u kojoj su se findesiècleovske bolesti pojavile prvi put, zadobivši svoju najoriginalniju formu. U njegovu se viđenju, sasvim ukratko izneseno, dekadencija izjednačuje s izopačenošću. Dokaze dekadentne umjetnosti pronalazio je u psihologiji autora, s osnovnom postavkom da se u modernoga čovjeka pojavljuju dva poremećaja: degeneracija i histerija, odnosno neurastenija kao njezina sekundarna manifestacija. Vodeći se za tezom da je dekadencija u književnosti pokazatelj dekadencije društva uopće, utvrdio je da su umjetnici prijeteći glasovi te degenerirane moderne kulture. U Nordauovu scenariju svi oni, glorificirajući perverziju, nemoral i društveni kaos, vode Europu prema sanjarskoj dekadenciji, ohrabrujući i svoju publiku da s njima pohrli u malaksalost. Degeneracija te izopačene inteligencije zarazna je za ionako nervoznu i mentalno nestabilnu publiku. To je dakle spiritus movens svih estetičkih škola: umjetnik proglasi formiranje nove tendencije, koja je proizvod njegove poremećene 
naravi, a potom se „drugi degenerirani, histerični, neurastenični umovi skupljaju oko njega, primaju novu doktrinu s njegovih usana te žive samo da bi je propagirali““ (ibid.: 31). Pritom je sve dekadentne umjetničke pravce sveo na tri osnovne kliničke slike - misticizam, egomaniju i lažni realizam - te u njima otkrio „nepravilnu aktivnost mozga iz koje proizlaze slabost volje, nepažnja, dominacija emocija, nedostatak znanja, izostanak simpatije ili interesa za svijet i čovječanstvo, atrofija koncepata dužnosti i moralnosti““ (ibid.: 536). ${ }^{31}$ Duševna iscrpljenost i melankolija, kao specifična moderna stanja i pokazatelji „onemoćaloga živčanog sustava“ (ibid.), zajednički su simptom svih dekadentnih umjetničkih škola.

Nordauova je početna točka Morelova definicija degeneracije kao morbidne devijacije u odnosu na originalan tip, tj. „,normalan“ oblik. Prema toj je poziciji sve devijantne osobine umjetnika proglasio atavizmima, označivši ih kao ,jedno od njezinih najkarakterističnijih obilježja“ (ibid.: 555). Ocijenivši da su moderne duševne bolesti regresija, korak unazad k primitivnijem stupnju ljudske vrste, utvrdio je da na njih - iako su sve varijante degeneracije uvjetovane i somatski, jer svoje podrijetlo vuku iz biomehaničkih i biokemijskih procesa u živčanoj stanici - bitno utječu i vanjski čimbenici, tj. okolina kojom je degenerik okružen. Najvjerojatnije pod Beardovim utjecajem koncepta neurastenije, mentalne aberacije svojih suvremenika pripisao je, uz pretjeranu konzumaciju alkohola, duhana i narkotika, intenzivnim moždanim napetostima generiranima urbanizacijom $\mathrm{i}$ industrijalizacijom, $\mathrm{tj}$. uvjetima modernoga velegradskog života. A kao izravan nusprodukt tih različitih modernizacijskih procesa obilježio je zamor koji rezultira upravo degeneracijom. Stanja iscrpljenosti i slabosti izravne su posljedice tehnološkoga, industrijskoga i urbanoga razvoja civilizacije, teza je koja dominira Nordauovom studijom, te se zato može govoriti o suvremenim patološkim fenomenima. Prema tome sav psihopatološki materijal kojim se u knjizi bavi posljedica je toga „prekomjernog organskog trošenja“ (ibid.: 43) zbog brzoga tempa života u metropolama. Samo se najsposobniji mogu prilagoditi urbanomu, dok na druge taj raspad organskoga integriteta djeluje pogubno.

Sve te društvene aktivnosti, pa čak i najjednostavnije, pretpostavljaju aktivaciju živčanoga sustava. Svaki redak koji napišemo ili pročitamo, svako lice koje vidimo, svaki razgovor koji obavimo, svaka scena koju percipiramo aktivira naše osjetilne živce i naš moždani centar. Čak

\footnotetext{
${ }^{31}$ Svjestan njihovih glavnih razlika, naveo je da se misticizam ogleda u ,nesposobnosti pozornosti, jasne misli i kontrole emocije, a glavni mu je uzrok slabost cerebralnih centara“, da je egomanija ,posljedica pogrešnoga prijenosa osjetilnih živaca, otupjelih centara percepcije, aberacija instinkata od žudnje za snažnim impresijama te prevlast organskoga osjeta nad reprezentativnom sviješću“, a da lažni realizam karakterizira ,pesimizam, sklonost raskalašenim idejama te najvulgarniji i najnečistiji načini izražavanja“" (Nordau, 1895: 536).
} 
i putovanje željeznicom, koje i ne osvještavamo, stalna buka i različito znakovlje na ulicama velegrada, neizvjesnost u iščekivanju nekoga događaja (...) troše naš mozak kontinuirano. U posljednjih pedesetak godina populacija se u Europi nije udvostručila, ali je zato zbroj naših napora deseterostruk, ponekad i pedeseterostruk. Svaki civilizirani pojedinac u ovom trenutku daje od pet do dvadesetpet puta više napora nego što se to od njega zahtijevalo prije pola stoljeća. (ibid.: 39)

Dakle degeneracija i histerija, odnosno neurastenija, izravne su konzekvencije slabosti volje. U degenerika, čiji mozak i živčani sustav pate od naslijeđenih malformacija i nepravilnosti, i histerika, koji je žrtva potrošenosti, volja postoji u izrazito niskom stupnju. A posljedica je pak njezine malaksalosti nesposobnost pozornosti. Budući da je volja, kao mehanizam koji čovjeka priprema na suočavanje sa životnom svakidašnjicom, u njih onemoćala, posljedična slabost pozornosti uzrokuje pogrešne procjene o objektivnom svijetu, a svijest pritom poprima iskrivljenu, zamagljenu perspektivu. Zbog iscrpljene volje oni nisu u stanju upravljati svojim opsesijama, oduprijeti se impulsima, kontrolirati raspoloženja. Umišljajući da će postaviti relevantniju dijagnozu degeneracije od svojih prethodnika, Nordau dodaje da je Morel prekomjernoj razdražljivosti kao osnovi svih vrsta fobija trebao pridodati „,cerebralnu debilnost koja implicira slabost percepcije, volje, pamćenja, procjene, kao i nepažnju i nestabilnost" (ibid.: 243). Tek bi tad uspješno opisao degeneraciju te „spasio“ psihijatriju da se izgubi u nizu krivih pojmova i dijagnoza. Premda svjestan mnoštva simptoma kojima se degeneracija manifestira, kao jednoga joj od glavnih prepoznaje već spomenutu egomaniju te je određuje fiziološkim procesima. Može se naime utvrditi da „sve nefunkcionalnosti i neregularnosti u razvoju degenerika svoje podrijetlo imaju u biokemijskim i biomehaničkim poremećajima moždane stanice, odnosno stanice uopće“ (ibid.: 254), a iz tih anomalija proizlazi nemogućnost dosezanja višega stupnja razvoja ličnosti koji bi izašao izvan okvira vlastite ličnosti, tj. nemogućnost altruizma. I zato, nastavlja Nordau, degenerik uvijek ostaje egomanijak: njegova su osjetila tupa te slabo reagiraju na podražaje vanjskoga svijeta, a osjetilni živci vrlo sporo prenose poticaje do mozga. Za razliku od intenzivne povezanosti senzacija i osjetilnih percepcija u zdravoga čovjeka „svijest emocionalno degeneriranoga subjekta ispunjena je opsesijama koje nisu motivirane vanjskim događajima“ (ibid.: 256$257) .^{32}$

\footnotetext{
${ }^{32}$ Premda su Nordauove procjene odavno nadvladane, a studija proglašena opsesivnom osudom tendencija koje sam autor nije mogao razumjeti, složit ćemo se s Bernheimerom koji pokazuje kako je Degeneracija ipak donekle korisna za fenomenologiju dekadencije (2002: 156). Moglo bi se naveliko razglabati o njegovim promašenim konstatacijama, ali ima u prvim poglavljima knjige tvrdnji vrijednih pozornosti; ponajprije se to odnosi na pregled
} 
Zaključujući ovo poglavlje s Nordauom, mogli bismo sumirati da je razvoj medicinskih i srodnih znanosti omogućio da se u povijesti kulture koncept dekadencije jače odlijepi od naslijeđa romantizma, a interes književnosti za psihopatologiju pojedinca koincidirao je s tim razvojem. Stoga ne čudi što pisci u svim europskim književnostima likove nerijetko portretiraju terminima iz područja psihijatrije i psihologije. U XIX. su stoljeću naime postavljeni temelji psihosomatske medicine te su mnogobrojne tadašnje rasprave imale bitan utjecaj na evoluciju dekadentnoga pisma i uopće na teoriju dekadencije u cijelosti. Koncept degeneracije, ukorijenjen u medicinskoj svijesti druge polovice XIX. stoljeća, vrlo je brzo apliciran u književnoj produkciji koja je otkrila što se krije iza iluzije napretka. Književnost i medicina našli su se na pola puta: „(...) liječnici su se koristili književnicima kao živućim primjerima degeneracije, posebno prema kraju stoljeća, a književnici su svoje teme i ideje tražili u medicinskim istraživanjima.“"(Carter, 1958: 69)

\subsubsection{Neurastenija}

Degenerirano tijelo, izmučeni živci - dijagnoza je to koja je, nerazmrsivo prepletena s problematikom individualizma o kojoj ćemo više govoriti u jednom od sljedećih poglavlja, presudno odredila fin de siècle. Temeljna je pretpostavka toga „nervoznog“ doba bila da u suvremenom (gradskom) životu postoje elementi potencijalno opasni za čovjekovo duševno zdravlje te se u skladu s tim procjenjivalo kako pojedinac sve češće posustaje pod pritiscima svakidašnjega života i rada te u bespoštednoj borbi za golu egzistenciju nerijetko završava slomljene volje, pa se ili prepušta strastima i iracionalnim impulsima ili ga pak iz životne kolotečine izbacuju histerija, neuroza ili neki drugi mentalni poremećaj. Općenito gledano, interes za sve oblike bezuspješnih mentalnih prilagodbi (inferiorna ili superiorna inteligencija, ludilo, živčani poremećaji) bio je iznimno velik jer su oboljenja, vjerovalo se, bila u snažnom porastu. Velik broj osoba sa simptomima poremećaja samo je dodatno otežavao povlačenje granice između običnoga zamora i patološke apatije, ekscentričnosti i ludila. ${ }^{33}$ Naime još se od ranoga XVIII. stoljeća, upozorava Scull, na nervne bolesti gledalo kao na cijenu koju pojedinac mora platiti za razvoj civilizacije: „Ludilo, tvrdili su psihijatri i njihovi saveznici, jest bolest

karakteristika toga vremena, posebno na činjenicu da vrijeme dekadencije određuje kao razdoblje primarno obilježeno disharmonijom i fragmentiranošću.

${ }^{33}$ Minois napominje da i bogatstvo termina „osvjetljava zbunjenost znanstvenih krugova pred tim misterioznim fenomenom slabljenja želje za životom. 'Životna bol' ostaje enigma za 'normalne' ljude i trajni izazov za optimiste" (2005: 248). 
civilizacije i civiliziranih. Nasuprot tomu, to je stanje gotovo nepoznato među 'divljacima' i primitivnim narodima.“ (2018: 243)

Iako nam problematika duševnih bolesti u ovom radu nije u prvom planu, nije naodmet podsjetiti kako su se kroza stoljeća i kulture duševne bolesti, koje su kao zasebna medicinska kategorija iskrsnule oko polovice XIX. stoljeća (usp. Shiraev, 2015), percipirale kao nešto krajnje atipično te su se ocjenjivale nepoželjnima i, u najmanju ruku, riskantnima, nerijetko i opasnima. Bile su naime neodvojive od volje i moralnosti, tj. od svih društvenih silnica koje su činile jednu naciju. A među tim su oboljenjima pozornost liječnika posebno privlačili ludilo, neuroza i histerija. Ludilo se, grubo rečeno, odnosilo uglavnom na dvije skupine sasvim suprotnih simptoma: s jedne se strane karakteriziralo kao agresivno, nerijetko nasilno ponašanje s ekstremnim emocionalnim ispadima, a s druge kao smanjena motivacija i izrazito snažan nedostatak volje, želje ili emocije. Neurozom se pak obuhvaćala ustrajna, sveprožimajuća tjeskoba, a neurotici su, za razliku od pacijenata kojima je dijagnosticirano ludilo, bili svjesni svoga stanja, odnosno nisu imali poteškoća u razumijevanju stvarnosti. Budući da se ideja kako zamor, odnosno iscrpljenost živčanoga sustava, uzrokuje abnormalne tjelesne simptome umnogome proširila, na velika je vrata uvedeno uvjerenje da pojedinac koji je pod stalnim pritiskom riskira razvijanje nekoga od neurotičnih oboljenja.

Prve tragove moderne upotrebe pojma neuroze u povijesti medicine i znanosti uopće López Piñero pronalazi na početku XVIII. stoljeća, kad taj koncept iskače kao alternativa galenskoj doktrini histerije (1983: 4). Termin je pak u 1760-ima skovao škotski liječnik William Cullen, kao neku vrstu neologizma za neurotično oboljenje, kako bi njime obuhvatio duševne poremećaje koji se nisu mogli objasniti organskim ozljedama, a nakon njegove inauguracije kroz mnogobrojne znanstvene i stručne radove dospjelo se do modernoga razumijevanja toga poremećaja, na što je naročito utjecalo novo shvaćanje bolesti i zdravlja. Naime nakon polovice XIX. stoljeća u psihijatriji se počelo govoriti o nejasnim granicama između zdravlja i bolesti, o maglovito određenoj zoni ,poluluđaka“. Neuroza se u takvoj konstelaciji, funkcionirajući poput sive zone između potpunoga zdravlja i ozbiljnih duševnih poremećaja (kao što je psihoza), postavila kao graničan slučaj, iznimno se brzo učvrstivši i u medicinskoj zajednici i u općoj populaciji.

Ovaj konceptualni izraz s vremenom je rezultirao artikulacijom dviju kategorija fundamentalnih za psihijatriju u XX. stoljeću: „psihotični“, čiji je kontakt s realnošću ozbiljno narušen, i „neurotični“, koji uz minimalne neadekvatne prilagodbe ostaju dijelom društva. (Goldstein, 2004: 1364) 
Prema tome teza da je modernizacija sastavni dio fenomena neuroze neosporna je. Borba za život, u doslovnom i prenesenom smislu, nameće intenzivnu aktivnost funkcijama moždanoga sustava, a društveni pritisak simboliziran kroz raznovrsne izazove svakidašnjice djeluje na stradavanje živaca, izazivajući „opstrukciju živčanih vlakana“ (Porter, 2004: 590). Koncept neuroze zasnivao se na ideji o važnosti živčanoga sustava za uspješnu prilagodbu na okolnosti, rezultiravši njezinom specifičnom psihološko-fiziološkom doktrinom. Oni koji su se bezuspješno naprezali da zadovolje društvena očekivanja našli su se paralizirani, preplavljeni simptomima zbog kojih su gubili i kontrolu nad svojim tijelom. Neuroza stoga nije samo medicinska dijagnoza, nego je vrijedna i za razumijevanje kulturnoga i društvenoga moderniteta. Jednako kao i histerija, ona je, s obzirom na to da počiva na sociološkim dihotomijama normalno-abnormalno, prihvatljivo-neprihvatljivo, prilagođeno-neprilagođeno, društvena bolest par excellence. Ne bi li dokazao da se o modernoj neurozi u kojoj čovjek svjedoči vlastitoj dezintegraciji može govoriti i u praktičnim primjerima, Le Rider, baveći se pripadnicima bečke moderne, podsjeća da se Beer-Hofmann žalio na živčane nemire koji su mu ometali san i sposobnost rada, da i Schnitzler piše o tjeskobama kojima se ne uspijeva oduprijeti, da Hofmannsthal savjetuje Leopoldu von Andrianu da se zbog neurastenije obrati liječniku (ni više ni manje nego netom spomenutomu Schnitzleru) te da Altenberg 1896. opisuje kako neka žena pati od hipertrofije sebstva te pritom govori o bolesti živaca (1993: 38). Nedvojbeno je stoga kako su neuroza i neurastenija kao njezina podvrsta te epilepsija i histerija bile bolesti koje su bjesnjele Europom upravo na prijelomu stoljeća. Tek su rijetki sumnjali u činjenicu da među njima osobito neurastenija poprima epidemijske razmjere, pa za ilustraciju dominantnoga stajališta izdvajamo Krafft-Ebinga koji u studiji $O$ zdravim $i$ bolesnim živcima već 1885. govori o živčanoj slabosti kao oznaci cijele generacije (prema Gijswijt-Hofstra i Porter, 2001: 184). U njegovu prikazu gradskoga života čovjek je užasnut političkim turbulencijama, tržišnim previranjima, ratom i nizom drugih zbivanja, pa u skladu $\mathrm{s}$ Darwinovom i Spencerovom teorijom evolucije glavni moto moderne civilizacije postaje „borba za opstanak“ (Pietikainen, 2007: 49).

Posebno mjesto u devetnaestostoljetnoj medicinskoj i društvenoj povijesti zauzima neurastenija, oblik neuroze koji se kao uzoran primjer spomenute mentalne neprilagođenosti krajem XIX. stoljeća postavlja kao nova svjetska bolest, kao reakcija na spomenuti nemilosrdni pritisak modernoga društvenog života. Kako sažima Pietikainen:

U desetljećima između ujedinjenja Njemačke (1870) i Prvoga svjetskog rata zapadna su se društva silovito i brzo mijenjala. Društveni, politički i kulturološki fenomeni koji su bili glavni 
pokretači moderniteta (industrijalizacija, urbanizacija, radna specijalizacija, antagonizam između buržoazije i proletarijata, nove tehnologije itd.) činili su ljude „nervoznima“. (2007: 341)

Neurastenija, patološka forma mentalne iscrpljenosti, jest rastrojenost živčanoga sustava, odnosno opće opadanje snage živaca koje se manifestira različitim simptomima, među kojima se kao najčešći navode kronična opća tjelesna i duševna malaksalost, bezvoljnost, nesanica i razdražljivost. Budući da se u svim nosografijama povezivala sa živčanim sustavom, nije naodmet istaknuti kako je u XVIII. i XIX. stoljeću živcima pripalo središnje mjesto u medicinskim teorijama zamora, tj. iscrpljenosti. Iscrpljenost se naime percipirala ponajprije kao živčana iscrpljenost, odnosno kao stanje definirano slabošću živaca, koje je moglo bitno djelovati na čovjekov karakter. Veliku je ulogu u prezentaciji iscrpljenosti kao poremećaja odigrao engleski liječnik John Brown koji je u svojim Osnovama medicine iz 1770. iznio vitalističku teoriju prema kojoj sve bolesti dolaze od suviška ili manjka energije - koja je prema njemu bit života - pa se sukladno tome može govoriti o steniji ili asteniji (prema Schaffner, 2016: 89). Uostalom, sjetimo li se uvodne cjeline u kojoj smo napomenuli kako se o kraju XIX. stoljeća beziznimno govori kao o „nervoznom“ dobu, možemo podcrtati da ta anamneza nije bila samo individualno oboljenje nego i kolektivna dijagnoza. „Živci su se pretvorili u najveću slabost civilizacije te su prijetili stabilnosti i pojedinačnoga i društvenoga tijela.“ (ibid.: 91)

Dakle u osnovama je neurastenije teza o krhkosti ljudske prirode i neravnoteži uma, odnosno ideja da kao što tijelu uvijek prijeti bolest, tako i umu uvijek prijeti ludilo. Premda se, kao što smo rekli, postavila primarno kao bolest modernoga doba, „urbani“ poremećaj, Porter ističe da se još za prosvjetiteljstva inzistiralo na kulturnoj etiologiji nervoze, tj. na njezinoj vezi s razvojem urbaniteta, koji čovjeka čini prijemčivim za sve vrste živčanih poremećaja, što je, kako vidimo, erumpiralo u XIX. stoljeću. Tad je koncept stekao široku popularnost u medicinskim krugovima:

U prosvjetiteljskom konceptu toga pojma bilo je nešto donekle prihvatljivo: bolest je civilizacije značila superiornost duha, talenta ili stila, ponekad i otpornosti i dugovječnosti. To se sad mijenja. Tamna strana pojma postaje dominantna. (Porter, 2004: 592)

U to ju je vrijeme posebno obilježila pretpostavka kako je ona kao psihičko oboljenje ujedno pokazatelj moralne regresije pojedinca te na taj način indikacija puno većega problema: propadanja civilizacije. Kako smo utvrdili i u slučaju degeneracije, u podlozi je gotovo svih 
njezinih prikaza te načina tretiranja i izlječenja uvjerenje da društvo treba počivati na zdravim i čvrstim temeljima. A u dominantnom stajalištu kako samo zajednica sa zdravim pojedincima, a ne egomanijacima, da se referiramo na Nordauovu diskvalifikaciju, može opstati krila se teza da širenje neurastenije implicira i rast individualizma, koji se također dovodio u vezu $\mathrm{s}$ destrukcijom čovječanstva. Postojala je opasnost da nacija, obremenjena zamorom u kojem strast trijumfira nad razumom, a ne obratno kako bi bilo poželjno, bude dokraja prepuštena pritiscima volje, emocija i svih drugih neprijatelja poretka produktivnosti (Rabinbach, 1992: 146-147). Već smo istaknuli da su izrazi te opasne dominacije fizičkoga i psihičkoga umora bili najvidljiviji u srednjoškolaca, o kojima se u medicinskim izvješćima piše kao o generacijama iscrpljenima intelektualnim radom i sjedilačkim načinom života (ibid.). Tomu u prilog ide i eksperiment koji je Hermann Griesbach, jedan od pionirskih njemačkih proučavatelja mentalnoga zamora krajem XIX. stoljeća, proveo na gimnazijskim učenicima $i$ mladim radnicima u obrtničkim i industrijskim radionicama. Dokumentiravši nevjerojatan intenzitet duševnoga umora u prvoj skupini, utvrdio je da je intelektualni rad zamorniji od posla u teškoj industriji ili uredu. I druga su istraživanja mahom pokazivala da se mentalni zamor, što tvrdimo otpočetka, može direktno povezati sa zahtjevima moderniteta. To je najočitije u njegovoj najekstremnijoj formi, neurasteniji.

Pojam neurastenije prvi je opisao američki psihijatar i neurolog George Beard 1869, definiravši je kao morbidno stanje živčanoga sustava obilježeno polimorfizmom simptoma. Medicina je naime duševnim poremećajima dotad prilazila s velikom dozom skepse. Budući da su u pacijenata često izostajali fizički simptomi bolesti, proglašavalo se da je „sve to u njihovoj glavi“" te se bolest shvaćala kao poza. Zamijetivši porast poremećaja u kojima su se pacijenti žalili na anksioznost, iracionalne strahove i perverznu seksualnost, Beard kao dijagnozu postavlja neurasteniju, poremećaj koji je moždanomu sustavu ono što je anemija vaskularnomu - nedostatak snage - te pojašnjava da se najčešće pojavljuje u naprednijim, intelektualno razvijenijim društvima kao neka vrsta kompenzacijskoga odgovora na progres i uglađenost (1869: 217). A zatim ju je u knjigama Praktična rasprava o živčanoj iscrpljenosti (1880), Američka nervoza (1881) i Seksualna neurastenija (1884) stabilizirao kao glavni termin, kojim je obuhvatio sve varijante moždane iscrpljenosti, navevši joj više od 50 simptoma te je proglasivši funkcionalnom bolešću. Uz tjelesni i mentalni zamor kao dominantne znakove, izdvojio je cijeli niz fizičkih i psihičkih manifestacija koje ju prate, od raširenih zjenica, migrena, šumova u ušima, dispepsije, spazama mišića preko ekstremnoga beznađa i nemira, fobije, tjeskobe i poremećaja pozornosti do nesanice, drhtanja i impotencije (Beard, 1881: 7- 
8), oslobodivši je na taj način „stigme koja bi se mogla pripisati jednoj duševnoj bolesti““(Schaffner, 2016: 92).

Beard je vjerovao da neurastenične simptome uzrokuje moždana slabost izazvana organskim čimbenicima, odnosno nesposobnost mozga te probavnoga i reproduktivnoga sustava da „obradi“ ekstremnu zahtjevnost modernoga života, osobito svakidašnjice u metropoli: industrijalizacija, urbanizacija, razvoj željezničkoga prometa, nove komunikacijske tehnologije - jednom riječju, modernitet. Dakle podliježu joj osobe čiji je živčani sustav neadekvatan podražajima svakidašnjega života, odnosno najrazličitijim proizvodima modernosti: „,snaga pare, tisak, telegraf, znanosti i mentalna aktivnost žena“ (Beard, 1881: 96). Interpretiravši je na taj način kao poremećaj suvremenoga društva, nazvao ju je „bolešću moderne civilizacije i to pretežno XIX. stoljeća“ te specifičnim američkim poremećajem (Beard, 1880: 3) ${ }^{34}$ No termin se vrlo brzo proširio europskim prostorom te su Beardove knjige prevedene na njemački i francuski i vrlo uspjelo aplicirane na europsku duhovnost. Ako je suditi prema uzrocima te duševne bolesti koje europski psihijatri detektiraju, privuklo ih je upravo njegovo stajalište da bi se neurastenija mogla pripisati šokovima moderniteta. Prema uvriježenom dramatičnom viđenju ona nije bila samo obična bolest nego i

intenzivirana bolest civilizacije koja je rezultat progresa cijeloga prošlog stoljeća; napredovala je do granice da čovječanstvo postaje sjedilačko, intelektualno aktivnije te je manifestacija intelektualne iscrpljenosti, koja je pak osnovni uzrok aktivacije ove neuroze (Rabinbach, 1992: 154).

A razmjeri koje je kao ozbiljan problem moderne zajednice poprimila najbolje su svjedočanstvo pesimistične prirode fin de sièclea. S obzirom na europski kontekst ne iznenađuje što je ideja neurastenije pustila svoje korijenje u Europi, postavši referenta točka u opisu bliske propasti zapadnih društava. Ili, kako primjećuje Goering, „tamo gdje je američki neurastenik bio tek korak do izlječenja, europski je bio samo za koju generaciju udaljen od izumiranja vrste“ (2003: 31). Nećemo onda pretjerati ako kažemo da je postala znak vremena, doživjevši društvenu rekonceptualizaciju. Uspjelo se povezala s popularnim teorijama degeneracije koje su u to vrijeme cirkulirale, ${ }^{35}$ pa ju je primjerice Nordau klasificirao kao mentalnu etiketu

\footnotetext{
34 Dijagnoza neurastenije još je s početkom Prvoga svjetskog rata počela uzmicati te je u modernoj dvadesetostoljetnoj medicini gotovo posve iščezla. Bolest, naravno, nije nestala, nego se počela zvati drugim imenom (uglavnom sindromom kroničnoga umora).

${ }^{35}$ Iako je i Beard utvrdio da može biti i nasljedna, ,prenoseći se na različite načine kroz različite grane obitelji““(1880: 120), tek se u francuskoj psihijatrijskoj literaturi snažno povezala s teorijom naslijeđa.
} 
degeneracije. ${ }^{36}$ A zapravo je premreženost s teorijom naslijeđa pomogla u etiologiji bolesti, omogućivši da se objasni neuropatskom predisponiranošću. Tako da su u operacionalizaciji pojma u europskom prostoru, koji se vrlo uspjelo integrirao u nosografije psihijatrije - mislimo pritom ponajprije na Francusku u kojoj su u posljednjim desetljećima XIX. stoljeća i prvima u XX. stoljeću proliferirale studije o zamoru tijela i duha - supostajale dvije donekle suprotstavljene postavke: s jedne se strane smatrala nasljednim svojstvom, a s druge se vezala za modernitet. No ipak je najveći broj autora procjenjivao da je ona najčešće kombinacija neuropatskih sklonosti i utjecaja modernoga okoliša. Tu je tezu do krajnjih granica doveo Nordau tvrdeći da su razvijenija društva ujedno i slabija te poentirajući da je čovjek pritisnut mahnitim ritmom civilizacije koji umanjuje njegove vitalne snage. Iako se čovječanstvo i prije susretalo s revolucionarnim izumima i pothvatima, koji su iz temelja mijenjali način života narušavajući postojeću ravnotežu, modernizacijski su procesi doista drastično promijenili velegradsku svakidašnjicu. ${ }^{37}$ Durkheimovim riječima:

Za neuropata je svaki dojam izvor nelagode, svaki trenutak napor; njegovi se živci uznemiruju i pri najmanjem kontaktu, kao da su nezaštićeni; izvršavanje inače automatskih fizioloških funkcija izvor je bolnih senzacija. (1951: 14)

Dakle dok su neki autori tvrdili kako su moderne neuroze dokaz dugotrajne disolucije ljudske vrste, ipak ih je većina zauzimala stajalište da su one rezultat novih silnica. KrafftEbingovo i Nordauovo stajalište da promjene $u$ društvenim, trgovačkim, političkim i privrednim odnosima, osobito migracije iz sela u grad, mogu negativno djelovati na čovjeka bilo je općeprihvaćeno. Prema tome kad govorimo o neurasteniji, fokus treba usmjeriti i na urbani rast Europe, koji nam također štošta sugerira o dekadenciji. Na dominantno čuvstvo strepnje i porast različitih mentalnih poremećaja, ponajprije neuroze, jednoglasni su kritičari, utjecao je rast i razvoj gradova, što se drži jednim od glavnih uzroka bolesti civilizacije. Forme dekadencije bile su u isti mah zrcalo urbanoga razvoja i reakcija na njega. Za razumijevanje neuroze i slabljenja volje poglavito je prigodan Simmelov model tragedije moderne kulture, zahvaljujući svomu širokomu zahvatu u kompleksne fenomene koji su opterećivali pojedinca u vremenu ubrzane industrijalizacije.

\footnotetext{
${ }^{36}$ Nordau je neurasteniju smatrao tek sekundarnom manifestacijom jednoga puno većega problema, histerije. Dok prva generacija pati od neurastenije, u drugoj se ona nasljeđuje kao histerija.

${ }^{37}$ Nasuprot tomu neki su teoretičari degeneracije elaborirali da ne postoji veza između razvijenosti civilizacije i umobolnosti, pa naprimjer Maudsley piše da je „najviše ludila ondje gdje ima najmanje ideala, gdje vladaju najjednostavniji osjećaji, najsirovije želje i navade“"(1884: 31).
} 
Iako je čovjek društveno biće, u svojoj aktivnosti usmjereno na interakciju s drugima, njegov se duh opire potpunomu podvrgavanju okolini u kojoj živi i djeluje, nastojeći održati vlastitu individualnost $\mathrm{u}$ susretu s nadindividualnim zajednicama, tj. sačuvati „samostalnost $\mathrm{i}$ osobitost svojega života od nadmoći društva“" (Simmel, 2001: 137). To se nastojanje međutim pokazuje kao paradoksalno ako se uzme u obzir da su spomenute zajednice proizvod toga istog čovjeka koji je sad pod pritiskom djela svojih ruku. U dinamici tehnološkoga razvoja stvara se modernistička razdražljivost koja u uvjetima velegradske napetosti, hektičnoga životnog stila koji „kida“ živce nerijetko rezultira ravnodušnošću. Urbani je razvoj tako neraskidivo premrežen s hipersenzibilnošću suvremenoga čovjeka. Uvidjevši ključne probleme metropola i tamošnjega duhovnog života, Simmel utvrđuje psihološke baze na kojima se razvijaju gradske individualnosti te kao osnovnu karakteristiku izdvaja ,intenziviranje živčanog života koje proizlazi iz brzih i neprekidnih izmjena vanjskih i unutarnjih dojmova“ (ibid.). U gradu je pojedinac suočen s drastičnim izmjenama koje mu se odvijaju pred očima: brzo gomilanje i smjenjivanje slika, susretanje gomile ljudi, objektivna nemogućnost ostvarivanja emocionalne povezanosti, neočekivanost dojmova. Zato Simmel govori o intelektualističkom karakteru velegradskoga života, o činjenici da se razumijevanje i doživljavanje svijeta odvija ponajprije kroz razum, a ne emocije, nasuprot životu „u malom gradu koji je više orijentiran na srce i osjećajne odnose“ (ibid.: 138). Brz tempo, vladavina novca, koji se postavlja kao temelj svih vrijednosti, ${ }^{38}$ i razuma te difuznost gradske zbilje, koja izaziva osjećaj simultanosti, iscrpljuju čovjeka koji na sve promjene, gubeći polagano élan vital, reagira mentalnim poremećajima, nerijetko histerijom i neurastenijom. Tenzije suvremenoga života narušavaju temelje stabilnosti. Kao najvažniju odliku modernoga velegradskog života Simmel navodi blaziranost, nemogućnost čovjeka da adekvatno reagira na promjene, implicitno nudeći izvrsnu definiciju dekadencije kao ravnodušnosti:

Kao što blaziranim čini život bezmjernih užitaka, zato što živce tako dugo pobuđuje na najsnažnije reakcije dok naposljetku više uopće ne reagiraju, tako i bezazleniji dojmovi brzinom i suprotnošću svoje izmjene iznuđuju od živaca tako nasilne odgovore, tako ih brutalno vuku na ovu i onu stranu da oni troše i posljednje rezerve svojih snaga i, ostajući u istoj sredini, nemaju vremena skupiti nove. (ibid.: 141)

\footnotetext{
${ }^{38}$ Kovalevski objašnjava kako trka za novcem potiče čovjeka da pred svoje tijelo postavlja najnevjerojatnije zahtjeve, a njegova smanjena sposobnost da se prilagodi promjenjivim okolnostima svakidašnjice može biti okidač degenerativnoga sindroma (prema White, 2014: 29).
} 
Može se stoga konstatirati da se u apsurdnoj osamljenosti čovjeka okruženoga gomilom izoštrava njegov mentalni sklop te on na gradska strujanja odgovara intenziviranjem svijesti, koja ga istovremeno tjera na umrtvljenje djelovanja. Ta dva dominantna osjećaja, „da je čovek usamljen i neprimećen s jedne strane, i utisak bučnog saobraćaja, neprekidnog kretanja i stalne promene s druge strane“, a koji pak „razvijaju impresionističko gledanje na život u kome se najtananija raspoloženja sjedinjuju s najbržim promenama osećanja“ (Hauzer, 1966: 378), obilježavaju modernoga čovjeka. I zaista, impresionistički obrazac po kojem je svaka pojava jedinstvena i neponovljiva u potpunosti korespondira s dekadentnom perspektivom u kojoj se rastače apsolutistička vizija svijeta, poprimajući karakter fragmentarnoga i trenutnoga.

Možemo dakle poentirati kako je bilo općeprihvaćeno mišljenje da je neurastenija osobito prisutna u velegradovima, koji su najživopisniji simbol patogenosti okoliša te kao centri društvene i intelektualne elite legla poroka i različitih devijacija. Grad isisava životnu snagu. „Vjerovalo se da gradski život čini čovjeka podložnim zamoru i bolesti, dok je hereditarnost bila tempirana genetska bomba skrivena od razuma." (White, 2014: 31) Drukčije rečeno, modernitet je bio patološko stanje. Ili, kako iznosi Blom:

Slika grada-ljudoždera - oči koje blistaju električnim svjetlom, tijelo od kamena i čelika koje istom mjerom istrebljuje i parazite i život i nezasitnom glađu guta svoje stanovnike - potječe od pomahnitalog boga Saturna koji jede vlastitu djecu: stvoritelj koji uništava, metropola kao zlo mjesto, koje siše krv onih koje privuče - vampirski kapitalizam u punom sjaju. (2015: 30)

Nije međutim nevažno da izjednačenje neurastenije s modernošću također reflektira simptomatologiju bolesti: ona je „kakofonija pritužbi koje odražavaju 'pravu' bolest bez ikakvoga primjernog organskog oštećenja“ (Rabinbach, 1992: 154). Stoga joj je jedan od osnovnih problema proizvoljnost i ekstremna subjektivnost, tj. činjenica da dijagnoza često ovisi o pacijentu i njegovoj istini. To objašnjava i deskriptivnu maniju u studijama o njoj, u kojoj se doista opisuje čitav niz fizioloških i duševnih manifestacija. Zato su mnogi, boreći se s maglovitostima termina koji istodobno kazuje sve i ništa, nastojali ponuditi konkretniju etiologiju bolesti, a pritom su klinička istraživanja u kojima su se tražile anatomske anomalije tek u rijetkim slučajevima uspijevala otkriti defekte. Upravo je nedostatak nepobitnih dokaza o strukturalnim, organskim promjenama utjecao na funkcionalno razumijevanje toga poremećaja 
koji je potvrđivao da je riječ o fizički teško dokazivom operativnom slabljenju produktivnosti, koje se očituje kao opadanje vitalnosti, tj. energije. ${ }^{39}$

No, unatoč tomu što je izrazito teško bilo pronaći fizičke promjene u organizmu neurastenika, pozorniji pogled na poremećaj, napose na činjenicu da oni redovito pate od abulije, otkriva da mahom sve teorije počivaju na ideji o neraskidivoj vezi volje i neuroze. Različitim nosografijama neurotičnih poremećaja zajedničko je bilo viđenje pojedinca koji je određen izvanjskim čimbenicima, a toj istoj izvanjskosti ne uspijeva nametnuti vlastiti subjektivitet. Neurozu je tolikim problemom učinilo upravo to suštinsko stanje fizičke pasivnosti. Kao primjer te prevladavajuće teze ovom prilikom možemo izdvojiti klasični priručnik Balleta i Prousta, ${ }^{40}$ koji u pregledu Higijena neurastenije (1897) njezine simptome (tikove, iscrpljenost, anksioznost, insomniju) pripisuju slabosti volje i nedostatku energije te, odbacujući ulogu naslijeđa, konstatiraju da su joj glavni uzroci imperativi modernoga života „u kojima borba za egzistenciju potiče neprekidnu i pretjeranu egzaltaciju funkcija živčanoga sustava“ (Proust i Ballet, 1903: 7). Kao rezultat prekomjernoga napora moždanih vijuga, ona je dakle najraširenija u gradovima, među srednjom i višom klasom, te je proporcionalna intenzitetu društvenih okolnosti. Iako su tvrdili kako je češća u pripadnika mentalno zahtjevnijih zanimanja, nisu držali da intelektualni rad sam po sebi podrazumijeva neurasteniju, nego su je pripisali moralnim pritiscima koje on sa sobom nosi. Neurastenici su, kratko rečeno, žrtve civilizacije. ${ }^{41}$

$$
* * *
$$

Vraćajući se još kratko problematici nejasnih granica između razuma i bezumlja te posredno i problematici dekadencije kao patološkoga, možemo podsjetiti kako se u području mentalnih oboljenja posebna pozornost pridavala ludilu, koje se relativno lako dijagnosticiralo, ali vrlo teško objašnjavalo. Premda se genijalnost izjednačavala s ludilom još od vremena Aristotela i Seneke, kako podsjeća Carter (1958: 64), ta je poveznica u XIX. stoljeću iznova zadobila snažan impuls. Mnogobrojni su autori u svojim djelima, čak i ako se nisu eksplicitno

\footnotetext{
${ }^{39}$ Premda nije bilo dvojbe oko toga da je neurastenija kronična ili akutna iscrpljenost, u medicinskim krugovima nije postojao konsenzus oko organskih uzroka te je njezin prividan „otpor“ zakonima fiziologije nepouzdanim simptomima „samo ojačao potragu za materijalističkim objašnjenjima toga poremećaja“ (Rabinbach, 1992: 163). ${ }^{40}$ Nije nevažno da je Adrien Proust bio otac slavnoga Marcela, koji je i osobno i profesionalno stajao posve izvan konvencionalnosti suvremenoga društva. U Adrienu i Marcelu, tumači Micale govoreći o muškoj histeriji i živčanoj onemoćalosti, reflektiraju se zapravo sve glavne dihotomije vremena: znanost/umjetnost, objektivizam/subjektivizam, zdravo/neurotično, heteroseksualno/homoseksualno (2008: 215). „Međutim dok je otac liječnik stvorio praktičan, moralizirajući medicinski priručnik, sin je stvorio kapitalno književno djelo ranoga europskog modernizma." (ibid.)

${ }^{41}$ Detaljnije o nekim drugim tumačenjima patologije volje pisat ćemo u poglavljima Na putu u otuđenje i Između prirode i društva.
} 
bavili teorijom ludila ili pak nisu posve poistovjećivali talent s ludilom, „demonstrirali rastuću tendenciju isticanja iznimne, abnormalne ili morbidne prirode svakoga izvanrednog talenta“ (ibid.) u gotovo svim umjetničkim područjima. Usprkos divergencijama u razumijevanju genija i ludila zajedničko je uvjerenje bilo da genija redovito prate mentalna oboljenja, posebno neuroze. Genij je dakle u gotovo svim diskursima kroz povijest bio inkarnacija patoloških ekstrema. A u devetnaestostoljetnim ga tumačenjima doista malo toga razlikuje od kriminalca, idiota ili luđaka. Prema Lombrosu, koga je ideja genija posebno zaokupljala, genij pod utjecajem niza objektivnih faktora (među kojima su naslijeđe, primarne organske bolesti, urbani okoliš i klima) može prerasti u pravi mentalni slučaj. U Čovjeku geniju genijalnost tumači kao rezultat oštećenja mozga, odnosno kao jedan oblik degeneracije.

Učestalost deluzija u degeneriranom multiformnom karakteru, gubitka afektivnosti, naslijeđa, posebno u potomaka roditelja alkoholičara, imbecila, idiota ili epileptičara, te iznad svega osebujan karakter inspiracije pokazuju da je genijalnost degenerativna psihoza iz skupine epilepsija. (Lombroso, 1891: 359)

Genija zato određuje kroza sve moguće manifestacije degeneracije: alkoholizam, ludilo, ekstremni egoizam, melankoliju, monomaniju i čitav niz drugih poremećaja. Dekadentni je genij u njegovim očima pravi neurotičar te prema njemu kreira kategoriju književnih i umjetničkih mattoida (među njih smješta i dekadentne pjesnike). Mattoid je zapravo u toj nomenklaturi graničan slučaj između zdravoga i bolesnoga, pojedinac koji po nekim osobinama nalikuje geniju, ali je zapravo „običan“ “ čovjek. ${ }^{42}$ Neovisno o tim diskvalifikacijama, kako objašnjava Hurley, Lombrosova je teorija u svojoj implikaciji da genij na štetu vlastitoga zdravlja pridonosi napretku znanosti, kulture i filozofije, dobroćudna. „Drugim riječima, morbidna biološka aberacija, degenerirani genij bio je, paradoksalno, najvrednije oruđe društvene evolucije.“ (Hurley, 2004: 77) A Lombrosov kontinuiran pokušaj da umjetničku i znanstvenu darovitost lokalizira u živčane strukture dobar je pokazatelj dominantnoga nastojanja psihijatrije XIX. stoljeća da medicinskim patografijama protumači umjetničke slučajeve koje je iz raznoraznih razloga smatrala morbidnima, odnosno njezina pokušaja da umjetnost reducira na medicinske termine. U takvom se viđenju književnost nerijetko držala nekom vrstom epifenomena shvatljivoga jedino kroz medicinu.

\footnotetext{
${ }^{42} \mathrm{Za}$ to vrijeme Nordau prekida sve veze s autorima, pa i s Lombrosom, koji tvrde da su degenerici nerijetko originalni, briljantni i domišljati te utvrđuje da umjetničke aktivnosti privlače ljude slaboga, nerazvijenoga intelekta.
} 
Završavajući ovu cjelinu kraćim odlomkom o ludilu, posve prikladno poglavlje o anatomiji dekadencije zaokružujemo, uspostavljajući vezu s uvodnim tekstom u kojem smo objasnili kako se ona gotovo redovito držala nekom vrstom patologije, idejom bezumlja, u smislu poremećaja uma, osjećaja i/ili intelekta. Ono kao čuvstvo izdvojenosti od zdravorazumskoga svijeta, u kojem iluzorno vjerujemo da obitavamo, „prkosi našem osjećaju do same granice što znači biti čovjekom“(Scull, 2018: 13).

\section{8. „Slavenska duša“}

Hrvatski lik dekadenta, nesumnjivo je, dio svoga karaktera duguje ruskomu suvišnomu čovjeku, jednoj od najistaknutijih figura u ruskoj književnoj i intelektualnoj povijesti koja se pojavljuje „ne samo kao književni tip nego i kao paradigma osobe koja je izgubila svoju uporišnu točku, svoje mjesto i prisutnost u životu: suvišni je čovjek čovjek bez utočišta“" (Patterson, 1995: 2). Iako je svojstven ruskoj književnosti oko sredine XIX. stoljeća, ideja suvišnoga čovjeka postala je dio širega kulturološkog promatranja konformizma odnosno nonkonformizma. Ta teza navodi na činjenicu da je sam termin prilično neprecizno definiran jer, ako bi se suvišnost u najširem smislu mogla odrediti kao pobuna i nepodobnost, tad bi listu suvišnih likova itekako valjalo produljiti. Unatoč tomu njime ćemo se nastaviti koristiti u ovom pregledu njegovih osnovnih karakteristika, koje u stanovitoj mjeri prepoznajemo i kao odlike našega dekadenta.

No, prije izlaganja tih osnovnih crta pogledajmo zašto je uopće ruski suvišni čovjek kao prototip dekadenta uspjelo zaživio i u hrvatskoj književnosti. Kritika je prilično složna u konstataciji da su gotovo svi naši dekadenti ,ništa drugo do jedne varijante oblomovskoga i turgenjevljevskog 'suvišnoga čovjeka'“ (Milanja, 2002: 291). Neupitno je da su naši književnici, držimo i mi, zapravo modernizirali ruske pasivne plemiće, uklapajući ih u svoje prozne modele likova, te da su kombinacijom zapadnoeuropske, prije svega filozofske tradicije i naslijeđa „slavenske duše“ stvorili specifičan muški lik. Prema Badaliću utjecaj ruskih pisaca - među njima osobito Turgenjeva, jednoga od najprevođenijih Rusa u nas - može se objasniti sličnošću ruske i hrvatske socijalne strukture:

Sredina je to, i u Rusiji i kod nas, koju karakterizira feudalizam u agoniji: ukidanje kmetstva u Rusiji (1861) kao i uklanjanje posljednjih feudalnih privilegija kod nas (...) obilježuju i kod nas 
i u Rusiji postepeno silaženje s vlasti jedne klase koja je stoljećima bila nosiocem materijalne i duhovne kulture svoje narodne sredine. (1972: 293)

Dakle srodna materijalna podloga i duhovna atmosfera uvjetovale su recepciju suvišnih ljudi koji se, iako proizvod ruske društvene stvarnosti, vrlo lako ukorjenjuju u hrvatsku sredinu. Hrvatska težnja za oslobađanjem od austrougarske vlasti te ispunjenjem nacionalne slobode „nalazila je u Rusiji moćno uporište - od Jurja Križanića do sloma Austro-Ugarske - pa je tako i hrvatska književnost tražila stanovit afinitet $u$ ruskom i hrvatskom književnom stvaralaštvu“ (ibid.: 294). Postojali su naime određeni nacionalno-psihološki suodnosi svojstveni i ruskom i hrvatskom okruženju, koji su bili odraz jedinstvenih devetnaestostoljetnih društveno-političkih prilika u objema zemljama. U bliskom prostornom i vremenskom okviru problematika se nametnula sama od sebe, odrazivši se kao specifičan oblik „turgenjevštine“. Pronalazeći u suvišnim ljudima svoju sliku i priliku, kako cinično komentira Prohaska (1919: 4), hrvatski dekadenti na sebe preuzimaju samo „najbolje“ od suvišnoga čovjeka, gubeći se također $\mathrm{u}$ onemoćalom stajalištu pasivnosti i jalovim kontemplacijama, nesposobni da na vlastitim leđima iznesu svoje probleme. Napose pod utjecajem Turgenjeva, mentora hrvatskih realista (usp. Badalić, 1972; Flaker, 1968), naši pisci iznose srodnu tematiku konkretiziranu hrvatskim društvenim prilikama. Kako rezimira Badalić, govoreći o Nehajevljevu Andrijaševiću te pritom na jednom mjestu okupljajući sve bitne karakteristike hrvatskoga dekadenta:

(...) privezani uz svoju društvenu sredinu svim svojim dobrim i naopakim životnim manifestacijama dotle, da zbir njihovih osobina, pozitivnih i negativnih, tvore u svojoj konkretizaciji nešto pretežito naše, krvno, povezano s našom teškomučnom društvenom stvarnošću pogubnoga khuenovskoga razdoblja: u zagušljivoj atmosferi khuenovštine nečujno su se srozavali i pogibali bezbrojni naši proletarizirani talenti - u vinu i bezvoljnom glavinjanju kao „suvišni ljudi“, nepotrebni ni sebi ni drugima. (1972: 344)

U galeriji izvornoga suvišnog čovjeka, koji počiva na specifičnoj duhovnoj i političkodruštvenoj klimi vremena, mahom su indolentni plemići, aristokrati nenavikli na rad, nerijetko visokoobrazovani i talentirani, spriječeni nekom nevjerojatnom iscrpljenošću u carstvu melankolije da aktivno djeluju. Bijeg od života i aktivnosti koji vodi izolaciji i paralizi uma i volje, što pak rezultira neprilagođenošću, pa time i osjećajem suvišnosti. Turgenjevljevi Čulkaturin, protagonist Dnevnika suvišnoga čovjeka iz 1850. kojim je termin populariziran, 
Bazarov i Rudin, Ljermontovljev Pečorin, Puškinov Onjegin, Herzenov Beltov, Gončarovljev Oblomov, nabrojimo tek najpoznatije. Apatija prema svemu što se oko njih događa i bezvoljnost, nerijetko i blaziranost proizlaze iz njihova odgoja i položaja u društvu, ${ }^{43} \mathrm{iz}$ intelektualnoga i moralnoga razvoja te iz društvenoga konteksta. Likovi s dobrim izgledima za uspjeh, koji ipak nikad ne uspijevaju ostvariti. S vremenom je koncept suvišnoga čovjeka prerastao značenje puke fizičke neaktivnosti, nerada i dangubljenja te otkrio svaku duhovnu inertnost, ponajprije intelektualnu zapuštenost i propadanje duha.

Možda je najekstremniji tip suvišnoga čovjeka, odnosno po nekim kritičarima njegov potomak, Oblomov, prema komu je Dobroljubov skovao pojam oblomovštine kao autohtone „tvorevine ruskog života, znamenje vremena“ (1966: 94) te ga transponirao na višu instanciju, označivši njime cjelokupno rusko plemstvo nenaviklo na praktičan rad. ${ }^{44}$ Ekstremno inertan, beskoristan i ravnodušan, Oblomov utemeljuje „svjetonazor 'dembela' koji bi željeli da im pečeni pilići sami padaju u usta (...), a da pri tom ni prstom ne pomaknu“ (Matutinović, 1973: 49).

On je stupio u službu - i nije mogao da shvati zašto se pišu akta; a pošto to nije shvatio, nije našao nikakvog boljeg izlaza nego da dâ ostavku i da ništa ne piše. On je i učio - i nije znao čemu može da mu posluži nauka; pošto to nije doznao, odlučio je da složi knjige u kut i da ravnodušno gleda kako ih pokriva prašina. On je odlazio i u društvo - i nije umio da objasni sebi zašto ljudi odlaze u goste; pošto to nije objasnio, odbacio je sva svoja poznanstva i po čitave dane ležao kod kuće na divanu. (...) Sve mu je dosadilo i ogadilo, i on je ljenčario, s punim, svjesnim prezirom prema „mravljem radu ljudi“, koji se satiru i znoje bog bi znao zbog čega... (Dobroljubov, 1966: 102)

Takvoga suvišnog čovjeka valja pokušati shvatiti u tradiciji snažnoga utjecaja pravoslavlja na razvoj zajednice te iz nje proizašle tendencije privilegiranja kolektiva iznad pojedinca (usp. Chances, 2001; Hamren, 2011). Religija je tijekom razvoja ruske civilizacije osiguravala stabilnost i osjećaj zajedništva sve dok se nije gotovo posve izjednačila $\mathrm{s}$ nacionalnim identitetom. „Izgubiti moralni kompas značilo je biti izopćen iz vjerske zajednice, pa prema tome i iz društva, i obratno.“ (Hamren, 2011: 11) Princip kolektiva iznad pojedinca

\footnotetext{
43 „Još od malena navikao je da bude lijenčina zahvaljujući tome što je imao tko da mu i prinese i uradi; zato on često i protiv svoje volje besposliči i uživa.“ (Dobroljubov, 1966: 95)

44 Morazé potvrđuje kako je Gončarov bio opčinjen banalnim životima, rastakanjem volje pod pritiscima razočaranja i poraza, a Oblomovljevu ,apatičnost, svojstvenu tolikim pripadnicima ruske zemljoposjedničke aristokracije koja se zalijenila zahvaljujući instituciji kmetstva, pisac je tako uspješno karikirao da je riječ 'oblomovština' ušla u svakodnevni govor" (1976: 174).
} 
implicirao je i osudu svakoga tko pokuša voditi samostalan, neovisan život. Tradicionalna su se vjerovanja sukobila s drugom matricom, prema kojoj su Rusi obrazovani na Zapadu osjetili da se budućnost zemlje može zasnivati na novim, zapadnjačkim vrijednostima individualizma i ratia. A to iskustvo pozapadnjačenih Rusa, koji su se sa studija u Europi vraćali u domovinu, indirektno se očituje i u portretiranju suvišnoga čovjeka. Dakle razumjeti suvišnoga čovjeka, ali time i hrvatskoga dekadenta, u nekoj mjeri znači razumjeti kulturnu borbu „sofisticiranije“ zapadne filozofije i ,instinktivnijega“ slavenskog naslijeđa. ${ }^{45}$ Naime oba književna tipa možemo promatrati kao potomke te veze između zapadne misli i slavenske duše (ibid.: 5). ${ }^{46}$ Suvišni je čovjek stoga tipičan proizvod tih dviju sfera, ruske kulture i „zapadnoga“ obrazovanja. I to mu je primarna karakteristika: kao kulturni hibrid on je previše Rus da bi bio zapadnjak, previše zapadnjak da bi bio Rus. Stranac u vlastitoj, stranac u tuđoj zemlji. Intelektualac često bolno svjestan činjenice da se znanje i iskustvo vrlo teško mogu pretvoriti u trajne vrijednosti, čovjek čije dostojanstvo potkopava suočavanje s realnošću.

Neovisno o književnim varijantama i fazama u razvoju, ${ }^{47}$ suvišnoga čovjeka obilježava pobuna protiv društva, koja uključuje borbu protiv ustaljenih obrazaca osjećanja i ponašanja. Cijena je te borbe dvostruka deformacija njegove osobnosti. S jedne strane, kako elaborira Friedeberg Seeley (1952), pobuna dovodi do hipertrofije individualnosti (ekstremnoga subjektivizma), dok s druge porast egoističnih emocija onemogućuje druga čuvstva jer se sve snage troše u službi dominantne personalnosti. „Taj egoizam i emocionalna inhibicija - dvije strane istoga razvoja - omogućile su fiziološko objašnjenje nesposobnosti suvišnoga čovjeka za osobne odnose i konstruktivno djelovanje.“ (Friedeberg Seeley, 1952: 112)

Gotovo je paradoksalno da je suvišni čovjek suvišan upravo društvu koje najbolje poznaje. Nepotreban mu je jer ga je prozreo. Uočavajući ono što mnogi ne vide, on primjećuje rasipanje vrijednosti te svoju nesposobnost da stvori nove. Zato Hamren govori o nepostojanju

\footnotetext{
${ }^{45}$ Odnosno, Nehajevljevim riječima: „Istina: Gogolj, Turgenjev, Dostojevski i Tolstoj unijeli su tipove ruske, život ruskoga sela i društva u evropske knjige; no pogled na to sve, ideja, duševna dispozicija umjetnička odgovarala je nivou Zapada: zvali se oni slavjanofili ili zapadnjaci, sve su ih jednako tištala pitanja društvenog razvitka njihova doba.“ (cit. prema Badalić, 1967: 392)

${ }^{46}$ Morazé taj dualizam prepoznaje kao specifikum cjelokupne ruske književnosti: on se očituje u podjeli ruske književnosti između ,puškinske“ i ,gogoljske“ tradicije, odnosno zapadnjačke usmjerenosti i slavenofilstva. U toj je perspektivi Turgenjev zapadnjak, a Dostojevski slavenofil. On pak na vrlo osobit i sveobuhvatan način iznosi svoj slavenofilski dekadentizam, u kojem produbljuje teme koje su obrađivali autori francuskoga romantizma. „Djelo Dostojevskoga bilo je neobičnim stjecajem okolnosti izvanredno značajno za dekadente 'fin de sièclea', koji su upravo kroz njega otkrili svoju sklonost za 'frenetičnu književnost'. Odnosi između spolova u Dostojevskoga su često slični onima što ih analiziraju dekadenti: u njima je muškarac sveden na to da igra ulogu žene, a žena, s druge strane, izgleda svojevoljna i premoćna.“ (Morazé, 1976: 176)

47 Friedeberg Seeley prepoznaje tri faze u razvoju suvišnoga čovjeka od 1815. do 1855: 1820-ih dendi, s Onjeginom kao prototipom, 1830-ih ,demon revolta“, s Pečorinom kao glavnim predstavnikom i vrhuncem koncepta, te 1840-ih propovjednik, s Rudinom u središtu, junakom koji stoji na raskrižju te vodi ili novim zapadnjačkim eksperimentima (poput nihilizma) ili stagnaciji lika (1952: 97).
} 
vrijednosti u suvišnoga čovjeka te o posljedičnom izostanku svakoga životnog usmjerenja kao onom što ga odvaja od literarnih utjelovljenja drugih intelektualaca (2001: 16). On, jednostavno rečeno, skončava bez vrijednosti, a ekstremna ga sposobnost spoznaje svijeta pretvara u jednoga od najogorčenijih književnih likova. Ne samo da nije sposoban povezati se s ljudima iz svoga okružja nego i ne uspijeva povezati se s ljudima sličnima sebi, koji također stoje između dvaju svjetova.

Vrlo je slično u Burrowoj interpretaciji suvišni čovjek primjer potrage za emancipiranim, ali nedostižnom sebstvom (2000: 148). Kako je već ovdje rečeno, ruska je inteligencija pod utjecajem Zapada snažno osjećala vlastitu iskorijenjenost, a žrtve tih okolnosti bile su osuđene na „stalnu anksioznu samosvijest, koja isključuje akciju ili obvezu, te im život raspršuje u riječi i preispitivanju samoga sebe, paraliziranoga kronično iscrpljenom voljom“ (ibid.). To je dijagnoza vječne potrage za istinom i vlastitim ,ja“ koje ne priznaje ništa drugo osim svojih principa. Prema tome fundamentalna je oznaka suvišnoga čovjeka otuđenje od okoline, što pak vodi skepsi i pasivnosti. Zato se on nerijetko opisuje kao lik osjetljiv na društvene probleme koji ipak ne uspijeva djelovati, „dijelom zbog osobne slabosti, dijelom zbog političkih i društvenih zabrana“ (Chances, 2001: 112). Njegova se alijenacija može tumačiti i na razini alijenacije ruske inteligencije od ostatka društva, kako to čini Friedeberg Seeley, jer je povijest suvišnoga čovjeka razumljiva tek u sklopu povijesti europeizacije Rusije. Baveći se problematikom inteligencije uopće i njezina smisla, utvrđuje da je paradigmi inteligencije inherentna podvojenost, osobito u društvima koja prolaze promjenu iz jednoga oblika političkogospodarske organizacije u drugi, jer se i intelektualci kao njezina srž osjećaju razapetima između vrijednosti staroga i novoga poretka. Problem je međutim što je inteligencija po svojoj prirodi u nekoj mjeri duhovno izolirana od ostatka zajednice. A nju taj ostatak zajednice percipira kao „reprezentanta i utjelovljenje strane kulture“ (Friedeberg Seeley, 1952: 94) i zato njezina drama leži u borbi da ispliva iz te izolacije te se organski poveže s vlastitim ljudima. No taj je proces u Rusiji bio vrlo bolan iz nekoliko razloga - jaka središnja politička vlast; košmar kmetstva koji je značio da se plemstvo, iz kojega je većina pripadnika inteligencije potjecala, mora nositi i s otuđenjem i s neprijateljstvom, što je nedvojbeno utjecalo na emocionalno nestabilnije intelektualce; dezintegracija obiteljskoga života - te je rezultirao „intenzivnim razvojem neuroza; duševnim raskolom; sukobom s autoritetima; duboko ukorijenjenim osjećajem krivnje; nesigurnim djetinjstvima bez ljubavi“ (ibid.: 96). Razdoblje u kojem suvišni čovjek postaje temeljna figura jest vrijeme konačnoga prijelaza inteligencije iz osamnaestostoljetne funkcije kao instrumenta autokracije u devetnaestostoljetnu funkciju protagonista novoga poretka. 
Kad već spominjemo neurozu, vrijedi se opet kratko vratiti temi neurastenije te vidjeti na koji se način ona može povezati sa suvišnim čovjekom. Sirotkina (2002) naime razlikuje rusku dijagnozu neurastenije od one zapadne u kojoj prevladava, kako smo pokazali, uvjerenje o ključnom utjecaju brzih procesa industrijalizacije. Dotičući se činjenice da su u kolektivnoj europskoj svijesti Slaveni smatrani apatičnim melankolicima, ljudima malaksale volje na koje bitno utječe i hladna i tamna klima, prisjeća se opažanja Havelocka Ellisa da su „,indolencija, apatija, rezignacija i mistični fatalizam“" (Sirotkina, 2002: 126) ponajprije slabost Rusa. Slično Ellisu, ruski se psihijatar Mukhin referira na Rusiju kao na plodno tlo za razvoj degeneriranih slučajeva koji se mogu tumačiti kao „proizvod nestašice i uvreda, siromaštva i opresivnoga režima, više nego kao akumulacija naslijeđenih bolesti“ (ibid.). Povlačeći paralelu sa Sirotkininom tezom kako je degeneracija u Rusiji poprimila poglavito političke konotacije (a puno manje naprimjer biološke), rekli bismo da su i u hrvatskom duhovnom prostoru nepovoljne gospodarske, društvene i političke prilike, posredno ili neposredno, bile okidači za tematiziranje patoloških slučajeva. Neurastenija se dakle u ruskom psihijatrijskom diskursu tumačila, i to napose nakon Revolucije 1905, kao poremećaj pojedinaca koji stradavaju pod pritiskom opresivnoga režima, pa se porast neurasteničnih i histeričnih slučajeva interpretirao i kao povećanje otpora autoritetu. Takvi oboljeli pojedinci nastanjuju rusku književnost na prijelomu stoljeća.

Zato bismo sa Sirotkinom mogli potvrditi da je hrvatskom dekadentu blizak ruski neurastenik, upravo onako kako ga, u odnosu prema Zapadu, ona tumači. Nasuprot zapadnjačkomu neurasteniku, koji je iscrpljen zbog lako dostupnih mu životnih užitaka, ruski rijetko kad može uživati povlastice svoga rada. „Arhetipski je ruski neurastenik radišan, inteligentan, često siromašan i fizički oslabljen, pritisnut nedostatkom slobode i patnjom zbog neispunjene želje da služi ljudima.“ (ibid.: 134) 


\section{FILOZOFSKI TEMELJI DEKADENCIJE}

\subsection{Schopenhauerova filozofija pesimizma}

Schopenhauerova je filozofija, kako smo naglasili govoreći posebno o fenomenu mal de vivre, višestruko vrijedna, ne samo za fin de siècle u kojem se šopenhauerovski momenti mogu pronaći na svakom koraku nego osobito i za našu temu dekadentnih likova kojima beznadnost, slabost volje i nemoć pred svijetom postaju fundamentalna obilježja. Kako se često navodi, rasprostranjenost i popularnost pesimizma nedvosmisleno se duguje Schopenhauerovu opusu jer ga je upravo on postavio kao filozofski sustav, pretvorivši ga iz osobnoga stajališta u metafiziku i kolektivno viđenje života (usp. Dienstag, 2006: 84; Beiser, 2016: 13).

Iz današnje je perspektive iznenađujuća, pomalo teško objašnjiva činjenica da je Arthur Schopenhauer bio najpoznatiji i najutjecajniji filozof u Njemačkoj od 1860. do Prvoga svjetskog rata. Ona prilično odudara od suvremenoga viđenja Schopenhauera kao disidenta i osamljenika, autsajdera i pustinjaka. (Beiser, 2016: 13)

Schopenhauerov je utjecaj na to razdoblje golem i nemjerljiv. On je u isti mah iznio ključne filozofske probleme svoga vremena te se pozabavio i njegovim kulturnim i intelektualnim krizama. Posebno je nevjerojatno da je, kako inzistira Beiser, svojom filozofijom usmjerio i dva oprečna mu pokreta kasnoga XIX. stoljeća, neokantovsku filozofiju i pozitivizam, prisilivši ih da u središte svoje pozornosti postave probleme koje bi inače vrlo vjerojatno zanemarili (ibid.: 15). Nastojeći odgovoriti na pitanje što je uopće smisao i vrijednost ljudskoga života, Schopenhauer je utemeljio pravu filozofiju pesimizma, iako zapravo ni u jednom trenutku pesimizam nije definirao: filozofiju u kojoj se život promatra kao patnja jer je proizvod nezasitne i neprekinute dominacije kozmičke volje. Kreiravši metafizički pesimizam, u kojem se pojedinac direktno suočava s vlastitom temporalnošću (Dienstag, 2006: 85), uvelike je odredio devetnaestostoljetni kulturni pesimizam koji je sumnjao u mogućnost povijesnoga progresa i poboljšanja svijeta pomoću znanosti, tehnologije i političkih reformi. Jer, neovisno o tome koliko se čovjek bori, njegov je položaj u svijetu nemoguće popraviti, stoji u pozadini Schopenhauerove filozofije. Pesimizam za njega ne znači propast civilizacije, što je, vidjeli smo, bilo jedno od glavnih razumijevanja dekadencije, nego pretpostavlja činjenicu da su ljudska bića po svojoj naravi „osuđena na život opterećen problemima koji se ne mogu riješiti. Upravo su nepromjenjivi uvjeti naše svakidašnje egzistencije izvor Schopenhauerova pesimizma, a među njima je prva čovjekova svijest o temporalnosti““ (ibid.). Schopenhauer 
međutim, za razliku od Nietzschea, nije filozof dekadencije, jer kod njega nije riječ o propadanju ili o svijesti o njemu, nego o radikalnoj bezizlaznosti iz života danoga voljom kao metafizičkom determiniranošću.

Volja je dakle središnja kategorija Schopenhauerove metafizike. Kako je očito i iz naslova njegova kapitalnoga djela Svijet kao volja i predodžba (1819, dopunjeno 1844), svijet se čovjeku daje kao volja i predodžba. Ključno je to što je volja metafizički određena, ona je „stvar po sebi“ (Windelband, 1988: 168) koju ne možemo spoznati zato što leži u pozadini svih djelovanja. Čovjek je može spoznati tek kroz predodžbu, odnosno po njezinu izvanjskom očitovanju. Određujući je kao negativitet koji treba prevladati zato što je čovjeku dana kao nagon koji ga neprestano tjera da nešto postigne, utvrđuje da je volja žudnja i strast. Kao takva prethodi svemu racionalnomu te je čovjeku jedini neposredni dodir s metafizičkom osnovom vlastite tjelesnosti. S obzirom na to da nije samo izvanjska uzročnost, poput kauzalnosti uma, nego i unutarnja motivacija kretanja, izuzeta je iz zakona uzročnosti: zato je neuvjetovana i jedinstvena. Time je metafizički shvaćena volja unutarnja bit svega što jest, odnosno onoga što uopće živi. Upravlja čovjekom kao nagon te on zbog toga pati, a pritom mu se svijet prikazuje kao sumorno mjesto; sve dok intelektom ne uspije najprije osvijestiti njezino postojanje, a potom i započeti s njezinim obuzdavanjem, što je pak moguće samo umjetničkom kontemplacijom. No budući da je volja premoćna „stvar po sebi“, koja upravlja svijetom i čovjek joj se u konačnici ne može oduprijeti, njezino je obuzdavanje uvijek samo privremeno. Zato pojedinac, svjestan te činjenice, živi u permanentnom pesimizmu, iz kojega će u krajnjoj konzekvenciji pokušaja njezina nadvladavanja izlaz često tražiti u samoubojstvu.

Nakon ovoga kraćeg iznošenja općega smisla Schopenhauerove metafizike valja zagrepsti u njegove osnovne teze kako bismo razumjeli kontekst koji je inspirirao i hrvatske autore u kreiranju likova dekadenata, koji utjelovljuju postavke pesimizma i patnje te svjedoče nestajanju svijeta pred vlastitim očima. Čovjek se nalazi u svijetu, uronjen je u njegove odnose te na vlastitoj koži osjeća sve nedaće koje mu nosi svakidašnjica, čita se između redaka Schopenhauerove teorije. Njegova je filozofija snažno utjecala na razdoblje koje obrađujemo, može se sugerirati, upravo zato što odstupa od idealističke filozofije koja iskustveni svijet obilježen patnjom, strahom, tjeskobom i drugim konfliktnim stanjima idejno ipak može prekoračivati. Zato on govori o svojevrsnoj ambivalenciji svijeta između subjekta i objekta koji se, suprotno idealističkoj filozofiji, nikad ne stapaju u jedno, zbog čega čovjek ima pogled na svijet koji izlazi iz samoga subjekta. Svijet postoji samo kao predodžba, samo u odnosu na nekoga - svijet je objekt u odnosu na subjekt. A subjekt je ,nosilac sveta, opšti i uvek pretpostavljani uslov sveg onog što se pojavljuje“ (Šopenhauer, 1981: 37). Schopenhauer dakle 
polazi od postavke da je svijet uvijek reprezentacija subjekta: empirijski se svijet sastoji od predodžbe koju čovjek ima, a ,egzistirati i biti predočen $u$ tom su pogledu sinonimi“ (Invernizzi, 1994: 21). Prema njemu volja nije samo predodžba ni sposobnost čovjekova uma, nego čovjekova bit: ona je iznad svake predodžbe i fenomena.

Svijet pak kao predodžba ima dvije nerazdvojive strane: objekt, čije su forme prostor i vrijeme, i subjekt, koji nije u tim formama. Ondje gdje se stapaju subjekt i objekt jest volja. Budući da nijedna jedinka ne može odvojiti volju od vlastita tijela, tijelo je njezin neposredan izraz. U njemu se stapaju subjekt i objekt te sve dok pojedinac živi, na svom tijelu osjeća manifestacije volje. Tijelo je, najkraće rečeno, manifestacija volje. Volja subjektu nudi ključ za razumijevanje njegove vlastite pojave, ,pokazuje mu unutrašnji mehanizam njegova bića, njegova delanja i njegovih pokreta“ (Šopenhauer, 1984: 11). Ona je slijep i nezaustavljiv nagon: dok postoji život, postoji i volja koja čovjeka prati kao sjena koje se ne može osloboditi. Jasno je stoga da je forma života i volje uvijek samo sadašnjost, dok su prošlost i budućnost samo pojmovi: „Nijedan čovek nije živeo u prošlosti, i niko nikad neće živeti u budućnosti; samo je sadašnjost forma sveg života.“ (ibid.: 18) Zato patnja i pesimizam, neodvojivi od sadašnjosti, postaju prirodna pratnja njegova položaja u svijetu. Schopenhauer dakle na elementima fenomena pesimizma razvija svoje kompleksno viđenje realiteta. Budući da je za njega volja izjednačena s voljom za život, a život pak kontinuirana izmjena materije između organizama i neorganskoga svijeta (Invernizzi, 1994: 24), održavanje je života moguće samo neprekinutim zadovoljenjem potreba - zato se volja za život otkriva kao generalna tendencija zadovoljenja potreba. Volja je samoj sebi cilj, ona „potvrđuje samu sebe“ (Šopenhauer, 1984: 27). U Schopenhauerovoj je teoriji samo volja slobodna te je, s obzirom na to da za nju ne vrijedi princip motivacije, bezrazložna - što znači da bića ne mogu spoznati načela njezina djelovanja. Stoga je cilj života pokušati je opovrgnuti, a to se može samo intelektom, odnosno kontemplacijom. Čovjek tako živi u neprestanom razdoru između volje i intelekta, jer svatko sebe a priori smatra slobodnim. Tek a posteriori, iskustvom, shvaća da nije slobodan, već da je podčinjen nužnosti, da ne može mijenjati svoje djelovanje te da preuzetu ulogu mora igrati dokraja. To je slikovit opis onoga što Schopenhauer naziva pesimizmom. Pojedinac uviđa da je ovaj svijet, kao objektivacija metafizičke volje, najgori od svih mogućih svjetova, a život pod njezinim diktatom obilježen stalnim i neizbježnim osjećajem patnje. Kako objašnjava Supek, Schopenhauer „s tugom utvrđuje da je ljudska individualnost, kao svaka pojedinačnost principium individuationis, slijepi proizvod životne bujice, koji se održava neko vrijeme silom svoje organizacije i svijesti, ali toj bujici konačno podliježe, biva rastrgan i nestaje“ (1950: 33). 
Iz perspektive se subjekta potreba i njezino eventualno ispunjenje pretvaraju u osjećaje zadovoljstva ili boli. Svaka potreba i svaki nedostatak percipiraju se kao bol i patnja, a temelj je svakoga htijenja potreba, odnosno bol, za koju je čovjek po prirodi vezan od svoga postanka. U tom kontekstu Schopenhauer promiče tezu o primarno negativnoj prirodi zadovoljstva te piše:

Svako zadovoljenje, ili ono što se obično naziva srećom, jeste zbilja i suštinski - uvek samo negativno, a nikad pozitivno. Ono nije usrećenje koje nam dolazi izvorno i samo od sebe, već svagda mora da bude zadovoljenje neke želje. Jer, želja, odnosno nedostatak jeste prethodni uslov svakog uživanja. Ali sa zadovoljenjem prestaje želja, pa dakle i uživanje. (1984: 72)

No, kao što sugerira Invernizzi, to ne znači da čovjek neće iskusiti zadovoljstvo kad zadovolji svoju potrebu, nego da je zadovoljstvo - s obzirom na to da se realizira uvijek kad se osvijesti neka potreba - negativnoga karaktera jer se osvještava tek kad jedinka neko „dobro“ izgubi (1994: 25). Nama je neposredno uvijek dan samo nedostatak, tj. bol, a zadovoljenje i uživanje u stanju smo spoznati posredno. Zbog toga se događa da prednosti uopće ne primjećujemo te da njihovu vrijednost spoznajemo tek nakon što ih izgubimo. Kad se zadovolji jedna želja, zamjenjuje ju druga te tako čovjek cijeli život bolno egzistira nastojeći zadovoljiti vlastite potrebe. Čim se oslobodimo jedne vrste zabrinutosti, na njezino mjesto stupa druga i tako ukrug.

(...) svako stremljenje proističe iz nedostatka, iz nezadovoljstva svojim stanjem; dakle ono je patnja sve dok ne bude zadovoljeno; ali nijedno zadovoljenje nije stalno; štaviše, ono je svagda samo ishodište novog stremljenja. Mi stremljenje vidimo svuda mnogostruko sputano, svuda uvučeno u borbu dakle uvek kao patnju; nema krajnjeg cilja u stremljenju, znači, nema mere i cilja patnji. (ibid.: 59)

Ako smo i uspjeli potisnuti bol u određenom obliku, ona se odmah pojavljuje u nizu drugih oblika, poput spolnoga nagona, strasne ljubavi, ljubomore, zavisti, mržnje, bolesti, pohlepe i sličnoga. A u slučaju da ti oblici izostanu, javlja se egzistencijalna dosada i zasićenost, od kojih se čovjek može osloboditi samo prepuštanjem novoj boli. Nekonzistentnost zadovoljenja najbolje potvrđuje fenomen dosade, stanja radikalnoga nezadovoljstva tijekom kojega čovjeku život postaje nepodnošljivo breme. Svjestan kako mu se život neprestano odvija između boli i dosade, jedinih nepobitnih činjenica, on cijeli život vodi brigu o vlastitoj egzistenciji. I ni na koji način ne uspijeva otkloniti patnju jer se ona javlja u bezbroj oblika: 
volja je unutarnji životni princip te stalno usmjerava želji za zadovoljenjem koja se najčešće ne može utažiti. I upravo u ovim tvrdnjama leži bit Schopenhauerova viđenja pesimizma - on proizlazi iz volje shvaćene kao trajno nezadovoljena težnja. U takvoj je konstelaciji prilika donekle sretan život onaj u kojem se potrebe i njezina zadovoljenja pravilno izmjenjuju, bez prevelikih intervala između vremena percepcije potrebe i njezina zadovoljenja, odnosno između zadovoljenja neke potrebe i iskrsavanja nove (Invernizzi, 1994: 25). Može se prema tome još jednom istaknuti da su htijenje i neprestana težnja te posljedična bol cjelokupna bit čovjeka. Kako razrađuje Dienstag, jaz između bezvremenitosti volje i vremenitosti iskustva podrazumijeva da su želje stalne, a njihovo zadovoljenje efemerno (2006: 94). Dakle pravo je zadovoljenje kratkotrajno i prolazno te neprekidno izmiče u prošlost: jednom kad se želja zadovolji, bol koja joj je inherentna nestaje; no kako nestaje želja, nestaje i zadovoljstvo zbog njezina zadovoljenja. Stanje nezadovoljene želje jedina je prava konstanta naših života. Ili, kao što objašnjava Windelband:

(...) bijeda života ostaje uvijek ista; mijenja se samo oblik njenog predočavanja. (...) Intelektualno usavršavanje ne mijenja ništa na voljnom životu čovjeka. Zato ne može biti ni govora o nekom napretku u povijesti. Ona pokazuje beskrajnu patnju volje za životom, koja uvijek s novim osobama izvodi istu tragikomediju. (1988: 200)

Odlučno je pak da, kako ćemo sugerirati i u središnjem dijelu rada, patnja ne dolazi izvana, „,već svako njen nepresahnjiv izvor nosi u samom sebi“ (Šopenhauer, 1984: 71). Zato ne iznenađuje kad protagonisti spominju neku neizrecivu bol koja ih obuzima, a s kojom su se, kako im se čini, i rodili. Možemo prema tome reći da egzistenciji doista pripada samo patnja te da je pravo zadovoljenje nemoguće, zbog čega čovjek neminovno zapada u melankolično raspoloženje, što će biti jedna od najprepoznatljivijih karakteristika naših dekadenata. Razlog je tomu činjenica da je svako zadovoljenje, tj. ono što se obično naziva srećom, u svojoj biti uvijek negativno. U nama ne postoji sreća koja bi dolazila iznutra, iz nas samih, jer ondje caruje volja. Utvrđujući da se čovjekov život odvija između triju krajnosti - moćnoga htijenja velikih strasti, čistoga spoznavanja uvjetovanoga oslobađanjem od služenja volji te letargije volje, povezane s čežnjom i dosadom koje umrtvljuju život - Schopenhauer zapisuje:

Zbilja je neverovatno kako prazno i beznačajno, kad se gleda spolja, a tupo i besmisleno, kad se osjeća iznutra, protiče život većine ljudi. On je otužna čežnja i mučenje, sanjalačko teturanje kroz četiri životne dobi do smrti, u pratnji niza otrcanih misli. (...) Svaka jedinka, svako ljudsko 
lice i njegov život samo je kratak san više beskonačnog prirodnog duha, istrajne volje za život, samo je nepostojana tvorevina više, koju volja, igrajući se, iscrtava na svom beskonačnom listu, prostoru i vremenu (...). (ibid.: 75)

Volja u čovjeku vidi svoj vrhunac jer kroz njega ima mogućnost spoznati samu sebe, tj. postati spoznajom. Ta se napetost odvija u najvišem stupnju manifestacije volje upravo u čovjeku, koji jedini egzistira u području patnje zato što je njegova spoznaja rastrgana između volje i inteligibilnoga pokušaja njezina prevladavanja. Patnja, tjeskoba, pesimizam, nihilizam, sjeta nusprodukti su te rastrganosti. Prema tome što je viši stupanj spoznaje, viši je i stupanj muke - svoj najviši stupanj doseže u čovjeku, a pritom najviše pati genij. Stoga se može sumirati „kako je, u stvari, sav život - patnja“ (ibid.: 60). Čovjek je uvijek orijentiran na smrt te mu se život odvija uvijek samo u sadašnjosti:

Svakim dahom mi se branimo od smrti koja jednako na nas navaljuje. (...) Na kraju, ona da pobedi: jer smo joj već rođenjem pripali, i ona se samo neko vreme igra sa svojim plenom pre no što ga proguta. Ali s velikim zanimanjem i staranjem mi nastavljamo svoj život dok god je to moguće, kao što i mehur od sapunice duvamo dok god je to moguće, iako dobro znamo da će se raspuknuti. (ibid.: 61-62)

Smrt je tako, tumači Dienstag, „krajnji izraz smisla naših života, odnosno preciznije, izostanka smisla naših života“ (2006: 102), a kao takva ona nije kraj naše egzistencije, nego kraj našega iluzornog svjesnog iskustva. Zbog toga Schopenhauer navodi različite načine opovrgavanja, odnosno pokušaje umrtvljenja volje kroz kategorije pravednika, asketa, sveca i samoubojice, kojima je zajednička patnja koja osvještava volju kao put njezina prevladavanja (usp. Sunajko, 2018). Međutim svi su putevi, kako pokazuje, bezuspješni, zbog čega čovjek i završava rastrgan u nastojanju njezina opovrgavanja. No, Beiserovim riječima, ,umjesto što nastojimo svim silama stvoriti bolji svijet, trebali bismo se odreći svoje volje za životom te pokušati pobjeći u svijet religiozne i estetske kontemplacije“ (2016: 43). Prvi je pokušaj prevladavanja put pravednika koji se udaljava od egoizma sudjelujući u tuđim patnjama.

(...) takav čovek, koji u svim bićima spoznaje sebe, svoje najdublje i pravo sopstvo, mora da i beskrajne patnje svih živih stvorova posmatra kao svoje i da tako prisvaja bol celokupnog sveta. Njemu više nijedna patnja nije strana. (Šopenhauer, 1984: 149) 
Suosjećanje koje ga definira temelji se na spoznaji da su ljudi jednaki i međusobno povezani jer osjećaju patnju onoga drugoga. No to osjećanje drugoga iznova budi volju kao suosjećanje, pa se naposljetku pokazuje da put pravednika nije izlaz iz takvoga stanja. Drugi je put asket, u kojega se volja posve okreće od života, a ,čovek dospeva u stanje dobrovoljnog odricanja, rezignacije, istinskog spokojstva i potpune bezvoljnosti“ (ibid.: 150). Pojedinac koji negira vlastitu individualnost donekle negira i velik dio patnje. Asket se pak, odričući se tjelesnih užitaka i potreba, dovodi do ruba smrti, što također predstavlja nemogućnost nadvladavanja volje. Treći je put sveca, koji preuzima patnju čovječanstva, ali uživa u takvoj poopćenoj patnji koja ponovo budi volju. On propovijeda potpunu rezignaciju, siromaštvo i ravnodušnost prema svjetovnim stvarima te je njegov karakter ujedno karakter određene tuge koju nosi za čovječanstvo. Kad tuga više nema konkretan objekt, vraća se u sebe, ,pri čemu čovek oseća izvesno popuštanje svojih okova, blago predosećanje smrti koja se najavljuje kao razlaganje tela i volje u isti mah; stoga ovu tugu prati prikrivena radost koja je, verujem, ono što je najmelanholičniji od svih naroda nazvao the joy of grief" (ibid.: 173). Patnja dakle opet budi volju koja je sad poopćena na čovječanstvo, a opovrgavanje volje za život (potpuna rezignacija i svetost) pretvara se u opovrgavanje života - samoubojstvo. Prema tome četvrti je pokušaj umrtvljenja volje (nama vrlo zanimljiv jer se gotovo svi naši dekadenti odlučuju na samoubojstvo) put samoubojice, što prema Schopenhaueru nipošto nije izlaz iz pesimizma nego je upravo učvršćenje volje. Samoubojica naime ne mrzi život, nego uvjete pod kojima mu je on dan. U toj je činjenici ključno što samoubojstvom nestaje konkretna jedinka, ali volja i dalje nastavlja živjeti. Njezinim ukidanjem rastače se svijet te ostaje samo ništavilo, protiv kojega se ipak buni naša volja za život jer je nihilizam izraz konačnoga vapaja za životom: „To što se mi u tolikoj meri užasavamo ništavila samo je izraz činjenice da mi snažno želimo život, da i nismo ništa drugo do ta volja, da ništa osim nje i ne poznajemo.“ (ibid.: 191) Posve sažeto, volja uvijek nadživljava jedinku. I zato se može zaključiti da je cjelokupan čovjekov život stalna borba za egzistenciju, a u toj je borbi jedino sigurno da je smrt „krajnji cilj tegobnog putovanja“ (ibid.: $63)$.

Imajući na umu ove kategorije pokušaja nadvladavanja volje, možemo dodati kako se u Schopenhauerovoj filozofiji pesimizma ona donekle može obuzdati umjetnošću, odnosno intuicijom pomoću koje se pojedinac izdiže iznad principa „puke volje“. Umjetnost tako postaje spoznajna moć (umjetničkoga) genija koji više nije ograničen voljom i žudnjom, nego izravno spoznaje objekt. No u krajnjoj se instanciji ni umjetnik ne uspijeva trajno osloboditi volje kao vječne i nezasitne žudnje jer je umjetnost ipak samo njezin privremen kvijetiv. Onaj koji se prepušta umjetničkomu djelu (osobito glazbi) na trenutke zaboravlja da je ovaj svijet najgore 
moguće mjesto te se, uživajući u melankoličnim tonovima, predaje umjetnosti znajući da je riječ o slici svijeta, a ne o svijetu samom (Sunajko, 2017: 73). Zato je umjetnost svojevrsno negiranje volje i time kratkotrajan zaborav ovoga svijeta.

Dienstag ipak napominje kako Schopenhauerov pesimizam nije nipošto stanje tromosti i ravnodušnosti ili neaktivnosti, nego pretpostavlja život kao stalno jačanje samoga sebe kroz odricanje. Pojedinac bi jednostavno trebao odbaciti ideju da je sreća nešto na što ima pravo ili što može postići:

Doista, moramo shvatiti da smo podložni sudbini i prilici, osnažiti svoju poziciju te od života očekivati malo ili ništa. (...) Sreća - radikalan izostanak nesreće - jest prilika ili okolnost na koju možemo nabasati, ili pak ne, s vremena na vrijeme. (Dienstag, 2006: 112)

\subsection{Von Hartmannova filozofija nesvjesnoga}

Iako bismo iz današnje perspektive vjerojatno zaključili drukčije, najpoznatiji pesimist u vrijeme Weltschmerza nije bio Schopenhauer, nego Eduard von Hartmann, njegov učenik danas gotovo posve zaboravljen. Von Hartmannova Filozofija nesvjesnoga iz 1869. bila je pravi bestseler te je mladomu autoru priskrbila veliku popularnost: prvo je izdanje rasprodano u rekordnom roku, a do 1880. literatura o njegovu životu i djelu brojila je oko 850 jedinica (Beiser, 2016: 122). Pitajući se o razlozima tolike popularnosti, Beiser ističe da dio njih možda leži u činjenici da se „mnogima činilo da von Hartmann nudi ne samo iscrpniji i sistematičniji pesimizam u odnosu na Schopenhauerov nego i njegovu blažu i nježniju inačicu, koja kombinira pesimizam o ljudskoj sreći s optimizmom o kulturnom napretku“ (ibid.: 123). On je doista bio dijete svoga vremena, pa zato nimalo ne čudi što u doba u kojem svi pokušavaju postaviti posljednju istinu o problemima suvremenoga svijeta i von Hartmann čini isto.

U trima knjigama izrazito opsežne i podrobne Filozofije nesvjesnoga von Hartmann je, u nastojanju da izgradi vlastitu metafiziku, dijelom i na osnovi postignuća prirodnih znanosti, potpuno posvećen temi nesvjesnoga, koje je za njega uzrok svemu postojećemu. Postavljajući ga u središte svoga zanimanja, pokušava dokazati da sve u čovjekovu životu proizlazi iz nesvjesnoga djelovanja te da je povijest bića uvijek razvoj silnica iz istoga izvora. Za njega je nesvjesno zapravo svjesno koje još nije dosegnulo svijest o sebi te ga ne razumijeva u psihološkom smislu, nego kao supstanciju s dvama atributima: voljom i idejom (Invernizzi, 1994: 128). Volja je iracionalan nagon, smješten u područje patnje, a ideja je smještena u 
poredak i svjesno. Von Hartmann prema tome uspostavlja sustav na Schopenhauerovu tragu, s voljom i predodžbom kao glavnim konceptima, ali ipak s velikom razlikom u odnosu na Schopenhauera: ono što je u učitelja razlika između „stvari po sebi“ i njezine predodžbe, u von Hartmanna je razlika između realnoga i idealnoga, egzistencije i esencije (Beiser, 2016: 137).

U prvom svesku von Hartmann ispituje golemo područje organskoga života, niz njegovih fenomena za koje utvrđuje da se ne mogu opisati mehaničkim terminima nego, baš naprotiv, duhovnima. Prikazujući manifestacije volje u polju prirodnih znanosti, eksplicira kako volja nipošto nije ekskluzivna čovjekova osobina - nesvjesna se volja naime kao izvor svake akcije može uočiti u svih živih bića (usp. Kenedy Darnoi, 1967: 32; Invernizzi, 1994: 126). Šopenhauerovski postavivši tezu da se psihička aktivnost može pojmiti u terminima volje i predodžbe, utvrđuje da svaku takvu aktivnost valja razumjeti kao nesvjesnu, dok u drugom svesku ilustrira te manifestacije nesvjesnoga u ljudi. Iako se svijest kao ontološka kategorija, stanje neposredne spoznaje, ostvaruje u čovjeku, to nipošto ne znači da djelovanje nesvjesnoga popušta te da mentalni procesi očituju manji stupanj utjecaja nesvjesnoga nego u biljnom i životinjskom svijetu. Nesvjesno igra veliku ulogu u našim životima, pa i u oblikovanju našega karaktera: način na koji čovjek djeluje, naročito njegova svjesna djelovanja, sugerira da se iza svake svjesne aktivnosti krije nesvjesna (Invernizzi, 1994: 126).

Zato u trećem dijelu knjige, za našu disertaciju najzanimljivijem, von Hartmann sistematizira i zaokružuje teze iz prvih dvaju dijelova te razmatra problem patnje i zla u modernom svijetu otvarajući raspravu o pesimizmu.

Kako bi opravdao svoj apriorni postulat, prema kojem je pobjednička prisutnost zla u svijetu nekompatibilna s postojanjem dobroga $\mathrm{i}$ inteligentnoga stvoritelja, za svoj praktično upotrijebljen pesimizam on konstruira metafizičku podstrukturu nesvjesnoga. (ibid.)

U proučavanju duhovnih fenomena koji pripadaju sferi svijesti posebnu pozornost pridaje osjećajima, središnjoj temi svoje filozofije pesimizma, te pritom prepoznaje da svi oni u svojoj podlozi imaju zadovoljstvo ili bol. U takvoj perspektivi i „najsloženija duševna stanja proizlaze iz različitih kombinacija tih elemenata te poprimaju specifične nijanse, ovisno o predodžbama za koje su vezana“ (ibid.: 135). Tumačenje o zadovoljstvu i boli kao učincima trajnoga ili trenutnoga zadovoljenja odnosno nezadovoljenja volje, kojim von Hartmann zauzima poziciju primata volje nad osjećajem, dopunjava konceptom svrhovitosti svijeta, $u$ kojem kao potencijalne životne ciljeve izdvaja sreću, moralnost i pravednost. No kako se moralnost i pravednost tiču fenomenološke raznolikosti, tj. odnosa među pojedincima, te tako 
ne dodiruju apsolut kao esenciju realiteta, ostaje za zaključiti da je svijet usmjeren realizaciji sreće kao svomu jedinomu pravomu cilju. Sreća se pak, s obzirom na to da je podložna svijesti koja percipira bol i zadovoljstvo, odnosi izravno na apsolut, odnosno na nesvjesno. Iskustvo međutim svjedoči da svijet ipak nije sasvim usmjeren navedenomu cilju jer se mnoštvo činjenica čovjekova života opire dostizanju sreće te pritom favorizira jedan drugi cilj, uzdizanje svijesti. „Želi li se sreću zadržati kao konačnu svrhu, sve boli valja iskoristiti za postizanje većega zadovoljstva ili barem manje nesreće.“ (ibid.) Tako von Hartmann karakterističnim pesimizmom afirmira eudajmoničku svrhovitost svijeta, u kojoj bol služi za postizanje sreće, no nakraju je sreća tek izostanak boli koji nastupa s prestankom postojanja svijeta. Prema tome ako se može dokazati da svijet u svom bivanju uvijek implicira prevlast boli, postat će evidentno da je nepostojanje svijeta eudajmonički prihvatljivije od njegova postojanja. Bol će dakle uvjeriti čovjeka da se odrekne vlastite egzistencije te mu tako ponuditi mogućnost ništenja svijeta. Na taj način von Hartmann, definirajući pesimizam eudajmoničkim terminima, iznova šopenhauerovski pojašnjava da je „ne-biti“ prihvatljivije od „biti“, odnosno da je nebivanje podnošljivije od bivanja. Možda je najjezgrovitije ključne postavke njegove filozofije pesimizma utvrdio Beiser sljedećim silogizmom:

Ako se (1) najbolji mogući život za ljudsko biće sastoji od odsutnosti boli; ako je (2) odsutnost boli jednaka nuli na ljestvici sreće; ako je (3) kompletno odsustvo boli nedostižno tijekom života, tad (4) vrijednost života pada ispod nule. A ako vrijednost života padne ispod nule, onda ga prema eudajmoničkim standardima nije vrijedno živjeti. (2016: 155)

Nijedan normalan čovjek, kako piše, ne bi prihvatio iznova proživjeti život zato što on sa sobom nosi više boli nego sreće. No iako je sumoran i prepun patnje, uzmu li se u obzir sva moguća zla, ipak je „ovaj svijet od svih mogućih svjetova najbolji“ (von Hartmann, 1893a: 368), a njegov se spas može postići uspješnim odnosom razuma i kulture. Stoga se postulati u njegovoj filozofiji eudajmoničkoga pesimizma dopunjuju teorijom evolucijskoga optimizma: po njegovoj viziji ta dva misaona i praktična koncepta jesu najprikladnije forme modernoga života. Iza njegova se pesimizma krije dakle ideja da život ne treba živjeti prema eudajmoničkim standardima, tj. prema idealu da dobar i ispunjen život čini jedino sreća odnosno zadovoljstvo, nego da život valja usmjeravati drugim modelima zadovoljstva i blaženstva. Sintetizirajući Hegelovu ideju sa Schopenhauerovim voluntarizmom, prema kojem je, kako smo vidjeli, volja kao esencija realiteta slijepi nagon i neukrotiv poriv ispod područja svjesnoga (Gottfried, 1973: 197), von Hartmann promovira tezu da čak i ako ne možemo biti 
sretni, u životu ipak možemo pronaći neke vrijednosti, težeći pritom za kulturnim uspjesima i moralnim napretkom. „Smisao u životu ne bi trebao proizlaziti iz vjerovanja u vlastitu sreću, jer je to samo oblik egoizma, nego iz vjerovanja da napor pojedinca da popravi svijet doista nešto vrijedi te da on napokon može učiniti razliku.“ (Beiser, 2016: 136)

Pitajući se na koji način čovjek može efektivno uspostaviti ravnotežu između zadovoljstva i boli, von Hartmann, vodeći računa o činjenici da nesvjesno utječe na čovjekov afektivni život, eksplicira da treba raskrinkati načine na koje se ono odražava na pojedinca, na njegova stajališta i djelovanja, te razotkriti iluzije, odnosno pogrešne predodžbe na kojima se zadovoljstva temelje. Jer razvoj svijeta demonstrira da se većina ljudskih zadovoljstava zasniva na iluzijama, što je, dugoročno gledano, prilično negativan proces. Von Hartmannovim riječima, valja ispitati ,zaslužuje li prednost postojanje ili ne-postojanje ovoga sadašnjeg svijeta“ (1893b: 1). Ne bi li dokazao navedeno, u trećem dijelu svoje knjige bilježi općenita razmatranja o ljudskoj prirodi i iskustvu, napose o zadovoljstvu i boli, te pritom opaža kako su ljudi osjetljiviji na bol, nego na užitak. Primjećuje da čovjekov živčani sustav svaki podražaj, ugodan ili neugodan, podnosi samo neko vrijeme: u nekom se trenutku u njemu očituje zamor, odnosno potreba da se taj podražaj okonča. Ako je podražaj bolan, povećava se bol koju on uzrokuje, ako je pak ugodan, smanjuje se zadovoljstvo. Teoretizirajući čak radikalnije od Schopenhauera, utvrđuje da se zadovoljstvo može percipirati samo indirektno, dok se bol svijesti nameće odmah. Tim tumačenjem ipak zauzima tipično šopenhauerovsku poziciju: bol kao rezultat potrebe traje sve dok se potreba ne zadovolji, a zadovoljenje je tek ,tren koji naglo iščezava“ (ibid.: 74). Prema tome ideja o ostvarivoj dugoročnoj sreći samo je iluzija, koja se odvija u tri stupnja.

U prvom se stupnju iluzije sreća percipira kao koncept dostižan za zemaljskoga života. No taj se koncept izjalovljuje jer je ona uvijek nedostižna, a bol i patnja uvelike nadmašuju zadovoljstvo. Razotkrivanje te iluzije odigrava se kroza segmente života u kojima čovjek, kako se uobičajeno pretpostavlja, može pronaći zadovoljstvo (ljubav, suosjećanje, prijateljstvo, ambicija, zdravlje, mladost, sloboda, materijalno blagostanje). Von Hartmann međutim smatra da ta dobra sama po sebi ne garantiraju zadovoljstvo, nego da u pojedinca osiguravaju takoreći neutralan stupanj osjetljivosti. Ona su ,izostanak starosti, bolesti, ropstva i neimaštine te, budući da se ne uspijevaju izdići iznad nulte točke senzacije zadovoljstva, u čovjeku ne uspijevaju proizvesti zadovoljstvo“ (ibid.: 23). I zato se može naglasiti da se sva dobra sastoje od izostanka boli, a ne od prisutnosti zadovoljstva. Zadovoljstvo što ih posjedujemo nastupa tek nakon što ih izgubimo te je ono uvijek kraće i manje intenzivno u odnosu na frustraciju nezadovoljenja. Nitko naime ne osjeća satisfakciju zato što je naprimjer zdrav sve dok ne 
postane bolestan, pa se sukladno tomu može reći da čovjek osvještava vlastitu egzistenciju tek kad ona postane ugrožena. Na taj način von Hartmann potvrđuje Schopenhauerovu ideju da sve što u životu pojedinac može postići uvijek podrazumijeva smanjenje boli. Drukčije rečeno, ne može postići ništa što bi bilo pozitivno te tako označilo premoć zadovoljstva nad boli (Beiser, 2016: 155). I zato u toj perspektivi navedena dobra, eudajmonički gledano, nisu ni na koji način superiorna u odnosu na nepostojanje. Ona su zapravo, promotri li se bolje, varljiva zadovoljstva koja čovjeku donose više zla nego ugode. Ili, von Hartmannovim riječima, „bol zbog određene sigurnosti ili vjerojatnosti neuspjeha bit će veća od odgovarajućega zadovoljstva u ispunjenju“" (1893b: 36). To se posebno ogleda u ljubavi, čije neizbježno proturječje leži u činjenici da čovjek prema impulsu nesvjesnoga instinkta mora voljeti, a kad iskustvo otkrije iluziju, već je u raljama nevolje, te u prijateljstvu, koje nije ništa drugo nego olakšanje boli samotnoga života. Tako von Hartmann, iscrpno i potanko analizirajući kako pojedinac mora proći kroz mnogobrojne patnje da bi sva ta zadovoljstva dosegnuo, demonstrira da bol dominira ne samo ovim svijetom uopće „nego i svim pojedincima, čak i onima koji se nalaze pred najpovoljnijim okolnostima“ (ibid.: 76). Iz toga pak implicitno proizlazi da je čovjek, što ćemo vidjeti i u našim primjerima dekadenata, nesretniji što je viši stupanj njegove senzibilnosti i intelektualnoga razvoja:

(...) manje osjetljivi pojedinci i oni s otupjelim živčanim sustavom manje su podložni nego osjetljiviji karakteri jer manja količina percipiranoga zadovoljstva i boli znači i da bol slabi. (ibid.)

Jer, premda s vremenom ideja nadvladava volju, čovjekova intelektualna superiornost, paradoksalno, povećava njegov kapacitet za patnju. Iako bi se moglo zaključiti da su, općenito govoreći, ljudi sretniji što je njihov živčani sustav blaziraniji, razvojem civilizacije došlo je do izokretanja procesa. Ljudi su naime sretniji, tj. manje nesretni u mladosti, što se može primijeniti i na civilizaciju općenito: zato ne čudi što govorimo o dominantnom devetnaestostoljetnom pesimizmu jer kako čovječanstvo napreduje, tako se iluzija o mogućnosti sretnoga zemaljskog života sve dramatičnije urušava. Rastom materijalnoga bogatstva i širokoga dijapazona svakidašnjih želja raste i osjetljivost živčanoga sustava te tako i superiornost boli nad zadovoljstvom, svijest o ispraznosti života i efemernih zadovoljenja. „U skladu s rečenim raste i bijeda te svijest o njoj, kako iskustvo pokazuje, a česta tvrdnja o poboljšanju sreće zbog progresa svijeta pokazuje se posve površnom.“ (ibid.: 115) 
U drugom pak stupnju, u kojem von Hartmannov metafizički pesimizam doživljava svoj klimaks (Kenedy Darnoi, 1967: 99), sreća se smatra dostižnom tek u životu nakon smrti; u toj se analizi posebno ogleda njegova kritika kršćanstva koja takvu iluziju njeguje (usp. Invernizzi, 1994: 179-180; Beiser, 2016: 155). To vjerovanje s jedne strane čini prezir prema ovozemaljskom životu, a s druge nada u transcendentnu sreću. No i ono je gruba obmana jer, razjašnjava von Hartmann, nema života izvan ovoga našega - jedini svijet koji poznajemo jest ovaj koji postoji u prostoru i vremenu. Volja kao ,izvor svega postoji samo u njemu te kroz njegova utjelovljenja; da nema volje, bilo bi ništavilo“ (Beiser, 2016: 155). Zato je krajnje uzaludno pokušavati pesimizam upakirati u misao o budućem životu jer je vjera $\mathrm{u}$ transcendenciju odavno izgubila svoju utješnu moć. Ova pak iluzija izrasta iz egoizma koji priželjkuje egzistenciju i nakon smrti: oni kojima je zanijekana sreća u ovom životu traže kompenzaciju u drugome. I zato se može izvesti zaključak da je glavno načelo ovoga drugog stupnja razvoj pojedinca koji je prema von Hartmannovu viđenju primarno vezan za egoizam. Nadvladavanje egoizma postaje puno lakše kad pojedinac shvati da njegova eudajmonička ravnoteža uvijek ima neizbježno negativan ishod. Tim se putem može dospjeti do odricanja od samih sebe, u čemu se ogleda upravo „velika etička vrijednost pesimizma“ (Invernizzi, 1994: 180).

Zato u trećem stupnju iluzije promatra na koji način čovjek može potisnuti vlastitu sreću u korist budućnosti svijeta. Promovirajući ideju o inherentno negativnom karakteru progresa čovječanstva, komentira da ono, koliko god napredovalo, nikad neće moći eliminirati najdublje izvore ljudske bijede, „bolest, starost, ovisnost o volji i moći drugih, oskudicu i nezadovoljstvo“ (von Hartmann, 1893b: 103).

Koliko god se lijekova protiv bolesti pronalazilo, osobito protiv nepodnošljivih kroničnih, bolest će uvijek napredovati brže nego medicina. Vesela mladost uvijek će činiti tek dio čovječanstva; ostatak će biti mračno zlovoljan. Glad zbog neograničenoga rasta ljudske populacije, koja se nikad neće moći iskorijeniti, pojavljivat će se u velikom dijelu civilizacije te pokazivati dugačak račun smrtnosti. (...) Najzadovoljniji su ljudi pripadnici primitivnih naroda koji žive u skladu s prirodom te neobrazovane klase moderne civilizacije; s kultiviranošću ljudi, pokazuje iskustvo, raste i njihovo nezadovoljstvo. (ibid.)

Što god radio, najviši položaj do kojega pojedinac može dospjeti jest, vidjeli smo, tek nulta pozicija na ljestvici zadovoljstva. Budući da, čak i kad se govori o progresu, pred njim uvijek ostaje isto pitanje na koje odgovora nema - kako uopće dati sadržaj vlastitomu životu - 
iz dubine von Hartmannova filozofskoga programa izbija problem konačne svrhe svijeta. Nakon što je uvidio prevrtljivost i obmanu individualne sreće, pojedinac se može okrenuti boljitku ovozemaljske egzistencije za dobro budućih generacija, eksplicira von Hartmann, inzistirajući na tome da čovjek zatomi svoju pojedinačnost te se angažira za spas cjeline. Pojedinac bi naime trebao zauzeti poziciju (samo)odricanja, koja se neće manifestirati primjerice kao samoubojstvo ili ekstremni solipsizam, i kreativnim djelovanjem sudjelovati u razvoju civilizacije. A kako se pokazalo da smisao života nije u sreći, odnosno da je ona nedostižna zamisao, te da je uzrok neminovne ljudske nesreće volja, kao smisao života nameće se svijest koja može biti instrument za negaciju volje. I zato se s vrhuncem njegova eudajmoničkoga pesimizma, procjenjuje Beiser, susrećemo upravo u nihilističkoj teoriji otkupljenja prema kojoj ljudi potpuno oslobođenje od patnji mogu dostići tek kolektivnim opovrgavanjem volje (2016: 156). Ako samo jedan čovjek opovrgne volju, patnja završava samo za njega, dok ostatak čovječanstva nastavlja patiti. No ako je ljudi jednodušno odluče opovrgnuti, to će uništiti volju samu jer ona postoji isključivo u samosvjesnim utjelovljenjima. Tako se eliminacijom volje kao izvora egzistencije kreira ništavilo u kojem se upravo ispunjava konačna svrha: život bez boli.

Dakle kakva god bila sudbina ovoga svijeta i čovjeka u njemu, ne ostaje se bez perspektive: „(...) povijest ima svoj smjer, razum će nakraju pobijediti nad iracionalnošću; doći će do oslobođenja od patnje, pa makar jedina alternativa bila ništa.“ (Invernizzi, 1994: 186) Prema tome i čovjekovo djelovanje ima smisla jer je iskupljenje svijeta moguće realizirati samo uz pomoć pojedinca, razvojem samosvijesti i razuma: on se mora vlastitim moralnim djelovanjem angažirati $u$ društvenoj evoluciji. Zato je von Hartmannovu pesimizmu komplementaran evolucijski optimizam prema kojem život valja živjeti, kad već nije moguće u skladu s eudajmoničkim načelima, prema moralnim standardima. Onoga trena kad se odreknemo iluzije da možemo postići sreću, koja se zapravo temelji na egoističnom interesu da se nadvlada druge, spremni smo posvetiti se moralnim idejama, koje zahtijevaju da pojedinac djeluje radi samoga principa. 


\subsection{Kierkegaardova psihologija očajanja}

U devetnaestostoljetnoj paradigmi beznađa, koju smo analizirali u okviru problematike mal de vivre, istaknuto mjesto pripada Kierkegaardu, danskomu filozofu od rane mladosti okupiranomu besmislom postojanja, ponajprije zbog osjećaja krivnje u vjerskom odgoju, a iz čega će razviti svoju cjelokupnu filozofiju. ${ }^{48}$ On se naime kao duhovni otac filozofije egzistencije među prvima okrenuo čovjekovim psihičkim stanjima te je, izrazivši temeljna raspoloženja svojih suvremenika, postao reakcijom na vrijeme u kojem je pojedinac izgubljen u masi, „u sutonu jednoga svijeta kojemu se budućnost zatvorila, na prijelomu epoha kad je sve bilo u znaku pitanja“ (Pejović, 1970: 88). Protestirajući protiv velikih, objektivnih sustava i nepromjenjivih istina, umnogome je utjecao na fin de siècle, koji na vidjelo iznosi neurozu, intimne strahove i dezorijentacije, a ne život hegelovskoga objektivnog ili apstraktnog duha. Jer nasuprot naporu tradicionalne filozofije da se ,prethodno razlikovano osjetilno i nadosjetilno, vremenito i vječno, sklope u smislenu cjelinu“ (Žunec, 1996: 158), Kierkegaard pojmom egzistencije, mišljene kao kršćansko iskustvo, dovodi u pitanje identitet i stabilnost svih dotadašnjih vrijednosti. Uzevši u razmatranje čovjeka zaboravljena u općenitosti anonimnih zbivanja, počinje ga promatrati prema onome što je on iznutra: ne kao ono što mu se izvanjski daje kao poredak objektiviteta, nego kao ono što on prema takvom svijetu osjeća. Jer, objašnjava Supek, onaj

tko želi spoznati istinu, mora sići do dna svoje „privatne“ svijesti, i otkriti tamo izvjesne odsudne i apsolutne momente svog ličnog postojanja. Što otkriva međutim pojedinac koji silazi u dubinu svoje svijesti? Tjeskobu i očaj (1950: 27).

To je srž Kierkegaardove filozofije. Manifestacije vanjskoga svijeta reflektiraju se u čovjekovoj psihi, zbog čega on život razumijeva kao rastrganost između ideala i stvarnosti, $u$ kojoj se svakodnevno suočava sa strahovima, boli, dvojbama i bolestima. Razvivši dakle svoju filozofiju u izravnoj opreci prema Hegelovu objektivnom duhu, zanima se za subjektivno, prolazno i neponovljivo. Nasuprot Hegelovoj perspektivi bića za Kierkegaarda „duh sa spekulacijom uznesen do vrtoglave visine nenadano se ruši u bezdan ničega svaki put kad se

\footnotetext{
${ }^{48}$ „Od dječje dobi bio sam pod utjecajem silne melankolije, dubina koje se može odmjeriti samo prema jednako tako silnoj spretnosti da to sakrijem prividnom veselošću i jois de vivre. Koliko mi pamćenje doseže, moja jedina radost bila je u tome da nitko ne primijeti koliko sam nesretan. (...) Već u najranijem djetinjstvu bio sam skršen teškim dojmom melankolije u koju je utonuo moj otac i koju je prenio na mene“, zapisao je Kierkegaard (cit. prema Žunec, 1996: 146).
} 
sjeti svoje pojedinačnosti“ (Zurovac, 1980: xv). Premda stvara specifičnu filozofiju religije, usmjeravajući svoje razumijevanje egzistencije vjeri te inzistirajući na njezinu pounutrenju, koje omogućuje da se pojedinac uspostavi kao ,ja“ te tako shvati samoga sebe, ${ }^{49}$ neke fundamentalne Kierkegaardove kategorije izravno, pa makar i na površnoj razini, možemo povezati s našim pojmom dekadencije: „bolest na smrt“ koja priziva očajanje, tjeskoba koja proizlazi iz slobode izbora te „strah i drhtanje“ kao neugodna čuvstva neprestane strepnje. Te kategorije odgovaraju trima stadijima - estetskomu, etičkomu i religioznomu - prema kojima se osobnost pojedinca gradi u dijalektici „ostajanja u zajedništvu, nerasplinutosti, u nekoj vrsti sinteze ili ravnoteže“ $i$,,suprotnih stremljenja koje egzistiraju unutar osobnoga ja“ (Lučin, 2015: 173). S punom sviješću o životu razapetom između subjektiviteta i objektiviteta, već mu knjiga Ili-ili (1843) sažima životnu dramu u kojoj se shvaća da su patnja i podnošenje tereta sudbine temeljne egzistencijalne formule. „Moje posmatranje života je savršeno besmisleno. Pretpostavljam da mi je neki zao duh natakao na nos naočare, čije jedno staklo ogromno uvećava, a drugo u istoj mjeri smanjuje.“ (Kierkegaard, 1990: 27) „Ili-ili““ jest životni princip iz kojega je posve očigledno da egzistirati znači biti neprestano izložen izborima, a pritom je izbor, budući da implicira odricanje od nečega, uvijek izvor tjeskobe. Tu će tezu Kierkegaard razraditi i u raspravi Pojam tjeskobe (1844), ${ }^{50}$ u kojoj kroz mit o Adamu i Evi demonstrira da je srž iskonskoga grijeha upravo tjeskoba slobode pred mnogobrojnim mogućnostima izbora.

Izbor dakle generira kajanje, osjećaj krivnje, očaj, a tjeskoba je u tom kontekstu esencija života. Ona je neutemeljen strah koji paralizira te se zato tjeskoban čovjek prepoznaje kao neaktivan, apatičan, izmučen nekom nevjerojatnom mučninom. U njoj Kierkegaard uočava „osnovno duševno raspoloženje, izvor i organ kojim lična svijest dolazi do pravog predmeta spoznaje“ (Supek, 1950: 27). Kako je zapisao u dnevniku:

Osoba koja pati od tjeskobe žali se na nešto neodređeno što joj je palo na leđa, poput tereta koji je prisiljena nositi. Taj pritisak, to breme, ne dolazi izvana: (...) on je zapravo unutarnja refleksija nečega izvanjskoga. (cit. prema Minois, 2005: 236)

Ova definicija neodoljivo podsjeća na melankoliju, također čestu pratnju emocionalno senzibilnijih osoba, neizrecivo stanje mahom nepoznata uzroka. Taj gubitak vlastitoga ,ja“, odnosno beznadna neobjašnjiva tuga, razlikovni je znak onih kojih prekomjerno promišljaju.

\footnotetext{
${ }^{49}$ Svoje je kršćanstvo koncipirao, solipsistički se otklanjajući od institucionalnosti religije, kao pojedinačno iskustvo popraćeno strahom, tjeskobom i očajanjem, čuvstvima koja su presudno obilježila i njegovu svjetovnu egzistenciju.

${ }^{50}$ Vratit ćemo joj se u jednom od nadolazećih poglavlja.
} 
Ili, kao što je napisao Kierkegaard na tragu srednjovjekovnoga razumijevanja, melankolija je „grijeh onih koji ne žele dovoljno jako i iskreno te je zato majka svih grijeha“" (cit. prema ibid.: 237). Ipak, melankolija i tjeskoba u čovjeku izazivaju neku sretnu krivnju jer nude utočište od objektiviteta modernoga svijeta te izlaz iz egzistencijalne dosade svakidašnjice: očaj kao oslobođenje moguće je doseći tek ,,izlaskom iz sebe samih kako bi se vidjela ispraznost svih ljudskih aktivnosti“" (ibid.: 238). Zato se može reći da je melankolija privilegirano stanje pomoću kojega pojedinac razumijeva svijet. A taj se svijet više ne percipira kao skladan, idejno postavljen poredak, nego kao odraz unutarnjega, psihičkoga rastrojstva koje svjedoči udaljenosti od harmonije. Zato Kierkegaard i upozorava da se život ne odvija kao roman, nego da je čovjek uvijek suočen s teškoćama njegova podnošenja. Sam izbor „ili-ili“ jest izbor između estetičkoga i etičkoga, između unutarnjih stanja duha koji opaža izvanjski svijet i vanjskih formi po kojima u tom svijetu moramo živjeti. Apsurd dan u kategoričkom „,iliili“ označava i čovjekovu razapetost između dvaju svjetova, unutarnjega i vanjskoga, pri čemu se pokazuje da je mogućnost izbora uvijek i uzrok rastrganosti. Kierkegaard sugerira da su ljudi ograničeni jer se ne koriste slobodama koje imaju, već traže one koje nemaju. Imaju primjerice slobodu mišljenja, a traže slobodu govorenja i pisanja. Drugim riječima, sloboda je mišljenja ono unutarnje čovjekovo koje nema potrebu izlaska u sferu javnoga jer javno diktira određene uvjete. Zato je mišljenje čovjekova autentična egzistencija oslobođena kolektiva javne sfere. Svemu što je ljudsko svojstveno je proturječje jer ,samo kroz suprotnost možemo doći do toga što želimo“ (Kierkegaard, 1990: 23). Prema tome sve su projekcije budućnosti jalove jer su dio objektivnih stremljenja koja s unutarnjim čovjekom nemaju veze. Život je postavljen u neizvjesnoj sadašnjosti u kojoj bivamo ne znajući što nam budućnost donosi:

(...) vidim pred sobom samo prazan prostor, i što me vuče naprijed, ponor je koji leži iza mene. Ovaj život je preokrenut i užasan da se ne može izdržati. (ibid.: 26)

Realnost života koji se ne može podvesti pod metafizičke ideje savršene cjeline i harmonije reflektira tugu i patnju jer se obija o idealizirani svijet koji je, kako s vremenom postaje razvidno, neistinit. „Govorim o svojoj tuzi kao što Englez govori o svojoj kući: moja tuga is my castle (je moj zamak): Mnogi smatraju da u životu treba iskusiti i jad.“ (ibid.: 24) U više navrata Kierkegaard slikovito opisuje nemogućnost bijega od sebe i vlastite patnje ne bi li demonstrirao da relativizam razdire čovjekovu svakidašnjicu te da njegovim životom dominira 
apsurd, koji se nadaje kao tautologija, kao Nietzscheovo vječno vraćanje jednakoga. ${ }^{51}$ Jedan je od tih apsurda dosada u kojoj prevladava doživljaj zasićenosti, gubitak interesa i nepoljuljana ravnodušnost, rezignirano predavanje životu u kojem ,ja ležim dokon; jedina stvar koju vidim to je praznina, jedina stvar u kojoj se krećem, to je praznina. Čak ne patim od bolova. (...) Umirem smrću“ (ibid.: 38). A budući da se život uvijek iznova vrti u apsurdu začaranoga kruga, „,ili-ili““ jest izraz te bezizlaznosti koja razdire čovjekovu unutrašnjost te se on pokazuje trajno zarobljen u njemu.

Duša mi je umorna i nesrećna, uzalud je podbadam mamuzama zadovoljstva, ona više ništa ne može, ona se više ne diže do kraljevskog skoka. Izgubio sam sve iluzije. Uzalud pokušavam da se predam beskrajnoj radosti, ona ne može da me podigne ili tačnije, ja sam ne mogu da se podignem. (ibid.: 42)

Pojam tjeskobe i Bolest na smrt (1849) možda su najbolje koordinate Kierkegaardove psihološke analize sebstva u odnosu na fenomene tjeskobe i očajanja. Dok u prvoj knjizi tjeskobu prezentira kao početnu poziciju suočavanja s iskustvom slobode, odnosno kao stanje u koje pojedinac upada kad je prepušten slobodi kreiranja vlastite egzistencije, u Bolesti na smrt dublje ulazi u duhovni život $\mathrm{i}$ iskustvo očaja, tumačeći na koji se način pojedinac, kad se neuspješno suoči s tjeskobom, nosi s očajem. On se javlja „upravo onda kada ono ja ne uspije doći do svojega odgovarajućeg, pomirujućeg egzistencijalnog stadija ili stupnja svijesti“ (Lučin, 2015: 182). Razvivši pravu psihologiju očajanja koja poprima gotovo metafizičko značenje, Kierkegaard tumači da očajanje kao „bolest na smrt“ obuzima cijeloga čovjeka - ono je apsolutno jer čovjek ne očajava nužno iz nekoga konkretnog razloga, nego jednostavno očajava. No, ipak procjenjuje, moći očajavati jest vrlina jer je očajanje priroda čovjeka koji se odnosi prema apsolutnome, a koja ga uzvisuje u odnosu na sva druga bića dokazujući da je on duh. „Dakle beskrajna je prednost moći očajavati; a ipak biti očajan nije samo najveća nesreća i jad, ne, to je naša izgubljenost.“(Kierkegaard, 1980a: 13)

Može se prema tome reći da je njegova misao duboko prožeta idejom smrti i očaja kao psihološkoga i duhovnoga iskustva. Inzistirajući na konceptu očajanja kao bolesti vlastitoga ,ja“, tj. smrtne bolesti od koje se nikad ne umire, ono je za njega permanentno stanje, a ne tek puki događaj. Kierkegaard objašnjava da je očajanje unutarnji nesklad sinteze, ali da pritom

\footnotetext{
${ }^{51}$ „Kada ustanem ujutru, vraćam se odmah ponovo u krevet. Najljepše mi je uveče, kada gasim svjetlost i navlačim ćebe preko glave. Još jednom se uspravim i gledam sa neopisivim zadovoljstvom sobu. A tada. Laku noć! Pod ćebe! (Kierkegaard, 1990: 28)
} 
sinteza nije nesklad jer, da je tomu tako, uopće ne bi bilo očajanja, nego bi bila riječ o konkretnoj bolesti, patnji ili smrti. Očajanje se javlja kad se čovjek odnosi prema samom sebi i onom tko je taj odnos postavio, odnosno kad se ne uspije odrediti: proizlazi ,iz odnosa u kome se sinteza odnosi prema samoj sebi, time što bog, koji je čoveka učinio odnosom, ovoga takoreći ispušta iz svojih ruku, što znači time da se taj odnos odnosi prema samom sebi“ (ibid.). Budući da pojedinac stalno očajava jer je to obilježje čovjeka kao duha, očajanje je trajnost koju je on navukao na sebe. Odnosno:

(...) to je stalno sadašnje vreme, tu ne postaje ništa u odnosu prema stvarnosti za sobom, ostavljenoj prošlosti; u svakom stvarnom trenutku očajanje, očajnik nosi svu moguću prošlost kao sadašnjost. To dolazi od toga što je očajanje određenje duha i što se odnosi prema večnom u čoveku. (ibid.: 14)

Ono nema ni svoj cilj ni svoj završetak te je zato, kao doživljaj umiranja, bolna kontradiktornost: ono znači umirati, a ne umrijeti. Pojedinac ga se ne može osloboditi: očajanje se naime uvijek iznova nudi kao mogućnost jer ne proizlazi iz nesklada, nego iz odnosa prema samom sebi. I zato se toga odnosa čovjek ne može osloboditi, jednako kao što se ne može osloboditi ni svoga ,ja“. Kao sama čovjekova bit te stalni suputnik njegova života, ono je, kako je razvidno i iz temeljne sintagme, „bolest na smrt“ - bolest od koje se ne umire, što bi bilo slično smrtno bolesnomu koji nije umro, ali je očajan jer umire. U očajanju se zrcali beznađe tegobna života. „U tom poslednjem značenju očajanje je bolest na smrt, ta mučna protivrečnost, ova bolest vlastitog ja da se večno umire, da se umire, a da se ipak ne umre, da se ubije smrt.“ (ibid.: 15)

Međutim „bolest na smrt“ nije tek stvar individualnoga očajanja niti je samo pitanje vjere. Naprotiv, ona proizlazi iz čovjekova očajna položaja u svijetu. „Svojom borbom protiv opšte nivelacije, premda zaboravljajući na čoveka kao tvorca ovog sveta, Kjerkegor je stekao zaslugu onog koji je najdublje istakao nerazrešivu 'singularnost' čak i onog univerzalnog“ (Žunjić, 1975: 24). Po njemu izlaz iz svakidašnjice života valja potražiti u vjeri koja treba biti autentična, s onu stranu svake kolektivne religije. Pounutrenom vjerom pojedinac pronalazi sebe i viši smisao. Postavivši se svojom doktrinom kao filozof vjere kao jedinoga načina odnosa prema sebi te uvidjevši da pozicije „straha i drhtanja“ proizlaze iz spoznaje o egzistencijalnom apsurdu i proturječnosti, Kierkegaard gradi metafiziku individualne slobode, nasuprot idealističkomu apsolutu, prema kojoj se pojedinac, izgubljen u bespućima nadindividualnoga i društvenoga, iz besmisla svijeta spašava svjesnim odabirom Boga. 


\section{DRUŠTVENO-POLITIČKI I KNJIŽEVNOPOVIJESNI OKVIR DEKADENCIJE}

\subsection{Defetizam Austro-Ugarske Monarhije}

Sumorno poimanje pojedinačne egzistencije, prema kojem je ona bitno određena svijetom kojim dominiraju bijeda i zlo, tipično za filozofije pesimizma i očajanja predstavljene u prethodnom poglavlju, u velikoj je mjeri korespondiralo s društvenim i političkim kretanjima. Budući da je teško razlučiti je li tadašnja dekadentna svijest reflektirala društveno-politička strujanja ili su se pak ona razvijala na temeljima filozofije i kulture, najoportunije je ustvrditi kako je dekadencija na prijelomu stoljeća rezultat suodnosa filozofskih, kulturnih i društvenopolitičkih faktora. Jer, kako smo istaknuli još na početku disertacije, dekadencija izranja iz konteksta vremena te se u našoj književnosti nameće kao neizravno svjedočanstvo svega što se u Austro-Ugarskoj događalo: u težnji da bude predvodnica kontinenta u njegovu duhovnopovijesnom razvoju u njoj se prelamaju različiti svjetonazori, često međusobno oprečni. Unutar toga se smisla prepoznaje i činjenica da je dekadencija u slutnji propasti svijest o nepostojanju vrijednosti koje jedno društvo drži na okupu. Ona je upozorenje na podvojenost i rastrganost ne samo aktualnih društvenih prilika nego i ljudi kao dijela njihova konteksta.

Vjerojatno nećemo pogriješiti ako se složimo s Marchand i središnju Europu nazovemo jezgrom fin de sièclea (2015: 131) te unutar te jezgre privilegirano mjesto damo AustroUgarskoj, zemlji koja se opravdano može nazvati izvorom dekadentnoga senzibiliteta. Usto ona je presudno odredila i kulturnu sudbinu Hrvatske, zemlje koja joj je bila fizički i duhovno upućena. Razumijevanja hrvatske povijesti, pa i hrvatske kulture, nema bez poznavanja širih okvira Habsburškoga Carstva, odnosno Austro-Ugarske Monarhije. Već smo dali naslutiti da je dekadencija u našoj književnosti bila jedinstven izraz političkih i društvenih okolnosti, koje su pak izravno zrcalile aktualna kretanja u matici zemlji koja prema kraju stoljeća sve više osjeća vlastite slabosti, što se posebno očituje u sferi građanske kulture. Za sve su zemlje središnje Europe karakteristična intenzivna prožimanja imperijalnih, liberalnih i buržoaskih strujanja na površini te kaotičnih, razornih dubina, iz kojih će proizaći niz političkih patologija koje će u potpunosti oblikovati Europu i svijet u XX. stoljeću. Kako utvrđuje i Paić, kulturni je pesimizam, to ključno obilježje druge polovice XIX. stoljeća, „pravo dijete njemačkoaustrijskog ressentimenta za predmodernim oblicima jedinstva duhovnosti u srazu s velikim preokretom moderne u ekonomiji, politici i kulturi“ (2007: 200). Historiografija posljednja desetljeća Monarhije slično određuje, nazivajući ih njezinim babljim ljetom (Taylor, 1990), sutonom (Judson, 2018) te epohom pada i razdora (Kann, 2002), a tomu se može pridodati i 
generalna ocjena da je ona bila autentičan simbol dekadencije i dezintegracije (Friedländer, 1985: 62). Prožimajući osjećaj urušavanja carskih temelja nakon političkih promjena 1867. te njegove polagane propasti, koji je prema kraju stoljeća kulminirao u dekadenciji, dobro nam je poznat. Važno je međutim prepoznati da je ta atmosfera sad kontrapunktirana osjećajem da se konačno uhvatio korak sa Zapadom. U takvoj klimi, u kojoj središnja kategorija postaje egocentrizam (Pynsent, 1989: 142), izvanjski znakovi propadanja sukobljavali su se s unutarnjim svjetovima inovacija. Istaknimo zato neke osnovne crte monarhijske politike i njezinih kulturnih osnova.

Kako povjesničari nerijetko procjenjuju, osnovna napetost u politici Austro-Ugarske Monarhije očitovala se u opreci tradicionalnih i liberalnih svjetonazora te politika koje su ih zastupale. S jedne se strane klasicistički duh bidermajera nastojao održati potpomognut monarhijskom i klerikalnom utemeljenošću, dok je s druge liberalni prodor ideja otvarao put građanskoj struji koja je Monarhiju nastojala učiniti kulturno-političkim predvodnikom. Ta se politička dvojnost reflektirala i kroz podvojenost društvenoga bića između konzervativizma i liberalizma, koje se odražavalo i u umjetničkim izrazima što će prikazivati nastalu rastrganost. Judson u svom pregledu Carstva (2018) kao jednu od važnih epizoda u njegovoj povijesti ističe nastanak „liberalne“ države sredinom XIX. stoljeća. Tad naime car Franjo Josip novim dekretima najavljuje, egzaktnije nego ijedan Habsburgovac prije, jačanje organskoga jedinstva zemlje pokretanjem modela društvene, gospodarske i kulturne obnove. Dakle može se reći kako se nakon revolucionarnih previranja 1848. krajnje formaliziranoj državi tražio društveni supstrat koji bi ga podupirao. Iako je utopija liberalne države potrajala nešto manje od desetljeća, dovevši zbog vojnih poraza i financijskih kriza do niza kratkoročnih i dugoročnih katastrofa te prisilivši cara na sklapanje Austro-ugarske nagodbe, u 1850-ima postavljena je solidna baza inovativnih ekonomskih, znanstvenih i obrazovnih promjena koje su dominirale politikom još dugo nakon 1867. U vremenu Bachova apsolutizma Judson kao jednu od karakterističnih odlika prepoznaje sklonost „uljepšavanju dinastije“ (2018: 269) koja, kako bi joj se povećala popularnost, provodi niz sitnih reformi i kadrovskih promjena. Tako bi se paradigmatskom mogla nazvati teorija Ernsta von Schwarzera o različitim razinama razvijenosti Monarhije, prema kojoj je bilo nemoguće primijeniti liberalnija načela u svim njegovim dijelovima, osobito $\mathrm{u}$ onima $\mathrm{s}$ izraženijim klerikalnim utjecajem ili industrijski zaostalima. Riječ je, dakako, pretežno o ugarskim dijelovima, pa se napetost pokazivala i u dvojnosti krune i zemalja koje su pod nju potpadale. Takve etničke i civilizacijske razlike car je nastojao smanjiti, no one su igrale veliku ulogu u daljnjim kretanjima. „Carstvo se sve više promatralo kao zbirka etnički različitih naroda koji su uz to navodno zauzimali različite 'razine' 
civilizacije (etnički Mađari, Bohemija, Hrvatska).“ (ibid.: 275) Te tvrdnje o različitim stupnjevima civilizacijskoga razvoja rezultirale su i usporedbama kulturne i političke nadmoći Austrije i drugih europskih zemalja. Tako je naprimjer Hammer-Purgstall austrijski pravnopolitički sustav smatrao slobodnijim u odnosu na ostatak Europe zato što je zemlja nastala savezima i ugovorima te zato što se u Austro-Ugarskoj njegovala različitost jezika (osim u službama), čime se poticala jednakost građana. Znakovito je zaključio da će europeizacija ubrzo donijeti sve veću višejezičnost, a kad se to dogodi, Austrija će biti daleko ispred ostalih država (ibid.: 275-276). Ključan korak u razvoju Monarhije, kao posljedica dubokih unutarnjih i vanjskopolitičkih kriza, bilo je stvaranje dvojne države, u kojoj su se dvije zajednice vrlo brzo razišle oko jezičnih pitanja i nacionalnoga identiteta. Austro-Ugarska, „kao društvo koje je prolazilo kroz procese regionalne industrijalizacije, urbanizacije, opismenjavanja, specijalizacije činovništva, unutarnje migracije i političke participacije“ (ibid.: 302), postala je tipična devetnaestostoljetna europska zemlja. Ili, kako kaže Stone, „minijaturna verzija Europe u cjelini““(1999: 226).

U austrougarskom društvu tako se s vremenom sve više počeo uvažavati autoritet kulture te je postupno rasla svijest o potrebi njezine afirmacije. Istodobno su postojale različite kulturne vizije i programi koji su pretendirali na određenje duhovnoga života u cjelini. Zaokret prema kulturnim argumentima odvio se, procjenjuje Judson, zato što se politika nakon 1867. polagano demokratizirala, pa je u austrijskom dijelu države širenje prava glasa bilo poduprto nacionalnom sviješću u izgradnji, ponajprije u kulturi koja je postala put konstrukcije identiteta, a onda i političkih težnji Monarhije i svake njezine zemlje. Izgradnja zajedničkih carskih institucija odigrala je ključnu ulogu u konstruiranju (nad)nacionalnoga identiteta, ali je u isti mah razvijala otpore naroda izgradnjom vlastitih identiteta (Judson, 2018: 312). Zato se može istaknuti da je doktrina o višenarodnosti i kulturnoj pluralnosti, osobito zaživjevši u 1880-ima i 1890-ima, za posljedicu imala centrifugalne tendencije jačanja nacionalnoga duha pojedinih zemalja u odnosu na ideju jedinstvenoga nacionalnog identiteta. Vrijeme je to osnaženja liberalnoga utjecaja koji sve više utječe na državnu birokraciju kao profesiju koja čuva meritokratski sustav od aristokratizacije Monarhije. S vremenom, nastavlja Judson, činovnici sve više preusmjeravaju svoju lojalnost s cara na parlament, odnosno s dinastije na ustav, što će pridonijeti produbljivanju ambivalentnosti duha Monarhije, rastrgane između aristokratizma, koji simbolizira tradicionalnost i konzervativnost, te liberalizma kao nosioca progresivnosti i novoga duha. Judson navodi da su liberalni programi, usmjereni protiv stupova tradicionalnoga austrijskog društva te poboljšanju kvalitete života širenjem znanja i kulture, mahom stvarali negativnu predodžbu o onima koji su se tim programima protivili te su pritom njihovo 
protivljenje pripisivali „odbijanju prosvjetiteljskih koristi“ (ibid.: 315). ${ }^{52}$ Liberali su ideju o nazadnosti projicirali osobito na hijerarhiju Katoličke crkve, ali i na nazadne snage u birokraciji i vojsci. Ipak, kad govorimo o „kulturnim ratovima“, važno je imati na umu da su se kulturne definicije nacionalnosti razlikovale. Dok su one u austrijskom dijelu nastojale u većoj mjeri osigurati kulturnu autonomiju unutar nacionalne zajednice, u mađarskome je na snazi bila asimilacijska politika umanjivanja razlika podvođenjem pod mađarski kulturni i jezični obrazac, osobito izražen u školskom sustavu. Mnogobrojne kulturne ambivalentnosti Monarhije režim je pokušavao nadići apostrofiranjem koristi koje jedinstvo države donosi njezinim narodima, veličajući ,raznolikost svojih naroda onako kako je njemu odgovaralo, prikazujući je kao snagu koja koristi svim njegovim građanima“ (ibid.: 354). Jedna je od tih misija bila izložba organizirana 1873. u Beču kako bi se Austrija legitimirala kao poveznica između Istoka i Zapada. Međutim, umjesto propagiranih kulturnih dostignuća pojedinih zemalja, vrlo su se brzo primijetile razlike među njima, što je samo produbilo tezu o velikim civilizacijskim razlikama unutar države. A problem je, među ostalim, ležao u činjenici što je stvoren dojam „da je Istoku trebalo civiliziranje, da su njegovi ljudi bitno drukčiji od onih na Zapadu i, da, u krajnjem slučaju nikada ne mogu ni postati poput onih na Zapadu“ (ibid.: 357). S ciljem usavršavanja različitih naroda primjenom kulturne paradigme otvoreno je i sveučilište s dominantnom njemačkom sastavnicom u najistočnijem od svih gradova Monarhije te je započeto objavljivanje golemoga enciklopedijskog izdanja Die österreichisch-ungarische Monarchie in Wort und Bild, koje je pod vodstvom dviju odvojenih redakcija okupljalo više od četiristo stručnjaka. Tragalo se, može se reći, za jedinstvom i zajedničkim identitetom, a taj je napor u isti mah demonstrirao nepremostive razlike koje su građani, osobito pripadnici učenih profesija, sve snažnije osvještavali.

Te su razlike sve očiglednije od 1880-ih, razdoblja velikih promjena. „Nova vrsta države za novu vrstu društva“ (ibid.: 371), sumira Judson. Uz razvoj komunikacijske i prijevozne infrastrukture, koja je pridonijela otvaranju svijesti ljudi prema drugim dijelovima Europe i svijeta, sve je više ljudi odlazilo u druge carske gradove, pa je u samo 20 godina, između 1890. i 1910, stanovništvo Beča, Budimpešte, Praga, Lavova, Zagreba, Rijeke i drugih gradova

\footnotetext{
${ }^{52}$ Težnja liberalizaciji u političkom se smislu osobito izrazila u ekspanziji na područje Osmanskoga Carstva, tj. $\mathrm{u}$ okupaciji Bosne i Hercegovine, kojom je ,provjerena austrijska sposobnost ravnopravnog tretiranja svih jezičnih i vjerskih skupina trebala dokazati superiornost liberalnog habsburškog nad etničkim nacionalizmom kao najboljeg sredstva za ostvarivanje napretka“ (Judson, 2018: 365). S jedne su strane habsburški činovnici, koji su dovedeni u Bosnu, željeli stvoriti uzornu koloniju, a s druge je kolonijalni režim pokušavao izbjeći sve dominantniji politički nacionalizam. „Teškoća je ležala u dramatičnom intenziviranju dinamike jedinstva i različitosti koje je svojevremeno pridonijelo stvaranju istih problema kod kuće.“ (ibid.: 366) Monarhija i nacija više nisu mogli bježati jedno od drugoga.
} 
poraslo za više od 60 \%. „Već 1900-ih blizu 40 posto Austro-ugara napustilo je svoj izvorni Heimat i odselilo u nove domove u drugim dijelovima monarhije." (ibid.: 372) Nije to nevažna činjenica i za našu analizu jer je dekadentna senzibilnost bila potaknuta i prelaskom stanovništva i profesija u građanski ambijent u kojem se, u užurbanosti života, nove vrijednosti hirovito suprotstavljaju starima, tradicionalistički uvjetovanima, što pogoduje potiskivanjima koja se gomilaju u podsvijesti onih koji intelektualno promišljaju svijet. ${ }^{53}$ Učvršćuje se dakle ambijent u kojem se opaža podvojenost između stvarnosti lokalnoga (zemaljskoga) identiteta i nadnacionalnoga, Monarhije u njezinu političkom i kulturnom samopostavljanju integritetske točke svih njegovih zemalja i naroda. Zato Johnston i piše kako je od 1867. do 1914. dvojna država bila ,izrazit primjer anomalije: dinastička država bez imena“ (1993: 17).

Izmijenjeno je društvo uvelike obilježio porast pismenosti, promjena potreba i želja građana te rast birokracije na svim razinama (sastavljene od Austrijanaca i Mađara, ali i lokalnih ljudi). Sve je to umnažalo utjecaj državnoga, liberalnoga duha. A posebno ga je pritom obilježila činjenica da pogonska snaga u to vrijeme postaju inicijative s margina Monarhije. „Poštanski radnici i učitelji u osnovnim školama počeli su za opću populaciju simbolizirati carstvo, jer su ga oni predstavljali u najčešćim svakodnevnim komunikacijama, čak i u najzabačenijim ruralnim okruženjima.“ (Judson, 2018: 375) Širenje vladinih funkcija poticalo je građane na udruživanje oko strukovnih i lokalnih organizacija te sudjelovanje $u$ predstavničkim tijelima vlasti, što je pak pobuđivalo snažniju političku svijest, osobito s osnivanjem Socijaldemokratske partije 1889, koja je, oslonjena na austromarksističku filozofiju, bila najpropulzivniji zagovaratelj interesa lokalnih ljudi.

Odlučujući je korak ipak bio prodor političkoga u cjelokupan društveni život jer je značio najviši mogući stupanj osviještenosti. Vlade i stranke, kako demonstrira Judson, počele su davati puno veću pozornost kreiranju javnoga mišljenja i manipuliranju njime. Drugim riječima, raslo je ono što bismo danas nazvali populizmom. Politika je sve više postajala instrument masovne mobilizacije, a političari su nakon 1880. sve više ,iskorištavali medije za prikazivanje pojedinačnih interesa kao skupnih - bilo klasnih, religijskih, stručnih ili nacionalnih“ (ibid.: 376). I u ovom se segmentu javljala ambivalentnost jer su konzervativniji političari nove liberalističke pristupe masovnoj politici smatrali neukusnima i zbunjujućima, pa se rađao otpor novomu obliku „demokratizacije“. Tako se vladavina liberalnih vizija i praksi

\footnotetext{
${ }^{53}$ Jedan je to od razloga zbog kojega će umjetnost fin de sièclea, osobito s prvim desetljećima XX. stoljeća, sve više biti usmjerena umjetničkim izričajima koji na razinu objektiviteta iznose subjektivna, unutarnja psihička stanja straha, neizvjesnosti, tjeskobe i mučnine - pesimistički i nihilistički ambijent inspiriran ubrzanim tempom života i urušavanjem vrijednosti koje su dugo vremena bile čvrst temelj pod nogama stanovnika Monarhije.
} 
postupno raspala sredinom 1880-ih, između ostaloga, i zbog pojave novoga oblika društva temeljenoga na masama. Obrasci masovne urbanizacije, potrošnje, komunikacije i društvene organizacije „dovodili su u pitanje izrazito ograničeni, individualistički i nezainteresiran pristup liberalizma društvenim problemima i upotrebi političke moći“ (ibid.: 386). Politička se i društvena ambivalentnost tako još produbljivala pridonoseći rastrojenosti svijesti intelektualnih krugova i mlađih političkih aktera. Judson upozorava da je uspon masovnoga društva stvorio i niz socijalnih problema za čije se rješavanje habsburški liberalizam činio potpuno nespremnim, što oslikava neke od ključnih razloga razvoja dekadentne svijesti uzrokovane rastrganošću između starih i novih pogleda na svijet.

Na prijelomu stoljeća privlačnost modernosti te cilj ostvarenja napretka u europskom rangu bio je vidljiv i u inicijativama koje nisu bile vezane samo za infrastrukturne intervencije, poput radničkih udruženja, feminističkih inicijativa te inicijativa o reformi obrazovanja i poboljšanje životnoga stila. Svi su ti programi bezrezervno težili preobrazbi osnovnih društvenih elemenata u skladu s europskim napretkom. „Dok su veći i manji gradovi AustroUgarske postajali utjelovljenja osviještene modernosti, mnoge je brinulo da ta modernost podrazumijeva i visoku cijenu. No, s druge strane, i same te brige, vješto preuveličavane u medijima, postajale su prepoznatljiv aspekt modernosti.“ (ibid.: 399) Naime uočava se da je nadnacionalni kulturni i politički identitet umjetno stvaran te medijski osnaživan, što je dodatno pridonosilo dvostrukosti u svijesti koja je sve više uočavala dva svijeta, fikcijski, koji je trebao usmjeriti snage na zajedničku kulturu, i stvarni, koji je opažao realnost suprotnu umjetno kreiranoj poželjnosti.

Pored kulturne problematike, u kojoj se očituje težnja snažnijemu kolektivnomu identitetu stanovnika Monarhije u svim zemljama, ključna je ipak bila ona ekonomska: goleme razlike u gospodarskoj razvijenosti, a time i velika razlika između razvijenosti građanskoga društva u sjevernim zemljama i nerazvijenosti na jugu i istoku. Socijaldemokracija koja je bila nositelj demokratizma nije mogla jednako utjecati u austrijskom dijelu i na jugu ili istoku, a oni čiju je ekonomsku afirmaciju trebalo razviti živjeli su pretežno baš u tim nerazvijenim dijelovima. Činjenica da su socijaldemokratske ideje austromarksizma bile samo dobra teorija (jer je za njih bilo potrebno razvijeno građansko društvo) dodatno je produbljivala pesimizam pripadnika intelektualnih zanimanja u nerazvijenim zemljama jer je postajalo sve jasnije da se modernističke ideje mahom odnose na dio države kojemu oni ne pripadaju. Tako će primjerice i književnost koju pratimo u nastavku za likove vrlo često uzimati intelektualce teškoga imovinskog statusa koji besperspektivnost ne uočavaju samo u propasti starih vrijednosti nego i u realnoj nemogućnosti prihvaćanja novih. Judson argumentira da pitanje nacionalnosti i 
socijalizma nije bilo samo pitanje taktike, nego je s vremenom ,postalo pitanje od teorijske važnosti za mogućnost uspostave istinski pravednog društva““(ibid.: 410). Svjesni ekonomskih razlika, austromarksisti su se protivili ideji da su nacionalističke posebnosti samo stvar društvene nadgradnje te su već s novim stoljećem ,vjerovali da su te razlike duboko ukorijenjene u materijalnoj realnosti svakodnevnog života u Austro-Ugarskoj“ (ibid.). Antagonizam između demokratizacije s jedne i aristokratske svijesti s druge strane, koji smo prikazali, bio je jedan od uzroka događaja koji će zateći Europu.

Vraćajući se tematski na početak ovoga poglavlja, u kojem smo postavili koordinate razumijevanja predosjećaja raspada Monarhije, za kraj recimo da i Judson svoju analizu godina pred Prvi svjetski rat zaključuje činjenicom kako povijesna znanost nije izmislila ideju o anakronoj državi koja je, i puno prije rata, bila osuđena ,na propast zbog navodne slabosti svojih unutarnjih institucija ili njihove nesposobnosti da se suoče s izazovima modernosti“ (ibid.: 420). Naime na njezin raspad nije utjecao samo institucionalni aranžman nego i čitav niz uzroka koji su pogodovali ambivalentnoj svijesti u svim porama društva, a koje su uočavali uglavnom intelektualci i elita. Pritom Judson skreće pozornost na činjenicu da mnogobrojni memoari i korespondencije pripadnika vojne, činovničke i aristokratske elite razotkrivaju „mračne, pesimistične procjene neposredne budućnosti carstva“" (ibid.). Kao primjer navodi kneza Karla Schwarzenberga, koji se požalio, govoreći o prijeko potrebnom moderniziranom apsolutizmu, „da 'kamo god se čovjek okrene, posvuda vidi propadanje, a nigdje onu čvrstu volju i čvrstu ruku'“, i grofa Osvalda Thun-Salma, koji izravno kazuje: „’U našoj državi optimist mora izvršiti samoubojstvo.'“ (ibid.) Swart pak podsjeća da su se diplomati nerijetko na Monarhiju referirali kao na drugo bolesno europsko carstvo (nakon Osmanskoga): „Nakon dva vojna poraza koja su rezultirala gubitkom teritorija i političkoga utjecaja, čak su i austrijski vladari izgubili povjerenje u kontinuiranu postojanost Carstva.“ (1964: 239) I princ Rudolf (koji se ubio 1889) izjavljivao je da ona sve više ostavlja dojam „moćne ruševine, koja može potrajati danas i sutra, ali koja će neminovno nestati (...) sad kad je došao kraj“ (ibid.). Kad već govorimo o intelektualnoj eliti, istaknimo da Schorske komentira kako su austrijski pisci 1890-ih bili djeca ugrožene buržoaske, liberalne kulture koja ustupa mjesto novim društvenim skupinama, modernim masovnim pokretima u političkom životu. Taj je poraz, kako tumači, imao „duboke psihološke reperkusije“ (Schorske, 1997: 26), a temeljno mu je raspoloženje bio osjećaj nemoći. Dionici austrijske kulture, suočeni s raspadom klasičnoga liberalnog shvaćanja čovjeka u vrtlogu moderne državne politike, prekinuli su sve spone „, povijesnim svjetonazorom ključnim za liberalnu kulturu devetnaestog stoljeća u kojoj su bili odgojeni“ (ibid.: 8). Masovni su pokreti intenzivirali postojeće tendencije istovremeno slabeći pouzdanje u zakone morala $\mathrm{i}$ 
progresa, a slom je toga liberalizma „estetsku baštinu preobrazio u kulturu osjetljivih živaca, u sjetni hedonizam i često neskrivenu tjeskobu““ (ibid.: 30).

Dakle Monarhija je sve više u različitim segmentima djelovanja osvještavala vlastiti kraj, propast jednoga konstruiranog svijeta i epohe koja će se, smatralo se, moći spasiti samo ratom. Zaključimo s Judsonom:

Raspoloženje egzistencijalnog pesimizma koje je vladalo među elitama 1914. bilo je jedan od faktora koji su potaknuli neke članove vrhovnog zapovjedništva i diplomatskog zbora da riskiraju uvođenje Austro-Ugarske u rat. (2018: 421)

\subsection{Hrvatski književnopovijesni kontekst}

Nakon što smo u prvim cjelinama rada detaljno razmotrili šire europsko duhovnokulturno okruženje, nastojeći osvijetliti atmosferu vremena, te se dotaknuli izabranih detalja iz austrougarskih političkih i kulturnih paradigmi, treba naglasiti da se i hrvatska književnost razvija u sličnim okvirima. Uvelike određena postavkom da je kultura, pa i književnost kao njezin integralni dio, ,imala jednu od odlučujućih i temeljnih uloga u oblikovanju subjekta građanskog društva, odnosno u konstituiranju moderne građanske Hrvatske“ (Milanja, 2012: 47), književna su djela zrcalila sve probleme naše realnosti. Nipošto dakle ne treba zanemariti činjenicu da su zahtjevi za novom osjećajnošću, koja je podrazumijevala i nova umjetnička rješenja, iako moda vremena i u neku ruku import, istodobno bili odraz specifičnih domaćih prilika. Dekadenciju u našoj književnosti u stanovitoj mjeri obilježava i činjenica da su se nadanja i entuzijazam književnika mijenjali pod pritiscima političkih razočaranja te se pritom, slabije ili intenzivnije, posrednije ili neposrednije, reprezentirali i u njihovim opusima. Fin de siècle u Hrvatskoj jest razumljiv tek s obzirom na prilike u njoj, napose nakon sklapanja Hrvatsko-ugarske nagodbe kojom je prepoznat

povijesni položaj Hrvatske kao neovisnog kraljevstva u savezu s Ugarskom i dana joj je ograničena kulturna i administrativna autonomija, pravo na zadržavanje izabranog sabora i pravo na samostalnu zastupljenost u Ugarskom parlamentu u situacijama kada se to tijelo bavi pitanjima od zajedničkog interesa (Judson, 2018: 298).

Hrvatska u toj zajednici međutim nije imala ni državnu ni političku individualnost. U takvim prilikama, na valu protumađarskoga raspoloženja, na bansku stolicu 1883. zasjeda 
Khuen Héderváry, zapamćen kao jedan od najomraženijih političara u hrvatskoj povijesti. Njegovo se banovanje tradicionalno drži vrhuncem mađarizacije, vremenom autokratske vladavine označenom i terminom kuenovštine (usp. Matković, 2003), u kojem su nevoljko ili pak nikako provođeni gospodarski i kulturni modernizacijski procesi, a sustavna se represija odnosila mahom na sve zone ljudskoga djelovanja. ${ }^{54}$ Uspostavivši na neki način apsolutističku vlast, Khuen je provodio mjere koje su Hrvatsku trebale pretvoriti u ugarsku pokrajinu, ne dopuštajući razvoj političkoga života te gušeći nacionalni identitet hrvatskoga naroda. Činjenica da je prijelomno obilježio hrvatsku povijest zadnje četvrtine stoljeća potiče nas da utvrdimo da su književnici reprezentacijama dekadencije bili obuzeti i zbog hrvatskoga položaja unutar dvojne države, u kojoj su se osjećali kao frustrirani subjekti iscrpljeni neslobodom, političkom, ekonomskom i društvenom inferiornošću te su tako pridonosili, pa makar i posve neizravno, jačanju društvene kritičnosti. Građena dakle na čvrstim temeljima nacionalne „psihologije“, u hrvatskoj je književnosti dekadencija imala doista jedinstven razvoj. Osjećaj političkoga poraza, pa i kad je Khuen otišao s dužnosti, ali i prije njega, prevladavao je upravo u vrijeme fin de sièclea, kad su se raspršile sve nade u samostalnost države.

Aktualna je hrvatska politička pozadina prema tome bila iznimno plodno tlo za prihvaćanje zapadnoeuropskih kretanja. Khuenova vladavina, nerijetko nazivana jednim od naših najtamnijih političkih razdoblja, pogodovala je ukorjenjivanju osjećaja općega rasapa, primjećuje Šicel i poentira:

Atmosfera u jezgri hrvatskoga buržoaskog društva, posebno onoga starije i srednje generacije, bila je u takvoj političkoj konstelaciji, najblaže rečeno, šopenhauerovski pesimistična: nepovjerenje u sve, u svoje najbliže, pa i u sama sebe, uvuklo se u pore svih intelektualnih društvenih slojeva (...): beskičmenjaštvo, poltronstvo, podmitljivost, dvoličnost i, konačno, potpuna rezignacija postadoše tipičnom karakteristikom suvremenoga hrvatskog građanskog društva toga doba. (2005: 17)

Stoga možemo podcrtati da je situacija uvjetovala recepciju određenih pisaca i tema te da se pritom hrvatska stvarnost nametnula kao optimalan kontekst za artikulaciju dekadencije

\footnotetext{
${ }^{54}$ Iveljić međutim, ne dovodeći u pitanje represivan karakter Khuenova banovanja, upozorava da se u Hrvatskoj stvorila radikalno negativna percepcija toga razdoblja te da ne treba smetnuti s uma da se tad bilježe i ,pozitivni pomaci poput važnih kulturnih projekata i završetka horizontalnog povezivanja Banske Hrvatske željeznicom“ (2009: 93).
} 
na kraju stoljeća kao literarnoga toposa. Riječima Milana Marjanovića, koji je već 1901. vrlo sugestivno i možda najbolje od svih aktera opisao mentalitet vremena:

Velika struja evropskih pokreta i misli tekla je i vrtložila mimo nas, a naši krajevi su bili mrtvi rukav, naše društvo i naš život mrtva, uvela nada. Šum i odjeci ispretrganih i mutnih glasova velikog života dopirali su do nas, atmosfera je bila ponekad jedna te ista, samo što je nad nama bila mirnija, pa je zato teže tištala grudi. Sve je to osjetljivije duhove nagonilo na prisluškivanja i razmatranja, jer im zabit nije dala zgode da razviju energije, koje se razvijaju samo u borbi. (1950: 135)

Zato u ovom radu dekadenciju u odabranom korpusu tekstova - podupirući svoju tezu i tvrdnjom da se o njoj, kao jednoj od temeljnih struktura hrvatske književnosti na prijelomu stoljeća, „može raspravljati tek na pozadini specifičnih tema i motiva koji funkcioniraju u osebujnoj duhovnoj atmosferi koja proizlazi iz eksplicitne estetike“ (Pogačnik, 1991: 42) promatramo kao osobit osjećaj inferiornosti. Naglasimo iznova da, iako ideja o življenju u vremenu političkoga i kulturnoga propadanja nije karakteristična samo za kraj XIX. stoljeća, osjećanje krize poduprto sviješću o kraju civilizacije postaje kudikamo intenzivnije. Konstelacija društveno-povijesnih čimbenika, povezanih s nezadovoljstvom odgovorima koje je dao književni realizam, ali i s dezintegracijom romantičarskoga građanskog projekta, uvelike je pogodovala preuzimanju navedenoga pojma kao slabljenja snaga u svim područjima djelovanja.

Cjelovitosti razumijevanja koncepta dekadencije u našoj književnosti pridonosi $\mathrm{i}$ činjenica da je nova kulturološka svijest, o kojoj smo detaljno referirali na početku, implicirala drukčiji sustav vrijednosti te da su razvoju modernističkih tendencija u našoj sredini odsudan impuls dale estetske premise koje su, shvaćajući da se književnost više ne može svesti isključivo na socijalnu ili nacionalnu funkciju, zahtijevale slobodu umjetničkoga izražavanja. Tako se u programskim manifestima, tom karakterističnom obilježju hrvatske moderne, kao najpoželjnije osobine „novoga“ umjetnika i intelektualca izdvajaju autonomnost misli i samostalnost uvjerenja. Iako autori kojima se u disertaciji bavimo nisu direktno sudjelovali u umjetničkim previranjima, odnosno oni koji jesu bili su čak pripadnici starijega naraštaja, bitno je naglasiti da se razvija nova vrsta osjećajnosti koja se može dovesti u vezu s novim umjetničkim i estetskim zahtjevima.

Jedna od prepoznatljivih odlika manifestne retorike bilo je negatorsko stajalište mlade generacije, koje je, premda pod utjecajem filozofskih i književnoteorijskih postavki u 
europskim kulturama, bilo ponajprije „reakcija na vladajuće stranačke, vjerske, društvene i kulturne nazore u domaćoj sredini““ (Flaker, 1977: 46). U isticanju samostalnosti ideja i umjetničkoga djelovanja nazirala se potreba za intelektualnom pozicijom neovisnom o ustaljenim vrednotama pa se tako antihistorizam, odnosno pobuna protiv svijeta očeva prepoznaje kao bitna crta naše moderne. Preuzimanje je dekadentne osjećajnosti prema tome donekle bilo i svjestan odabir strujanja koja su se razlikovala od dotadašnjih, uvriježenih književnih kriterija. Možemo reći kako su se pripadnici mlade generacije, odabravši antitradicionalne vrijednosti, ,adekvatno modernoj osjećajnosti svog vremena odjednom osjetili baštinicima cijele evropske kulture i njenih tradicija“ (ibid.: 63). Jer upravo moderna kao svoj program iznosi „orijentaciju prema Evropi, povezivanje s njome i uključivanje u tokove njezina literarnog razvoja“ (Košutić-Brozović, 1970: 345) te hrvatska književnost u kontaktu s novim strujanjima konačno hvata korak s Europom.

\subsubsection{Bečko duhovno stanje}

Usmjerenost Europi konkretizira se ponajprije u fizičkoj i duhovnoj upućenosti na Beč, jedno od njezinih najvažnijih kulturnih i društvenih središta fin de sièclea. Recepcija inovativnih tendencija artikulirala se ne toliko $\mathrm{u}$ konkretnim detaljima u književnim ostvarenjima, koliko u preuzimanju cjelokupnoga duhovnog stanja. ${ }^{55}$ Govoreći o provodnim misaonim motivima u stilskoj raznolikosti bečke moderne, Žmegač piše:

Ono što se u nekim sredinama doima poput puke mode, $u$ pluralističkom je kulturnom središtu grada na Dunavu mnogo više od toga: naime izraz korjenite krize koja je zahvatila neke od temeljnih odrednica devetnaestoga stoljeća - uvjerenje o mogućnosti stalnoga napretka u razvoju društvene vlasti nad prirodom, vjera u potpunu instrumentalizaciju jezika (mimetičkoga sredstva po tom shvaćanju), pouzdanje u pozitivističke metode u duhovnom životu. (2012: 42)

Ova nam misao daje prigodan ,šlagvort“ za svojevrsnu digresiju o nekim segmentima austrijske duhovnosti koji svjedoče o rastrganosti i ambivalentnosti te velike kulture između

\footnotetext{
55 Tako Košutić-Brozović bilježi da bečka moderna „svojoj originalnom literarnom produkcijom nije osobito djelovala na našu književnost; doduše, austrijski se kulturni život u nas redovito prati, a glavni se pisci Jung Wiena dosta prevode i izvode (Altenberg, Hoffmansthal, Schnitzler i dr.), ali sav se taj posao obavlja nekako po inerciji i bez naročitog oduševljavanja“ (1970: 362). Odnosilo bi se to na epigonski karakter pojedinih književnih ostvarenja iz moderne, primjerice Dežmana Ivanova koji, kako utvrđuju Nemec i Bobinac, zbirkom Protiv struje ,upravo afirmira poetiku dekadencije kao hrvatsku literarnu modu“ (1997: 88).
} 
tradicionalizma i modernizma, osobito u zadnjoj četvrtini stoljeća kad dekadencija u svim svojim pojavnim oblicima postaje glavni pojam Zeitgeista. Pritom se ponajprije referiramo na Beč, izvorište dekadentne misli koja se naglo i u golemim razmjerima širila europskim intelektualnim horizontom. Beč je na prijelomu stoljeća ,akutno osjećao drhaje društvenog i političkog osipanja“ (Schorske, 1997: 8), a njegov se socijalni karakter, „neobični spoj provincijalnosti i kozmopolitizma, tradicionalnosti i modernizma“ (ibid.: 17), pokazao kao vrlo zahvalna tema za proučavanje intelektualne i društvene povijesti na prijelazu dvaju stoljeća. Neke jedinstvene crte bečkoga moderniteta objašnjive su samo u terminima društvenopovijesnoga položaja Austro-Ugarske u Europi, koja je uvijek istodobno bila korak ispred i iza drugih zemalja, upozorava Le Rider (1993: 11).

Razdoblje Carstva tj. Monarhije od 1848. do 1918, za kojega je Austrija dala možda najutjecajnije intelektualce cijeloga XX. stoljeća, Hermann Broch posve je znakovito nazvao „vedrom apokalipsom“ (prema Johnston, 1993: 9). Obrasci bečke dekadencije bili su uglavnom inspirirani problemima u političkom životu grada, ali i dvojne države: doista je postojao nepomirljiv kontrast između apsolutističke vladavine i društva u procesu modernizacije.

Osobna antipatija cara Franje Josipa I. prema manifestacijama „modernoga“ života, uključujući telefone, automobile, dizala, kupaonice i elektrika - da ne spominjemo suvremenu umjetnost $\mathrm{i}$ arhitekturu - prerasla je u pravu legendu te je simbolizirala kontradikcije društva koje se činilo ranjivim i na najmanje promjene. (Le Rider, 1993: 21)

Kako tvrdi Johnston, na intelektualni razvoj austrijskoga društva bitno su utjecala barokna stajališta, koja su u njega unijela prožimanje religije i svjetovnosti (1993: 20). Svijest o polaritetima presudno je uvjetovala privrženost dobru cjelovitosti, koja je umanjivala sklonost narušavanju statusa quo. Barok je naime „usadio vjeru u kozmički red koju je devetnaesto stoljeće sekulariziralo u bezbroj oblika esteticizma, pozitivizma i, s vremenom, impresionizma“ (ibid.: 21). Bio je to temelj bidermajerske kulture, kombinacije političke rezignacije i estetske slobode koja je učvršćivala svijest o nužnosti opiranja novitetima progresivnoga, liberalnoga duha. Duhovni ambijent između 1890. i 1914. s jedne je strane odavao vjeru u stabilnost političkoga sustava, „dugovječnost krhkosti“ (ibid.: 36), kako to Johnston naziva, a s druge je iskazivao slutnju propasti. Dok naprimjer Stefan Zweig i Max Graf pišu o vedroj buržoaziji koja ne prestaje gajiti nade u napredak, bez ikakve slutnje propasti, Robert Musil u Čovjeku bez svojstava i Joseph Roth u romanu Radetzkymarsch portretiraju, prihvaćajući katastrofične vizije raspada, dijametralno oprečne likove koje izjedaju zle slutnje. 
„Gubitak iluzija kakav nalazimo u pisaca poput Musila i Rotha navodi neke u iskušenje da povijest Austro-Ugarske pretvore u priče o raspadanju“ (ibid.: 37), istaknut će Johnston prigovarajući svima onima koji s nedovoljno argumenata govore o slabostima Carstva. Složili se mi s njegovom procjenom ili ne, neosporno je ipak da „Beč nije bio samo prijestolnica Habsburškog Carstva; Beč je bio duševno stanje“ (ibid.: 123). Označujući kao feačanstvo jednu od najprepoznatljivijih bečkih odlika, sklonost zabavi i pretvaranju, Johnston navodi da su se u svjetonazoru većine Bečana prepletali esteticizam, odnosno „bezbrižno uživanje u umjetnosti““, i ,terapijski nihilizam“, tj. ravnodušnost prema političkim i društvenim promjenama.

Krugovi kojima je bilo mrsko donošenje ikakvih odluka uveseljavali su svakodnevni život spektaklima i zabavom. (...) Feačanstvo je pogodovalo terapijskom nihilizmu, pa su kicoši Ringstraßea uživali u Schopenhauerovim esejima. Esteti su militantnom apolitičnošću glorificirali „,bezvoljnu percepciju“ umjetnosti kao utočište od sukoba. (ibid.: 124)

Osobit su moment dekadentne senzibilnosti bile bečke kavane, „duhovno“ mjesto u kojem se ogledala snažna svijest dokolice i prolaznosti. Nastupio je „trijumf konverzacije u kavani i feljtonu“ (ibid.: 127), a mladim intelektualcima za koje je kavana bila gotovo neka vrsta institucije, esteticizam je ponajprije bio bijeg od ljenčarenja kroz amaterske djelatnosti i povremeno pisanje. Budući da se amaterskim bavljenjem umjetnošću, iznosi Johnson, moglo ugodno i donekle korisno prikratiti vrijeme bez potrebe za bavljenjem krupnijim problemima, među intelektualcima se kristalizirala nihilistička i dekadentna svijest. ${ }^{56}$

U takvoj je svijesti osobito značenje imao motiv smrti. Očaranost smrću, gotovo pravi kult mrtvih, bila je izraz sigurnosti protiv promjene, i to gotovo na razini nacionalnoga motiva. „Svi raznoliki stavovi kojima se odlikuje austrijska misao - esteticizam, terapijski nihilizam, impresionizam - dio su nacionalnog stava prema smrti.“ (ibid.: 175) Kao simbol prolaznosti, postala je dio opće kulture, izlaz iz pesimističnoga vremena koje nije ništa obećavalo. Zato

\footnotetext{
${ }^{56}$ Tako je naprimjer Hermann Bahr prerastao u pravoga „kavanskog tračera, te je poput seizmografa bilježio svaki novi obrat javnog ukusa“ (Johnston, 1993: 128), a Peter Altenberg pisao je impresionističke crtice u dekadentnom duhu himni prolaznosti trenutka prema kojima „svi su susreti prolazni; život se sastoji od letimičnih zapažanja i slučajno načutih razgovora; iskustvo se stječe in mediis rebus, gdje se ništa ne poduzima niti se išta dovršava“ (ibid.). Osobitu je popularnost u to vrijeme stekao feljton koji će biti obilježen kao svojevrsna dokonost dekadencije. Iako je postao paradigmom dobroga ukusa, mnogi su ga intelektualci s gnušanjem odbacivali kao simptom dekadencije i pravi vrijednosni vakuum. Tipično feljtonističko zahvaćanje u sadašnjost, u kojem su se prepoznavali znakovi neozbiljnoga pisanja, tumačili su kritičari kao osobit izraz dekadentizma koji ne posjeduje povijesnu težinu, nego samo efemernu svijest što pridonosi relativizmu ustaljenih vrijednosti. U oštroj kritici feljtona Karla Krausa može se detektirati bit onoga što se pripisivalo tadašnjemu trenutku Monarhije: riječ je o „,̌lamperaju“, i u političkom i u književnom smislu. Kraus je u feljtonu, pokazuje Johnson, vidio ono što je Monarhiju trenutno razdiralo: ambivalentnost subjektivnoga i objektivnoga.
} 
Johnson i piše da je za pripadnike krupne i srednje buržoazije smrt nudila „oslobođenje od dosade; u ustajalom, pljesnivom svijetu smrt je bila jedina moćna nepoznanica“" (ibid.: 179). S obzirom na to da je promatranje smrti i poniranje u nju bilo naličje bečkoga feačanstva, može se govoriti o fasciniranosti prolaznošću i smrću, koja je postala izvorni austrijski kulturnodruštveni fenomen. Ta svojevrsna barokna vizija smrti kao simbola prolaznosti te istovremeno izraz ispunjena života išla je toliko daleko da je samoubojstvo postajalo konačno utočište bečkih mislilaca. Kao prototipske primjere pripadnika impresionističkoga $\mathrm{kruga}^{57}$ očaranih efemernošću života Johnston izdvaja Schnitzlera, Hofmannsthala, Beer-Hofmanna, Schaukala i Altenberga. Dakle, osim u filozofiji egzistencije i psihologije u nastajanju, smrt se prometnula u osobit motiv i u djelima mnogobrojnih austrijskih književnika, koji je gotovo u psihoanalitičkom ključu, puno prije Freuda, smještaju u područje podsvjesnoga. Tako primjerice Schnitzler naglašava trenutak spoznaje koji preobražava ličnost oslobađajući dotad potisnute sukobe:

Poštujući emocije kao nešto još zaraznije i komunikativnije od jezika, Schnitzler je pokušao razotkriti latentni svijet iza očitog svijeta. Ništa manje od Freuda, Schnitzler je vjerovao da svaka impresija pruža odjednom i znanje i iluziju, te tvrdio da riječi mogu kao jeka ponoviti supstrat iskustva, ali ga ne mogu nikada istinski prenijeti. Otuda i paradoks (...) da se poznato čini neobičnim, a nepoznato običnim. Bečkim impresionistima smrt je bila vrhovni arbitar koji je istodobno simbolizirao latentni sadržaj života - nesvjesno i emocije koje riječi ne mogu prenijeti. (ibid.: 183)

Međutim, više od autora koji smrt umjetnički obrađuju, dokaz da ona nije bila samo filozofski ili umjetnički motiv već konkretna stvarnost samoubojstva su austrijskih intelektualaca. Johnston navodi da je između 1860. i 1938. iznenađujuće velik broj njih počinio samoubojstvo, a princ Rudolf bio je samo najpoznatiji od onih „koji su odlučili prekratiti nepodnošljivu tjeskobu“ (ibid.: 184). S obzirom na to da ove činjenice prigodno osvjetljavaju anksioznost koja je prijelomno obilježila drugu polovicu XIX. i početke XX. stoljeća, izdvojit ćemo neke slučajeve radi stjecanja uvida u taj „trendovski“ findesiècleovski senzibilitet. Je li

\footnotetext{
${ }^{57}$ Nije slučajno da i Hauser definira impresionizam kao urbanu umjetnost posvećenu promjenjivosti, nervoznom ritmu i prolaznim impresijama gradskoga života (1966: 371). Duh austrijskoga impresionizma, koji je više bio estetsko stajalište, a manje razrađen umjetnički sustav, bio je uvelike nadahnut austrijskom filozofijom, naročito onom Ernsta Macha. On je naime u okviru svoje fizikalističke filozofije kritizirao metafizičku nerazdvojnost duše i tijela, odnos koji je ,pretpostavljao proces depersonalizacije u kojem duša utječe u tijelo, a tijelo u vanjski svijet, razarajući sve istine sagrađene na platonskom dualizmu duha i materije“"(Johnston, 1993: 195).
} 
bila riječ o tome da je impresionistički kult prolaznosti činio samoubojstvo privlačnim ili prirodnim, pita se Johnston te ističe:

Spreman da postoji samo tako dugo dok je mogao izbjegavati izbor između života i smrti, Austrijanac je dopuštao da mu život degenerira u promašenu priliku. To oklijevanje naličje je bečkoga impresionizma; ovakvom svjetonazoru prolaznost je bila tako draga da nije mogao prigrliti preživljavanje. Odbijajući da se angažiraju za život, impresionisti su prihvaćali terapijski nihilizam poput Weiningera Ehrensteina, ili ga s grižnjom savjesti trpjeli poput Schnitzlera, Hofmannsthala i Bahra. (ibid.: 190)

Bilo kako bilo, smrt je postala mainstream. Zbog depresije su se ubili književnici Stifter, Saar i Raimund, ovaj posljednji navodno i zbog književnoga neuspjeha, simbolično samoubojstvom potvrđujući „bespomoćnost bidermajerskog 'malog čovjeka'“ (ibid.: 184), te sociolog Gumplowicz. No kao intrigantan je slučaj u zemlji odjeknulo samoubojstvo popularnoga fizičara Boltzmanna koji je, izmoren dugogodišnjim radom u laboratoriju i razdražen bolešću, pao u nepodnošljivu depresiju. Njegov se čin nije uklapao u model optimističnoga znanstvenog pozitivizma, pa se akademskim krugovima proširilo uvjerenje da nije bio pri zdravoj svijesti jer ,samo čovjek koji nije pri sebi (nicht bei Sinnen) može sebi oduzeti život" (ibid.: 185). Međutim za austrijske su prilike još simptomatičnija bila, procjenjuje Johnston, samoubojstva potaknuta diskrepancijom između vlastitih uvjerenja i vanjskih okolnosti, pa kao primjere uvjetovane tim sukobom ističe samoubojstva Eduarda van der Nülla, Moritza Thausinga, Richarda Gerstla, Maxa Steinera i Otta Weiningera, napominjući pritom da je samoubojstvo odigralo, i izravno i neizravno, odsudnu ulogu i u Freudovu životu; naime, njegov se prethodnik na neurologiji Medicinskoga fakulteta Nathan Weiss ubio, što je vjerojatno potaknulo Freuda da se jednoga dana počne baviti i nagonima smrti. Možemo zato s Johnstonom rezimirati da je smrt kao izabrano utočište bila tragičan dokaz „destruktivnih sila koje su mučile Habsburško Carstvo možda nesmiljenije nego drugdje“ (ibid.: 188).

Prema tome više je nego očito kako su u kulturi i političkom životu Austro-Ugarskoga Carstva postojali stanoviti momenti kojima se može legitimirati naš odabir reprezentativnih djela u kojima smo prepoznali literarizaciju nekih temeljnih preokupacija europskoga fin de sièclea. S prigušenijim ili izraženijim dekadentnim obilježjima, izabrani likovi u tim djelima paradigmatski razotkrivaju principe dekadentnoga senzibiliteta, temeljne misaone i psihičke dispozicije razdoblja na prijelazu stoljeća. 


\section{REPREZENTACIJE LIKOVA DEKADENATA}

\subsection{Uvodno}

\subsubsection{Dekadencija kao privilegij}

Zaključivši prethodno poglavlje sumarnom ocjenom iznimno povoljnoga konteksta za literarizaciju dominantnih duhovnih preokupacija, prikladno možemo analitički dio disertacije započeti konstatacijom da su se hrvatski findesiècleovski književnici, inspirirani tom klimom skorašnje propasti, pa i, izravno ili neizravno, pasivnošću bečke kulture, uza stalnu svijest o psihološkom impresionizmu kao temeljnoj oznaci epohe, naročito zanimali

za „dekadenciju“, za fenomene tjelesne i duhovne klonulosti, ali i estetske profinjenosti u znaku rasapa, za pojave kojima je duhovna Europa potkraj XIX. stoljeća bila fascinirana na način koji danas nije lako razjasniti (Žmegač, 2001b: 32). ${ }^{58}$

Zato naš korpus tekstova čine proze, točnije romani i pripovijetke, u kojima smo prepoznali uzorne primjere te filozofije razočaranja, a koji će nam poslužiti kao ilustracija manifestacija uznemirene duševnosti na razmeđu stoljeća. Pogledom u duševne potrese likova naši autori otkrivaju modernistički mentalitet u kojima su dominante nervoza i rastrzanost te osjećaj stalne izdvojenosti od drugih i odvojenosti od zbilje. Destrukcijom realizma temeljenom u prvom redu na aktancijalnoj razini (Nemec, 1995: 77) poniru u unutrašnjost likova, odbacuju praktičan svijet te uranjaju u onaj iracionalni, nedokučivi da bi otkrili latentne sadržaje ljudske psihe. Akutno osjećanje povijesne i egzistencijalne beznačajnosti vodi pritom izostanku svake konkretnije radnje, koja se zamjenjuje načelom rezignacije: potpuno nesposobni za borbu, njihovi likovi polagano propadaju, strpljivo podnoseći sudbinu koja beziznimno završava izjalovljenim nadama. I dok je u nekih pisaca dekadencija bila anticipacija ili naslućivanje modernističkih zahtjeva, u drugih je ona izraz aktualnih društvenih i poetičkih emanacija. A u svih se iskazuje kao stanje duha generirano općom društvenom klimom.

\footnotetext{
${ }^{58}$ I dok je s vremenom postalo jednostavnije prepoznati i vrednovati europeizaciju hrvatske književnosti, recimo kako su u to vrijeme tek rijetki pozdravili unošenje dekadentnoga repertoara. Tako da se naprimjer Krnicova (1900) i Hranilovićeva (1900) kritika, u kojima se dekadencija u književnosti proziva zrcalom dekadencije same književnosti, a preuzimanje dekadentnih poticaja proglašava najobičnijim pomodarskim imitiranjem francuske $i$ njemačke literature, mogu nazvati oglednim primjerima tadašnjega stajališta.
} 
To nije neki filozofski sistem, nije ni neko određeno čuvstvo, niti je to sam intelekt, koji rađa nezadovoljstvo, nemir, bol i tugu. To su (osobito u današnje doba) raspoloženje, atmosfera vremena. (Marjanović, 1950: 126)

U djelima koja odišu nekom vječnom tugom i besperspektivnošću shvaća se besmisao postojanja, a čežnja za nedohvatljivim kombinira se s čuvstvom dubokoga razočaranja u svijet, izražavanjem nezadovoljstva poretkom stvari, ali i banalnošću svakidašnjice. Svjesno odabravši takav način vegetiranja, njihovi se likovi prenaglašenoga ega usredotočuju sami na sebe, provodeći svojevrsni psihološki ,terapijski nihilizam“. ${ }^{59}$ Naime u skladu s doktrinom da je bolest sastavni dio života te da se kao takva valja shvatiti a ne liječiti, vjeruju da je najbolje ništa ne poduzimati, nego se jednostavno prepustiti tijeku vremena. U nejasnu strahu od svega što ih okružuje, ti likovi njeguju ,neki tmurni i plačni pesimizam, neku dosadu i ogavnost života, neku bezvoljnu klonulost i apatičnu izmorenost““(Gruber, 1910: 2). „Hamlet je otac svoj toj djeci Weltschmerza“ (1964c: 163), sažeo je najbolje Nehajev. ${ }^{60}$ Mahom su to mladići prerano ostarjeli, „djeca sa staračkim licem“ (1951: 85), kako se na novi naraštaj referira Dežman u kultnom proglasu u Mladosti, čije egzistencije degeneriraju u promašene slučajeve te završavaju ili prepuštanjem potpunoj rezignaciji ili smrću. Iz koncentriranosti likova na sebe proizlazi i ekstremnost solipsizma moderne. Potpuno nesposobni postojati udvoje, egzistencija se protagonista, čim se pojavi i najmanja naznaka za zajednički život, destruira, a upravo je to po Milanji „ono novonadošlo s evropskog horizonta kraja 19. stoljeća“ (1987: 31). Jednom kad se čovjek povukao iz aktivnoga sudjelovanja u javnom životu, individualizam se lišio svake udobnosti manifestirajući se kao destruktivna osamljenost.

I zato, s obzirom na prethodna poglavlja u kojima je naglasak primarno stavljen na horizont suvremenih zbivanja, valja podsjetiti da je odnos realiteta i književnosti višestruk i višesmjeran: nedvojbeno je da su se u književnost prenosila stanja i situacije kojima se svjedočilo u stvarnosti, ali i da se na stvarnost preslikavao senzibilitet prezentiran u književnim djelima. Ako se složimo s tvrdnjom da je književnost odigrala vrlo važnu ulogu u izgradnji hrvatske građanske kulture u XIX. stoljeću te na sebe ,preuzela etičke, ideološke i političke zadatke“ (Milanja, 2012: 47), možemo pridodati da je pritom poseban interes iskazivala za pojedince koji na bilo koji način ispadaju iz društvenoga poretka. Nov odnos prema pojavama

\footnotetext{
${ }^{59}$ Termin preuzimamo od Johnstona koji ga upotrebljava u medicinskom kontekstu te njime označava vjeru u iscjeliteljsku snagu prirode, odnosno doktrinu prema kojoj je najbolje liječenje ono u kojem se ništa ne poduzima (1993: 234).

${ }^{60} \mathrm{U}$ tom kontekstu uopće ne treba čuditi isticanje Hamleta. On je naime kao arhetip lika s nedovoljno snage za aktivno djelovanje, razapetoga borbom između želje i volje, jedna od najčešćih književnih figura koja kola psihijatrijskim diskursom.
} 
i ponašanjima koja se uobičajeno kvalificiraju kao nepoželjna, nakazna, morbidna, odbojna, frojdovski rečeno zazorna, obilježio je i hrvatsku modernističku književnost. Iako je u gotovo zanemarivom broju slučajeva u našem korpusu riječ o ,pravoj“, organskoj bolesti, možemo reći da je retorika bolesti i zdravlja, propasti i degeneracije, patologije i normalnosti zajednička točka svih djela kojima se bavimo. Smatramo naime da se dekadencija u odabranim likovima može čitati kao neka vrsta nenormalnoga, tj. iščašenja u odnosu na normu. Sa stajališta funkcionalnosti društva zdrava i/ili normalna osoba jest ona koja je u stanju ispuniti namijenjenu joj društvenu ulogu, tj. djelovati onako kako to društvo od nje očekuje. Povučemo li razliku između prilagođenoga i neprilagođenoga, normalnoga i neurotičnoga, a imajući pritom na umu Foucaultovu teoriju o ludilu kao odstupanju od normativnoga poretka, dospijevamo do sljedećega zaključka, koji ponajbolje sažima sve ono što dekadencija po našem mišljenju implicira:

(...) osoba koja je normalna s obzirom na svoju dobru prilagođenost često je manje zdrava od neurotične osobe s obzirom na njene ljudske vrednosti. Ona se često dobro prilagođava jedino po cenu odustajanja od svog ličnog ja, da bi manje više postala onakva kakva veruje da treba da bude. Pri tom su možda iščezle sva istinska individualnost i spontanost. S druge strane, neurotičara možemo označiti kao osobu koja nije bila spremna da se potpuno preda u borbi za svoje lično ja. Svakako da njen pokušaj da spase svoje pojedinačno ja nije uspeo, te je ona, umesto da svoje lično ja stvaralački izrazi, potražila spasenje u neurotičnim simptomima povlačeći se u fantazijski život. Pri svem tom, ona je, sa stanovišta ljudskih vrednosti, manje osakaćena od one vrste normalne osobe koja je potpuno izgubila svoju individualnost. (Fromm, 1984: 102)

Zato možemo sugerirati da su neurotični i tjeskobni dekadenti manje osakaćeni od pojedinaca koji su negdje putem izgubili vlastitu individualnost nastojeći slijediti društvena pravila. Još konkretnije, odbijanje ispunjenja društvenih očekivanja i zahtjeva mjera je njihove vrijednosti. Pa ih prema tome nenormalnima možemo nazvati samo utoliko što nisu u skladu s normom, odnosno zato što vide svijet kojemu ne žele pripadati. Pozornije nam čitanje tih proza otkriva jedan skriven aspekt fenomena dekadencije kao svojevrsne bolesti: kad svjesno rabimo riječ „,bolest“ referirajući se na dekadenciju, mislimo ponajprije na njezinu provokativnu funkciju u odnosu na vrijednosti i norme građanskoga društva. Naime tiranija normalnosti jedno je od specifičnih obilježja društvene paradigme zapadnoga čovjeka. U njoj se zdravlje nameće ponajprije kao ,politički i društveni imperativ. Biti normalan pretpostavka je takve egzistencije. Sve preko, izvan ili protiv takve normalnosti ne smatra se dijelom normalne egzistencije. Takvi 
su ljudi suvišni, marginalni, devijantni, nenormalni, bolesni, ludi ili samo odviše različiti od onoga što je normom pretpostavljeno“ (Sunajko, 2016: 454). Zato nam se čini da dekadenciju u našim likovima možemo čitati i kao egzistencijalni projekt čija je zadaća problematizacija i reevaluacija utvrđenih vrijednosti onoga što se naziva normalnim, što je također jedna od odlika njezina europskoga koncepta. To joj je možda i najveća vrijednost: bolest se prezentira kao dimenzija koja nudi nov pogled na egzistenciju i životne istine skrivene od pogleda zdravih (usp. Lyytikäinen, 2014). Da bi govorila istinu, književnost treba bolest. Prema tome findesiècleovski su poremećaji zapravo privilegij koji dekadenta odvaja od užasavajuće normalnosti društva, odnosno od njegove ideje zdravlja. Te su devijacije, podsjetimo, u isti mah baština raznolikosti „književnih“ romantičarskih poremećaja, poput spleena, i modernih tumačenja psihopatologije, koja je nosografijama oboljenja poput neuroze, tj. neurastenije i histerije u kombinaciji s višestoljetnom melankolijom osigurala temelje za nove imaginarije $u$ književnosti dekadencije.

\subsubsection{Kriza muškosti}

Društvena anksioznost s kojom je dočekan fin de siècle sa sobom je donijela i krizu maskuliniteta. Povijesna slika muškosti koja se u modernoj zapadnoeuropskoj misli uzimala zdravo za gotovo u velikoj je mjeri u posljednjim dvama desetljećima XIX. stoljeća stavljena pod upitnik, i to ponajprije suočavanjem s usponom feminizma kao političkoga pokreta, koji je direktno izazivao ideologiju dviju posve odvojenih sfera i ozbiljno ugrožavao društvenu poziciju muškaraca, te s muškom homoseksualnošću, koja je postajala sve javnija (usp. Micale, 2008). Bila ona osobni ideal ili javni simbol, ta se slika izoštravala u sudaru s pravim ili imaginarnim neprijateljima, a za to je odlučan period bio fin de siècle, iz današnje je pozicije prilično neosporno. Ideal muškosti tad je naime bio ugrožen i generalnim osjećajima propasti i dezorijentiranosti. Dojam poljuljanih načela i tradicionalnih koncepata ženskosti i muškosti posebno se proširio među pripadnicima srednje i više srednje klase u gradovima i predgrađima, a pritom su učvršćenju konzervativnih moralističkih prosudbi o ljudskoj seksualnosti pridonijela neka kapitalna djela europskih stručnjaka, tad prilično popularna (ibid.: 167). Od Charcota i Magnana, koji su privlačnost istomu spolu objašnjavali kao znak nasljedne degeneracije, preko Paula Moreaua i Émilea Laurena, koji su feminizirano ponašanje izjednačavali s homoseksualnošću, do Krafft-Ebingove „enciklopedije“ medikaliziranih seksualnih perverzija Seksualna psihopatija (ibid.: 174), podupirući uvriježena poimanja 
„normalne“ muškosti i ženskosti svi su patologizirali manjinske oblike seksualnosti. Pa i spomenuta Krafft-Ebingova knjiga, Nordauova Degeneracija, Lombrosova kriminalna antropologija, Galtonova eugenika, Darwinova evolucijska teorija, Weiningerov Spol i karakter - sve su to bili instrumenti intelektualne tehnologije kojima su se dodatno nastojali stabilizirati rodni i spolni stereotipi. ${ }^{61}$

Budući da je muškost figurirala kao obrambeni bedem u vremenu disolucije vrijednosti, uopće ne čudi što likove tankoćutnih patnika, koji se ni na koji način nisu uklapali u paradigmu snažna, nepokolebljiva muškarca, susrećemo i u književnosti. Zapravo je i sam koncept dekadencije, predstavljajući stanovite anomalije, izazivao uvriježen model muškosti. „Ideal maskuliniteta smatrao se obranom od dekadencije, predstavljajući u književnosti, slikarstvu i kiparstvu sliku čedne muškosti, duboko ukorijenjenu u modernoj svijesti.“ (Mosse, 1996: 101) Taj ideal muškosti, kao što iznosi Oraić Tolić, naslijeđe je Descartesova racionalističkoga apsoluta koji je bio postavljen kao vladalački subjekt, a čiju je važnost poljuljala već spomenuta siva zona neprilagođenih, „nesubjekata, nepojedinaca i negrađana koje kontroliraju moderni subjekti““ (2006: 292), poput žena, djece, bolesnika, staraca, pripadnika drugih rasa i klasa i sličnih. Zato se i može reći da naši dekadenti s feminiziranim rodnim crtama također pripadaju tom području u kojem stoje negdje na razmeđu tradicionalne muškosti i ženskosti.

U simboličnom smislu moderni su antiapsoluti bili androgini. To ne znači da su oni imali bilo kakvih androginih sklonosti, nego samo to da su sami sebe zamišljali i konstruirali s pomoću ovih ili onih ženskih rodnih crta. (ibid.: 296)

Dodatno, lik plačljivoga dekadenta usko je prepleten sa zamorom, osipanjem energije koje se reflektira na tjelesnom i duševnom zdravlju, s oslabljenim živcima koji uvelike usmjeravaju egzistenciju pojedinca, te s idejom degeneracije jer se nerijetko prekomjerna emocionalna osjetljivost ili fizička indisponiranost interpretirala kao regresija u odnosu na zdravije i duševno stabilnije pretke. Posve drukčiji s obzirom na svojstva koja su oblikovala stereotipni model muškosti - boležljivi umjesto zdravi, iscrpljeni umjesto energični, pretjerano osjetljivi umjesto čvrsti i stabilni - dekadenti su bili pravi izazov muškosti i strogoj razlici između spolova. U svjetlu tvrdnji o krizi maskuliniteta postaju još smislenije konstatacije o neurasteniji i degeneraciji predstavljene u prvom dijelu rada, kojima smo nastojali pokazati da

\footnotetext{
${ }^{61}$ Kako procjenjuje Gilman, težnja rigidno razgraničenim kategorijama zapravo nam je inherentna. Dio ljudske prirode jest potreba za „,̌́istim“ i jasno razdvojenim konceptima, a budući da od toga ne možemo pobjeći, ,moramo se ili suočiti s činjenicom da im se neki realiteti jednostavno ne mogu podvrgnuti ili pak moramo oslijepiti na neadekvatnost koncepata“" (1985: 19).
} 
su mnogobrojni navodi o tome da čovjek može ispravno funkcionirati samo sa zdravim živčanim sustavom, pravom materijalnom osnovom svoje egzistencije, bile upravo tipično findesiècleovske. ${ }^{62}$ Jer, kako smo zabilježili govoreći o neurasteniji, pojedinci onemoćala živčanoga sustava popunjavali su dubok jaz između stabilne paradigme ,prave“ muškosti i njezinih ekstremnih pojavnih oblika.

Da bismo demonstrirali na koje se sve načine maskulinitet dovodio u pitanje, kao primjer mehanike tranzicije poslužit će nam histerija, jedno od najstarijih opisanih oboljenja u povijesti medicine. Iako se kroz povijest doživljavala mahom kao ženska bolest te se vezala uza žensko tijelo, ženski reproduktivni sustav i (seksualno) nezadovoljstvo (usp. Borossa, 2001), nakon što ju je Charcot 1880-ih konačno definirao i sistematizirao, legitimiravši je kao bolest s objektivnim simptomima, te proglasio i muškim psihijatrijskim poremećajem, histerija se sve jače odljepljuje od feminiteta te se slični simptomi sve glasnije uočavaju i u muškaraca. ${ }^{63}$ Zadan je tako snažan udarac normativnoj muškosti jer su nova klinička istraživanja ukazala na višestoljetni pogrešni smjer zapadnoeuropske medicine. Kao što primjećuje francuski liječnik Pierre Briquet još 1859, ,vidjeli smo vrlo malo histerije u muškaraca jer je nismo željeli vidjeti“ (cit. prema Micale, 2008: 193). ${ }^{64}$ Naime ideja da su muškarci jednako podložni histeriji izravno se suprotstavljala povijesnim patrijarhalnim idejama i tradicionalnomu razumijevanju muške prirode. Budući da je muška histerija izravno projicirala ideju o duševnoj i emocionalnoj feminiziranosti muškaraca, uglavnom se tumačila kao demaskulinizacija. Na muške se histerike nije gledalo kao na „prave“ muškarce, nego su gotovo isključivo opisivani kao ženskasti mekušci koji nisu kadri uspješno odgovoriti na suvremene društvene zahtjeve da budu izdržljivi, stabilni i nepokolebljivi te ,da ne prestaju proizvoditi, bez obzira na okolnosti“ (Borossa, 2001: 55). ${ }^{65}$ Zato je histerija ne samo odličan pokazatelj na koji su se način čak i medicinske teorije usklađivale $\mathrm{s}$ dominantnim shvaćanjem o muškim vrlinama, ugrožavajući pritom stabilno muško ,ja“, nego i izvrstan primjer urušavanja konstrukcije

\footnotetext{
${ }^{62}$ Rastuću svijest o sve većem broju muškaraca krhkih živaca izvrsno oprimjeruju mnogobrojne reklame i članci u njemačkim novinama upravo krajem 1890-ih: „Muškarci slabih živaca, ovaj lijek garantira ozdravljenje!“” ili pak „Bolest muških živaca, njezina prevencija i izlječenje“ (cit. prema Mosse, 1996: 83).

${ }^{63} \mathrm{O}$ konkretnim kliničkim slučajevima oboljenja muškaraca usp. Micale (2008).

${ }^{64}$ Kao kuriozitet navodimo činjenicu o vizualizaciji muške histerije. Dok se naime u medicinskoj literaturi ženska histerija vizualizirala u najdramatičnijim detaljima - najčešće se histerična žena prikazivala kao mlada osoba neuredne kose, zabačene glave, krutoga tijela, iskrivljenih udova i kolutajućih očiju (Micale, 2008: 217) ilustracija muških primjera gotovo da i nema.

${ }^{65}$ Zanimljivo, kako iznosi Borossa, nakon Prvoga svjetskog rata muškarci, među njima osobito sudionici rata, postaju najuočljivijom skupinom oboljelih, a činjenicu da su se tako našli u raskoraku između simptoma oboljenja i vrlina koje su im pružale osjećaj muškoga identiteta potvrđuje i dominantna dijagnoza: u medicinskim se i novinarskim krugovima govori o granatnom šoku, a ne o histeriji (2001: 58).
} 
muškosti: histerika je naime moguće promatrati kao pojedinca svjesna lažnosti društvenih okvira koji mu grade identitet, koje potom potkopava prokazujući ih kao lažne.

Mada u bogatom repertoaru muških findesiècleovskih histerika u medicinskom diskursu jedna figura zastrašujuće izostaje - heteroseksualni bijelac, pripadnik srednje klase - ona se u izobilju pojavljuje u književnosti. „U viktorijanskom dobu nije amblematska figura luda žena na tavanu, nego nervozan muškarac u salonu“ (2008: 208), sažima Micale prikladno potvrđujući našu tezu o dominantnim (muškim) likovima dekadenata i u hrvatskoj književnosti. U mnogim su slučajevima živčana oboljenja obilježila i živote književnika i živote njihovih likova. Uostalom, i prve cjeline disertacije poslužile su da pokažemo da takvi fikcionalni karakteri nipošto nisu bili slučajni: dekadencija, koja prijelomno obilježava njihovo sebstvo i društvene pozicije koje zauzimaju, nastajala je doista na izvorima suvremene zbilje.

\subsubsection{Neurotični fragmentarni identiteti}

Što je očitije od činjenice da izvan pojedinca postoji objektivan svijet te da on mora pronaći najbolji način da se nosi s njim? Čovjek se obično zamišlja kao subjekt koji u tom svijetu donosi odluke te se suočava s drugima, a njegovu percepciju o svijetu oblikuje vlastito nastojanje da organizira i sintetizira sve dimenzije svoga iskustva u koherentnu, jedinstvenu cjelinu. Zato je naša vizija o svijetu uvijek ujedno prezentacija naših očekivanja. Pritom veliku ulogu u suočavanju s njim imaju naše strukture utjelovljenja, odnosno konstrukcije boli i zadovoljstva, jer biti tijelo znači biti otvoren za interakciju s drugima; tek njime uspostavljamo kontakt s realnošću (Russon, 2003: 21). Uz te činjenice možemo cjelovitije pristupiti problematici dekadencije u naših likova, kako bismo demonstrirali da se ona - iako je uvijek i stvar prirode lika i urođenih sklonosti - rađa iz odnosa koji bi trebali dati supstanciju životu: iz sposobnosti interpretacije i interakcije s drugima. Budući da smo prepoznali da te strukture imaju u razvoju čovjekova identiteta ključnu ulogu, u prozama kojima se bavimo okrenut ćemo se duševnim stanjima likova, koja gotovo beziznimno prepoznajemo kao neurotična, ne bismo li pokušali otkriti dinamiku u srži njihove egzistencije.

Pomičući se u tumačenju neuroze od psihoanalitičkih razumijevanja prema sociološkoj teoriji, složit ćemo se s Russonom koji primjećuje da svakidašnja očekivanja, iskustva i napetosti pridonose razvoju neuroze kao izrazu nemogućnosti u kojoj ,,jedan dio čovjekova života ne može funkcionalno odgovoriti na zahtjeve intersubjektivnoga života“ (ibid.: 81). Suočen s problemom samodefiniranja i proturječjima, pojedinac gradi različite vrste 
samoobrane kako bi uspješno razriješio izazove svijeta koji ga okružuje ili se od njih obranio. Dakle s obzirom na to da svijet pred njega postavlja najrazličitije prepreke, emocionalni je život način na koji se čovjek nosi s tim zahtjevima. On se konstantno suočava s izazovima koji su, kao osnova identitetske disocijacije, s jedne strane posve prirodan temelj egzistencije, dok su s druge izvrsna podloga za razvoj neuroze. Kako on razvija svoj život u svim mogućim sferama, one interagiraju, posredno uvijek pokazujući da je pojedinac tek subjekt podložan normama. Zato je za Russona neuroza fundamentalno ljudsko stanje, rana konstrukcija identiteta koja se zasniva na intersubjektivnosti: ona je konflikt između dviju interpretacija realiteta, odnosno način na koji čovjek kao interpretativno biće funkcionira. Normalan je subjekt u stanju djelovati u skladu s društvenim očekivanjima, bez preispitivanja ispravnosti kulturnih normi, te pretpostavlja samokontrolu kao „središnju vrijednost narativa civilnoga života“ (ibid.: 84). Neuroza pak, sprečavajući dosezanje toga normalnog sebstva, podrazumijeva ,,ja“ ugroženo društvenim uzorcima ponašanja.

Biti neurotičan znači da pojedinac ne uspijeva kontrolirati svoje ponašanje u područjima koja bi, prema narativu normaliteta, trebala biti područja u kojima ,ja“ mora imati neograničenu slobodu izbora. (ibid.)

Podsjećajući da je neurozu moguće promatrati kao smetnju normalnu životu, ali i da normalan život gotovo uvijek ispod površine reflektira prijeteću neurozu par excellence, napominjemo da naše tumačenje gotovo nikad nije medicinsko, nego je transferirano u područje društva. Zato se u ovom radu medicinskim terminima najčešće i koristimo u deskriptivnom, a ne u nosografijskom smislu. Jer, Russonovim riječima, upravo kulturni narativ nudi sustav za interpretaciju neuroze, a ona nas pritom neprestano izaziva da preispitamo narative normalnoga koji određene obrasce, ponašanja i pojedince određuje kao neurotične (ibid.: 83).

Takvo se društveno tumačenje neuroze može dopuniti psihoanalitičkom interpretacijom jer se nagon za analiziranjem samoga sebe i kopanjem po nemirima vlastite duše može povezati „s procesima koje je Freud definirao kao intelektualiziranje i racionaliziranje, a oba procesa predstavljaju ustvari, i to je paradoks neuroze, otpor spoznaji nesvjesnih, potisnutih duševnih procesa“ (Matijašević, 2008: 237). Neuroza je dakle posljedica sudara čovjekovih nagona i odricanja koja kultura od njega traži. Jer ondje gdje postoje potiskivanja, u smislu zadržavanja predodžbi čije zadovoljenje prijeti izazivanjem neugode (Laplanche i Pontalis, 1992: 328), postoje i neurotična oboljenja. Prema tome i psihoanalitičke interpretacije neurozu vežu uz 
„socijalni konstruktivizam“ (Matijašević, 2008: 241), kako bi potvrdile da je ona sinteza svega stečenoga.

Stoga u svjetlu svih dosadašnjih postavki možemo konačno potvrditi da tamo gdje Freud i Breuer histerično tijelo vežu uz traumatične događaje, ${ }^{66}$ treba govoriti o metafori kulturnih silnica koje su pojedincu izmakle iz ruke. Neurotično se tijelo buni protiv dominantnih društvenih okolnosti. U ovom radu zato kao osnovni problem toga neurotičnog tijela prepoznajemo fragmentiranost identiteta, koja nas i potiče da dekadenciju, u ključu Nietzscheovih teza o disharmoniji cjeline, kroz različite duševne i tjelesne manifestacije interpretiramo kao disipaciju cjelovitosti.

Identitet je, trajno zadržavajući svoju kompleksnost u zapadnoj kulturi i znanosti, posebnu važnost stekao upravo krajem XIX. stoljeća, kad subjekt gubi svoja identitetska uporišta, univerzalna središta koja su mu svojedobno omogućavala da pronađe svoje mjesto u svijetu. Tresu se temelji njegova identiteta. Kao što smo već akcentuirali, govoreći u uvodnom dijelu o subjektu kao središnjoj kategoriji nove estetike imanencije, a kako potvrđuje i Le Rider, nesumnjivo se može govoriti o dominantnom modernističkom rasipajućem subjektivitetu (1993: 30). Zato nas konstatacija da je ideja moderniteta učvršćena u egzaltaciji individualizma i subjektiviteta, koji se istodobno prepoznaju i kao mana i vrlina, motivira da u radu kao temelj koncepta dekadencije postavimo problem identiteta. Individualizam je nakon Nietzschea postao ambivalentan fenomen: $\mathrm{s}$ jedne se strane dijagnosticirao i kritizirao kao moderna bolest, a $\mathrm{s}$ druge se egzaltirao kao temelj „prave“ kulture. Individuacija izbacuje pojedinca iz poretka svijeta te stvara iluziju egocentričnosti, nerijetko i ekstremnoga solipsizma, koji truju međuljudske odnose utječući na kidanje spona između subjekta i objekta. Zbog toga je sasvim opravdano osamljenost tumačiti kao glavnu pratilju deklariranoga individualizma, odnosno kao njegovu najveću cijenu. Budući da primjećujemo da društveni odnosi nemilosrdno utječu na živote odabranih dekadenata, za potporu naše teze prikladno je Simmelovo razmatranje. On naime u središte svoje sociološke misli postavlja upravo problem individualizma te njome

\footnotetext{
${ }^{66}$ Freud i Breuer svojim su istraživanjima učinili ključan pomak u razumijevanju toga oboljenja jer su, uključivši u svoje Studije o histeriji iz 1895. pet slučajeva ženske histerije, dali pravo glasa histeričnim pacijenticama. Nije nebitno da je baš histerija bila polazišna točka Freudove psihoanalize, dovevši ga „,do otkrića nesvjesnog funkcioniranja psihe, tumačenja simptoma, objašnjenja neurotske strukture, ukratko do definicije nesvjesnog“"(Matijašević, 2006: 74). Freud ju je pojasnio idejom traume, odnosno intenzivnih duševnih previranja koje je pacijent zaboravio, tj. potisnuo, a koji su konvertirali u fizičke simptome. Traumu je pritom u svim slučajevima povezao s potisnutim libidom, dok je ozdravljenje podrazumijevalo prisjećanje na traumu kroz razgovor s terapeutom. Takvo ga je tumačenje histerije - koje je dakle u tijesnoj vezi s mehanizmom potiskivanja - i dovelo do njegove poznate definicije potiskivanja, kojoj je pak prethodila ideja cijepanja ličnosti (ibid.: 20). Naime cijepanje je ličnosti, pa makar i u rudimentarnom stupnju, prisutno u svakoj histeriji, a ,tendencija je disocijaciji (...) temeljni fenomen svake neuroze“ (Breuer i Freud, 1957: 12). Najkraće rečeno, tamo gdje postoji potiskivanje, postoji i neuroza.
} 
provlači tezu da se moderan čovjek nalazi u stanju konstantne tjeskobe jer su „esencija modernoga psihologizam, iskustvo i interpretacija svijeta prema reakcijama našega unutarnjeg 'ja'“ (cit. prema ibid.: 29). Simmel pritom razlikuje kvantitativni individualizam, izvorno iz XVIII. stoljeća, i kvalitativni individualizam XIX. stoljeća koji presudno određuje poziciju suvremenoga čovjeka: u neprestanoj potrazi za sobom, on kao da više ne posjeduje samoga sebe te osjeća da ne pripada tradicionalnim društvenim strukturama. „Individualizam je bio razarajuća sila koja se više nije mogla vratiti u ujedinjujuću sociološku dinamiku sve dok društvo nije uspješno 'desubjektiviralo pojedinca'." (ibid.: 32)

Budući da se na odabranim primjerima može demonstrirati da kriza identiteta likova implicira njihovo isključivanje iz realnoga svijeta, odnosno da svjedočimo njihovoj dezintegraciji u nekom obliku, kao osnovnu karakteristiku naših dekadenata prepoznajemo činjenicu da većina njih egzistira samo izvan ikakve pripadnosti. Nepripadanje je njihova ključna supstancija obilježena bolnom dvostrukošću: poput svih drugih i oni žude za mjestom, dok su istodobno nespremni prihvatiti mjesto koje im se nudi. Drukčije rečeno, ono što se nudi, nikad nije ono što se želi. Zato prepoznajemo da upravo u tom očaju identitet rascijepljeno živi. Pitanje „tko sam“ stoga je u isti mah i pitanje „gdje sam“. Identitetski se izraziti znači preuzeti mjesto, pronaći svoj prostor. Pa s obzirom na netom izvedeno možemo reći da je potraga za mjestom, u onom apstraktnom i najširem smislu, ujedno potraga za identitetom. Zato je dekadencija u našem korpusu tekstova svojevrsna kriza identiteta.

Identitet protagonista u našem fokusu, u smislu načina na koji vide sebe i uspostavljaju u društvu, prezentira se kao trajno izjalovljen proces, nestabilan i nedovršen entitet. Počevši od obitelji kao najmanje društvene skupine, društvo generira bezbrojne mogućnosti za njihov razvoj, nudeći istovremeno prilike za samorealizaciju i zapreke za identitetsko uspostavljanje. Naš je pogled prema tome usmjeren na nepotpune, fragmentarne identitete koji ne uspijevaju transcendirati surovost društveno-ekonomskih okolnosti ili osobnih odnosa. Budući da razvoj pojedinca možemo promatrati kao kompleksan proces njegovih interpretacija uloga koje bi trebao zauzeti i reakcija drugih na te interpretacije, za zaključiti je da izloženost drugima gradi naš identitet, svijest o onome što jesmo. U primjerima se dekadentnih likova upravo procjep između onoga što jesu i onoga što bi trebali biti pokazuje kobnim. Identitet se dakle konstruira kroz društvenu interakciju: ,ja“ je uvijek rezultat suživota s drugima. Za ilustraciju bezuspješne identitetske uspostave u likova dekadenata može nam poslužiti Giddensovo (1991) čitanje identiteta, prema kojem se identitet ne stječe rođenjem, nego se mora izgrađivati cijeloga života. On je projekt za koji se pojedinac tijekom života mora (iz)boriti. A kako smo prepoznali da je egzistencija likova u našem fokusu ozbiljno ugrožena melankolijom i tjeskobom koje prijete 
nemogućnošću nadilaženja okvira u koje su postavljeni, priču o fragmentarnim identitetima nadograđujemo pričom o tim dvjema dispozicijama, konstitutivnim elementima kulturnoga imaginarija dekadencije.

\subsubsection{Tjeskoba i melankolija, dva lica hrvatske dekadencije}

Snažno prepletene, tjeskoba i melankolija zapravo su dvije strane istoga fenomena: simptomi neuroze kao početne i završne točke svih dekadentnih identiteta. Iako bi se moglo prigovoriti kako je ovo poglavlje nepotrebno, pa i pomalo nasilno razgraničenje dviju intenzivno povezanih dispozicija, njime nastojimo pokazati kako su stanja koja detektiramo u naših likova ponajprije povijesno naslijeđe melankolije, duševnoga stanja sjete, čežnje za nedostižnim i izgubljenim i sveopće tuge, te tjeskobe, nejasnoga paralizirajućeg straha, kao kulturno-društvenih pojava.

\subsubsection{Melankolija: Od patološke forme do teorije subjektiviteta}

Nema sumnje da je tuga posve uobičajena emocija, normalan odgovor na svakidašnje pritiske, izazovne životne situacije, pa i na osjećaj gubitka u svakom mogućem smislu. Ipak, ako ona bez jasnoga razloga naraste do granica u kojima se više ne može kontrolirati te ako pritom utječe na pojedinca, na njegovo iskustvo i percepciju svijeta, može se govoriti o njezinoj patološkoj formi. Od davnina pa sve do početka XX. stoljeća naziv je za tu patološku formu bila melankolija, koja se u medicinskom i kulturnom diskursu najčešće opisivala kao sjeta odnosno tuga bez evidentnoga i nedvosmislenoga razloga. Tumačenje melankolije, za razliku od tuge, mijenjalo se s intelektualnim i medicinskim trendovima te se može reći da je taj pojam oduvijek bio i nešto više od puke dijagnoze. Melankolija je uvijek podrazumijevala različite kulturološke interpretacije toga stanja (filozofske, antropološke, književne, medicinske), a pratiti na koji se način ona u kulturi rabi za obilježavanje goleme tuge znači otkriti štošta o terminu samom, o subjektivnom iskustvu, ali i o vremenu u kojem iskrsava. S jedne strane sinonimija tih termina u svakidašnjem govoru donekle zamagljuje značenje tuge kao psihološkoga, emocionalnoga iskustva i melankolije kao kulturološki obremenjenoga diskursa. S druge strane to stapanje značenja najbolje pokazuje i neku vrstu semantičke zamjene: tuga nerijetko sa sobom nosi „teret“ melankolije, a melankolija je pak popraćena osjećajima gubitka, 
praznine ili očaja. Zato možemo sumirati da melankoliju kao pojam s bogatim konotacijama prati širok raspon subjektivnih iskustava koja su, najopćenitije govoreći, spojiva s tugom. Čak i kad su joj se razumijevanja mijenjala, osnovni su joj simptomi - tuga, bespomoćnost, strah, gubitak interesa, emocionalno uzmicanje, krivnja, sram, depresivna ponašanja - ostajali isti. Stapanje i prelijevanje njihova značenja od XV. stoljeća nije samo obojilo melankoliju nekom subjektivnom neodređenošću, nego je i pojmu tuge osiguralo značenje intenzivne zamišljenosti:

Ishod tih interpretacija moglo je biti samo neko iznimno kompleksno afektivno stanje duše, u kojemu bi ta subjektivna i prolazna emocija „tugovanja“ bila kombinirana s dubokosmislenim povlačenjem od svijeta i sa sjetom koja se opasno približavala bolesnom stanju melankolije u emfatičkome smislu. (Klibansky, Panofsky i Saxl, 2009: 201)

Čak ni očigledne razlike u znanstvenom i književnom pristupu melankoliji ne mogu utjecati na činjenicu da se ona tretirala i kao književna i medicinska pozicija. Baš je i zbog toga medicinski diskurs o njoj poprimao gotovo simbolične dimenzije, a najbolji je primjer navedenoga interpretacija melankolije kroz važnost crne žuči, koja je od originalnoga znanstvenog pojašnjenja prerasla u pravi književni fenomen. Stoljećima se naime vjerovalo da melankolični temperament obilježava prevlast crne žuči, koja joj je i dala ime (melaina kole). Indikativno je da je od svih humora upravo melankolični postao vrlo rano predmetom interesa, poprimivši najizraženije patološke konotacije.

(...) upravo je oboljenje zvano „melancholia“ ponajviše bilo obilježeno simptomima mentalne promjene, simptomima koji su bili rangirani počevši od straha, mizantropije i depresije, pa do ludila u njegovih najstrašnijim oblicima. Kasnije će melankolija biti definirana kao tjelesno oboljenje s mentalnim reperkusijama ili, pak, kao neko „permixtio rationis“, „pomućenje razuma“ fizičkoga podrijetla, a što je jedna osobitost koja je morala značajno olakšati proces odvajanja običnoga melankoličnog temperamenta od melankoličnog oboljenja. Jer, dvoznačnost psiholoških simptoma zamagljuje graničnu crtu između bolesti i normalnosti i sili na priznavanje jedne psihosomatske konstitucije koja, iako melankolična, ne čini nužnim da se njezin subjekt opiše kao onaj tko je stvarno cijelo vrijeme bolesnik. Ova osobitost pomaknut će cijelu koncepciju melankolije u područje psihologije i fiziognomije, utirući time put za preobrazbu učenja o četiri humora u teoriju karaktera i mentalnih tipova. (ibid.: 14; isticanje naše) 
S vremenom su se simptomi oboljenja počeli promatrati kao tipovi ljudskoga karaktera, pa su izrazi kolerik, flegmatik, sangvinik i melankolik mogli označavati ili patološka stanja ili prirodnu konstitucionalnu sklonost. Kako navodi Minois, govoreći o prvim manifestacijama fenomena mal de vivre, za liječnike je u pokušaju definiranja toga stanja beskrajne tuge $\mathrm{i}$ beznadnih projekcija budućnosti nedvojbeno bila riječ i o psihološkoj sklonosti (2005: 11). Hipokrat je na osnovama Empedoklova učenja o četirima elementima, koji čine ljudsko tijelo te svojim odnosima utječu na njegovu stabilnost, razvio teoriju o temperamentima, odnosno tjelesnim tekućinama, tvrdeći da je melankolija najbliža stanju bolesti, ako već i nije bolest sama po sebi. Zdravlje je dakle bilo pitanje ravnoteže među humorima. Melankolični temperament, izrazito prijemčiv za pesimistične refleksije, u njegovoj je teoriji posljedica prekomjernoga lučenja crne žuči koje, kako ocjenjuje, može biti rezultat prirodnoga stanja ili neke psihološke traume. Ona se prema tome već tad smatrala fiziološkim i psihološkim fenomenom, a rasprava o melankoliji, piše Foucault, sve do XVII. stoljeća ostala je fiksirana u toj tradiciji „o četiri vrste vlage i njihovim suštinskim svojstvima: postojanim svojstvima koja zapravo pripadaju jednoj supstanci koja se jedina i može smatrati uzrokom“ (1980: 96). Ili, kako su saželi Klibansky, Panofsky i Saxl, različita značenja melankolije „,evoluirala su u tijeku jednoga razvoja koji je pokrivao više od dvije tisuće godina. Pa iako su se stalno pojavljivala nova značenja, ipak ni stara značenja nisu uzmicala: ukratko, nije se radilo o raspadanju ili o metamorfozi, već o paralelnom postojanju“ (2009: 3).

Zato kulturni imaginarij melankolije obuhvaća široku lepezu slika te, grubo rečeno, seže od koncepta memento mori s naglaskom na prolaznosti ljudskoga postojanja do možda najpoznatije slike melankoličnoga genija. Naime melankolija se sa superiornošću genija povezivala još od davnina te je tu vezu, uz određene izmjene, zadržala uglavnom kroza sva stoljeća. Proširivši tezu o fiziološkom utemeljenju melankoličnoga temperamenta na oscilacijama u temperaturi i konzistenciji crne žuči, Aristotel je označava kao karakteristiku iznimnih ljudi. U knjizi Problemata physica, koja mu se tradicionalno pripisuje, uspostavlja distinkciju između patoloških melankolika i melankolika po naravi: dok u prvih akutna promjena melankoličnoga humora izaziva ,prava“ oboljenja te rezultira depresivnim, fobičnim ili epileptičnim epizodama, u drugih je prevelika količina crne žuči stalna i prirodna (Minois, 2005: 16). Aristotelova je filozofija prva dakle povezala medicinski pojam melankolije s platoničkom mahnitošću (pomračenje uma, depresija, strahovi) kao posljedicom te supstancije. Upravo su melankolici po naravi, koji mogu biti posve zdravi, najčešće ljudi velikih sposobnosti: oni mogu biti nesretni, ali ne i depresivni, tjeskobni, ali ne i neurotični. Melankolija je na taj način počela figurirati kao izvor najviše duhovne egzaltacije te je s 
Aristotelom ,postala koekstenzivna nemiru čovjeka u bitku“ (Kristeva, 2014: 10). Onako kako ćemo je i mi postaviti: melankolik - čovjek izvan uobičajenoga poretka stvari, uronjen u neku duboku tugu, ekstremno svjestan svijeta oko sebe.

Ipak, korak dalje od svih drugih antičkih anatoma, liječnika i filozofa otišao je Ruf iz Efeza svojom tezom da su ,životnoj boli“ sklonije sofisticiranije, inteligentnije duše te da je melankolik, najjednostavnije rečeno, tužan bez ikakva razloga. Ta se konstatacija prilično dugo zadržala u kulturnoj povijesti melankolije, pa je i Burton u svom kapitalom pregledu kao njezine stalne pratitelje imenovao tugu i strah kojima se ne nazire pravi razlog. „Oni koji su istančana duha i velike pronicljivosti, ti lako zapadaju u melankoliju, zato što su promjenjivih duševnih stanja i odviše su misaoni i maštoviti“ (cit. prema Klibansky, Panofsky i Saxl, 2009: 45), utvrdio je Ruf. Dakle dok je intelektualna superiornost za Aristotela bila neposredna posljedica melankolije po naravi, a za stoike predispozicija za njezinu patološku formu, za Rufa je upravo umna aktivnost izravan uzrok bolesti.

Koncept melankolije kao pokazatelja iznimnosti iznova je snažno oživio u renesansi, koja se nerijetko poima i kao epoha melankolije, te $\mathrm{u}$ devetnaestostoljetnoj ideji romantičarskoga genija, koji svugdje oko sebe uočava „svjetsku bol“ kojoj ni sam ne može pobjeći. Između Dürerova bakroreza Melencolia I (1514) i Burtonove Anatomije melankolije (1621) smjestilo se cijelo jedno stoljeće melankolije, vezano ponajprije s novim duhom koji, s obzirom na okolnosti, i nije mogao biti ništa drugo do melankoličan.

S Kristoforom Columbom Zemlja postaje veća; s Kopernikom svemir nezaustavljivo raste (Giordano Bruno čak predmijeva da je bezgraničan); s Lutherom se udaljuje Bog; nema više ikona, nema više posrednika ni oprosta. Humanist počinje uočavati osamljenost čovjeka u svemiru. (Minois, 2005: 65)

U središte melankoličnoga imaginarija dospijeva nov, osamljen intelektualac zatvoren među knjigama, čovjek koji postaje svjestan neizmjernosti znanja i svoje nemogućnosti da ga obuhvati. I ta svijest o granicama mogućnosti i sposobnosti čini ga anksioznim. Nije slučajno što se mit o Faustu kao simbolu frustracije intelektualca pred ograničenošću ljudskoga znanja i razuma rađa upravo u XVI. stoljeću. Jer u pozadini se mita krije jedan od ključnih okidača melankolije: pretjeran intelektualni rad i nezasitna žeđ za znanjem. Neiscrpna tema koju će naši književnici provlačiti i u svojim devetnaestostoljetnim prozama. Kako smo dali naslutiti, za renesanse se melankolija rehabilitira i kao znak genijalnosti i duhovnosti. Naime Marsilio Ficino pomiruje aristotelovski koncept melankolije kao izvrsnosti, platoničku inspiraciju 
mahnitosti, astrološki utjecaj Saturna i fiziološki utjecaj crne žuči. Kako objašnjava, čovjekov je um podložan utjecaju planeta, a oni koji su rođeni pod znakom Saturna pate od melankolije. Već je to znak genijalnosti jer Saturn, najplemenitiji od svih planeta, ,uzdiže duh do kontemplacije o skrivenim, superiornim stvarima koje dopuštaju pristup transcendentnom svijetu, nedostupnom drugim ljudima“ (ibid.: 73). Prema tome u Ficinovoj teoriji veliki mislioci, a među njima posebno filozofi koji se upuštaju u duboke kontemplacije i spekulacije, ponajviše pate od melankolije, koja se uzdiže gotovo do razine sublimnoga.

No, crni humor ipak posebno prevladava među misliocima koji, posvećeni ustrajnom učenju filozofije, apstrahiraju um od tijela i tjelesnih stvari, fiksirajući ga na izvantjelesnu realnost: možda zato što je riječ o teškoj aktivnosti, koja zahtijeva posebnu mentalnu napregnutost; možda zato što su, sve dok um drže u vezi s netjelesnom istinom, prisiljeni držati ga odvojenoga od tijela; tako da je njihovo tijelo često tek poluživo i gotovo ugušeno melankolijom. (cit. prema ibid.)

Tako u njegovu tumačenju pojam melankolije, kao amalgam prethodnih tradicija, postaje značenjski polivalentan te zadržava ideju privilegirane melankolične elite, odnosno „običnoga“ čovjeka kod kojega ona i dalje označava samo fizički ili duševni poremećaj uvjetovan prekomjernošću crne žuči. U takvom modelu, zanimljivo za naša tumačenja, dolazi do bitne promjene: melankolija se počinje shvaćati kao teret patnje.

U drugim je pak epohama mahom negativno ocjenjivana, pa je primjerice za skolastičke mislioce bila indikator grijeha bezvoljnosti odnosno duševne tromosti (poznat kao acedia) te je čak smatrana izravnom posljedicom iskonskoga grijeha. Od kraja XVI. i napose u XVII. stoljeću ona postaje jedna od najupadljivijih odlika tadašnjega diskursa o ludilu (Scull, 2018: 99), a u XVIII. se stoljeću, na krilima proučavanja živčanoga sustava, širi uvjerenje da se uzrok melankolije krije u njegovoj funkcionalnosti te se procjenjuje da pojedinac može biti melankoličan ne samo zbog svoga položaja u svijetu ili interpretacije vlastite egzistencije nego i zbog fizičke predodređenosti. Kao što obrazlaže Földényi, upravo je kroz tumačenja melankoličnih stanja medicina uvela koncept slaboga živčanog sustava, stvorivši prividnu vezu između njegove potrošenosti i malaksalosti duše (2016: 248). Međutim „budući da pojedinca u načelu uvijek određuje neka vrsta Weltanschaunga te da je interpretacija života jedan od preduvjeta postojanja, melankolična eksplikacija egzistencije ne podrazumijeva nužno bolest“" (ibid.). I baš su zato devetnaestostoljetni mislioci bili primorani razlikovati dvije vrste melankolije: melankoliju kao psihičko stanje, dispoziciju koja ne zahtijeva medicinsku obradu, 
i psihozu koja pripada psihijatriji. Dakle prema kraju XVIII. stoljeća rapidno se širi patološka anatomija melankolije te teorija o humoralnom disbalansu gotovo posve uzmiče pred objašnjenjem o ulozi živčanoga sustava. Međutim iako ideja o temperamentu kao zadnjem ostatku teorije o humorima nema više svoje mjesto u znanstvenim teorijama, ona i dalje živi kao metaforički izraz potištenih pojedinaca.

U XIX. je stoljeću dijagnosticiranje melankolije kao prave duševne bolesti, odnosno neke vrste „poluludila“, naročito zbog kliničkomedicinske usmjerenosti kognitivnim i afektivnim poremećajima, konačno zaokruženo nosografijama njemačkoga psihijatra Emila Kraepelina (od 1880-ih godina), koje se postavljaju na „kraju jednoga stoljeća koje je donijelo velike promjene u razmišljanju o duševnim bolestima“" (Radden, 2009: 38), odnosno za vrijeme rastuće medikalizacije svih oblika ludila. Kraepelin melankoliju, uz maniju, klasificira kao dio manično-depresivnoga poremećaja, čime je postavio do danas nepromijenjene temelje psihijatrijske klasifikacije skupine duševnih bolesti dementia praecox (ono što se danas naziva shizofrenijom) i manično-depresivnih, odnosno afektivnih skupina bolesti (ibid.: 41). Razvojem psihijatrije na početku XX. stoljeća melankolija je ustupila mjesto depresiji te zato ona iz današnje perspektive evocira posebnu vrstu kontemplacije, ekstremnoga uranjanja u sebe, snažne introspekcije, postajući gotovo nostalgičnom točkom u kulturnoj povijesti.

Tako ovaj tek naznačen pregled prikladno demonstrira da su joj se značenje i važnost mijenjali od epohe do epohe te da ona zapravo podrazumijeva golem dijapazon fenomena koji se najčešće mogu, pa makar i posve labavo, spojiti s univerzalnim iskustvom tuge.

Snažan pečat melankoliji, pa i njezinu današnjemu razumijevanju, dala je psihoanaliza, naročito Freudova. Iz mora radova te tematike kao kamen temeljac iskrsava Freudov tekst Žalovanje i melankolija (1917), napisan u vrijeme kad su pod melankoliju „utrpavane“ različite psihološke dijagnoze. U njemu je postavio razliku između žalovanja kao normalne reakcije na gubitak $^{67}$ i melankolije kao patološkoga stanja koju, podupirući tumačenje i svojom teorijom podsvjesnoga, također utvrđuje na gubitku. Opisavši melankoliju kao narcistički poremećaj gubitka usmjeren sebi, Freud je prvi gubitak direktno povezao s melankolijom, stvorivši od njega središnji koncept toga fenomena. Na taj je način uveo novu teoriju koju kulturna povijest

${ }^{67}$ To može biti gubitak voljene osobe ili pak nečega apstraktnoga, poput domovine, ideala ili slobode (Freud, 1984: 252). 
u mnogobrojnim tumačenjima melankolije kao humoralnoga disbalansa ili u njezinu razumijevanju u okviru biokemijskih modela još nije poznavala.

Freudovo pisanje o melankoliji konstruira melankoliju i melankolična stanja u bitno drukčijim terminima. Od stanja neravnoteže i raspoloženja potištenosti i nemira ona postaje okosnicom uma koji karakteriziraju dvije stvari: nedostatak nečega i želja za tim nečim ili, bolje rečeno, nekim, koji postaje gubitak (...). (ibid.: 45)

Temeljna se razlika između melankolika i onoga koji „tek“ žaluje postavlja u činjenici da se žalovatelj može identificirati s objektom koji gubi pa zato može i žalovati zbog svoga gubitka, dok melankolik zbog gubitka snažno pati, često ni ne znajući zašto. Afekti u pozadini žalovanja i melankolije isti su, a distinkcija se postavlja u ekonomiji njihove razrade: žalovanje je uspješno razrješenje odnosa s objektom, melankolija neuspješno.

Svijet je melankoličnoga subjekta prožet neumornom tugom, $i$ to ponajprije zato što se objekt gubitka ne može identificirati, pa stoga ni odbolovati kroz proces žalovanja. Žalovanje je kao „ekonomija boli“ (Freud, 1984: 244) proces koji neminovno završava nakon što prođe određeno vrijeme. Iako podrazumijeva velika odstupanja u svakidašnjici, ono nikad nije patološko stanje niti zahtijeva medicinski tretman jer - kako subjekt koji se s traumom nosi uči odvojiti svoje afekte od njega - s vremenom gubi svoje traumatične snage. Melankolija se pak javlja kad je uobičajen proces žalovanja iz nekoga razloga zaustavljen. Na taj način afekt i dalje ostaje usmjeren na objekt te se proces nadvladavanja gubitka ne odvija u željenom smjeru. U duševnom je smislu Freud prepoznaje kao „duboku utučenost, izostanak interesa za vanjski svijet, gubitak sposobnosti za ljubav, inhibiciju svih aktivnosti, smanjenje osjećaja dostojanstva do razine koja svoj izraz pronalazi u samookrivljavanju i samoporuzi, kulminirajući u mahnitim očekivanjima kazne“ (ibid.: 252). Sve su to zapravo karakteristike koje također naziva okvirom žalovanja. No odlučna je razlika u tome što nam je poznato kako se proces žalovanja odvija, pa se zbog toga ne smatra patološkim stanjem; jer onoga trenutka kad se ego oslobodi afekta koji ga je vezao za izgubljeni objekt, žalovanje je završeno, a ego je ponovo slobodan i lišen svih inhibicija. Melankolija međutim u većoj mjeri ostaje nerazumljiva zato što nije očito kojim se mehanizmima odvija. Freudu je jasno tek da je odnos s izgubljenim objektom nepoznat svijesti te se doima da on nije integralan dio ega, a inhibicije melankoličnoga subjekta zbunjujuće su za analitičara upravo zato što nije jasno što ga to toliko obuzima. Dakle njezin izvor često i nije razvidan: „pacijent ne može svjesno percipirati što je izgubio“ (ibid.: 254). Freud tako jasno daje do znanja da je njegovo razumijevanje dvaju pojmova opterećeno time što ne može otkriti 
na koji način oni zapravo djeluju, odnosno kojim se to mehanizmima subjekt oslobađa povezanosti s izgubljenim objektom. No ono što je sigurno jest da, dok u žalovanju osiromašuje svijet, u melankoliji osiromašuje ego. Stoga se može reći da se ona ,ponaša kao otvorena rana te privlači na sebe energiju libidnih investicija, prazneći ego do potpunoga osiromašenja“ (ibid.: 262). Zato melankolika uvelike obuzima izrazit manjak samopoštovanja, u kojem vlastitu bezvrijednost proširuje i na svoju prošlost. Usto u melankoliji je ambivalencija, Freud dalje sugerira, gotovo jednakovrijedan čimbenik kao i gubitak: različite emocionalne borbe uključuju ljubav i mržnju dok se subjekt pokušava „odlijepiti“ od objekta svim silama zadržavajući libidnu privrženost.

U melankoliji prilike koje dovode do bolesti najčešće nadilaze slučaj gubitka zbog smrti te uključuju niz različitih situacija u kojima je pojedinac podcijenjen, zanemaren ili razočaran, a koje mogu rezultirati oprečnim osjećajima ljubavi i mržnje ili osnažiti već postojeću ambivalenciju. (ibid.: 260)

Ne dvojeći o originalnosti Freudova uvida, napominjemo tek da, unatoč njegovu pokušaju da ta duševna stanja odvoji, nije nimalo jednostavno posve ih razgraničiti: oni međusobno kolidiraju te sugeriraju da je kategorije normalnoga i nenormalnoga uvijek moguće problematizirati. Kako upozorava Kearney, čak je i Freud kapitulirao pred pitanjem melankolije objasnivši nakraju da zapravo o toj patološkoj formi ne znamo gotovo ništa (2003: 165). Ona izaziva naše spoznaje svijeta dovodeći do ruba razuma.

Prema tome neovisno o raskoracima u viđenjima, melankolija i melankolična stanja primarno ostaju poremećaji sebstva i identiteta te problem gubitka. ${ }^{68} \mathrm{~A}$ uza znanstvenu liniju melankolije paralelno se razvijala ona u književnosti, u kojoj se predstavljala kao senzibilitet i vrijednost po sebi. S vremenom je dakle taj termin u povijesti kulture izgubio svoje medicinsko značenje te se počeo koristiti kao oznaka za duševno raspoloženje, kao sinonim za bezrazložnu

\footnotetext{
${ }^{68} \mathrm{Na}$ Freudovu su tragu suvremeni tumači te problematike inzistirali na povezanosti gubitka i identiteta, posebno iz feminističke perspektive. Tako je naprimjer Enterline melankoliju definirala kao žalovanje bez vidljivoga kraja i dostatnoga razloga, kao stanje koje dokida subjektov identitet kao seksualnoga i govorećega bića (prema Radden, 2000: 44), a Schiesari joj je kao glavnu odliku prepoznala gubitak kao takav, a ne objekt koji je nepovratno izgubljen (1992: 11). Svojim se interpretacijama melankolije i depresije izdvaja Kristeva (2014) koja, nasljedujući Freudov model žalovanja za majčinskim objektom, postavlja teoriju o specifičnosti ženske sudbine u tom procesu introjekcije ili inkorporacije izgubljenoga objekta.
} 
tugu i depresiju neovisnu o fiziološkim predispozicijama. Pridjev „melankoličan“ u smislu raspoloženja i atmosfere počeo se transferirati na sve moguće razine te je takva koncepcija, zasjenivši učenja o temperamentu i bolesti, postala uobičajenim značenjem melankolije u modernom mišljenju.

Do posljednjih desetljeća XIX. i početka XX. stoljeća pojam „melankoličan“ pokrivao je nekoliko različitih polja - u prvom redu: nestalna raspoloženja, duševne poremećaje od ozbiljnih do vrlo blagih, normalnih reakcija te trajne karakterne osobine. (Radden, 2000: 4)

Stoga nećemo pogriješiti ako kažemo da je ona u zapadnoeuropskoj misli središnja ideja koja je pokazala kako čovjek vidi i tumači svijet oko sebe te ujedno okvir društvenih, medicinskih i epistemoloških obrazaca. Nedvojbeno je da kulturološki, društveni i biološki čimbenici mogu utjecati na manifestacije tuge i melankolije te na to kako je pojedinac doživljava i iskušava. Naime u književnim se tekstovima u kojima se tematizira ta patološka tuga najčešće otkrivaju procesi vezani za drugo. Pa tako lijek za melankoliju postaje povratak „,normalnomu“ stanju, nerijetko i nasilan, stanju očišćenomu od emocionalne nestabilnosti, društveno prihvatljivomu i u granicama poretka. Otkriva se nepoželjnost individualne melankolije na razini kolektiva. U takvom je kritičkom čitanju melankolik kao ono drugo simptom društvene patologije koja, poričući svaki egzistencijalni nedostatak, zahtijeva stabilnost i sreću. U terminima psihoanalize, izgubljeni je objekt upravo taj egzistencijalni nedostatak koji društvo potiskuje. Budući da konstantno osjeća tu istinu, melankolik svoje simptome istine očituje kroz ponašanje i osjećaje. Iz druge bi se perspektive međutim moglo reći kako je baš zato sam melankolik odgovoran za svoje stanje: on je beskrajno sjetan ne samo zbog svijeta u kojem je takav nego i zbog svoje urođene patološke sklonosti.

Melankolija je u dekadenata kojima se u radu bavimo zapravo odraz i jednoga šireg fenomena: ona je odgovor na krizu modernoga subjektiviteta i gubitak tradicionalnih uporišta. Iako bi se moglo raspravljati o tome jesu li stanja tih likova doista medicinski patološka, složit ćemo se da su uzroci njihove tuge, u najvećem broju slučajeva, postavljeni i u izvanjskom svijetu, izvan melankoličnoga ili depresivnoga subjekta (a ne samo u njemu). Melankolično raspoloženje ili pesimističan pogled na svijet tek je individualna realizacija puno šire egzistencijalne tjeskobe kojoj nitko ne može pobjeći. Melankolija je način spoznaje svijeta.

Ambivalentnost melankolije kao odgovora na gubitak s jedne te perpetuirajućega anksioznog stanja s druge strane obogaćuje njezin koncept simbolikom kroz koju se izražava i kritika svijeta i položaja pojedinca u njemu. Tako dekadent samoga sebe podvrgava 
preispitivanju, razmatrajući svoj položaj u društvu ne bi li pronašao uvjerljiv razlog za mračnu životnu perspektivu koja ga pritišće. Zato melankolija neprekidno talasa između unutrašnjosti i izvanjskosti, pojedinca i kolektiva, između „ja“ i „drugi“, bezizlazno tražeći utjehu svomu očaju. Duboka se utučenost izabranih dekadenata spaja dakle s povijesnim događajima te tako nadilazi njezinu pojedinačnost. Melankolični je imaginarij krajem XIX. stoljeća upravo literarizacija findesiècleovskih nagovještaja kraja svijeta i civilizacije. Individualno iskustvo nadvladava pojedinačnost da bi predstavilo sliku pravoga stanja stvari, izraze dugotrajne „bolesti civilizacije“ na prijelomu stoljeća. Na kraju će se ispostaviti da se i sama naracija o melankoliji opire konačnim i nedvosmislenim objašnjenjima o njezinim uzrocima te da ostaje otvoreno polje u kojem se čita kao znak složenosti odnosa svijeta i sebstva. Zato se u „ladicu“ melankolije mogu smjestiti proze u kojima se detektira problematičan položaj pojedinca u društvu, njegova nelagoda dok pokušava pronaći odgovore na pitanje o uzrocima vlastite tjeskobe. Prema tome ona u velikoj mjeri ovisi o društvenom kontekstu. Iako subjektivno iskustvo, na neki način prerasta u kolektivno osjećanje. Transformirajući donekle Aristotelovu poveznicu melankolije s izvanserijskim sposobnostima, utvrđujemo da ona $u$ odabranim likovima nema samo veze s njihovom iznimnošću nego i s razvijenom sviješću o svijetu. Spoznaja svijeta čini ih nesretnima te rađa raspoloženje koje se očituje u povlačenju od društva te u izrazitom, gotovo bolesnom stanju sjete i tuge. To su likovi koji ne uspijevaju svoju tugu sublimirati u nešto uzvišenije. I zato je prigodno završiti s Kierkegaardom koji piše:

Osim mog općenito širokog kruga poznanika, imam jednu blisku prijateljicu - moju setu; usred radosti, usred rada, ona mi maše, poziva me nastranu, premda bih najradije ostao na licu mesta. Da, moja seta je najvernija ljubavnica koju sam upoznao, kakvo je onda čudo što je ponovo volim. (1990: 23)

\subsubsection{Tjeskoba: Poetika strepnje}

Tjeskoba je, nedvojbeno se može reći, također esencijalna ljudskomu stanju. U razumnim granicama oslobađa od egzistencijalne dosade, izoštrava osjetila te osigurava dovoljnu dozu napetosti potrebnu za održavanje života. Drugim riječima, implicira vitalnost jer sve dok se psiha pokušava boriti s nejasnim ili nepoznatim demonima, konstruktivno je rješenje moguće. No ako prijeđe tu „razumnu“ granicu koja pojedincu jamči zdravlje, velika je vjerojatnost da će nastupiti njezina patološka forma. I zato u ovoj disertaciji tjeskobu koja se 
javlja u dekadentnih likova detektiramo upravo kao patološko stanje: u svima ona neumorno priječi konstruktivno osmišljavanje života.

Budući da nam, kako smo i upozorili, u radu nije cilj psihičkim stanjima likova pristupiti iz medicinske perspektive, nego iz kulturnoantropološke i filozofske, za početak valja istaknuti kako naše moderno razumijevanje tjeskobe primarno određuju dvije premrežene kulturne paradigme (usp. May, 1977). Jedna je dihotomija tijela i mišljenja koju je u XVII. stoljeću najavio Descartes, odredivši na stanovit način čak i Freudovo psihoanalitičko viđenje, a čije će dalekosežne posljedice biti psihološka razjedinjenost ličnosti i tjeskoba u kasnom XIX. i u XX. stoljeću. Druga se pak paradigma oslanja na činjenicu da, sasvim općenito govoreći, u nekom društvu prevladava zanimanje za racionalne obrasce, dok se racionalno neobjašnjiva iskustva pokušavaju potisnuti. A kako je tjeskoba uvijek barem djelomice neobjašnjiva, lako je razumjeti potrebu za njezinom represijom ili, u najmanju ruku, za njezinim pojašnjenjem terminima straha. Samo se na taj način ona može racionalizirati. Od XVII. stoljeća sklonost potiskivanju iracionalnih elemenata ljudskoga iskustva išlo je ukorak s razvojem društva i ekonomije koji su u obzir uzimali samo ono što se moglo izračunati i praktički upotrijebiti. Međutim za pretpostaviti je da ispod povjerenja u racionalnoga, samostalnoga čovjeka, bujaju izvori anksioznosti u osjećaju psihološke izoliranosti pojedinca. Pa i Descartesov racionalistički „Mislim, dakle jesam“, kako smatra May, implicira da povjerenje u vlastitu egzistenciju pojedinac stječe in vacuo, odnosno u odnosu na izdvojenost od društva kojega je dio.

Uvjerenje da je fizičku prirodu i ljudsko tijelo moguće matematički i mehanički kontrolirati imalo je snažne efekte u razvoju tjeskobe. To je bilo istinito ne samo u suočavanju s čovjekovim materijalnim potrebama i nadvladavanju stvarnih prijetnji fizičke prirode nego i u oslobađanju ljudskoga bića od ,iracionalnih“ strahova i tjeskobe. (ibid.: 22)

Dakle tjeskoba kao nezaobilazna tema iskrsava upravo u XIX. stoljeću, u okviru potrage za novim osnovama jedinstva ličnosti, ali i na tragu inzistiranja na čovjekovu subjektivnom iskustvu i psihičkim proživljavanjima. To je razdoblje obilježila kompartmentalizacija, novi kulturni model koji je značio razjedinjenje, tj. podjelu u svim područjima života i rada (ibid.: 31). Povjerenje u racionalnu kontrolu emocija, koje je došlo s XVII. stoljećem, s vremenom je evoluiralo u sklonost represiji neprihvatljivih intimnih stanja. Pa i model psihičke nejedinstvenosti koji će postati središnji problem Freudova opusa može se shvatiti tek u širem kontekstu kompartmentalizacije, odnosno findesiècleovske razjedinjenosti ličnosti. U tu se dominantnu potragu za čovjekovom cjelovitošću, za njegovim jedinstvom kao bića koje i misli 
i osjeća, uključuje i Kierkegaard. Nastojeći kompartmentalizaciju kulture nadvladati idejom čovjeka kao jedinstvenim, iskustvenim bićem, on postavlja tjeskobu u središte svoje misli u studiji Pojam tjeskobe te joj se vraća i u drugim djelima, stvarajući „najdirektniju te u nekim segmentima najdublju studiju tjeskobe u povijesti toga pojma“ (ibid.). Središnje je načelo njegova djela odnos tjeskobe i slobode, tj. ideja da tjeskoba uvijek dolazi s novim izborom koji se postavlja pred čovjeka. Definirajući slobodu kao mogućnost, a tjeskobu kao stanje koje se u njemu rađa kad se sa slobodom suoči, Kierkegaard jasno daje do znanja da unutarnji konflikt ne mora nužno biti neurotični fenomen. Naprotiv, konflikt je prisutan u svakoj mogućnosti, u svakom iskustvu tjeskobe te pritom razliku između njezina ,zdravoga“ i „,neurotičnoga“ stanja opisuje kao činjenicu da zdrav pojedinac svoju slobodu aktualizira neovisno o konfliktu, dok je bolestan pojedinac žrtvuje. Budući da „mogućnost znači Ja mogu“ (Kierkegaard, 1980b: 44), proces postajanja pojedincem tijesno se veže s idejom slobode jer izbor može presudno odrediti njegov razvoj. Prema tome biti izložen slobodi znači ući u okrilje tjeskobe, biti prepušten neiscrpnim opcijama, te se baš zato čovjekova dezorijentiranost u modernom svijetu može smatrati posljedicom njegove slobode. Tjeskoba je stoga posve razumljiva pojava jednom kad se pojedinac suoči s mnogobrojnim opcijama koje su pred njim, a na koji će se način razvijati i identitetski uspostaviti ovisi i o tome kako se s njom nosi. Sumirajući osnovne Kierkegaardove postavke, May pojašnjava:

U stanju nevinosti nema odvajanja pojedinca od njegove okoline, a tjeskoba je dvosmislena. U stanju samosvijesti međutim postoji mogućnost odvajanja. Tjeskoba je u tom slučaju reflektirajuća; pojedinac samosviješću može donekle usmjeravati vlastiti razvoj te sudjelovati u povijesti čovječanstva. (1977: 37)

I to je ključna odlika uspostave sebstva: tjeskoba je kao mogućnost slobode unutarnji sukob, ona ugrožava cjelovitost pojedinca pretvarajući se u očajanje i nelagodu izbora. Ili, kao što je zapisao Kierkegaard, ona je ,želja za onim čega se boji, simpatična antipatija; strana sila koja pojedinca obuzima i on je se ne može osloboditi (...). Tjeskoba pojedinca oslabljuje (...)““(1980b: 235). Zato se može reći da uspješno suočavanje s njom i njezino nadilaženje gradi sebstvo. Osim toga, prisjetimo li se drugih Kierkegaardovih koncepata o kojima smo pisali u poglavlju o filozofskim temeljima dekadencije, možemo istaknuti kako su doista svi oni „uvjet koji tjera da grcamo za istinom koja će oblikovati individualitet“" (Lučin, 2015: 182), jer biti ljudsko biće podrazumijeva neprekidan rad na sebi. To je zadatak da tek postanemo ,ja““. 
S obzirom na to da je tjeskoba evidentno vezana uz problem identiteta i načina na koje se on realizira, Giddens (1991) uvodi pojam ontološke sigurnost te ga promatra kao temelj osobnoga identiteta. Svaki pojedinac ima nesvjesnu potrebu za ontološkom sigurnošću koju, dok se zasniva na stvaranju odnosa od povjerenja, obilježava poznavanje svakidašnjih rutina. Temeljno je povjerenje, poziva se Giddens na Erika Eriksona, „originalna spona iz koje proizlazi kombinirana emocionalno-bihevioralna orijentacija prema drugima, svijetu kao predmetu i vlastitom identitetu“ (1991: 38) te se ono gradi od djetinjstva, vremena kad se utvrđuju veze među rutinom, reproduciranjem konvencija i osjećajem ontološke sigurnosti. U toj je paradigmi posebna važnost stavljena na rutinu koja kreira okvir egzistencije njegujući osjećaj ,ja“ i njegova odvajanja od „ne-ja“, tih konstitutivnih elemenata sigurnosti, a uspostava se povjerenja pokazuje kao preduvjet konstruiranja identiteta. Giddens dakle postavlja tezu da stečene navike i rutine postaju „sastavni element emocionalnoga prihvaćanja realiteta 'vanjskoga svijeta' bez kojega je sigurna egzistencija nemoguća“" (ibid.: 42). Pritom napominje da je prihvaćanje realnosti vanjskoga svijeta kroz učenje o onome što sam „ne-ja“ u korijenu samoidentifikacije. A kao jednu od odlučnih karakteristika uspostave vlastitoga ,ja“ izdvaja tjeskobu koja se veže s osjećajem izostanka nekoga objekta te je drži općenitom reakcijom na sigurnosni sustav koji pojedinac razvija, a ne samo specifičnim odgovorom na konkretnu prijetnju ili opasnost. Koliki će njezin intenzitet u pojedinca biti, uvelike ovisi o njegovu znanju i osjećaju moći. Može se prema tome reći da je tjeskoba strah bez konkretnoga objekta kroz nesvjesno kreirane emocionalne tenzije koje predstavljaju unutarnje opasnosti. U tjeskobi ne postoji jasna predodžba opasnosti: osoba gaji neko neobjašnjivo čuvstvo straha i strepnje, ali ne zna otkud joj opasnost prijeti. Upravo je znakovito što osobe koje od nje pate naprosto ne mogu izreći ili ne znaju čega se boje, odnosno ne mogu prepoznati objekt svoje emocije. Nije li u njezinoj biti upravo ta nemogućnost prepoznavanja podrijetla opasnosti, pita se pak Kurt Goldstein te razjašnjava da ona napada „s leđa“. Jer dok strah potiče na djelovanje te izoštrava osjetila, tjeskoba osjetila paralizira:

U strahu postoji odgovarajuća obrambena reakcija, tjelesni izraz tenzije i ekstremne usmjerenosti na određen dio okoline. U tjeskobi, naprotiv, pronalazimo besmislenu mahnitost, kruta i iskrivljena izričaja te ograničene afektivnosti, popraćenu povlačenjem iz svijeta. U tom se smislu svijet čini posve nebitnim, a svaka se referencija na njega, svaka korisna percepcija ili akcija obustavlja. (cit. prema May, 1977: 55) 
Zato se primjećuje da tjeskoba zamagljuje svijest o sebi te utječe na percepciju svijeta i situacije u kojoj se pojedinac našao. Djelujući dakle na dva prepletena fenomena, jer svijest o sebi implicira svijest o objektivnom svijetu kojemu se pripada, ona zapravo prekida nit koja veže ,ja“" i svijet. Ozbiljna tjeskoba doista radikalno osiromašuje ličnost te se, s obzirom na to da ona i jest „dezintegracija sebstva, 'disolucija egzistencije njegove ličnosti'““ (ibid.: 56), može odrediti kao svojevrstan gubitak svijeta. Pitajući se o tome što određuje hoće li čovjek uspjeti razriješiti sukob koji se u tjeskobi otvara ili će se ona manifestirati objektivnim simptomima bolesti, May zaključuje da se može govoriti o čovjekovu iskustvu od najranije dobi, prirodi i intenzitetu neposredne prijetnje i kulturološkim prilikama kao njezinim osnovnim konstitucionalnim čimbenicima (ibid.: 80).

Kao potporu našemu razumijevanju dekadencije u odabranim likovima možemo izdvojiti Harryja Stacka Sullivana koji je koncept tjeskobe postavio u središte interpersonalnih odnosa. Naglašavajući značenje osjećaja sigurnosti još od najranije dječje dobi, Sullivan elaborira kako je ta potreba za sigurnošću bitnija čak i „od poriva koji proizlaze iz osjećaja gladi ili žeđi““ (prema Giddens, 1991: 45). Za ideju osobnosti fundamentalno je iskustvo odnosa s drugim ljudima, napose veza djeteta i majke, a u tom se kontekstu tjeskoba promatra kao stanje koje ,proizlazi iz djetetova straha od neodobravanja bitnih ljudi u njegovu interpersonalnom svijetu“ (May, 1977: 152) te na taj način ograničava njegov razvoj. Tako iz Sullivanova tumačenja kao najvrednija proizlazi teza da se ,ja“ formira kako bi se zaštitilo od tjeskobe te osiguralo emocionalno zdravlje kao sinonim za svijest o samom sebi (ibid.: 154). Zato se može reći da tjeskoba - kao osjećaj općega iskustva povezan s reakcijama drugih i s razvojem samopoštovanja - jednom kad se aktivira osnovni sigurnosni sustav, napada samu jezgru sebstva te ju je baš zbog toga pojedincu teško objektivizirati.

Dakle što se prirode tjeskobe tiče, neosporno je da se za nju, za razliku od straha kao reakcije na stvarnu ili pretpostavljenu opasnost, vežu neugodna čuvstva nesigurnosti i bespomoćnosti pred opasnošću, koja može biti stvarna i predvidiva, ali je ipak češće izazvana nepoznatim ili neprepoznatljivim uzrocima. Ona napada puno dublje i intenzivnije, utječući na način na koji pojedinac vidi i vrednuje sebe i zajednicu kojoj pripada, te se u tom ključu, vidjet ćemo osobito kod nekih likova, može definirati kao subjektivna strepnja izazvana prijetnjom nekoj vrijednosti koju pojedinac smatra ključnom za vlastitu egzistenciju.

May razlikuje normalnu i neurotičnu tjeskobu, primjećujući da se u znanstvenoj literaturi, kad se govori o tjeskobi, mahom misli na ono što on određuje neurotičnom tjeskobom. Normalna tjeskoba, kojom smo i započeli ovo poglavlje, jest reakcija razmjerna objektivnoj prijetnji, ne uključuje represiju ili druge mehanizme intrapsihičkoga konflikta te ne zahtijeva 
neurotične obrambene mehanizme koji bi njome upravljali. Može joj se konstruktivno svjesno pristupiti ili se može razriješiti kad se prijeteća situacija promijeni ili okonča (ibid.: 193). Kao „važna signalna funkcija za stvarne ili zamišljene opasnosti u pokušaju da se spriječi emocionalno preopterećenje organizma“ (Emanuel, 2005: 22) ona čovjeka prati tijekom cijeloga života te se ne pojavljuje u svojoj radikalnoj formi. U njegovu uobičajenom, „normalnom“ razvoju individualno je iskustvo uvijek na neki način manja ili veća prijetnja egzistenciji, odnosno vrijednostima koje čovjek s njom identificira. Posve suprotno tomu, lako je naslutiti, neurotična je tjeskoba nerazmjerna prijetnji, uključuje represiju i druge mehanizme intrapsihičkoga konflikta te se zato njome upravlja različitim oblicima smanjenja aktivnosti i svijesti, ponajprije neurotičnim obrambenim mehanizmima (May, 1977: 198). Jednom riječju, ona paralizira. U većem ili manjem stupnju utječe na stvaralačke aktivnosti pojedinca, na njegovo razmišljanje i mogućnost djelovanja.

Neurotična se tjeskoba dakle javlja u slučajevima u kojima nesposobnost adekvatnoga suočavanja s prijetnjama nije objektivna, nego subjektivna, tj. nije posljedica objektivnih slabosti, nego unutarnjih psiholoških obrazaca i konflikata koji priječe pojedinca da upotrijebi vlastite snage. (ibid.: 199) ${ }^{69}$

A u kliničkim je slučajevima neurotične tjeskobe represija objekta, koja nerijetko započinje $u$ djetinjstvu te se pojavljuje tijekom života, središnji problem. Upravo represija pojedinca čini ranjivijim na prijetnje, povećavajući izglede za pojavu njezine neurotične varijante: s jedne strane utječe na psihološku ravnotežu, ključnu za svakidašnje rutine, a s druge umanjuje čovjekovu autonomiju i sposobnost da razluči strah te se protiv njega bori. „Konačno, represija uvećava osjećaj bespomoćnosti pojedinca jer uključuje smanjenje njegove autonomije, unutarnje ograničenje i odlaganje vlastite moći.“ (ibid.: 200) U tom je kontekstu posebno problematično što je to uvijek dvostruk proces: stanje ustrajnoga, neriješenoga konflikta može voditi do potiskivanja, što će pak uzrokovati neurotičnu tjeskobu, a ta će tjeskoba potom potencirati čuvstva bespomoćnosti, jalovosti i pasivnosti, koja mogu iznova pokrenuti ili ojačati već postojeći psihološki konflikt. Dakle neurotična je tjeskoba nerješivo ponavljajuće stanje. Govoreći o različitim konfliktima u pozadini tjeskobe, May im zajednički nazivnik pronalazi u „dijalektičkom odnosu pojedinca i njegove zajednice“ (ibid.: 212). Jer, s obzirom na to da se pojedinac uvijek i u svakom trenutku razvija i kao član neke zajednice, što

\footnotetext{
${ }^{69}$ May napominje da ti konflikti svoje podrijetlo najčešće imaju u najranijem djetinjstvu, u slučajevima u kojima se dijete nije moglo objektivno suočiti s prijetećim problemima (1977: 199).
} 
smo već nekoliko puta podcrtali, razvoj je ličnosti moguće razumjeti tek u interakciji s drugim članovima društva i društvom u cjelini.

Giddens međutim, referirajući se na tu distinkciju, objašnjava da je tjeskoba uvijek u isti mah i normalna i neurotična: normalna jer mehanizmi osnovnoga sigurnosnog sustava podrazumijevaju elemente koji je generiraju, odnosno neurotična jer, frojdovski rečeno, nema objekta (1991: 45). Dakle s obzirom na to da ona prije svega ovisi o nesvjesnim operacijama, ne postoje različite vrste tjeskobe, nego njezin intenzitet i učinak „sakaćenja“ pojedinca u prvom redu ovisi o njegovu psihosocijalnom razvoju, posebno o prirodi represije uz koju je vezana. Ontološka se sigurnost pojedinca temelji na različitim rutinama: ljudi se naime s opasnostima i strahovima koji iz njih proizlaze nose kroz različite emocionalne i bihevioralne modele koji su dio njihove svakidašnjice. A s obzirom na to da biti ontološki siguran znači imati odgovore na temeljna egzistencijalna pitanja, tjeskoba je na neki način intrinzična ljudskoj slobodi, upravo onako kako to postavlja Kierkegaard kad govori o njoj kao o „mogućnosti slobode“. Sloboda nije tek puka odlika: ona proizlazi iz ontološkoga razumijevanja realnosti i osobnoga identiteta.

Kao što se moglo primijetiti, u gotovo se svim raspravama o tjeskobi ističu kulturni čimbenici. Posve je evidentno da, s obzirom na to da smo već nekolicinu puta apostrofirali kontekstualnost kao prijelomno obilježje fenomena kojima se bavimo, oni imaju veliku ulogu u razvoju psihosomatskih bolesti i bihevioralnih poremećaja. Jer pojedinac živi i djeluje u specifičnoj kulturi koja određuje obrasce njegova ponašanja, utječući i na način na koji će se nositi sa sukobima u sebi i s društvom u kojem živi. Kako ćemo istaknuti napose na primjerima nekih dekadenata, „upravo će se afekti, biološke potrebe i načini ponašanja koji se najviše potiskuju u nekoj kulturi najčešće manifestirati simptomima bolesti“ (May, 1977: 82). Navedeno potvrđuje i nevjerojatna činjenica da je društveno prihvatljivije bolovati od neke organske bolesti nego od duševnoga poremećaja. Preciznije rečeno, kultura društva određuje na koji će se način pojedinac nositi s tjeskobom, odnosno koje će simptome manifestirati. Dakle društveno je okruženje sastavni dio koncepta. Kako ističe Sullivan, odnosi pojedinca sa svijetom zamjećuju se u svakoj točki njegova razvoja, ,od stanice in utero do odrasloga čovjeka uključenoga u intimne odnose i poslove s drugim članovima jedne zajednice“ (prema ibid.: 156). Pitajući se o kulturnim vrijednostima odnosno standardima koji je mogu uvjetovati, možemo naglasiti kako je, s obzirom na veliku pozornost koju društvo pridaje vrijednostima uspjeha, tjeskoba povezana s mogućnošću neuspjeha toliko dominantna da bi se moglo 
pretpostaviti da je uspjeh pojedinca $u$ isti tren glavni cilj naše kulture te najočigledniji okidač tjeskobe. Te vrijednosti kompetitivnoga uspjeha imaju jedinstvenu povijesnu genezu: „Tjeskoba pojedinca uvjetovana je činjenicom da on živi u određenoj kulturi u određenom trenutku povijesnoga razvoja te kulture.“ (ibid.: 159) Ta tvrdnja potiče da pretpostavimo kako nemjerljivu ulogu u čovjekovu psihičkom razvoju igra njegovo okružje i povijesna pozadina. Razumijevanje povijesnoga razvoja karaktera modernoga čovjeka umnogome pomaže da razumijemo i suvremeni koncept tjeskobe jer je svijest o povijesti, odnosno o specifičnim obrascima i ponašanjima ujedno svijest o samom sebi. Ne bi li se otkrilo na koji način kompetitivni individualizam, kao jedna od središnjih karakternih struktura modernoga čovjeka, utječe na otuđenje i anksioznost, valja započeti s renesansom. Nasuprot srednjovjekovnomu konceptu čovjeka kao elementa društvenoga organizma u renesansi se razvila - u okviru ideje da je čovjek donekle izoliran entitet koji uspijeva nešto postići usprkos društvenim okolnostima - vizija moćnoga, samostalnoga pojedinca, što će, kako smatraju May i Fromm, postati temelj obrasca moderne tjeskobe. Pojedinac se pozitivno vrednovao samo kao jaka, snažna individua. Već se tad prema tome zamjećuje prepletanje individualizma i kompetitivnosti:

Osiguravši apoteozu jake individue, koja je zajednicu promatrala primarno kao arenu u kojoj se bori za eminenciju, koncept uspjeha povezao se s kompetitivnošću. Cjelokupna je kulturna konstelacija dala prednost samorealizaciji pojedinca u smislu izvrsnosti i trijumfa nad drugim osobama. (ibid.: 165)

No u tom „vrlom novom svijetu“ teče podstruja očaja i napetosti jer je sloboda koja je omogućila osjećaj autonomije i snage urodila skepsom i tjeskobom. Tjeskoba koja se tad rađa nije proizvod frustracije zbog nepostignutoga individualnog uspjeha, već svoje širenje zahvaljuje „stanju psihološke izolacije i nedostatku pozitivnih vrijednosti zajedništva, rezultata prekomjernoga individualizma“ (ibid.: 167). Pa se, unatoč očiglednim razlikama između renesansne tjeskobe $u$ nastajanju $i$ one moderne (a jedna je od ključnih svijest findesiècleovskoga čovjeka o anksioznosti koja je rezultat individualnoga otuđenja), može zaključiti kako su počeci fenomena devetnaestostoljetne tjeskobe vidljivi već u renesansi. Društveni je prestiž, u smislu uspjeha koji se najjednostavnije može definirati kao stjecanje materijalnoga bogatstva, prihvaćen kao dokaz individualne moći, a s obzirom na to da se uspjeh uvijek mjeri u odnosu na druge, on je kompetitivno načelo i kriterij samoprocjenjivanja. Uspjeh se dakle nameće kao primaran cilj i svrha čovjekova života uopće, pa i njegovih osobnih odnosa, a iz otuđenja od drugih (koji također žive prema uzorku samopotvrđivanja koji ovisi o trijumfu 
nad drugima) kao rezultat individualističkoga kompetitivnog uzorka izranja tjeskoba. Pritom je kulturološki prihvaćena metoda njezina ublažavanja udvostručenje napora za postizanjem uspjeha. U tom smislu pojedinac, ne bi li ostvario navedeni cilj, pojačava svoje natjecateljske težnje, što znači da se intenziviraju i osjećaji otuđenja i osamljenosti. S obzirom na to da iz toga začaranog kruga nema izlaza, upravo te „metode koje se najčešće koriste kako bi se smanjila anksioznost u takvoj konstelaciji zapravo omogućuju anksioznost na 'duge staze"“ (ibid.: 218).

Kao što smo dosad istaknuli, problem moderne tjeskobe posebno je aktualan od druge polovice XIX. stoljeća, kad se govori o dezintegraciji pojedinca i svijeta kojemu pripada. Jer ideali i vjera u harmoniju svijeta koji su svojedobno mogli utjecati na razrješenje tjeskobe više to nisu mogli činiti te se razjedinjenost prepoznaje kao prevladavajuća činjenica. U tom je smislu neosporno da je pojedinac skloniji tjeskobi jer se povećava broj situacija u kojima ne može odlučiti kako djelovati i što napraviti. A jednom kad su mu ugrožene vrijednosti i ciljevi, teško se orijentira jer ne pronalazi stabilan vrijednosni sustav u vlastitoj kulturi. Ugrožene vrijednosti znače i ugroženo sebstvo, podsjetimo se. Pa kako sumira May, „ono što se objektivno može činiti malom prijetnjom vrijednostima pojedinca, u toga istog pojedinca $u$ našoj kulturi može rezultirati panikom i dubokom dezorijentacijom“ (ibid.: 221). Moderno se društvo suočava s radikalnim strukturnim promjenama te pojedinac uviđa da gubitak uporišta u poznatim vrijednostima postaje generalna pojava. A ta teza o nesigurnosti kao dominantnom obilježju, zajedničkom većini članova neke zajednice, ponovo usmjerava na ono što smo u nekoliko navrata jasno istaknuli u uvodnim cjelinama disertacije: „dominacija anksioznosti u nekom razdoblju proizlazi iz činjenice da su ugrožene vrijednosti i standardi koji su u temeljima moderne kulture“ (ibid.).

Blizak Mayevoj hipotezi kako se kompetitivni individualizam suprotstavlja iskustvu zajednice te da pritom otuđenje od zajednice postaje važan čimbenik u suvremenom shvaćanju tjeskobe, Fromm (1984) raspravlja o psihološkoj izolaciji pojedinca koja je pratila rađanje osjećaja slobode od renesanse nadalje. Povezujući tjeskobu s ekonomskim razvojem, pokazuje da ,izvesni činioci u modernom industrijskom sistemu uopšte, a u njegovoj monopolističkoj fazi posebno, doprinose razvitku ličnosti koja se oseća nemoćna i usamljena, nespokojna i nesigurna“ (Fromm, 1984: 168). Prema tome iskustvo izolacije i otuđenja, koje u velikoj mjeri obilježava naše dekadente, vrlo je blisko tjeskobi, odnosno njezin je integralni dio. Pitanje je zapravo koliko se pojedinac, s vlastitim iskustvom slobode, uspijeva spojiti sa svijetom oko sebe, upravo u kjerkegardovskom smislu tjeskobe, jer, kao što smo upozorili, ideja individualne slobode zapravo uvijek izranja iz koncepta anksioznosti. U kontekstu Kierkegaardove izjave da „poduzeti pothvat znači izazvati tjeskobu, ali da ne poduzeti ga znači izgubiti sebe“ (cit. prema 
May, 1977: 371), suočavanje s tjeskobom i prihvaćanje odgovornosti podrazumijeva rast samosvijesti i slobodu.

Utvrđujući da želja za slobodom na neki način uvijek supostoji sa željom za podređivanjem, Fromm pojam slobode kreira u dijalektici dvaju viđenja: u pozitivnom smislu ona uključuje mogućnost da se iskoristi za uspostavljanje novih međuljudskih odnosa, a u negativnome je ona oslobođenje od okova i autoriteta. Kako upozorava, „'sloboda od' nije istovetna s pozitivnom slobodom, sa 'slobodom za'“ (Fromm, 1984: 29). I baš ta „negativna“ sloboda, po njegovu mišljenju, rezultira otuđenjem. Navedena je dijalektička priroda slobode najuočljivija u razvoju modernoga čovjeka zapadne civilizacije od renesanse. Naime njegov razvoj podrazumijeva ono što Fromm naziva individuacijom, oslobađanje od ovisnosti o autoritetima i strukturama te posljedičnu svijest čovjeka o tome da je samostalan, ali i osamljen entitet.

Tim odvajanjem od sveta koji je, u poređenju sa vlastitim postojanjem pojedinca, neodoljivo snažan i moćan, često pun pretnji i opasnosti, stvara se osećanje nemoći i nespokojstva. Dok god je čovek deo tog sveta, nesvestan mogućnosti i odgovornosti pojedinačne radnje, on ne mora da ga se plaši. (ibid.: 26)

Tu dvostruku prirodu slobode moguće je promatrati i na razini kulture. Već smo naime naveli renesansu kao epohu koja čovjeku donosi slobodu od ekonomskih, crkvenih, društvenih i političkih spona. Tim se oslobođenjem čovjek istodobno oslobađa veza koje su mu pružale sigurnost, utočište i osjećaj pripadnosti jer „nova sloboda obvezno stvara duboko osećanje nesigurnosti, nemoći, sumnje, usamljenosti i nespokojstva“ (ibid.: 47). Pod utjecajem novih ekonomskih sloboda, kapitala i tržišta, on gubi svoje mjesto u svijetu, gubeći tako i odgovore na pitanje o smislu života.

Njegov odnos prema bližnjima (...) pretvorio se u neprijateljstvo i otuđenost; on je slobodan to jest, usamljen, izolovan, ugrožen sa svih strana. Ne posedujući bogatstvo ni moć koje je posedovao renesansni kapitalista, a izgubivši i osećanje jedinstva sa ljudima i svemirom, njega svladava osećanje pojedinačne ništavnosti i bespomoćnosti. (ibid.)

Dakle moderne ekonomske i društvene strukture djeluju na pojedinca na dvojak način: on se osjeća sve nezavisnijim i kritičnijim, a time i sve osamljenijim i izoliranijim. Intenzivira se njegovo čuvstvo beznačajnosti i osamljenosti. Kao jedan od načina ublažavanja tjeskobe od 
XVI. stoljeća nadalje Fromm prepoznaje pojačanu radnu aktivnost, odnosno inzistiranje na radu. Rad je naime postao vrijednost per se, pa se može reći da je snaga koja je čovjeka poticala na nezaustavljiv rad bila jedna od temeljnih proizvodnih sila, „za razvitak našeg industrijskog sistema ništa manje bitna od pare i elektriciteta“ (ibid.: 66). Posljedice takvih okolnosti za razvoj psihologije modernoga čovjeka bile su, naravno, višestruke i kompleksne jer u situaciji u kojoj tržište postaje glavni kriterij čovjek se počinje vrednovati kao roba. Njegova se generalna vrijednost izjednačava s njegovom tržišnom vrijednosti, koja potom postaje i način na koji čovjek ocjenjuje i procjenjuje samoga sebe. Tako da samopouzdanje i iskustvo samoga sebe u velikoj mjeri postaju refleksija onoga što drugi o čovjeku misle. Zato Fromm utvrđuje da ekonomski procesi ne pridonose samo otuđenju čovjeka od čovjeka već i otuđenju čovjeka od sebe samoga. Ljudski su odnosi dakle obilježeni alijenacijom, no možda je najintenzivnija alijenacija od vlastitoga ,ja“ jer u kapitalističkom sustavu čovjek prodaje i sebe te se osjeća kao roba. Ekonomske slobode pristigle s kapitalizmom obrnule su se u činjenicu da pojedinac postaje sve otuđeniji i nesigurniji, oruđe u rukama drugih. Društvo ne uspijeva obuzdati snage koje je samo stvorilo. Stoga čovjeka u novim uvjetima bitno obilježava osjećaj izoliranosti, neslobode i samoće. Iako on nastavlja podržavati obmanu kako je i dalje središte svijeta,

ipak ga obuzima duboko osećanje beznačajnosti i nemoći, koga su njegovi preci nekad bih svesni u svom odnosu prema bogu. Osećanje izdvojenosti i nemoći modernog čoveka još je više uvećano obeležjem koje su dobili svi njegovi ljudski odnosi. Odnos jednog pojedinca s drugim izgubio je obeležje neposrednosti i čovečnosti, a dobio obeležje manipulacije i instrumentalnosti (ibid.: 87-88).

Međutim postavka da su međuljudski odnosi postali instrumentalizirani ne mijenja činjenicu da pojedinac i dalje njeguje potrebu za drugim: oni su nužan i neizbježan dio svake egzistencije. Da bi opstao, on jednostavno mora surađivati s drugim. Zato se može reći da je potreba za izbjegavanjem samoće, za povezanošću sa svijetom oko sebe, baš poput potreba ukorijenjenih u fiziološkoj strukturi čovjeka, jedan od nepromjenjivih životnih čimbenika. Naime „osećanje potpune usamljenosti i izdvojenosti dovodi do mentalne dezintegracije, kao što fizičko gladovanje dovodi do smrti“ (ibid.: 19). A taj osjećaj povezanosti podrazumijeva i vezanost za određene ideje, vrijednosti i socijalne obrasce koji pružaju osjećaj pripadnosti. Čovjek, samosvjesno ćuteći da je pojedinačno biće koje se razlikuje od drugih, traži svoje mjesto u svijetu jer se tek s njim može uspješno vezati za sustav koji će osmisliti i usmjeriti njegovu egzistenciju te mu omogućiti sposobnost djelovanja, tj. življenja. I zato se tjeskobi, 
kako smo, uostalom, i upozorili na početku ovoga potpoglavlja, posebna pozornost posvećuje u filozofiji, napose u filozofiji egzistencije, u kojoj se ona razumijeva kao jedan od ključnih segmenata čovjekova života koja na presudan način obilježava njegov odnos prema sebi i prema drugima. U takvom je viđenju, kao što smo već pisali, tjeskoba temeljna emocija postojanja, izraz sveprožimajuće nelagode postojanja i općenite metafizičke osamljenosti. I pritom poprima sva obilježja neuroze:

U prvom redu, zbog odcjepljenja pojedinca od stvarnosti, društvene i obiteljske, što se odražava u principu subjektivnosti i ništavila, u poricanju objektivnih vrednota, determinizma i progresa; zatim, zbog osjećaja krivnje, očaja i poraza (...); te, konačno, radi uklanjanja tjeskobe pomoću „angažovanja“, zalaganja u životu, koje nije nikada potpuno, već samo simbolično, jer se iza svake akcije krije ponor ništavila i besmisla, tako da svaka akcija (...) gubi stvarni, nužni karakter i dobiva samo privremeni, simbolični, proizvoljni i neurotičko-prinudni karakter. (Supek, 1950: 86)

Tako tjeskoba postaje izraz trajne neravnoteže u kojoj pojedinac, boreći se s čuvstvima poraza, osjeća nepreglednu muku neuspjeha. Postupno se oslobađajući uronjenosti u svijet, vanjske stvarnosti, postaje sve izloženiji strahovima i patnjama koje dotad nije poznavao. Nasuprot medicinskim tumačenjima, koja ne mogu ponuditi stvarne uzroke tjeskobe kao sastavnoga dijela nekoga povijesnog doba, za egzistencijalizam je tjeskoba posljedica odvajanja pojedinca od društvenoga realiteta i popratni fenomen svake ideologije u raspadu: ona je, najsažetije rečeno, metafizički korijen čovjekove egzistencije (ibid.: 90). Stoga se može zaključiti, uzimajući u obzir navedene Frommove tvrdnje te vodeći računa o pozicijama naših dekadenata, kako je tjeskoba konačan ishod jaza ,između ideološke nadgradnje građanskog društva, koja je doživjela slom u svom racionalnom vidu, i načina postojanja pojedinca u građanskom društvu, sebičnog, konkurentskog, nečovječnog“ (ibid.: 88).

Naši su likovi dekadenata upravo gonjeni potrebom da se ukorijene, u domu i u pozivu, te da postanu dijelom zajednice. No društvo ostaje nemilosrdno ostavljajući ih bez smjera $u$ njihovu vlastitom životu, izolirane od ostatka svijeta. Posredno, njihova tjeskoba i izolacija proizlaze i iz činjenice da prijelom stoljeća naglašava mehaničku, racionalističku ravnotežu po cijenu osobnoga integriteta. Zato su oni simptom nelagode građanske kulture koja sva nepoželjna ponašanja nastoji racionalizirati potiskujući ih. Osim toga, prisjetimo li se priče o imploziji moderniteta, odnosno njegovu urušavanju u samoga sebe, teško se ne prikloniti Breitenbergovu tumačenju tjeskobe kao stanja inherentnoga maskulinitetu: muška tjeskoba 
naime istovremeno otkriva kontradikcije i pukotine u patrijarhalnom sustavu te omogućuje reprodukciju toga istog patrijarhata (1996: 2). Ona je nusprodukt koji razotkriva slabosti sustava i instrument njegove perpetuacije. Igra formativnu ulogu u uspostavi muškoga identiteta.

\subsection{Tjeskoba u nastajanju: Priča jednoga protodekadenta}

Tragičnu sudbinu mladoga intelektualca koji pokušava nadići društvena ograničenja, a koja će postati paradigmatskom u hrvatskoj književnosti, prvi je u nas iznio Šenoa 1873. u pripovijesti Prijan Lovro. Poslužio mu je kao predložak Slovenac kojega je upoznao za studija u Pragu, postavši ilustrativan obrazac života talentiranoga čovjeka u neprijateljskim okolnostima, slika kakvu će u više ili manje modificiranom obliku preuzeti drugi naši pisci. Mada se stječe dojam da je Lovrina priča iznesena gotovo usputno, jer je plod razgovora pripovjedača i njegove sugovornice, nije slučajno odabrana ta pripovijest o pametnom i osjetljivom mladiću kao ona koja ponajbolje oslikava egzistencijalne probleme darovitoga pojedinca u ograničenoj sredini. Ona je, dobro je poznato, odgovor na primjedbu pripovjedačeve sugovornice da u našoj stvarnosti nema života dovoljno velikih da bi bili literarizirani: „Jesu li pisci krivi da u nas ne ima velikih katastrofa koje znadu uzdrmati dušu? Jesu li pisci kadri naslikati u malenu okviru velike divovske slike, može li u naših okolnostih postati kakav zanimiv junak romanu?“ (Šenoa, 2001: 27) Ne bi li se demonstriralo kako, nasuprot tomu uvjerenju o vremenu bez genija, iznimaka, originala koji bi se pojavili na horizontu književnoga djela, itekako postoje ljudi vrijedni pozornosti, prepričava se tragedija o nemogućnosti zasnivanja normalne egzistencije, tragedija dvostruke naravi: ne shvaćajući pojedinca, društvo ga odbacuje, što pak u njemu rađa duboku psihološku krizu. A tu krizu prepoznajemo kao nepronalaženje vlastitoga identiteta, neurotičnu nemogućnost čovjeka da se konstituira kao subjekt.

Smisao tadašnjega društva najbolje je sažeo Frangeš komentirajući da je „seljak potjeran u grad, a grada nije bilo. Pred seoskim sinovima otvorila se dilema: crna škola ili činovnički stol. Tako se rađaju prijani Lovre“ (1972a: 357). Programatska je prema tome Lovrina uloga u razvoju hrvatskoga lika dekadenta. Već u ovoj prvoj prozi koja začinje taj put uočavamo jedno od bitnih obilježja hrvatske dekadencije. Kako smo prethodno napomenuli, ona u našoj književnosti uopće nije rezervirana za pripadnike viših društvenih staleža, za elitu koja se, neopterećena materijalnim problemima, u bogatstvu prepušta dokolici i intelektualiziranju, rezonirajući o smislu života. Naprotiv, karakteristična je za „male“ ljude 
„plebejskoga“ podrijetla, intelektualce, ${ }^{70}$ seljačku i građansku djecu predodređenu za svećenike, učitelje i književnike koji, često i pod pritiskom posve konkretnih životnih poteškoća, pogibaju pod teretom nemilosrdne sudbine. Navedeno potvrđuje jednu od naših teza iz prvoga dijela rada, onu da je dekadencija bila prilagođena hrvatskim prilikama te da je kao takva bila naš specifikum: može se detektirati kao jedinstvena atmosfera polaganoga propadanja, egzistencijalnoga besmisla, duh vremena, osjećaj neslobode i inferiornosti.

Hrvatska naime nije razvijena Europa. Još petnaestak godina prije Šenoa je u raspravi Naša književnost (1865) apostrofirao važnost književnosti kao sredstva emancipacije naroda, inzistirajući na usmjerenosti „običnomu“, napose hrvatskomu čovjeku, pa se u skladu s tim temeljni pojam naše disertacije smješta izvan plemićkoga habitusa, svojstvenoga europskomu monarhizmu, u ambijent uobičajenih seoskih i građanskih zanimanja u kojima čovjek životari pritisnut tegobnom svakidašnjicom. I zato se Lovrina uloga preteče dekadencije može čitati, s obzirom na aktualne prilike u Austro-Ugarskoj Monarhiji, osobito nakon sklapanja Hrvatskougarske nagodbe, i kao suptilan bunt protiv krupnoga, napose mađarskoga plemstva. Surovi materijalni uvjeti vrlo prigodno svjedoče o realitetu jer se doima da se svijet učitelja, svećenika, umjetnika i drugih „duhovnih“ zanimanja raspada pred važnošću materijaliziranoga i ekonomiziranoga svijeta koji proizvodi snažne osjećaje egzistencijalne rastrganosti pripadnika jedne zajednice koja polako nestaje. Dekadencija je u našem radu shvaćena upravo u šopenhauerovsko-ničeovskom smislu okrenutosti „malomu“ čovjeku, njegovim psihičkim stanjima obilježenima iznimnim senzibilitetom, što sugerira da se možda baš u nas ispravno detektira smisao dekadencije kao bitnoga pojma filozofije egzistencije usmjerene konkretnosti ljudskoga života, a ne tek idealnomu svijetu.

Dakle priča o Lovri jest tipična priča hrvatske književnosti, ali i priča o hrvatskim dekadentima. Lovro je seljačko dijete odraslo u neimaštini, kojemu su roditelji predodredili svećenički poziv: „zvonarski dječak, krotko đače, niklo iz seoske kolibe, snuždeni mladi bogoslov“ (Šenoa, 2001: 41). Već je tu začeta njegova tjeskoba u kojoj će mu cijeli život odrediti izbori i načela nekih drugih ljudi. Iako su mu kao iznimno bistrom i željnom znanja predviđali blistavu karijeru, visok položaj u crkvenoj hijerarhiji, ,žarkomu srcu mladića bijaše i svijet preuzan, prezalo se ono preliti preko svijeta, više svijeta, a ovamo ustadoše kidat ga od svijeta, zatvorit ga u sebe“ (ibid.: 32). Premda nesiguran, romantičarski spreman na žrtvu, ipak

\footnotetext{
${ }^{70}$ Mogli bismo stoga sugerirati da je položaj naših dekadenata, čak i kad je društvena problematika u djelima posve apstrahirana, uvjetovan i specifičnom atmosferom kuenovštine u kojoj je intelektualac nerijetko bio prisiljen povući se iz djelatnoga, javnoga života.
} 
pristaje odigrati tu tradicionalnu, nametnutu ulogu, koja se s vremenom pretvara u okove koji ga sve očitije guše:

(...) nastade u Lovrinoj duši noć, tamna noć, burna noć. Dugi hodnici sjemeništa zijevahu na nj kao otvorena ždrijela. Lovro se odbi od drugova. Bivao sve bljeđi. (...) Zakopao se u Augustina, Hrizostoma i druge svete oce, zadubio u psalme. Badava, badava! Duh mu se svraćao na Bérangera, Goethea, Byrona i Mickiewicza. Tu je nalazio sebe. (...) Lovro stao čitati, učiti u noć. Ali nije učio svetih otaca. Učio povijest, jezike, matematiku. (...) Primiv toliko slika pjesničkih velikana, toliku silu razlikih misli i osjećaja u sebe, buktilo mu srce kao vatrena gora. Bivao sve bljeđi, sve suhlji, a oči sve plamnije. Nađoše u njega Kanta, nađoše Rousseauove Confessions. (ibid.: 34)

Lovro se dakle okreće romantizmu koji se, afirmirajući tankoćutnost, iracionalnost, narodnost i zavičajnost, postavlja nasuprot kršćanskim idealima, suviše apstraktnima za razumijevanje konkretnoga čovjeka $\mathrm{u}$ konkretnom ambijentu. Nasuprot Augustinovu univerzalizmu stoje Béranger, koji u duhu socijalno angažiranoga pjesništva favorizira slobodu i građanska prava, i Goethe, koji u svojim kapitalnim djelima možda najsnažnije artikulira osjećaje „svjetske boli“ kroz tjeskobno proživljavanje životnih antinomija, podvojenosti između dobra i zla, duha i materije, života i ništavila. U Mefistofelesovu duhu, koji predstavlja duh srednjovjekovnoga praznovjerja, mogla bi se ogledati i Lovrina pozicija, u smislu onoga što mu je dano, u Faustovu, kao utjelovljenju spoznaje i neiskušanih mogućnosti u stvarnom životu onkraj transcendentnoga, ono što Lovro želi biti. Naposljetku u nemogućnosti konačne pobjede individualnoga besmisla i leži Lovrina geteovska tragedija. Byron pak, bježeći u prevratničkom romantizmu iz sredine koja ga osuđuje i ne razumije, inzistira na borbi pojedinca za vlastitu slobodu i samostalnost, uz neizostavan osjećaj Weltschmerza i neminovan poraz pojedinca u srazu s objektivnim svijetom, dok u Mickiewicza uočava odlučnost duha usmjerena narodnomu uzdizanju jedne slavenske zemlje, ali i protivljenje kršćanskomu univerzalizmu kroz društveni angažman. U konačnici, filozofska mu literatura, napose Kant i Rousseau, daje poticaj za snagu volje, odlučne principe obaju filozofa, a bogatstvo europskoga romantizma pružaju mu i Rousseauove Ispovijesti, u kojima autor svjedoči o okrenutosti prirodi, prirodnomu, neiskvarenomu čovjeku koji gradi autonomiju što se opire suvremenomu dobu racionalizma koji guši njegovu prirodnu slobodu (usto Rousseau mu može biti neposredan uzor jer pokazuje kako je odrastao u ambijentu svećenika, teologa i metafizičara te kako je i sam bio pod utjecajem njihove literature). Dakle čitajući sve spomenuto, Lovro bilježi navedeno 
proturječje, rastrganost između nužnoga, neželjenoga svijeta i slobodnoga kojemu se hoće okrenuti. Nužnost i sloboda, uvriježena filozofska napetost, razdiru njegovu intimu, u čemu se zrcali smisao epohe i razlog dominantnoga dekadentnog čuvstva.

Prema tome pod svim se tim utjecajima poništavaju teološka naučavanja aspiracijom nečemu višemu. A nakon što je zbog lektire koju strasno guta optužen da je tek najobičniji svjetovnjak pod crnom haljom, u jednom odlasku u rodni kraj upoznaje Malvinu, ženu u koju se zaljubljuje, te, svjestan činjenice da od ljubavi mora odustati zbog crkvenoga poziva, razapetost između nametnute uloge i vlastitoga subjektiviteta - između tijela, sapetoga svećeničkom haljom, i duha, usmjerenoga kreaciji - postaje sve razornija:

Samo jedno mjesto u njegovu tijelu bijaše život, mahnito - samo srce bijaše mu živo, a sve ostalo tijelo mrtvo. 1 srce ga je bolilo; bijaše mu kao da ga iščupa iz grudi. Po cijele dane znao Lovro po svojoj sobici koracati amo-tamo nijem, blijed, bez svijesti. Glas orgulja činjaše mu se olujom gdje bjesni na uzbibanom moru, sveta pjesma bijaše njegovu uhu uzdisanje umirućih, a riječi njegove molitve ne bijahu neg zrna padajuća na pust, neplodan kamen. (ibid.: 36)

To supostojanje dvaju suprotstavljenih sustava, objektiviteta svijeta, simbolično prezentiranoga u Crkvi, i subjektiviteta vlastite pojavnosti, koja ima potrebu istrgnuti se iz svijeta koji ga stišće, prezentira se indikativnim snom, koji će ga nakraju, jednom kad se pretvori u realnost, i stajati života: „On da je bio ptica podrezanih krila, zatvorena u gajbi. A vani u zelenu lugu sjedio na grančici slavuljak slažući mile pjesme. I htio poletjeti iz gajbe, poletjeti svome slavuljku u zelenom lugu. Tri puta razmahnuo krila, tri puta lupi glavom o gajbu i s glave poteče mu krv.“ (ibid.)

Prava realizacija njegovih sposobnosti, koja će biti jednako neuspješna kao i zaređivanje, započinje u gradu kad Lovro, izašavši iz sjemeništa te se na taj način oslobodivši propisane mu pozicije, postaje odgajatelj sina nekoga grofa. U uvjetima lagodnoga života njegov neobuzdani kritički duh konačno uživa slobodu donedavno uskraćenu roditeljskom odlukom i sapetu okovima vjere. Nastojeći obuhvatiti kompletno ljudsko znanje, uči prirodoslovlje, matematiku, filozofiju, književnost, povijest političke misli, a promjena životne paradigme, naročito svakidašnjica oslobođena financijskih briga, u njemu potiče i emocionalnu stabilnost te napokon „disaše slobodno, sretno“ (ibid.: 41). Međutim harmonija se urušava susretom s udanom Malvinom, koja se, nastojeći se materijalno situirati, udala za nekoga kotarskog predsjednika, i grofovom nemogućnošću da mu osigura upis na diplomatsku akademiju. Tad se kriza produbljuje i Lovro iz senzibilna mladića kojemu je tuđom voljom 
obučena svećenička halja prerasta u čovjeka koji ne uspijeva ostvariti ambicije ni zasnovati emocionalnu vezu. Odbija potom grofov savjet da se iznova veže praktički jedinim mu preostalim poslom, činovničkim ,živovanjem“, te se odlučuje za učiteljski poziv koji bi mu mogao pružiti barem prividnu slobodu i relativno zadovoljstvo: „Utekoh iz sjemeništa da se dokopam slobode. Nijesam bio jak u nijemoj zabiti probaviti nekoliko godina. A da budem svezan sav svoj vijek? (...) I najbolja služba bila bi mojemu duhu što je Herkulu bila Nesova haljina." (ibid.: 49-50)

No povratka više nema te Lovro sve očiglednije propada, transformirajući se iz znatiželjna mladića u čovjeka koji sve jasnije minorizira vlastite ciljeve. Odlaskom u Prag na studij jezikoslovlja, financijski nesiguran i neosiguran te suočen sa svakidašnjom borbom za golu egzistenciju, postaje sve svjesniji nedostatnosti znanja, toga nematerijalnog bogatstva $u$ društvu kojim dominiraju novac, ekonomske, političke i društvene povlastice:

Znanje mu smetalo. Šta će sa filozofijom, sa svimi evropejskimi jezici u maloj kolibi sred pusta kamena? Šta hasni bogatstvo kad ga ne može potrošiti? Nujan verao se po cijele dane po goloj vrleti čitkajuć sad Byrona, sad Bérangera, sad Goethea. A kakva mu korist od toga čitanja? Bijaše nemiran, zabrinut. (ibid.: 50)

Premda se znanosti objeručke prihvatio i u Beču, dovršavajući studij uz očevu pomoć, osjeća se ipak da je to načeta egzistencija: gubi se sloboda učenja, urušava se duh otvoren i prijemčiv za novo te prevladava dojam o jarmu „koji mu steže živu krilatu dušu“ (ibid.: 53). Budući da mu je otac teško stečenim novcem, ponajprije od mukotrpnoga rada na zemlji, omogućio daljnje školovanje, Lovrin će duševni slom nositi i biljeg obiteljske žrtve. Dakle ono za što on sam nije bio predestiniran, kao, uostalom, i svi drugi dekadenti - bavljenje konkretnim poslom - osigurat će mu kakvu-takvu egzistenciju. Usto dramatičnost njegove propasti potencirat će okrutni uvjeti velegrada koji nikoga ne štedi: „Sto i sto briga navalili na jadnog mladića, a duša da mu bude kraj toga mirna, mareći samo za nauk, kad često ni korice hljeba ne ima?“ (ibid.) Upravo tu u prvi plan dolaze još neke jedinstvenosti hrvatske dekadencije, ponajprije činjenica da je ona u likova često uvjetovana i materijalnom neimaštinom. Velegrad ga je iscrpio, natjerao na vegetiranje u kojem, pod teretom financijskih briga, spoznaje uzaludnost i nepraktičnost znanja, njegovu neupotrebljivost u stvarnom životu, utjelovljujući na taj način svu bijedu hrvatske inteligencije. 
(...) nije li Jacques Rousseau istinu govorio, odgovoriv dižonskoj akademiji da znanosti čovjeku više škode nego hasne? (...) I ja sam živi atom te istine. Šta je meni trebalo stablo spoznaje? Volio bih znojiti se za očevim plugom nego brodit za Akilom pred Troju ili uzvitlati prah junaka Igora. Buditi znanjem želje u sebi a ne dovit se činu, letiti mišlju preko mora, preko zvijezda, a tijelom biti prikovan do groba na jedno mjesto, to je prokletstvo. Blaženi slaba uma ljudi! (ibid.: 54 ; isticanje naše)

Referirajući se na Rousseauovu tezu o prirodnoj dobroti i neiskvarenosti ljudske prirode, pripovjedač provlači Lovru kroz neke glavne postavke Rousseauove Rasprave o znanosti $i$ umjetnosti kako bi prigodno ilustrirao njegovu životnu agoniju. Napisao ju je kao odgovor na nagradno pitanje u natječaju Akademije u Dijonu o tom djeluju li znanosti i umjetnosti na poboljšanje ili kvarenje morala, ustvrdivši da pridonose napretku čovječanstva, ali da što su razvijenije, to više korumpiraju izvornu ljudsku dobrotu (usp. Rousseau, 1979). Drukčije rečeno, sve ljudske snage koje svijet proizvode na umjetan način narušavaju i devalviraju vrijednosti koje je čovjek primio od prirode. Lovrina je priča prema tome dobra ilustracija upravo opisanoga jer se i sam postupno uvjerava da razvoj u spoznaji, odnosno znanju dovodi do očaja. Čovjek naime nije samo biće željno uvećanja znanja nego i temeljne okrenutosti prirodi i njezinim danostima. Možda i tu leže uzroci njegove dekadencije: na neki je način kažnjen zbog odvajanja od tla, izvornosti, zavičaja, te spoznaje prokletstvo aspiracije za znanjem, zbog čega se u njemu gradi dekadentna svijest utemeljena u procjepu tih dvaju ljudskih određenja, prirode i razuma. Nasuprot romantičarskomu okretanju iracionalnomu, transcendentalnomu, prirodnomu, subjektivnomu, koje je bilo odgovor na velike filozofske sustave XVII. i XVIII. stoljeća, stoji hladni ratio, koji iz svijeta života nastoji odstraniti sve ono unutarnje ljudsko, zrcaleći tako svijet objektiviteta kojem su sva subjektivna stanja nešto strano i drugorazredno. Društveni uspjeh nameće se zakonitostima uma i funkcijama koje pojedinac u zajednici zauzima.

Prema svemu dosad rečenom, možemo poentirati da je Lovrina dekadencija oznaka društveno-političkoga realiteta, ali i njegove sasvim objektivne nemogućnosti da taj realitet nadiđe. Dijagnosticiramo je dakle ponajprije kao potragu za mjestom u društvu, za uspostavom vlastite cjelovitosti te svijest o praktičnoj neupotrebljivosti znanja u materijalnim neprilikama, koja se promeće u svijest o vlastitoj suvišnosti u svijetu. Ona je sociološki objašnjiva: socioekonomski je kontekst uvjetovao njegov život, stvorivši sve predispozicije za propast. Upozorava naime pripovjedač da bi Lovro „u velikih sretnih okolnostih bio postao velikim čovjekom“ (Šenoa, 2001: 68). No u ograničenim je prilikama, u društvu nejednakosti „postao 
žrtvom, šakom praha i pepela; stablo koje bi nosilo zlatna ploda, da ga ne bude oborila nemila bura“ (ibid.). Podsjetimo kako je racionalizam osobit izraz poprimio u spoju s materijalizmom završavajući u ekonomizmu XIX. stoljeća. Ratio, koji će poslije Adorno i Horkheimer odrediti kao organ kalkulacije i plana, konzekventno je završio u egoističnom ekonomizmu koji, osobito izražen u buržoaskim velegradskim društvima, postaje sve bitniji kriterij društvenoga uspjeha. Pogubna je za Lovru bila ta razlika u moći, bogatstvu i statusu. Zato Zeitgeist, koji se prikladno može prezentirati Hölderinovom „Čemu pjesnici u oskudnom vremenu“, za njega predstavlja gubitak smisla svijeta.

Lovro dakle nigdje ne uspijeva pronaći svoj mir, on zapravo nigdje ne pripada: ta istrgnutost iz vremena i prostora bit će za njega kobna. Otišao je u svijet, shvatio je da mu ne pripada; vrativši se u rodni kraj, samo se suočavao sa spoznajom o vlastitoj nepotrebnosti. Zato će i njegovo književno potomstvo besciljno lutati, suvišno svijetu i, nakraju, sebi samomu. Prema tome njegovu dekadenciju promatramo kao polaganu propast, duševni slom u kojem on uviđa uzaludnost napora da se uklopi, postane dio sustava, i nemoć da s takvim frustrirajućim životom, koji ga ne zadovoljava, nastavi. Obrazovanje i izniman intelekt stavili su ga u nezavidnu poziciju da vidi svijet koji radije ne bi vidio. To je njegova „bolest“. On ne uspijeva sintetizirati spoznaje kojima ga je opskrbilo obrazovanje i životno iskustvo sa željom da se spoji s ljudima i taj neuspjeh u njemu konačno gasi svaku daljnju želju za interpersonalnim odnosima. A s obzirom na to da s vremenom postaje svjestan nedostojnosti ljudi oko sebe, ali i činjenice da po tom pitanju ne može ništa poduzeti, morat će biti žrtvovan. Lovru stoga čitamo kao model neprilagodbe pojedinca autoritarnomu društvu koje od njega traži adaptaciju, konformizam, zadovoljenje standarda ponašanja, dominantnih vrijednosti. Socijalne ga norme nagrizaju te on životom plaća pobunu protiv ustaljenih modusa djelovanja, potrebu da se izdigne iznad prosjeka, iznad konzervativnoga doživljavanja života koje je takvima poput njega namijenilo ili hladnu crkvenu haljinu ili prašinu činovničkoga stola. Naime dok neprekidno nastoji dati smisao životu, svaki ga sljedeći korak podsjeća da ne može zadovoljiti funkcionalne datosti pozicija koje zauzima.

Premda možemo zaključiti da Lovrina dekadencija nije izraz neke patološke neuravnoteženosti, poglavito ne u opsegu u kojem ćemo je pronaći u drugih dekadenata, znakovito je da Lovro na upit o podrijetlu svojih crnih misli priznaje da ,nosim ih uvijek sa sobom, brate, kao rob svoje verige“ (ibid.: 55). Prema tome ipak je „nešto“ već u njemu, „nešto“ što će se u dekadentnih likova nakon njega razviti do neslućenih razmjera. Usto za istaknuti je da je - vratimo li se problemu nemoći obuhvaćanja kompletnoga ljudskog znanja te se složimo s elaboracijom Karen Horney (1950) - za čovjekovo zdravo funkcioniranje 
istodobno potrebna vizija mogućnosti, odnosno perspektive beskonačnosti, i realizacija ograničenja, tj. konkretnoga. U slučaju pretjerane orijentacije na beskonačno, koju Horney drži simptomom neurotičnoga karaktera (1950: 35), čovjek gubi osjećaj za „ovdje“ i „sad“, odnosno sposobnost življenja u trenutku. Tako da onoga trena kad iščezne njegova vještina djelovanja i postojanja u konkretnoj svakidašnjici, Lovro neurotično spoznaje besmisao svijeta kojega je dio. Taj je besmisao međutim u toj pripovijesti još uvijek u potpunosti konkretiziran socijalnim uzrocima, koji pomažu da zaista razumijemo zašto na kraju diže ruku na sebe.

U kojem god se ambijentu našao, Lovro osjeća tjeskobu neslobode. Neslobodan je u svećeničkoj halji, neslobodan je kao odgojitelj, neslobodan je za studija u velegradu, neslobodan je u nesretnim vezama, a možemo pretpostaviti da je neslobodan i kao učitelj. Usudili bismo se poentirati da je Lovrina dekadencija zapravo i nepristajanje na srednji put, odnosno snažna želja da se bude sve ili ništa, cijeli čovjek, a ne pola čovjeka. Kako sam tumači, to i jest njegovo prokletstvo: ići iznad realnih mogućnosti, stalno pokušavati transcendirati društveno-ekonomsku stvarnost te se na taj način identitetski uspostaviti. Mogli bismo se zapitati zašto se nije naprimjer mogao zadovoljiti odgojem grofova sina. A kao najbolji nudi nam se odgovor da je, prema Nietzscheu, baš to stalno traženje vlastita smisla, neprestana potraga za autentičnošću, traženje izlaza iz prosjeka jedna od odlika dekadencije. Svjestan dakle niza ograničenja koja nameće društvo, okolina i povijest, postaje svjestan i ništavnosti takve egzistencije i uopće svijeta kojemu pripada. U svakom trenutku opterećen činjenicom da je dio cjeline koja ga stišće, nemoćan da joj se podredi, odgovori na njezine zahtjeve ili da prestane biti njezin dio, Lovro nosi klice sumnja koje će se u potpunosti razviti u likova drugih autora. Budući da on doista ne može - iz posve realnih razloga, a ne kao dekadenti što će nakon njega nastati, koji su vrlo često dekadentni iz vlastita egoizma - išta promijeniti, ta će nesretna spoznaja uništiti njegov život dokraja. Malo-pomalo uništavan, njegov će kraj biti samouništenje. Naravno, tomu će pripomoći i tragični završeci svih Lovrinih intimnih veza, motiv nezaobilazan u prikazu života dekadenta. Različitih motivacija, u gotovo se svim prozama egzistencija tih tjeskobnih melankolika urušava kad se pojavi mogućnost zajedničkoga života. Život udvoje za njih je nemoguć.

Kao što smo i upozorili naslovom ovoga potpoglavlja, Lovru promatramo kao protodekadenta. Takva je pozicija ponajprije uvjetovana činjenicom da Šenoa, slijedeći umjetničke konvencije svoga vremena, ne ulazi suviše u psihologiju lika. Inspiriran nacionalnom problematikom, nije se mogao upustiti $u$ apstraktne probleme individualne egzistencije te stvoriti lik pravoga dekadenta kakav će za dvadesetak odnosno tridesetak godina kreirati naprimjer Leskovar i Nehajev, ali je suptilno nagovijestio neke karakteristike koje smo 
detektirali kao dekadentne. Uostalom, njegova namjera i nije bila prezentiranje psihologije protagonista jer, ne zaboravimo, Šenoa, pišući za protorealizma, naglasak stavlja na društvena i politička zbivanja. Unatoč tomu stvorio je lik iz kojega će proizaći svi naši dekadenti (Frangeš, 1972a: 357), lik koji je kao provodni motiv aktivan osobito u vrijeme moderne, odredivši karakterologiju muških likova u idućim desetljećima.

Sumnja koju će junaci realističke književnosti uopće, u svim sredinama, nositi u srcu, i činiti od nje jedan od glavnih motiva svoga stvaranja, ta se sumnja načela u Šenoinu prijanu Lovri. Zanimljivo je da je taj motiv (nazovimo ga „,motiv prijana Lovre“) „najčistiji“ upravo u Šenoe, gdje bi se to, možda, najmanje očekivalo. Kulminirat će u Ivici Kičmanoviću, a onda će se, kako vrijeme bude prolazilo, sve više približavati turgenjevskoj ideji „suvišnog čovjeka“, u počecima odnosno u završnom cvatu modernističke proze, od Janka Borislavića preko leskovarovskih slabića sve tamo do Nehajevljeva Andrijaševića u Bijegu. (Frangeš, 1970: 153)

Kasniji je književni razvoj demonstrirao da je ta tematika i te kako karakteristična za razvoj hrvatskoga građanskog društva, sasvim tipična za naše skučene prilike, ni po čemu zapravo iznimna, kako je Šenoa vjerovao. Dakle Lovro će kao motiv opstati tijekom cijeloga fin de sièclea, pa i daleko nakon njega, a knjiški će slabići malo-pomalo gubiti i onaj Lovrin „muževni bol“ (Frangeš, 1972a: 376), zbog čega ćemo ih moći proglasiti bezvoljnim melankolicima i neuroticima koji, oslabljene energije i inhibirane volje, ne uspijevaju prevladati duševne potrese i okrutnost okolnosti u kojima egzistiraju. Nakon Lovre svi dekadenti, i oni ovdje tumačeni i oni kojima se u disertaciji ne bavimo, žive sa sviješću o otuđenju i suvišnosti.

\section{3. Šopenhauerizacija tjeskobne muškosti: Borislavić i Ivanović}

U tematski i stilski raznovrsnu opusu Gjalskoga, jednoga od naših najvitalnijih književnika na kraju XIX. i u prvoj polovici XX. stoljeća, prepoznali smo dva „prava“ lika dekadenta, koji svoju dekadenciju vode do mjesta bez povratka, u prozama uobičajeno nazivanima pravcem ,intelektualizacije hrvatskog romana“ (Nemec, 1999: 204). ${ }^{71}$ Janka

\footnotetext{
${ }^{71}$ Prilično popularan u čitateljskim i književnim krugovima, Gjalski je nerijetko proglašavan Šenoom svoga vremena. Naime s jedne se strane povezivao s didakticizmom i patriotizmom, zbog čega su ga voljeli „stari“, a s druge s esteticizmom i europeizacijom, zbog čega su ga voljeli „,mladi“. Kao što pojašnjava Nemec, „svaka je generacija otkrila u njegovu djelu slojeve 'za sebe', i to u rasponu od društvene kritike, psihološke analize i filozofske meditacije do dekadentne bolećivosti, metafizike, misticizma, okultizma i spiritizma. (...) Takav kohezijski, sintetizirajući duh bio je prije njega još samo Šenoa“ (1999: 198).
} 
Borislavića Gjalski piše u vrijeme kad se već afirmirao u književnom životu te ga kao prvi naš roman ideja (ibid.: 206) i putokaz k modernoj psihologizaciji i defabularizaciji pripovjednoga teksta objavljuje 1887. Ono što je započeo Šenoa nastavio je Gjalski univerzalizacijom teme prijana Lovre, obrađujući slučaj koji pretendira biti ne samo naš nego i univerzalan, te je pritom uveo neke karakteristične crte po kojima Borislavića prepoznajemo kao istinskoga dekadenta. Često isticane faustovske implikacije romana, koje se raspoznaju ponajprije u pitanju o životu i smrti te u nastojanjima glavnoga lika da dokuči istinu života, potvrđene su i autorovim priznanjem da se u njemu prihvatio tematizacije „Faustovskog problema, zahađajući kod toga za tragovima naše hrvatske duše“ (Gjalski, 1997: 261). Zaokupljenost smislom odnosno besmislom egzistencije bit će tako idejna potka toga djela u kojem se sve vrti oko senzibilnoga dekadenta opterećenoga mistično-filozofskim problemima, koji je, za razliku od Šenoina Lovre i svoga „brata“ Radmilovića, sin bogatih roditelja, plemićkoga podrijetla, financijski stabilan. Izostaje dakle u romanu svaka društvena uvjetovanost protagonistove dekadencije te on propada sam od sebe, približavajući se tako ponajviše ruskomu suvišnomu čovjeku, plemiću koji živi od tuđega rada te baštini respektabilan imetak svojih predaka.

Nadomještajući „odsutnost fabulirane napetosti i dramatike“ (Nemec, 1993: 188), Gjalski romaneskni prostor ispunjava duševnim potresima glavnoga junaka te brojnim esejističkim dionicama, razmatranjima dominantnih filozofskih i kulturnih poticaja vremena. Životni put Janka Borislavića paradigmatski je put findesiècleovskoga intelektualca: pod utjecajem prirodoznanstvenih i filozofskih učenja on postaje nevjernik, skeptik i pesimist, a potom, razočaravši se u tim tradicijama, iznova traži Boga. Život ispunjen sumnjom i neprestanim propitivanjem njegove vrijednosti i svrhe te dokučivanjem univerzalnih tajni, koje se međutim nikad ne može realizirati dokraja. Upravo ta nepresušna želja za spoznajom stvara u romanu jedinstvenu atmosferu kojoj je temelj, u nedostatku razgranatoga fabuliranja, stalna napetost unutar glavnoga lika. Kako je primijetila struka, Janko Borislavić najočiglednija je aplikacija Schopenhauerove filozofije u nekom književnom djelu, s voljom kao glavnom metafizičkom kategorijom, zbog čega se i ocjenjuje kao „najizrazitije filozofski fundirano djelo Đalskoga“ (Nevistić, 1927: 594). Gjalskoga se zbog toga najžešće i kritiziralo; prigovaralo mu se naime da je pojedine odlomke gotovo posve prepisao iz kapitalne Schopenhauerove Svijet kao volja i predodžba, što ga je učinilo prilično slabim djelom. No ne sprečava nas to da u protagonistu uočimo pravoga hrvatskog dekadenta, pametnoga i znatiželjnoga mladića obrazovanoga na izvorima europske kulture, koji u potrazi za odgovorima na „najteža i najzamršenija pitanja o najuzvišenijim no ljudskomu razboru najmanje dokučivim stvarima“ (Đalski, 1964: 8) stradava, na različite načine, od vlastite ruke. 
Proces Borislavićeve neminovne propasti i predaje pred zagonetkama života započinje na samom početku romana. Njegov duh bogobojaznoga klerika, prvorazrednoga poznavatelja „i poganskih filozofa i crkvenih otaca“ (ibid.: 9) ne zadovoljava se doktrinom kršćanske filozofije te za odgovorima traga u prirodnim znanostima i nekršćanskim filozofskim sustavima. Naime shvativši da mu vjera i sva teološka znanja ne mogu ponuditi odgovore na pitanja koja ga muče, svlači svećeničku halju i upisuje studij u Beču ne bi li otkrio početak života, rekonstruirao prapočelo tvari. Izlazeći iz okvira crkvene tradicije koja mu je namijenjena kao jedan od putokaza budućega života, sumnjajući u ono u što je donedavno bespredmetno vjerovao, prokazuje religiju te se okreće prirodi kao vrhovnomu autoritetu:

Ja sam progledao! - gotovo očajno i bijesno poviče Borislavić. - Jest, ja ne vjerujem ni u šta. Ne vjerujem u sve ove komedije; sve to nije nego da ljudski um ostane slijep. Ne vjerujem - ne vjerujem ni u šta, sve to vaše puka je opsjena, puka mašta. Moje oči progledaše, i ja je vidim sjajnu, veliku, uvijeke tvoračku, tihu, besvjesnu prirodu koja nema nego ljudski hladni razum da se kroza nj sama spoznaje i kroza nj da svojim stvorovima pruža sreću i blagostanje dok ih na svojoj grudi nosi. Ne vjerujem u vašega jedinoga Boga, stvoritelja neba i zemlje (...). Oh, jedno je samo, a to je tvar i sila! (ibid.: 12)

U Beču pak, otkidajući od sebe cijelu svoju „dosadašnjost“ (ibid.: 13), nemilice „guta“ filozofsku i prirodoslovnu literaturu, čita Schopenhauera i von Hartmanna, pionirske filozofe pesimizma, Milla, filozofa liberalnoga empirizma, Darwina i Haeckela, teoretičare evolucije, sve odreda antireligijske autore koji tumače da život valja graditi nasuprot Crkvi, te mu se čini da napokon prodire u ,svjetsku tajnu“72 i pronalazi odgovor o postanku svijeta. Međutim ubrzo će se kristalizirati da ni ireligiozne teorije, znanstvena egzaktnost racionalizma i empirizma, ne mogu smiriti njegovu težnju za spoznajom: „Svu mu dušu svladala neopisiva, gotovo boljetna žeđa za znanjem i gonila ga neprestance i bez odmora da traži uzvišene istine, vijek hrleći dalje - dalje, a da se ipak nije mogao do sita naužiti.“ (ibid.) Ona se ne zadovoljava ni formalnim obrazovanjem, pa tako Borislavić, u potrazi za znanjima koja bi mu otkrila nepoznate predjele ljudskoga bivstovanja, „trči od fakulteta do fakulteta, da dozna posljednju tajnu u vječnoj pravilnosti prirodnih zakona“ (Nehajev, 1927: 247). Nakon doktorata iz filozofije sluša medicinu i pravo, ali ništa mu ne nudi toliko željeni mir. Taj nagon za sveobuhvatnošću znanja, izjednačujući ga s nagonom za slavom, Horney drži upravo simptomom neuroze: „Neurotik je Faust koji nikad nije zadovoljan time što zna štošta, nego

\footnotetext{
${ }^{72}$ Naslov je to Haeckelove knjige iz 1899.
} 
mora znati sve.“ (1950: 35) Uranjanje u neizmjerno određeno je dakle potrebama koje se kriju iza nagona za slavom, a pritom je potreba za apsolutnim i konačnim toliko snažna da nadjačava sve sile koje pojedinca vežu za „normalno“ i aktualno.

Borislavićeva grozničava potraga za prapočelom potencira se suočavanjem sa smrću brata, odnosno s njegovim mrtvim tijelom. Naime kad mu umre brat, Janko postaje nasljednikom imanja u rodnom kraju te se odriješenih ruku može posvetiti problemima koji ga zaokupljaju otpočetka, rješavanju „svjetske tajne“. „Uostalom, ta hekelovska Weltträtsel, ta svjetska tajna i jest osnovna ideja te generacije“ (1972b: 23), potvrđuje Frangeš našu početnu pretpostavku. Međutim zaokupljenost apstraktnim problemima učinit će od njega čovjeka koji ne živi realnost, koji u misaonosti pronalazi nadomjestak za autentično doživljavanje.

Ako se mrtvo tijelo može nazvati vrhuncem zazornosti jer „ono što je nepovratno propalo, kao smrdljivo mjesto i smrt, još silovitije potresa identitet onoga tko se s time suočava poput krhka i varljiva slučaja“ (Kristeva, 1989: 9), možemo naglasiti da Borislavić zaista nema problema sa zazornim. U suočavanju sa smrću po prvi put na praktičnom primjeru prepoznajemo njegovu pretjeranu ogrezlost u apstraktna pitanja čovjekova postojanja koja onemogućuje da se sa smrću nosi na ljudski, „običan“ način. Kontakt s bratovim truplom ne izaziva u njemu melankolično čuvstvo gubitka voljenoga objekta - što će biti problem nekih Leskovarovih likova - nego samo iznova uzburkava nepresušno vrelo najrazličitijih pitanja, u kojem se kao temeljne izdvajaju dihotomije života i smrti, tijela i duše, materije i duha. Slijedeći Schopenhauera, prema kojem je duša pokretač tijela, jednako kao što je volja pokretač djelovanja u svijetu, uviđa neodvojivost duše i tijela te se pita:

Ludo, zar baš ova smrt najbolje ne dokazuje kako duša nije neodvisna od tijela i nije nego jedna od njegovih manifestacija, upravo isto gibanje organskih atoma kao i svako drugo njihovo gibanje; baš ta smrt dokazuje istinu monizma a obara dualizam. (...) Napokon - velika dotjeranost duše u savršenosti, njena tajnovita svojstva kojih ne možeš protumačiti zakonima realnoga svijeta, zar sve to ne dopušta predmnjevu da je duša po sebi samostalan pojav nekoga drugoga svijeta i da joj je tijelo tek potrebno materijalizaciono sredstvo za bitak u ovom materijalnom svijetu? (Đalski, 1964: 20-21)

Sve svjesniji da mu ništa ne može ponuditi odgovor na pitanja o smislu života $\mathrm{i}$ „svjetskoj tajni“, što prepoznajemo kao univerzalan interes modernoga čovjeka, po povratku u zavičaj Borislavić upada u bezizlaznost pesimizma te polako prerasta u sve ranjivijega dekadenta bremenitoga spoznajom o uzaludnosti ljudskih napora u sumraku suvremenoga 
svijeta. Ne videći više poantu žrtvovanja svoje „mladosti““ i „veselja“, zamjećuje apsurdnost dotadašnjega djelovanja te se zatvara u nemir vlastite egzistencije, što će postati jednim od ključnih biljega njegove dekadencije. Njegova težnja za znanjem prije je bila kudikamo aktivnija, utjelovljena $\mathrm{u}$ interesu za izdizanjem iz prosječnosti, za dosezanjem odgovora na pitanja koja ne muče „običnoga“ čovjeka. A od povratka rodnoj kući detektiramo je kao metafizički pesimizam, tragičnost zbog nemogućnosti zadovoljenja te težnje: „(...) bolno prizna da je na tom svijetu sve samo prolazno i ne bez druge svrhe nego da propadne“ (ibid.: 22). Postaje mu jasnije da ni znanost, kojoj se okrenuo razočaran religijom, u nadi da će proniknuti u životne tajne nedokučive empiriji, ne može ponuditi odgovore na probleme koji ga zaokupljaju. Zato se njegova bijeda postupno produbljuje: kad se odgovori na pitanja o smislu egzistencije čine sve daljima, a budućnost sve neizvjesnija, on pada u beznadna očajanja u kojima se mladenačka želja za spoznajom pokazuje kao pogibeljna strast. Upravo kao da je ispao iz renesansnoga melankoličnog imaginarija dok utjelovljuje sliku osamljena intelektualca koji anksiozno postaje svjestan neiscrpnosti znanja i svoje nemoći da ga cjelovito obuhvati. Rascijepljen između znanstvenih i religijskih istina, on živi pravi šopenhauerovski pesimizam koji se i sastoji u tome da ni religija ni znanost, dakle ni krajnje duhovan ni krajnje empirijski svijet, ne mogu dati odgovore na pitanja o ljudskom biću i njegovoj patnji.

Ta pak pitanja otvaraju izravan put do tematiziranja problema volje koji će, kao temeljna ideja Schopenhauerova filozofskoga sustava, dominirati romanom sve do njegova kraja. S obzirom na to da nasljeđuje glavne teze Schopenhauerove filozofije, sasvim je neminovno da će protagonist u konstantnoj potrazi za uzrokom svih stvari završiti baš onako kako jedino može završiti netko tko živi u skladu s glavnom postavkom njegove metafizike pesimizma: tragično. Egzistencijalno ništavilo koje se pred Borislavićem otvara, kako odmiče njegova nada u znanost i njezinu konačnu pobjedu, bezgranično je:

On se je držao najnesretnijim čovjekom ovoga svijeta, a opet je požudno zidao kule svoje sreće koja bi ga bila snašla da mu je um pogodio i našao odgonetku svemu. Sva duša mu se tresla u poziranju one sreće da opet padne u to jače razočaranje i da se sunovrati u crno bezdno sumnja, izgubljenih nada, pa da bolno zavapije: „Zašto - zašto nije bijednom smrtniku takva sreća moguća!““ (ibid.: 25; isticanje naše)

Schopenhauerova filozofija, središnja referencija njegova razmatranja svijeta, demonstrirala je da se patnja i besmisao ne mogu prevladati ni znanstvenim ni religijskim putem jer su kategorije takvoga nadvladavanja nedostatne za umrtvljenje onoga što je ovomu svijetu 
skriveno - volje. Volju dakle, kao „stvar po sebi“ koja upravlja čovjekom u njegovu ovosvjetovnom životu, prepoznajemo po manifestacijama tjelesnih radnji u vremenu i prostoru, što će biti i temelj daljnje Borislavićeve bijede. Naime nakon što se zaljubio u Doricu, u njemu se otvara nov, dotad nepoznat egzistencijalni raskol. Kako se na početku pripovijeda, doima se da se pod utjecajem ljubavi pretvorio u drugoga čovjeka:

Filozofije netragom nestalo ili barem ga više nisu morile pređašnje sumnje i ona vječna pitanja. Sada nije na drugo mislio niti što želio nego se sjećao prizora u šumi i čeznuo za njom. (...) Noću pak odbjegavao ga san, a žudnja za divnim mladim stvorom sasvim ga razgarala; sav se je tresao od strasti, a zubi mu kao u groznici cvokotali. Kad je napokon teškom mukom usnuo, omamili bi ga raskošni prelesni sni za kojima je tek ujutru kod uranka žalio i trpio bolno što bijahu tek sni. (...) Ta silna pohota u koju je posve upao, učini ga potpuno gluhim za svaki glas savjesti koja je, uostalom, u razrovanom duševnom raspoloženju njegovu mogla biti tek posve slabašna. (ibid.: 32-33)

Međutim već se sad susrećemo s nekima od ključnih značajki u gradnji dekadentnoga junaka: sklonošću stalnomu odgađanju, neodlučnošću i umornom voljom.

Bilo je karakteristično po nj što se potkraj sve one silne volje i požude za djevojkom ipak nije mogao odlučiti da koga pita za nju i da tako sazna barem za ime njezino. Ne dao mu stid, ponos, bojazan, da se ma tko bavi njime, i napokon oteščavalo takav korak ono stanje u kojem se nalazio radi toga što nije općio ni s kim u čitavom kraju. (ibid.: 33; isticanje naše)

Premda se dakle sugerira da bi on kao filozofski skeptik mogao postati novi čovjek te da bi se mogao promijeniti baš zbog ljubavi, koja bi mu mogla ponuditi slamku spasa iz apsurda života koji neprestano osvještava - pa priznaje Dorici „Vi me podižete k novomu životu, vi me spašavate od crnih mojih misli, ja uz vas učim opet cijeniti ovaj život, ovaj svijet“" (ibid.: 75) svaka će se promjena pokazati varljivom, a pokušaj nadvladavanja dekadencije uzaludan. S obzirom na to da mu vjeru nisu mogle nadomjestiti ni filozofija ni moderna znanost, privremeni će spas potražiti u ljubavi. No i promjena njegova fizičkoga izgleda (upravo arhetipskoga opisa jednoga pravog dekadenta), od starmala, slabašna čovjeka upalih obraza do „čitavoga momka““, bit će samo privid: „Iz sagnuta, gotovo u preranu starost ugrezla čovjeka mrklih blijedih obraza, upalih očiju i uleknutih prsiju, eto sada snažna, plećata muža odvažnih crta u licu, doduše još uvijek blijedu, ali čisto rasplamćenu od života i krepčine.“ (ibid.: 65; isticanje naše) 
Borislavićeva skepsa prema tome zadobiva novu dimenziju kad u njegov život uđe žena, pa njegovu dekadenciju možemo promatrati i kao destrukciju svakoga pokušaja zajedničkoga života. Hartmanovski dvojeći o mogućnosti čovjekova ispunjenja u ljubavi, sve ga intenzivnije opsjeda činjenica da je čovjek tek slijepo oruđe volje, a ljubav se u tom svjetlu razotkriva kao još jedna iluzija. Iluzija koju će srušiti nemogućnost uspostavljanja ravnoteže između uzvišenosti ljudskih osjećaja i primitivnosti sirovih strasti. Čovjek se time, zaključit će, ni po čemu ne razlikuje od životinje:

Svagdje, svagdje prevlada nas slijepa bezrazložna volja besvjesne prirode, a onda da vjeruješ u sreću ljudsku! (...) - Ja hoću tek ljubiti, čisto ljubiti, a ne da padam u iste mreže kao i glupa zvijer! (ibid.: 78)

Prisjetimo li se ovom prilikom von Hartmannova učenja prema kojem su osnovni ljudski nagoni - za hranom i seksualnim zadovoljenjem - izvori patnje, a ne sreće, jer čovjeka, jednom kad ih zadovolji, dovode tek do neutralne pozicije na ljestvici zadovoljstva, posve je razumljivo zašto Borislavić ljubav drži još jednom tlapnjom. On u potpunosti preuzima Schopenhauerov koncept metafizike seksualne ljubavi, što je navelo kritiku da proglasi kako on „i nije živo lice nego bezlična spekulativna filozofija“ (Nevistić, 1927: 594): u takvoj izrazito bolnoj aktivnosti čovjek ustraje ne zbog osobne sreće, nego zbog prokreacije, bit će i Borislavićevo stajalište. Postaje tako u romanu eros simbolom zla, a nakraju i okidačem smrti te glavni junak umire kao žrtva prirodnih nagona protiv kojih se očajnički borio, a u čemu mu nisu mogle pomoći sve znanosti ovoga svijeta. Njegova dilema, koja će se javiti u nekom obliku u svim likovima kojima se u ovom radu bavimo, izvorno je šopenhauerovska misao o tome „koliko je čovjek pojedinac igra u rukama instinkta, u rukama prirode; koliko se priroda u ime svojih ciljeva (...) služi pojedincem kao igračkom i koliko pojedinac u svim svojim najplemenitijim htijenjima i nastojanjima nije ništa drugo nego izvršilac te nesvjesne igre prirode“ (Frangeš, 1972b: 24).

Borislavićeva spoznaja da je sve zakone ljudskoga djelovanje doista moguće podvesti pod zakon djelovanja prirode nestalna je, nejednakoga intenziteta u različitim životnim fazama, a emocionalni prijelazi iz jednoga stanja u drugo - čas u spokoj potencijalne sreće oslobođene od požude, čas u beznadnu anksioznost saznanja o slijepoj volji, čas u bijesnu malaksalost vrlo neobuzdani. Ta emocionalna nestalnost i duhovna nestabilnost postaju pravilom njegove dekadencije. Nagla oscilacija između zadovoljstva što će vidjeti Doricu i frustrirajućega shvaćanja primitivnosti čovjekovih potreba, kolebanje između potrebe za ljubavi i odmicanja od nje. 
Samo što nije sastavio filozofsku formulu kojom će svijet zadiviti i čovječanstvu dokazati kako je moguće $u$ isti čas podati se slatkim čuvstvima duše, a oteti se željama koje rađa slijepa besvjesna priroda jedino u svoje svrhe u čovjeku! (...),,Svladat ću ja i posljednji trzaj strasti, pa ću onda stupiti pred nju - i naša ljubav bit će samo ljubav, bit će vječno proljeće, neće se iz nje izleći jad, dosada, neprilike, nesreće, u kojima najposlije prestaje ljubav!“‘ (Đalski, 1964: 87)

No, vrlo kratkoga vijeka, takvo i slična pobjedonosna raspoloženja redovito završavaju u bezdanu pesimizma. Njegova prijemčivost za šopenhauerovsko-hartmanovsku ideju života kao neprekidne boli i patnje uvjetovana je i neurotičnim zamorom koji, kako piše von Hartmann, „povećava bol u boli, odnosno smanjuje užitak u užitku“ (1893b: 73). Ili, Schopenhauerovim riječima, „svaka životna istorija jeste istorija patnje“(1984: 78), zbog čega razborit čovjek na kraju svoga života neće poželjeti ponovo ga proživjeti, nego će radije odabrati ništavilo.

Oh, ti užasna prirodo, sa tvojim ludim instinktima. (...) Taj jadni ljudski duh! Tek tlapnja, opsjena, ludost bijaše misliti da možeš ljubiti a da ne budeš u isti čas ravan i najnižoj životinji. A ja mislim na blaženstvo! Nije, nije taj život, taj svijet za čovjeka, za njegov duh ovdje, nego je čovjek za nj tudijer. Cilj leži izvan nas. Ne ide život za našim savršenstvom nego za divljim pregnućem nekakve volje koja ne zna niti može znati svoga cilja. I jest bez izlaza, bez oslobođenja. Eto, sva ta moja bijeda jest u tom što se usudih pomisliti da ljudski duh jest nešto.

(Đalski, 1964: 110-111)

Borislavićevo bezizlazno uranjanje u ništavilo svakim je danom sve dublje, a čežnja za djevojkom s jedne strane te želja da se riješi duševnih muka, koje mu uzrokuje teret saznanja da je čovjek obično oruđe u rukama prirode, s druge sve jača. S obzirom na to da se „,neprekidnim naporima da se otkloni patnja ne postiže ništa više od promene u njenom obliku“ (Šopenhauer, 1984: 66), u Borislavića se potiskivanje boli koje ga je opterećivalo kao nemogućnost razumijevanja svijeta kroz religiju ili prirodne znanosti pojavljuje u jednom od svojih drugih oblika, u obliku spolnoga nagona. Njegov je emocionalni pesimizam posljedica težnje da estetskim uživanjem doživi i realizira čistu ljubav, što je, pokazuje se, nemoguće. Taj pesimizam proizlazi iz unutarnje uskrate nagona jer Borislavić u potpunosti preuzima Schopenhauerovu devizu kako zadovoljenje užitaka uvijek budi želju za novima, rađajući na taj način i novim nezadovoljstvom. Apstraktna osjećajnost, kao asketsko savladavanje tjelesnih nagona i prizemnih želja radi više duhovne ispunjenosti koju Janko pokušava njegovati, žestoko se sukobljava s realnošću te rezultira neobuzdanim psihičkim proživljavanjima. Razapetost 
između neizmjerne žudnje i pohote te čežnje za „ozbiljnim stvarima“ (Đalski, 1964: 89), popraćena razdraženošću živaca dok besciljno luta „bez prave svijesti, bez zorna motrenja i uvijek samo u bolovima silna trzanja duše i tijela“ (ibid.), u njemu rađa frustrirajuće uvjerenje o nepomirljivosti materije i duha, koja će ga nakraju, zbog slabosti karaktera, i stajati života. Tako se gotovo cijeli roman odvija u naglim izmjenama Borislavićevih psihičkih previranja, promišljanja o nagonima i osjećajima, erosu i thanatosu, koja redovito završavaju otkrivanjem groteske ljudskoga postojanja, koju međutim ne iskušava na vlastitoj koži, nego je preuzima iz lektire. Prema tome kad se pozornije pristupi dinamici radnje, jasno je da sve u razvoju događaja vodi nesretnomu ishodu, koji potvrđuje našu tezu s početka ove cjeline: Borislavić je findesiècleovski dekadent kojemu, kako smo postavili u prethodnim poglavljima, um ne da živjeti. Svakomu se propitivanju vlastitoga ,ja“, u smislu suočavanja s problemima unutar sebe, snažno suprotstavlja analitički demon koji probleme redovito traži izvan sebe. Primjerice i kad mu sine da je očaju koji proživljava kriv on sam te se pita nije li povratak Dorici isključivo stvar njegove volje, opsjeda ga misao o braku kao pukoj konvenciji građanskoga društva, na isti onaj način na koji ga je i Kierkegaard odredio kao najobičniju konvenciju i formalnu dovršenost koja poništava ljubav kao osjećaj.

„Zar nisam u ženidbi opet ništa drugo nego prosto sredstvo besvjesne prirode, samo još pogoršano time da u njoj ne vršim samo bezrazložnu volju naravi nego i lude oblike barbarskoga ljudskoga društva i slijedim ciljeve države i njenih građana? Zar se upravo ženidbom ne bacam u ovu kaljužu u kojoj se mora ugušiti tako fino i uzvišeno čuvstvo kao što je ljubav? Ne, ne, ja neću, ja ne mogu!“ (...) I on (...) nije mogao nego da se straši pred tako filistarskim raspletom kao što je ženidba (...). ,Izgubljeno - izgubljeno!“”-kliktao je silno uzdrman od boli i proklinjao čas kad je zamislio da u ljubavi traži blaženstva i naslade. (ibid.: 90-91)

Iako je dakle nedvojbeno da ljubav u nekoj mjeri može osigurati zadovoljstvo, patnje koje ona sa sobom nosi neizmjerne su. Jer, kao što tvrdi von Hartmann, kojega Janko također nepromišljeno slijedi, „bol u mogućem neuspjehu uvijek će biti veća od odgovarajućega zadovoljstva u ispunjenju“ (1893b: 36). Odnosno, najjednostavnije rečeno, ljubav pojedincu, naročito ako se okuje brakom kao pukom formom, priskrbljuje više boli nego zadovoljstva. Stoga Borislavićevo ogorčenje materijalnim svijetom malo-pomalo prerasta i u ozlojađenost ljudima jer uočava kako se sve ideje u ljudskim rukama izopačuju. Koncept braka kao nametnute obveze, kao vječnoga vezivanja u kojem čovjek slijepo poštuje društvene norme koje guše svaku pravu emociju, u njemu izaziva „neizrecivo silno nezadovoljstvo“ što se uvlači 
„u sve tančine duše“ (Đalski, 1964: 90). Paklene muke bezdana koji zjapi pod njim sa svih strana, a koji se otvorio ponajprije mučnom spoznajom da čovjek trpi neumoljive zakone prirode, pojačavaju se građanskodruštvenom idejom braka i ženidbe. Zato možemo reći da se i u ovom slučaju glavni junak bolno uvjerava da u svijetu ne vlada apsolutna sloboda, tj. da je i on sam dio društva koje ga pod svaku cijenu želi podčiniti, uklopiti u svoje standarde jer, kako će izjaviti, ono ljude ,trapi i goni svojim uredbama, svojim običajima, još nesnosnijim od zakona prirode“ (ibid.: 113). Iskazuje se dakle kao i kod ostalih likova, ljubav tek kao potencija, a u toj zaokupljenosti primitivnošću strasti bit će najgorče saznanje da je funkcija ljubavi isključivo produženje vrste. Misao da i on jednoga dana bude začetnik „bijednomu jednomu ljudskomu stvoru“ (ibid.: 112) nepodnošljiva mu je i tjeskobna te dodatno potresa njegove ionako rastrojene živce:

(...) i pred njegovim umom zaredaju sve iluzije, sve opsjene života, koje nisu nego slaba koprena strašnoj bijedi i ništetnosti, njemu sasvim jasnoj, a najposlije i za najobičnije čeljade tako silnoj i gorkoj da skoro shvati varavost svih tih iluzija. (ibid.)

Nije međutim Jankov problem samo neumoljiva priroda koja čovjeka podčinjava svojim zakonima nego i slabost karaktera, nesposobnost hvatanja ukoštac sa stvarnim životnim teškoćama, kolebljivost u odluci. Sve su to odlike tipičnoga dekadenta. Zato možemo reći da je Borislavić, unatoč tomu što je kao lik ispao prilično sterilan, papirnat i površan (Šicel, 1984: 165), prava slika preosjetljivoga, neurasteničnoga intelektualca na prijelazu stoljeća, ne samo u hrvatskoj nego i u europskoj sredini. Nije slučajno da René-Pierre Colin najbolju publiku za Schopenhauera pronalazi baš u krugu neurotika:

Dekadentna „Velika Neuroza“ se širi. Razdoblje poslije rata obilježila je opčinjenost morbidnim: posvuda se otkrivaju anemija i iscrpljenost, u novinama bujaju reklamni oglasi koji hvale lijekove koji vraćaju snagu ili smiruju. (...) Čini se da je bolest trajno stanje: glavobolje, blage mučnine, luesi postaju elementi koje se ne može odvojiti od života, odnosno od mentalnoga krajobraza umjetnika iz osamdesetih (...) uvjerenih da je fizička patnja danak koji svaki stvaralac mora platiti umjetnosti. Koja je to klijentela za filozofa pesimista! (cit. prema Šoštarić, 2016: 78)

Naime Schopenhauerova se filozofija, uz Nietzscheovu, držala posebno „zaraznom“. Procjenjivalo se da su njezin pesimističan predznak i egocentrično inzistiranje na važnosti pojedinca iznimno opasni te da mogu uzrokovati devijantna ponašanja (White, 2014: 151-152). 
Ipak, uz te zapadnoeuropske poticaje Borislavić baštini i određene crte „slavenske duše“ od ruskoga suvišnog čovjeka jer su život u knjigama i plemićka nenaviklost na (praktičan) rad paralizirali svako aktivno djelovanje i egzistiranje u sadašnjem trenutku, što je pak u njemu probudilo osjećaj neprilagođenosti i suvišnosti.

Stoga, pogledamo li pozornije, otkrit ćemo da izvori dekadencije, koja će ga nakraju prisiliti da digne ruku na sebe, leže i u njegovu karakteru. Razlozi preosjetljivosti mogli bi se potražiti u genetskom naslijeđu, u odgoju, u suviše blagom, nekarakterističnom djetinjstvu obilježenom neobičnom dječačkom mirnoćom. Mekušasto gospodsko dijete, od majke je naslijedio „nježnu ćud, sanjarenju sklonu dušu“ (Đalski, 1964: 17) te je zapravo cijelo djetinjstvo proveo samujući, tek gledajući djecu kako doista žive život: „Nije mu se sviđalo njihovo bučno veselje, njihova smjelost, njihove vratolomije.“ (ibid.: 18) No usto Janko kao atavizam nasljeđuje pretjeranu ranjivost i osjetljivost od svoga djeda Kristofora - ne od oca, bitno je primijetiti, jer, kako su neke teorije degeneracije tumačile, degenerativna svojstva obično preskaču generaciju. Tako da, kao što se naprimjer Leskovarovi i Novakovi protagonisti određuju odmalena opterećenima nekim neobjašnjivim zamorom, i Borislavić oduvijek u sebi nosi klice vlastite propasti. On zapravo ne može djelovati zbog osobne slabosti. Djed je Janku ostavio u naslijeđe opterećen, nikad zadovoljen duh i neutaživu težnju za spoznajom i konačnom istinom. Uostalom, u njegovu je laboratoriju i stao teoretizirati o prapočelu, stvarajući surogat stvarnosti, što će mu ostati doživotnom manom.

Razigrana mašta u bolnoj mu duši stvarala nov poseban svijet u kojem mu se i živci i krv uzrujavaše, pa bi kao u vrućici plamenim obrazima i rastvorenim sjajnim očima zurio po čitave sate u istu praznu točku. (ibid.: 27)

Možemo prema tome sumirati da je Jankovo iscrpljivanje filozofsko-estetskim analizama posljedica mlake volje, onemoćalosti duha, zamora koji je u isti mah naslijeđen $\mathrm{i}$ stečen. On uvjete svoje bijede „sam u sebi nosi“ (ibid.: 140), reći će liječnik promatrajući portrete dvaju skeptika koji se cijeloga života nisu mogli zadovoljiti onime što im je dano, Janka i djeda mu Kristofora. „Pak da nema takvih ljudi, zar bi mi danas bili ono što jesmo? Zar ne bi s našim bratučedima orangutanima bili prilično jednaki?““(ibid.) Jankova je bolećivost pritom najrazvidnija, kao što smo nastojali pokazati, u sudaru s realnošću života, osobito u odnosu prema drugome. A kako je cijela njegova povijest pasivno promatranje idealiziranoga života, kontemplativno doživljavanje i svakidašnjica uokvirena knjigama, pri čemu je izostala svaka iskustvenost kao rezultat „pravoga“ življenja, on se ne snalazi u realnim uvjetima te i na odnos 
prema ženi preslikava ono što ga je naučila literatura. Stoga možemo reći da cjelokupan razvoj događaja, protagonistovi unutarnji duševni potresi, koji napreduju od blažih duševnih nemira preko neurotičnih trzavica do patološke izbezumljenosti, služe kao demonstracija ispravnosti jednoga filozofskog sustava prema kojem se volja ne može nadvladati nijednom kategorijom. Užas Borislavićeva konačnoga rasapa, koji je krajnja točka njegovih dramatičnih, luđačkih proživljavanja, možda najbolje ilustrira sljedeći odlomak:

Misli i osjećaji Borislavićevi rasli u toj gluši kao divovi i svakim mu je časom bivalo burnije u unutrašnjosti. Najvećma se dizale pred njim slike iz prošle noći. Od pretrpljenih dosad duševnih muka bila mu volja preslaba a da bi to mogao od sebe otjerati. Sve, sve, svaka i najmanja sitnica redom stade broditi mimo njegove oči, pogotovo svaki kretaj i njegov i njezin, eto gle, on je opet vidi, on je osjeća, oh, ali sad se čisto kida i lomi od srama, od ogavnosti, od ljutine, i uzalud se muči da se zaboravi. - Jao, kako sam ono - i zastiđenost nije mu dala da izrekne, tek u mislima dovrši. Utroba sva mu se svijala od fizičke boli. U grlu kao da ga nešto sapinje. I svejednako reži i zja za nj opet spomen na ovu ili onu malenkost. Neopisivim je bolom pratio taj grozni za nj kaleidoskop, užasne muke parale mu srce i grudi, strašne misli točile mu mozak, i on naposljetku gotovo bez pameti osjeti nešto kao da je zamrzio na Doricu. (...) Oh, taj čas nije moglo u njemu biti ni traga pravednosti, ni traga blagosti; previše je patio što mu je opet porušen čitav svijet, što opet gleda neumolnu prirodu i svu bijedu kojom dariva ljudsku dušu. (ibid.: 109-110; isticanje naše)

Destruiravši sve prilike za zajednički život i ostvarenje intimne sreće, Borislavić priznaje svoj poraz i pobjedu prirode te, i dalje ne odustajući od potrage za smislom života, nastavlja lutanja. Ne smiruju se u njima njegove sumnje te ga „veliki“ svijet u koji je opet pošao ostavlja jednako nezadovoljnim kao i onaj „mali“. Nenaučen da doista živi, počinje ga mučiti „strašna zasićenost, gotovo dosada““ (ibid.: 135) te pomišlja na potpuno asketsko odricanje kako bi život učinio ,podnošljivim i bližim koncu“ (ibid.). Jer, čini se, upravo je askeza od svega ovozemaljskoga jedina mogućnost da se pojedinac ukloni bezvrijednosti i praznini života. Zapravo ga je ta namjera odricanja, koju će u konačnici izjednačiti sa samoubojstvom, i dovela ponovo u rodni kraj - „Ovo šest godina porušilo ga kao dvadeset. 'Izgleda kao starac' - rekne kasnar“ (ibid.: 129) - u kojem se napokon uvjerava o ništavilu svih nastojanja ljudskoga duha. U potpunoj negaciji, bez ikakva sadržaja u životu, svoju potragu za emancipiranim sebstvom koje ne bi podlijegalo nikakvim zakonima Janko tragično okončava. To njegovo egoistično samoubojstvo, prema Durkheimovoj klasifikaciji (1951), ishod je ekscesivnoga, dramatičnoga 
doživljaja vlastita neuspjeha kojim je iznevjerio ponajprije svoja očekivanja, a tek onda i društvena.

Pa se, prema svemu navedenom, može sumirati kako je bol doista ,izvor i zadnja stanica života“ (Nevistić, 1927: 593). Borislavićev je otpor zakonima prirode donekle trajao sve dok nije digao ruku na sebe, vjerujući da je tako napokon ugušio volju. Međutim iznevjerio je tim potezom jednu od Schopenhauerovih ideja, i to onu o opovrgavanju volje samoubojstvom. U njegovu filozofskom sustavu ono je upravo suprotno: fenomen snažnoga potvrđivanja volje jer samoubojica, razarajući sebe kao pojedinačnu pojavu, kao jedinku, ne ubija volju nego život. „Upravo stoga što samoubica nije kadar da prestane da hoće, on prestaje da živi, i volja tu sebe potvrđuje baš ukidanjem svoje pojave (...).“ (Šopenhauer, 1984: 176) Jednostavno rečeno, ona nastavlja živjeti. Stječe se dojam da je tim posljednjim Jankovim potezom Gjalski i simbolično, ne usvajajući Schopenhauerovu filozofiju u potpunosti, označio konačan povratak Bogu. Doživjevši brojna razočaranja, Janko se, pjevajući Magnificat anima mea Dominum, vratio svomu početku.

Još jedan izrazit primjer šopenhauerizacije tjeskobne muškosti Leskovarov je Ivanović, glavni lik novele Poslije nesreće (1894), kojom autor na neki način zaokružuje prvu fazu svoga stvaralaštva u kojoj intenzivna autoanalitička misaonost završava ludilom ili smrću. ${ }^{73}$ Njegujući „čuvstvo neke tjesnoće“ (Leskovar, 1997: 51), osjećaj gotovo opipljive tjeskobe, Leskovar je svoju galeriju tipiziranih individualaca ${ }^{74}$ upotpunio Ivanovićem, još jednim osamljenikom izgubljenih ideala, u kojega se radikalna tankoćutnost (također) može interpretirati kao degenerirana muškost, odnosno kao posljedica intelektualizacije:

Bijaše srednje veličine, a iz ciele njegove pojave nije izbijao čvrsti, mužkarački karakter. Već kosti - bijaše nekako nježnije građenih, no ipak ne izgledaše slabašan; to mu podavaše samo vid neke plemenitosti. (...) Te crte prije su bile otisak stoljetne inteligencije i težko bi se moglo vjerovati, da je njegov otac vlastitim rukama obrađivao zemlju. Brade nije brijao, no njegova brada ne bijaše snažna mužkaračka brada i rasla mu dosta slabo, a ni brk mu nije bio jak. A ta

\footnotetext{
${ }^{73}$ Toj bi fazi pripadale novele Misao na vječnost, Katastrofa i Poslije nesreće (Milanja, 1987: 19). Detaljnije ćemo o svima pisati u sljedećim poglavljima.

${ }^{74}$ Zamjerio je Prohaska Leskovaru tu pretjeranu tipiziranost, nazvavši mu protagoniste preuzetim književnim konstruktima: „Nijesu njegovi heroji Hrvati, premda se kreću usred valovitoga Zagorja i premda je to Zagorje autentično vjerno opisano, jer svi ti ljudi boluju od tudjinštine, primljene lektirom. A obični Hrvat, šta više ni $10 \%$ njih ne bolovaše i ne boluje od lektire Turgenjeva i Schopenhauera kao Leskovarovi junaci. Oni su fikcije. Vanjštinu im je pisac doista uzimao iz zbilje (...), ali komentar, to jest nutarnje psihološko obrazloženje ili je čisto leskovarovsko ili ravno reminiscencija iz lektire.“"(1917: 695)
} 
njegova kratka, ne gusta brada, gotovo mladenački brk, pa ona tiha plava boja i zamjetljiva mekoća dlaka - posve se slagaše s crtama njegova lica. (ibid.: 59; isticanje naše $)^{75}$

U trenutku pripovijedanja glavni je lik postavljen kao prepoznatljiv dekadent: asteničan, mekoputan muškarac, već sa svojih tridesetak godina obremenjen nekom nevjerojatnom težinom života. S obzirom na to da je kratkoća forme ograničila mogućnost iskorištavanja svih osobina jednoga dekadenta, u toj se noveli kao glavni simptomi dekadentnoga karaktera prepoznaju lektira kao surogat stvarnosti, što posredno priziva i glavni problem svakoga dekadenta, slabost volje, te snažno čuvstvo melankolije. To se esencijalno iskustvo traumatične, paralizirajuće egzistencijalne tuge može protumačiti kao prava patologija djelovanja. Ivanović naime nakon sudara s grubom realnošću, simboliziranom u ženinoj nevjeri, život zamjenjuje filozofijom, ne bi li u njoj pronašao opravdanje za sve što proživljava, te pritom materijalizira karakterističnu melankoličnu nemogućnost artikulacije vlastitoga ,ja“. Dramatičan će događaj potvrditi da gubitak, za koji ćemo pretpostaviti da ga je nekad činio cjelovitim, odsudno definira dekadentni subjekt, odnosno da je melankolija konstitutivan dio njegova identiteta: „bijaše nalik na čovjeka, koji je izgubio neku stvar vanredne vrednote“ (ibid.: 62). S obzirom na to da je Ivanovićeva opsjednutost traumom gubitka shvatljiva u svjetlu teze da se gubitak uvijek asimilira naknadno (Caruth, 1995: 5) - o čemu ćemo konkretnije govoriti na primjerima drugih Leskovarovih likova, Martića i Imrovića - ne iznenađuje nas činjenica da protagonista prošlost opsjeda onemogućujući ikakvo doživljavanje sadašnjosti. U uvriježenoj Leskovarovoj maniri, sav je prethodni život lika zgusnut u uspomenama te o svemu što se dogodilo doznajemo iz sjećanja. Ivanović ne uspijeva žalovanjem okončati svoju usmjerenost na objekt, već ostaje za njega neprekidno vezan; zato je, s obzirom na to da je gubitak uvijek smješten u prošlosti, sasvim jasno zbog čega ga prošlost upravo opsjeda. Naime melankolija se nerijetko tumači, uz osnovnu pretpostavku da je čovjekov život uvijek usmjeren budućnosti, kao vremenski poremećaj (Enderwitz, 2015: 12): pojedinca gura k prošlosti, sputavajući ga da sam osjeti da je sposoban aktivno živjeti. Ona je, kratko rečeno, tek potencija postojanja. I zbog toga se u Ivanovića melankolija prepoznaje kao beskrajna utučenost i paraliza djelovanja, odnosno inhibicija svih aktivnosti koje, prema nekom uobičajenom vjerovanju, čovjeka zapravo čine čovjekom.

\footnotetext{
75 Spomenimo i kako u ovoj noveli Leskovar Ivanoviću oponira Marcela Bartića, ,jaku, snažnu gotovo malo krupnu pojavu svoga druga, komu su obrazi upravo sjali od zdravlja, a kad su si ruke pružili, u onoj ugodnoj toplini prijateljeve ruke poćutio, kako u tom tielu snažno krv kola, i pri dodiru njihovih ruku osjetio, kako je on sam mlohav, hladan“ (1997: 63). Predstavljavanjem snažnoga, energičnoga lika, koji funkcionira kao dopuna protagonistu, dodatno naglašava njegovu duševnu i tjelesnu fragilnost.
} 
Nije međutim teško između redaka pročitati da je Ivanovićeva sjeta, premda individualizirana i motivirana konkretnim događajem, oznaka kolektivnoga osjećaja nadolazeće propasti čovječanstva. Naime Leskovar u noveli prvi put izrijekom individualnu dekadenciju spominje kao zajedničku osobinu generacije na razmeđu stoljeća, obogaćujući Ivanovićevu patografiju idejom o findesiècleovskom raspadu vrijednosti. Zato Ivanović, slično Marcelu Bušinskomu, nesreću koja ga je snašla nije smatrao „samo svojom vlastitom nesrećom, nego je u njoj gledao udes i kob cieloga čovječanstva“"(Leskovar, 1997: 61), a vlastitu duševnu jalovost i dotrajalost nazvao je „nemoć cielog svemira, nemoć obćenita, nemoć vječna“ (ibid.: 70). Dakle na ovom je primjeru posve jasno izraženo kako se pojedinačno iskustvo melankolije, u kojem spoznaja beznačajnosti i apsurda svijeta rezultira povlačenjem od njega, pretvara u kolektivno osjećanje, u generalnu „bolest stoljeća“ koja pojedinca čini otupjelim, neurasteničnim, praznim. Individualna je psihologija simptom duha vremena.

Ivanovićeva dekadentna nemoć i neodlučni kukavičluk, radikalno materijalizirani u činjenici da čak i kad je ženu zatekao s drugim, njemu se ,usne nabirahu na plač i bijaše nalik dobroćudnu dječaku, gdje stoji nad razbijenom milom igračkom, a nemoćan je, da se obori na protivnika“" (ibid.: 59), potenciraju se životom u lektiri, neprirodnim uvjetima u kojima svaki pokušaj utopijskoga pomirenja sa stvarnošću rezultira mahnitošću. Dok njegova žena poseže za vjerskom literaturom, on čita Schopenhauera, Lassallea i von Hartmanna, apostole pesimističke misli u kojima se nada pronaći ono što je imao „prije nesreće“. Neprestano razmišljajući o uzrocima nesretnoga ishoda, preuzima metafizičko uvjerenje o bezrazložnoj volji, nečemu nepoznatom i tajanstvenom što vlada svime te usmjerava čovjekove postupke presudno mu određujući egzistenciju.

On se nije nikako mogao da utješi običajnim u takvim nesrećama izgovorima: nevaljan uzgoj, družtvena izkvarenost, odstupanje od religije. Nešto drugo, drugo mora da je jezgra cieloj toj nesreći, a ono je samo obrana. (...) Njemu je sada godila nauka o glupoj, bezsviestnoj volji, pa ono grubo, pesimistično shvaćanje ljubavi, koja nije ništa nego obsjena te glupe volje u bezsviestnom njenom nastojanju za razplođivanjem. (ibid.: 60-61)

Baštini na taj način Ivanović nikad zadovoljenu Borislavićevu potragu za spoznajom koja bi mu argumentirano približila čovjekove postupke (pa tako u ženinoj prevari prepoznaje čin primitivnoga nagona), doduše u puno manjem opsegu u odnosu na Gjalskijev lik, te uvjerenje da je sve zakone ljudskoga djelovanja moguće podvesti pod zakon prirode, tj. slijepe 
volje. To će mu uvjerenje poslužiti da barem prividno umiri raskol nastao traumom gubitka, koji međutim nikad neće uspjeti nadvladati.

Život je to dakle osmišljen u okviru filozofskoga pesimizma, koji je Leskovar postavio kao izvrstan paravan za objašnjenje jedne nesretne egzistencije, objeručke prihvativši mogućnost da filozofijom Schopenhauera i njegovih nasljednika racionalizira probleme svoga lika. Pesimizam je, može se prema tome reći, dao značenje Ivanovićevu melankoličnomu iskustvu gubitka te osigurao potporu znanstvenomu diskursu degeneracije. ${ }^{76} \mathrm{U}$ naporu da se kontekstualizira njegovo postojanje, autor predstavlja na koji način egzistencijalna praznina može u potpunosti definirati život. Schopenhauerova ideja da čovjeka pokreću volja i želje koje se nikad ne mogu dokraja realizirati, što neizbježno rezultira osjećajima frustracije i nezadovoljstva, te von Hartmannova teza da pojedinac ispunjenjem svojih potreba može dospjeti tek do neutralne pozicije zadovoljstva, ponudit će opravdanje za Ivanovićevu tjeskobu, u kojoj će se demonstrirati kako je sreća čovjeku naposljetku uvijek nedostižna. Glavni lik preuzima pritom i negativno razumijevanje ljubavi kao najobičnije opsjene i svijest o nemogućnosti usklađivanja plemenitih ljudskih osjećaja i primitivnih nagona, sve kako bi se pokazalo da se i u ovom slučaju poništava svaka mogućnost zajedničke egzistencije. Zato i Ivanovića određujemo kao prototipskoga modernog dekadenta kojemu um ne dopušta da se aktivno angažira u životu, već ga tjera da od života apstinira. U prekomjernoj zaokupljenosti prošlim događajima demonstrira se kako mu je lektira oduzela mogućnost življenja u realnosti, ali i sposobnost praštanja. U intelektualizaciji se naime kukavički traži utočište od beznačajnosti svakidašnjice, odnosno nadomjestak za svako autentično proživljavanje života. A to narcističko povlačenje u sebe zapravo je rezultat Ivanovićeve nesposobnosti da se suoči s problemima pred sobom. Pa iako se na trenutke doima da u njega ipak prodire neka „struja života“ koja bi mogla potisnuti „njegov umišljeni sviet“ (ibid.: 66), filozofska će mu analitika do samoga kraja osiguravati blaziranost, pokazujući da je sadašnjost, kao i u drugim djelima iz korpusa, nepovratno izgubljeno vrijeme. Uostalom, vidjeli smo u jednom od poglavlja, dekadent je već po definiciji statičan, bezvoljan, umni karakter, zastrašujuće spriječen nekom dramatičnom

\footnotetext{
${ }^{76}$ Vraćajući se usputno na izvanknjiževnu zbilju s kojom je ova književna snažno korespondirala, spomenimo kako je početkom XX. stoljeća bilo prilično rašireno uvjerenje da filozofija izrazito negativno utječe na društvo, osobito na mladež. Gilman (1985) navodi da su posebno „zaraznima“ proglašene Schopenhauerova i Nietzscheova. Kao intrigantno svjedočanstvo činjenice da je Nietzscheovu recepciju u prvoj polovici XX. stoljeća obilježilo uvjerenje da je on doista opasan filozof, i to ne zbog njegovih ideja koje bi netko mogao držati štetnima, nego zato što je njegovo učenje motiviralo opasno ponašanje, Gilman izdvaja slučaj jednoga ubojstva u kojem je javni tužitelj u procesu suđenja inzistirao na povezanosti takvoga čina s čitanjem Schopenhauera te naročito Nietzschea (1985: 61-65). Njihov pesimizam koji je ,,promicao destrukciju i neograničenu važnost individualnoga smatrao se iznimno opasnim jer je njegovao egocentrične stavove koji su često vodili u devijantno ponašanje“" (White, 2014: 151-152).
} 
povijesnom nemogućnošću djelovanja. „(..) srdce otčevo kao da je ležalo zakopano pod kovnom hladnoćom nebrojenih gotičkih slova, kojima bijahu otisnute one bezćutne knjige. Taj čovjek bijaše posve u vlasti misli.“ (ibid.: 62) Svi su depresivni osjećaji u ovoj klasičnoj melankoliji transformirani u neki isprazni bijes koji se ni na koji način ne uspijeva kanalizirati.

Radikalna odvojenost od realnoga i svakidašnjega, od života „ovdje“ i „sad“ - što je, prisjetimo se Horneyina tumačenja, jedna od značajki neurotične karakterne strukture (1950: 35) - nasilno življenje u askezi i preziranju, svojevrsnom umrtvljenju, morbidno se manifestira i u Ivanovićevu odnosu prema bolesnom sinu, kojega promatra na samrtničkoj postelji te, $u$ skladu s uvjerenjem da je nepostojanje na ovom svijetu prihvatljivije od postojanja, komentira:

Ah, šta i jest napokon život. Vječita muka, naprezanje bez razumievanja. Umri, umri, mali, dok još ne znaš za te muke (...). Vrati se u nevidljivi sviet bezbolnog nebitisanja. (ibid.: 71)

Dakle Ivanović je kao autentični homo melancholicus obuzet tipičnim dekadentnim umovanjem, u ovoj noveli potaknutim traumom gubitka, i traženjem surogata života u listovima knjiga. I pritom je svaki njegov pokušaj davanja značenja daljnjemu životu, s obzirom na to da nije usmjeren ,prema“, odnosno k budućnosti, nego je bijeg „od“, unaprijed osuđen na propast. Jer jednom kad su se prekinule sve interpersonalne spone, taj dekadent paralizirane volje i slomljene energije našao se posve izoliran i osamljen, ne uspjevši osamljenost nadvladati nadilaženjem jaza između ,ja“ i drugoga. I u toj se nemogućnosti ponovo vraća vjeri kojom će se, $u$ trenutku smrti njegova sina, potrti sva filozofska naučavanja te demonstrirati da filozofija ne može dati odgovore na pitanja o funkcioniranju svijeta. Kroz finalnu se Ivanovićevu rastrojenost izlaz pronalazi u religijskom kontempliranju, koje se može izjednačiti $\mathrm{s}$ kjerkegardovskim individualističkim religijskim egzistencijalizmom što traži duhovni smiraj ponad neobuzdane i kontingentne volje. Bol zbog gubitka anulira se notama crkvene pjesme.

\subsection{Na putu u otuđenje: Šegota, Mirković, Grančarić}

Kroz uvodna smo poglavlja i dosadašnje interpretacije demonstrirali kako se otuđenje kao jedno od glavnih obilježja dekadentnoga karaktera može razumijevati s obzirom na površnost međuljudskih odnosa, porast neurotičnih poremećaja, nepostojanje ili nepronalaženje smisla u životu i smisla života uopće. Na kraju krajeva, s obzirom na iščezavanje svih relevantnih vrijednosti koje bi pojedincu trebale pružiti osjećaj ontološke sigurnosti. Usto ono 
je intenzivno premreženo s predstavljenom pričom o fragmentarnim dekadentnim identitetima te neumjerenim modernističkim individualizmom. Iako je otuđenje prilično složen fenomen kojemu se može pristupiti iz različitih perspektiva, lako je sumirati da ono uvijek implicira neki oblik odvajanja pojedinca od određenoga segmenta društva ili od društva u cjelini te vrlo često posljedičan osjećaj beznačajnosti i nemoći.

Čovjekova potreba da se uspostavi kao cjelovit subjekt, da se ukorijeni i poveže, da si osmisli identitet, odnosno stvori okvir orijentacije, jest među osnovnim ljudskim potrebama, već smo utvrdili. Zato je svaka nemogućnost njezina ispunjenja popraćena čuvstvima tjeskobe kao stanja u kojem pojedinac osvještava potencijalno nebivanje (Tillich, 2000: 35). Tjeskoba je u tom smislu strah od nepostojanja. A budući da je nepostojanje prijetnja čovjekovu samopotvrđivanju na trima razinama - ontičkoj, u smislu smrti, duhovnoj, u smislu beznačajnosti, i moralnoj, u smislu osude - Tillich utvrđuje tri forme tjeskobe: tjeskobu smrti, tjeskobu beznačajnosti, tj. gubitka smisla, i tjeskobu krivnje i osude (ibid.: 41). Pritom tumači da su sve forme karakteristične za čovjekovu egzistenciju kao takvu, a ne za abnormalno stanje uma kao naprimjer u neurotičnoj ili psihotičnoj tjeskobi. Biti čovjek podrazumijeva upravo odnos prema značenju, prema oblikovanju i razumijevanju svijeta s obzirom na vrijednosti, pa je u kontekstu netom navedenoga razumljivo zašto prijetnja duhovnoj egzistenciji implicira i prijetnju cijelomu sebstvu. Dakle egzistencijalna tjeskoba kao strepnja pred beznačajnošću, odnosno mogućim gubitkom smisla koji daje značenje životu truizam je koji se može primijeniti, kako smo pokazali u uvodu, na kompletno razdoblje fin de sièclea, pa i na sve naše dekadente. Suočeni s gubitkom duhovnoga središta, opterećeni spoznajom o praznini, oni se nalaze pred pitanjem o smislu egzistencije. A s obzirom na to da ga ne uspijevaju dokučiti kroz vlastito djelovanje, iz potencijalne slobode bježe u tjeskobu da bi se nakraju našli posve otuđeni: od svijeta i od samih sebe. Zato Milanja postavlja tezu, vrlo blisku našemu razumijevanju stvari, o likovima smještenima između dvaju svjetova:

Njih načelno karakterizira dekadentan i destruktivan element, bilo da su promašili profesiju (kao Tito Dorčić po nagovoru roditelja), pa su u biti duboko nesretna bića, ili su se potpuno odnarodili, kao Juraj Stipančić, pa su svojevoljno iskorijenjeni i kao takvi djeluju razarateljski na najbližu, rodbinsku sredinu (sestru, majku), bilo da su faustovski opsjednuti strašću za apsolutnim znanjem koje ne mogu apsolvirati, kao što je to slučaj s Jankom Borislavićem, pa oni predstavljaju, a time i anticipiraju, Foucaultovu epistemološku katastrofu, bilo pak da kao umjetnici propadaju u provincijskim zaturenim hrvatskim prilikama i njezinim malograđanskim 
formama mentis, kao Amadej Zlatarić ili Đuro Andrijašević, te na kraju polude i čine samoubojstvo. (2011: 868)

Dakle u našem korpusu zaseban segment dekadencije čini problem razapetosti između domovine i tuđine, provincije i grada, pa posredno i između staroga i novoga, konzervativnoga i modernoga. Likovi stilizirani tako da ne pripadaju ni tu ni tamo, obezglavljeni u osmišljavanju svoga života, opsjednuti tmurnom spoznajom da su ostali negdje ,između“. Stoga je prikladno njihovu dispoziciju protumačiti Tillichovim razlikovanjem dviju vrsta tjeskobe koje zrcale paralizirajući strah od nepostojanja, a koje izvrsno opisuje zatečeno stanje svijesti: između tjeskobe zbog nemogućnosti bijega, horora zarobljenosti, i tjeskobe zbog zastrašujuće otvorenosti, beskrajna, amorfna prostora u kojem se zatječu, a ne pronalaze mjesto koje bi mogli zauzeti (2000: 61). To su dvije strane iste realnosti.

Prema tome iako je, kako smo napomenuli na početku, egzistencijalna tjeskoba u navedenim okolnostima sasvim normalno stanje, ona $\mathrm{u}$ dekadentnih likova degenerira $\mathrm{u}$ patološku formu koja onemogućuje postojanje. Neurotična anksioznost, prezentirana primarno kroza zakočenu volju, u kojoj pojedinac zapinje u procjepu između ,nekad“ i ,sad“, nedorastao ustrojiti vlastiti sustav vrijednosti te uspostaviti odnose s drugima, posebno opsjeda neke Novakove i Nehajevljeve protagoniste.

$* * *$

U svom širokom literarnom potezu kojim, po Barčevu mišljenju, „nadvisuje sve hrvatske pripovjedače svoga razdoblja“ (1951: 786), Novak je, uz Leskovara, najcjelovitije zahvatio u tip dekadenta dominantnoga u hrvatskoj prozi fin de sièclea, izrazivši različite pojavne obrasce dekadentnoga senzibiliteta u svojim romanima lika, nastalima u rasponu od petnaestak godina, u kojima ,individualne perspektive uvijek neposredno korespondiraju sa sudbinom kolektiviteta (klase ili naroda), a redovito su dopunjene i socijalnom analizom“ (Nemec, 1999: 226). Gotovo su svi njegovi protagonisti žrtve izmještenosti iz prirodne sredine te subjektivne $\mathrm{i} / \mathrm{ili}$ objektivne nemogućnosti nadilaženja realiteta ili nedoraslosti prilagodbi (novomu) društvenomu okružju. To praćenje neprilagođena pojedinca Novak započinje Pavlom Šegotom, junakom svoga istoimenog romanesknog prvijenca iz 1888, te preko Nikole Baretića (protagonista istoimenoga romana iz 1896) i Viktora Jerkovića (iz Zapreka iz 1905) i Amadeja Zlatanića, o kojem ćemo također pisati, dospijeva do intrigantnoga Tita Dorčića (1906), radikalnoga primjera pogubnih posljedica ,čupanja“ pojedinca iz prirodnoga okoliša. 
Šegota je izvrstan prototip Novakovih likova (polu)intelektualaca u kojima kombinacija nemilosrdnoga socijalnog konteksta, odnosno mnogobrojnih zapreka očuvanju osobnoga integriteta, te duševne bolećivosti i smanjena élan vitala rezultira tragičnom neuspostavom identiteta. Zapravo, ne samo Novakovih likova, valja precizirati, nego i svih drugih dekadenata koje u radu analiziramo. „Bistar, skroman, povjerljiv, a svojom vanjštinom lijep $i$ čedan kao djevojka“ (Novak, 1931: 84; isticanje naše), Šegota je, jednako kao i Šenoin Lovro i Gjalskijev Borislavić, od samoga početka odsudno definiran nemogućnošću donošenja odluke, s ozbiljnim reperkusijama na kompletan daljnji život. „Ženskasto“ osjetljivomu, po izboru majke predviđena mu je svećenička odora, uobičajeno zanimanje „maloga“ provincijskog čovjeka, kojemu je suđen mogao biti još samo činovnički stol. Naime u dalekom bi tuđem svijetu mogao zabludjeti te završiti „slomljenih krila i skršene volje“ (ibid.: 18) - što će se svakako ipak dogoditi, neovisno o prostoru u kojem se nalazio - dok bi, na marginama toga svijeta, $\mathrm{u}$ skromnom zavičaju svomu narodu mogao biti od velike koristi. Tako da je svaki Pavlov korak unaprijed osuđen na propast jer je iskorijenjen iz mjesta kojemu po prirodi pripada. Mada mu je fatalna sudbina prilično slabo motivirana, pa naposljetku skončava kao žrtva vlastite naivnosti i nepromišljenosti, ne možemo ne opaziti da je i on oblikovan kao prepoznatljiv dekadent te pritom smješten negdje na pola puta između romantiziranoga Lovre i modernistički profiliranijih junaka (poput Andrijaševića). Neovisno o prilično banalno izvedenom konačnom kraju (posljednji je okidač Pavlove agonije pljačka rasipne zavodnice kojom se oženio), i u toj prozi glavni junak životom plaća svoju psihičku nestabilnost u surovosti socioekonomskih prilika. On je, baš poput drugih protagonista, sam svoj krivac. Sudar svjetova koji Novak nije dokraja dosljedno izveo, ali ga je definitivno načeo. ${ }^{77}$

Pavao Šegota u mnogim aspektima slijedi životni put hrvatskoga inteligenta s kraja stoljeća, no ipak čini iskorak u odnosu na tradiciju: ne odlazi na studij humanističkih ili društvenih znanosti, nego se odlučuje za prirodoslovlje koje će mu, nada se (sjetimo se samo Borislavića), omogućiti spoznaju smisla i svrhe egzistencije, koju mu dogmatizam religije nije mogao ponuditi. Taj svijet čuvstava i misli ponajbolje ilustriraju sljedeće reprezentativne izjave analitičkoga duha koji znanjem pretendira obuhvatiti čitav svijet, pa i dalje od njega:

Što je život?... Rat, vječni rat, da sačuvaš oblik, u kom si se pojavio... čim malakšeš, otima gospodstvo drugi i opet se vraćaš u život drugoga oblika, druge snage, nikad vječan, nikada nepredobiv... (...) Što je mir, - što bi bio raj mir?... Mrtvilo. A ima li mrtvila?... Kaljuža, smradna

\footnotetext{
77 Prigovorit će mu Frangeš da je trebao ustrajati u razradi, kako je, uostalom, i započeo, okrutnoga sukoba ,arhaične idiličnosti zavičaja i pozitivističke orijentacije Pavlove“ (1970: 156).
} 
bara veli da mrtvuje... a zar se i u njoj ne stvaraju organizmi, koji se nameću drugomu životu, da budu živi? (...) Zar nije ta rastvorba anorganizama i tvorenje organizama opet biljeg vjekovitog života, mijene?... Ali dalje, dalje!... Zemlja je sićušna, milijuni svemirskih tjelesa progutali bi bezbroj tih zemalja (...) Kad je u svemiru toliko svjetova, zar da na ovom samo sićušnom planetu živu najsavršeniji svemirski stvorovi - ljudi? (ibid.: 36)

Prema tome i on je paradigma spomenutoga tragičnog sukoba koji je, kako se može detektirati, oznaka čitave literature s kraja stoljeća. Pozitivizam znanosti ne zadovoljava te kontemplativne, filozofske prirode koje nisu mogle pronaći utjehu u vjerskim istinama, pa im preostaje tek sa Schopenhauerom i von Hartmannom dokraja se odreći ovozemaljskoga života ili se pak vratiti kršćanstvu. Prisutna je stoga i u gradnji ovoga karaktera stanovita neurotična čežnja za univerzalnom spoznajom, za dohvaćanjem kozmogonijskih prirodnih tajni, iz koje će, na Lovrinu tragu, proizaći samo tmurna misao o suvišnosti znanja. ,Ja tražim sa strastvenom nasladom početke života, ja bih svojim životom platio, da mi je prodrijeti i zeru dalje u tu tamu, ja tražim začetak, uvjete, razloge i svrhu svemu, što opstoji ili o čem slutim, da je bilo.“ (ibid.: 73-74) I doista, platit će nakraju Pavao životom tu svoju potragu za početkom svega jer će se svijest o nepotrebnosti znanja u modernom svijetu razviti „do duboke prestravljenosti“ (Frangeš, 1970: 157). Naime čak mu ni slavna Darwinova knjiga O postanku čovjeka, koju s velikim očekivanjima čita, neće ponuditi odgovore za kojima traga pa će je, razdraženih živaca, s indignacijom odbiti jer je samo pojačala njegovu sumnju. To ,prazno umovanje i beskorisno istraživanje“ (Novak, 1931: 73) kao simptom suspregnute volje bit će povod i za konačan razlaz s prijateljem Rikardom, antipodom Pavla dekadenta, praktičarem, zagovornikom sugestivnoga egzistencijalnog realizma i uživanja u onome što život nudi. Život se živi, a ne promišlja:

Briga mene, je l' nam Bog sveopćeg praoca stvorio u ovome liku, kakav sam ja danas, ili su se moji pradjedovi natjeravali po šumama (...). Tu smo, živi smo, računajmo s onim, što jest i kad se već ljudsko društvo tako uredilo - s onim, što će biti. Te stare stvari stoje pred nama, kao vjekovita tmina, a svaki napor, svaka misao, da je odgonetne, propada u nju kao biser u more, u nepovrat. Zar ne bi um tih učenjaka više ljudskomu rodu koristio, da to krasno vrijeme, što ga u uzaludna istraživanja troše, uprave na sadašnjost, na budućnost, a mrtve jedamput za svagda da blagoslove (...). Meni je do života a ne do mrtvog umovanja. (ibid.)

Bergsonovski životni polet nasuprot kontemplativnosti, nagon i zadovoljenje nasuprot obrani i potiskivanju - sve ono što će nedostajati Pavlu, životni i stvaralački zamah koji bi mu 
osigurao dostojno mjesto u društvu i posljedičnu uspjelu konstrukciju identiteta. Pasivizirajući strah pred nepoznatim, bezgraničan interes za temeljna pitanja ljudskoga postojanja i nemirna, nikad zadovoljena misao u stalnoj potrazi za odgovorima, a koji blokiraju svaku djelatnost motivirajući isključivo na kontemplaciju, bitni su biljezi te egzistencije u kojoj se dekadencija može eksplicirati kao neuspjela prilagodba na novo, pa stoga i kao primjerena kazna za izmještenje iz prirodne okoline. Naime put u tjeskobno otuđenje, koje je nagovješteno već na početku njegova prostornoga putovanja, Šegota započinje onoga trenutka kad se odlučuje za studij u Pragu, napuštajući idiličnost rodnoga mjesta te se prepuštajući velikomu gradu u kojem će potpisati konačnu kapitulaciju.

U gustoj tmini, kroz koju su se razabirali tamni predmeti u nejasnim crtama, bijaše Pavlu nekako tjeskobno, njegova je duša prodirala tu tminu stvarajući sama za se nekakav nesretni svijet, ružne slike i strašne prikaze, a štropot onaj odjekivao mu je u duši kao grožnja i vika silnika i kao očajni vapaj potištenih i bijednih ljudi. (ibid.: 64)

Bez prave svijesti o samom sebi, a ipak narcistički obremenjen poniranjem u vlastitu unutrašnjost, Pavao u grad stiže kao već pasivan dekadent po naravi. Njegova mekoputnost i sklonost pretjeranomu analiziranju polagano jačaju u sudaru s velegradskim prostorom i senzacijama koje on nudi te je u tom smislu Šegota par excellence uzorak odsutnosti decizionizma, jednoga od ključnih obilježja dekadenata. On izvrsno oprimjeruje rastrganost pojedinca između dviju vrijednosti, tradicionalizma jednostavna zavičaja i modernizma svjetske metropole, te će za njegovo neiskustvo i osjetljivu narav to stanje biti pogubno. Put u novo nepoznat je te pretpostavlja čvrstu volju, vitalnu snagu za uspostavu egzistencije u stranom svijetu i odlučnost za njezinim održavanjem u društvu kojim vladaju okrutne ambicije. Sve ono što Pavao nema. Vratimo li se pak uvodnim dijelovima rada i findesiècleovskoj zbilji koja je bez sumnje imala golem utjecaj na fikcionalizaciju mentalnih dispozicija, valja podsjetiti da je na intenziviranje osjećaja tjeskobe uvelike djelovao rast gradova i stanovništva. Ta je pak postavka, kao prevladavajuća društvena slika vremena, prepletena s tezom o ,moralnom i kulturnom vakuumu“ koji se smatrao nekom vrstom kršćanske ostavštine (Burrow, 2000: xi). Naime u pesimističnim viđenjima, kako smo opisali (dovoljno je prizvati u sjećanje Bearda i Nordaua), rast je gradova bio među glavnim uzrocima bolesti moderne civilizacije. Brz tempo i mnogobrojne stimulacije gradskoga okružja iscrpljuju pojedinca koji na to nerijetko reagira mentalnim poremećajima, osobito neurastenijom i histerijom. Uhvaćen u koloplet promjena, pribojava se da će izgubiti kontrolu nad svojim životom. Sve to proživljava i Šegota: 
U prvi mah nije se mogao razabrati u buci i vrevi velegradskoga života. Prolazeći raznim ulicama svuda je nalazio nešto novo i dok bi se zaustavljao kraj jedne stvari, javljalo se oko njega sto drugih, koje su mu pozornost na se svraćale. (Novak, 1931: 70)

Zato nije naodmet Simmelovu tumačenju ideologije grada iz uvodnoga dijela pridružiti i Bahrovo, prema kojem velegradski život stvara preduvjete za razvoj novih kulturnih fenomena i psiholoških oblika, pa tako i dekadentnih tipova. Velegrad se naime postavlja kao ekskluzivni legitimator nečije vrijednosti: „Tko se ne iskaže u velegradovima današnjice, nema izgleda da išta znači.“ (Žmegač, 2012: 40) Prema tome i u Bahrovoj teoriji grad, kao složena organizacija i mjesto necjelovitosti i difuzije koje razara identitet, postaje simbolom modernističke živčane napetosti. Jasno je stoga zašto će Novak urbanitet zolijanski artikulirati kao leglo pokvarenosti i zala te ga optužiti za raznovrsne duševne malformacije, ne prepoznajući da ,nije problem u gradu kao urbanom prostoru i određenoj kulturnoj paradigmi, nego u počecima liberalnoga kapitalizma i novčarsko-bankarskoj moći kao sferi odlučujuće kompetencije“ (Milanja, 2012: 260). Međutim za potpuno razumijevanje značenja Šegotina života u Pragu i djelovanja kompleksnih velegradskih fenomena krucijalan je odnos s rodnim krajem. Jer, kao što smo nagovijestili, svi protagonisti u ovom poglavlju plaćaju kaznu otuđenja od zavičaja te im se postignuća prosuđuju s obzirom na uspješno ili neuspješno samoostvarenje u gradu. Novak dakle zahvaćajući $\mathrm{u}$ metropolu $\mathrm{u}$ isto vrijeme zahvaća $\mathrm{u}$ provinciju te pritom inzistira na arkadijskom poimanju rodne grude. Prikazuje ju krajnje romantizirano, kao sigurno utočište za oslabljeni duh koji je sve svoje snage upro da bi preživio zlokobnost metropole, koja se u romanu potencira i likom fatalne Lore, posljednjega faktora Pavlova završnoga sloma. Grad je strukturiran kao mjesto tjeskobne neizvjesnosti, a protagonistov je prelazak iz periferije, rubnosti, u središte svijeta obilježen neminovnim rasapom ličnosti. Drugim riječima, „u Novakovoj pripovjednoj konfiguraciji napuštanje ishodišnog okoliša donosi rizik obesnaživanja vlastita značaja“ (Čuljat, 2012: 443).

U duši mu bijaše kao u paklu, kao da je tu plamsao bijes i mržnja, kao da je na toj vatri kipjela divlja strast, kao da se cijelom mu nutrinjom potajno provlačila tiha, ali jaka bol. Današnji doživljaj, toli čudan, nepojmljiv doživljaj uzbibao mu još ono mira, što ga je u duši ostalo, pošto se od rodnoga kraja udaljio. Kolika razlika u tihom životu siromašnoga Podgorja i u ovom vrtlogu neslućenih ljudi! Onamo mir, blagost, ljubav, djetinja prostodušnost - a ovdje... Ta šta? Toga još nije shvaćao. Onamo ljudi, život, cijeli kraj kao blaga dušica nevinog djevojčeta, a ovdje - šta? Bog si ga znao! - Onamo shvaćanje prirode i čovjeka u predsudama po pjesmi i priči, što se rađa kraj siromašna ognjišta, - a ovdje duh ljudski na svom vrhuncu, bogatstvo, 
znanost, umjetnost, prosvjeta. Onamo pastirsko djevojče u odrtim haljinama (...) - ovdje veličanstvena žena, krasna, odjevena kraljevskim odijelom (...). (Novak, 1931: 133)

Na taj način autor preuzima opću sliku hrvatskoga i europskoga realizma, podvojeno viđenje u kojem se selo imaginira kao mjesto izvorne dobrote, a grad kao središte nemoralnosti i grijeha. Između „onamo“ i „ovdje“ zjapi dubok bezdan u kojem se krije frustrirajuća nemogućnost uspostave cjelovitosti. U prostornoj se rastrganosti glavnoga lika razabiru identitetske pukotine. U potrazi za spoznajom otrgnut od čistoće rodnoga mjesta, svoje referentne točke. ${ }^{78}$ No iako se lako složiti s tezom da je takav iskorak iz prirodne sredine najveća „prijetnja razvoju stabilnoga pojedinca“ (Čuljat, 2012: 45), treba naglasiti da se Pavlova anksioznost, intenzivirana životom u velegradu, zapravo začela puno prije. I to nas, jer nam je takav način gradnje dekadentnoga tipa dobro poznat, nimalo ne čudi. Naime dekadencija je kao osipanje životne snage već upisana u genetski kod gotovo svakoga tematiziranog protagonista. Svi su oni unaprijed oblikovani odgojem i obrazovanjem ili pak urođenim sklonostima, vrlo često degenerativnim naslijeđem. Uostalom, i pronicljivi mu je Rikardo iznio pravu dijagnozu utvrdivši da je za sve kriva njegova priroda: „tvoja narav, tvoje srce traži u svijetu ono, što ne će nikada naći“ (Novak, 1931: 64). U Pavla se tjeskoba naočigled rađa onda kad shvaća da na sebe ne želi preuzeti majčinu odluku i otići u svećenike te osvještava zaljubljenost u Evicu.

\footnotetext{
${ }^{78}$ Povratak sebi kroz povratak svojim izvorima radikalizirao je Gjalski u romanu Na rođenoj grudi (1890), pokazujući da smirenost i čistoća zavičaja itekako mogu poništiti sve životne poteškoće. Ono što nije uspjelo Šegoti realizirat će Lav Blinjević, također još jedan nadaren mladić koji je u potrazi za znanjem napustio svoje korijene, te u harmoničnoj slici zavičajnoga okružja uspostaviti svoju novu identitetsku točku. On se, nastojeći se pod svaku cijenu izbaviti iz ralja mefistovske metropole, u kojoj su jedni „u piću ili u naručju kupljenih žena, u lijenosti i u besposlici, a drugi u grozničavoj hitnji za novcem, za moći i za slasti tijela izgubili razumijevanje za svaku nesebičnu ideju, za svaki plemeniti osjećaj i za svaki pokret - ama za sve, a najviše za poštenje“" (Đalski, 1980: 10), vraća u rodni kraj te se ondje prepušta glavnoj zanimaciji suvišnoga čovjeka, slatkom dolce far niente, odnosno primamljivoj besposlici: ,....) neka slatka sumornost lijegala mu na dušu i u taj tren poćutio je želju za mirom i bezdjelicom. Uzeti život takav kakav jest, trpjeti i dobar biti, pokoriti se neumolnim zakonima općenitosti - oj, kako bi to divno bilo. Tiho i neznano sprovoditi svoje dane u prostim dužnostima svakidašnjega života kolike li blaženosti!“ (ibid.: 52) Nije nevažno što to prepuštanje dokolici, hedonističkomu promatranju prirode i žudnja za običnim, svakidašnjim poslovima - dakle nekim specifičnim simptomima oblomovštine - u impresionistički idealiziranom krajoliku u Gjalskoga ovaj put nema moralizirajući, osuđujući prizvuk. A nema ga jer autor navedeno želi što uspješnije suprotstaviti onomu što nazivamo „pravim“ dekadentnim mehanizmom: hirovitu životu u velegradu u kojem pojedinac, pod utjecajem brze izmjene dojmova, juri od jedne obveze do druge te u blaziranoj osamljenosti ostaje bez prilike da uspostavi međuljudske odnose. Naime nakon što je bolno preživio prevrtljivosti metropole, mentalno se i tjelesno sasvim iscrpivši, Blinjević prokazuje sve „one grdne silesije laži, pretvaranja i prikrivanja“ (ibid.: 10) koje u njoj vladaju te iz vatrenoga mizantropa evoluira u optimističnoga panteista, koji u vjeri i ljubavi prema ženi i rodnome mjestu ekstatično pronalazi novo ,ja“". Odbacuje svoju neurasteničnu prošlost, $\mathrm{u}$ kojoj ga je autor prepoznatljivo strukturirao kao nedjelatnoga subjekta, izmučena slabića koji i fizičkim izgledom sugerira tjelesnu boležljivost, te u sakralizaciji zavičaja ostvaruje nov identitet. Unutarnji mir, osiguran tek povratkom u rodno mjesto, omogućuje ponovnu konstrukciju vlastitoga ,ja“ načetoga teškom velegradskom egzistencijom. Dakle krajnje neuvjerljivo i nemotivirano, topos domaćega ognjišta u ovom djelu poprima začudnu snagu anulacije jednoga pravog šopenhauerovsko-hartmanovskog pesimizma, pa i radikalnoga nihilizma, te omogućuje da se glavni junak naposljetku ushićeno odredi kao „rabotnik rođene grude“ (ibid.: 145).
} 
Stoga je njegovo anksiozno stanje moguće razumjeti s obzirom na to da se dihotomija dužnosti i žudnje u širokom smislu može poistovjetiti s dihotomijom razuma i nagona te u ključu Breitenbergove (1996) teze o maskulinitetu kao implicitno tjeskobnoj konstrukciji identiteta. Tjeskoba je naime logičan plod patrijarhalnoga sustava u kojem se od muškarca očekuje reprodukcija jasno specificiranih uloga. „Pojedinci čije identitete gradi pretpostavka vlastitih privilegija u sebe su morali inkorporirati i različite stupnjeve tjeskobe zadržavanja ili mogućega gubitka privilegija.“ (Breitenberg, 1996: 3) Jednom kad se odrekao povlastica sigurnoga svećeničkog života, Pavao je bio primoran krenuti u traganje za svojim ,ja“. Njegova je fatalna sudbina ishod odlaska u svijet, a posredno i sankcija za odbijanje svećeničkoga poziva. U toj potrazi vrlo brzo u njemu prepoznajemo uobičajene dekadentne crte, opsjednutost nejasnim predosjećajima i nagovještajima „nečega“, što će ga spriječiti da ostvari cjelovito jedinstvo: „Nešto teško stezaše mu grudi, nekakve slutnje pritisnuše mu dušu, kao da se u njoj oluja sprema. Badava se pokušao umiriti (...); onu težinu, koja mu se poput olovne ploče na dušu slegla, nije mogao razbiti.“(Novak, 1931: 25) Tako da bismo mogli poentirati da već tad postaje izgledno da njegov život nema perspektivu: odricanje od onoga što se drži prirodnim mora se na neki način sankcionirati. Njegova je dezintegracija doista počela onoga trena kad se odlučio za drugost ne bi li pronašao sebe. A drugost se primarno veže za grad u kojem se Pavao suočava sa svime što je, iz perspektive zavičaja, seoske zajednice i obitelji, bilo etiketirano kao nepoćudno, nemoralno, nepoželjno - jednostavno rečeno, drukčije. Prema tome protagonistov put aktualizacije osobnoga identiteta otpočetka je signiran neizbježnom propašću te na tom putu on učvršćuje tipične probleme hrvatskih dekadenata: „nemir mladih generacija, njihovo nezadovoljstvo ustajalim oblicima života, čežnja za novim, dalekim i (...) neizbježan poraz.“ (Frangeš, 1970: 158)

Nije stoga riječ samo o tome da je Pavao nedorastao korumpiranosti metropole. Naprotiv, on je stiliziran kao tjeskobni melankolik koji, i prije nego što je uopće pošao u svijet, živi uzoran pesimizam šopenhauerovskoga podrijetla prema kojem je, ,život čovjeku neizreciva muka; da o njoj uvijek mislimo, zavoljeli bi smrt i zahvalili se tom daru, što se život zove“ (Novak, 1931: 51). Tegobno obgrljen dobro „poznatim strahom, nekim neobičnim, bolesnim stanjem duše" (ibid.: 117), bolno će osvijestiti vlastitu neprilagođenost, nepotrebnost i neupotrebljivost znanja u aktualnim okolnostima, težnju nekim višim istinama koja ga je spriječila da živi u praktičnoj svakidašnjici, sumornu osamljenost i otuđenost od svijeta te pogibeljnu suvišnost društvu u koje se želio uklopiti. Potrošen i poslovično umanjene snage, kažnjavajući sam sebe zbog pokušaja uspostave sebstva daleko izvan topline rodnoga doma, neće ni pokušati pronaći neku uporišnu točku nakon povratka u zavičaj, premda će saznati da 
ga Evica čeka. U idili zavičaja priznat će svoj poraz. „(...) sad je propalica, bjegunac i traži rodni kraj, da tu umre, da izbriše trag svoj s toga svijeta, koji ga je prevario, otrovao mu dušu, iščupao srce i ostavio to otrcano tijelo, taj teret, što ga po svijetu nosi...“ (ibid.: 153)

No znakovito je da Novak, kako i sugeriramo otpočetka, izravnu krivnju za Pavlov rasap ne pripisuje ni Lori ni pokvarenosti velegrada, nego upravo glavnomu junaku, tj. njegovim naglašenim urođenim slabostima. Posve klonuo i asteničan, sam će Pavao poentirati:

- To si!... A što si? Otimač, ubojica! A što si mogao biti s onom dušom, koja se hvatala zlatnih zvijezda, s onim srcem, što ga je nebeska dobrota u tvoje grudi metnula! Duši si slomio krila, a srce ti otrovala razuzdana žena. Zar je ona kriva? Ne, ti sam! Zar nijesi stražar svoga života, da, ali kakav si stražar bio? Meka kukavica, svačijim daškom topila bi se snaga kao vosak, pa kad si se htio staviti, da braniš u sebi čovjeka, svoj značaj, svoju volju, - onda su ti prvim udarcem izbili oružje, ti si pružo ruku: - Na, vodite me kao slijepca kod zdravih očiju!... I vodili su me, i evo me na kraju... (...) A živjeti? Ovako? Ta to je gore od smrti... (ibid.: 161-162; isticanje naše)

Prema tome kad u Slavićeva usta stavlja procjenu tipičnih problema mlade generacije, Novak se priključuje findesiècleovskoj liniji tumačenja dekadentnih karaktera u kojih su afektivna stanja poput melankolije i tjeskobe temelj ličnosti. Kako smo i pokazali, „emocionalna patnja tako svojstvena melankoliji i depresivnoj subjektivnosti, barem onako kako se ona raspoznaje na Zapadu, može biti medicinski simptom, ali i puno više od toga“ (Radden, 2009: 12). Ona možda jest oznaka pojedinca, ali je nedvosmisleno i oznaka vremena. I u Šegotinu se slučaju emocionalna stanja duboke potresenosti mogu protumačiti u okviru teorije koja subjektivnost smješta u središte identiteta te sa stanovitim civilizacijskim vrijednostima koje propisuju „normalno“ i patološko žalovanje. Naime kao što upozorava Radden, žalovanje je društveno sasvim primjeren odgovor na gubitak s kojim se pojedinac može suočiti, dok naprimjer u onoga koji ne žaluje primjećujemo nešto gotovo abnormalno (ibid.). A budući da vjerojatno nijedan aspekt našega mentalnog života nije bitniji od osjećaja, za zaključiti je kako biti čovjek znači patiti. Međutim patiti na pravi način znači stvoriti preduvjete za ispravno djelovanje. Zato ne iznenađuje što prekomjerna sjeta onemogućuje aktivno življenje: ona u dekadenta, kako pokušavamo pokazati, sprečava svako angažirano djelovanje te ga još dublje gura u provaliju neurotične kontemplacije. Melankolija se u takvoj društvenoj klimi, koja zahtijeva iznimno snalaženje u dehumanizirajućim uvjetima i snagu odluke, 
postavlja kao esencijalno stanje, a duševna i tjelesna bolećivost, morbidna zakočenost volje i živčana razdražljivost njegove su prepoznatljive crte:

- Naša je narav nesrećna. Možda misliš, da si mi rekao nešto nova, kad si malo prije budio moju klonulu dušu, da se snova mladenačkim krilima naoruža? Sve sam to osjećao, sve to prošlo je mojoj dušom i ostalo u srcu pod zemljom ukopan spomenik... Vidiš li, takvi smo mi Hrvati: osjećamo ljepotu, plemenitost nas uznese, ali ne znamo uprijeti i drugu stranu svoje duše - volju, rad. Svaka malenkost zastraši nas, kod svake zapreke klonemo i postanemo bljutavi sentimentalci čekajući, da će nam se netko smilovati i da će se sav svijet topiti u suzama obožavajući našu bol. I kad mislimo, da je to laž, da je to bolesna utvara naše duše, kad bismo morali zasukati rukave, prenemo se svojom mekoputnosti gubeći pouzdanje u vlastitu snagu... (Novak, 1931: 88; isticanje naše)

Jedna je to od glavnih dijagnoza hrvatske inteligencije, njezinih pripadnika sumnjičave i bezvoljne naravi, koji, nesposobni osobno se i profesionalno angažirati, živote okončavaju asketskom rezignacijom, bijegom iz sredine koja ih sili na odluku ili pak prepuštanjem smrti u kojoj vide jedino utočište od bolesti civilizacije i svoga dezintegriranog ,ja“. U uvodnom smo dijelu rada predstavili degeneraciju i neurasteniju kao svojevrsne anatomije dekadencije, no nije suvišno ponoviti kako su neurastenici najprepoznatljivi po osiromašenoj energiji, što je u većini slučajeva posljedica prekomjernoga negativnog utjecaja modernoga društva na njihovo zdravlje, te se zato oni primarno određuju kao slabići volje. Ili, Durkheimovim riječima, „bez obzira na to ima li je previše ili premalo, energija koja se ne troši kroza svrhovit rad jest energija koja se rasipa, generira slabljenje, stres i socijalnu napetost“ (cit. prema Jervis, 2015: 62). A neovisno o različitim tumačenjima moždanoga sustava te unatoč tomu što ne postoji znanstveno prihvaćen model ljudske energije (Schaffner, 2016: 15), može se istaknuti da je za fin de sièclea vladao konsenzus oko važnosti živaca koji kao spona između tijela i vanjskoga svijeta prenose osjete do mozga te usklađuju funkcioniranje organizma. Središte koncepta neurastenije zauzima tako, da se poslužimo Deschampsovom usporedbom, predodžba organizma kao rezervoara energije koji pokreću „moždani valovi“, srodni elektromagnetskima, a koji osiguravaju dostatnu dozu energije u tijelu (prema Rabinbach, 1992: 164). S obzirom na tu vezu posve je očigledno da svaki živčani poremećaj utječe i na tjelesni sustav, jednako kao što svaki tjelesni poremećaj djeluje na živce. Da bi održavali tjelesne funkcije, živcima je potrebna dovoljna količina energije. Međutim kad ona izostaje, govori se o asteniji, tj. općem opadanju snage i iscrpljenosti. Zato se zapravo svim dekadentima kojima se u disertaciji bavimo može 
dijagnosticirati neurastenija, živčana slabost usko vezana s problemom volje, odnosno njezina zakočenja. Svi su naime odreda stilizirani kao tjeskobni abuličari (uz, naravno, iznimku Lovre, kojega smo s razlogom postavili kao preteču) te pritom u nekima od njih kao povod bolesti prepoznajemo, kako i argumentiramo u ovom poglavlju, velegradski život.

Jedan od autora koji se u vrijeme kad se pišu te proze izdvojio svojom teorijom neurastenije te je - prikladno našemu inzistiranju na morbidnoj iscrpljenosti i nevjerojatnoj nemogućnosti dekadenata da doista djeluju, da se ,pokrenu“ - povezao s voljom bio je Théodule Ribot. Predstavljajući u svom pregledu Bolesti volje (1884) volju kao najviši stupanj fiziološkoga i moralnoga razvoja, njezinu patološku suspregnutost, abuliju, definira kao nemogućnost pojedinca da svoju želju za djelovanjem pretvori u sam čin. U svakom se voljnom činu, kako pokazuje, krije proces dvostruke prirode: „stanje svijesti, 'Ja hoću', koje označava situaciju, ali samo po sebi ne znači realizaciju“ i ,,složen fizičko-psihološki mehanizam u kojem počiva moć djelovanja ili obuzdavanja“ (Ribot, 1896: 2). A u tom je kompleksnom procesu najbitnija želja kao spona između refleksa i voljnoga čina. Željeti, tj. htjeti znači djelovati te se zato htijenje može odrediti kao kamen temeljac svake egzistencije. No za neurastenika je ključno što on načelno želi djelovati, ali mu nedostaje snage. A s obzirom na to da se u njega „ja hoću“ ne uspijeva ostvariti u voljnom činu, ugroženi su sami temelji njegove egzistencije. Za potvrdu te vrste inhibicije Ribot iznosi slučaj iz prakse Etienna Esquirola, jednoga od utemeljitelja francuske psihijatrije, koji kao uzor abulije iznosi obrazovanoga suca, frustrirajuće svjesnoga svoje nemogućnosti djelovanja. On naime zna da bi trebao djelovati, ali djelovati ne može. Nemoguće je u tom opisu ne prepoznati neke temeljne crte lika hrvatskoga dekadenta:

„Sigurno je“, rekao mi je jedan dan, „da nemam volje osim ne-volje; jer za to imam svoje razloge; znam što bih trebao raditi; ali izdaje me snaga kad bih trebao djelovati.“ (ibid.: 29; isticanje naše)

Dakle neosporno je da su već sa Šegotom koji se, predisponiran za taj poremećaj, iz velikoga grada kao prostora ,radikalne drugosti i otuđenja koje djeluje negativno na sebstvo“ (Durić, 2009: 85) vraća kao neurastenik, uspostavljeni čvrsti dodiri između neurastenije i književnoga mita o „bolesnim“ intelektualcima, što će se u velikoj snazi proširiti i u kliničke slike drugih likova.

$$
* * *
$$


Mračnu viziju europske metropole prepune pojedinaca koji u narcističkoj okupiranosti sobom ganjaju isključivo vlastitu korist, a koja kao prostor društvenoga otuđenja negativno djeluje na neprilagođene ličnosti, nakon Novaka preuzeo je i Nehajev, kreiravši na samom početku XX. stoljeća u pripovijetkama Veliki grad i Zeleno more likove koji se neuspješno nose s vlastitom hibridnošću, raskoljenošću između nacionalnoga i kozmopolitskoga. Oba glavna junaka materijaliziraju pravu modernističku urbanu otupjelost koju smo predstavili kroza Simmela, zauzimajući pozicije dekadenata izrazito svjesnih svoga stanja, što bi prema Nietzscheu trebao biti put za nadvladavanje dekadencije. Međutim opterećeni baštinom svoje izvorne okoline te onemoćale volje, ne uspijevaju svijest o propadanju razviti u novo postojanje.

Studijski boravak u Beču te kontakt s bečkom modernom, a posredno i s ostalim europskim koncepcijama, nedvosmisleno su odredili podlogu Nehajevljeve poetike. Osim što su bili bitni u nadogradnji njegova književnoga profila nakon početničkih uradaka, bečki su fenomeni djelovali i na autorovu psihičku dispoziciju. Razvijajući se u atmosferi koju je označila orijentacija prema čovjekovu intimnom svijetu, Nehajev je prozama u kojima tematizira depresivne, izgubljene i razočarane pojedince koji, usprkos iznimnim kvalitetama, padaju kao žrtve individualne i kolektivne sudbine, nastojao ponuditi što vjerniju sliku epohe. Uvjeren da je čovjek modernoga doba pritisnut tragikom civilizacije, ali i objektivnom hrvatskom stvarnošću, za protagoniste je odabirao „osobe slabe volje, napetih živaca, utonule $\mathrm{u}$ sumornost, hamletovske prirode mučene sudarom plemenitih uzbuđenja i stvarnosti“ (Zaninović, 1964: 16). Zato će kritika i pozdraviti njegovu sintezu nacionalnoga i kozmopolitskoga, „narodnog duha i univerzalne misli“ (Šicel, 2005: 281). Svi su njegovi likovi u europskim metropolama iskusili bolećivu pasivnost, jedan od osnovnih biljega razdoblja, te svijet promatrali u impresionističkoj blaziranosti. Mada je svoju opsesiju takvim licima eksplicite izrazio u proznim djelima, ništa manje nisu važni članci i studije (ponajprije o Leskovaru i Hamletu) u kojima je razotkrio vlastite teorijske i filozofske postavke. A tom je prilikom kao misao vodilju postavio jednadžbu prema kojoj je moderan autor onaj koji vjerodostojno ilustrira duh vremena. Tako je, navodimo kao primjer, baveći se Hauptmannovim i Ibsenovim dramskim opusom, elaborirao da pisci trebaju obratiti pozornost na suvremene psihičke dispozicije, poglavito na čovjekova duševna zbivanja, te kao ključno obilježje modernoga junaka izdvojio „ono čuvstvo polovične snage i polovičnih rezultata - ne snage opće čovječje koja se lomi u borbi s protivštinama života - nego snage specifično moderne, prirođene i prirasle čovjeku naših stečevina, snage preslabe da po njoj individuum, otvorenih očiju za produkte današnje znanosti i današnje kulture, podnose veličajnost i ogromnost njihovu“ (Nehajev, 1964b: 58). Dakle sve ono što će i sam upisati u psihografiju svojih likova. 
Raspoloženje epohe Nehajev je tek naznačio u proznoj skici Poloneza (1902), u kojoj glazbenik Mihaljević, utapajući se u dosadnoj svakidašnjici u čuvstvu neobjašnjive praznine, rezignirano sanjari i, tako karakteristično dekadentno, priziva u sjećanje davne uspomene kojima se podaje poslušno i mazohistički radoznalo. Neki od bitnijih motiva dekadentnoga repertoara već su tu: mekoputost i tjelesna krhkost, izrazita sklonost prisjećanju, uživanje u sumornoj atmosferi te hedonističko prepuštanje umjetnosti koja zamjenjuje praznu egzistenciju. Mlad čovjek star kao da je proživio sto života.

Njegova meka narav (on je u sebi zbilja bio posve drugčiji nego što se pričinjao ljudima) razumjela je i poimala svaku tu notu ne samo osjećajem glasbenika. (...) Borba sa neumoljivim, okrutnim udesom, nevjerovanje u sama sebe, - muke nezadovoljnih sanja, koje tako ljuto razaraju život, u krikovima glasbe i u bolestnoj ljubavi nalazila oduška. (...) I nad svim tim užitak u toj samoj boli, žrtva umjetnika, koji iza svega toga može da se još savlada i da svet te boli svietu poda, da ih u svoju glasbu prelije, da sebe žrtvuje - umjetnosti i ljepoti. Propaćeni, izlomljeni život živi u svakom glasu njegovu - jad čovjeka, koji ništa više ne može da traži ni da ima. (Cihlar Nehajev, 1944a: 11-12; isticanje naše)

To iskustvo mladoga starca, njegovo preplavljujuće čuvstvo ništavnosti i tjeskobne samoće razradio je potom Nehajev u Velikom gradu (1902). Oslikavajući posljednje dane Frana Mirkovića, prikazuje njegov slom u stranom svijetu, koji razotkriva agoniju čovjekova otuđenja kao odraza urođene patološke inertnosti, ali i pokazatelja krize suvremene civilizacije. Grad je naime i u ovom djelu i mjesto imaginacije i mjesto reprezentacije (Bridge i Watson, 2003: 7), prostor aktualizacije sebstva koja se izjalovljuje zbog emocionalne i fizičke izolacije. A izolacija se realizira kao povlačenje iz djelatnoga života, odnosno pasivno podnošenje sudbine. Vratimo li se pak na osamljenost pojedinca tijesno prepletenu s problemom tjeskobe $u$ modernom društvu, pa i u gradskom prostoru koji nam je ovdje u fokusu, možemo primijetiti da je osamljenost upravo neka vrsta alijenacije. Biti alijeniran znači osjećati nedostatak povezanosti s ljudima, ali i s načelima jednoga društvenog sustava. Zato se dekadencija svih ovih likova prepoznaje kao opterećujuća svijest o nepripadanju, koja se radikalizira jednom kad zakorače u urbano. Budući da otuđenje implicira razdvajanje, odnosno prekidanje, znači da se gubi nešto što je svojedobno postojalo. Opet je prema tome riječ o melankoličnoj poetici gubitka koju je moguće dovesti u vezu s njihovom dominantnom pasivnošću i inhibiranošću volje. 
Bilo je to lice muškarački nepravilno i gotovo lijepo. Fino čelo i jaki, koščati nos davali su mu nešto snažno, gotovo otmjeno. Koža je njegova bila neke čudne žute boje - ali da nije bilo nabora na sljepočicama i uvučenih kostiju na obrazima, ono bi se moglo pričiniti mladim, sa svojim obrijanim podbratkom i gotovo ženskim ustima. No i neka tromost, neki mrtvi mir počivao je na tom licu, jednako kao i na čitavom držanju Mirkovićevu. Oči su mu bile potpuno bez sjaja - sivozelene, nisu se gotovo ni okretale ispod dugih trepavica. (...) I kao uvijek, tako se i sada neki ironični posmijeh dizao u njegovoj duši - on je kao s nasladom promatrao propalost vlastite prikaze. (Nehajev, 1964: 286; isticanje naše)

Apatično nezainteresiran za svijet i ljude oko sebe, Mirković je, preuzevši sve velegradske kodove socijalizacije, nakon jedanaest godina u Beču svoj život sveo na ustaljene mehanizme koji mu osiguravaju emocionalnu i socijalnu ravnodušnost. Da bi, negdje na pola puta između velegradskoga luksuza i prave njegove bijede (i u ovom smislu u procjepu), kao čovjek „koji ništa više ne čeka i ničega ne želi“ (ibid.: 295), uhodano njegovao svoj mir:

Ujutro spava do dvanaeste, odlazi na sveučilište i šeće četvrt sata po auli, zatim ide na objed, pa u kavanu, pa na večeru, pa opet u kavanu. Iz dana u dan; on ima određen broj cigara koje popuši, određenu napojnicu koju daje konobarima, određen mjesečni dug kod svih ljudi od kojih nešto treba. Frane Mirković ima potpuno određen čitav život. Danas kao i sutra; zna da se to ne mijenja i otuda njegov mir. (ibid.: 281-282)

Postavio ga je Nehajev kao tipičan primjer čovjeka zapaloga u životnu rutinu, koji u njezinoj izvjesnosti zrcali vlastitu neautentičnost. Svojevoljno isključen iz mišljenja svijeta, Mirković materijalizira ničeovsku ne-volju za moć dok se prepušta opijajućoj svakidašnjici koja, suprotno svakomu vitalizmu, gasi želju za originalnom egzistencijom. Tu neautentičnost možemo povezati s činjenicom da se grad i u tom antiurbanom imaginariju određuje kao „mjesto anomalije, otuđenja, korupcije, bolesti, nemorala, kaosa, zagađenja, prenapučenosti i prijetnje društvenom redu“ (Bridge i Watson, 2003: 15), odnosno u svojoj složenosti i nemjerljivom mnoštvu osjetilnih dojmova kao prostor potresne desubjektivacije. Urbanost je doista početna i završna točka protagonistova identiteta: u grad je došao na studij ne bi li se uspostavio i osmislio si život, a onda ga je taj isti grad dezintegrirao do krajnjih granica. Zato je Mirković izvrsna ilustracija Simmelove teorije urbane kulture u kojoj se inzistira na nerazdruživom spoju psihičkoga života pojedinca i zasićenja fenomenima moderne metropole, što pak rezultira specifičnom otupjelošću. U pravu je prema tome kritika kad jednoglasno procjenjuje da se na taj način autor, oblikujući pozitivistički, taineovski predestinirana junaka, 
„približava naturalističkom shvaćanju da sredina (milieu) određuje čovjekovo ponašanje pa se nameće usporedba s romanima u kojima 'prostor' postaje junak zbivanja“ (Flaker, 1995: 78). To je, uostalom, i sam Nehajev izrijekom konstatirao kad je, pišući o Leskovarovoj modernosti, utvrdio da je za umjetničko stvaranje najvažniji Taineov milje, ,tj. ono što umjetnik ima zajedničko s misaonim pokretima svoga vremena“ (1964a: 65). A taj misaoni pokret bila je, elaborirali smo, ideja dekadencije.

Nije međutim riječ samo o tome da Mirković propada u gradu jer on dovodi do raspada uvriježenih moralnih načela i stabilnih međuljudskih odnosa nego i o tome da završava poražen zbog velike želje da dokine svoje dotadašnje ,ja“ i uspostavi drugo. U objema se Nehajevljevim pripovijetkama, kao i u Novakovu romanu, zorno izlaže da se svako istrgnuće iz prirodnoga habitusa, kojim se protagonisti suočavaju s gubitkom duhovnoga i životnoga središta, mora na neki način sankcionirati. Potreba da se bude moderan kozmopolit sukobljava se s nacionalnim identitetom i percepcijama, koji pretpostavljaju čvrsta, ustaljena egzistencijalna pravila. Mirkovićevo nastojanje da se izdigne iznad ograničenja provincije i osvoji metropolu, da dokine proturječje u kojem se našao te prestane biti provincijsko dijete i napokon postane svjetski čovjek, razlog je zbog kojega će naposljetku i umrijeti. On je dekadent necjelovita identiteta koji će, slično kao i Šimunovićev Stanko Lukavac, ostati na pola puta, ni tu ni tamo. Neće se moći vratiti u svoju prirodnu okolinu niti će se uspjeti uklopiti u novu, što će nam omogućiti da primijetimo kako takvi likovi iseljenika čine zasebnu kategoriju likova, mladića koji su na studije odlazili u Europu, najčešće u Beč ili Prag, te su kapitulirali pred životom ne mogavši se prilagoditi nijednomu kontekstu, ostavši „u 'rascjepu' između ponuđenoga europskoga kulturnoga modela koji, izgleda, nisu bezostatno usvojili, i vlastitoga, domaćega, hrvatskoga, koji nisu bezostatno napustili“ (Milanja, 2011: 867-868). Njihova podvojenost simbolizira i ideološka ograničenja hrvatskoga nacionalnog prostora unutar Austro-Ugarske Monarhije. Hrvatski se prostor naime u fikcionalnoj prostornosti „,pretvara u mjesto podvojenog osjećaja pripadnosti ili zatajenog navlastitog identiteta“ (Čuljat, 2012: 215). Odnosno, procjenjuje Lasić, i Mirković i Grančarić skončat će poraženi

jer su željeli apsolutno ukinuti svoje nacionalno biće i postati Evropljani. Oni su specifično hrvatski „les déracinés“. Nehajev ovim novelama poručuje ono isto što i svojom cjelokupnom aktivnošću ovih godina: ljudsko i istinsko rješenje hrvatskog intelektualca jeste u tome da ostane hrvatski intelektualac. A to znači da bude sinteza suprotnih polova. Tjeskoba. Sloboda (1967: 79). 
I zato će sve u ovoj pripovijetki, nakon izložena privida savršeno organiziranoga života, biti podređeno predstavljanju toga iznevjerenog očekivanja. No unatoč tomu što se Mirkovićev neurasteničan nedostatak volje i pomanjkanje snage za promjenom donekle može opravdati borbom s modernim građanskim društvom, osobito „nelagodom u kulturi“, jasno je da klice njegove intimne tragedije leže u njemu samom. Mirković je izrazito svjestan svoje pozicije dekadenta te nastoji otkloniti sve što bi mu moglo poremetiti ustaljenu rutinu u kojoj vegetira prema načelima pukoga automatizma. On zapravo demonstrira što bi se dogodilo s dekadentima da se od započetoga procesa osobne fragmentacije pokušaju skloniti u učmalost i iluzoran spokoj. Za dekadenciju, osim čvrstoće volje i snage odluke, lijeka jednostavno nema. U svom makinalnom miru glavni lik tek naizgled pronalazi zaklon od uspomena - „Samo nikakvih uspomena - samo nikakvih slabih časova!“ (Nehajev, 1964: 285) - od sindroma prošlosti tako svojstvenoga dekadentnom imaginariju te se predstavlja kao subjekt kojemu je kopanje po vlastitoj unutrašnjosti, za razliku od drugih likova, iznimno neprivlačno: „,...) opet me smetate u mom miru, opet me silite da prekinem odabrani mehanički način svoga života, opet hoćete da mislim o sebi i o drugima, opet mučite mene i sugerirate mi grižnju savjesti i nervoznost.“ (ibid.: 284) Mirković odbija egoističnu autoanalitičnost jer je svjestan da ona, kao što i nastojimo elaborirati kroz cijelu disertaciju, dodatno izolira. Dekadencija je ta koja, kao neka vrsta bolesti u smislu ispadanja iz poretka pravilnosti građanskoga društva koje želi umjerenost i stabilnost, alijenira od drugoga, od zajednice, motivirajući onoga koji od nje boluje da je promatra drugim, prodornijim očima. Zato ona i jest dvostruka realnost, privilegij i nedostatak.

Mirkovićev se otpor prirođenoj bolećivosti slama onoga trena kad prima majčino pismo kojim se, jer ga podsjeća na „pravu“ pripadnost, simbolično urušava „sva ta umjetna zgrada upokojenja“ (ibid.: 296) te iz ljušture izlazi prepoznatljiv dekadent, neodlučan melankolik koji ne zna

što da odluči? Što da učini? (...) sva neodređenost i neduševnost njegova života padala i lomila se pod teretom bola koji se godinama i godinama zatajivan bio sakupio u srcu. Ne, što da učini, o tom nije mogao da misli. (ibid.: 287)

A zatim se kroz analeptičko pripovijedanje, koje u svim prozama iz našega korpusa $\mathrm{i}$ metaforički konkretizira tipično dekadentno prebiranje po prošlosti, traga za etiološkim uzrocima njegove propasti te se otkriva da su i prošlost i stanovite predestiniranosti upisali svoje tragove u sadašnjost. Odmalena talentiran i radoznala duha, djetinjstvo su mu osobito definirala ograničenja odgoja, pri čemu „očeva strogost kao i majčina ljubav u njem ugušiše svaki 
strastveniji poriv“ (ibid.: 289). Ne zaboravimo, obitelj je „psihološki agent društva“ (Elliott prema Durić, 2009: 90) te se korak po korak okovi obitelji projiciraju na okove društva kojima se, potpuno trom i bezvoljan, također neće uspjeti othrvati. Osim toga kao nadopunu navedenomu tumačenju valja priključiti i razmatranje provincije kao mjesta $u$ kojem zadovoljenje, u svakom pogledu, treba odložiti, odnosno ograničiti. Mirkovićeva je rana mladost dakle bila obilježena obuzdavanjem nagona koji su u punoj snazi provalili kad se iz provincijske sredine izmjestio. „Ako je na selu potiskivanje jamčilo određenu mjeru sigurnosti, onda je grad kao područje koje karakterizira odsutnost potiskivanja (...) lokus koji označava nesigurnost, a time i spomenuto lomljenje individualne svijesti.“ (ibid.: 89) Ili kako će potvrditi Nehajev: „Fran nije mogao da se stegne - njegova zatomljena narav morala je da prodre. Bile su to sitnice: jedna noć, probdjevena uz karte, jedan izlet na kojem smiješ da se raskalašiš po volji - i sto sličnih zabava kojih do sada nije poznavao.“ (1964: 289) Uza sve to i na Mirkovićevu će se primjeru pokazati da likovi jednom izdvojeni iz lokalnoga i regionalnoga okružja vrlo teško usmjeravaju svoju darovitost.

Prema tome i u ovom slučaju, kao, uostalom, i u Pavlu Šegoti, grad u duševnom i moralnom smislu predstavlja civilizacijsku regresiju jer se u njemu zatire svaka potencijalna individualnost. Mirkovićevo propadanje i postupan gubitak vrijednosti potencira se i maničnom željom za apsolutnim obuhvaćanjem svega znanja, što dodatno apsorbira njegove ionako malaksale životne snage. Pritom nije nimalo nebitna činjenica da se, napuštajući studij konkretne znanosti (medicine), „stao baviti ostavljenim diletiranjem umjetnosti“ (ibid.: 291). Jer, kako ćemo primijetiti i u sljedećim poglavljima, dekadentna se osjećajnost može tumačiti i u ključu pojačane umjetničke senzibilnosti.

Zato je, s obzirom na sve istaknuto, posve jasno da je Mirković kroz privid mira sam sebe nastojao zaštititi, mučno svjestan krhkosti iluzije blaziranosti koju je dugo i mukotrpno gradio. Prolazeći različita misaona i duševna razdoblja, grad je isprva nastojao apsolutno osvojiti, nadvladati ga u prvim borbenim, aktivnim fazama, od kojih je ostala tek poražavajuća ideja u kojoj se, kako je vjerovao, krila formula opstanka: „,...) 'treba se pokoriti'. To je postala njegova omiljena rečenica. Treba se pokoriti, treba mirno i razumno urediti život. Čemu da se dalje brine?“ (ibid.: 294). Ta se misao, izražavajući „terapijski nihilizam“ prema kojem se stvari apatično prihvaćaju baš onakvima kakve jesu, razvila iz simptoma duševne bolesti, neurastenije kao nusprodukta velegradske napetosti, života opterećena prekomjernim užitcima. „Od takva života oslabi, postane nervozan i razdražljiv; napokon dobije strah od samoće. Bojao se sam ostajati u sobi, osjećajući da bi se mogao ubiti.“ (ibid.) Razdraženi će ga živci, nesposobni za nove podražaje, naposljetku i dovesti do otupjelosti. 
Pa tako u raljama Beča, koji ga je dezintegrirao i smlavio, ugušio svaku mogućnost individualnoga uspjeha koji se ne temelji na pukim materijalnim aspiracijama, postupno evoluira u izoliranoga jadnika te toliko bolno osjeća vlastitu propalost i besperspektivnost da se predaje bijesnoj melankoliji, generalnoj slabosti duha i tijela, postajući paradigmatskim modelom dekadenta koji se, dok razmišlja o uzrocima vlastita nestajanja, pita:

(...) tko je kriv svemu tomu, tko ima da odgovara što je on tako - propao? Da je propalica, bivalo mu je u dnu duše sve jasnije - no jednako je nastojao da pred drugima zadrži dekorum staroga đaka. Tko je kriv? - pitao se uzalud, a nije nalazio odgovora. Da li odgoj njegov, vruća krv i nagla narav? Da li njegov preveć živahan duh? Ljubav njegova i njegovo nestegnuto uživanje slobode? Ne, nitko nije kriv - samo je sve tako došlo. (ibid.; isticanje naše)

Patološki zapriječene volje kojom bi nešto u životu promijenio, kao pravi neurotik Mirković kultivira nepokolebljiv fatalizam, vjerujući da se stvari odvijaju upravo onako kako i trebaju. Za svoju dekadentnu propast, jednako kao i „brat“ mu Grančarić, on pronalazi savršeno opravdanje, pa će za tjeskobu pred beznačajnošću života, koja ga sprečava da se uspostavi kao cjelovit subjekt, okriviti sudbinsku neminovnost. U identitetskoj neurozi svoju nemoć konkretnoga djelovanja on objašnjava nekom apstrakcijom nužnosti.

To korištenje nužnosti kao alibija dovedeno je do savršenstva u kliničkoj slici Hektora Grančarića iz Zelenoga mora (1903), još jednoga letargičnog dekadenta koji se, proživjevši mladost u internacionalnim društvima, prepušta rezigniranomu promatranju života: „(...) najprije smrt otčeva, onda računi, pa onaj čudnovati način života, - sve ga je to učinilo pretromim, da se poda ikakvom jačem čuvstvu.“ (Cihlar Nehajev, 1944b: 66) Kao što smo dosad pojasnili, stimulacija živčanoga sustava nigdje nije toliko intenzivna kao u metropoli, u kojoj je čovjek prisiljen štititi svoj integritet i autonomiju pred nasiljem društvenih sila. A u takvim uvjetima snažnoga pritiska, ponovimo, kao jedinstven tip izranja pojedinac čija je psihološka baza fundirana na intenzifikaciji živčanoga sustava, sastavljenoj od nagle izmjene vanjskih i unutarnjih dojmova. I tako se rađa jalov, isprazan neurotik Grančarić koji baš poput Oblomova jedva ustaje iz kreveta:

Kao svaki dan, Hektor se Grančarić i danas nekoliko puta sjetio Oblomova. I premda nije „izpitivanje savjesti“ (tako je on nazivao razmišljanje o samom sebi) bila njegova navika, Grančarić se je i protiv volje nekoliko puta gorko nasmijao u sebi. Pa tko bi bio uistinu pomislio, da će on, on, isti Grančarić, koji se je već bio priviknuo nekom urednijem, ako i ne odviše brzom, 
životu čovjeka od trideset godina, iza tri mjeseca boravka kod kuće spasti na to, da ovako u kvietističkom ležanju ubija nekoliko sati dana, u gotovo tmičnoj ovoj sobi, koju tako sigurno od svietla štite zavjese. (...) Čemu da se miče, da ustaje - ta ovdje je tako, tako voljko. (ibid.: 54 $55,56)$

To psihološko „otvrdnjivanje“ volje u osoba prisiljenih na proživljavanje velegradskih napetosti mehanički je odgovor na disperziran pritisak moderniteta, odnosno neka vrsta zaštite sebstva. Međutim Grančarić, oblomovski nepoduzetan i nepokretan, nakon povratka u rodnu kuću polagano srasta s tamošnjim nedinamičnim ozračjem te se prepušta oživljavanju uspomena. Početna mu je točka dakle istovjetna Mirkovićevoj. Zatječemo ga isto u psihičkoj i tjelesnoj inerciji koja je rezultat razuzdanoga života i jedinstvenoga genetskog koda, a koja će ga u okolnostima prirodnoga okruženja (u koje se vratio saznavši za obiteljsku financijsku propast) prisiliti na spoznaju egzistencijalnoga besmisla. „Ta je samospoznaja, ispit sebe, izvršena i u specifičnoj atmosferi i u momentu koji bi mogao biti prekretnica." (Lasić, 1967: 82) No premda će ga primorati na pogled u sebe, neće to biti nikakva prekretnica, nego samo dodatna stabilizacija dekadentne otupjelosti.

Poput ostalih protagonista, Grančarić je bio nadaren dječak te je imao perspektivnu, materijalno osiguranu budućnost. Ali, spletom okolnosti, plahi mladić s početka studija, prolazeći kroz najraznovrsnije poroke jednoga velegrada te se praktično suočavajući s različitim životnim filozofijama (od radikalnoga cinizma i nihilizma preko avanturizma do epikurejstva), s vremenom je postao čovjek koji o životu samo razmišlja:

A nije imao ni volje ni snage, da samo i pokuša rješavati taj zadatak. Ta kako bi! Kako će se on moći naučiti na ljude, s kojima se je bio razkrstio - kako da se odreče načina života kozmopolitskog, kako da se zabije ovdje negdje - u ta gniezda, koja su ga plašila samom svojom tišinom! (Cihlar Nehajev, 1944b: 79; isticanje naše)

Grančarićeva abulija, kao jedan od glavnih simptoma neurastenije, objašnjiva je i dosad apostrofiranom opozicijom grada i manje sredine, u kojoj bi iskorijenjeni intelektualac napokon trebao uspostaviti svoj identitet. No Grančarić iznevjeruje i to očekivanje jer će se ispostaviti da ni na koji način ne može nadići taj raskorak koji „funkcionira kao prostorna metafora za obesnaženo djelovanje raslojene osobnosti““(Čuljat, 2012: 178). Tako da se u toj prozi briše jasna distinkcija između provincijskoga i velegradskoga, koju smo susreli u prethodnim dvama tekstovima: glavni se lik toliko fragmentirao da nije ni provincijalac ni građanin te, za razliku 
od Šimunovićeva Stanka Lukavca, koji iskazuje barem načelnu namjeru pronalaženja vlastitih korijena, ostaje dokraja izgubljen čovjek. „Hektor Grančarić posve je ukinuo svoju prošlost i postao kozmopolita, ali njega je grad preplavio - on više nema doma.“ (Lasić, 1967: 81)

„Od prirode meka i bistra narav“ (Cihlar Nehajev, 1944b: 67), opet dakle na neki način predisponiran za propast, u životnoj potrazi za svojim ,ja“ postao je neurotikom, što je neizbježan ishod tjeskobne rascijepljenosti ličnosti. Nakon godina i godina u inozemstvu nije se uspio realizirati ni na profesionalnom ni na ljubavnom planu, pa je ostao „napola umjetnik, napola žurnalista, napola liečnik, - pače i napola čak i muž svoje žene““ (ibid.: 79), pravi suvišni čovjek koji glavinja od jedne aktivnosti do druge, što se može čitati u ključu činjenice da neurastenija doista jest bolest volje i nesposobnost odluke. Živci naime nisu samo izvor boli nego i htijenja i emocija, iznimno osjetljivih na vanjske podražaje. I zato Ribot, kao što smo protumačili, neurasteniju određuje primarno kao funkcionalnu patologiju strukturiranu oko nemogućnosti djelovanja, proširujući na taj način Beardov koncept toga poremećaja kao nedostatka moždane snage. Ona je poremećaj volje koja nema dovoljan kapacitet za usmjeravanje pojedinca u ciljanom pravcu. Pa se zbog toga Grančarić, nesposoban konkretno djelovati i usmjeriti si život, ovaj put suočen s financijskom nesigurnošću te bez izgledne budućnosti, u roditeljskom domu odlučuje prepustiti nekim nejasnim sudbinskim silama koje mu upravljaju životom. Spašava se Mirkovićevim lijekom, utapajući se u monotoniji svakidašnjega te promovirajući fatalistički determinizam s glavnim motom „Ne uzrujavati se i odgađati rješenje“ (ibid.: 80). Pritom zbacuje odgovornost sa sebe te uzroke urođene bolećivosti i mentalne slabosti pronalazi u nečemu izvan sebe samoga. U životu se sve odvija prema unaprijed zapisanom slijedu događaja te se u skladu s tim na njegov tijek ne može utjecati, pasivno zaključuje i naposljetku poentira:

Nije ga zadovoljavala misao, da je „slučaj“ kriv - Grančariću je postalo nekom potrebom, da sve to izjasni - sredi - da ima neka drama, novela o tom - što li... I nejasni, nesigurni osjećaji redali se zbilja u njegovoj duši. Tri mjeseca nesaveznog razmišljanja urodilo je ipak nečim jasnim i logičnim, kako mu se činilo - i Grančarić, ne nalazeći snage, da se opre zlu, što ga je snašlo, zadovolji se time, što je u sebi vidio žrtvu nečega slabo poznatoga i nejasnoga. (ibid.: 81)

A u tom mu prebacivanju odgovornosti osobito pomaže očevo samoubojstvo, što će ga natjerati da zaključi kako u sebi oduvijek nosi klicu vlastite propasti te da se predodređenom slijedu zbivanja ne može odupirati. Njegova je neuroza prema tome degenerativno naslijeđe. 
Mi smo prvi, koji smo pali žrtvom dodira s tim, što dolazi iz daljine. I otac, kojemu je iz te daljine došla požuda za spekulacijom, i ja, kojega je ta daljina učinila nesposobnim za život. Ne radi se samo o novcu, ne, - radi se samo o tom, da sam ja morao pasti, jer prvi uviek padaju u bitci... (ibid.: 84; isticanje naše)

No Grančarić se neće ubiti, nego će blazirano nastaviti s prijašnjim životom. Za razliku od Mirkovića koji će u manijakalnoj agoniji, kao posljednjoj stanici vječnoga drhtanja živaca, dospjeti do uvjerenja da je za sve kriv velegrad te konačno spoznati da je nemoguće postati njegovim dijelom i na tom putu održavati zdravo i stabilno ,ja“. Od goleme želje da pokori urbanost neće mu ostati ništa; prerast će u pokorenoga čovjeka, „bogalja i slabića“ (Nehajev, 1964: 297) izgubljene mladosti, koji će život okončati pod kotačima tramvaja.

$\mathrm{S}$ obzirom na to da je problematika samoubojstva nezaobilazan segment hrvatske dekadencije, vrijedi napomenuti da je samoubojstvo, posljednja točka čovjekove patnje, specifičan aspekt neurastenije. Kako smo dosad objasnili, ona se smješta negdje između mentalnoga otuđenja i savršene ravnoteže inteligencije. Neurastenik nije, suprotno uvriježenomu mišljenju, lud niti je nesposoban za zdravo prosuđivanje. Naprotiv, kako i bilježimo u našem radu, vrlo je osjetljiv, rafiniran, podložan dojmovima, a moždani mu je sustav oslabljen te on kao takav nerijetko biva žrtva modernih civilizacijskih dosega. Društvena je nelagoda, prisjetimo se poglavlja o fenomenu ,životne boli“, u vrijeme fin de sièclea postala gotovo opipljivom te se bez zadrške možemo složiti s Minoisom kad kaže da „nije riječ ni o kakvoj naknadnoj povijesnoj izmišljotini: 'životna bol' u drugoj polovici XIX. stoljeća doista je dosegnula nikad viđene razmjere“ (2005: 261).

Komentirajući da se u samoubojstvu na jedinstven način reflektira odnos čovjeka i društva, Durkheim (1951) utvrđuje da su upravo neurastenici predisponirani za taj čin. Naime da bi uspješno funkcionirao na svim životnim poljima, čovjeku je prijeko potrebna stabilnost, $\mathrm{i}$ to osobito u odnosu na društveni okoliš. „Čovjek se u društvu savršeno uređeno može održavati tek uz čvrstu mentalnu i moralnu konstituciju. To je ono što neuropatu nedostaje.“ (Durkheim, 1951: 15-16) U vremenu nestalnih vrijednosnih načela pojedinac, razočaran i nesiguran u postojanost vlastitih uporišta, tendira udaljavanju od zajednice, od vanjskoga svijeta, te se zatvara u sebe i meditira o sebi, njegujući na taj način radikalni solipsizam, tu specifičnu findesiècleovsku filozofiju. U Durkheimovoj analizi samoubojstva kao društvenoga fenomena tipičnoga za cjelokupnu findesiècleovsku kulturu melankolije simptomatična je tvrdnja kako su toj praksi najmanje sklone osobe čvrsto stabilizirane u institucijama koje im pružaju potrebnu podršku. Zato je podudarnost Durkheimova anomičnoga samoubojstva, koje tumači kao 
posljedicu nedovoljne integriranosti pojedinca u društvo (ibid.: 201-239), i posljednjega poteza naših tjeskobnih dekadenata otuđenih od okoline više nego evidentna. Samoubojstvo je dakle ishod nepronalaženja smisla u životu (što je također moguće čitati u ključu tjeskobe beznačajnosti o kojom smo govorili na početku ovoga poglavlja), osamljenosti i alijenacije tako svojstvenih našim likovima. Izolirani od društva, oni ne uspijevaju održavati kontakte s drugima, nužne da bi se uopće uspostavili kao cjelovite jedinke: „Zadovoljstva više ne privlače; on sve vidi kroz mračan oblak. Život mu se čini dosadan i bolan. A kako ti osjećaju jačaju, tako i ideja samoubojstva postaje kronična (...).“ (ibid.: 10)

Prigodno je zato zaključiti, uz potporu teze da se svaki obrazac sebstva može promatrati kao zrcalo društvenih procesa (Frosh, 1991: 4), činjenicom da je integritet svih ovih protagonista opasno narušen prijetnjom izvanjskih sila, koje imaju moć urušiti sva dotadašnja postignuća u održavanju vlastitoga ,ja“. Od Šegote preko Mirkovića do Grančarića, svi oni propadaju u gradu koji služi kao simbolična pozadina za beznadne snove, pa smo zato i nastojali pokazati kako njihova dekadencija nije leskovarovska, već je određena sredinom i prirodom iz koje potječu. Teško uspostavljajući odnose s drugima te gubeći iz vida vrijednost vlastita života, završavaju dezintegrirani jer (dovoljno je prisjetiti se poglavlja o neurotičnim fragmentarnim identitetima) individualno je uvijek rezultat interakcije s drugima. Opterećeni tjeskobom pred besmislom egzistencije i neurastenijom, iscrpljenom živčanom energijom povezanom is općom osjetljivošću organizma, oni nisu u stanju svoju patnju nadići te se uputiti u pravcu produktivnoga života.

\subsection{Između prirode i društva: Radmilović, Zlatanić, Andrijašević}

Apostrofirana jedinstvenost hrvatske dekadencije, u kojoj se model slaba, izrazito ranjiva i neurotična umjetnika stilizira s obzirom na aktualne društveno-ekonomske konstelacije, najjasnije je došla do izražaja u Gjalskijevu Radmiloviću, Novakovu Zlataniću i Nehajevljevu Andrijaševiću, protagonistima djela objavljenih u rasponu od petnaestak godina, koja nastavljaju spomenutu dezintegraciju realističke pripovjedne strukture. Od prvoga hrvatskog romana o umjetniku (Nemec, 1999: 207) preko Novakova o iznimnom, iznadprosječnom hrvatskom glazbeniku do ponajboljega romana naše moderne (Šicel, 2005: 193) - u središtu je odnos talentiranoga intelektualca i uskogrudne zajednice koja ne prepoznaje i ne priznaje njegovu iznimnost, odnosno pozitivističko prikazivanje s idejom determinizma u središtu. Ti su autori, može se zato reći, izravnije od drugih nastavili Šenoinu liniju sukoba 
pojedinca i društva, kroatizirajući nacionalno nedefiniranu problematiku Prijana Lovre ocrtavanjem položaja hrvatskoga intelektualca te je bitno produbljujući pogledom u intimna stanja glavnih likova koja kriju različite varijante dekadentnih dispozicija. Slijedeći koncept društvene uvjetovanosti koja čovjeka pozicionira u odnosu na njegov milje, oni promatraju njihova psihička previranja da bi razotkrili mehanizme (bez)uspješne adaptacije na tu istu sredinu.

„Austro-Ugarska je ležala na periferiji zapadne Europe, a hrvatske zemlje na periferiji te Monarhije, na 'turskoj granici' - kako se govorilo u Europi, a to je značilo na rubu i granici kultura.“ (Pavličević, 2009: 147) To je, sasvim kratko izneseno, okvir unutar kojega su hrvatski književnici bili silno nezadovoljni političkom i kulturnom podređenošću i neslobodom, što će prenositi i u oblikovanje likova; okvir unutar kojega se u književnosti crpe činjenice iz društvenoga i političkoga života. Jer književnost je, podsjetimo, ponajprije imala ,zadatak 'čitati' stvarnost hrvatskoga subjekta u njegovoj povijesnoj putanji, pa je dakle bila i sociologija, i to sve do naših dana, pa i politologija u mjeri 'čitanja' političkog““ (Milanja, 2012: 284). U takvoj se dvostrukoj marginalnosti, koja podrazumijeva kolonizacijski modalitet, kroz fatalne učinke kolektiviteta kreiraju dekadentni tipovi kako bi se predstavila epohalna kriza vrijednosti o kojoj smo pisali u prvim dijelovima disertacije. Njihov se duhovni put kontekstualizira unutar dominantnoga senzibiliteta fin de sièclea te uokviruje aktualnim društvenim okolnostima. Prema tome sva se ovdje tumačena djela postavljaju kao primjeri „politizacije“ tjeskobe u kojima glavni likovi propadaju i krivnjom primitivne provincijske sredine koja provocira njihovu tragediju. Nemogućnost da takvu zbilju nadiđu te se napokon integriraju kao subjekti obilježava, u većoj ili manjoj mjeri, sve naše dekadente, a naročito ove tipove „hamletovsko-šopenhauerovskog umjetnika“ (Milanja, 2011: 869) koje dekadencija ne vodi do epifanizirajućega otkrivenja i uspostave vlastite cjelovitosti, nego do tragičnoga završetka. Ona je osobina političke i društvene naravi te istovremeno znak njihove nemoći da to stanje prevladaju.

Oni su na taj način potvrdili izgubljenost $u$ višestrukom smislu: pokazali su da su izgubljeni $u$ prostoru društveno-političke zbilje koju su tobož prevladali, jer ona, prema njima, pripada u nižu sferu bića. Pokazali su također da ne stoje dobro ni s epistemološkim pitanjima, jer su u pojedinačnim specijalizacijama tražili ono što bi eventualno mogli razriješiti, ili barem naslutiti, bitno filozofskim mišljenjem, a specijalistička znanja nisu znali koristiti ni za epistemološku sistematizaciju koja bi im ponudila „moć znanja“ kao takvoga. Našli su se, nadalje, otuđeni i od društvena korpusa, od najbližih, prijatelja, obitelji, voljene, od staleške i nacionalne pripadnosti. 
Tako su završili ili krajnjim odnarođivanjem, kao Juraj Stipančić, ili su kao Borislavići, Pavli Šegote, završili vlastitom destrukcijom, kao i oni koji su u umjetnosti (neuspješno) kušali realizirati vlastito biće (Đure Andrijaševići ili Amadeusi). (Milanja, 2012: 259-260)

Mogućnost konstruiranja identiteta, kao neprikosnovenoga prava pojedinca, s obzirom na poistovjećivanje s jednim sustavom vrijednosti u središtu je svih tih romana. I Andrijašević, i Radmilović, i Zlatanić vode nepodnošljive živote koji ih tjeraju da se ponašaju u skladu s normom te ih možemo nazvati nenormalnima jer ispadaju iz uobičajenoga reda stvari i neprestano osvještavaju da je to svijet kojemu ne žele pripadati. Svi oni, dok traže vlastito mjesto pod suncem, najavljuju slom vrijednosti i sumnju u neke nedodirljive zasade i nepromjenjive principe. A pritom se, kao što smo naglasili govoreći o anatomiji dekadencije, svako odstupanje od uvriježenih obrazaca potiskuje daleko na margine, neovisno o kategoriji neprilagođenosti. Koji god razlog za izlaženje iz okvirom propisanih formi bio, on nikad nije dovoljno dobar da bi se, prema mišljenju mediokriteta, opravdala neuspješna egzistencija. Zbog svega smo navedenoga u ovom dijelu disertacije identitetskoj konstrukciji pristupili i iz sociološke perspektive, primjećujući da je u svim primjerima glavni lik stiliziran kao pojedinac kojega presudno određuje činjenica da je on proizvod društvenih procesa. Složimo li se s Frommom, moglo bi se reći da čovjekove sklonosti nisu dio biološki utvrđene prirode,

već proizlaze iz društvenog procesa, koji uobličava čoveka. Drugim rečima, zadatak društva nije samo potiskivanje - mada je i to - već i uobličavanje. Čovekova priroda, njegove strasti i nespokojstva jesu kulturni proizvod; u stvari, sam čovek je najvažnija tvorevina i dostignuće neprestanog ljudskog truda, čije svedočanstvo nazivamo istorijom (1984: 15).

Međutim kroz te ćemo proze posvjedočiti da ne postoji ekskluzivno djelovanje kulture na kojem Fromm inzistira, nego da je najispravnije govoriti o međudjelovanju dvaju obrazaca. Ljudska je priroda proizvod biologije, karakteristične čovjekove „biološke opreme“, i kulture, koja tu „opremu“ usmjerava. S obzirom na to da svoje (fiziološke) potrebe i društveni sustav čovjek ne može mijenjati, forma života postaje prvi čimbenik pri određivanju čitave njegove karakterne građe, ,jer ga bezuslovna potreba za samoodržanjem prisiljava da prihvati uslove u kojima mora da živi“ (ibid.: 18). Društvo kao složen mehanizam, u kojem je svakomu namijenjena „ladica“ i etiketa, uvjetuje živote usmjeravajući ih u određenom pravcu, odnosno k unaprijed utvrđenim ulogama. Kao što je utvrdio i Lasch, „svako društvo reproducira svoju kulturu - svoje norme, svoje osnovne postavke, svoje načine organiziranja - u pojedincu, u 
vidu ličnosti““ (1986: 38) te nastoji oblikovati čovjekovu narav tako da se uklopi u poredak. A kad se pojedinac drzne izaći iz predviđenih granica, društveni ga mehanizam ili pokušava vratiti u postojeće granice ili razvija nova pravila, oduzimajući mu pravo na vlastito mišljenje. I zato je on na neki način već unaprijed osuđen: preostaje mu povratak u prvobitno stanje, jer je u pravilu nemoćan boriti se $\mathrm{s}$ tom mašinerijom, ili nemilosrdna borba na život i smrt. To prilagođavanje nerijetko izaziva ekstreman nemir, dovodeći do još dublje podčinjenosti, a ponekad i prkos usmjeren ne samo protiv struktura nego i protiv života uopće. Jer, opaža se, doista primjenjivo za sve naše dekadente,

ako ekonomski, društveni i politički uslovi, od kojih zavisi čitav proces ljudske individuacije, ne daju osnovu za ostvarenje individualnosti u smislu koji je upravo pomenut, a ljudi istovremeno izgube one veze koje su im pružale bezbednost, taj raskorak čini od slobode nepodnošljiv teret. Ona se tada izjednačava sa sumnjom, sa življenjem kome nedostaju značenje i smer (Fromm, 1984: 30).

A egzistencija bez značenja i smjera, temelj ovih romana, postaje okidačem tjeskobe, glavne dijagnoze sve trojice protagonista. Ona je ugroza svijesti o vlastitom identitetu u kojoj pojedinac, primjećujući da se sve teže identificira s društvom, počinje preispitivati svoj osobni sustav vrijednosti, umnogome sastavljen od općeprihvaćenoga, univerzalnoga, kolektivnoga, te shvaća da je vrlo malo toga s čime se može povezati i poistovjetiti. Preispitivanje otvara sumnju u smisao svega što ga okružuje te podrazumijeva silan napor uspostave novih obrazaca vrijednosti. Kako piše i Gilman, tjeskoba se javlja kao posljedica narušavanja osjećaja reda, bilo stvarnoga bilo zamišljenoga, između ,ja“ i drugoga (1985: 19). Samopouzdanje je naime povezano sa slikom o sebi i bitnim objektima i osobama u društvenom svijetu. Prema tome čovjekova slika o samom sebi ne samo da reflektira njegovu reprezentaciju svijeta nego je istodobno i oblikuje. Zato se može napomenuti da u toj reprezentaciji likovi dekadenata svjesno ili nesvjesno prkose konvencijama: zajednički im je otpor, pa makar i posve pasivan, zadanim formama djelovanja, mišljenja i ponašanja i apriorno postavljenim ulogama. U tom se ključu pokazuje da su modernističko beznađe, gubitak ontološkoga oslonca i nemogućnost kanaliziranja novih vrijednosti jednako opasni kao društvena represivnost i negiranje individualiteta - jedno proistječe iz drugoga.

Kako bi se u teoriji demonstrirali razarajući razmjeri psihološkoga otuđenja od sebe, specifične vrste otuđenja koja se u različitim oblicima i intenzitetima detektira u dekadenata te prati svaku tjeskobu, korisno je referirati se na Horneyino psihoanalitičko razlikovanje 
„aktualnoga ja“, kao iskustvenoga sebstva koje podrazumijeva osjećaje, vjerovanja i želje, ,idealiziranoga ja“" i ,realnoga ja“:

Aktualno ,ja“ sveobuhvatan je izraz za sve što osoba jest u određenom trenutku: duša i tijelo, zdravlje i neuroza. Imamo ga na umu kad kažemo da želimo spoznati sami sebe; odnosno, želimo znati tko smo zaista. Idealizirano ,ja“ jest ono koje imamo u našoj nerealnoj zamisli, tj. ono što bismo trebali biti prema diktatu neurotičnoga ponosa. Realno je ,ja " originalna sila koja nas tjera prema osobnom rastu i ispunjenju, pomoću kojih možemo postići kompletnu identifikaciju, jednom kad se oslobodimo okova neuroze. (1950: 158; isticanje naše)

Na temelju te distinkcije Horney razlikuje dvije vrste alijenacije. Dok otuđenje od „aktualnoga ja“ tumači kao izolaciju od svega što osoba trenutno jest, uključujući njezinu vezu s prošlošću i sadašnjošću, otuđenje od „realnoga ja“ interpretira kao nemogućnost čovjekova povezivanja s najbitnijom središnjom pokretnom silom $\mathrm{u}$ samom sebi koja motivira na samoispunjenje i osobni rast. Upravo alijenacija kakvu detektiramo u izabranim likovima: „Ona je gubitak osjećaja da je pojedinac determinirajuća sila u vlastitu životu. Gubitak osjećaja da je organski cjelovit.“ (ibid.: 157) Zato bismo mogli reći da je, uz otuđenje od društva i od drugoga, za sve naše dekadente još pogubnija činjenica što su oni zapravo, na tragu netom istaknutoga otuđenja kao nemogućnosti uspostave cjelovitosti ,ja“, uvijek otuđeni od samih sebe.

Prema tome otuđenje od sebe, u smislu gubitka usmjerenja u vlastitu životu, otuđenje od drugih članova zajednice te sukob individualnoga i kolektivnoga, s ishodima kojima on neizbježno rezultira, osnova su svih triju romana. Oni su povezani na razini propalih iluzija, frustriranih ambicija i razornih psiholoških potresa te pritom predočuju destruktivne posljedice identitetskoga nepripadanja, koje smo najavili u uvodnom poglavlju o manifestacijama dekadencije u našoj književnosti. Turoban osjećaj necjelovitosti u isto je vrijeme i uzrok i posljedica djelovanja glavnih junaka. Zato izvore njihove dekadencije možemo tražiti u uzrocima emocionalne prirode (nestabilan doživljaj samoga sebe, odnosno nepotpun identitet) ili pak u kognitivno-bihevioralnim distorzijama, točnije u njihovoj nesposobnosti da se prilagode realitetu, izvuku najbolje od njega te konstruiraju ispravnu sliku o sebi.

U kontinuiranoj težnji nečemu višemu, glavnom životnom kredu, svi će protagonisti stradati i kao žrtve zadrtosti i ograničenosti, kao žrtve društva prosječnosti koje potiče utapanje u osrednjosti mase kočeći razvoj pravih talenata. Čak i tragičniji od činjenice da intelektualac, književnik, učitelj živi u financijskoj oskudici jesu ,nekulturnost naše sredine, snobizam viših staleža, nehaj, jal i zloba domaćih ljudi i njihov nemar za kulturne napore idealnijih i talentiranih 
ljudi“ (Nevistić, 1927: 590). Zato vjerni prikazi jednostranosti i dogmatičnosti prilika u tim djelima ilustriraju konflikt nadarenoga individualca i malograđanstva, motiviranoga isključivo materijalnim dobrima, kako bi se istaknuo nenadvladiv raskorak između njegove intelektualne superiornosti i inferiornosti javnoga položaja. Ti primjeri zorno demonstriraju na koji je način psihopatologija vezana s (ne)mogućnošću djelovanja u socijalnom kontekstu, a kad se u njima ističu duševne slabosti likova, to se čini ponajprije kroz prizmu činjenice da društvo sve one koji se ustaljenim modelima ponašanja i djelovanja ne mogu prilagoditi odbacuje i isključuje. Duševni poremećaj izranja u uzročno-posljedičnoj vezi s okolinom te se promatra kao neposredan rezultat društvene uloge koju pojedinac igra. Zajednica je mjesto njegove individualne realizacije. Dekadencija je tih likova dakle snažno sociološki kodirana - ona je otpadnuće od društva.

$$
* * *
$$

Motiv iznimna pojedinca u sukobu s malograđanskim mentalitetom i nemoći da se on nadvlada među prvima je, nakon Šenoe, iznio Gjalski u Radmiloviću, prvom hrvatskom romanu o umjetniku objavljenom 1894. Prateći liniju tematizacije intime hrvatskoga intelektualca s kraja stoljeća, započetu Jankom Borislavićem, u središte interesa postavlja lik književnika, koji je prema ocjeni kritike, za razliku od svoga sterilnog „brata“ Janka, ispao puno konkretniji i životniji. Dok je Borislavićeva patnja bila gotovo umjetno proizvedena, Radmilović propada u nemilosrdnoj kombinaciji problema socijalne prirode i vlastite naravi, ekstrinzičnih i intrinzičnih čimbenika. Njegova specifična dekadentna agonija opsjeda romanesknu strukturu do te mjere da se objektivna zbivanja, kako roman ide svomu kraju, sve više reduciraju, a pozornost se posve usmjerava na njegova unutarnja proživljavanja, koja se nerijetko iznose u opsežnim monološkim dionicama. Prema tome cijelo je djelo, u pokušaju otkrivanja uzroka i posljedica, izvora i načina razvoja jedne dekadentne ličnosti, njezinih psihičkih promjena pod izvanjskim utjecajima, strukturirano kao nagla izmjena složenih duševnih proživljavanja. A pritom je Radmilović kreiran kao sasvim običan dekadent, ispijen, izmučen čovjek.

Bio to mlad čovjek od kojih trideset do trideset i tri godine, dosta visoka rasta, stasit i elegantan u kretnjama i odjeći. (...) Na prvi pogled ovo lice i nije više izgledalo mlado. Previše je ozbiljnosti, strogosti i tuge ležalo na njemu, te je svaka crta odavala, da je tu život morao zaigrati svoje vrzino kolo, još teže i kobnije nego inače. (Gjalski, 1932: 15; isticanje naše) 
„Nježna tankoćutna njegova duša“ (ibid.: 18), daje naslutiti Gjalski već na prvim stranicama, otpočetka se bori s unutarnjim demonima i okruženjem da bi dohvatila smisao egzistencije u društvu izokrenutih vrijednosti koje potiče prosječnost, a kažnjava svako iskakanje iz poretka. „Sva tragika genija, koji stoji sa svijetom svojih misli osamljen od cijeloga mora općenitosti i koji uza sve bogatstvo duševno mora da gladuje (...).“(ibid.: 298) Kao glavne se bolesti takve zajednice predstavljaju nepriznavanje, omalovažavanje i uništavanje slobodnih intelektualaca te u tom smislu glavni lik, vjerna „slika i izraz bijednog života hrvatskog književnika u khuenovskoj noći“ (Šicel, 1984: 65), konkretizira sudar individualnoga i kolektivnoga: talentiranoga pojedinca, koji teži pronaći mjesto u društvu sukladno svojim sposobnostima te tako realizirati vlastitu cjelovitost, i društva koje ga odbacuje, prisiljavajući ga na taj način da si utvrdi nova vrijednosna načela koja međutim nikad neće postati dio univerzalnih.

(...) unesrećio ga nemar njegova naroda, a donekle i sama njegova narav i ćud; onaj njegov nesklad između uma i srca, živa njegova fantazija, fatalizam nekakav, komu se katkad podavao, nihilizam, koji ga spopadoše, i ona nejasnost, netočnost u mislima, zadojena vjerom u nešto neponjatno, nepoznato, nikad izgovoreno. (Gjalski, 1932: 29; isticanje naše)

I zato se Radmilovićevo fundamentalno psihičko stanje, vitalna tjeskoba koja u različitim intenzitetima dominira čitavim romanom, može opravdavati činjenicom da je ona „strepnja koju izaziva prijetnja nekoj vrijednosti koju pojedinac drži esencijalnom za svoje postojanje“"(May, 1977: 189). Naime premda se prijetnja može odnositi na njegov fizički život, o tjeskobi se ipak češće govori kad je ugrožena neka apstraktna vrijednost. Neovisno o prilikama koje su je izazvale ili vrijednostima na koje se odnosi, krucijalno je da je ta vrijednost sastavni dio egzistencije pojedinca kojemu prijeti. On je poistovjećuje sa samom egzistencijom i osobnom sigurnošću. Jer, nasuprot čuvstvu straha koje se doživljava na osnovi vlastitih sigurnosnih obrazaca, tjeskoba ugrožava sam sigurnosni obrazac: „S obzirom na to da ona napada temelj (srž, esenciju) ličnosti, pojedinac se ne može 'držati izvan' prijetnje, ne može je objektivizirati. I zato je nemoćan da poduzme korake u suočavanju s njom.“ (ibid.: 190) Taj osjećaj intenzivne, preplavljujuće nelagode kao prijetnje onomu esencijalnomu u pojedincu naveo je neke psihoanalitičare i psihijatre da je protumače kao kozmičko iskustvo, u smislu da ona 
prodire u naš kompletni subjektivni svijet. Mi ne možemo stajati izvan nje da bismo je objektivizirali. Ne možemo je odvojiti od samih sebe zato što će i naša percepcija u tom slučaju biti preplavljena tjeskobom (ibid.).

A činjenica da je najčešće definira izostanak objekta, tj. da je on vrlo često apstraktan, potaknula je mnoge autore da zaključe kako je tjeskoba „bezobjektna“ jer udara na same temelje psihološke strukture, odnosno na razlikovanje sebe od svijeta objekata. Svijest o sebi jest korelat svijesti o objektima izvanjskoga svijeta, a upravo se ta distinkcija subjektiviteta i objektiviteta, odnosno sposobnost subjekta da se odredi u odnosu na objekt, urušava ovisno o ozbiljnosti proživljene tjeskobe. S tim na umu uočavamo kako je anksioznost moguće opisati kao spoznaju pojedinca da može prestati postojati kao ,ja“, što kao pravilo zamjećujemo u svim našim primjerima. Jer, kako smo rekli, ona ugrožava temelje ličnosti utječući na osjećaj gubitka svakoga smisla. Kao svijest pojedinca koji je postavljen pred opasnosti koje prijete njegovu bitku, tjeskoba je reakcija na suočavanje s, ,nekom vrstom destrukcije egzistencije ili onoga što pojedinac s egzistencijom izjednačuje“ (ibid.: 342).

U Radmilovića su, već smo zaključili, nerazmrsivo premrežene socijalna motivacija i (pre)osjetljivost ljudske prirode. On je stiliziran kao slabašan dekadent nadraženih živaca, uznemiren čovjek koji u neprekidnom razmišljanju o svom ,ja“ sustavno uništava svaku mogućnost svrhovite egzistencije. Ničeovski rečeno, odabrano bolećiv, „nekako sav kao slomljen, umoran, rasijan“ (Gjalski, 1932: 32), paradigmatski kontemplativni inteligent kojemu vlastiti analitički demon ne dopušta živjeti. Njegova se misao ukorjenjuje u slabosti te prelazi $\mathrm{u}$ sveprožimajući mal de vivre u kojem se frustrirano osvještava besmisao postojanja. Tjeskobno nepronalaženje odgovora na pitanja „kamo“ i „,̌emu“, koja u kulturi dekadencije obilježavaju svaku egzistenciju (von Sydow, 1922: 47-49), rađa u njemu niz metafizičkih ponora u kojima se više ne pronalazi oslonac. Zato ističemo, prisjećajući se prvih poglavlja o raspadu vrijednosti i posljedičnim stanjima pesimistične bezizlaznosti i skepse, kako Radmilovićeva beskrajna melankolija nije postavljena samo kao osoban, individualan problem, već kao univerzalna sjeta, svijest o vremenu u kojem polagano iščezavaju sve dotad poznate zasade. Odnosno, kako je ocijenio Frangeš, u njemu se susreću „dvije ljudske muke, muka čovjeka in abstracto i muka hrvatskoga čovjeka in concreto“ (1972b: 25). Njegova bezgranična tuga teži se predstaviti kao spoznaja smisla i općenitih pitanja ljudskoga bivstvovanja. Ona se rađa kao svijest o zagonetkama života, inzistira na egzistencijalnim misterijima, te se u stilu kozmičkoga pesimizma pita: 
A gdje je onda još stvor, koji će svijesno pogledati na sav taj svemir oko sebe, da najprije u svemu tom vidi tek nakit dvorova stvoriteljevih (...), da atomi opet traže novo središte, stvaraju nove magle, nova sunca, nove planete, nove crve i nova srca - i tako ljudskomu umu bez kraja, bez konca, ta i bez početka! Ah - njega je sasvim poništavala ova misao; od nje je jasno osjećao, kako je ništetan, malen - sitan on i sve oko njega, sav život - sve - sve! - I čovjek se muči! Deset se hiljada godina kolje, stvara i rastvara države i društva, vjere i filozofije, pjeva i stvara, ah, da najzad iščezne sve - sve, što je uradio, i vraća se u besvijesni svemirski prah - oh - samo iščezne u neumolnom procesu prirode, kojoj je samo - što? (Gjalski, 1932: 159)

Tako se Radmilovićeva životna muka u „tipičnoj kranjčevićevskoj kozmičkoj viziji“ (Frangeš, 1972b: 25), iako fundirana u objektivnim problemima hrvatskoga društva, univerzalizira i širi na kompletan svijet, izlazi iz okvira nacionalnoga, pa čak i ovozemaljskoga. No krajnje pojednostavljeno, u njezinoj je pozadini ipak narcistička okrenutost sebi. Naime detektirali smo da je od samoga početka romana osnovni problem glavnoga lika smješten u njemu samom. On je toliko usredotočen na sebe, neumorno usmjeren mazohističkomu, anatomskomu seciranju vlastite ličnosti i hladnomu promatranju svega oko sebe, da ga to priječi u aktivnom, konkretnom, ,životnom“ bivanju. I zaista, Radmilović u bilježnicu zapisuje sve o sebi i oko sebe, ,gotovo kao malakolog ili ornitolog ili etnolog, ah, sabirač ili pače u neku ruku i industrija“ (Gjalski, 1932: 77). I to ne samo zato da bi spoznao svoje ,ja“ nego i da bi imao što slikovitijega materijala za svoje književne radove, napose za psihološki roman znakovitoga naslova Mučenici, koji će biti i simbolična točka njegova tragičnoga kraja. Zaokupljenost sobom blokira svako konstruktivno djelovanje, prezentirajući kako i u ovom slučaju veliku ulogu igra opća slabost živaca te posljedična izmorenost volje i morbidan manjak vitalizma. To je život koji se odvija u stalnom promatranju i kontempliranju, prisjetimo se uvodnih dijelova disertacije. S neprestanom potrebom „da sebe motri, da bilježi svoja opažanja, da bude tako vječno na straži i uhoda sebi samomu“ (ibid.), on doista malodušno živi jedan pravi rezignirani pesimizam, razrovanu osjećajnost u kojoj konstantno oscilira u razmišljanju i ponašanju.

Kao sve žarke naravi bio je i on razdražljiv i podavao se naglim promjenama između dobre i zle volje. Iz raskalašena veselja mogaše ga kakva sitnica, koju bi drugi jedva zamijetio, baciti u gotovu zlovolju, očaj, pače tugu, kao što bi opet u najvećoj žalosti koji put dovoljna bila kakva dobra vijest ili srdačna riječ ili susret s kojom dragom osobom, da mu dušu dirne anđeo mira i da ga povrati dobroj volji, ako ga i ne bi istrgao melankoliji, kojoj se ni za najveće šale nikad nije mogao oteti. (ibid.: 54) 
Ipak, glavna mu dispozicija zauvijek ostaje melankolija, ta daleka, teška tuga u kojoj ćuti „nemilost života i vječnu blizinu nesreće“ (ibid.: 234), u isto vrijeme subjektivno stanje i bihevioralni poremećaj. U uvjetima neurotične findesiècleovske duševnosti, kao „narcistički poremećaj gubitka intrinzično usmjeren vlastitomu sebstvu“ (Radden, 2009: 50), ona je sasvim normalno čuvstvo i duševno oboljenje, osjećaj i način ponašanja.

Ah, i njega je opet svladala silna sumornost, neka daleka turobna sustalost, u kojoj je tek mogao da se neprestance pita: čemu sve ove muke, rašta mu se život pokazuje tako neprijatan i protivan? - I to dakle, što bih mogao misliti da mi s pravom pripada, što svako postiže, i to se kod mene ne razumije da bi došlo po sebi! I tu moram imati zapreka, i tu moram da čekam već godine i godine! - govoraše bolno i gotovo bez trunka aktivne energije u duši. (Gjalski, 1932: 143 ; isticanje naše)

Nije naodmet ovom prilikom podsjetiti kako se imaginarij melankolije kroza stoljeća uglavnom kretao između dviju paradigmi: paradigme medicinski orijentirane, koja se za očaj i tugu zanimala kao za emocionalne abnormalnosti, i poetiziranoga prikaza koji je, držeći da čovjekove intelektualne kvalitete uvećavaju njegovu ranjivost i sklonost sjetnim čuvstvima, naglašavao vezu između tuge $i$ inteligencije te je povezivao uglavnom $s$ „normalnom“ psihologijom pojedinca (Radden, 2009: 62). I upravo je između tih modela Gjalski smjestio svoga Radmilovića, omogućivši nam da zaključimo kako je njegova patnja posljedica umjetničke iznimnosti i inteligencije, što će se naposljetku pokazati i u Zlatanića i Andrijaševića. Njegova vječna duševna prenapregnutost, beskonačna senzibilnost zapravo je kombinacija urođenih svojstava, neurastenične volje i bavljenja književnošću: „Već po naravi njegova je pjesnička duša bila nježno sadjeljana, a petogodišnji je literarni rad učinio, da je postala još osjetljivija, a živci razdražljiviji.“ (Gjalski, 1932: 25) Naravno, viša razina umjetničke rafiniranosti podrazumijeva i sve drastičnije slabljenje životne energije. Jer svijest se intenzivira kroz frustraciju i bol; što je razina svijesti viša, bol je snažnija. Kako je u svojoj Fiziologiji i patologiji uma pisao Maudsley:

(...) ljudi velike rasudne moći (...) očigledno su često potkapacitirani u energičnoj akciji, vješto balansiraju s razlozima tako da nijedan ne pretegne i ne mogu donijeti nikakvu odluku: s njima, kao i s Hamletom, meditacija paralizira svaku akciju. (cit. prema Sirotkina, 2002: 127-128)

Zato je Radmilovićevo dekadentno povlačenje iz realiteta, iako dijelom uvjetovano i oštrim analitičkim okom, u velikoj mjeri motivirano književnim radom, koji ga gura u 
neprestanu fikcionalizaciju. Umjetnost $u$ isto vrijeme postaje način izlaženja iz svijeta, ali i zadržavanja u njemu. Ispostavit će se tako da je baš to predano bavljenje književnošću, koja „,ne daje ni kruha ni društvena položaja“ (Gjalski, 1932: 65), u plitkosti i okrutnosti stvarnosti jedan od pokretača njegova kraja: ona obilježava njegov odnos prema svijetu i samom sebi. Dakle Radmilovićev je konačni krah otpočetka obilježen činjenicom da je u stranom svijetu cijenjen i poznat, dok u Hrvatskoj, na periferiji Europe, za njega nitko nije ni čuo.

Još u društvu s Vulakovićem mučio ga neki nemir, neko neodređeno nezadovoljstvo (...). Ali sada spozna taj uzrok i sve je opet pred njim stojalo živo. Ponovo je vidio i čuo, kako gotovo niko u kavani ne zna za njega (...). A ipak koliko ljubavi, samozataje, požrtvovnosti uložio je u taj svoj rad sve od želje, da narodu priopći svoje sanje, da mu ugodi, da mu uzradi na polju umnoga razvoja. U taj čas pričini se Radmiloviću, kao da je sve njegovo nastojanje bilo uzaludno i da su njegove godine prošle utaman. (ibid.: 22-23)

U takvom indolentnom društvu njegov je talent teret, smetnja svakomu mogućemu napredovanju u položaju (u odvjetničkom poslu). Općenito se može reći kako su se nerijetko u građanskom društvu duhovne sklonosti doživljavale kao nepoželjna kvalifikacija, kao odstupanje od uvriježenoga i „,normalnoga“ jer odvraćaju od svrhovitoga, djelatnoga života, a naklonjenost knjigama (i umjetnosti uopće) često je bila predmetom duboke zabrinutosti za budućnost osobe koja je gaji. Usto u tom romanu umjetnička sklonost poprima dodatno zlokobnu dimenziju jer se shvaća i kao izravna prijetnja prototipu muškoga identiteta koji bi valjalo usvojiti. Kao što ćemo vidjeti i na posebno radikalnom primjeru Bušinskoga, umjetnost je Radmiloviću oduzela mogućnost „pravoga“, iskustvenoga življenja, neprestano mu nudeći neke iluzije, te se on našao razapet između književnosti - prema kojoj, jer je shvaća kao „pravi“ posao koji ne trpi kompromise, razvija upravo neki robovlasnički odnos - i ljubavi. Kod njega naime jedno na neki način isključuje drugo:

I on bi sav klonuo pred veličajnom, u isti mah i raskošnom i neumolnom vlasti, kojom ga je vezala umjetnost - knjiga. Vidio se kao skučena, sapeta roba, da u isti mah ćuti prelest toga ropstva, a još više mu bude jasno, da se neće nikad oteti tomu gospodstvu. (...) Ali ljubav k mladoj djevojci opet bi uzbuktala silno i žarko. Gotovo je trpio strašne muke, što mu ta njegova tiranica priječi u toj ljubavi. No iz svega je ćutio, da joj se unatoč silnoj ljubavi ne može oprijeti. Pa se utekao izgovorima, isprikama - sam u sebi. (ibid.: 111) 
I tako mu preostaje tek vječno apstraktna, spekulativna egzistencija jer cjelinu svoga fragmentiranog bića ne uspijeva zadobiti ni profesionalnim ni ljubavnim ispunjenjem. Njegov se očaj zbog društvenoga nepriznanja i inferiornosti položaja potencira neuzvraćenom ljubavlju prema Olgi, koja se skrasila s materijalno si ravnopravnim partnerom, a naposljetku i ženidbom sa siromašnom Stankom, pa se može sumirati da ,iluzije književnika padaju zajedno s iluzijama čovjeka“ (Nevistić, 1927: 591). Smanjena vitaliteta, trajno opterećen intelektualizmom, nenaučen na praktičnost $i$ angažirano djelovanje te mučno svjestan razlike između svoga svijeta i svijeta drugih, Radmilović ne poduzima konkretne korake da bi realizirao vezu s Olgom, bezvoljno se povlači u svoju ljušturu te stalno lavira između egoizma i odricanja od sebe. Stoga nije pretjerano zaključiti da je njegov odnos s drugima zapravo cijelo vrijeme zaražen narcizmom, pretjeranom zaokupljenošću sobom koja zamagljuje granice između ,ja“ i vanjskoga svijeta. Sjetimo li se njegove autodestruktivne potrebe da bez prestanka sebe proučava, možemo se prikladno referirati na konstataciju da upravo narcis, sam sebi dovoljan, traži „osnovna zadovoljenja u sopstvenim unutrašnjim duševnim zbivanjima“ (Frojd, 1970: 286). Kad govorimo o narcizmu, toj čestoj pratnji dekadencije glavnih likova, ne tvrdimo da bi se na njih mogla aplicirati klinička slika narcističkoga poremećaja ličnosti, nego u njima prepoznajemo stanovite karakteristike koje bi se mogle opisati kao narcističke, poput ekstremne usmjerenosti sebi, autoanaliziranja, promišljanja i propitivanja. Sve su to likovi u kojih se proces individuacije, inficiran intenzivnim solipsizmom, pokazuje kao vječna potraga. Jer narcizam, pitajući se o vanjskom svijetu samo u odnosu na to što on znači za sebstvo, „pretpostavlja kontinuiranu potragu za vlastitim identitetom, koja međutim ostaje frustrirana“"(Giddens, 1991: 170) i uvijek nedovršena. A ironija je njihove egzistencije da, iako misle samo o sebi, nikad sebe doista ne mogu spoznati. Nemoguće je izmjestiti se izvan sebe da bi vidio kakav si zaista.

No, kako bismo bolje shvatili taj fenomen i složene komplekse koji se u njegovoj pozadini odvijaju, valja podsjetiti da ga je klinički utemeljio Freud u okviru svoje nagonske teorije, usmjerivši njome sva daljnja psihoanalitička proučavanja, prema kojima se razlikuju normalni i patološki narcizam.

Oni se razlikuju po stupnju adaptivnosti, odnosno neadaptivnosti s obzirom na karakternu strukturu i procese koji su u pozadini psiholoških potreba za očuvanjem visoke razine pozitivne slike o sebi kroz pristranu samoevaluaciju i traženje samopotvrđujućih iskustava od socijalne okoline (...). (Čuržik i Jakšić, 2012: 22) 
Naime dok normalni narcizam, povezan s pozitivnom percepcijom samoga sebe, pridonosi dobrobiti ličnosti, patološki narcizam podrazumijeva niz stresnih stanja i disfunkcionalnih poremećaja, u koje spadaju, među ostalima, anksiozni poremećaji i antisocijalni poremećaji ličnosti te povećan rizik od samoubojstva (ibid.: 23). Posebno je interesantno da empirijska istraživanja i klinička promatranja unazad nekoliko desetljeća uobičajenomu opisu grandioznoga oblika narcizma dodaju i vulnerabilan oblik za koji su simptomatični intenzivna senzibilnost, ,samokritičnost, depresivnost, potencijalna suicidalnost te pretjerana osjetljivost na kritiku od drugih povezana sa socijalnim povlačenjem, odnosno izbjegavanjem međuljudskih odnosa“ (ibid.: 25). Dakle sve ono što je u manje ili više izraženom stupnju prisutno u svih dekadenata.

Teza da narcizam, s obzirom na to da je u suprotnosti sa zahtjevom za održavanjem intimnih veza te da pokazuje iznimno neuspješno adaptivno funkcioniranje, bitno utječe i na destruktivnost društvenih odnosa potaknula je Lascha (1986) da fenomen narcizma poveže s apokaliptičnom prirodom modernoga društvenog života. Premda primarno analizira američku postmodernu kulturu, Laschevu postavku da su procesi individuacije u direktnoj vezi sa slabljenjem povijesnoga kontinuiteta u smislu osjećaja pripadnosti (1986: 5) možemo bez sumnje primijeniti i na razdoblje u našem fokusu. Naime žudeći za uznemirujuće neuhvatljivom sigurnošću i osjećajem vlastite dobrobiti, pojedinac s jedne strane traži sve veće zadovoljstvo u društvenim odnosima, a s druge uočava sve veći jaz između sebe i drugih. A upravo se zbog toga Radmilović prepoznaje i kao tipični Durkheimov homo duplex, o kojem ćemo konkretnije govoriti na primjeru Šimunovićeva Lukavca: teži integraciji u društvo te pritom želi zadržati individualan identitet. $\mathrm{U}$ narcisa dojam o vlastitoj vrijednosti te osjećaji ispraznosti $\mathrm{i}$ neautentičnosti supostoje s maglovitom predodžbom o potrebama drugih. Stoga nimalo ne čudi što Nordau govori o egomaniji u smislu bolesne findesiècleovske preokupiranosti vlastitom ličnošću. Međutim za razliku od postmodernističkih tumačenja, narcizam je u to vrijeme, „utjelovivši nadu za radikalizacijom modernoga individualizma kao reakcije i odgovora na procese individuacije“ (Le Rider, 1993: 61), imao gotovo utopijsku dimenziju. Svako društvo, izgrađujući vlastitu kulturu, njezine norme, eksplicitne i implicitne pretpostavke, presudno utječe na pojedinca. Zato Durkheim i piše kako je ličnost „socijalizirani pojedinac“ (cit. prema Lasch, 1986: 38), podcrtavajući pritom važnost društvenih uvjeta u oblikovanju ličnosti, koju smo i sami istaknuli u više navrata. Dakle u procesu čovjekove socijalizacije golemu ulogu igra društvena interakcija koja njegovu prirodu nastoji prilagoditi vladajućim obrascima te u tom nastojanju producira karakterističnu formu ličnosti pomoću koje se pojedinac podređuje zahtjevima društvenoga bivanja. Prema svemu se tome s razlogom zaključuje da su neuroze i 
psihoze, kao rezultat dinamičkoga prilagođavanja vanjskim okolnostima, specifičan izraz kulture. Ili, kako je pisao Jules Henry, one su „konačan ishod svega što je naopako u nekoj kulturi“ (cit. prema ibid.: 39). Stoga se i u naših dekadenata narcizam, koji interpretiramo kao iznimnu okrenutost sebi, može objasniti na pozadini specifičnoga Zeitgeista, jer, kao što smo prije obrazložili, svako doba razvija karakteristične patologije koje reflektiraju njegove fenomene koji ključaju ispod površine.

Činjenica da se melankolija, kao neizdrživa tuga zbog besmisla svijeta i čovjekova položaja u njemu, i tjeskoba, kao težak osjećaj žilavoga straha zbog sloma vrijednosti, u Radmilovića neprestano izmjenjuju ili pak supostoje usmjerava nas opet na problem iscrpljenosti i bezvoljnosti. Vraćajući se problemu njegovih složenih unutarnjih proživljavanja, ne možemo ne primijetiti kako je Radmilović, iako mlad, nevjerojatno umoran, izmučen čovjek koji je, doima se, proživio bezbroj života. Duševna se slabost, tipično za gradnju dekadentnoga lika, prenosi i na tjelesnost, pa se u iscrpljujućim izmjenama emocionalnih stanja njegovo tijelo bori i s različitim somatskim simptomima, ${ }^{79} \mathrm{~s}$ generalnom fizičkom klonulošću koja se drastično pojačava nakon naporna, osobito intelektualnoga rada. To je pak sasvim razumljivo u ključu devetnaestostoljetne teze kako prekomjerno intelektualno naprezanje može utjecati na mentalni i fizički zamor.

Od prevelika napora i posla, od hotimična još k tomu uzrujavanja, Radmilović je silno spao. I onako oduvijek blijedi i suhi obrazi još su bljeđi postali, još više uleknuti i usko nategnuti. $P a i$ osjećao se nekako nezdravim, vječno uzrujanim, istrošenim i nekako teškim i nemoćnim u cijelom tijelu. Noći su mu neprestano bile nemirne, mučili ga teški snovi, u kojima je ili nastavljao svoje dnevne brige ili opet dalje živio u svijetu svoje novele. Ujutro bi ustajao gotovo kao isprebijan, izmučeniji i sumorniji nego što bi bio noću legao. (Gjalski, 1932: 293; isticanje naše)

Nije prema tome smisao njegova poraza isključivo u kolektivnome nego, možda prije svega, u individualnome. Jer, kako vidimo, on je tip rođenoga slabića, hipersenzibilne, letargične ličnosti nesposobne za sučeljavanje s pravim životnim poteškoćama. Zato se i može reći kako ga svaki grublji kontakt s društvom čini još delikatnijim i nestabilnijim te ga motivira na sve jaču izolaciju od drugih. Apatično vjerujući kako se prepreke s kojima je suočen ne mogu nadići te kako se „treba pokoriti, sve podnijeti, ni protiv čega ne ustajati“ (ibid.: 234),

\footnotetext{
79 „Stala ga mučiti stara njegova bolest u srcu, tomu se pridružila i časovita muka u glavi. Noću nije mogao gotovo ni malo spavati, pa mu se i po svem tijelu slegla neka bolna sumornost i trzavica u svim mišicama." (Gjalski, 1932: 94)
} 
Radmilović ne primjećuje da ključan razlog nemogućnosti uspostave vlastite cjelovitosti leži upravo u njemu. Naime poput Mirkovića i Grančarića siguran je da mu život predodređuje neka fatalistička nužnost, ,zla nesreća i neprijatna sudbina“ (ibid.: 197), zbog čega se njegovi melankolični osjećaji stiliziraju u beskonačnu tugaljivost, u pravi Weltschmerz u kojem se svodi ovakva životna bilanca:

Gotovo s nevjernim je strahom gledao svoju kob, za koju je mislio, da ima dosad pravo držati, da mu nije ništa drugo, nego vječna donositeljica nesreće, boli i muke. Dugim crnim redom dižu se pred okom duše doživljaji njegovi, kao kobni zlosretni vjesnici, koji mu svi glasno, jasno - i zlobno, oh, toliko zlobno govore, da za njega nema sreće. Tužno mladenaštvo, uvijek $s$ osjećajima povrijeđenim i potisnutim, pače i materijalna nevolja, onda nesreća s roditeljima, pak njegov dojakošnji trajni neuspjeh u svem i svačem, njegovo uzaludno nastojanje, da osvoji ma i što najčednije - sve - sve mu opet prođe dušom. (ibid.: 139; isticanje naše)

I u njega je dakle dekadencija upisana kao naslijeđe, kao ishod prijašnjega života, nekarakterističnoga, pretjerano osjetljivoga mladenaštva, složenih međuljudskih odnosa, pa i materijalne neimaštine. Jer, prisjetimo se, osjećaji ontološke sigurnosti ključni za konstruiranje identiteta i obranu ličnosti od patološke forme tjeskobe grade se od najranijega djetinjstva. A iz toga njegovanja sudbinskoga uvjerenja da se sve odvija kako je unaprijed zapisano izranja beznadan homo melancholicus koji, čeznući za ispunjenijim bivanjem, bolno uviđa destruktivnu otuđenost $i$,,neku nedoglednu osamljenost“ (ibid.: 173), što je cijena deklariranoga modernističkog individualizma: „Sasvim mu postane jasno, kako je u svojoj bijedi sam samcat i da nema nikoga, ko bi pomislio ili htio samo da mu pomogne i da ga izvuče iz ovoga kukavnoga stanja.“ (ibid.) Pa se kao konačna točka Radmilovićeva potresnoga poraza krajnjega rezultata svih prethodnih psihičkih drama u kojima je uvijek jasno pred sobom vidio tek „nedogledni ponor ništavila, strašan osjećaj potpuna nestanka“ (ibid.: 166) te osvještavao i objektivne i subjektivne nemogućnosti uspostave vlastitoga ,ja“ - predstavlja završni živčani slom u kojem pali neprodanu nakladu svoga romana, dijagnosticirano „neizlječivo bijesno ludilo“ (ibid.: 302).

$$
* * *
$$

Problem međuljudskih odnosa, bitno obilježenih kompetitivnim individualizmom, i razvoja modernih društvenih i ekonomskih struktura u znatnoj mjeri korespondira s fenomenom tjeskobe, kako smo pokazali u uvodnim poglavljima ovoga analitičkog dijela referirajući se na 
Fromma i Maya. Oslobađanje od okova autoriteta, objasnili smo, u pojedincu rađa svijest o osamljenosti i izolaciji te tjeskobu izazvanu činjenicom da nestaju poznate mu vrijednosti, pri čemu jedna od njegovih ključnih osobina postaje opća egzistencijalna nesigurnost. A budući da ta dijalektika osobne slobode postaje pretežak teret, preostaje mu odreći se slobode kako bi izbjegao anksioznost i otuđenost ili pak razviti upravo tu drugu vrstu ovisnosti kroz obrasce neuroze. Naime već smo nekoliko puta istaknuli kako su svi likovi dekadenata iz proza kojima se bavimo u potrazi za socijalnim kontaktima te su pritom istodobno svjesni da im oni donose samo patnju. Ili kako je, govoreći o jedinstvenoj dekadentnoj dilemi, zapisao Thornton:

Dekadent je čovjek zarobljen između dvaju suprotnih i naizgled nekompatibilnih polova: s jedne ga strane privlači svijet, njegove potrebe i atraktivni dojmovi koji iz njega proizlaze, dok s druge teži vječnomu, idealnomu i nadzemaljskomu. Igra tih polova stvara tipičnu dekadentnu tematiku (...). (1979: 26)

Ova dihotomija, koja ujedno sugerira specifično dekadentno uzmicanje od zbilje, može se poistovjetiti s nesuglasjem između pojedinca i društva, subjektiviteta i objektiviteta, odnosno s borbom svjetova čije je kobne posljedice Novak tako sugestivno prikazao u svom pretposljednjem romanu Dva svijeta (1901). Taj naslov simbolično sažima sve moguće dihotomije koje se njime provlače: spomenut binarizam između iznimnoga intelektualca i malograđanske sredine koja ga kanibalski proždire, između unutarnjega svijeta osjetljive ličnosti i izvanjskoga svijeta realnosti, između elitne (klasične) i popularne umjetnosti, visoke i niske kulture, autentične umjetničke vještine i genijalnosti i pukoga zanata, između onoga koji glazbu ne razumije i onoga koji je svakodnevno živi.

Ta ja osjećam i u sebi i oko sebe dva svijeta. Jedan pojima svu jasnoću, istinu i pravu vrijednost svega što opstoji, ne kakvo je, nego kakvo bi imalo biti. Drugi se svijet opire prvomu, promjenljiv je i nepojmljiv u svojoj nedosljednosti. (Novak, 2009: 392-393)

Ukratko, to je sukob ,estetički-uzvišenoga i pragmatično-profanoga“ (Milanja, 2012: 267) koji svoje najtmurnije odjeke pronalazi u glavnom junaku, rafiniranom glazbeniku u potrazi za osobnim i profesionalnim identitetom. Amadej Zlatanić kao „,istinski bogomdani glazbeni talent" (Nemec, 1999: 234) umjetničkom se superiornošću, ali i prekomjernom tankoćutnošću izdvaja iz društva masovne prosječnosti. Osjetljivost je naime za liječnike i moraliste u XIX. stoljeću (ali i puno prije toga) bila potencijalna opasnost jer je mogla odvesti 
u emocionalne ekscese te posljedičnu tjelesnu i moralnu degeneraciju. U najmanju je ruku smatrana štetnom jer nije bila samo degeneracija u odnosu na „normalan“ oblik emocionalnoga doživljaja nego i regresija s obzirom na ono što je muškost implicirala: smatrala se fundamentalnom osobinom neprilagođenoga subjekta koji nedopušteno stoji u maglovitoj zoni, negdje između ukorijenjenih koncepata muškosti i ženskosti. Zato je dekadencija likova u našem fokusu, uzmemo li u obzir karakteristične osobine kojima se oblikuju, iz perspektive društvene funkcionalnosti i svrhovitosti najjednostavnije rečeno zazorna. Zazorno „potresa temeljne kategorije znanja i iskustva te u isto vrijeme o njima ovisi; ono izaziva granice iskustva i razumijevanja svijeta u kojem (mislimo da) živimo“ (Jervis, 2008: 11), prijeteći stabilnosti osnovnih findesiècleovskih postavki, razumu i znanosti. U tom je ključu shvatljivo i zašto dekadenti, izmoreni, ispijeni, bljedunjavi i ranjivi, zauzimaju prostor opskurne nesigurnosti, smješteni u procjepu čvrstih kategorija. Zazorno nigdje ne pripada te baš zato što ne pripada i jest zazorno. Ova nas postavka iznova vodi do konstatacije o kojoj smo pisali u prvom dijelu rada: u hrvatskoj se findesiècleovskoj književnosti predstavljaju (i) teme koje stoje na rubovima građanske kulture.

Ono što je u hrvatskoj kulturi 19. stoljeća proizvedeno kao nenormalnost - da bi se ustrojila koherentna zajednica sa stabilnim institucijama, identitetima i funkcionalnim okvirima pojavljuje se kao književno nenormalno, kao tema i retorička izvedba nenormalnog u književnosti moderne. (Vuković, 2016b: 199)

Prema tome Zlatanićevu je prekomjernu osjećajnost također moguće smjestiti između privilegija i patologije: ona je u jednu ruku sredstvo u potrazi za vrlinom, dok je u drugu uključena u epidemiju neurotičnih oboljenja XIX. stoljeća. Općenita ocjena kako s takvim, pretjerano delikatnim i oslabljenim pojedincima „nešto nije nešto u redu“, koja se kroz kritiku primitivnoga društvenog okruženja između redaka čita i u Novakovu romanu, iznova upućuje na problematiku prihvatljiva okvira u koji bi se svaka jedinka trebala uklopiti. Pripadnici bi zajednice trebali egzistirati po pravilima ili ne bi trebali egzistirati. Stoga u svjetlu ovih tvrdnji postaje jasnije zbog čega Zlatanić, nemoćan da se nosi sa zahtjevima filistarske sredine koja ga na različite načine prisiljava na neprihvatljive kompromise, doživljava potpun rasap identiteta, ne uspijevajući obraniti ni svoj profesionalni ni svoj osobni integritet. Raskorak između zamišljenoga, onoga kako bi želio da svijet izgleda, i realnoga, onoga kako svijet izgleda, osnova je njegove ,životne boli“, u kojoj naposljetku jasno artikulira kako je ovaj svijet doista najgori od svih mogućih: „Naš je život beskonačna disonanca, prekinuta samo gdjekada kratkim 
konzonantnim akordom.“ (Novak, 2009: 388) Nepreglednu provaliju između sebe i drugih, koja je idejna potka romana, Amadej osjeća baš onako kako to postavlja Vesely:

Što imate u sebi, samo je to vaše. Škola vas može i iskvariti: možda ste rođeni da izrastete kao hrast u šumskoj slobodi; a oni će na vas ucijepiti voćku što uspijeva samo u zatvorenom uzduhu njihovih škola. (ibid.: 308)

Prema tome temeljno duševno raspoloženje glavnoga lika postaje sumorno klonuće „od teškoga umora duše“ (ibid.: 379), uobičajeno dekadentna „mračna tjeskoba“ (ibid.: 384) koja paralizira svaki angažman u borbi za samoga sebe: „Svega me je bila ovladala bol od neke teške nemoći, od osjećaja da se borim proti nečemu neizvjesnomu i da ću konačno klonuti i ostati pobijeđen.“ (ibid.: 378) Metafizičke odjeke melankolične tjeskobe kao neprevladivoga egzistencijalnog stanja povezanoga u prvom redu s gubitkom apstraktnih ideala, stanja koje potresno obuzima sve bolećive ličnosti, Novak dosljedno primjenjuje na svom posljednjem „pravom“ dekadentnom liku. ${ }^{80}$ Zlatanića strukturira kao modernoga dekadenta, pasivnoga, nervoznoga umjetnika izrazito sofisticirane naravi, koja produbljuje ionako golem ponor između svjetova. Stoga se može zaključiti kako se istovremeno ustraje na objektivnim zaprekama u protagonistovu neposrednom okruženju te na nemogućnosti njegova mentalnoga sklopa da se nosi s mehanizmima stvarnosti. Drukčije rečeno, iako se nedvosmisleno prezentira da je pojedinac „određen sredinom i poretkom stvari u svijetu“ (Milanja, 2002: 289), slabosti su u njemu samome. Jer, kako je upozorio pripovjedač još pri početku, veliki pothvati koji zahtijevaju suočavanje sa surovom stvarnošću nisu za nježnu dušu i slabe živce: „,(..) stupio onakovom rezignacijom duše koja ovlada ljudima nježnih živaca kad imaju da se odvaže na

\footnotetext{
${ }^{80}$ Prije Zlatanića u stanovitoj je mjeri stilizirao Novak kao dekadente i Nikolu Baretića i Viktora Jerkovića, a potom je Tita Dorčića, protagonista svoga posljednjeg romana, oblikovao u degenerativnom diskursu. Dok Dorčić upada u bezizlazno stanje tjeskobne tuge i pravoga očaja, ćuteći pogubnu identitetsku disharmoničnost „u svem rasklimanom organizmu“ (Novak, 1964: 291), zbog toga što je istrgnut iz svoga prirodnog okoliša te društvenim regulacijskim procesima deformiran do krajnjih granica, Jerković iz Zapreka, u specifičnoj tematici zabranjene svećeničke ljubavi, uvriježeno dekadentno odustaje od svake odluke, kukavički se povlači od mogućnosti promjene te završava svladan ,teškom umornosti“ (Novak, 1932b: 278): „U sve to dublju bol prelazila je njegova slaboća, sve jačim jecajima plakalo je u njegovoj nutrinji ono veliko, što se stalo raspadati u samom trenu, kad je mogao da posegne rukom za srećom, što ju je njegova fantazija dizala iznad svega na zemlji. Konac!... Kao da nije bilo u njegovoj duši snage, da odoli toj osudnoj riječi, opet je pao u mrtvilo (...).“ (ibid.: 281) Baretić pak od potpunoga duševnoga i fizičkoga sloma, u kojem se prepoznaju ,prvi znakovi preteče teške i rijetko izlječive bolesti, kojoj je naginjao po svojoj porodici“ (Novak, 1932a: 5), očaja i samoubilačkoga nihilizma dospijeva do uspostave identiteta te na nevjerojatan, posve nemotiviran i pomalo karikaturalan način ozdravlja, ushićeno se deklarira, slično Gjalskijevu Blinjeviću, kao strastveni domoljub te povratak domovini i vjeri upotpunjava pomirenjem sa ženom: „Sve je zaboravio, oko njih raširila je božja dobrota svoje ruje - da kako bi ovo zvao? Prepatio je, zaboravio i oprostio samom sebi sve. (...) Ah, bio mi se zamračio vid, a kad su mi se one oku zastrle, bio sam najbijedniji čovjek na svijetu. A sada ih eno sjajnijih i ljepših, nego bijahu onda, kad stupah odvažnom nogom u prvu mladost. Ti ih znaš, Marijo! One su: Bog, Hrvatska i - dušo - ti!““ (ibid.: 177)
} 
odlučan kakav korak“ (Novak, 2009: 281). Gubeći postupno svoju individualnost, svladan mentalnim zamorom kao posljedicom napornoga umovanja, postaje prototip iscrpljenoga dekadenta koji mišlju fragmentira život. Tako da sve konflikte s kojima je sučeljen apatično prihvaća kao sudbinsku predodređenost te ih rješava isključivo povlačenjem $u$ sebe, odmicanjem od svake moguće borbe. Iznimno aktivan u apstraktnome, iznimno nedjelotvoran u konkretnome. U tom čuvstvu osobite klonulosti gubi se sva energija i volja, a duševna se astenija pojačava beskrajnim idealiziranjem i osjećajem genijalne izdvojenosti koje izolira od praktičnosti svakidašnjega života. Prema tome razvidno je kako vrsnoća karaktera zahtijeva i veliku žrtvu te se u konačnici potvrđuje da izvanserijska kvaliteta ne može preživjeti ni u centralnom polju zbivanja, u velikom gradu, ni u žabarskoj sredini ograničenih izbora. Nasuprot Jahodinu idealističkomu uvjerenju kako bi bogomdani talent morao nadići sva prostorna ograničenja, pa i uskost hrvatskih prilika, žrtvovat će se pojedinačno u ime kolektivnoga: iznadprosječan pojedinac ostat će poražen u tom nerazmjeru između vlastite superiornosti i zajednice koja ga svim silama nastoji sebi prilagoditi ili od sebe odbaciti. „Tko nema novaca za škole, neka ne teži za gospodstvom“ (ibid.: 246), proročki će upozoriti Plavčić. Ne čudi stoga što u uzaludnoj borbi za nedostižnim glavna Zlatanićeva dispozicija ostaje „čeznuće sapeta orla“ (ibid.: 384), u kojem vječno osjeća zloslutan jaz između „dvaju svjetova““.

Dakle početna je i završna točka njegove dekadencije postavljena u umjetničkoj izvanrednosti, u urođenom talentu koji ga još odmalena tjera da živi u nekom „osamljenom, vilinskom svijetu, što ga mladost prede zlatnim i rumenim zrakama svjetla bez sjena“ (ibid.: 269) te da neprestano naslućuje svoju izdvojenost u odnosu na prosječno i uobičajeno:

A eto, svijet to poima drukčije... Pa kako to, otkuda to da ne mogu svi barem naslućivati ono bajno u svijetu tonova što ne može iskazati ljudski govor, kako da ne osjećaju svoju nemoć pred onim što kazuje glazba? Zar se zbilja ne može i njihova duša dići na krilima sjajnih akorda onamo u visine, gdje leti od zvijezde do zvijezde i sluša govor kojim govore, kojim plaču, i smijeh kojim se smiju anđeli? (ibid.: 273)

Karakteristična je to umjetnička dekadencija u kojoj je glazba, na tragu Nietzscheova razumijevanja umjetničkoga djela kao obrane od svijeta, pozicionirana kao glavno načelo života, kao transcendencija i bijeg iz realnosti svakidašnjice. Budući da Amadej, kao i svi neurotici, ima problema sa sagledavanjem cjelovitosti stvarnosti, odnosno da je cjelinu zamijenio jednim njezinim segmentom koji pretendira prezentirati se kao apsolut, njegovo će otrežnjenje biti vrlo mučno, onoga trena kad ga takvo poimanje umjetnosti i realiteta prisili da 
se suoči s materijalnim ograničenjima i oprečnim vrijednostima. Od spekulativnoga razumijevanja egzistencije, koje je moguće interpretirati kao tipično dekadentnu strategiju negacije „životnoga“, konkretnoga svijeta kroz njegovanje glazbe, do okrutne spoznaje da glazba gubi svoje kompenzacijske mogućnosti te da ni na koji način ne može nadomjestiti besmisao. Život se ne može sublimirati plemenitom ljepotom, pa ni umjetnošću. Despotski karakter primitivne provincije potkopava sve mehanizme sublimnoga.

Putovanje prema tragičnoj izolaciji od drugih i od sebe te tjeskobi beznačajnosti, $\mathrm{u}$ smislu nemogućnosti da se uspostavi kao cjelovit subjekt (o kojoj smo, pozivajući se na Tillicha, pisali u prethodnom poglavlju), glavni junak započinje odlaskom na konzervatorij u Prag, kako bi se pokazalo da se boravak izvan rodnoga mjesta nadaje kao zatiranje osobnosti i autentičnosti. Iako je i život u provincijskoj sredini nemilosrdan, pa i pogibeljan, život u velikom gradu figurira kao simboličan početak puta u otuđenje i desubjektivaciju. Na tragu svojih reprezentacija u Pavlu Šegoti te u skladu s realističkom paradigmom i modelima velegradske kulture koji ilustriraju kako tehnološki, industrijski i kulturni razvoj metropole u isti mah podrazumijeva humanu regresiju, Novak i ovdje grad imaginira kao mjesto u kojem moderne strukture dvojako utječu na čovjeka: on je sve nezavisniji i samostalniji, ali u isti tren i sve otuđeniji i osamljeniji te osjeća „kako ga nestaje u mnoštvu ljudi velikoga grada“ (ibid.: 276). A budući da rastakanje Zlatanićeva identiteta počinje onoga trenutka kad stupi u urbano, sasvim je razumljivo zašto je njegova potraga za cjelovitošću otpočetka obilježena strepnjom pred nepoznatim i predosjećajem neke nejasne opasnosti, što će potencirati njegovu ionako prirođenu senzibilnost. „- Kamo ja idem? - upita se on i poćuti prvi put strah od nemoći pred ogromnim poduzećem na koje se otputio. Stao se smućivati u duši: jesam li ja za ovo što sam poduzeo?..."(ibid.)

Tim će mu simptomatičnim pitanjima na početku njegova velikoga pothvata Novak simbolično definirati život, čak i prije nego što se agonija otuđenja počne dosljedno odvijati. Već se u prvim koracima u velegradu susreće sa zaprekama s kojima se teško nosi, samodopadno uvjeren u vlastitu superiornost, čime će se samo dodatno moći pojasniti narcistička okrenutost vlastitomu ,ja“ i asocijalnost koja će ga odvesti bolnomu otuđenju od ljudi. Tegoban osjećaj nemoći da nešto poduzme i promijeni dani poredak stvari u velegradu potpiruje i njegova objektivna nemogućnost da utječe na činjenicu da, usprkos silnomu talentu, jedva spaja kraj s krajem. Snovi o vlastitoj genijalnosti bešćutno se sukobljavaju s grubim životnim brigama: neshvaćanje i nehaj zajednice, nezainteresiranost i sabotiranje, sitničavi prigovori. Pa kad odbiju poslužiti ga jelom jer ga nema čime platiti, Zlatanić na krajnje praktičnom primjeru spoznaje kako se ponor između svjetova nikad neće moći prevladati. 
To je bilo za njegovu mekanu dušu previše. Nikada se još nije sudario ovako grubo svijet što je živio, u njegovoj duši sa svijetom u kom je on živio. Morao je klonuti od takove povrede svoje duše, od neočekivanog razočaranja, od leda što je tako bolno pao na njegovu toplu i svjetlu dušu koja je ljubila sve ljude i vjerovala svakomu. (...) Je li moguće te mogu da ga odbijaju nemilom grubošću od sebe - njega, koji ćuti da mora biti štićen, ljubljen i željno dočekivan, jer nosi u sebi ono što je najbolje i najljepše u duši čovječjoj? (ibid.: 287 ; isticanje naše)

Raskol se pooštrava u drugom dijelu romana kad Amadej, vrativši se u rodni kraj, pokušava iznova osvojiti prostor kojemu misli da prirodno pripada. Njegovo kreativno buđenje, stimulirano i samouvjerenim maštanjima o razdraganom, veličanstvenom dočeku u rodnom mjestu, ${ }^{81}$ bit će kontrastirano zatucanoj i netolerantnoj lokalnoj zajednici, koja će postati simbolikom provincije koja uništava vlastitu djecu, prisutnom u svim tim romanima. Na taj se način izjalovljuje uobičajena reprezentacija maloga mjesta koje se u pravilu, kao rusoovski idilično mjesto tradicionalnoga načina života i čvrstih međuljudskih odnosa, suprotstavlja naglašeno pesimističnomu i sumornomu prikazu (vele)grada. „U toj tvrđavi navika gdje vladaju diletantizam, neznanje i nenavidnost“ (Čuljat, 2012: 206), gdje će svi njegovi prosvjetiteljski pokušaji podizanja životne i radne kvalitete postati suvišnima i neupotrebljivima, ostat će Amadej posve sam, pojedinac nasuprot kojemu stoji cijeli svijet. „Maleni, zapušteni, bijedni i nesretni - to je moj svijet.“ (Novak, 2009: 392) Krajnje bespomoćan, ali i potpuno trom u praktičnim pokušajima nadvladavanja ograničenja svoga društvenog statusa, s vremenom gubi motivaciju, napušta svoje stvaralačke principe te, dok propadaju njegovi „visoki snovi“ i „umjetnički ponos“ (ibid.: 405), od plemenite uzvišenosti glazbe dospijeva u nemilosrdnu borbu za goli život, što će ga natjerati da nakraju proda i vlastito ime. Društveni se uspjeh određuje imperativom hladnoga razuma i praktične materije koja vlada nad idejama:

Svega se odričem, samo dajte novac!... Ja nijesam žalostan, ni srdit, niti me ne grize savjest, ja sam samo tup. Ne osjećam ništa. Prodao sam svoje ime, ponos svoje duše, i ostao sam prazan kao od proste građe posuda iz koje ste istočili plemenitu tekućinu. (ibid.: 407)

\footnotetext{
81 Nakon uspješno izvedenoga koncerta na završnoj godini studija, popraćenoga općim oduševljenjem, hiperbolizirano se zanosi svojom ulogom promicatelja i proroka umjetnosti u domovini te slavnom budućnošću, sasvim nesvjestan svega što će ga ondje dočekati: „U tom zanosu gledao je jasno kako lako provađa svoje umjetničke namisli i diže razumijevanje za svoju umjetnost i u posljednjoj kolibici rodnoga si mjesta. A slava mu se i glas širi i do središta hrvatstva - i eto, on je ugledao sebe pred sveskom nota na stalku u zagrebačkoj pozornici. (...) Amadej je digao ruku, prvi sjajni akord zamnije dvoranom, a onda sva glazbala i trijumfalni pjev ljudskih grla stane izvoditi kompoziciju (...). A onda - kao ono Dvořaku - digao se buran pljesak ruku i silno klicanje od kojega se trese dvorana: 'Slava Amadeju, slava!'“ (Novak, 2009: 323)
} 
Vratimo li se pak na Zlatanićevo duševno stanje, možemo reći kako on razvija - cijeloga života prisiljen na izdvojenu, marginalnu poziciju u kojoj je odvojen i od svoje duhovne srodnosti i od svoje prostorne pripadnosti - simptome ozbiljne neurotične tjeskobe. Njegovo iskustvo neuspjele integracije vlastitoga ,ja“ i bezuspješnoga pokušaja uklapanja u pripadnu sredinu preuzima glavnu riječ u posljednjem dijelu romana, u kojem se u dramatičnom ispovjednom tonu dnevničkih zapisa prikazuju sve „strahote evolucije rasula i dekompozicije“ (Hranilović, 1902: 298). Svijest o pokidanim vezama, dominantno čuvstvo razapetosti između pojedinačnoga i kolektivnoga, ,između ideala i stvarnosti, između plemenitih ciljeva i očajničke borbe za koricu kruha“" (Nemec, 1999: 234) te nemogućnost njihova pomirenja, koje posve gospodari njegovom egzistencijom, proizvodi tjeskobu, intenzivne osjećaje bespomoćnosti i frustracije. Nije to više normalna tjeskoba kojoj bi mogao konstruktivno pristupiti, odnosno ona koja bi se mogla razriješiti kad bi se prijeteća situacija izmijenila ili okončala. Ona je naime prerasla u svoju patološku formu, generiranu neurotičnim obrambenim mehanizmima, koja paralizira svaku mogućnost djelovanja.

Jednom kad se suoči s prijetećom situacijom s kojom se ne može nositi, pojedinac pada u bespomoćno stanje unutarnjega konflikta te razvija simptome tjeskobe, koja se pak psihoanalitički može tumačiti kao energija potisnutih nagona koji provaljuju u svijest, „što dovodi do cijepanja ravnoteže koja postoji inače između 'ja', lične svijesti, i 'nad-ja', društvene svijesti“ (Supek, 1950: 83). Tjeskoba je dakle posljedica kidanja veze između osobne svijesti i društvene stvarnosti. Ostavljajući postrani Freudovu prvu teoriju anksioznosti kao rezultata „Zapriječenja ili neadekvatnog rasterećenja libida“ (Rudan, 2007: 68), prema kojoj pojedinac, da bi bio organski zdrav, mora ili reinvestirati libido ili razriješiti anksioznost koja ga preplavljuje, Zlatanićevu tjeskobu možemo prikladno objasniti njegovom drugom teorijom prema kojoj je tjeskoba središnji problem svake neuroze. U njoj je anksioznost Freud promatrao kao izravnu posljedicu traumatičnih situacija: u njima se ona „razvija automatski jer je psiha zatrpana prevelikim prilivom podražaja s kojim više ne može ovladati niti se od njih može rasteretiti u 'opasnim situacijama' u kojima osoba nauči anticipirati opasnost prije nego što ona postane traumatska“ (ibid.). Dakle s obzirom na sve dosad istaknuto, pridružujući ovoj psihoanalitičkoj perspektivi kulturnoantropološku, možemo zaključiti kako je u glavnoga lika tjeskoba, kao središnji problem svakoga emocionalnog i bihevioralnog poremećaja, odnosno dinamički centar neuroze, trauma poremećenih načela i struktura. Budući da izravno djeluje na svijest o vlastitom ,ja“, koja pretpostavlja i svijest o svijetu kojemu se pripada, ona raskida vezu između ,ja“ i svijeta, snažno utječući na dezintegraciju ličnosti i otuđenje od drugih te pojedinca istovremeno onesposobljava da uspostavi harmonično jedinstvo sa svojim „,realnim 
ja“, o čemu smo pisali na početku ovoga potpoglavlja. Amadej ni na koji način ne uspijeva postati determinirajućom silom u vlastitom životu. Naposljetku otuđenje od sebe u izravnoj je korespondenciji s otuđenjem od drugih, a iz toga se začaranog kruga sjetan dekadent slomljene energije jako teško može izvući. Budući da je potreba za povezanošću s ljudima, idejama i društvenim obrascima ključan segment čovjekova života - jer, kao što smo napomenuli, osjećaj apsolutne osamljenosti vodi do potpune duševne dezintegracije - razumljivo je zbog čega tjeskoba postaje Amadejevo fundamentalno stanje. Kako piše Fromm:

Pojedinac može biti godinama fizički usamljen a da ipak bude vezan za ideje, vrednosti ili bar za društvene obrasce koji mu daju osećanje opštenja i ,pripadanja“. S druge strane, on može da živi među ljudima a da ga ipak savlada osećanje krajnje izdvojenosti, čiji je ishod, ako ono pređe izvesnu granicu, stanje ludila koje predstavljaju shizofrenički poremećaji. Taj nedostatak vezanosti za vrednosti, simbole, obrasce možemo nazvati moralnom usamljenošću i reći da je moralna usamljenost nepodnošljiva kao i fizička, ili da fizička usamljenost postaje nepodnošljiva samo ako obuhvata i moralnu usamljenost. (1984: 19)

Dakle Zlatanićevo se otuđenje neposredno odnosi na činjenicu da u društvu ograničenih pogleda i skučenih izbora njegova profesionalna i stručna satisfakcija ovise gotovo isključivo o uvjetima izvan njegove kontrole. Ako je prema općim društvenim pravilima uspješan, pojedinac tek tad nešto vrijedi; ako ta pravila ne zadovoljava, tad je posve beznačajan. Tako da je njegova frustracija sasvim opravdana: neovisno o prekomjernoj osjetljivosti i manjku angažmana on iskušava kako njegovu istinsku vrijednost ne legitimiraju neosporne stručne i ljudske kvalitete, već ponajprije kolektivno prihvatljiv uspjeh na promjenjivom tržištu natjecateljskih ambicija. Zato se lako detektira da je njegova tjeskoba potaknuta strahom pred prijetnjom načelima koja čine njegovu koncepciju svijeta, pred principima koje izjednačava $\mathrm{s}$ vlastitom egzistencijom. Bez obzira na vrstu prijetnje tomu cilju individualnoga uspjeha, prijetnja uzrokuje „duboku tjeskobu koja pogađa pojedinca jer je riječ o opasnosti za vrijednosti koje se drže ključnima za njegovu egzistenciju“ (May, 1977: 167). No Amadej, premda cijelo vrijeme svjestan izvrnutih vrednota, i po cijenu razvijanja neurotičnih obrazaca ne odustaje od slobode stvaranja i življenja. Pa onoga trenutka kad se konačno odrekne svega što je bio, kad se granice njegove slobode dokraja suze, završit će u luđačkoj košulji poput Radmilovića, kažnjen jer je živio u prevelikom raskoraku između svojih načela i stvarnosti, idealnoga i realnoga. Shvaćajući kako njegovo ludilo implicira nesuglasje s normama, ispadanje iz poretka, 
neprilagođenost izvanjskomu svijetu, znakovito će nakraju zaključiti da su jednako neprilagođeni oni koji se bespogovorno i nekritički normama klanjaju:

Sad napokon vidim da sam dospio u društvo luđaka. Ima ih sva sila! Mi šećemo svaki dan po prostranu vrtu, gdje se s njima sretam i razgovaram. Koliko gluposti ne doživim. Sami luđaci! No napokon događa se sve to što gledam i izvan zidina ludnice. (Novak, 2009: 418; isticanje naše)

Sasvim konkretno, luđaci su jednako, ako ne i manje osakaćeni od (naizgled) zdravih. Otpor konvencijama i unaprijed postavljenim ulogama, pa čak i kad je krajnje pasivan poput Zlatanićeva, kriterij je njihove prave vrijednosti.

$$
* * *
$$

Fragmentarnu narativnu strukturu iz posljednjega dijela Novakova romana, koja dosljedno materijalizira fragmentaciju dekadentne ličnosti te iz prvoga plana prezentira osjećaj frustrirajuće nemoći pred sudbinom, u još je radikalnijem obliku upotrijebio Nehajev u svom Bijegu (1909). Posluživši se disharmoničnim pripovijedanjem kao zrcalom dezorijentacije glavnoga lika, ilustrativnim odrazom složenoga unutarnjeg stanja, autorsko, linearno pripovijedanje prekida njegovim monološkim, ispovjednim dionicama, dnevničkim zapisima i korespondencijom. Individualizam tako postaje pripovjedna strategija, onako kako na tome još ekstremnije inzistira Kamov u Isušenoj kaljuži. Raspad ličnosti reflektira se na strukturi djela: fragmentarno sebstvo zahtijeva fragmentarnu romanesknu strukturu.

Bijegom je Nehajev zaokružio vlastitu i kolektivnu fasciniranost pretjerano osjećajnim prirodama, emocionalno napregnutim, razdraženim likovima, sintetiziravši u Andrijaševićevu psihogramu

sve tipske osobine i karakteristične duhovne i etičke dvojbe hrvatskih intelektualaca u rasponu od Šenoina prijana Lovre, preko Gjalskijeva Janka Borislavića i Novakova Amadeja Zlatanića do Leskovarovih dekadenata (Nemec, 1998: 47-48).

I dok će Matoš istaknuti da bi Đuru, koji ga kao istinski psihopatološki materijal podsjeća na Goetheova Werthera i Flaubertova Frederica, „radije vidio prevedenog nego ponovno doživljenog“ (1973b: 283), ostatak će struke mahom jednoglasno procijeniti kako je 
riječ o (po)najboljem romanu hrvatske moderne, koji je inzistiranjem na univerzalnosti ljudske patnje izašao iz „naše regionalne zatvorenosti“ (Šicel, 2005: 193). Time i simbolično zaokružujemo ovo poglavlje: u svim romanima pojedinačno iskustvo melankolije postaje metafora kolektivnoga osjećaja Weltschmerza. Đurina individualna tragedija u kojoj propada kao žrtva borbe sa sobom i društvom kojemu se ne uspijeva prilagoditi postaje projekcijom sudbine cijele moderne generacije. Kako je nakraju shvatio Jagan, „mi smo određeni da propadnemo, i to ne samo kao narod nego i svaki pojedinac za sebe“ (Nehajev, 1963: 123; isticanje naše).

S obzirom na to da smo, govoreći uvodno u ovom poglavlju o sukobu pojedinca i okoline, napomenuli kako se taj pojedinac slama ponajprije zbog vlastitih slabosti, treba odmah istaknuti da društvene okolnosti i u Bijegu funkcioniraju kao okvir „prave“ radnje. Izabrani su momenti društvenosti suptilno signirani, dovoljno sugestivno da prikažu kako prostor snažno oblikuje pojedinca, utječući na njegovu mogućnost konstruiranja svoga ,,ja“. „Mučili su me kao Krista, ispili mi krv. Opijao sam se, da ne moram misliti na sebe; postao sam propalica, da mogu pobjeći od života.“ (ibid.: 147) Vraća nas navedena teza i na prethodno poglavlje, u kojem smo utvrdili kako je Nehajev, inzistirajući na taineovskoj ideji kako prostor snažno modelira ličnost, vjerno slijedio misao prema kojoj lik valja oblikovati u skladu s raspoloženjima vremena. Pa kad u Tošina usta stavlja dijagnozu osnovne teme hrvatske književnosti i ujedno njezinu kritiku, prema kojoj naši pisci kao „nekakvi užasni slabići“ opisuju „uvijek neke nervozne i izmučene ljude“ (ibid.: 34) te kroz Đuru izrijekom potvrđuje navedeno postavljajući znak jednakosti između likova i autora koji ih stvaraju bilježeći kako „mi ih ne opisujemo, mi jesmo nemoćni. Ljudi smo hira i časa, bez otpora“ (ibid.: 55) - Nehajev na neki način, držeći se elemenata iz vlastite biografije, ocrtava i vlastiti intimni proces. Pritom je shvatio da je jedno od krucijalnih obilježja modernoga hrvatskog inteligenta rastrganost između modernizma europske metropole, u koju odlazi u potrazi za znanstvenom i kulturnom legitimacijom, i konzervativizma skromne provincije, u koju se vraća dezorijentiran i iscrpljen. Naime kako smo prikazali kroz prizmu Simmelove i Bahrove teorije, velegrad kao kompleksan mehanizam postaje mjestom rastakanja identitetskoga jedinstva, prostor koji, potičući individualizam, taj isti individualizam guši i pojedinca tjera da se utopi u prosjeku mase. Upravo se iz takvih prilika Đuro vraća u domovinu da bi, poput Šegote, Mirkovića i Grančarića, shvatio da je zapeo negdje u rascjepu te egzistencijalni i profesionalni slom doživio u nemilosrdnoj senjskoj sredini. Njegov rafinirani duh formiran u velegradskom blještavilu izbora propada $u$ zajednici ograničenih mogućnosti i destruktivnih odnosa. „Skromnost prilika, duhovna tromost 
sredine, besperspektivnost, životna monotonija“(Nemec, 2010: 108) samo će potaknuti njegov ionako predestiniran pad.

Toša moj, ja ne spadam među ove ljude. Zašto, ne znam; ali znam to da je meni za život potreban neki milieu, ne možda bogat i luksuriozan, ali svakako takav da ne moram zapinjati pri svakom koraku. (...) Jesam li ja kriv što sam dosada išao preko granica koje nam pruža naše društvo, ili je tomu kriv tko drugi - o tom svemu ne mogu da sebi stvorim suda. Samo osjećam da mi je strašno. (Nehajev, 1963: 95; isticanje naše)

Dakle iako se njegov strah od mogućnosti neuspjeha u novoj sredini, o kojoj je pisao Veri priznajući da „strah me hvata - strah kao da ću u ovom novom svijetu u koji hrlim naći nešto nepoznato i novo na što se neću moći priučiti“ (ibid.: 8), pokazao opravdanim, on ipak propada zbog vlastitih slabosti, odnosno zbog toga što ga svaki bešćutniji potez društva čini još osjetljivijim. Premda mu ionako istrošene snage sve očitije kopne u tom sudaru s drugima, konflikt je zapravo u njemu. Rigidno se okružje tek nametnulo kao plodno tlo za razvijanje tipično dekadentne psihologije boli. Pa ako smo utvrdili da u Radmiloviću i Dvama svjetovima protagonistova intimna stanja potiskuju sva objektivna zbivanja u pozadinu, možemo reći kako su u Bijegu unutarnja proživljavanja posve u prvom planu. Sve što se u djelu događa ima za cilj prikazati protagonistove duševne nemire i traženja te postaje povodom za iscrtavanje njegove duhovne fizionomije. Cijeli je roman prema tome građen u izmjeni različitih Đurinih razdražljivih stanja u ambijentu negostoljubive okoline, pri čemu on ne samo da budno promatra vlastiti poraz nego i pokušava ponuditi njegovu etiologiju. Suočen s ispraznošću života koju tako tegobno osvještava na svakom koraku, prepušta se reminiscencijama, promišljanjima i autoanalizi koji ga vode neizbježnoj tragediji: u nemogućnosti da se izvuče iz egzistencijalne provalije, u koju je dospio težeći nekoj vrsti apsoluta, prepustit će se smrti. Možemo zato reći kako je Nehajev možda najcjelovitije od svih autora kroz analeptičko pripovijedanje elaborirao podlogu duhovne depresije svoga lika. A budući da je, jednako poput drugih dekadenata, Andrijašević poražen već na početku vremena pripovijedanja, jasno je zašto je u glavnini proza, pa i u ovoj, naglasak na analepsama u kojima se traga za potencijalnim uzrocima njihova stanja.

Gadan, tužan bio je moj život. A tko je kriv? Mislio sam o tom - i nisam riješio zagonetke. Je li moj odgoj, što su me učinili pjesnikom i literatom i dali mi zahtjeve kojih život nije mogao ispuniti? Je li ljubav za Veru koja se nije mogla dobro svršiti radi bijede i siromaštva moje 
službe? Jesu li ljudi oko mene - taj mali grad, zloban i sitničav? Je li alkohol, sanjarenje, slabost živaca, bolest duše? Ne znam, ne znam. Samo ćutim: valja svršiti. Valja pobjeći dokraja - uteći iz toga života gadnoga, sramotnoga. (ibid.: 148)

U središtu je dakle dekadentni misaoni subjekt, književnik i nastavnik, otuđeni intelektualac iznimnih kvaliteta koji, promatrajući svijet kritičkim očima, u procesu demaskiranja društva ostaje živjeti na margini, izoliran, otuđen, suvišan. S obzirom na to da ga razvijena spoznaja priječi da konstruktivno djeluje - jer ona implicira, kako smo ustanovili na drugim primjerima, iscrpljenu životnu energiju i bezvoljnu neodlučnost - on ostaje bez vrijednosti te stoga i bez smjera, bez mogućnosti izlaza iz frustracije svijetom koji ga okružuje. Andrijašević je još jedna uzorna figura dekadenta koja život fragmentira refleksivnošću. Prema tome sve društveno utemeljene prepreke u romanu - od njegove materijalne ovisnosti i nedostatka financijskih sredstava za život dostojan čovjeka preko protivljenja zarukama s Verom i sukobâ u zadrtoj sredini do negativnih kritika i književnoga neuspjeha - pomažu da u njegovoj perspektivi svijet zauvijek ostane reprezentacija ponora.

Pritom je bitno istaknuti da, pozicionirajući ga kao dekadenta, Nehajev Andrijaševića u isti mah pozicionira kao prototipskoga narcisa, čime se i taj roman upisuje u findesiècleovsku kulturu radikalnoga solipsizma. U njemu nagon da stalno o svemu promišlja, i to, naravno, ponajviše o sebi i stvarima koje se za njega izravno vežu, supostoji s intenzivnim osjećajem egzistencijalne beznačajnosti i ispraznosti. Ne čudi stoga što se o narcizmu može govoriti kao o nekoj vrsti ,pseudofunkcioniranja odnosno desocijalizacije“ (Frosh, 1991: 73). A budući da su sve životne snage usmjerene vlastitoj intimi, predodžba o drugom gotovo da i ne postoji. Zato će i Toša ispravno dijagnosticirati da je „odviše egoista“ (Nehajev, 1963: 24); Andrijaševićeva koncepcija svijeta naime druge ne uključuje. Nesposoban da se doista veže za drugoga, napose za ženu, da o njoj ovisi u smislu emocionalne obveze, angažmana i predanosti, može se prigodno objasniti Žižekovim (1986) modelom patološkoga. Kad osvijesti da je braku sve bliže, a od njega emocionalno sve dalje, glavni lik amnestira sam sebe nekim moralnim opravdanjima i neizglednom financijskom budućnosti kojom, tobože, nikoga ne želi opteretiti: „Što bih ja njoj mogao podati iza ove dvije godine gdje sam se već odvikao paziti na sebe, pače se i ne brinem da li mi je košulja čista... Samo pijemo... Jagan ima pravo: Treba propasti.“(Nehajev, 1963: 125) Međutim kod patološkoga narcisa, Žižek procjenjuje, ne može se govoriti o samilosnom suosjećanju i bolnoj iskrenosti, već je glavni problem 
u tome da ga data riječ ne obavezuje iznutra, ne obuzima: obećanja, veze, paktovi, sve su to za njega više ,pravila igre“ koje izvana valja poštivati, uvažavati, ali ga oni egzistencijalno ne obavezuju (1986: 321).

Kao što smo dosad vidjeli, a potvrdit će se i u sljedećim primjerima, dekadenti su pred licem žene obični neodlučni kukavice: nesposobnost da joj se predaju nesposobnost je izgovaranja zavjeta koji bi ih zauvijek vezao. „Što je Vera više naglašavala svoju vjeru u njega, on se osjećao bespomoćniji, bjedniji. 'Pobjeći, pobjeći' bila mu je jedina misao." (Nehajev, 1963: 51; isticanje naše) I Đuru umovanje upravo paralizira, blokira svaki „pravi“ životni angažman zato što je zarobljen u granicama samopromatranja te se čvrsto drži sebstva odbijajući drugoga, a neuspjeh da dopre do samoga sebe nudeći se drugomu leži upravo u tom narcističkom diskursu, u riječi izgovorenoj isključivo sebi. Bez drugoga kroz kojega bi gledao ta se ljubav prema ,ja“ $\mathrm{u}$ isto vrijeme, kako smo nekoliko puta istaknuli, promeće u poseban oblik samootuđenja: riječ koja zapravo nije nikomu upućena susreće se tek s vlastitom jekom. Otuđenje od drugih uvijek je praćeno otuđenjem od samoga sebe, koje pak vodi disoluciji sebstva kao završnoj točki permanentnoga sukoba između ,ja“ i društva kojim je ono okruženo. Društvena alijenacija, u kojoj se glavni lik sa svima nalazi u nekoj vrsti sukoba, onemogućuje identifikaciju samoga sebe.

Usto Đurin je narcizam moguće tumačiti i u svjetlu supstancijalne tjeskobe i autentičnoga čuvstva čame jer je, prema Laschu, jedna od ključnih oznaka narcisa tjeskobno čuvstvo u kojem se

žali na „nejasno rasplinuto nezadovoljstvo životom“ i osjećaj da je njegovo „amorfno postojanje neplodno i besciljno“. On opisuje svoj „tanani ali prožimajući osjećaj praznine i depresije“, „silovite oscilacije samopoštovanja“ i „opću nesposobnost snalaženja“ (1986: 42).

A osjećaj sveprožimajuće praznine, kako pojašnjava Žižek pružajući argumentaciju našoj tezi o dekadenciji kao rastakanju jedinstvenosti, ,znači upravo to da se subjekt nije uspio ujediniti, 'totalizirati' u homogeno egzistencijalno biće“ (1986: 312). U toj nemogućnosti uspostave jedinstva neuroza kao privatno i javno stanje postaje njegovim glavnim načinom nošenja sa svijetom. Proizlazi iz njegova odnosa prema svijetu te $u$ isto vrijeme na taj odnos presudno utječe. Odnosno, kao osoban problem sa snažnim društvenim implikacijama uvelike određuje način na koji se odnosi prema svom neposrednom okruženju. U tom se zatvorenom krugu, pasivan i nemoćan pred sudbinom, i Andrijašević vrti. Uza sve to njegovu neurozu kao 
neposredan rezultat društvenih zahtjeva, odnosno kao frustrirajući osjećaj sputanosti, možemo promatrati i u svjetlu Freudove „nelagode u kulturi“. Naime kako je Freud pojasnio, ljudi „s jedne strane, žele odsustva bola i nezadovoljstva, a s druge strane doživljavanje snažnih zadovoljstava“ (1970: 277). Smisao života proizlazi iz principa zadovoljstva, može se nedvosmisleno zaključiti te pritom ne mislimo samo na ono nagonsko nego i na ulogu koju u čovjekovu životu igra ekonomska sigurnost te društveni uspjeh i zadovoljavajući položaj. No patnja pojedincu prijeti iz triju izvora: iz vlastitoga tijela i njegove trošnosti, čime je u konačnici osuđen na neizbježno propadanje i nestajanje, iz vanjskoga svijeta, tj. iz prirode koja nemilosrdnim i razornim silama djeluje protiv čovjeka, te iz odnosa s drugima, odnosno iz „nesavršenstva ustanova koje upravljaju vezama među ljudima u porodici, državi i društvu“ (ibid.: 289). Pritom se čovjek, svjestan da ne može ništa promijeniti u svezi s prvim dvama izvorima, jer prirodu ne može ni na koji način svladati, opire socijalnomu izvoru patnje zato što spoznaje da ga kultura u složenom sustavu društvene organizacije tjera na prilagođavanje, odnosno potiskivanje. On ,postaje neurotičan jer ne može da podnese obim odricanja koja mu je nametnulo društvo radi svojih kulturnih ideala“ (ibid.: 291). Prema tome osjećaj „nelagode u kulturi“ zapravo je isti onaj osjećaj otuđenosti i osamljenosti iz priče o ekstremnom findesiècleovskom individualizmu, isti gubitak vjere u smisao čovjekova bivanja $\mathrm{u}$ društvu koje mu je strano, ista tjeskobna uznemirenost zbog nestajanja poznatih načela $\mathrm{i}$ nemoći da se stvore nova. Osjećaj okovanosti u svim područjima - od materijalnih briga, koje ga tjeraju da novac neprestano posuđuje i veže se dugovima, preko emocionalne obveze prema Veri, koju zapravo cijelo vrijeme odgađa, do profesionalne sputanosti koja ga tjera „da se drži suhe šablone zadavanja i ispitivanja lekcija“ (Nehajev, 1963: 81) - proizvodi u Andrijaševića silno nezadovoljstvo u društvu koje podriva njegove koncepte sreće i zadovoljstva. Uhvaćen u trenutku u kojem za njega više ne postoji sutra te zarobljen u misli kako ništa nije moguće, anksiozno osjeća težinu vlastitoga ,,ja“. Dok teži uspostavi cjelovitosti, raskida sve veze koje bi ga mogle učiniti cjelovitim.

Vraćajući se na etiologiju Đurine „,bolesti““, bez pogreške se može reći kako je njegova propast odavno upisana u životnu strukturu. On je, kao što smo već sugerirali, žrtva vlastita karaktera, bolećivosti koju, poput drugih dekadenata, nosi u sebi te je svojevoljno i čvrsto u sebi zauvijek održava: „(...) makar da nije doživljavao nikakvih silnih događaja, mladenačko doba bilo je za nj vrijeme jakih kriza koje su udarile biljeg svemu njegovu kasnijemu naziranju na svijet.“ (ibid.: 15; isticanje naše). U njegovoj je patografiji zabilježeno da je oduvijek bilo posve jasno da će „od tjelesno inače dosta slaboga dječaka“ (ibid.: 14) biti ,ili nešto ili ništa“ (ibid.: 15). Dakle manjak je njegova élan vitala čak i fizički utemeljen: ne iznenađuje 
stoga što će i godinama poslije, s nedovoljno bioloških preduvjeta, biti nesposoban voditi aktivan život. Usto primio je u naslijeđe ,teret“ mentalne razvijenosti - jer se s majčine strane „sva obitelj sastojala od duševno silno razvitih ljudi što su ipak više ili manje pustolovno završili život“" (ibid.: 14-15) - te nesigurnost, neizvjesnost i opterećenost vezane uz najužu obitelj. Obitelj je naime prva i osnovna sfera međuljudskih odnosa u kojoj pojedinac započinje s prepoznavanjem svijeta i načina na koji mu njegovo ,ja“ pripada. Dakle jednako kao što ga određuju njegovi vlastiti segmenti, tako ga određuju i specifične forme odnosa koje vodi unutar obitelji. U identitet se upisuju i tragovi obitelji kao uporišne točke svake egzistencije te ona, s obzirom na to da je početno mjesto iz kojega se kreće u složenost društvenoga iskustva, igra bitnu ulogu i u svim budućim odnosima. Obitelj nas određuje, smatra Russon, u tolikoj mjeri da se može reći da je pojedinac prepoznat kao „netko“ tek onda kad ga prizna obitelj, koja mu ujedno postavlja parametre vrijednosti koje će slijediti u budućnosti (2003: 79). Prema tome očevo često izbivanje (što mu je osiguralo tjeskoban osjećaj rastanaka i odlazaka te ga na neki način prisililo da se na njih nauči, pa će mu bježanje ostati doživotan poriv) i njegova prerana smrt te snažna majčina religioznost i kruti vjerski odgoj, koji su djelovali i na kompleksan osjećaj spolnosti, nesumnjivo su u velikoj mjeri usmjerili Đurin život. „Mati koja ga je uzgojila kao samotnu biljku, čuvajući dječačića od dodira ulice“" (Nehajev, 1963: 15), onemogućujući da proživi prijeko potrebno „obično“ djetinjstvo, što će utjecati i na kasniju socijalnu neprilagođenost. A dojam gađenja i moralne prljavosti nakon prvoga seksualnog iskustva imat će daleke reperkusije na njegov doživljaj žene, pa i na doživljaj ljubavi koja će zauvijek ostati platonska i nepraktična. Apstraktna čuvstvenost, kao i u drugih dekadentnih figura.

Osim toga njegovu su stanju duhovne ispraznosti pridonijela opterećujuća očekivanja okoline jer se oduvijek pretpostavljalo da će, nadaren od malih nogu, biti velik čovjek: „,...) sa sedamnaest godina vrijedio je već i u očima sudrugova i kod profesora kao sigurna buduća veličina.“ (ibid.: 14) Doista, pokazalo se nakraju da je postao i prevelik za sredinu koja primitivnošću i zaostalošću zatire svaku iznadprosječnost. Lako se onda složiti s Milanjom kad primjećuje da Đuro

propada uglavnom svojom krivicom, to jest poradi dihotomije intelektualne superiornosti, bolje bi bilo reći kvaziintelektualne, spram životne praktične nesposobnosti, a tek potom i krivicom društvene sredine, koja je ispod njegove kulturne i intelektualne razine (2002: 292).

Dakle njegova je odgovornost u tome što je želio ići iznad realnih mogućnosti, iznad onoga što jedno duhovno ograničeno društvo može podnijeti i prihvatiti. Egzistirajući u takvim 
uvjetima, ne pristajući na neko srednje rješenje, već težeći nikad dohvatljivomu apsolutu, postaje „bolesno nervozan“ (Nehajev, 1963: 7) te silom prilika, baš poput svih drugih dekadenata, ,prestar za svoje godine““(ibid.: 27). Živčana su ga napetost i pretjerana rafiniranost učinile i fizički bolesnim čovjekom, čovjekom na čijem je licu, kako zlokobno proročki najavljuje Jagan, „napisano da će umrijeti mlad“ (ibid.: 138):

Nije mogao dugo gledati svoju sliku. Vlastite oči zurile se u nj iz stakla ispite, bez izraza: crveno, nabuhlo lice, okruženo raskuštranom, neurednom, davno nestriženom bradom, imalo je vid kao u teško bolesnog čovjeka. (ibid.: 141)

Naposljetku valja istaknuti i možda najvažniju činjenicu, onu da se sav Andrijaševićev životni razvoj i dekadentna filozofija, pa i mentalni zamor koji će se razviti do zavidne razine, može razjasniti s obzirom na intelektualne sklonosti, ${ }^{82}$ posebice s obzirom na umjetničku hipersenzibilnost. Njegova je troma nevitalnost, kultivirana od mladenaštva, izravna posljedica umjetničkoga doživljavanja života, odnosno pokušaja nadvladavanja realiteta književnim djelovanjem, a artistički eskapizam kojemu rado pribjegava - pa primjerice piše dramu o društvenim okolnostima i odnosima u senjskoj sredini, a književnost i pisana riječ uopće bile su, na kraju krajeva, i artikulacija njegove ljubavi prema Veri - reakcija je na vladavinu prosječnosti i banalnost svakidašnjice, ali i jedini način koji mu preostaje za suočavanje s realnošću. Za drugi mu naime nedostaje životne snage. Takvoj će spekulativnoj egzistenciji, ne bi li se još bolje istaknule Đurine slabosti, biti suprotstavljen životni vitalizam njegova prijatelja Toše. Apstraktnost Đurine životne ideologije prožete beznađem i osjećajem polovičnoga uspjeha najsugestivnije opisuje Tošin praktični realizam, prema kojem se svako melankolično umovanje i letargično predavanje nevoljama predstavlja kao degeneracija: ${ }^{83}$

\footnotetext{
${ }^{82}$ Obvezna su mu lektira naime bili i Schopenhauer i Nietzsche: „Onda mi je bio jasan i Nietzsche sa svojom anarhističkom mišlju o ubijanju samoga sebe (natčovjek sam sebe žrtvuje, odričući se čovještva), a kod Schopenhauera još me je i smetao njegov smisao za umjetnost. Gledao sam sve crno - nemilo.“ (Nehajev, 1963: 38)

${ }^{83}$ Ekstreman primjer pogibeljnoga sudara aktivne i kontemplativne egzistencije iznio je Kolarić Kišur u romanu Laž (1905), suprotstavivši dva brata u borbi za naklonost jedne žene. Karakteristično strukturiranomu Ivanu, dekadentnomu, neurotičnomu književniku morbidno smanjene životne energije, koji neprestano ćuti „duševnu težinu, klonulost i sumornost cijele volje, svega intelekta“ (Kolarić Kišur, 2013: 15), suprotstavlja Krstu, poduzetnoga, energičnoga individualca: „Što je u Ivana slabo i nejasno, to je u njega silno i izrazito.“ (ibid.: 48) I dok će Krsto djelovati krajnje poduzetno te mu oduzeti ženu koju voli, Ivan će bez prestanka razmišljati, gajeći snažne osjećaje slabosti i nemoći, te život okončati upravo onako kako je cijelo vrijeme živio: spekuliranjem o pokvarenosti ljudskih odnosa.
} 
Eh, pjesnik, vidi se! Ja bih ti odmah odredio lijek, da me hoćeš slušati: počni ti raditi kao ja ili moj otac (Toša je svršio maturu, bio godinu dana na nekoj višoj gospodarskoj školi i vratio se kući da pomaže ocu), pa ćeš vidjeti kako nestaje melankolije. (ibid.: 23)

A za potpunije shvaćanje Đurine tjeskobne melankolije vrijedi referirati se na neurasteniju kao specifičnu baštinu modernoga urbanog života. Naime nakon povratka iz Beča on nastavlja promatrati svijet u impresionističkoj besposlici, pasivno se prepuštajući dojmovima te uviđajući kako „sve što je stabilno i čvrsto povezano raspada se u metamorfoze i uzima karakter nedovršenog i nepotpunog“ (Hauzer, 1966: 372). I on se vraća kao karakterističan neurastenik, ,potrošen i pohaban“, ${ }^{84}$ te možemo pretpostaviti da je jedan od pokretača njegove neurastenije, uz urođenu predisponiranost o kojoj smo govorili, i velegradski život. Sjetimo li se findesiècleovskih teorija o nekim pogubnim socijalnim navikama koje utječu na degeneracije različitih vrsta, poput konzumacije alkohola kao „lijeka“ za nemirnu i nervoznu ličnost koja bježi od puke dosade, ne možemo ne uspostaviti vezu između Đurine živčane razdražljivosti i poročnoga života u Beču.

Privikne se na duge večeri u začađenim i blatnim lokalima, na društvo stalnih pivopija i pomalo i sam dođe na to da se umiruje alkoholom. Uloga očajnika postane mu drugom naravi - i gotovo s deklamatorskim gestama stane se opijati noć na noć, brinući se jedino za to kako će provesti sutrašnji dan bez dosade. (...) Par puta pokuša da piše, da stvara; - ali uvjerenje o beskorisnosti svega tako ga bilo zaokupilo, da je svaki put iza uzaludna napora bacio pero i sa još ojađenijom dušom išao u gostionu da svoj nemir utopi u alkoholu. (Nehajev, 1963: 22)

U domovinu se vraća opasno narušene egzistencije, izmučenih živaca zbog čega ,izgubi interes za nauku i stane tražiti načine da sam sebe ponizi još gore, podavši se dokraja misli da nije vrijedan života“ (ibid.: 21). To čuvstvo nedostojnosti i nedoraslosti kombinirano s čuvstvom vlastite superiornosti pratit će ga do samoga kraja. Opsjednut osjećajem bespomoćnosti i jalovosti svakoga napora da životu pronađe smisao, neizlječivo lišen snage volje, dane provodi inertno se pokoravajući nevolji jer mu skepsa oduzima svaku mogućnost praktičnoga djelovanja u stvarnom svijetu. Svijet se lišava vrijednosti i značenja, život gubi svrhu, pa mu preostaje tek pitanje zašto se ičemu posvetiti kad su sve inicijative unaprijed osuđene na propast.

\footnotetext{
${ }^{84}$ Nerijetko se naime govorilo kako su neurastenici žrtve „trošenja i habanja“ (wear and tear).
} 
Andrijaševićeva patologija izranja dakle kao nemogućnost organiziranja vlastitoga ,ja“, u kojoj ga nihilistička ravnodušnost u carstvu tjeskobnoga nepronalaženja smisla života onesposobljuje da djeluje. Opterećenost sobom i promatranjem svojih stanja, čemu ćemo se još vratiti, umanjuje ili posve onemogućuje aktivan angažman u praktičnoj svakidašnjici, što je i u ovom slučaju moguće povezati sa zamorom i općom slabošću živaca, odnosno zakočenošću volje. S obzirom na to da se i ova egzistencija odvija kroz razmišljanje i samoproučavanje te je pritom nedvojbeno da se mogu uspostaviti odnosi između iscrpljenosti i mentalnoga, intelektualnoga rada, nije naodmet naglasiti kako je patološka inhibiranost volje kao simptom neurastenije ponukala Charlesa Féréa, jednoga od najglasnijih zagovornika hereditarne veze u neurozi, na zaključak da se kroničan zamor može opisati „prekomjernom moždanom aktivnošću, intelektualnom, posebno moralnom potrošenošću i neprestanom brigom za različite životne bitke“" (cit. prema Rabinbach, 1992: 155). U njegovoj nam je teoriji napose zanimljiva teza da su neurasteniji podložniji pripadnici intelektualnih zanimanja ,zbog njihova duševna stanja koje pobuđuje ekstreman nemir, a koji pak često poprima aspekte melankolije“ (ibid.: 156). Iako je mogla pogoditi ljude svih zanimanja i društvenih kategorija, neurastenija se dakle tumačila i kao posljedica prekomjernoga mentalnog rada koji rezultira smanjenom aktivnošću. Držalo se da je ona, za razliku od histerije, ,privilegij“ obrazovanijih slojeva, naročito intelektualaca koji svoj mozak danonoćno opterećuju. Oni su u isti mah žrtve te uzori modernoga stila života, pokazatelji kulturnoga napretka i njegov nusprodukt. I Janet je volju i zamor smatrao ključem za razumijevanje svih psiholoških poremećaja te je emocije (posebno traumatične) držao glavnim izvorom duševnih poremećaja. U njegovoj teoriji, u kojoj se kao najveća novost uvodi termin psihastenije, postoji hijerarhija energija potrebnih za različite vrste djelovanja, a moderan život pritom iz čovjeka crpi goleme količine energije. „Rad, aktivnost neophodna za zarađivanje za život, zahtijeva od gotovo svakog pojedinca veliku potrošnju snage“ (Janet, 1925: 161-162), a uspješna adaptacija na te zahtjeve ključ je mentalnoga zdravlja. Budući da je zamor psihički poremećaj koji, za razliku od emocije, nastupa nakon intenzivne i ponavljajuće aktivnosti (ibid.: 155), može se najkraće istaknuti da je neuropat umoran do krajnjih granica. A pritom je indikativno da se neurastenici iznimno često „izjašnjavaju iscrpljenima od zamora, tvrdeći kako su rođeni umorni te da njihova bolest nikad i nije bila ništa više od zamora“" (ibid.: 86). Prema tome čovjekova je psiha neprestana borba između energije i zamora.

U Andrijaševića se na tu „urbanu“ formu mentalne iscrpljenosti i živčane osjetljivosti povezanu sa životom u velegradu i porocima moderniteta nadovezuje pritisak društvenih sila, tako da njegova neurastenija izrasta kao specifična neuroza generirana i društvenim stresom, 
devijantnim pritiscima i očekivanjima. Neurastenija je, podsjetimo, kao koncept bila neodvojiva od iscrpljenosti koja se, kao duhovno i emocionalno stanje, manifestirala kao letargija i apatija, tj. slabost u svakom smislu. Pritom je intrigantno što je priča o rastrojenim živcima dosegnula danas možda i teško shvatljivu popularnost. Naime ako ijedna riječ vjerno ilustrira prijelom stoljeća, sumirajući u sebi sve njegove temeljne postavke - individualnu moždanu i emocionalnu iscrpljenost, koja se potom kolektivizira šireći se u sve pore društva onda je to bez sumnje neuroza. Uspješno cirkulirajući iz medicinskoga diskursa u književni, kako smo već pisali, ona je bila nevjerojatno privlačna tema, pa Carter nabraja niz francuskih autora koji su, referirajući se na naslijeđenu krhkost i neurotičnu onemoćalost, izveli pravu malu revoluciju u književnoj psihologiji: od ideala do ennuija, od idealizirane emocionalne hipertrofije romantizma do neurastenije (1958: 63). Tako da hrvatska književnost slijedi tu modu vremena, govoreći zapravo vrlo rijetko izrijekom o bolesnim živcima, ali zato suptilno naslućujući suvremena europska kretanja. ${ }^{85}$

Kući nije htio da ide jer se bojao da neće zaspati od uzrujanosti i nemira (živci bili su već sasvim slabi, ruke osušile se i drhtale). (...) Ali ni alkohol nije često mogao da svlada živčane napetosti; Đuro bi legao u krevet i uzalud nastojao da zaspi. Svaki šuštaj zabolio bi ga, kao da ga je netko bocnuo u mozak; gdjekad činilo bi mu se da je netko drugi uza nj u sobi. (Nehajev, 1963: 146)

\footnotetext{
${ }^{85}$ Naturalistički imaginarij fatalnoga naslijeđa i ,pravi“ medicinski diskurs degeneracije, u hrvatskoj književnosti prisutan u vrlo malo primjera, detektirali smo u Treščecovoj pripovijetki Listak romana (1903), u kojoj glavni lik Vladislav Gorjanović, uzorno u sebi oduvijek njegujući čuvstvo duboke melankolije, obolijeva od neurastenije. Ona mu se izrijekom dijagnosticira: „Stvar nije tako nedužna. Neurastenija u jakoj mjeri.“ (Treščec Borotha, 1969: 255) Iako je u njega ona posljedica očne bolesti i oslijepljenja u ranoj mladosti, intenzivira se nakon suočavanja s činjenicom da mu se urušava svijet kakav poznaje - doznaje da mu žena voli drugoga. U njemu, urođeno bolećivom i razdražljivom, uvjerenom u besmisao života, sumnja u ženinu vjernost i vlastitu vrijednost pokreće posljednji stupanj neurastenije. Pa u beskrajnoj tuzi u koju upada od tjelesnih i duševnih boli povlači okidač, označavajući na taj način i kraj generacije: on je naime posljednji potomak jedne degenerirane obitelji te s njim upravo kroz degenerativno naslijeđe izumire cijela loza. „Samoubojicama od poroda kao da se samo oružje utiskava u ruku, (...) kao da ih nagon, sila neka koja struji u baštinjenoj krvi goni na samokrv, ispunjajući ih zamamnom žeđi za ranom smrti. Moralo je tako doći, mišljaše on; to je opet narav htjela da se u meni zatre taj bolesni rod. (...) Ja sam osuđen, ja ne smijem više rađati bolesnih potomaka, kod mene je kraj. Onda mu se nadala misao: tko šta gubi ako njega nestane? Zar čovječanstvo, kojemu je bolesno udo? Zar ta domovina njegova, za koju nije nikad mario? Ona se trza iza sna, stotine novih klica proklijavahu u njoj da se zazelene u novo proljeće; ona treba ljudi, jakih, zdravih, koji su podobni za nju raditi. Slabića, sanjara, Hamleta ne treba Hrvatskoj. Gnjilih panjeva treba i tu da se uklone mladim zelenim hrastićima makar se isjekla cijela ta trula šuma besvjesnog naraštaja kojemu je on pripadao. Suvišan čovjek, koji je svršio, doživio, svakomu na putu." (ibid.: 260; isticanje naše)

Moderna bolest živaca kao glavna dijagnoza postavljena je i Niki iz Draženovićeve pripovijetke Zeleni zastor (1902). Generirana preosjetljivošću, onemoćalim vitalizmom te melankoličnim stanjima glavnoga lika, koji tumači da „,kadno po prviput osjetih tu ubitačnu sjetu, tu bol života, nije ona mene sve dosele ostavila“ (Draženović, 1902: 309), bolest će u atmosferi zavičajnoga okružja čudesno netragom nestati nakon što se izmiri s voljenom ženom: „Uminuo je mahom onaj teški nalet bolesti - duševne!“ (ibid.: 327)
} 
A imajući na umu da se Đuro ne bavi ,pravim“ poslom, onim kojim se privređuje, lako se priklanjamo Ribotovu opisu neurastenije kao otpora radu ili aktivnosti u bilo kojem obliku, tj. kao nesposobnosti da se posao obavi efikasno. Zamor, koji je, kako smo vidjeli u uvodnim dijelovima, izrastao na ideji radne snage tijela, energije i produktivnosti, u naših se dekadenata ne veže uz tjelesnost (iako se naposljetku reflektira i na njoj): on nije rezultat fizičke potrošenosti tijela, nego se može tumačiti kao nedoraslost ili nesklonost obavljanju praktičnoga posla. Prema tome efikasan su rad i duševni poremećaj uzročno-posljedično vezani te se patologija promatra kao direktan rezultat društvene uloge koju dekadenti zauzimaju. Njihov je zamor nerazdvojivo povezan i s manjkom produktivnosti u socioekonomskom kontekstu, a tjeskoba koja ih obuzima u većoj je ili manjoj mjeri razumljiva i u svjetlu Frommove teze da je rad jedan od načina njezina ublažavanja. Jasno je stoga zašto oni tjeskobu ni na koji način ne mogu umanjiti ili je se riješiti. Dekadencija je entropija tijela i duha. Usto patologija je generalne tromosti jasna i u ključu dobro nam poznate dekadentne dihotomije između vita activa, u smislu proizvodnje ili bilo koje aktivne djelatnosti, i vita contemplativa, u smislu meditativnoga načina života udaljenoga od svjetovne svakidašnjice. Život koji se živi nasuprot životu koji se motri i promišlja.

Pritom se u Đurinu životu kontemplacije kao osnovni generator pasivnoga prepuštanja svemu što život nosi izdvaja motiv fatalizma, koji izravno korespondira s motivom bijega. Pa kad mu Toša savjetuje da uzme stvar u svoje ruke, on jednostavno nije svjestan da Đurina melankolija i bezvoljnost ne ovise o njemu već o zakonima izvan njega. Naime kao glavno opravdanje svoje pasivnosti Đuro promovira neoromantičarsku ideju da je sve već zapisano u zvijezdama te da jedino što čovjeku u takvoj situaciji preostaje jest pokoriti se slijedu događaja, jer svaka je borba unaprijed osuđena na propast. Zato se njegovo bivanje odvija kroz umarajuću bezvoljnost u kojoj se, sve se više duševno iscrpljujući, prepušta rezigniranomu promatranju; sve se ionako događa upravo onako kako je unaprijed određeno. Od iznimno rijetkih radosnih trenutaka preko živčane napetosti do apatije i depresije, svaki je dan novo pokoravanje nevolji. Takav je fatalistički doživljaj posve shvatljiv u svjetlu dobro nam poznatih činjenica: suspregnute volje i kukavičke nesposobnosti da se doista aktivira i pokuša nešto promijeniti. Patološka se nemoć konkretnoga angažmana legitimira sudbinskom predodređenošću:

(...) podao se misli da će se morati promijeniti ili neočekivano doći nešto što će popraviti svu nevolju. Odluka ,podavati se životu“ nije za nj bila ništa novo. Svaki put kad bi ga nešto zateklo što se nije dalo odmah svladati ili je bilo u neskladu s njegovom duševnošću koja je žudjela za harmonijom i mirom, kad god bi se našao oko u oko s neprilikama običnog života, koje se nisu 
dale protjerati ni mislima ni sanjarenjem, Andrijašević bi bez otpora doskora zaključivao da nema smisla s tim razbijati glavu, i - čekao što će doći. (ibid.: 81)

Prema tome jasno je da se iz stalne egzistencijalne napetosti i neprekinutoga procesa identitetskoga raslojavanja, pri čemu ostaje trajno opsjednut klonućem, tjeskobnom spoznajom o svemoći duševne i materijalne bijede te sumnjom u zatečene vrijednosti, mogao izbaviti jedino smrću. Eskapizam kao životni moto ostaje završna i posljednja stanica njegove egzistencije:

(...) čini mi se da sam ja uvijek bježao od života i od ljudi. Nikad se nisam opro - uvijek sam se maknuo na stranu. A kad sam došao u dodir s ovim životom naših ljudi, životom u bijedi i u sitnim prilikama, bježao sam od njih. Bježao sam i od sebe, ne hoteći vidjeti kako propadam; opijajući se, samo čekajući konac. (ibid.: 148)

Zaokružuje na taj način Andrijašević krug ovih triju proza u kojima se inzistira na nerazmjeru između čovjekovih sposobnosti i ograničenja društvenoga položaja koji mu rođenjem i klasom pripada. A budući da se melankolija intenzivirana traumom društvenoga odbijanja napaja na pozadini njihove osjetljivosti, refleksivnosti i neaktivnosti, može se zaključiti da je u njima pozitivistička interpretacija dopunjena i nadvladana idejom psihičke predisponiranosti lika. Utjelovljujući tjeskobu beznačajnosti iz prethodnoga poglavlja, oni ne uspijevaju pomiriti vrijednosti svjetova između kojih su razapeti, pa kao svoju egzistencijalnu formu izabiru bijeg u sebe. A s obzirom na to da, složimo li se s Russonom, održavati normalno sebstvo kao ideal znači održavati neovisan izbor kao najvišu vrijednost ljudskoga života (2003: 88), jasno nam je zašto se njihov pokušaj pronalaska svoga mjesta u zajednici izjalovljuje. Praktično nesposobni i patološki inertni, preplavljeni „dojmovima sadašnjeg osamljenog, dosadnog, besmislenog“ života (Nehajev, 1963: 92), iako kroz pesimizam i radikalno negiranje dospijevaju do „ništa“, neće uspjeti zadobiti moć za životom. 


\subsection{Pamćenje gubitka: Martić i Imrović}

Svojim prvijencem Misao na vječnost (1891), koji se opravdano naziva paradigmom njegove pripovjedne matrice i uvodom u ostatak opusa (Milanja, 1987: 22), Leskovar je stekao danas kultni književni status. Nastavio je dekanonizaciju stilske formacije realizma, odnosno dezintegraciju tradicionalne pripovjedne strukture, koju je nagovijestio Gjalski u Janku Borislaviću, te njime inaugurirao novu umjetnost za kojom će mlađi književni naraštaj žudjeti tek nekoliko godina poslije, a koji će Dežman ovako opisati u Mladosti 1898:

U toj živčanoj trzavici, usred patnja i nade digla se nova umjetnost. Nije to stanoviti pravac teoretički konstruiran - ne, nego je to odraz duševne borbe nove generacije. Borba protiv materijalizma u umjetnosti je deviza. Još tapka po tmini, tek ovdje-ondje sine koja zraka novog sunca. Zvali se moderni: simbolisti, dekadenti, impresionisti i t. d., jedno im je zajedničko: traže nove ciljeve, idu neutrtim stazama; bježe u svijet. Gube se u tihoj čežnji za novim idealima. (1951: 85)

Razvijajući svoju subjektivističku estetiku neovisno o programima i manifestima te suptilno naslućujući modernu osjećajnost, na vrhuncu moderne Leskovar je već imao koherentan, gotovo dovršen opus, s dominantnim likom dekadenta čije glavne osobine postaju labilnost i prenaglašena osjećajnost. Zanimljivo je da je dekadenciju vrlo uspjelo prezentirao u njezinim fragmentarnim oblicima, izabirući tek nekoliko segmenta iz kompleksnosti toga fenomena (najčešće u kratkoj formi), te nevjerojatno pomno istaknuo sve ono što je obilježava. Predosjećajući postojanje latentnih sadržaja u čovjekovu životu, nastojao je doprijeti do nepoznatih sfera čovjekovih dubina te je nedvojbeno predvidio nešto što će na velika vrata ući tek početkom XX. stoljeća. ${ }^{86}$ On je među prvima u nas za svoj predmet uzeo modernoga, jalovoga dekadenta koji se, pritisnut tjeskobnim nemirom, okreće svojoj unutrašnjosti da bi otkrio ono „nešto“ što mu upravlja sudbinom, te ga u različitim nijansama portretirao u cjelokupnom svom proznom opusu. ${ }^{87}$

\footnotetext{
${ }^{86}$ Iako je nezahvalno naslućivati poticaje i načine na koje je Leskovar došao do uvjerenja o postojanju latentnih sadržaja u čovjekovoj svijesti, ipak se možemo prikloniti Lehrerovoj zanimljivoj tvrdnji kako pojedini (europski) umjetnici možda nisu anticipirali znanost samu, ali su definitivno vidjeli nešto što znanost tad još nije vidjela niti je u potpunosti racionalizirala (2007: 11). Predosjećalo se ono što je tek imalo doći.

${ }^{87}$ Neki su kritičari procijenili da je Leskovarovo zanimanje za takve teme umnogome odredila i neostvarena ljubav s Milkom Trninom. Na to ih je potaknuo i njegov znakovit autobiografski zapis: „Ali u mojoj podsvijesti, negdje u dubinama, uzela je ona stalno mjesto. Što se tu događalo ne znam i ne mogu znati. Običnim našim razumom tamo ne dopiremo. Samo po metapsihičkim pojavama, kojih se je iza Swedenborga dovoljno nakupilo, daje se naslutiti da pokraj našeg iskustvenog svijeta postoji još jedan metapsihički svijet.“(Leskovar, 1963: 245)
} 
Dakle već na početku stvaralaštva Leskovar utemeljuje pesimizam šopenhauerovske provenijencije, u kojem se i svako eventualno pozitivno raspoloženje prevladava beznađem kao primarnim osjećajem. Nedvojben je bio Schopenhauerov utjecaj na Leskovara (usp. Stančić, 1994) ${ }^{88}$ kolikogod ga Cerovac imao potrebu braniti tvrdeći da „ni po kojoj definiciji Leskovar nije dekadent, a niti su dekadenti njegovi junaci jer kod njih nedostaje ono primarno za dekadentstvo: pesimističko naziranje na svijet, pasivnost, sumornost““ (1969: 220). Pomalo bizarno zvuči to opravdanje kad znamo da je navedeno, u većoj ili manjoj mjeri, svojstveno upravo leskovarcima (Frangeš, 1963: 8) te da je to psihoanalitičko profiliranje glavnih junaka kao osobenjaka i čudaka možda ključna komponenta njegove modernosti. Odnosno, kako piše Nehajev, proglašavajući Leskovara prototipom modernoga autora:

Ono što filozof izrazuje matematičkim shemama i misaonim sumnjama, umjetnik ćuti, osjeća. Makar intuitivno, u današnje doba mora da u njegovoj umjetnosti bude izraženo ono što se zove „,ideja novoga vijeka“ ili, kako je još zgodnije rekao Brandes, „ideje inteligentne Evrope“. Tek onda je on moderan pisac - moderan po tome, jer ga muči i uznemiruje ono isto što uznemiruje Fausta našeg doba u ovim danima kušnje koja nijednom idolu ne da počinka, nijednoj nedokazanoj tvrdnji opstanka - makar da je i sama tek začela graditi trudnu zgradu svojih snažnih stečevina. (1964a: 65-66)

Kobna sudbina svih Leskovarovih protagonista rezultat je njihove neodlučnosti i kukavičluka, nesposobnosti da žive u sadašnjosti, zbog čega pod pritiskom prošlosti ne uspijevaju donijeti ključne životne odluke. Njegovi su junaci tragičari, „pa i kad imaju sve predispozicije da žive relativno sretnom egzistencijom, pate od misli na prošlost, odnosno od analitike prošlosti, koja ih progoni u sadašnjosti sprečavajući i uništavajući njihovu budućnost “ (Milanja, 1987: 21). I to je možda najbolje sažeta bit Leskovarove filozofije dekadencije.

S obzirom na to da u novelama Misao na vječnost i Jesenski cvijetci, kojima se u ovom poglavlju bavimo, izostaje socijalna motivacija, ne možemo govoriti o društvenoj i političkoj klimi kao preduvjetu dekadencije glavnih likova. Ali to ne znači da je ona manje uspjela. Dapače, likovi neuvjetovani društveno-političkim okolnostima puno su bliži zapadnjačkomu modusu ,prave“ dekadencije. ${ }^{89}$ Unutar korpusa odabranih tekstova te se proze mogu izdvojiti

\footnotetext{
${ }^{88}$ U jednoj je bilježnici napisao: „U filozofiji je moderna struja pesimizam. Shopp. je bog - Hartman njegov profet." (cit. prema Cerovac, 1969: 232)

${ }^{89}$ Pomalo je iznenađujuće što „prave“ dekadentne tipove stvara baš Leskovar, čovjek koji se u Hrvatskoj školovao i proveo čitav radni vijek. Za razliku od naprimjer Nehajeva koji se razvija na izvorištu europskih kultura, za
} 
prema specifičnim motivima koje držimo okidačima njihove dekadencije te prikladno interpretirati kroz prizmu Freudova (1984) i Derridaova (2005) rada u kojima se tumače kompleksni procesi žalovanja, melankolije i traume kao presudnih odlika sebstva. Prisjetimo se, Freud je taj koji nam je omogućio da razmišljamo na koji način dramatičan događaj poput gubitka definira čovjeka: bez iskustva radikalnoga odvajanja od prethodnoga stanja vlastite samodostatnosti čovjek zaista ne može razumjeti svoju konačnost. A Derrida pak, nastavljajući tamo gdje je Freud stao, potiče da o čovjeku razmišljamo kao o toposu gubitka. Na taj se način oblikuje slika pojedinca prema kojoj je on već „nastanjen“ gubitkom te postaje nekom vrstom arhiva, mjesta u kojem se gubitak održava i njeguje (Boulter, 2011: 1). Uz njihovo ćemo tumačenje pokušati vidjeti kako u tim novelama žalovanje i melankolija izgrađuju dekadentne subjekte koji postaju arhivima gubitka u kojima se zauvijek zadržava sjećanje na traumu. Pritom se referiramo na razumijevanje arhiva kao mjesta sabiranja povijesnosti, mjesta „tjeskobe zbog mogućnosti gubitka: arhiv postoji samo kao anticipacija (...) gubitka povijesti; kao takav, on djeluje proleptički kako bi sačuvao ono što će neminovno biti izgubljeno“ (ibid.: 4). Usto Freudov je melankolik, u analogiji s neurasteničnom iscrpljenošću, netko u koga je prekomjerna stimulacija podražajima uzrokovala abnormalnu zakočenost volje, zbog čega više nije u stanju djelovati.

U Misli na vječnost iznio je Leskovar prototip slabića, bolećivoga čovjeka bremenita prošlošću, koji čak i fizičkim izgledom sugerira psihološku delikatnost, ostavljajući upečatljiv dojam bolesnoga čovjeka. „Ljudi držahu da je bolestan, no zapravo on toga nije ćutio, ali se opet nije osjećao kao nekad prije. Sada su mu jako izbile modre žile (...). A i njegove usne nekud povenuše i uši se utanjiše, pobliedješe (...).“ (Leskovar, 1997: 29) Protagonist Đuro Martić, najkraće rečeno, sublimira sve bitnije odlike modernističkoga taedium vitae. Njegov se život odvija kao intenzivno, mazohističko seciranje vlastite psihe koje rezultira mentalnom uznemirenošću te polagano evoluira u autodestrukciju:

(...) ali njemu nešto nije dalo da odahne, nešto ga uviek tjeralo, da razmišlja - razmišlja bez oduška, dok ga najzad ne bi zaboljela glava. Tada bi mu se živci stali na vjeđama trzati, žile na sljepoočicama poigravati i on bi se do kraja izmoren bacio na krevet. (ibid.; isticanje naše)

studija u Beču. Naravno da je Leskovar čitao stranu literaturu koja mu je u oblikovanju likova sigurno pomogla, ali upravo je nevjerojatna ,sama ta duša koja je usred nas, u kutiću Zagorja, mogla da proživi i proćuti sve ono što je u misaonom životu naših vremena prohujalo duhovima Evrope“" (Nehajev, 1964a: 78). 
Neka tiha patnja što neprekidno struji ovim tekstom potencira uspomene te ubrzo postajemo svjesni da sadašnjost živi isključivo kroz prošlost: Martićeva je svijest sastavljena od mnoštva impresija i sjećanja. Njegov je svijet prestao postojati onoga trenutka kad se zbog njegove neuzvraćene ljubavi ubila djevojka, a odgovornost koju je zbog toga osjećao samo je pojačala iskustvo traumatične melankolije. Tako da sve ono što se čita na početku novele, $u$ vremenu pripovijedanja, ekstremna sklonost promišljanju od koje anksiozni dekadent i tjelesno propada,${ }^{90}$ postaje razumljivo u kontekstu traumatičnoga događaja.

Novelom Jesenski cvijetci (1897) Leskovar pak započinje novu stvaralačku fazu u kojoj tragične završetke pogubne introspekcije glavnih likova zamjenjuje nesposobnošću njihova odlučivanja i rezignacijom koja se svemu pokorava, ostavljajući ih i dalje na milost i nemilost sjeti i apatiji. Ondje je dao riječ Imroviću koji također figurira kao zamišljenik u prošlost, sanjar čiji život sudbinski određuje smrt žene i djece, čvrsto uvjeren da postoji neki nedokučiv tajanstveni svijet, „,koji je nad našim eksperimentalnim duhom“ (ibid.: 80).

Da bismo protumačili kako to uopće prošlost može progoniti sadašnjost, dotaknut ćemo se problematike traume i smrti. Kako iznosi Caruth (1995), govoreći o iskustvu traume, patologija se ne može definirati tek događajem koji, sasvim razumljivo, nikad nije jednako katastrofičan za svakoga niti se može objasniti njegovim iskrivljenjem uzrokovanim osobnim željama, žudnjama ili reprezentacijama koje subjekt veže za traumatičan događaj. Patologija se, naprotiv, sastoji u strukturi iskustva, odnosno recepcije: traumatičan se događaj nikad ne asimilira, tj. ne proživljava u vrijeme kad se odvio, nego sa zakašnjenjem, i to u neprestanom posjedovanju onoga tko ga je doživio. ${ }^{91}$ Biti traumatiziran znači upravo „biti opsjednut slikama ili događajima iz prošlosti“ (Caruth, 1995: 5). Zato možemo reći da traumatizirani nose u sebi svoju povijest, postajući i sami njezinim simptomom koji nikad ne mogu dokraja posjedovati. Biti opsjednut znači biti progonjen prošlošću - prošlost progoni sadašnjost onemogućujući ikakvu budućnost. U tim se novelama smrt tako prepoznaje kao temeljni faktor koji presudno obilježava one koji ostaju ,iza“.

Smrt je dragoga bića, piše Jankélévitch, ,gotovo naša, skoro isto tako bolna kao i naša; smrt oca ili majke skoro da je naša smrt, i na stanovit način ona je zapravo naša vlastita smrt: neutješan čovjek tu oplakuje nenadomjestivo“ (2011: 39). Prošireno Derridaovim tumačenjem,

\footnotetext{
${ }^{90}$ Kako će na jednom mjestu Leskovar istaknuti: „Svi bijahu dobro ugojeni, samo on suh, žut. (...) I oči mu neprestano pogledahu na tanke noge i suhe ruke, na kojima se opažaše svaka žilica, a tak bi kradom posmatrao i svoje susjede; a kakove pune ruke i snažna bedra bijahu u njih!““(1997: 31)

${ }^{91}$ Kao što piše Jankélévitch, govoreći o problematici smrti, „smrt drugoga spoznaje se objektivno i jasno tek naknadno, odnosno kad je prekasno; još točnije rečeno, smrt je u tom pogledu spoznata 'smrtno', postumnom i posljedičnom spoznajom (...)“(2011: 24).
} 
smrt drugoga nije samo izostanak, nestanak, kraj „drugoga“ života: ona je i kraj svakoga mogućeg svijeta za osobu koja umrloga nadživljava, kraj svijeta u njegovu totalitetu (2005: 140). Stoga, s ovim tumačenjima na umu, možemo naglasiti da se u tim prozama melankolija, u frojdovskom smislu nemogućnosti nadvladavanja traume gubitka, pokazuje konstitutivnim elementom identiteta. Subjektivnost se formira poetikom melankolije.

Životi protagonista funkcioniraju u osobitom odnosu prema prošlosti te postaju arhivima u kojima se reflektira melankolija u psihoanalitičkom razumijevanju toga pojma. Ponovimo, u nastojanju da otkrije na koji se način čovjek suočava s gubitkom Freud uspostavlja dva smjera kojima se može poći nakon suočenja s traumom. Normalna je reakcija na gubitak žalovanje, u kojem se gubitak razumije i prihvaća. Iako je proces mukotrpan, ${ }^{92}$ izgubljeni se objekt uspijeva preboljeti. Nasuprot tomu melankolija kao patološka reakcija na gubitak subjekt ostavlja u procesu stalne identifikacije s objektom. Budući da je normalan proces žalovanja obustavljen, afekti i dalje ostaju trajno vezani za objekt te se gubitak ne može odbolovati. Bez iscjeljujućega učinka vremena trauma se stalno reproducira. Može se stoga reći da je melankolija sabotirano žalovanje. Ona proizvodi egzistencijalni nemir koji poručuje da nešto nedostaje. Zato je teško ne složiti se s Kristevom kad poentira da govoriti o melankoliji znači govoriti „o ponoru tuge, o nepriopćivoj boli koja nas katkad, a često i trajno, toliko obuzima da izgubimo svaku želju za govorom, djelovanjem, pa čak i želju za životom“ (2014: 7). Odnos ,ja“ prema prošlosti, a osobito prema mrtvima, izvan je kontrole onoga koji je traumu doživio. Izmučeni nepodnošljivim teretom nadživjelosti, u kojem se cijela jedna povijest odnosa čuva i hrani prisjećanjem i „oživljavanjem“, glavni likovi tih proza živote proživljavaju u rastrganosti između prošlosti i sadašnjosti.

No usprkos snazi melankoličnoga mehanizma u Imrovića postoje naznake za mogućnost „,normalnijega“ života. U jednom se trenu čak čini da će prigrliti novu budućnost te se odlučiti za Olgu. „U sebi osjećah veselosti i radovah se potajno životu. (...) Bijaše to prvi put nakon toliko godina, što sam zapao u neko radostno razpoloženje.“ (Leskovar, 1997: 89) Odustaje tako, doduše tek nakratko, od svakoga pokušaja racionalizacije te posve neočekivano shvaća da se umovanjem ipak ništa ne otkriva. Međutim unatoč tim povremenim bljescima zadovoljstva, u skladu sa Schopenhauerovim stajalištem o razočaranju kao temeljnoj ljudskoj emociji, potvrdit će se pobjeda vječnoga pogleda unatrag. Jer dok jedan dio njegova melankoličnoga rascijepljenog bića kaže „da“, drugi kaže „ne“, dok jedan odolijeva društvu uživajući u samoći, drugi društvo priželjkuje. Lavira između prošlosti i sadašnjosti, odnosno budućnosti,

\footnotetext{
${ }^{92} \mathrm{Ne}$ čudi stoga što ga i zove radom (die Arbeit).
} 
pokazujući nakraju da su sadašnjost i budućnost ipak zauvijek izgubljeno prošlo vrijeme. U trenutku suočavanja s ljubavi prema Olgi, licem u lice sa zajamčenom srećom, bježi od odluke, povlači se u intelektualiziranje te opstruira novi odnos jer vjeruje da u njega valja ući bez prošlosti iza sebe:

A ja osjetih taj čas, da je u toj ljubavi sakriveno nešto tugaljivo. --- Od toga trenutka poče to nešto da bude sve jasnije; stale me obuzimati sjetne misli. Bijahu to misli na moju prošlost. Ah, Olga bijaše još djevičanska, netaknuta, a ja sam proživio već jedan život. To bijaše za me stvar uvelike zamašna, te ne samo da nije mogla da se zaboravi u toj sreći, nego - što mi se ta sreća većom pričinjaše, to se i te misli jače podizahu ostavljajući iza sebe sve to bolniji trag... (ibid.: 100)

Jer najveća je snaga melankolije upravo njezina najveća slabost: razočaravajuće, isprazno, neizdrživo, neprihvatljivo bivanje. ,(...) jedan se prazan prostor prostire uvijek preda mnom, ali ta je posljedica smještena iza mene i ona me gura naprijed. Taj je život užasan, on je nepodnošljiv.““ (Buci-Glucksmann, 1988: 246)

Premda se na trenutak čini da i kod Martića postoje izgledi za sretniju budućnost, kad dogovara susret s mladom učiteljicom, evidentno je da je baš priprema za susret početak njegova raspada. U njemu su duboka tuga i grižnja savjesti dodatno učvršćeni teorijom metempsihoze, odnosno vjerovanjem o preseljenju duša koje je pak blisko vezano s glazbom. Njegovo fatalno osjećanje egzistencijalne malaksalosti povlači se tek pred veličanstvenošću glazbe, toliko kompleksne da se može poistovjetiti s misticizmom:

Još dva-tri puta ponovi isto mjesto, a tad se zagleda nekud daleko, daleko. Izpred njega izginuše i šiljata koljena i suhe ruke, soba i oni snježni brežuljci vani; on bijaše u svemirskoj praznini, u kojoj još dugo, dugo odzvanjaše posljednji akord, udaljujući se sve dalje i dalje, dok negdje daleko, daleko ne izginu. (Leskovar, 1997: 32)

Uz opasku da je poetici dekadencije imanentna potraga za glazbom kao sredstvom izvanlogičnoga, mističnoga iskustva (Binni, 1936: 28) te napomenu da je i Schopenhauer smatrao da se besmisao građanskoga društva može nadići samo umjetnošću (naročito glazbom), istaknimo da je u Misli na vječnost ona iznimno važna jer rađa razmišljanje o vječnosti, prelasku duša u onkraj. Dakle spiritus movens Martićeve metempsihoze jest glazba, odnosno njezina „senzitivna, oćutna, spiritualna i metafizička narav“ (Milanja, 1987: 27). A upravo će sjetna slutnja tajanstvenoga svijeta, uvjerenje da je sve utisnuto u vječnosti, da je ljudski duh mjesto 
u kojem ništa ne nestaje, pa tako ni odgovornost za smrt djevojke - čime će, usput rečeno, Leskovar započeti svoju preokupaciju motivom neostvarive ljubavi - označiti konačnu vladavinu podsvjesnoga, odnosno potpuno ludilo.

Oh, Bože, Bože, ništa ne izgiba, ne propada, sve, sve je vječno. Ah, što me to samo toliko glava boli... Kad umrem, možda će duša poput misli prhati sa zviezde na zviezdu. Ah divote, ona će saznati prošlost svih viekova, sve, sve je to zabilježeno u svemiru, ništa nije izginulo; svjetloslika svakog trena bivstvovanja otisnuta je u svemiru... (Leskovar, 1997: 32)

Od toga trenutka Martića opsjeda prošlost, naročito upečatljiva slika mrtve djevojke blijedih, upalih očiju, poprskana krvlju. Tako se na samom kraju novele otkriva da on cijelo vrijeme funkcionira kao arhiv, melankolično mjesto dekadentnoga beznađa u kojem se potire svaka mogućnost harmonične i neproblematične egzistencije. Samoga sa sobom i sebe s drugima.

Prema tome može se reći da i Martić i Imrović, suočeni s traumom, ostaju izvan svijeta drugoga te na taj način i izvan svijeta samoga. Njihova je egzistencija oscilacija između krize smrti i krize života, priča o nepodnošljivoj traumi i nepodnošljivom životu nakon preživljavanja traume. To se posebno odnosi na Imrovića jer, mogli bismo sugerirati, njegova je tragedija kudikamo veća: dok Martić nastavlja tjeskobno živjeti s odgovornošću zbog smrti djevojke koju očito nije volio, Imrović živi sa saznanjem da je pokopao ženu i djecu. Obojica su prisiljeni nositi i teret svoga svijeta i teret svijeta drugoga, pa otuda proizlazi njihovo uvjerenje da čovjekovom sudbinom upravlja nešto tajanstveno i nedokučivo. To je sudbina traumatiziranoga dekadenta: biti u svijetu izvan svijeta i lišen svijeta.

Derrida međutim postavlja tezu kako melankolija nije tek patološka reakcija na gubitak. Ona je inherentna svakomu odnosu te je uvijek prisutna, čak i prije nego što se konkretan događaj odvije, jer je ona veza između drugoga i ,ja“. U eseju Ovnovi piše:

(...) smrt nije ništa drugo nego kraj jednoga svijeta. Ne samo jedan kraj među mnogima, kraj nekoga ili nečega $u$ svijetu, kraj života ili živoga bića. Smrt ne označava samo kraj nekoga u svijetu ni kraj jednoga svijeta među mnogima. Ona svaki put označava, prkoseći aritmetici, apsolutni kraj jednoga i jedinoga svijeta, onoga koji se otkriva kao jedan i jedini svijet, kraj jedinstvenoga svijeta, kraj totaliteta (...). (Derrida, 2005: 140) 
Imajući u vidu oba lika, s Jankélévitchem i Derridaom možemo zaključiti da je smrt drugoga uvijek i vlastita smrt, nestanak cjelovitosti, uništenje poznatoga i priznatoga svijeta. Međutim, za razliku od uvriježenoga psihoanalitičkog mišljenja da se valja odreći sjećanja koja nas vežu s umrlima, Derrida tvrdi kako je smrt drugoga konstitutivna i za vlastito sebstvo te na taj način premješta koncept melankolije iz uskoga područja patologije u područje etike. Izravno se referirajući na Freuda i distinkciju žalovanja i melankolije, napose na njegovo inzistiranje da se treba odreći svake privrženosti izgubljenomu objektu te da čovjek mora prihvatiti kraj toga svijeta introjicirajući ga u sebi, Derrida melankoliju podvlači pod žalovanje, pri čemu ona „pozdravlja neuspjeh i patologiju toga žalovanja“ (ibid.: 160) te postaje moralno djelovanje.

Ali ako ja moram (a to je upravo bit etike) nositi drugoga u sebi da bih mu ostao vjeran, da bih poštovao njegov jedinstven alteritet, melankolija i dalje mora prosvjedovati protiv normalnoga žalovanja. Ona se nikad ne smije svesti na idealizirajuću introjekciju, već se mora pobuniti protiv onoga što Freud o njoj govori s tolikom samopouzdanjem, kao da time želi potvrditi normu normalnosti. „Norma“ nije ništa više nego dobra savjest amnezije. Ona nam omogućuje da zaboravimo da držati drugog unutar sebe, kao samoga sebe, znači već ga zaboraviti. Tu počinje zaborav. Zato je potrebna melankolija. (ibid.)

Dakle ono što je Freud odredio kao patološko stanje za Derridaa je jedini moguć odnos $\mathrm{s}$ izgubljenim objektom. Dok se $\mathrm{u}$ žalovanju drugi introjicira u sebstvo, idealizira te time postupno zaboravlja, pa u skladu s tim „normalno“ žalovanje implicira da se objekt čak i u prenesenom smislu mora prepustiti smrti, melankolija sprečava takav razvoj protestirajući protiv zaborava te zauzimajući etičku poziciju (Davis, 2007: 148). Iz srodne etičke perspektive komentira i Žižek da u procesu gubitka uvijek preostaje jedan dio koji se kroz rad žalovanja ne može integrirati u ,ja“, a krajnja je vjernost upravo vjernost tomu preostatku. Zato konstatira da je u tom smislu žalovanje izdaja, ,drugo ubijanje (izgubljenog) objekta, dok melankolični subjekt ostaje vjeran izgubljenom objektu, odbijajući se odvojiti od njega“ (Žižek, 2000: 258). Drugim riječima, ne treba se žalovanjem objekta odreći, nego ga kroz melankoliju treba sačuvati. No u slučajevima Martića i naročito Imrovića, bez mogućnosti sublimacije, ona ne uspijeva dosegnuti tu etičku razinu, već se takoreći zadržava na nižoj razini transformirajući se u egzistencijalnu sabotažu. Ti likovi ne uspijevaju rekonstituirati sebe kroz odnos prema mrtvima te se ta neriješena veza za njih pokazuje pogubnom. Njihova je kob samoća jer je onaj koji je nadživio svoje bližnje svjestan da je nestankom drugoga jedan svijet došao svomu kraju. Kao labilni subjekti koji su preživjeli raspad cjelovitosti svijeta, smješteni su upravo između 
dvaju svjetova, između ostataka svijeta koji su poznavali i naznaka novoga koji im je stran i nelagodan. Ta je rastrganost mjesto njihovih intenzivnih unutarnjih sukoba kojima se dokida svaka mogućnost daljnjega postojanja. Njihov je život postao monolog, a činjenica da u sebi nose tjeskobno sjećanje na one kojih više nema postaje im razdiruća karakteristika. Premda Leskovar, prilično je sigurno, nije tad čitao Freuda, ne možemo u ovom slučaju ne povući analogiju između stilizacije tih likova i njegove teze da se neurotici i histerici, u čijim su osnovama potiskivanja, razbolijevaju od reminiscencija i sjećanja (Breuer i Freud, 1957: 7).

Žižekova konstatacija o odricanju od objekta kao njegovoj ponovljenoj smrti mogla bi se ponajprije primijeniti na Imrovića. U Imrovićevu je slučaju upravo uznemirujuće što on zapravo ni na koji način ne želi pustiti svoje mrtve, nego neprekidno zadržava vezu s traumatičnim događajem. A time zadržava i samoga sebe u patološkom stanju jer trauma je ono kroza što se on izgradio kao subjekt - ona ga je učinila čovjekom kakav je sad. U knjizi Ego $i$ id (1923) Freud podcrtava činjenicu da upravo melankolija gradi ,ja“ te objašnjava da pripajanje izgubljenoga objekta „uvelike određuje formu koju 'ja' zadobiva snažno pridonoseći izgradnji onoga što se naziva 'karakterom'“ (1984: 368). „Ja“ je sastavljeno od niza ostataka izgubljenih objekata. Za Imrovića neprekinuto patološko žalovanje predstavlja čin vjernosti kojim izražava želju da svoje mrtve vječno zadrži uza sebe. To inzistiranje na suživotu s mrtvima posebna je vrsta kažnjavanja samoga sebe. No već sama činjenica što se uopće može melankolično održavati na životu implicira da živi bez objekta gubitka te ga tako ostavlja iza sebe. Zato se Imrović, permanentno vezan za svoje mrtve, suočava s teškom ambivalencijom: svjestan da mora nastaviti živjeti, istovremeno spoznaje da je time nevjeran onima koje je sahranio i spremio u povijest.

Nije naodmet ovom se prilikom referirati i na Machovu tvrdnju kako upravo sjećanje kao „ponovno buđenje prijašnje konstelacije osjeta“ (prema Johnston, 1993: 194), pamćenje o samom sebi, čini čovjeka jedinstvenim. U tom je kontekstu posve razumljivo Imrovićevo uvjerenje da je čovjek i nakon tjelesne smrti živ sve dok traje sjećanje na njega. S obzirom na to da bi realizacija odnosa s Olgom značila da ubija svoje mrtve, simbolično i po drugi put, sve propada:

(...) njih nema za obični sviet. No jesu li zato i prestali da bivstvuju - je li ih zato nestalo bez traga? Ah, je li to moguće? Ta što ja osjećam! Što je to u dubinama moje duše. Ah, da, njih nije nestalo...! (...) Sve je to pohranjeno u mojoj duši... Raztali smo se i ne ćemo se možda prije vjekova da vidimo, nu gle, tih tragova nijesu ponieli sa sobom u one krajeve vječnog mira, oni su ih ostavili iza sebe, da budu ljestve (...). (Leskovar, 1997: 103; isticanje naše) 
Stoga se još jednom ispostavlja da je svaki pokušaj nadvladavanja prošlosti unaprijed osuđen na propast jer je u ljudskoj duši uvijek „sahranjen već jedan život, sahranjena ciela poviest jednoga bivstvovanja““ (ibid.: 104). Možemo zato zaključiti da je svijet te dvojice likova frustrirajuće zrcalo u kojem svugdje uočavaju drugoga koji ih je napustio. Prisjećanje čovjeka na cjelovitost odnosa s izgubljenim objektom, koji je i njega činio cjelovitim, podupire i našu elaboraciju da je tu riječ o dezintegriranim, fragmentarnim egzistencijama. Otud i one paradigmatske Imrovićeve riječi, koje izvrsno opisuju sve dekadente, a posebno leskovarce:

No moj je život - život samotnika u zabitnoj dolinici, u praznim dvorovima, gdje se ništa zamašna ne događa, ništa ne saznava (...) - ah, ništa, ništa nema tu znamenita, da potisne događaje prošlosti u zaleđe. (ibid.: 106; isticanje naše) ${ }^{93}$

Prema tome, vodeći računa o svemu dosad izdvojenom, možemo reći da ni Martić ni Imrović ne uspijevaju kroz procese žalovanja i sazrijevanja odbolovati svoj gubitak te ga „pospremiti“ u „normalno“ sjećanje. I zato se s Kearneyjem može govoriti o nemogućem, odnosno traumatičnom sjećanju koje poput sablasne prikaze opsjeda život pojedinca odbijajući terapeutsku obradu (2003: 141). Frojdovski rečeno, internalizacija je gubitka toliko intenzivna da destruira ego te subjekt ostaje vječno uronjen u svoj gubitak, posve nesposoban prihvatiti ga i od njega se odvojiti. Izgubljeni objekt tako nastavlja postojati u strukturama melankoličnoga subjekta koji nije u stanju odvojiti vlastitu subjektivnost od objekta u sebi. Nemoćan da odustane od vlastite privrženosti, on postaje stalno mjesto razgovora živih i mrtvih. Praznina nastala smrću ne uspijeva se popuniti.

\subsection{Marcel Bušinski, dekadent bez opravdanja}

Svoj prodor u najsuptilnije dijelove ljudske psihe, u nedokučive podsvjesne svjetove u kojima se egzistencija doživljava gotovo iracionalno, kao nešto čime upravlja nepoznata sila izvan čovjeka samoga, Leskovar je sintetizirao u kraćem romanu Sjene ljubavi (1898), čiji se glavni junak Marcel Bušinski može prozvati simboličnim vrhuncem svih njegovih likova. Kao što smo naglasili, nevjerojatno predosjećajući modernu osjećajnost koja će se u punini razvijati tek na početku XX. stoljeća, kreirao je u cijelom svom djelu specifičan lik dekadenta oslabljenih živaca, melankolika sebično zatvorenoga u svom ,ja““.

\footnotetext{
${ }^{93}$ Za paralelu Jesenskih cvijetaka i Turgenjevljeve Asje usp. Flaker (1968) i Pavešković (2002).
} 
To ni u kojem slučaju više nije bio samo tip ,čudaka“ kakva nam je u svoje vrijeme bio ponudio Šenoa, nego posve nova, složena ličnost: moderni, senzibilni, hipertrofirani intelektualac, karakterni slabić, tipični neodlučni, zbunjeni i nedefinirani hrvatski provincijalac „filozof“ Khuenova doba, u određenom smislu srodnik Borislavića i Radmilovića, ali možda još tananijih osjećaja, u svojoj psihi još složeniji. (Šicel, 2005: 86)

Tako je na neki način Bušinskim zaokružio priču započetu Martićem u prvoj svojoj prozi s početka desetljeća, pozicioniravši ga kao arhetipskoga dekadenta, idealnoga čovjeka pasivnosti čija je klinička slika fundirana u kolektivnom povijesnom i filozofskom pesimizmu, obogaćena melankolijom u njezinim tipičnim oblicima, čamom i radikalnom neodlučnošću, te opterećena monotonijom postojanja i trivijalnošću života. Bušinski, najkraće rečeno, razotkriva sve bitnije principe dekadentnoga senzibiliteta. Njegova dekadencija počiva na čvrstim osnovama o kojima smo pisali na početku: na dojmu o kraju civilizacije u vremenu urušavanja poznatih vrijednosti i nemoći da se uspostave nove, na tjelesnoj krhkosti uvjetovanoj sve artificijelnijim okolnostima modernoga života, na rastu živčane osjetljivosti koja vodi stalnoj razdražljivosti i psihičkim nemirima te atrofiji volje. Nije dakle motivirana društvenošću hrvatskoga konteksta, kao što je to u Frana Ljubića, Novakovih Pavla Šegote i Amadeja Zlatanića te Gjalskijeva Radmilovića. Bušinski je književnik, pasivna umjetnička duša, nekadašnji činovnik ${ }^{94}$ koji vodi relativno lagodan život, nakon što je u nasljedstvo primio malo imanje, i sve što će u svom romanesknom životu činiti činit će iz inherentnih slabosti.

Iako je dekadent po svojoj definiciji statičan intelektualni lik, kao što smo utvrdili u jednoj od prethodnih cjelina, Bušinski je upravo ekstreman primjer cerebralnoga junaka koji se, odbijajući suvremeni svijet, egoistično povlači u sebe te postaje pravim čovjekom od „neakcije“. Bušinski je, procijenila je struka, „kvintesencija Leskovarove filozofije, najčistiji izraz njegova svjetonazora i senzibiliteta“ (Nemec, 1995: 76), a roman je pritom kao „najleskovarskije djelo Leskovarovo“ (Frangeš, 1963: 13) i eksplicitna poetika dekadencije. U toj je prozi ona postavljena možda u svojoj najčišćoj formi jer estetska, umjetnička ideja života jest temeljno dekadentna. Umjetnost je pozicionirana kao glavna vrijednost koja isključuje sve druge principe te se kao takva preslikava na život. Marcel živi oponašajući umjetnost, ona je njegov raison d'être. „A taj sugerirani život donosio mu više užitka, radosti - no, i napora, nego život, što ga je uistinu proživljavao“ (1997: 263), zapisat će Leskovar inzistirajući na

94 „Međutim, nije bio zadovoljan u svom stališu. No teško da bi bio našao zadovoljstva u ikojoj službi...“ (Leskovar, 1997: 256), već je tim jasno dano do znanja da je on uobičajen dekadent nezadovoljan u svim područjima djelovanja. 
neraskidivoj vezi psihologije i estetike dekadencije. Glavni se lik povlači u svoju „kulu od slonovače“, izolirajući se od ostatka svijeta te njegujući umjetne rajeve svojih zamišljaja, što pak priziva i aktualan kontekst. Naime takav artistički eskapizam odgovor je na vladavinu mediokriteta, na vulgarno društvo bez vrijednosti, na svijet koji više nema smisao po sebi jer se zaokružuje jedan povijesni proces s kojim nestaju i staroeuropski sustavi i načela. A kako je običan život prebanalan, u onome knjiškome pronalazi se zaklon od efemernosti svakidašnjice. Njegova umjetnost alijenacije zapravo je neurotičan strah od realnosti. Promovirajući postavku da bi od života valjalo stvoriti umjetnost, Bušinski u potpunosti usvaja teorijske postavke esteticizma kao „filosofije apsolutno pasivnog i čisto kontemplativnog stava prema životu“ (Hauzer, 1966: 384), prenoseći svijet knjige u onaj realni. Njegov pokušaj pronalaženja viših, vječnih vrijednosti u kontingentnom i prolaznom svijetu, kombiniran s osjećajem zle kobi i svijesti da se stoji na kraju civilizacije, posljedica je neburžoaskoga pogleda na svijet, pobuna protiv građanske rutine i discipline koja ga nagoni da se izolira od svega što ga okružuje. No Marcelova individualna sumnja, koja se pretendira postaviti kao kolektivna zabrinutost za čovječanstvo, pri čemu se civilizacijski napredak prati s velikim nezadovoljstvom i prazninom duha, zapravo je rezultat urođenih neurotičnih nemira.

A Bušinski osjeti u duši svojoj nesuglasje. On se nije zadovoljavao time, što jest, što postoji, i u njegovoj duši postojala je težnja, da taj život prodahne nečim višim. (Leskovar, 1997: 195; isticanje naše)

To „nešto više“ besmislena je i nepotrebna potraga za univerzalnim, kozmopolitskim smislom izvan ovoga prostora i vremena. ${ }^{95}$ Kao puka ,iluzija, fikcija, platonizam, pa dakle i fantazmagorija“ ono je ujedno osnovna dilema europske dekadencije, čime se Marcel ukorjenjuje u tlo „evropskog neoidealizma“ (Milanja, 1987: 61). U nemogućnosti realizacije svojih aspiracija u stvarnosti, svjestan da su mu vrijednosti u konačnici sasvim suprotne vrijednostima građanskoga društva, on kreira umjetnu realnost. Nije, doduše, ni upola tako ekstreman kao Huysmansov Des Esseintes, koji u fascinantnom spoju živčane rastrojenosti i tankoćutne sofisticiranosti, tražeći umjetne, neprirodne forme života koje bi zamijenile protuslovlja modernoga, utemeljuje radikalnu formu esteticizma (Moroni, 2004: 67). No i u

\footnotetext{
${ }^{95}$ Zato će mu barun jednom prilikom i savjetovati da sreću prestane tražiti u spekulacijama i „filozofiranju“ te da je pokuša naći u onome što mu je najbliže: „Lijepo je služiti velikim ciljevima čovječanstva, no rijetki su na to zvani. Sreća nas običnih ljudi je drukčija: poživjet za svoje bližnje, živjeti među njima, osjećat se jedno s njima. I sretan je onaj, koji je među svojima, taj nije izgubljen, a teško onomu, koji nema domovine i ostaje tuđinac u narodu. (...) Dolazi vrijeme, kad pusta umovanja ne mogu čovjeka više da udovolje. Treba potražit drugdje umirenja, treba se obratit k bližnjemu, k narodu..." (ibid.: 265)
} 
Bušinskoga se artificijelnost prepoznaje kao destrukcija „pravoga“ života, kao izoliranost i rezerviranost, povlačenje u vlastito ,ja“ popraćeno paralizom djelovanja i specifičnim oblikom Weltschmerza, čamom kao jedinstvenim osjećajem preplavljujuće tjeskobe i slabosti nadvladavanja ravnodušne dosade. Čama je zapravo zastrašujući jalov bezdan u kojem glavni lik ne zna što bi sa sobom, jedan od pojavnih oblika generalnoga fenomena ,životne boli“ $u$ kojem se raspršuju sve nade i iluzije, a jedino što preostaje jest zatvoriti se u vlastitu ljušturu. Svijet se oslobađa svoga značenja, egzistencija gubi smisao. Bušinski, njegujući „,svjetsku bol“, uzorno materijalizira modernistički ennui. Taj se ennui, kao dugotrajno stanje egzistencijalne besposlice, nemoći da se odupre pasivnomu i praznomu raspoloženju, pretvara u kompletno iskustvo obuzimajući i dušu i tijelo. Iako joj je uzrok primarno u duševnoj sferi, ona obuzima i tjelesnost te je najčešće posve neovisna o vanjskim okolnostima. I tu dolazimo do već spomenutoga: bit Marcelova problema leži samo u njemu, iako će on sam sugerirati da su uzroci postavljeni i u vanjskom svijetu. Dienstag će međutim potvrditi da je zapravo posve normalno da čovjek

jednostavno osjeća vlastitu egzistenciju u vremenu; dosada je dakle jedna od posljedica navedenoga. Budući da izranja iz osnovnih atributa samosvijesti, ona je doista osnovno duševno stanje iz kojega se može izbaviti samo patnjom ili nemilosrdnom aktivnosti (2006: 30).

Uostalom, prisjetimo se da je sa Schopenhauerom čama postulirana kao metafizički princip te da se volja ostvaruje kao dijalektika patnje i dosade. Čovjek bježi od patnje da bi završio u dosadi, a potom iz dosade opet pristiže u patnju. Prema tome iz perspektive filozofskoga pesimizma čama je sasvim pojmljiva te ju je moguće povezati s nedostatkom pravoga užitka. Ona je ,tužno olakšanje od bolnoga stremljenja za objektom želje, zasićenost kao posljedica paradoksalnoga i tragičnoga gubitka objekta upravo kroz ispunjenje želje“ (Feld, 2011: 69). Dakle i Bušinski u svojoj tjeskobnoj dosadi živi duševni nemir, pokazujući da je melankolija, simbolično rečeno, prazna dubina moderniteta. Melankolija je postala amblemom moderniteta ponajprije zbog svoje samodostatnosti, što se može povezati i s modernističkim individualizmom: kao bezrazložna tuga ona je razumljiva posljedica jaza, koji se otvorio s razvojem modernoga zapadnog društva, između dvaju suprotstavljenih svjetova, subjekta i objekta. Taj moderni spleen kao pravo duhovno opredjeljenje i svjestan odabir u potpunosti odgovara čuvstvu ispraznosti i anksiozne osamljenosti pojedinca u dehumanizirajućim, racionalističkim, tehniziranim sredinama, $u$ vremenima relativizacije svih tradicionalnih sustava. Bušinski utjelovljuje kozmopolitski relativizam te se, oblomovski inertan, ni na koji 
način ne veže: ni intimno, emocionalno za ženu, ni regionalno ili lokalno za primjerice zavičaj. A u skladu s tim pretendira odgonetnuti smisao ljudskoga života, poistovjećujući se sa stanjem na prijelomu stoljeća te potencirajući tezu da su tjeskobe pojedinca istovremeno i odlika svjetskoga duha.

Zato se, razočaran realnim životom, svim silama trudi postati njegovom negacijom da bi glavnu ulogu preuzela umjetnost. A budući da cjelinu zamjenjuje jedan njezin aspekt, umjetnost, također je opravdano govoriti o dekadentnom raspadu cjelovitosti, odnosno o transformaciji ideje cjeline. Umjetnost je veća od života. Marcel je, posve je jasno, utjelovljenje svih tipičnih dispozicija s kraja stoljeća, pri čemu melankolija postaje njegov temeljni modus vivendi. Ona je, napominjemo na tragu svega što smo prije pisali, potraga za značenjem, stanje modernoga subjekta neprestano izazivanoga da odredi samoga sebe. Nije dakle posljedica nekoga konkretnog događaja ili traume iz njegove neposredne ili dalje prošlosti, već je prije svega dispozicija, percepcija koja snažno oblikuje doživljaj svijeta. U toj turobnoj, neurotičnoj perspektivi pojedincu svijet zauvijek ostaje stran, otuđen, nedostupan. Budući da njegova melankolija počiva u nekom nevidljivom uzroku te je vođena uvjerenjem da postoji nešto izvan čovjeka što mu određuje postojanje, a on je nemoćan usmjeriti ga onako kako bi želio, možemo reći da je objekt Marcelova gubitka nepoznat, odnosno nedovoljno prepoznatljiv. Melankolija je kao „devitalizirana egzistencija“ (Kristeva, 2014: 7) prokletstvo njegova karaktera. Iako esencijalno neizreciva, jasno je da mu ograničava život:

Talasi premilog čuvstva zaplavljivali mu se dušom samo o pomisli na tu djevojku - i on je nju ljubio. No sada se i ona tiha sjeta, što mu nije dala da joj se približi - podigla do boli. (Leskovar, 1997: 272; isticanje naše)

Vratimo li se toj općenitoj problematici, grubo se može reći kako su se nakon Freuda psihoanalitička tumačenja melankolije razgranala u dvjema strujama: jedna je struja gubitak upotrebljavala u specifičnom smislu personificiranoga drugog kojeg je melankolik nekad posjedovao, druga je pak gubitak (u smislu bilo kojega nedostatka) promatrala kao sve što subjekt priželjkuje, a što mu nije nužno nekad pripadalo (Radden, 2000: 47). U drugoj se struji izdvaja Aaron Beck koji u pacijenata detektira pogrešne i iskrivljene prosudbe i uvjerenja, dvojbene i netočne zaključke te pretjerano generaliziranje, $\mathrm{i}$ to na tragu Kanta i Boerhaavea koji u srž melankoličnoga stanja smještaju neuspjeh rasuđivanja i obmanjujuća vjerovanja. Napuštajući Freudov koncept, Beck pojašnjava da se gubitak može odnositi na bilo kakvo razočaranje te piše: 
Pacijent percipira da je izgubio nešto što smatra esencijalnim za svoju sreću ili mir; predviđa negativan ishod te drži da ne posjeduje kvalitete potrebne za postizanje važnih ciljeva. Ova se teza prema tome može formulirati u sljedećoj kognitivnoj trijadi: negativna koncepcija samoga sebe, negativna interpretacija životnih iskustava i nihilistička projekcija budućnosti. (cit. prema ibid.: 318)

Tako osjećaj nenadoknadivoga gubitka i negativne percepcije budućnosti rađa stanja koja se mogu povezati s depresijom, poput apatije, tuge i razočaranja. Marcelovu je melankoliju stoga posve lako pojmiti u svjetlu netom navedenoga. On dakle pati od gubitka vrijednosti koje drži esencijalnima za svoju egzistenciju, što je, kako smo pokazali, problem s kojim se susreću i svi likovi iz prethodnoga poglavlja. Jer, kako je utvrdio Fromm, čovjeku je za održanje normalne egzistencije nužan osjećaj pripadnosti:

Međutim još jedan element postoji zbog koga je potreba za „pripadanjem“ tako neodoljiva: samosvest, sposobnost mišljenja, pomoću koje čovek biva svestan da je pojedinačno biće, da se razlikuje od prirode i drugih ljudi. Mada se stupanj ove svesti menja, kao što će biti istaknuto u idućem poglavlju, njeno postojanje suočava čoveka s problemom koji je suštastveno ljudski: svešću da je odvojen od prirode i drugih ljudi, svešću — ma i veoma nejasnom — o smrti, o bolesti, o starenju; čovek nužno oseća da je beznačajan i sićušan u poređenju sa svemirom i sa svima drugima koji nisu „on“. Kad ne bi imao negde svoje mesto, kad njegov život ne bi imao neki smisao i put, on bi se osećao kao trunčica prašine i bio bi svladan svojom pojedinačnom beznačajnošću. On ne bi bio kadar da se veže ni za kakav sistem koji bi dao smisao i pravac njegovom životu, obuzela bi ga sumnja, a ta sumnja bi, konačno, paralizovala njegovu sposobnost delanja — to jest življenja. (1984: 20; isticanje naše)

Zato se Bušinski, „oslabljena vitaliteta, smanjene životne energije, slomljene volje, malaksalih živaca“" (Nemec, 1995: 78-79), otuđuje od svijeta te, nigdje ne pronalazeći svoju poziciju, odabire unutarnji bijeg da bi, sadistički uživajući u autoanalizi, užitak postavio u pasivnosti te tako „pod pritiskom teške sumornosti““ (Leskovar, 1997: 272) svaku akciju raspršio u refleksiji. To je dakle uobičajena struktura jednoga dekadentnog ,ja“, egocentrično usmjerenoga samomu sebi. „Sva snaga njegove duše bijaše uprta na njegov nutarnji svijet. A tu je bilo sve napeto do boli.“ (ibid.: 321)

Uza sve to izostanak svake aktivnosti indikativan je i u ključu spomenute estetske sofisticiranosti, zbog koje se glavni lik životom povlači kao umoran plemić, vjerojatno posljednji sin jedne obitelji u izumiranju. Složenost je Marcelove ličnosti produbljena jazom 
između njega kao prototipa melankoličnoga dekadenta te njegova oca i Koričića kao zastupnika životnoga realizma. Jer, vidjeli smo, u svakom od tekstova iz korpusa nasuprot dekadentnomu analitičaru stoji praktični sintetičar koji mu oponira i u teoriji i u praksi. Koričić naime glasno diskvalificira netendencioznu, larpurlartističku književnost dok citira misli onoga nekog „umnika“, ni više ni manje nego Nordaua koji je, kako smo protumačili, svim silama nastojao institucionalizirati patologiju književne dekadencije:

Kakav užitak! Petrojelska svjetiljka, zagušljiv zrak, upaljene oči, uzrujavanje živaca! Napokon u knjizi tražiti užitak - surogat. Besmislica, danguba. Evo svijeta, evo života! (ibid.: 251)

Međutim još je bitnije što je Marcelova duševna onemoćalost i artistička rafiniranost određena tjelesnom degeneracijom - ona je biološki atavizam. Naime više nego u ijednom drugom djelu, naglašena je protagonistova fizička regresija u odnosu na oca „čvrstih živaca“ i „jakih mišica“ (ibid.: 261). Njegov je otac, kao „čovjek staroga kova, čovjek, koji se u svom držanju, u svojim navikama nije nikomu prilagođavao“ (ibid.: 259), glasnogovornik jednoga vremena u izumiranju, vremena koje ne razumije umjetnu neurotičnu tankoćutnost $\mathrm{u}$ koju zapada moderni svijet. Pa tako romanom odzvanja njegova nemilosrdna kritika Marcelove bezličnosti, nepoduzetnosti i hipersenzibilnosti, kojom prigovara i suvremenim dekadentima uopće:

- Ti si mi čovjek! - planu stari Bušinski uspraviv jače svoje krupno tijelo. - Ja tebe ne razumijem, ne razumijem vas mlade, moderne. (...) O, Bože, kakvi ste! Krvi ko da nema u vas. Usidjelice! Psetance vam treba na svilenoj uzici, molitvenik, igle pleteće. Suknja je za vas, a ne brkovi. Izrodili ste se, kukavci. Ovodnili ste. Hodate pokunjenih nosova, važno, kao da je cijeli svijet propao, - a sunce je isto kao negda, dan je isti, noć je ista. Koji je to bijes? Mrtva puhala! (...) Mudrujete, gledate na sve krajeve, na sve načine, na vanjštinu - na nutrinju... i na koncu ništa! A to vi zovete psihološkom analizom. (...) Sve mrvite, uništujete i tim analitičkim nožem, tom psihološkom sondom. (...) Tražite angjele, a angjela na zemlji nema - nego treba podnositi, praštati... (ibid.: 261, 262; isticanje naše)

Dijagnosticirajući da je pravi uzrok njihove zanesene, apatične naravi lektira, a ozbiljnost i kompleksnost knjiški proizvod - „Ne treba mi tih vaših naklapanja (...) tih vaših dubina. U to se razumijete i raspravljate! O to je vaše! No živjet ne umijete. Oh, te vaše dubine - iz knjiga!“ (ibid.: 263; isticanje naše) - Marcelov će se otac predstaviti kao zastupnik životne 
praktičnosti koji na tipičan dekadentni ennui odgovara realizmom. ${ }^{96}$ Osim što će eksplicirati da je postojanje u kojem se neprestano mudruje i bavi unutarnjim previranjima, ono u kojem se njeguju umjetni rajevi snova, nelegitimno, njegov će prijekor implicirati i tezu o feminiziranosti Leskovarovih muških likova, adekvatnu onoj o generalnoj demaskulinizaciji dekadenata prema kojoj je očito da svi oni stoje negdje na raskrižju uvriježene muškosti i ženskosti. Njihove su uobičajene osobine, vidjeli smo, kvalitete koje se u tradicionalnim dihotomijama roda i spola pridaju ženama. Riječima Oraić Tolić, Marcel nastupa kao antisubjekt protiv apsolutnoga subjekta:

U sukobu s očevima sinovi su otišli u susjedno rodno polje i počeli se presvlačiti $u$ ženske simbolične krpe. Mijenjajući ili miješajući simboličnu odoru, nadopunjuju muška ideološka obilježja ženskim detaljima, moderni su muškarci, a da toga sami nisu bili svjesni, izveli autohtonu unutarnju samokritiku moderne kulture. (2006: 296; isticanje naše)

Dakle komplementaran, materijalistički aspekt njegove melankolije sadržan je u njegovoj tjelesnoj i duševnoj degeneraciji u odnosu na oca koji orijaški staje pred sina

krupan, mišićav - kao da bi htio time reći: Eto takovi su Bušinski, gledaj. Pradjed nam je jednim udarcem sravnio ličkog medvjeda. (...) a na njegovo krupno lice navuče se odjednom nešto žalobno... i tiho doda: - Mati, mati, cijela mati (Leskovar, 1997: 260).

Marcel je nježnost naslijedio od majke, a predisponiranost za preplavljujuća čuvstva i neurotičnu tjeskobu od svoga djeda, majčina oca. I u njega baštinjena slabost tjelesne konstitucije reflektira psihičko stanje. „Na toga djeda opominjaše Bušinski mnogo već svojom vanjštinom. I slabo bljedilo u njegovu licu, ono tamno oko, pa izražajne crte dadoše naslućivati, kakova se duša krije u tome čovjeku.“"(ibid.: 256)

Njegova se degeneracija kao slabljenje tijela kroz opadanje životne energije intenzivira kako jača umjetnička profinjenost te Marcel u svojoj letargičnoj introspekciji utjelovljuje neku vrstu epikurejskoga esteticizma u kojem se želi sve ili ništa. Zato je on, u smislu žudnje za onime čega u iskustvenoj zbilji nema, metafizički dekadent (Ridge, 1961: 48) te kao takav specifična vrsta dendija, osobito u smislu nepristajanja na međuljudske odnose, kojemu je društvo dosadno jer mu ne nudi interese ili uzbuđenja. Dendi se, podsjetimo, iz zajednice izdvaja ,ženskom semiotikom tijela i vanjštine, aristokratske dosade, blaziranosti i

\footnotetext{
${ }^{96}$ Indikativno je pritom da se otac, za razliku od sina koji se zanosi umjetnošću, zanima za prirodne znanosti.
} 
nemotiviranosti““ (Oraić Tolić, 2006: 298). Preciznije rečeno, on kao da i želi odgovoriti na eventualna uzbuđenja, ali ne može. To držanje postrani njegova je egzistencijalna poza.

Marcelova je dekadencija $u$ isti mah, možemo sumirati, rezultat naslijeđa i njegove pozicije u svijetu, tj. pretjerane svijesti o svijetu kojega je dio, koja ga perpetuirano tjera da sve preispituje, ali i boravka u formativnim godinama kod baruna u Glogovcu, koji ga je zarazio sklonošću fantaziranju jer nije imao „pametnijega posla no brbljati o metafizici kamena“ (Leskovar, 1997: 261). Sve je to utjecalo na njegov „općeniti nemir, neko tajno, duboko nezadovoljstvo, što istiha podgriza dušu čovjeka današnje kulture“ (ibid.: 256), na čuvstva koja ga prate od samoga početka romana. Stoga jedino što mu preostaje jest prebiranje po vlastitoj duši. Imanentna ozlovoljenost i istrošenost, beskrajan zamor koji ga obuzima, kojemu se teško nalazi konkretan, očigledan izvor, natjerat će ga da se zapita:

Jesmo li mi krivi? Zlo je u nama i mi trpimo, mi stradamo. No je l' u našoj ruci-promijeniti! Tko je začetnik? Treba ispitati, za čije grijehe mi trpimo. (ibid.: 262; isticanje naše)

Kao što smo vidjeli u prethodnim poglavljima rada, moglo bi se objasniti kako je $u$ modernoga dekadenta nesamostalna, malaksala volja i smanjena tjelesna snaga konzekvencija prevlasti živaca. Otud tolika senzibilnost karakteristična za suvremenoga čovjeka - kontekst pretjerano uzbuđenih živaca i ekstremne sofisticiranosti vodi do povećanja individualne osjetljivosti. Odnosno, kako smo istaknuli u prethodnim poglavljima, abulija se kao patologija volje može objasniti kao činjenica da se želja za djelovanjem ne pretvara u konkretan čin, a karakterističan nedostatak energije pritom pripisati smanjenju ili nedostatku uzbuđenja i kroničnoj nemogućnosti aktivacije volje. No, neovisno o medicinskim tumačenjima, za primijetiti je da je Marcel autentična hamletovska figura koja nastanjuje pasivan svijet patološkoga manjka volje. ${ }^{97} \mathrm{U}$ toj dijagnozi on život promišlja, a ne živi. To je život koji prolazi u pitanju. Njegovo stanje naizmjenične tjeskobe i sjete, malodušnosti i neuroze, koje presudno obilježava intiman odnos s Ljerkom (u koju se zaljubljuje, usput rečeno, nakon što je triput već bio na korak do braka), kulminirat će oživljavanjem prošlosti. Sindrom prošlosti, u kojem Marcel neprekinuto i ustrajno analizira „svoje ruševno ja kao kakvu sablasnu kuću odjeka“ (Biti, 2005: 32), što je odlika glavnine naših dekadenata, također je moguće interpretirati u okviru melankolije jer je ona kao afektivno stanje fundirana na osjećaju gubitka koji naime uvijek pripada prošlosti. Ludwig Binswanger naprimjer bilježi da melankolični

\footnotetext{
${ }^{97}$ Kuhn međutim tvrdi da čama nema baš nikakve veze s voljom te da je čovjek pred njom sasvim nemoćan (1976:
} $12)$. 
pacijenti objašnjavaju da se „ne mogu riješiti prošlosti“, da su „zalijepljeni za prošlost“, „odvojeni od budućnosti“ te da je sadašnjost „sasvim isprazna“ (cit. prema Enderwitz, 2015: 11). Dodatno, uz pretpostavku da je orijentiranost prošlosti nezaobilazna jer je ondje gubitak i smješten, možemo zaključiti da je u naših dekadenata taj pogled unatrag usko povezan $\mathrm{s}$ osjećajem odvojenosti od budućnosti. Orijentira se prošlosti jer je predodžba o budućnosti maglovita. Bolje rečeno, budućnost za melankolika i nije mogućnost; ona je nedostatak. Zato je on „osuđen na trajnu anihilaciju: njegova je vječnost vječnost koja se odvija upravo sad“ (Földényi, 2016: 319).

Osim toga, posve prikladno za tumačenje Marcelove dekadencije, Gebsattel je iskustvo konkretnoga egzistiranja povezao s dojmom pojedinca da je u stanju učiniti određene stvari: „Osjećaj pojedinca da je 'sposoban' omogućuje mu da iskusi da mu se život kreće prema budućnosti.“ (cit. prema Enderwitz, 2015: 13) Zato nas, s obzirom na citiranu konstataciju koja je u tijesnoj vezi s procesom konstruiranja identiteta, nimalo ne čudi što su ti likovi zapeli u procjepu između prošlosti i budućnosti. To prožimajuće čuvstvo da „nisu sposobni“ ili da jednostavno „,ne mogu“ čvrsto ih drži u sadašnjem trenutku, bez ikakve mogućnosti da napreduju k budućnosti. Iskustvo nemoći i bespomoćnosti gospodari njihovim egzistencijama te ih razdvaja od budućnosti bacajući ih u prošlost. Umjesto da ,pravi planove i zamišlja projekte, melankolik se okreće unazad, okružujući svoj gubitak“ (ibid.).

Prema tome ako melankoliju nazovemo poremećajem, pa i u smislu iščašenja, tj. ispadanja iz norme, valja napomenuti da ona nikad nije samo tjelesno i duševno stanje pojedinca. Ona je prava egzistencijalna trauma. Melankolik kao „bolesna“ osoba svijet vidi drukčijim u odnosu na ,zdrave“ pojedince.

U bolesti se odnos između pojedinca i svijeta mijenja na isti način na koji se mijenja i jedinstvo njegova tijela i duše, što je izvrstan podsjetnik da bolest nije samo fizička promjena, nepodnošljivo stanje u pacijentovu životu, nego središnja točka sustava međuljudskih odnosa. (Földényi, 2016: 278)

I zato ne iznenađuje što melankolija u dekadenata uvelike utječe na percepciju društva i svijeta, na odnose s drugima, ali i na odnos prema samom sebi. Dakle vraćajući se Sjenama ljubavi, možemo naglasiti da je i u tom djelu prošlost fatalnost. Ona oživljava samo da bi protagonista gurnula u još snažniju letargiju, odnosno ponudila argument za kroničnu nemogućnost donošenja odluke. Za razliku od drugih Leskovarovih djela u kojima se prošlost čita kao sjećanje, kao misao, tu se ona doslovno revitalizira kroz lik fatalne barunice Helene. 
Međutim pripovjedač je zapravo još na prvim stranicama romana utvrdio kako su se „njegova prošlost, proživljeni život“ (Leskovar, 1997: 257) ${ }^{98}$ uvukli u odnos s Ljerkom. Stoga se može poentirati da je svaka mogućnost za realizaciju ljubavnoga odnosa uništena već na početku. Premda se na trenutke čini da sretan kraj nije tako neizgledan, ${ }^{99}$ što je, podsjetimo, uobičajena konvencija u gradnji dekadentnoga karaktera, postat će razvidno da se prošlost ipak ne može pobijediti te će, utječući na emocionalnu deformiranost, u krhkoj modernističkoj duši izazvati fulminantne potrese:

U njegovoj se duši dizahu ćutljivi, nježni glasi šapćući neprestano: „nijesi vrijedan!“ No javljao se i mefistofelski porug i smijeh na te nježne glase. Javljalo se podrugivanje na to, kako tu čuči kao pustinjak težeći za nečim višim, što prelazi radost običnoga svijeta. Što se i on bez grižnje savjesti ne poda realnosti? Zašto da se i on ne posluži smjelo i drsko svime, što mu može pribaviti užitak? (...) Ali tih mefistofelskih glasova nekud nestajaše, kad bi se pred njegovim duševnim okom pojavila slika Ljerkina. I sva niskost, što se sakrivala u tom mefistofelskom podrugivanju - bila mu je ogavna. I Bušinski je osjećao duboko nezadovoljstvo samim sobom. (ibid.: 299-300)

Zarobljen u bolesnom stanju bezvoljne melankolije koje onemogućuje svako djelovanje - a ključ za sve probleme zapravo je u njegovoj ruci - te u skladu s tim nesklon ikakvoj promjeni, nakon susreta s Helenom, koja je pokolebala njegove osjećaje prema Ljerki, živi u uvjerenju da se ništa ne može modificirati. Konstantno se suzdržava, dvoumi, propitkuje te naposljetku otklanja svaku mogućnost aktivnosti i odluke:

Što da počne? - Da pođe do nje? Kojim licem? Čemu? Što li će ondje? Nije li napokon svemu već kraj - svemu? A ostati, ne ići... Koliko muke za nj i misliti na to! (ibid.: 304$)^{100}$

\footnotetext{
${ }^{98}$ Fascinantno slično svim starmalim dekadentima iz našega korpusa, posebno Bušinskomu kojemu će bogato proživljeno životno iskustvo biti paravan za bijeg, Žunec ovako opisuje Kierkegaardov raskid zaruka s Reginom Olsen: „(..) bio je opterećen svojim mladenačkim religijskim iskustvima krivnje i grijeha kojima su kasnija 'osjetilna' iskustva samo doprinijela - ne navršivši ni tridesetu Kierkegaard je već bio starac izjeden melankolijom, stalnim propitivanjem vlastite krivice i krivice koju je naslijedio od oca ('vita ante acta'): 'Za nju sam bio prestar za cijelu jednu vječnost'.“ (1996: 148-149; isticanje naše)

${ }^{99}$ „U životu njegovu malo bijaše takovih dana. U njima kao da se povratilo sretno doba mladosti. Bušinski je istom sada osjetio, kako se bio već otuđio životu, kako udaljio, i sada mu se opet vraćaše. (...) Njegovu dušu ostavila je muka naprezanja za rješavanjem visokih problema $i$ on lišen toga upinjanja našao se lak $i$ gotovo $s$ djetinjem čuvstvom očima u oči životu jednostavnom, narodnjem. (...) I njegov otac kao da se pomladio. On se sa sinom izmirio. (...) I njihov dom opet jednom oživio.“(Leskovar, 1997: 279-280)

100 „Nešto bijaše u njemu, što nije dalo da se kod nje zaustavi“ (ibid.: 255; isticanje naše), upozorio je pripovjedač još na početku romana.
} 
Dakle Marcelova se abulija kao odraz ništavila života radikalizira nakon silovitoga sudara s prošlošću. Iz toga se suočavanja potencira sva njegova daljnja tjeskoba, neurastenična nadraženost, nemir i podvojenost. A tjeskoba se kao dominantno čuvstvo u kolopletu navedenih duševnih stanja ne rađa samo kao direktna posljedica protagonistove nemoći da donese odluku nego i kao, u svjetlu Kierkegaardove teorije o anksioznoj slobodi izbora, sasvim normalna dispozicija pred alternativama. Nedjelovanje se uza sve to može i medicinski protumačiti jer tjeskoba, s obzirom na to da joj se izvor ne može nedvosmisleno odrediti, kako smo već pojasnili, paralizira osjetila. Budući da ona tjera na povlačenje iz života, u Marcelovu slučaju, slijedeći Mayevu hipotezu iz uvodnoga dijela, možemo govoriti o njezinoj ekstremnoj formi u kojoj se blokira svaka potencijalna aktivnost.

To nas međutim ne sprečava da na Nietzscheovu tragu utvrdimo da je Marcelova bolećivost upravo odabrana te da je njegova kvazietička dvojba između Ljerke i Helene, sadašnjosti i prošlosti, najobičnija „knjiška transplantacija“ (Milanja, 1987: 61). Potonja konstatacija iznova vodi do procjene da bi se njegovom životnom filozofijom moglo proglasiti epikurejstvo, u smislu pravoga užitka koji leži u umjetničkom uređenju vlastita života. Ono degenerira u senzualizam koji će - kroz dilemu između čistoće nježne platonske ljubavi i hedonističke putenosti koja ne mari za posljedice - anulirati svaku mogućnost realnoga života. Umjetnost u njega znači otuđenje od života. A takav egzistencijalni esteticizam, u kojem se ne uspijeva razriješiti dihotomija između realnosti i ideala, opet upućuje na ekstremni solipsizam i kult ega u kojem se destruira svaka mogućnost kolektiviteta. Dakle Marcelova je dekadentna estetika isključivo solipsistička. Marjanović pak epikurejstvo prepoznaje kao temeljno obilježje cjelokupne leskovarovske dekadencije:

Ali oni toga užitka ne nalaze, jer ih budna i nadražena misao sjeća prošlosti ili ih upozoruje, da bi ih na tu prošlost mogla u buduće podsjetiti, i eto, takve egoističke vrste je onaj etički pritisak, tu je izvor „moralnoj odgovornosti“, a idealni zahtjevi su zapravo zahtjevi čistoga užitka, koji govori: ili sve ili ništa! (1950: 132)

Iako nakraju imanentnu inertnost i kukavičluk Bušinski narcisoidno opravdava nekim višim moralnim razlozima koji mu tobože ne dopuštaju da bogatim ljubavnim iskustvom ukalja Ljerkinu čistoću i nevinost, može se utvrditi da on nakraju ne odlazi zato što sumnja u njihovu ljubav, nego zato što jednostavno zna da će biti nesposoban za njezino ispunjenje. To je „obogaljeni subjektivizam koji razara život“ (Hauzer, 1966: 386). Rađaju se prema tome svi Leskovarovi muškarci s prvim grijehom, pod čijim su teretom izgubili svježinu života. I kad 
Marcelova hiperosjetiljivost zaprijeti kolapsom živčanoga sustava, preostaje mu ludilo, smrt, povratak prirodi i normalnomu ili pak nešto četvrto, najčešće bijeg, odnosno pretpostavka kretanja od nule. Zato Bušinski svoju dekadenciju nosi do mjesta s kojega više nema povratka i bježi zbog vlastitih slabosti kojima se ne nazire ozdravljenje. Zapreke se ostvarenju sreće, kao što smo i dosad vidjeli, nalaze u unutrašnjosti protagonista koji ne poduzima konačan korak te postaje odgovoran za vlastitu intimnu dramu. Povlačeći se kao potrošen čovjek pred odlučujućim odlukama svoga života, stalno se kolebajući te ne znajući što zaista želi, ništa ne poduzima i odlazi.

Znao je, da ga djevojka ljubi, nadao se, da će se ona udobriti - no tužna ga misao stade obuzimati - kakav život bi to bio, kakav?... Može li biti još govora i nepomućenoj sreći? Nju zar da osudi na vjekovite tajne zašućivane misli? Kakav život, kakav život!... (Leskovar, 1997: 326)

\subsection{Stanko Lukavac, čovjek bez identiteta}

U galeriji dekadentnih junaka kao radikalan se primjer lika bez identiteta, koji na tragu Nehajevljevih i Novakovih likova ostaje bez mjesta kojim bi konstruirao identitet, izdvaja Stanko Lukavac, protagonist Šimunovićeva Tuđinca iz 1911, romana indikativna naslova koji prigodno, posve sažeto predočava životnu dramu još jednoga dekadenta. Iako su za kompletno Šimunovićevo književno djelovanje karakteristični slabi, neprilagođeni likovi koji na specifičan način iskaču iz pravilnosti poretka svijeta, kao tipičnoga pasivnog dekadenta prepoznajemo dakle Lukavca. Kako su, uostalom, jednoglasno procijenile književna kritika i povijest, opus mu je u cijelosti protkan zanimanjem za jedinstvene ljudske sudbine te pritom, temeljen na regionalnome i lokalnome, nauštrb fabularne dinamike obojen jedinstvenom atmosferom unutarnjih proživljavanja. Zapravo sve u njegovu literarnom stvaranju proizlazi iz autobiografije, utvrđuje Šicel:

(...) i onda kad crta određeni pejzaž ili opisuje svakodnevni život svojih junaka, upotpunjujući često fabulu motivima tradicionalnih običaja sredine koju crta ili pak unoseći simboliku što je izvodi iz narodnih legendi - osnovno inspiracijsko žarište kao i krajnji smisao svoje proze 
Šimunović izvlači iz sebe samog: iz osjećanja vlastite otuđenosti, totalne usamljenosti u životu, „tuđinstva“ uopće, što i rađa temeljne psihičke komplekse autorove. (2005: 204)101

U središtu je romana povratak Stanka Lukavca u rodno mjesto koji bi mu trebao ponuditi rješenje za budućnost te pokušaj da ljubavnom vezom konačno osmisli vlastiti život. Društvena nedeterminiranost i neodređenost te odsutnost analize socijalnih situacija u modelu uzročnoposljedičnih veza korenspondira sa subjektivitetom glavnoga junaka, što je, ponovimo, ono inovativno pristiglo s findesiècleovskoga horizonta raspada vrijednosti. Sindrom unutarnjega tuđinstva, koji se gotovo redovito okončava porazom pretjerano osjećajna, povučena, neotporna pojedinca, dominira osobito ovim romanom. Uklopivši se njime u literarnu tendenciju oslikavanja neprilagođenih individualaca koji, bježeći od konkretnoga djelovanja, svoj život najčešće završavaju bijegom ili tragičnom smrću, Šimunović je Lukavcem obogatio repertoar dekadentnih likova, koje uvijek obilježava zajednička komponenta: „(...) fatalno osjećanje slabosti i nemoći u borbi sa životom i prirodom, nemoći kojoj nisu direktni krivci, i iz tog sukoba s nemilosrdnom i bešćutnom prirodom ili društvom proistječu i njihovi unutarnji sukobi, traume, tuge, tjeskobe.“ (ibid.: 210-211) Premda Frangeš procjenjuje da su Šimunovićevi likovi u stanovitoj mjeri suprotstavljeni Novakovim, Leskovarovim i Nehajevljevim suvišnim ljudima (1987: 250), s tim se sigurno ne bi složio Matoš, koji je u osvrtu na roman udario na Šimunovićevo strukturiranje lika i nedovoljnu motiviranost njegovih postupaka. Iako prilično radikalna, pisana iz pozicije njegova svjetonazorskoga vitalizma, Matoševa se kritička ocjena podudara s onim što, zajedno s recentnijom kritikom, tvrdimo i mi:

Sposoban samo za pasivne, negativne, bolne životne gestove. On misli da je stranac u domovini, ali takvi kukavci su stranci svuda, jer su, lišeni svake energije, nesposobni za život, jer su svuda u ljudskom životu stranci. Oni u stvari ne mogu ljubiti, jer su nesposobni za svaki rad, za svaku inicijativu, jer su slabići. Samo jaki jako vole. U bezenergijskim narodima su ti bolesnici volje tipske pojave, a taj Tuđinac baš kod nas, u zemlji proskribovane i prodonkihotisane energije nije tuđinac, već je reprezentativna pojava poput Oblomova u indolentnoj, pospanoj, lijenoj i umočvarenoj moralnoj atmosferi stare Rusije. Stanko Lukavac je brat Leskovarovih tipova što ne mogu ljubiti i ljubav ostvariti jer su lišeni energije ljubavne i životne. (1973a: 194-195)

\footnotetext{
${ }^{101}$ U pismu Branku Vodniku, ogorčen negativnim kritikama romana, naročito njegova glavnoga lika, Šimunović je zabilježio: „Karakter Stankov to je moj karakter, a njegova sudba je moja, pa mi je, po mom mišljenju, i uspjelo dobro ga ocrtati, niti je takav karakter po tom ne moguć i ne pojmljiv.“(cit. prema Čolak, 1966: 65)
} 
Zato Stanka naziva oblomovskim neuropatom i histerikom, izvrsnim predmetom ,za Ribotove studije o bolesnoj volji“ (ibid.: 194) te osuđuje njegovu blijedu, hipersenzibilnu narav i brojna psihička protuslovlja. Ostavljajući postrani intoniranost Matoševe diskvalifikacije, možemo mu se pridružiti u procjeni te istaknuti da je Šimunović, usmjerivši roman u smjeru analize psihologije otuđena junaka, postavio iskorijenjenost kao lajtmotiv djela, $\mathrm{i}$ to upravo $\mathrm{u}$ smislu koji smo tumačili u uvodnom dijelu o fragmentarnim identitetima. Na Lukavca se naime priča o pojedincu bez mjesta u društvu, mjesta koje je ujedno i odgovor na pitanje o vlastitoj biti, može primijeniti u potpunosti: s obzirom na to da smo ustvrdili da uspostava vlastitoga „ja“ podrazumijeva pronalaženje pozicije, vidjet ćemo zašto je Lukavčev pokušaj stjecanja identiteta osuđen na propast.

Bolesna zakočenost volje, koja prilično nedvosmisleno priziva dijagnozu neurastenije, a zrcali se u nemogućnosti aktivnoga, konkretnoga djelovanja, tj. u neprestanom „osobnom intuiranju zbilje“ (Detoni Dujmić, 1991: 84), u Stanka Lukavca proizlazi iz njegova tragičnoga proturječja sa samim sobom, ali i sa svijetom u kojem pokušava pronaći svoje mjesto. Jer, kako navodi Kant kad implicite utvrđuje paradoksalnu „nedruštvenu društvenost“ (Donskis, 2011: 8) - čovjekovu žudnju za kreativnom samoćom i samoispunjenjem te istodobnu neodvojivost od društva, njegovih normi, vrednovanja i osjećaja zajedništva - dok nas jedan dio našega bića motivira da se držimo podalje od zajednice, drugi nas potiče da joj se priključimo kako bi nas identificirala, uključila u svoj sustav ili ga iz njega isključila te vrednovala. Čovjekova se priroda prema tome sastoji od dvaju međusobno isključivih odnosa prema društvu, „ekskluzivnoga i inkluzivnoga, individualističkoga i holističkoga, a pritom svaki jamči neku vrstu egzistencije“ (ibid.). Zato Lukavca prepoznajemo kao tipična Durkheimova homo duplexa: dualnost naravi potrebe za identitetskom uspostavom izvire iz njegove želje da bude dio društva, ali da pritom zadrži jedinstven, individualan identitet. Kako Durkheim primjećuje,

kad pojedinac promišlja kroz pojmove i ideje koje mu je dalo društvo, individualizira ih te ih određuje vlastitim jedinstvenim obilježjem. Pritom ne postoji ništa osobno što ne bi bilo podložno ovom tipu individualizacije (...). Ta dva aspekta psihičkoga života (...) međusobno su suprotstavljena kao što su suprotstavljeni osobno i neosobno. (...) Zato se može reći da staru formulu homo duplex verificiraju upravo te činjenice. Prilično složen, naš unutarnji život posjeduje nešto poput dvostrukoga centra gravitacije. S jedne je strane naša individualnost (...), s druge je pak sve drugo u nama što izražava sve ono što nismo mi sami (cit. prema ibid.: 9). 
Dakle Stankov je povratak u zavičaj pokušaj tuđinca da otkrije vlastite korijene, da se vrati zajednici, ljudima koji je čine, te na taj način dokine svoju iskorijenjenost i identitetski se uspostavi.

Pače i neko neslućeno ganuće oblada njime, kad je pomislio, da eto i on ima svoje rodno mjesto kao i ostali te da će vidjeti zacijelo i onu kuću, gdje se rodio, gdje je progovorio prve riječi i učinio prve korake. I zbilja oćuti neko dosad nikad okušano čuvstvo kao u nijednom od drugih mjesta, gdje je sve bio bez posla, bez cilja i bez nada. (Šimunović, 1952: 230)

Identitetska uspostava u njegovu slučaju podrazumijeva pronalazak doma u kojem bi se smirio, profesionalnu satisfakciju i zasnivanje zajedničkoga života. No ta je potraga unaprijed osuđena na propast: obilježen je naime tjeskobnim nemirom koji izvire iz njega sama, iz dubine njegova dekadentnoga bića, te frustrirajućom nemogućnošću da pronađe svoje mjesto pod suncem i postane dijelom zajednice, što će posebno biti vidljivo na kraju romana. Taj nemir, primarno uzrokovan potragom za svojim korijenima, u isti će mah onemogućiti svaki pokušaj osmišljavanja egzistencije te se zato on neprestano vrti u začaranom krugu vlastita života. Pritom je presudna činjenica da je Stanko čovjek bez povijesti, što će odlučno utjecati na njegovu sadašnjost, pa i trajno na njegovu budućnost. Ne bi li pronašao tragove svoga ,ja“, Stanko se kao „,̌ovjek od svijeta“ (ibid.: 186) vraća u Sabljare, mjestašce u kojem se rodio, ali vrlo kratko živio. Naime zbog očeva se posla u djetinjstvu stalno selio: tu pronalazimo izvore njegove životne traume koja će svoje posljednje obrise poprimiti upravo $u$ vremenu pripovijedanja.

Odatle me odnesoše, kad su mi jedva dvije godine bile, a tada sam bivao po različitim mjestima, gdje se gradila kakva crkva, škola, cesta ili opet kakav most i samo toliko, koliko bi trajala ona gradnja. I tako ja nisam nigdje proživio više od dvije godine (...). (ibid.: 187-188)

Ne uspjevši se nigdje realizirati, Stanko se prezentira kao čovjek bez doživljenoga djetinjstva, koje dočarava riječima „blijedo, vodeno“ (ibid.: 190), sintagmom koja će mu odrediti čitav život te se romanom provlačiti u različitim situacijama. Zbog toga su mu sva mjesta ,jednako tuđa. Bio ovdje ili ondje, meni je posve svejedno. Nemam nigdje ni rodbine ni prijatelja“ (ibid.). Kako je opisao Pavlović, nazvavši ga tuđincem izvan ljušture života, na taj je način stvoren „literarni čovek bez doživljaja topline, razdragane neobaveznosti i radosti 
detinjstva, sa životom koji mu postaje neka apstraktna ljuštura oko koje je samo hodao, jer nije mogao u nju, nije znao kako da uđe“ (1986: 102).

A budući da je osobni identitet kompleksan fenomen koji u sebi uključuje mnogobrojne silnice i poticaje, Lukavčeva se egzistencijalna apstraktnost, utemeljena u njegovoj apovijesnosti i sveprostornosti, odvija na dvjema razinama, možda najvažnijima za identitetsku uspostavu: na profesionalnom i ljubavnom planu. On pripada svugdje i baš zato ne pripada nigdje, pa je stoga odličan reprezentant dekadenta bez identiteta u onom najužem smislu riječi. Boravak izvan jednoga, čvrstoga uporišnog mjesta, pa i izvan zavičaja, tj. u inozemstvu, put je njegove desubjektivacije, dekadentne fragmentacije ličnosti. „Ali ja nijesam građanin, jer se nijesam odgojio u gradu, ali nijesam ni seljanin ni varošanin. Ja sam svagdje živio, tako reći, po malo dana i nemam nikakve boje i ništa svoje“ (Šimunović, 1952: 190), reći će već na početku, kako bi potvrdio da se kod njega dekadencija, baš kao i u drugim primjerima, prepoznaje u neuspješnoj izgradnji sebstva kroz međuodnos ,ja“ i drugih životnih sfera. Lukavac žudi za drugim kako bi se kroz drugoga gledao i na taj način uspostavio, nadomještajući manjak koji mu je zadan.

Iako je u tom romanu profesionalno (ne)ispunjenje tek naznačeno, za pretpostaviti je da Stankova nemogućnost ili nesposobnost obavljanja posla koji bi ga zadovoljio dodatno utječe na nestabilnost identiteta. Zapravo, ispravnije je govoriti o nevoljkosti donošenja odluke, tako uobičajenoj osobini hrvatskoga dekadenta.

Priznajem, da ni sâm sa sobom nijesam načistu i ne znam, što da počnem. Ja se naukom nijesam bavio ozbiljno nikad, ali sam čitao i mislio mnogo, pa bih sada htio da stanem ozbiljno živjeti i raditi, ako što bude. (...) Ja sam počeo da pišem... znate... onako... obične novele, jer me nešto tjera da budem... Da, i napisao sam dosta toga, ali kad čitam, uviđam i sâm, da je to nešto preveć blijedo, vodeno, bez ikakva žara... a riječi su tu tako lijepe... zvonke... A ipak ništa! Sve iziđe nekako neprirodno i lažno. (ibid.: 189; isticanje naše)

Dakle materijalno osiguran, za razliku od nekih drugih dekadenata, nema nikakve potrebe da se bavi konkretnim, „ozbiljnim“ poslom (na tragu ruskoga suvišnog čovjeka, jer mu je otac priskrbio dovoljno da ne mora uopće raditi), a još k tomu i nije siguran čega bi se uopće primio. I on naime pretendira na književni rad, pa mu je dekadencija razumljiva i u svjetlu pojačane umjetničke senzibilnosti. Tako se njegova iskorijenjenost projicira ujedno na polje stvaralaštva te se može reći da „sustavno čezne za umjetničkim iznošenjem osobnih osjećajnih i misaonih sadržaja, ali u tome ne uspijeva“ (Detoni Dujmić, 1991: 89). „A što bih znao reći ja? 
Eto mi je duša puna čuvstava, tuge... A nikada ne bih složio dva retka, da mi odlane, da se osokolim pa saznam, da i ja nešto mogu.“ (Šimunović, 1952: 296) Primjećuje se stoga kako ni profesionalnim ispunjenjem ne uspijeva popuniti identitetske pukotine.

Međutim više od fenomena tuđinstva našu pozornost zaokuplja činjenica da on svoju alijenaciju doista podnosi posve pasivno te $s$ teretom neke neshvaćene krivnje živi život ispunjen „samo glupošću i dosadom“ (ibid.: 233). Stanko je prema tome oblikovan kao uzoran dekadent: neaktivan i bezvoljan, nezadovoljno tjeskoban i emocionalno nesiguran, suvišni čovjek odmalena opterećen strepnjom koja se za života pretvorila u golemu tugu koja mu je izbrisala svijest i svijet u kojem je egzistirao. Ne mogavši se ostvariti u formativnim godinama niti odrediti sebe za budućnost, u svijet odrasla čovjeka ušao je neisplanirane i neutemeljene egzistencije. Budući da nije mogao uspostaviti jedinstvo s ljudima koji su ga okruživali, postao je iskorjenik koji se nije uspio infiltrirati u osmišljen svijet. Zato i neprestano potencira da „sve mi je tako tuđe, znate, onako neugodno tuđe...“ (ibid.: 190). Bez ikakve mogućnosti izbora i životnoga usmjerenja, prijelomno definiran činjenicom da nikad nije bio dio ijedne zajednice, cijeloga je života samo osjećao vlastitu suvišnost: „,...) i ja sam tuđi svagdje, gdje dođem, i korijena ne mogu pustiti““ (ibid.: 198). Referirajući se na početke našega rada, možemo reći da se u Stankovu slučaju ne može govoriti o raspadu vrijednosti. On vrijednosti naime ni ne poznaje. Ta nam tvrdnja i omogućuje da procijenimo da on jednostavno ne može pronaći sustav na koji bi se oslonio. Prema tome, prisjećajući se uvodnih cjelina o raspadu vrijednosti kojim smo odredili fin de siècle, možemo utvrditi da dok se drugi dekadenti nastoje osloboditi autoriteta i okova društva koji ih pritišće i guši općeprihvaćenim normama i obrascima ponašanja, Lukavac konstituiranje vlastitoga ,ja“ obilježava upravo potrebom da bude dio sustava, dio cjeline. I u tom mu procesu misao „kamo ja samo pripadam“ (ibid.: 287) posve okupira svijest, postajući lajtmotivom njegova života. Zato se njegovo djelovanje svelo isključivo na odlaske i ahasverska lutanja te je pritom zapeo u rascjepu između dotadašnjega životnog modela, koji podrazumijeva „pravo“ tuđinstvo, život izvan rodnoga mjesta, i „domaćega“, zavičajnoga modela u koji se nastoji uklopiti. Međutim pokazat će se da je svaki pokušaj pripadanja osuđen na propast.

To potencijalno uklapanje u romanu je u prvom redu određeno ljubavnom pričom, osnovnom točkom oko koje se pripovijedanje vrti. Kako smatra Detoni Dujmić, iz Stankove intimne dvojbe proizlazi čak i nekohezivnost fabule, ,'prevrtljivost' akcije te nemoć i odustajanje da se radnja definira“ (1991: 86). Odnosno, iz unutarnje podvojenosti njegova bića, iz prirođene nesigurnosti duha slijedi i ljubavna neodlučnost, ali zapravo i svaka druga neodlučnost, što je najbolji pokazatelj njegove oslabljene energije. Iako se isprva tješi kako će 
nastaviti svoje skitnje, „pa niti ću koga ljubiti niti ko mene kao i dosad“ (Šimunović, 1952: 199), zaljubljivanje u Made ponukat će ga da pomisli da se u toj ljubavi krije sve za čim je tragao. Međutim nastavak putovanja u Sabljare bit će definitivan početak kraja njihova odnosa i Stankova pokušaja da pronađe samoga sebe. Njegova nespokojna priroda, razapeta između spomenutih tragičnih proturječja, neće mu tek tako dopustiti da pronađe sreću. Premda će susret s Madom u njega donekle unijeti svježinu novoga, ubrzo će ga iznova preplaviti prijašnji osjećaji žalosti i osamljenosti - ta varljiva potencijalnost promjene, koja se vrlo brzo urušava, česta je konvencija u izgradnji dekadentnoga karaktera, kao što smo mogli vidjeli i u drugih protagonista. U takvom stanju opetovane beznadne sjete Stanko nastavlja put u rodno selo, gdje upoznaje i Anđeliju te mu se napokon čini „kao da je došao u svoju, davno zaboravljenu obitelj, bez koje je i bio uvijek tako zamišljen i tužan“ (ibid.: 232). Zatomljuje čuvstva tuđinstva i iskorijenjenosti, napokon osjećajući kao da je upravo ,u središtu narodnog života pa je bio potpuno sretan, kad je opazio, kako je moguće i njemu da postane domaće čeljade i ne bude uvijek suvišni tuđinac" (ibid.: 233; isticanje naše).

Tako će se na tren činiti mogućim njegovo sjedinjenje sa zavičajem, s izvornošću prirodnoga. Jer, ako je vjerovati Šimunovićevu pismu Vodniku 1912, u kojem se detaljno osvrće na kritike Tuđinca, napose na Matoševu, Stankova neenergičnost i egzistencijalna izgubljenost ponajprije su odraz činjenice što na njega, kozmopolita koji se obrazovao i živio vani, nije uspjela djelovati tradicija i autohtona narodna kultura. „On je baš taki što su svi oko njega prožeti snagom narodne kulture i tradicije, a on sam nije.“ (cit. prema Čolak, 1966: 68) Njegov pokušaj da se povratkom u rodno mjesto stopi sa svojima i nadvlada dekadenciju, koja se najvećim dijelom može smatrati senzibilitetom uvjetovanim putovanjima i odlascima, posve će se izjaloviti. Pobrinuo se dakle Šimunović da se njegov junak nikad ne ukorijeni te dopustio da rastrganost između dviju žena pokoleba njegov ionako nemiran i tugaljiv duh. Čvrsto uvjeren da će svijetom lutati zauvijek, Lukavac tek pokušava živjeti, kako je i sam jednom prilikom izjavio, a zapravo luta od mjesta do mjesta, indiferentno podnoseći sve što mu život donese, bez prave volje da išta promijeni.

A u Stanku se kovitlale čudne misli, jer se sukobiše u njemu radost i tuga; pa ljubav i nada sa sumnjom i strahom borile se u pustoši, što je nastala u njegovoj duši (...) Ali je ipak pojmio, da je on u tom vrtlogu samo treščica, kojom su prilike vitlale po svojoj volji, te da on nije učinio ništa, da s njima okuša svoju snagu. (Šimunović, 1952: 254) 
Taj fatalistički dojam da mu je život jednostavno tako posložen pojačava čuvstvo njegove duševne i tjelesne izmučenosti, koja raste usporedno s približavanjem konačne odluke i početka zajedničkoga života s Madom. Nakon što je razriješio potencijalnu emotivnu vezanost za dvije žene, suočava se s paralizirajućim strahom da bi ljubavni smiraj napokon mogao biti kraj za njegova fizička i duhovna lutanja. Naime upravo u tim trenucima najjasnije svjedočimo njegovoj kolebljivosti. Budući da je, tumačili smo, iskustvo alijenacije premreženo s konceptom tjeskobe, nećemo pogriješiti ako procijenimo da Lukavca u velikoj mjeri određuje tjeskoba. Tjeskoba koja nije samo posljedica njegove iskorijenjenosti, nego upravo tjeskoba pred mogućnošću izbora, u kjerkegardovskom smislu riječi, baš kao i kod Marcela. Dok stoji pred najvažnijom odlukom svoga života, potvrdit će se ono na što smo upozoravali otpočetka: mlaka narav i neodlučnost u krucijalnim životnim trenucima. Baš poput Leskovarova Bušinskoga, odabrano bolećiv, njegova će izjava kako ne traži „borbe ni velikoga rada“, već priželjkuje ,život čovječji, bliz prirodi, domaći“ (ibid.: 190) doista ostati samo to: izjava, nipošto konkretan pokušaj, jer je preslab da bi nadjačao klonuće. Susrećemo se tako u posljednjim scenama romana s pravim cerebralnim junakom, analitičarem vlastita života atrofične volje. Svako Stankovo daljnje djelovanje onemogućeno je dobro nam poznatim prekomjernim intelektualiziranjem i pesimističnim projekcijama budućnosti kao posljedicama patološke slabosti volje.

- Eno, ja ne ću zaspati i ustat ću slab, blijed, sa vodnim očima i crnim kolobarima ispod njih, činit ću se stariji za deset godina: takova će me vidjeti Made i u svom mjestu, gdje sve cvate i pjeva. A Vlaho će se eto naspavati i probuditi svjež i krepak kao uvijek, jer on, čim legne, zaspi, i nikakove suvišne misli njega ne mute. I Stanko je počeo misliti, kako će ga Made uspoređivati s drugima, i da će to biti samo na njegovu štetu. Jer je on eto bojažljiv, a drugi su odlučni, bezbrižni i šaljivi, što se djevojkama tako mili. A bojažljive i preziru, jer su i same take. (ibid.: 274 ; isticanje naše)

Kako smo zamijetili i u drugim prozama, tjelesna je i duševna slabost dekadenta u pravilu dodatno naglašena njegovom konfrontacijom s ,,pravim“ muškarcima. Iako se Stankova duševna onemoćalost zrcali i u tjelesnom izgledu, ta je vrsta degeneracije, u smislu slabljenja vitalnih svojstava tipičnih za ,prave“ muškarce, ipak najrazvidnija u njegovu odnosu prema doktoru Mirku, praktičnom čovjeku koji ga i savjetuje jer se Stanko vrlo teško odlučuje, Vlahu, snažnom mladiću koji zna što želi i što radi, te Madinu ocu kojem su smiješne njegove apstraktne, spekulativne „,bezimene boli“ (ibid.: 262): 
A što bih ja istom mogao reći, koji provodim mučne dane... bez pravoga zdravlja, izlomljen od oluja na moru i raskidana srca od toliko... Pa da nije već sama ona jedna nesreća bila, kad mi jedinca sina proždrije ocean zajedno s mojim lijepim brodom, na kojemu sam plovio unakrst cio svijet!... A kamoli vaši izmišljeni jadi! (ibid.)

Stanko se prema tome neprestano zadržava izvan vremena, nedorastao životu u sadašnjem trenutku, opterećen nekom nepojmljivom težinom života. Pa ga počinje razdirati pomisao na budućnost te ga pritom jedna ideja posebice proganja: bojažljivo ćuteći da će i Madi postati nepotreban kad bude svoja na svome, vjeruje da je zajedničku sreću moguće ostvariti tek ako oboje budu na nepoznatu tlu, posve iskorijenjeni. Naime, kako smo napomenuli pišući o dominantnoj devetnaestostoljetnoj pojavi mal de vivre, što pojedinac više razvija svijest, to se povećava njegova nelagoda zbog položaja u svijetu. Zato će se i Stankov pokušaj pronalaženja pozicije izjaloviti - uočivši raskorak između želje i realnosti, između zamišljenoga i ponuđenoga, samo će ući u novi apsurd vlastite egzistencije.

Ja vidim, da mi ovdje nije opstanka, jer je za mene sve tuđe i jer sam tuđi svakome, osim, eno, njoj. Mi ćemo ovdje nesretni biti uvijek pak hoću da živimo ondje, gdje ćemo biti tuđi oboje, a ne samo ja. (ibid.: 303)

U narcističkoj okrenutosti samomu sebi, u njemu predodžba o vlastitom ,ja“ posve zaklanja predodžbu o drugome te ga obuzima sebično uvjerenje da će samo ako zatre i Madinu povijest biti moguća zajednička im budućnost. Njegovoj psihološkoj rastrganosti presudit će činjenica da mu ni kupnja kuće, koja bi trebala biti simbolična točka novoga života, neće osigurati toliko željeni osjećaj pripadanja. Dapače, što je bliže definitivnoj odluci, to je od nje dalji. „I sve je očekivao, kad će se pojaviti u njemu takova čuvstva, ali uzalud, jer je osjećao samo tjeskobu i sram.“ (ibid.: 291) Shvaća da ne može tek tako postati dijelom zajednice, onako kako je priželjkivao, jer se društveni odnosi i osjećaj zajedništva kojemu toliko teži njeguju godinama. Sve dakle vodi spoznaji o uzaludnosti napora da se ukorijeni te, dok radi ono što mu ide najbolje - besciljno luta, stalno se vraćajući na zlokobno pitanje „A odakle ste, zbilja, vi, gospodine?“ (ibid.: 292) - više ne pronalazi utjehe nemirnim živcima i uskovitlanim mislima. Stoga kao pokretač propasti njegova pokušaja dokidanja otuđenosti i identitetske uspostave promatramo fiziološku predisponiranost organizma, upravo neku vrstu neurastenije kao posljedice prekomjernoga iscrpljivanja energije. Prisjetimo li se samo Janetova tumačenja neuroze, odnosno neurastenije i objašnjenja kako se neurastenici iznimno često određuju 
umornima od rođenja (1925: 86), postaje nam sasvim jasno zašto se i Lukavac naziva čovjekom oduvijek iscrpljenim: ,- A ja sam taki oduvijek - reče u sebi - i ne sjećam se, da je kada u meni bilo snage..." (Šimunović, 1952: 294; isticanje naše). Njegovo pamćenje o sebi samom pamćenje je traumatične povijesti čovjeka atrofične energije, čovjeka bez podloge, obilježenoga neizgrađenom egzistencijom koja mu je u potpunosti odredila budućnost.

Zato se „,izmučen i pomodrjela lica“ (ibid.: 297), razdiran osjećajem da je poput prosjaka koji moli milostinju u tuđoj zemlji, pojavljuje pred Madom tražeći od nje da odu zajedno u Ameriku. No bez snage za razgovor te, pretpostavljajući da bi ga mogla odbiti, zauvijek odlazi bez pozdrava, ne uspijevajući ostvariti jedinstvo s ljudima i pronaći samoga sebe.

\subsection{Dekadentno tijelo u raspadu: Ljubić i Toplak}

Kad smo govorili o anatomiji dekadencije, o neurasteniji i degeneraciji kao pojavama koje se uz nju usko vežu, dotaknuli smo se i činjenice da građanska kultura provodi neku vrstu diktature nad tijelima pojedinaca te posredno istaknuli da se zdravlje promiče u pravu ideologiju. Apologetski se inzistira na zdravim, stabilnim, čvrstim tijelima koja se grade na samodisciplini te se pritom ona uzimaju kao dokaz moralnosti pojedinca. Zdravo tijelo jest disciplinirano tijelo. A zdravi ljudi uspješno ispunjavaju svoje društvene funkcije. Prema tome sa stajališta društvene funkcionalnosti bolest je vrsta devijacije i sva „druga“ tijela - umorna, deformirana, degenerirana, labilna, iscrpljena, ranjena - izvor su društvene tjeskobe. Zato se vrlo lako prikloniti Kristevinu mišljenju da zazorno nije tek „odsutnost čistoće ili zdravlja, već ono što remeti identitet, sustav, red. Ono što ne poštuje granice, mjesta, pravila“ (1989: 10). Pritom društvo, anatemizirajući nestabilne pojedince, regulativnom praksom marginalizira sve one koji nisu (posve) zdravi. Kako eksplicira Wendell, u zapadnim društvima s razvijenim medicinskim i drugim znanstvenim sustavima, u kojima je prisutan kontinuiran i intenzivan napor za kontrolom, bolesni su ono drugo koje bi društvo rado zaboravilo (1996: 63).

U društvima u kojima postoje čvrsti ideali tjelesnoga savršenstva kojima bi svi trebali težiti, ljudi s invalidnošću nesavršeno su „drugo“ koje se tim idealima nikad ne može dovoljno približiti; poistovjećivanje s njima podsjetilo bi one bez invalidnosti da njihovi ideali impliciraju stupanj kontrole kojima se i sami naposljetku moraju podvrgnuti. (ibid.) 
Iako bismo dakle u širem smislu u ovu „ladicu“ mogli smjestiti sve likove iz našega korpusa, jer njihovu dekadenciju tumačimo kao pomaknuće u odnosu na društvene norme, prakse i ponašanja, u ovo smo poglavlje smjestili bolesno tijelo u pravom smislu riječi da bismo demonstrirali na koji način tijelo odnosno bol organiziraju ličnost. U klasičnoj, „normalnoj“ konstelaciji prilika tijelo se, kroz jedinstvo s umom, prikazuje kao cjelovit entitet. Kartezijanski dualizam mišljenje-tijelo sa sobom je zapravo donio devaluaciju tijela, odnosno razumijevanje tijela kao „smetnje“ koja se umom mora nadići. Međutim indikativno je da pojedinac de facto svoje tijelo ne osvještava. Ono je u pravilu odsutno iz njegove svijesti, osim kad pati, stječe nove vještine ili proživljava iznenadne i impulzivne promjene (ibid.: 169-170). Tek kad je suočen s bolešću, nekom vrstom invaliditeta, priziva ga u svijest jer ono tad više nije gotova činjenica, puki aksiom, nego prerasta u problem. Uostalom, spoznaja tijela, u najvećem broju slučajeva, jest spoznaja boli, nelagode ili fizičke poteškoće. Bolest, možemo stoga naglasiti, pojačava osjećaj tjelesnosti, prisutnosti samoga tijela, prisiljavajući pojedinca da se suoči sa svojim promijenjenim stanjem: ograničenošću. Ta disfunkcionalnost utječe i na uspostavu njegova identiteta te ga tjera da bolest prihvati kao novo, normalno stanje svoje egzistencije. Dakle budući da patnja uključuje kompletnu osobu, ona zahtijeva odbacivanje isključivosti navedenoga dualizma jer je subjekt patnje uvijek „tijelo-sebstvo“ (Kleinman prema Frank, 1995: 169). A patnja započinje onda kad se počne percipirati prijeteće razaranje sebstva te se nastavlja sve dok se prijetnja dezintegraciji ne okonča ili dok se integracija ne uspostavi na koji drugi način.

Porazan smisao fragmentarne egzistencije cijena je koju čovjek mora platiti za ulazak $u$ društvo i vlastiti subjektivitet te se u tom kontekstu može zaključiti da zapravo nije sama bolest ta koja ulijeva strah, nego je to ranjivost kao konstitutivan element sebstva. Naime nepotpuno, zazorno tijelo narušeno bolešću podsjeća druge da je ideja o cjelovitosti doista samo iluzija i zato pogled na izmorenoga dekadenta izaziva paničnu tjeskobu. Pronicljiva simbolika Susan Sontag (1978) o bolesti kao putovanju možda najbolje svjedoči o toj krhkoj granici između zdravlja i bolesti. Sontag u svojoj knjizi o bolesti kao metafori inzistira na demistifikaciji bolesti, ukazujući na to da je ona stanje neodvojivo od tijela:

Bolest je tamna strana života, jedno tegobno državljanstvo. Svatko po rođenju prima dvostruko državljanstvo - carstva zdravih i carstva bolesnih. Iako nam je svima draža dobra putovnica, svatko je primoran bar neko vrijeme biti građaninom drugoga reda. (1978: 3) 
Usto bolest je neraskidivo vezana $\mathrm{s}$ našim razumijevanjem vlastite egzistencije. $\mathrm{S}$ obzirom na to da je, koliko god se trudilo zadržati utopijski smisao cjeline, tijelo uvijek podložno (re)prezentaciji, koja ima vrlo veliku ulogu u načinu na koji ga percipiramo, očigledno je da je čvrstu granicu između biološke realnosti i društvene konstrukcije bolesti nemoguće povući. Ona se naime pojavljuje u društvenom, psihološkom i fizičkom kontekstu te nerijetko poprima metaforičko, duboko složeno značenje, što ćemo najbolje vidjeti u odlomcima koji slijede.

Frana Ljubića, glavnoga lika Leskovarove Katastrofe, i Arsena Toplaka, glavnoga lika Kamovljeve Isušene kaljuže, povezuje tek činjenica da obojica boluju od tuberkuloze te da su jedini akteri u čitavom našem korpusu proza koji pate (i) od organske, ,prave“ bolesti. Njihova tuberkulozna tijela evociraju upravo fragmentirano sebstvo, razlomljeni, labilni subjekt o kojem smo pisali na početku disertacije. Oko nedostatka zdravlja, što funkcionira kao početna točka urušavanja svih vrijednosti, gradi se njihova dekadencija.

Sve što smo susreli u Misli na vječnost Leskovar je još pregnantnije izveo u Katastrofi (1892), noveli u kojoj je problematika dekadenta klonula od teškoća „prave“ bolesti te intelektualističkih analiza i sjena prošlosti suzbijena u tek nekoliko odlomaka koji nevjerojatno sugestivno iznose svu bijedu jednoga hrvatskog učitelja. Pa čak i ako se moglo misliti da je Leskovarova prva proza slučajan književni izlet, druga je potvrdila da autor nije zalutao na ove ceste pokušavajući doprijeti do skrivenih prostora ljudske psihe. Protagonist Fran Ljubić boluje od tuberkuloze, bolesti koja se u književnosti razvila u pravi kult. ${ }^{102}$ Svrstavši se među najstarije poznate bolesti čovječanstva, u semantičkoj tipologiji bolesti vlastitoga ,ja“ i bolesti drugoga tuberkuloza je postala prilično zanimljiv i paradoksalan slučaj obavijen zapanjujućom aurom. Teško da se može pronaći enigmatičnija i mistificiranija bolest u kulturnoj i književnoj povijesti. Karakterizira je nevjerojatan raskorak između reprezentacije u književnim djelima i stvarnosti, između dobro strukturiranoga narativa i zastrašujućih bioloških činjenica ${ }^{103}$ te je fascinantno kako je ona, iz današnje perspektive teško pojmljivo, postala gotovo idealan način

\footnotetext{
102 Za povijesni pregled razvoja i percepcije bolesti usp. Bynum (2012).

${ }^{103}$ Vrhunac epidemije tuberkuloze dosegnut je u ranom XIX. stoljeću, isprva u Engleskoj, za koje desetljeće i u Francuskoj te drugim dijelovima Europe (Herzlich i Pierret, 1987: 24). U svjetskim i europskim metropolama u 1890-ima - dakle u desetljeću nakon Kochova otkrića njezina uzročnika - smrt je na tisuću stanovnika varirala primjerice od 4,6 u Moskvi, 4,1 u Budimpešti i Sankt Peterburgu, preko 3,9 u Parizu i 2,5 u New Yorku, do 2,3 u Berlinu i 1,3 u Londonu. Niže su stope, očito je iz navedenoga, bile prisutne u razvijenijim industrijskim zonama zapadne Europe i Sjeverne Amerike (Bynum, 2012: 111).
} 
umiranja (i to osobito za romantizma). Kulturna se reprezentacija bolesti uvelike odmakla od biološke realnosti te je postala načinom na koji se vrijednost situira upravo u odsutnosti zdravlja. Valja shvatiti da, kako piše Lawlor, tuberkuloza nije građena na nekom mitskom temelju, nego je sama bolest posjedovala određene biološke obrasce koji su nametnuli njezino kulturološko razumijevanje (2007: 4). Spomenuta Sontagina studija opisuje upravo tu paradoksalnu prirodu tuberkuloze i raka te začudnu razliku u metaforama koje su one generirale. Za razliku od raka, kojemu su beziznimno pridavane negativne vrijednosti, tuberkuloznomu bolesniku pripisivale su se fascinantne kvalitete, poput sofisticirane tankoćutnosti, umjetničke kreativnosti i produhovljene, eterične ljepote. Poprimila je reputaciju poželjne, privilegirane bolesti. Ili, kako je Sontag utvrdila, „kao što je TB bila bolest vlastitoga 'ja', tako je rak bio bolest drugoga“(1978: 68). Stoga se može reći da je društvena konstrukcija bolesti uspješno konsolidirala nacionalne, rasne, klasne i spolne, odnosno rodne kategorije, a povijesni su procesi stabilizirali viđenje identiteta bolesnoga kao onoga drugoga.

Simbolika bolesti o kojoj govore Sontag (1978) i Byrne (2013), kao što je to primijetio Vuković (2017), izvrsno se može primijeniti na Katastrofu. Sudbina Frana Ljubića sudbina je čovjeka koji doživljava krah pod teretom društveno-političkih prilika i jednoga ekonomskog sustava. Upečatljiv, zbijen prikaz tegoba njegova posljednja dana - u koji je stao cijeli jedan život - ilustrativna je simbolika načina na koji opresivni sustav može u potpunosti odrediti jedan život. On je izvrsna ilustracija mizernoga stanja učiteljskoga zvanja onoga vremena, ${ }^{104}$ prava slika čovjeka koji je svu svoju energiju, koja mu je trebala osigurati dostojanstven život, usmjerio samo na zadovoljenje osnovnih egzistencijalnih potreba u okrutnim gospodarskim i društvenim uvjetima. I tu posve konkretno prepoznajemo ono o čemu smo pisali u poglavlju o položaju Hrvatske u Austro-Ugarskoj: sredinom determinirana junaka, intelektualca kojemu vanjski pritisci dezintegriraju vlastito ,ja“ - i duh i tijelo. U takvoj, vrlo suptilno signiranoj društvenoj analitici pretvara se tuberkuloza u društvenu bolest obilježenu mučnim egzistencijalnim problemima. Dakle ona nije tek medicinska dijagnoza nego je i socijalna kategorija - instrument nejednakosti. Ona je, podsjeća Byrne, prijetnja društvenoj produktivnosti na dvjema razinama: u jednu je ruku ekonomski problem jer je bolesnik nesposoban za rad, pa je stoga i financijski ovisan o drugima, a u drugu je ugroza nataliteta jer

\footnotetext{
${ }^{104}$ Cerovac ističe da je Leskovara na pisanje novele, isprva zamišljene kao veća cjelina naslovljena Bez nade, bez utjehe, nagnalo upoznavanje siromašnoga učitelja u Kastelu u blizini Krapinskih Toplica: „Ovaj je doista formalno gladovao i bijedno propadao sa svojom obitelji zbog prosjačkog stanja velikog dijela naših učitelja u to vrijeme dok su neki zagorski feudalci (...) imali još na tucete služinčadi i vozili se u četveroprezima s praporcima na konjima i kočijašima u livreji.“ (1969: 205)
} 
se vjerovalo da se prenosi na potomke (2013: 36). I tako nas sve vraća na jednu od temeljnih hipoteza ovoga rada, na činjenicu da je moderno društvo agens svoje vlastite destrukcije: 105

Novela se zato može čitati kao reprezentacija duboke patologije smještene u samoj jezgri te opsesije: zamišljajući i rabeći zdrava tijela kao najjači pogon, građansko društvo postaje direktan izvor bolesti. Ovdje tuberkuloza funkcionira kao katakreza svih devijacija u odnosu na građansko društvo i njegovu ekonomsku logiku, ali i svih strahova buržoazije. (Vuković, 2017: 103)

Dakle u drugim Leskovarovim novelama apstrahirana društvena problematika tu je došla do punoga izražaja. U kontekstu društvenoga razumijevanja tuberkuloze važna je činjenica da je upravo XIX. stoljeće obilježio dvostruki značenjski pristup: s jedne su se strane objeručke prihvaćali tuberkulozni pripadnici viših klasa, s druge su se stigmatizirali „prljavi“ tuberkulozni pripadnici nižih klasa (Lawlor, 2007: 122). Sontag upozorava da se tuberkuloza od posljednjih desetljeća XIX. stoljeća počela smatrati primarno bolešću uboge radničke klase, kad se siromaštvo i svi njegovi nusprodukti počinju dijagnosticirati kao glavni uzroci oboljenja (1978: 15). Kako slično navode Herzlich i Pierret, proleter se u javnom diskursu počeo percipirati kao opasan nositelj bacila tuberkuloze, čime je poljuljano dotadašnje čvrsto uvjerenje da je bolest rezervirana samo za bogate pripadnike elite (1987: 27). Tuberkuloza prerasta upravo u paradigmatsku bolest radničke klase te se sve jače učvršćuje teza da čovjek može oboljeti zbog prekomjernoga fizičkog rada i mizernih životnih okolnosti. Ona postaje fatalnim neprijateljem čovjeka radnika. I zato je posve jasno zbog čega Ljubić skončava u katastrofalnim uvjetima posvemašnje bijede, kojima je prethodila surova realnost u kojoj „nekoliko mjeseci jeli su slabo, prazno varivo, a samo blagdanima mesa, da prištede za odielo i obuću“ (Leskovar, 1997: 43). Kao pripadnik najnižega društvenog sloja, „proleter u pravom smislu te riječi“ (Vuković, 2017: 101), on je ropski trošio i trošio tijelo ne bi li uspio štogod priskrbiti djeci i ženi. To je život kondenziran u nekoliko bitnih rečenica:

Pa ne ubija samo škola. Na blagdane čitav je dan u crkvi: dvie mise, večernja. On je uobće čudnovat, što se za to još i uzrujava. Kad se vrati iz crkve, baca se samo na naslonjač, pa ne može s umornosti i nekakve lude uzrujanosti ni da jede. Pa nije to samo na blagdane!... (Leskovar, 1997: 42)

\footnotetext{
${ }^{105} \mathrm{U}$ pregledu Katherine Byrne tuberkuloza je društvena bolest par excellence: ona je čita kao „metaforu za sve što je pogrešno u 'neprirodnom', kapitalističkom svijetu“ te ujedno kao prijetnju tom istom sustavu (2013: 55).
} 
Prema tome to je tragična sudbina hrvatskoga intelektualca čije je tijelo, slomljeno nemilosrdnom zbiljom, konzumirano do krajnjih granica. Takvo uništeno, potpuno iscrpljeno tijelo ono je iz priče o energiji i zamoru, koji se prepoznaje kao kamen temeljac fizičkih i duševnih oboljenja. Tuberkuloza je deziluzija findesiècleovskoga ekonomskog ideala. U njezinu je prikazu posebno dramatičan opis Ljubićevih ruku koje ,imaju mrtvačku boju, kao da se iz njih izciedila sva krv, pa ostale samo prazne mrtve žile tamno-modre boje“ (ibid.). ${ }^{106}$ Tuberkuloza naime čini tijelo posve transparentnim, osobito u finalnoj fazi svoga razvoja.

Kako bolest napreduje, bolesnik postaje sve mršavijim te se postupno pretvara u kostura: usne su mu razvučene te pritom otkrivaju zube, očne su mu duplje naglašene, a kosti kao da izlaze iz mesa. Hektička se groznica u pravilu pogoršava prema večeri dajući njegovoj koži živahno rumenilo, koje je u snažnom kontrastu s njegovom izblijedjelom i ispijenom pojavom. Modre žile obično se naziru pod očigledno prozirnom kožom. (Lawlor, 2007: 5)

No bolest ne fragmentira samo Ljubićevo fizičko tijelo nego - kao metafora surovoga kapitalističkog sustava koji gazi sve neprilagođene i pomaknute - satire i njegov osobni i profesionalni integritet, radnu etiku, kako bi se ispostavilo kako znanje u takvoj konstelaciji prilika ne vrijedi baš ništa.

(...) on je u toj službi zaboravio već misliti za se i za svoje; njemu su se vječno mele po glavi teorije pedagoga, školski paragrafi, vrt, pčelinjak, ložnjak, zapisnici, izvješća i ono spajanje registara na orguljama, počevši od najsitnijih do onog najkrupnijeg od trideset i dvije stope, pa njihovo prelijevanje u najrazličitijim bojama. (Leskovar, 1997: 49)

Ni uzorna radna odgovornost i robovska poslušnost nije mu mogla pomoći da lakše preživi. Naprotiv, ona je samo potpirila činjenicu da je Ljubić s nepunih trideset godina već izmučen starac u umirućem tijelu: „(...) to bijaše zagrljaj dvoje izmučenih ljudi, bijaše tihi zagrljaj samilosti. Zabavljeni borbom, brigom, nijesu ni opazili, kako ih je siromaštvo ubilo: oborilo ljubav, otrovalo život. Pred njima leži sada samo gotov čin: mrtvo, sve je mrtvo.“ (ibid.: 47)

Međutim u prikazu Ljubićeve sudbine posebno intrigira činjenica da je Leskovar primaran moment socijalne i klasne motivacije uspjelo spojio s njegovom dekadencijom kao

\footnotetext{
${ }^{106}$ Matoš je jedan od prvih kritičara koji je u slikara Miroslava Kraljevića prepoznao ruke kao pokazatelja stanja lika koji snažno pridonosi njegovoj psihologizaciji: „Kao Goya je Kraljević slikarski čarobnik, heiromant, astrolog ruke, čitajući, kao proročka Jeđupka, s ruke tajnu duše svog modela.“"(1973c: 217)
} 
onemoćalosti duha. Vezivanje dekadencije kao slabosti duha i tijela, napose živaca, s tuberkulozom uopće ne treba čuditi: i u njoj naime veliku ulogu igraju baš živci. Devetnaestostoljetna je medicina u opisima tuberkuloze zadržala koncepciju prema kojoj prekomjerno razmišljanje, s pogubnim posljedicama za moždani sustav koji je smatrala jezgrom životne vitalnosti, može rezultirati tuberkulozom. Kako objašnjava Lawlor, već spomenuti liječnik John Brown svojom je teorijom o višku odnosno manjku podražaja uvelike odredio smjer reprezentacije tuberkuloze u europskoj medicini XIX. stoljeća te tako pomogao širenju uvjerenja da intenzivne i nesretne strasti mogu postati okidači bolesti, odnosno da je ona, u nekom svom „najprimitivnijem“ obliku, asteničan poremećaj koji iz pojedinca isisava životnu snagu (2007: 114). Usto William Buchan u priručniku Kućna medicina iz 1772, govoreći o tuberkulozi, upozorava na opasnost od bavljenja mentalnim radom te piše kako ,ništa ne djeluje toliko destruktivno na živce kao intenzivna misao“ (cit. prema ibid.: 120). Prema tome ako se u obzir uzmu navedeni primjeri, zaključuje se da nije riječ samo o disfunkcionalnosti u primanju podražaja nego i o poremećajima u samom umu.

Da bi se uspješno kontekstualizirala povezanost tuberkuloze i živaca, valja shvatiti i mehaniku razvoja medicinskih koncepata o tijelu. Razumijevanje kulta tuberkuloze u XIX. stoljeću posljedica je promjena u medicinskom doživljavanju tijela. U XVIII. se stoljeću, uz prevlast njutnovskoga mehanicističkog modela, razvila „,medicina ’živčane osjetljivosti'““ koja je snažno obilježila i društvene i umjetničke sfere te se transformirala u širi koncept „kulture osjetljivosti“ (ibid.: 44). Tuberkuloza se u tom razvoju u kasnom XIX. stoljeću spojila s neurotičnim poremećajima, osobito s neurastenijom, koja postaje jednom od karika u lancu tuberkuloznoga oboljenja. Pa je u svjetlu ovih tvrdnji shvatljivo zašto Leskovar piše:

Osjeća, kako mu glava gori, kako mu je u moždanima mračno, a napeto, da sve boli. (...) Osjeća, kao da su mu kosti oko očiju bolestne, pa i oči i oni živci u njima, sve se nekud napinje i boli. (1997: 37; isticanje naše)

U Ljubića je dakle tjelesna onemoćalost u potpunosti komplementarna moždanoj iscrpljenosti i duševnoj krhkosti te s razlogom Leskovar umrežuje tuberkulozu kao „fizičku bolest osjetljivosti“ (Lawlor, 2007: 9) s oslabljenim živcima. Uostalom, i Sontag upozorava da, premda se prikazuju i kao energični i strastveni, tuberkulozni bolesnici ipak češće oskudijevaju u vitalnosti, odnosno životnoj energiji (1978: 25). Svojedobno se naime smatralo da je tuberkuloza „patologija energije, bolest volje“ (ibid.: 61-62). Zato možemo pretpostaviti da je Ljubićeva bolest potpomognuta i neurastenijom, odnosno malaksalošću živaca te prirođenom 
sklonošću sjetnomu nespokoju i opterećenošću prošlošću. Jer, vidjeli smo, problemi uma direktno utječu na tijelo. Njegova se bolest može interpretirati i kao fizička posljedica psihičkih problema: ona je oznaka misaonosti i duševne osjetljivosti, rezultat emocionalnoga nemira. Usto za pretpostaviti je da su njegovi živci dodatno izmoreni i pritiscima specifičnih muških dužnosti, prema kojima muškarac privređuje i prehranjuje obitelj. Pored svega možemo se prisjetiti da je prema Schopenhaueru bolesno tijelo metafora slabe volje (1984: 66), odnosno da je, Sontaginim riječima, bolest „volja koja govori kroz tijelo, jezik koji dramatizira ono duševno: oblik samoizražavanja“ (1978: 44). Dakle Ljubićeva je klinička slika upotpunjena teškim životom u materijalnoj bijedi. Posve sumirano, njegova dekadencija, u smislu pretjerane okupiranosti samim sobom, u kombinaciji s društvenim problemima rezultirala je smrtnom bolešću. Tako da je on, uz druge dekadente, ekstreman primjer čovjeka koji nakraju skončava kao žrtva destruktivnoga samopropitivanja. Razumljivo je prema tome da Leskovar Ljubićevu bolest veže uza sklonost evociranju prošlosti i intelektualističkim analizama:

On ćuti, kako se umornost, koja mu već toliko dana pritište moždane, a misli goni u neku nesviestnu tamu, prelieva tamo dolje u ruke i noge. (...) Stade se sjećati prošlosti, no ta je jednostavna, neumoljiva, neutješiva. Čudnovato, zašto li ga neka tajna sila goni, da baš misli na prošlost, pa da se ionako u bolestnu već krv prilije još i neutješivosti i sjete... (1997: 38; isticanje naše)

Uočavamo tu pokušaj rekapituliranja životnih postupaka, toliko svojstven dekadentima, koji aktivno izjeda ionako izmučeno tijelo. Tragovi vlastite prošlosti, u kombinaciji s fatalističkim vjerovanjem u ono „nešto“ izvan čovjeka što upravlja njegovim postojanjem, razaraju mu osobni identitet te ga upravo proganja misao o smrti kao slobodi: „dugo na sve vieke počivati“ (ibid.: 40). Međutim iako se smrt pretpostavlja kao olakšanje, proces umiranja vrlo je potresan te se na kraju novele bolest napokon manifestira u punoj dramatičnosti:

U sobi stoji ona u bijeloj košulji do njegova uzglavlja. Gornjim tijelom visi on iz kreveta, ona ga desnom rukom prihvatila otraga ispod pazuha, a lijevom mu podržava čelo. Na podu je mlaka krvi, zgrušane tamnocrvene krvi. Njezina bijela košulja i bijele noge sve je zaprskano krvlju. Na ormariću gori nemirno svijeća, pa drhturećim svijetlom obasjava cijeli prizor, i njegovo obnemoglo, mrtvo lice, i njene prestrašene crne oči, i onu mlaku krvi i poprskanu košulju i noge... (ibid.: 48) 
Njegovo se tijelo isušuje i kopni dok mu se ,pojačava kašalj kako se pluća polagano raspadaju“ (Lawlor, 2007: 5). Sve napadnije ostaje bez daha, sve očitije gubi kontrolu nad tijelom te pritom nema ni sekunde umirujućega predaha, zadržavajući ipak dokraja compos mentis. A kad govorimo o progresiji bolesti, odnosno o njezinu konačnom kraju u književnim reprezentacijama, zorno je da muškarac i žena ne umiru na isti način. Kako je konstatirao Lawlor, „muška je bolest bila strukturirana prema drugim društvenim i osobnim očekivanjima te prema ideji da su živci u muškaraca drugačiji po stupnju, ako ne i po vrsti, u odnosu na one u žena“ (ibid.: 85). I upravo nam i te činjenice pomažu da shvatimo zbog čega Fran umire u mukama. Dakle osim što tuberkuloza u njegovu slučaju, u smislu društvene reprezentacije bolesti, nije uopće bolest ,ja“, nego se pretvara u bolest drugoga, ona se razvija i kao bolest muškarca. On doista, vidjeli smo, umire ,ružnom smrću“ (ibid.: 87). Umjesto da nakraju doživi produhovljenje, kao što je to najčešće bila praksa u idealiziranim prikazima oboljenja u žena, završava poput životinje. Njegova patnja na samom je kraju sasvim „fizička“, dok u završnim trenucima dana iskašljava krv i u hektičkoj vrućici proživljava svoje posljednje trenutke.

Problem identiteta kao temelja svake dekadencije i dekadencije kao disharmoničnoga raspada cjelovitosti najradikalnije se i najočiglednije u cijelom našem korpusu proza prezentira $\mathrm{u}$ Arsenu Toplaku, protagonistu Isušene kaljuže, Kamovljeva (para)autobiografskoga modernističkog romana obavijena fascinantnom mističnom aurom koja uvijek i nanovo izaziva na nova čitanja. Pisan od 1906. do 1909. te objavljen tek pedesetak godina poslije, roman je ostao bez konteksta i pravodobne recepcije, a potom ga je kritika postavila na same početke hrvatske avangarde.

Upravo će se pitanje izvornog konteksta pokazati ključnim za interpretativna određenja koja počivaju na pretpostavci da iščitavanje značenja književnog teksta nužno zahtijeva naknadnu rekonstrukciju prvotnog recepcijskog okvira. Premda ionako iščezao za kasnija razdoblja, izvorni je kontekst u slučaju Isušene kaljuže već od početka odsutan (...). (Brlek, 2004: 151)

U romanu, koji se i danas može nazvati djelom bez premca, taj se izvorni kontekst i lepeza najrazličitijih značenja gradi na glavnom junaku, tuberkuloznom, osjetljivom intelektualcu izrazito razvijene svijesti i sofisticirane percepcije svijeta. Ostavljajući postrani kompleksnu tematiku identifikacije pripovjedača, glavnoga lika i autora (usp. Brlek, 2004; Biti, 
2005), složit ćemo se s kritikom kad kaže da je u tom izokrenutom Bildungsromanu bolest jedan od glavnih pokretača naracije (Gašparović, 2005: 217). Jer društvo koje pretendira biti zdravo sve svoje „bolesti“ prenosi na pojedinca, kako bi ga zatim ispljunulo iz sebe. Ona je okidač protagonistove autoanalize koja će zamršeno vladati romanom sve do njegova kraja.

Bolest me skupi oko sebe i stadoh studirati sebe. I otkrih bolest ne samo na prsima, nego u mislima, osjećajima, spolu... (...) Bacil u plućima, prevrat u mislima, apsurd u osjećajima, perverzitet u spolu. (Polić Kamov, 2004: 133)

Prema tome sve što u djelu postoji i način na koji se odvija zahvaljuje se upravo bolesti, tuberkulozi kao okosnici koja postaje Arsenovom životnom i pripovjednom strategijom: „Bacil je u njemu, razorni bacil, što se baca blatom na rimu njegovu i ideju njegovu.“ (ibid.: 10) U romanu na neki način sve proizlazi iz nje; pa i metaforički signiran naslov „isušene“ kaljuže može se dovesti u vezu s terminom sušica, u ključu iscrpljenoga, istrošenoga, posve bolesnoga tijela, ali i psihe iscijeđene do samoga kraja. Tjelesnost je kao spiritus movens prisutna od njegova početka, u naturalistički uprizorenim simptomima tuberkuloze u kojima se svjedoči doslovnom otkidanju od sebstva:

U malenoj, ispratoj flašici poslao je Arsen nekoliko pljuvački na analizu svojemu liječniku. On je dobio plućni katar, izbacujući dnevno čitave tucete žutih i punih komada. Arsen ih prispodobljaše koralima i spužvama, tako bijahu izdjelani. A za boju govoraše, da je žuta kao kanarinac ili žganac. (ibid.: 7)

Za tom slikom bolesti Kamov nije trebao predaleko posezati. Ona je naime gotovo arhetipski model prikaza bolesti kao polaganoga propadanja i otkidanja od organa još od XVIII. stoljeća: „Tijelo je bolesnika nagrizeno (isušeno) zbog propadanja krvi i posljedične dekompozicije pluća.“ (Lawlor i Suzuki, 2000: 462) Budući da su bila izvorište urušavanja tijela, pluća se opisuju kao središnje mjesto odbojnoga, smrdljivoga i gadljivoga truljenja. „A valjalo je disati, jer u tome bijaše patnje; valjalo se patiti, u tome bijaše život.“ (Polić Kamov, 2004: 106) Međutim indikativno je da se Kamov bolešću ne koristi kako bi je iscrpno prikazao kao organsko oboljenje, nego kako bi na njoj utemeljio svoj psihologizam kao glavnu oznaku epohe. Polazeći od fenomenologijske distinkcije između živućega tijela (Körper) kao „tjelesnoga“ tijela, njegove fiziološke i neurološke datosti, i subjektivnoga tijela (Leib) kao proživljenoga tijela u smislu iskustvenosti te fizičke strukture u svakidašnjem životu (Aho i 
Aho, 2008: 1), ${ }^{107}$ možemo reći da potreba glavnoga lika da prenese svoje iskustvo ranjenosti proizlazi iz činjenice da drugi njegovo tijelo i ono što proživljava mogu spoznati samo ako se izrazi. Pa u tom svjetlu treba promatrati i Arsenovu potrebu ,piskaranja“ i pripovijedanja. Valja interpretirati vlastito tijelo kao konkretan način življenja. Dakle ako se vratimo na opise otkidanja, fenomenologijskom interpretacijom rečeno, upravo otpaci omogućuju da tjelesno tijelo postupno preraste u proživljeno. Fragmentacija je nužna da bi se živjelo. To nas i potiče da utvrdimo da u Arsenovu slučaju tuberkuloza postaje bolest vlastitoga ,ja“, onako kako to tumače Sontag (1978: 68) te Lawlor i Suzuki (2000). ${ }^{108}$ Arsen bolest, nasljedujući osamnaestostoljetno viđenje tuberkuloze kao unutarnjega ukrasa, doista pounutruje, čini je dijelom sebe - ona iz njega progovara dajući mu pravo glasa. „Bolest je stala postajati nešto intimna, unutarnja, nešto sasma osobna u familiji, nešto posve familijarna u domovini i nešto sasma narodna u tuđini.“ (Polić Kamov, 2004: 186) Pretvara se u integralni dio njegove osobnosti te on, paradoksalno, ali opet posve karakteristično, iz nje izvlači samo ono najbolje. Prema tome transformirajući bolest u nov način odnošenja protagonista prema samom sebi, Kamov preuzima uvriježene slike o tuberkulozi kao „dezintegraciji, grozničavosti, dematerijalizaciji“ (Sontag, 1978: 13) te u isti tren krajnje jedinstveno reinterpretira njezin mit.

I zato se može reći da je Toplak dvostruko bolestan. S jedne je strane tuberkuloza, a s druge dekadentna svijest o dezintegriranom sebstvu, nejasnom identitetu u vremenima poljuljanih standarda, svijest koju građansko društvo, s obzirom na to da dovodi u pitanje njegove temelje, svim silama nastoji zatomiti. Prelazeći iz ograničene sfere fizičkoga, bolest napreduje u duhovnost, moralnost i društvenost. Transformacija organizma pokrenula je transformaciju duha. Organska je bolest simbolika Arsenove dekadencije, ona mu oduzima sklad misli, otima sabranost i identitetsku harmoniju. No nužna je da bi se revitalizirao duh. Odnosno, treba razgraditi kako bi se razdvojeno spojilo, razgrađeno obnovilo. „Isušivanje“ psihe, koja se odvija kroz kompletan roman kako bi veličanstveno doživjela vrhunac u ,širini“ i ,visini“, pokušaj je duševne i tjelesne revitalizacije jer „samo pogubna razgradnja omogućuje spasonosno obnavljanje onoga što je razgrađeno“ (Biti, 2005: 35). Hektička stanja koja mu pruža bolesno tijelo osiguravaju umjetničko nadahnuće i usmjeravaju

\footnotetext{
${ }^{107}$ Iz te dihotomije Kevin i James Aho izvode i razliku između engleskih termina disease i illness, koje pak u hrvatskom jeziku nema: dok se disease odnosi na organsku patologiju te se ukorjenjuje u biologiji, illness je na neki način proživljeno iskustvo bolesti smješteno „u glavi“ (2008: 3).

${ }^{108}$ Nastojeći pronaći točku nakon koje se može govoriti o tuberkulozi kao o oboljenju vlastitoga sebstva, a ne o oboljenju drugoga, Lawlor i Suzuki tumače da se u XVIII. stoljeću pojavljuje taj posve novi element u kulturi tuberkuloze u odnosu na identitet bolesnika: estetizacija, koja joj je omogućila da se transformira u bolest vlastitoga ,ja“ (2000: 461). Ona otad postaje izvorom vrijednosti, kapitalom koji osigurava prestiž, signalom genijalnosti i tankoćutnosti. Premda se estetizacija tuberkuloze odvijala u skladu s klasnim i rodnim normama (ibid.: 476), može se reći da se stvorio generalni obrazac prema kojem se barem djelomice razumijevala kao blagotvorna za sebstvo.
} 
u pokušaju konstruiranja vlastitoga ,ja“. Bolest je oznaka nadmoćnosti intelekta jer kako ona napreduje, tako raste razina misaonosti i pronicljive percepcije svijeta. Širi vidike i utječe na kompleksnost svijesti:

Tolikoga bogatstva misli i riječi prije ne imađaše. Ali što je glavno, sad je mogao tek s pravom nasladom misliti. „Čudnovato. Što slabiji, to jači. A vele: zdrav duh u zdravom tijelu.“ (Polić Kamov, 2004: 20; isticanje naše)

Uostalom, kao što potvrđuje i Žmegač, postojala je tajna veza između tuberkuloze i određenih aspekata književnosti jer se tuberkulozi „,pripisivala stanovita mentalno obilježena narav, gotovo osobit duh, koji je na skrovit način odgovarao sveukupnom duhu bolećive senzibilnosti, umjetničkom biljegu razdoblja“ (2001a: 56). A prihvatimo li Milanjinu (1981: 466) i Machiedovu (1986: 35) procjenu o trodijelnoj strukturi romana kao danteovskim etapama „čišćenja“, možemo reći da bolest preuzima ulogu vođe u putovanju glavnoga lika kroza spoznaju vlastitoga identiteta. Naime kako će utvrditi Kamov, Arsenov se govor o sebi poklopio upravo s bolešću: sve dok se nije razbolio, „o sebi ne govoraše nikada“ (2004: 12). Književnim pokušajima razasutima po cijelom romanu i autodijegezom u njegovu drugom i trećem dijelu bolest iz objekta priče prerasta u subjekt - tijelo postaje tekst, način Arsenova bivanja u svijetu. Arsen najbolje prezentira kako je njegovo tijelo njegova priča, u kontekstu Frankove teorije o „ranjenom“, tj. bolesnom pripovjedaču. Kao što Frank pojašnjava, ozbiljna je bolest „gubitak 'odredišta i karte' koja je prethodno usmjeravala život bolesnoga čovjeka: bolesni ljudi moraju naučiti 'razmišljati drukčije'“ (1995: 1). A oni uče slušajući se kako pričaju priču o sebi i svom tijelu, upijajući reakcije drugih te iskušavajući na koji način njihova priča cirkulira. Tako glavnoga junaka kao pripovjedača profilira upravo njegova bolest; ona nije samo predmet njegove priče nego i njezina legitimacija. Drukčije rečeno, to nije samo priča o njegovoj bolesti: to je priča koja se odvija kroz bolesno tijelo. Dakle pripovijedanje o bolesti u svim se trima dijelovima razumijeva kao svjedočanstvo, koje započinje (fizičkom) patnjom koja pak potom shvaća samu sebe upravo slušajući to svjedočanstvo. Ono je pokušaj da se da glas iskustvu koje medicina ne može opisati: „Ljudi koji pričaju priče o bolesti ne opisuju tek svoja bolesna tijela; tijela njihovim pričama daju jedinstven oblik i smjer.“ (ibid.: 27) I zato je shvatljivo zbog čega se Arsenova priča odvija tako kako se odvija. Njegovo zazorno, disfunkcionalno tijelo govori istinu koja izlazi iz ranjivosti, iz jaspersovskih graničnih situacija koje čovjeka guraju u očaj, ali mu istovremeno omogućuju da osjeti istinsku slobodu izbora. Arsen balansira između biološke i kulturne perspektive bolesti kako bi priznao da smo naposljetku biološki utemeljeni 
u tijelu te da tu biologiju izražavamo kroz pripovijedanje, tj. kroz jezik. Reprezentacija oboljenja, odnosno pripovijedanje o njemu nije dodatna vrijednost iskustvu o bolesti i zdravlju nego temeljna (Morris prema Lawlor, 2007: 4).

Dakle bolest se pokazuje i kao izvrsna pripovjedna strategija jer se kaos tijela prenosi na organizaciju teksta te destruira klasično romaneskno pripovijedanje. Otuda, među ostalim, proizlazi jednoglasna ocjena kritike da je Kamov na taj način prekinuo sve spone „sa šenoinskom literarnom tradicijom“ (Nemec, 1998: 61), uvidjevši da je i harmoničnost diskursa sastavni dio književnoga kanona. Naraciju razlama različitim asocijacijama, refleksijama, esejističkim i feljtonskim odlomcima, tablicama, Arsenovim literarnim pokušajima i snovima, „potičući 'vječno vraćanje' i neočekivano 'daljinsko' priključivanje već zaboravljenih fabularnih segmenata“ (Biti, 2005: 33) te slijepo slijedeći Arsenovu devizu da pisati valja „onako, kako se je živjelo“ (Polić Kamov, 2004: 240). Govoreći o takvom neskladnom, kaotičnom diskursu kao ne-pripovijedanju, Frank će poentirati:

Kaos je suprotan obnovi: njegova radnja zamišlja život koji nikad neće biti bolji. Priče su kaotične u odsustvu narativnoga reda, a događaji se pripovijedaju onako kako pripovjedač iskušava život: bez reda i jasne uzročnosti. Nedostatak koherencije jest prvi razlog zbog kojega je kaotične priče teško slušati; ne čini se da pripovjedač uopće priča „pravu“ priču. No što je još bitnije, doima se da pripovjedač te kaotične priče uopće ne živi „pravi“ život jer, u životu kao i u priči, jedan događaj slijedi drugi. Kaos upravo negira to očekivanje. (1995: 97)

Bolest je uza sve to pokretna sila Arsenovih putovanja. I doslovnih, tj. prostornih, $\mathrm{i}$ prenesenih: temporalnih, u kojima se ponire u fragmente sjećanja, i duševnih, u kojima se ponire u vlastite dubine. Terapija putovanjem i promjenom zraka, dominantna od XVIII. stoljeća pa nadalje, može se tumačiti kao kapitalizacija „kulture narcističke dramaturgije koja se stvorila oko bolesti“" (Lawlor i Suzuki, 2000: 470), a postupan razvoj konzumerističkoga društva pridonio je porastu toga medicinskog turizma, naročito na Mediteranu. Prije nego što se bolest $u$ potpunosti zatvorila $u$ sanatorije, vjerovalo se da će tuberkuloznim pacijentima $u$ izlječenju ili usporavanju progresije bolesti pomoći putovanje koje se doživljavalo kao neka vrsta apoteoze života i avanture. Na istom tragu i Arsen putuje u Italiju ne bi li se pokušao izliječiti boemskim skitnjama (Sontag, 1978: 32-33) i izmještenjem iz domovine. „Italija i njezine kulturne atrakcije bile su u zraku, u pravom fizičkom smislu. Drugim riječima, putnik je Italiju osjećao sa svim njezinim sadašnjim privlačnostima i slavnom prošlošću kroz respiratorne senzacije, udišući atmosferu kao da će se asimilirati sa zrakom“ (Lawlor i Suzuki, 
2000: 473). I dok balansira između elitnih kulturnih vrijednosti, rezerviranih za pripadnike više klase, te svakidašnje alkoholne besvjestice i financijske oskudice koja ga prisiljava da kulturu konzumira poderanih hlača i prazna želuca, ulazi u dubine svoga ,ja“ te otkriva da se bolest potencira u tuđini.

Prebacivši se u subjektivni modus, Arsen pripovjedač minuciozno analizira vlastito sebstvo, izravno se referirajući na tu činjenicu i opaskom o snažnoj interiorizaciji bolesti kroza simboliku smrada, čestu u imaginariju tuberkuloze (dah se tuberkuloznoga bolesnika naime opisivao kao smrdljiv i „gnjio“), kao posljedice raspadanja tijela i duha:

Ne iznašam druge; pišem o sebi. Zato će sve ovo izići nepotpuno i neizdjelano. Meni dapače ponestaje, da tako kažem terena, jer odlučih pisati samo o sebi. A tu je bilo prigode osvjetljavati sebe u drugome, ogledavati svoje oči u očima drugoga. (...) Sve ono mrsko, bijedno i prezreno, što autoanalizom konstatovah u svojoj prošlosti, stadoh osjećati u manjoj snazi i količini sada u odnosu s čovjekom i ljudima. Smrad je bio jači, jer je bio bliži... (Polić Kamov, 2004: 279; isticanje naše)

Prema tome Arsen je bolestan „na dnu“ te se strmoglavljuje u široki bezdan svoje psihe, koja je ,praznina puna tereta; tišina puna žamora“ (ibid.: 327), gdje uviđa da nije „,bolest uvjet individualnosti“ (ibid.: 133), nego da je, posve suprotno, individualnost uvjet bolesti. Ona se pak u romanu ,preobražava u razne oblike - tuberkuloza, alkoholizam, oteklina na ruci, kvrgava izraslina na vratu - mjestimice se gubi do zaborava pa opet vraća, no najvažniji je svakako njen postupan pomak u duševnu sferu“ (2005: 215), kako procjenjuje Gašparović. Naime nakon što je spoznao da ne može nadvladati vlastito tijelo, tjelesnost se intenzivno prepleće s duševnim nemirima jer, kao što je istaknuto u uvodu, ,psihologija počinje tamo, gdje zdravlje prestaje“ (Polić Kamov, 2004: 145). A kako bi pokazao na koji način živjeti s ranjenim tijelom i duhom, Arsen se obrušava na čitav niz ustaljenih dogmi, prezentirajući protugrađanski revolt na svim mogućim razinama te promičući pritom ničeansku misao o nužnosti prevrednovanja svih zatečenih struktura: obitelji, doma, domovine, ljubavi, seksualnosti, religije, kulturne, književne i umjetničke tradicije. Kroz njegovo bolesno tijelo rasipa se i stara slika svijeta koja je, pokazali smo, počivala na dvama sustavima koji su podjednako nagrizali čovjeka: na metafizici, koja mu je oduzela individualnost, spontanost i autentičnost, te na znanosti, koja je inzistirala na objektivističkom principu svijeta. Zato u Arsena bolest preuzima presudnu ulogu u urušavanju uvriježenih modela egzistencije. Ona je dakle društveno snažno provokativna te daje opravdanje za propitivanje i destruiranje poznatoga i priznatoga svijeta. Arsen prilično 
inteligentno prepoznaje moć zazornoga, u smislu svega što ugrožava postojeći poredak, i zato ga prisvaja kao način ponašanja i djelovanja. Pa kao što i etimologija termina (od latinskoga tūberkulum, što znači oteklina, kvržica) sugerira neprirodan, morbidan rast (Sontag, 1978: 10), tako i glavni lik raste poput abnormalne izrasline na tijelu društva. Tuberkuloza je stoga, na tragu opaske da ,,izolira pojedinca iz društva“ (ibid.: 38), metafora za otuđenje - jer „on već nije pristupačan društvu“ (Polić Kamov, 2004: 10) - ali istovremeno i za buđenje osjetila:

Bolest ga povuče u se, jer ona ga odijeli od svijeta. Bolest ga baci u rasuđivanje, jer njihov organizam imadijaše u sebi nešto, što površina ne da. I cinik lakoumnik postane razumni osjećajnik, budući otac vječni momak, ne plaćajući poreza speciesu; bespravan, ali i bezobziran, van zakona - slobodan. (ibid.: 67)

Ona, sad je i više nego razvidno, nije samo fizičko stanje tijela već ima niz ideoloških, političkih, društvenih i kulturnih implikacija. Poticaj da se napokon prizna da je sve lažno, da ideali (više) ne postoje. Zato je i u kontekstu oboljenja i u kontekstu zastupanja apsolutne slobode protagonist zazoran subjekt koji narušava ustaljene paradigme kako bi ukazao na hipokriziju građanskoga društva, a njegovo oboljenje „metafora nesigurnosti koja se pojavljuje na razmeđu muškosti i ženskosti, normalnosti i perverzije, domaćega i tuđega, kapitalističkoga i proleterskoga u građanskom društvu“(Vuković, 2017: 106). I zbog toga se Arsen kontinuirano razračunava s društvom koje ga je prognalo na „boemsku periferiju“ te pritom „,nametnutu zbiljsku izdvojenost kompenzira odabranom izdvojenošću“" (Lugarić, 2006: 205). Osim što ga otuđuje jer je gadljiv, zastrašujući, bolest ga alijenira jer ga tjera da se okrene samomu sebi kako bi napokon otkrio da su duša i tijelo beskrajan prostor u kojem se ,ja“ i drugi proždiru da bi zajedno supostojali. „Ovo je bolest, što osamljuje čovjeka, odstranjuje iz društva i posvećuje samome sebi.“ (Polić Kamov, 2004: 10) Preostaje mu da bude sam, što mu daje dodatnu legitimaciju za narcističko njegovanje ličnosti. Zapravo mu je upravo ona omogućila slobodu jer je društvu služio sve ,dok nije došla tuberkuloza i denuncijantski izdala sve tajne, namjere i ciljeve gospodara, mecene i dobrotvora. Ko da mu govoraše: 'Ti daješ više no što primaš. Društvo hoće od tebe 'kastraciju' poput vlasnika sikstinske kapele, koji obećavaju pjevačima raj'“ (ibid.: 151).

Iako se neograničena sloboda kojoj Toplak neprestano teži najneposrednije očituje u slobodi tjelesnosti (bludu, tj. perverziji), njegova je žudnja za nesputanošću i neovisnošću puno šira kategorija: ona je žudnja za političkom i ideološkom slobodom, u smislu oslobađanja od ikakvih autoriteta; društvenom slobodom, u smislu oslobađanja od normi prihvatljivoga 
ponašanja; obiteljskom, ljubavnom i seksualnom slobodom, u smislu oslobađanja od građanski prihvatljivih oblika suživota i emocionalnih veza. Ona doista implicira krajnje solipsističko, narcisoidno shvaćanje individualiteta. Arsen zapravo sve institucije kojima je inherentna namjera oblikovanja pojedinaca $u$ podložne individue radikalno osporava te, neurotično potkopavajući svijet kojega je dio i na svjetonazorskoj i na idejnoj razini, nastoji odbaciti identitet stečen rođenjem, nametnut i osiguran zakonom. Otud anarhistička potreba da si destabilizacijom svih vrsta normi pronađe novi:

- Koliko sam puta poželio da sam nezakonito dijete, da ne nosim zakon od poroda na sebi! Gnječi me zakonitost svojom antipatijom! Da mi je mutan izvor, da nemam nikakvih veza, da je prošlost crna ko duša. Crna ko duša... Onda bih bio slobodan u toj zemlji... (ibid.: 30)

Njegova težnja za kontinuiranom i dosljednom negacijom, odnosno za oskvrnućem svih kanona, čime automatski postaje zazorno drugo, potječe ponajprije od činjenice da mora odbaciti drugo u sebi da bi se sam afirmirao. Zato je on permanentno destabilizirani identitet, permanentno disfunkcionalno tijelo. Svjesno se ni na koji način ne ukorjenjujući, posve je suvišan društvu od kojega se i sam toliko želi odijeliti. On je jalov višak koji mu ni na koji način ne pridonosi i zato mu je neprihvatljiv: „(...) traže se ruke, treznoća i razbor - a ja sam tjelesno melanholik, intelektualno lump i... psihološki spekulant““ (ibid.: 159). No kulturni projekt prevladavanja primitivne patologije $u$ drugom dijelu romana raspršit će tu iluziju da je „ja“ stvoreno na negaciji drugoga. Drugo se vraća, i to osobito dok Arsen boravi u tuđini, kao trajna čežnja, ,poricana i žuđena razlika“ (Grossberg prema Lugarić, 2006: 206). Jer, kao što smo utvrdili u jednom od poglavlja, pojedinačni se identitet uspostavlja kroza složene odnose s ,ne-ja“:

Dok sam bio ljubavnik, patriota, brat, sin i mislilac - bio sam psovač. Kletva je bila moja domovina, moj odgoj, moj život, moj karakter, moj temperamenat, moja ideja: moja volja i snaga. Ona je bila moj ,ja“. Smiješak nije moj. A ipak to sam ja! Jer ja nisam ni ljubavnik ni brat ni patriota ni mislilac - ni život ni karakter ni temperament... ni volja... Ja t. j. nisam ja. (Polić Kamov, 2004: 345)

Rascjep je pojedinca i društva već u njegovoj unutrašnjosti, baš kao i bacil kojim je zaražen. I zato glavni junak identitet ne može uspostaviti ,poniranjem ka $d n u$ radi istrebljenja drugoga u sebi, već jedino izvlačenjem prema van, $u$ šir, radi pronalaska sebe u drugome “ (Biti, 
2005: 45). No pronalazak sebe u drugome ipak će se izjaloviti jer pokušaj socijalizacije implicira gubitak sebe. Modernistička opsjednutost individualizmom i agresivno nastojanje da se on suzbije čita se zato kao pokušaj nadvladavanja dekadencije kulturom, kao zahtjev da se odustane od vlastitoga ,ja“ uklapanjem u masu i postajanjem dijelom cjeline, što će Arsena navesti da neurotično podvrgavanje kulturi poveže s gubitkom karaktera i čovječnosti:

Moje se biće stade iz temelja mijenjati, izvraćati, revolucionirati; ja se najposlije oslobodih i posljednje dogme: života samoga kao dogodovština, iskustvo, borba i osjećaj. I ja sam potpunoma napustio afirmaciju moga individualizma u mome životu... Stao sam živjeti kao filistar, ili bar nastojao živjeti. Uobičajenost i jednostavnost i nehote istisne s mene sve one posebne, individualne oznake nošnje i ponašanja. Uživah gotovo u tome: biti jednak svim tim ljudima, s kojima me ništa ne veže i s kojima ništa ne dijelim i od kojih sam tako drukčiji, dalek i osebit. Ošišah se i nastojah uporno biti uredna života i odijevanja - odstraniti od sebe sve ono, što udara u oči i izaziva. Sveopća beskarakternost učini me skromnim, tihim i plahim; u debatama i prepirkama postah obziran, pristojan i uslužan; toleransa me obujmi dobrodušnošću, smješkanjem, i trbuh mi stane rasti. (...) Stadoh gubiti jednom riječju vanjske karakteristike svoga ja - postadoh beskarakteran: izgubih najprije za sebe život, onda stadoh gubiti sebe u životu. (Polić Kamov, 2004: 292-293; isticanje naše)

Dakle kad Arsen preuzme pripovjedačevu palicu u drugom i trećem dijelu, ispostavit će se da je svaka spoznaja, odnosno nadgradnja ubila djelovanje. Zato se identitetsko raslojavanje - iskustvo nasuprot umjetnosti, instinkt nasuprot kulturi, norma nasuprot slobodi, individualno nasuprot kolektivnomu - postavlja kao glavni problem, ne samo ovoga romana nego i cjelokupna Kamovljeva opusa: „Jedamput sam mogao i ono, što nisam htio. Bio sam onda život, osjećaj. Onda sam htio i ono, što nisam mogao. Bio sam tada uzrujanost i um. Sada niti što hoću niti što mogu. Sad sam zaborav i duh.“ (ibid.: 343)

Naime kad na jednom mjestu počne okupljati vlastito iskustvo i sve proživljeno, uvidjet će da je, cijeloga života prekoračujući granice dopuštenoga te podrivajući temelje na kojima se jedna „zdrava“ zajednica gradi, zapeo u procjepu između prirode i kulture, psihoze i neuroze. On je zapravo puno prije kraja romana, dok je još životario u glibu svoje kaljuže, sugerirao da je svaki pokušaj nadvladavanja sebe i načela ugode kojim se vodio osuđen na propast:

Pričini mi se tada, da sam došao do svrhe, kulminacije života: da sam doživio svoj život. Jer nikada ne saznah, mišljah, ništa novijega i većega. Izdrljah pjesmu i ona je ostala na papiru ko testament. Uhvati me turobnost: sve sam rekao i više nemam što reći. Svršio sam. I 
samoubojstvo postajaše razumljivo: sve će odsada da bude beskorisno i suvišno. Sve. (ibid.: 96; isticanje naše)

Hvatanje ukoštac s tabuiziranim poljima ljudskoga iskustva i djelovanja najočitije je u području seksualnosti koje se, ako se složimo sa Sontag, također može dovesti u vezu s bolešću. U jednu se ruku ,vjerovalo da tuberkuloza djeluje poput afrodizijaka te da bolesniku daje osobitu moć zavođenja“ (Sontag, 1978: 13), dok se u drugu tumačila kao rezultat zapriječenoga libida, odnosno seksualne frustracije. S obzirom na to da bi pitanje seksualnosti valjalo prešutjeti jer je njezina jedina prihvatljiva forma ona koja se odvija skrivena od pogleda drugih te vodi prokreaciji, sasvim je evidentno zašto Kamovljevo odnosno Arsenovo inzistiranje na seksusu izaziva sablazan. Problematiziranje vlastite seksualnosti, osobito kroz različite forme perverzije kao devijacije od „normalnih“, dopuštenih oblika seksualnoga ponašanja, pokušaj je da se tjelesnošću isprovocira okolina i tako nadvladaju ograničenja. Vratimo li se pak degenerativizmu iz prvoga dijela rada, možemo utvrditi da je perverzija najopasnija forma unutarnje dezintegracije. Opasna je, tumači Dollimore, zbog toga što ju je, paradoksalno, omogućio evolucijski proces koji je moralnost morala proći te je zato bila kodirana kao oblik regresije koji signalizira povratak instinktivnim i nekontroliranim libidnim silama (2001: 135). Kratko rečeno, seksualna se perverzija, izjednačena s primitivnim i atavističkim, shvaćala kao forma degeneracije. ${ }^{109}$

I zbog svega je toga Arsen, stalno rascijepljen između načela ugode i načela stvarnosti, prototip neurotičnoga subjekta. Neuroza je naime prema Lacanu upravo posljedica tjeskobne rascijepljenosti subjekta, a mentalno je zdravlje ,iluzoran ideal cjelovitosti koji se nikad ne može postići jer je subjekt uvijek nužno rascijepljen“ (prema Evans, 1996: 126). Ona je stoga sasvim normalna struktura. I zato Lacan, dok je Freud promatra kao bolest koja se može izliječiti, neurozu drži strukturom koja se ne može promijeniti (ibid.). A složenosti Arsenove neuroze najbolje svjedoči činjenica, ,što je nesvjesno do te mjere potisnuto da ne uspijeva (for better or for worse) izvršiti proboj preko ustaljenih mentalnih okvira neurotskog, mislećeg, autoanalitičkog, introspektivnog subjekta“ (Matijašević, 2008: 236-237). I upravo se u tome krije jedan od temeljnih uzroka neuspjeha njezina izlječenja kroz pripovijedanje o samom sebi, odnosno kroz pokušaj ovladavanja bolešću pisanjem: to je „strategija zmije koja pokušava uhvatiti vlastiti rep“ (ibid.: 237). Arsen je posve svjestan negativnoga ishoda svoga nauma, no to ga ne priječi da u njemu ustraje sve dokraja:

\footnotetext{
${ }^{109}$ Za Freuda i Lacana perverzija je upravo negativ neuroze kojom se pojedinac bori protiv neurotskih nagona
} (prema Evans, 1996: 142). 
Kako da dođem radi studija do salona, ako sam literata? Lektirom. Kako da dođem do bolnice, ako sam literata? Bolešću. Kako da dođem do tamnice, ako sam literata? Zločinom. Kako da dođem do ludnice, ako sam literata? Ludošću. T. j. --autoanalizom. (Polić Kamov, 2004: 312; isticanje naše)

I njegova detaljna dihotomija psihoze - seksualna hiperestezija, osjećaji, aktivnost, hiperbulija, meso, pijanstvo, ljudi, manija, „nabujalo srce“ - i neuroze - seksualna anestezija, osjetljivost, pasivnost, abulija, kostur, trijeznost, osama, fobija, ,istančani nervi“ (ibid.: 306307) - izrijekom priziva opoziciju prirode, necivilizacijskoga, emocionalnoga, nagonskoga i kulture, društvenoga, civilizacijskoga. ${ }^{110}$ Arsen zaista izvrsno prezentira Freudovu naslovnu sintagmu ,nelagode u kulturi“ te najbolje svjedoči na koji način „naša takozvana kultura snosi veliki dio krivice za našu bedu“ (Frojd, 1970: 290). Takva kultura od pojedinca zahtijeva poštivanje imperativa, civilizacijskih postavki na kojima je izgrađena, napose ljepote, reda i čistoće te uređenih međuljudskih odnosa (ibid.: 298-299), a Arsen i svojim ponašanjem i pripovjednom strukturom svoje životne priče ima potrebu pružiti im otpor. Kultura je dakle veliko drugo koje pojedinac ni na koji način ne može sebi prilagoditi te se s tjeskobnom mukom odriče svojih žudnji. I nakraju se pokazuje da je individualnost najobičniji teret. Kulturi pripada sve što pojedinca ograničava i zbog čega on pati, ali ona istovremeno ima sve čime se taj isti pojedinac može zaštititi (ibid.). Njegova je neuroza prema tome neodvojiva od fizičkoga i društvenoga iskustva. Tako da možemo sa Žmegačem istaknuti da se „impotensa“, znakovit pojam Arsenova života, ne odnosi samo na seksus (2001a: 58). Ona konotira i generalnu nesposobnost i nemoć intelektualca da si u društvu pronađe djelotvornu ulogu, ulogu koja bi zadovoljila i njega i društvo.

I doista, dok histerično balansira između egzistiranja u takvoj kulturnoj i društvenoj stvarnosti i otpora toj istoj stvarnosti, Arsenov kjerkegardovski „ili-ili““ ostaje nerazriješen, tj. trajno utemeljen u navedenom sukobu. Analiza koja je završila bez sinteze. Pisanje koje je završilo činjenicom da pojedinac ne može uspostaviti svijet; ne može naime uspostaviti ni vlastito ,ja“ (usp. Pająk, 2005). Cjelovitost je pojedinca puka fikcija. „Jer ja - nisam ja!“ (Polić Kamov, 2004: 345), opsesivno će ponavljati. Sve se perspektive u konačnici sažimaju u njegovu razarajućem djelovanju: pokušaj nadvladavanja prirode i instinkta kroz umjetničku sublimaciju

\footnotetext{
${ }^{110}$ Matijašević naglašava kako Arsenova shema vrlo precizno, točno i iscrpno ocrtava ta dva oboljenja: ona „priziva temelje Freudove antipsihijatrijske revolucije, psihoanalitičku reviziju neuroza i psihoza, zatim objašnjenje psihičkog preko različitih temperamenata koji uzrokuju, u konačnici, da su svi poremećaji, grosso modo, svodivi na dva tipa koja od sedamnaestog stoljeća predstavljaju - manija i melankolija, a u Toplakovoj verziji to su - manija i fobija“" $(2008: 240)$.
} 
plaća raspadom tjelesnosti, a nastojanje da u svemu tome spozna sebe završnim odricanjem od ikakvoga identiteta i mogućnosti identifikacije.

Naš je život čik; bio je jedamput cigara... I tinja... Sav je žut, ižvakan, zaslinjen... I to je moja duša! Već godine i godine autoanalize: utežem, sišem, gnječim, griskam, palim i pripaljujem... (...) I sve je otišlo u dim; i pepeo: dim se je izgubio u zraku, pepeo je raznio vjetar širom svijeta. Kod mene je ostao čik, da se baci u - smetište. (ibid.: 324)

Lišavajući se vlastite tjelesnosti, s kojom je sve i započelo, svega materijalnoga, zakona prostora i vremena, puštajući da apsolutno sve nestane u dimu cigare, Arsen ostaje zarobljen u procesu kontinuiranoga stjecanja identiteta, ideala koji se nikad ne može dosegnuti. „Nestaje me. Ja sam bijel ko prašina, ne oblak. Sâm sam se zdrobio i sada pitam: ko me je ubio? Jer ja sam mrtav. Ne mogu da mislim. (...) Mozak je prašina; nervi vjetar. Ideje nema. Gotov sam." (ibid.: 338)

Njegov je kraj kao svijest o nemogućnosti fiksiranja identiteta moguće povezati i s njegovim romanesknim početkom, odnosno izravno s bolešću kojom je sve i započelo. Naime bolest funkcionira kao radikalan prekid, otvara jaz između „nekad“ i „sad“, između identiteta „prije“ i identiteta ,poslije“. Ona, nastojali smo prikazati, uključuje specifičan oblik alijenacije, ne samo od društva nego i od samoga sebe i svoga tijela, kako će se nakraju pokazati i u Arsenovu slučaju. Jer spoznaja o bolesti urušava subjektovu sliku o sebi i temelje njegova sebstva, u smislu onoga „tko sam nekad bio“ (usp. Rimmon-Kenan, 2002). I zato se identitet nikad ne može uspostaviti: pojedinac ostaje vječno rastrgan između onoga što je bio prije i onoga što je postao u bolesti.

Ostaje nam nakon svega direktno poentirati da je Arsen - iako je donekle aktivniji i energičniji od ostalih dekadentnih likova, a problematika u središtu romana iznimno kompleksna i puno slojevitija u odnosu na druge proze - zapravo tipičan dekadent. Osobito po svojoj introspekciji, sklonosti radikalnomu propitivanju svijeta i uloge pojedinca u njemu te svijesti o rascijepljenosti pojedinačne egzistencije u vremenu nestabilnih vrijednosti. I on, poput Borislavića, Lovre i Šegote, proživljava obrat iz fanatične religioznosti, u kojoj se prepliću slike dobroga vjernika i dobroga Hrvata, u ekstatičan ateizam. Taj obrat međutim u romanu nema onu težinu koju ima u drugim prozama, u kojima neposredno djeluje na rađanje tjeskobe koja potom preplavljuje protagonista, te se temelji ponajprije na Arsenovoj generalnoj želji rušenja bilo kakvoga autoriteta: 
S mene je već izvaljena jedna gromada predsuda, praznovjerja i mračnosti. I čini mi se, da je to jedino, što me je tištilo i omrčivalo čađom i dimom svijetli uspon i let misli... Meni laska, što sam bezvjerac, ateista i heretik. (Polić Kamov, 2004: 231)

Usto susrećemo i u njega karakterističnu, iznimno sofisticirano izvedenu opterećenost sindromom prošlosti. Isušena kaljuža naime vrvi fragmentima sjećanja, rekapitulacijama pojedinosti iz Arsenova života, koje ipak nikad nisu dokraja izvedene, nego se predočavaju kao odlomci kojima valja sastaviti cjelinu. I zato se teško ne pridružiti Bitiju kad kaže da ga sve dosad istaknuto čini ,tipičnim modernističkim junakom, svijesti toliko prenadražene dramatičnim rubnim stanjima da gubi sposobnost kontrolirana povezivanja svojih dojmova podliježući njihovu opsesivno opetovanu napljavljivanju. Prošlost mu se nadvija nad sadašnjost poput nerazriješene traume“ (2005: 32). Osim toga on izrazito teško ili gotovo uopće ne uspostavlja interpersonalne odnose, što je u uskoj vezi s problematikom drugoga o kojoj je bilo riječi. Naime uspostaviti odnos značilo bi prihvatiti drugoga kao sebi jednakoga i ravnopravnoga, što u potpunosti odudara od onoga što jedna narcistička ličnost može prihvatiti. U konstataciji kako je narcis onaj „koji se podsmijava obitelji, koji odbacuje patrijarhalni autoritet“" (Žižek, 1986: 310) vrlo je lako prepoznati Arsena te ga pritom poistovjetiti sa Žižekovom idejom borderlinea, tj. graničnoga poremećaja kao korelata patološkoga narcizma. A to pak ide u prilog tezi o Arsenovoj rascijepljenosti između neuroze i psihoze: s jedne strane nalazimo „’'suviše prilagođenog' histerika koji se previše identificira s društvenim zakonom“, koji mu se kroz potiskivanje vraća u nizu simptoma, a s druge ,'neprilagođenog psihotika' koji se isključio iz (socio-simboličke) realnosti““ (ibid.: 311). Njegov se život tako odvija u balansu između egzistiranja u stvarnosti i ekscesivnoga protivljenja toj stvarnosti.

Zato Toplak u nekoj mjeri radikalizira sve što smo istaknuli kao glavne karakteristike dekadentnih likova, pa i postavku da sačuvati egzistenciju znači sačuvati pojedinačnost, individualnost, nezajedništvo. I to nam, među ostalim, omogućuje da roman, odnosno njegov glavni lik promatramo kao paradigmatski primjer dekadencije kao raspada cjeline, nečega što je svojedobno bilo jedinstveno:

Arsen ležaše bez pravca. Bijaše to razmrskani organizam, kup dijelova porušene cjeline. I kad ga pridigoše, moradoše ga pridržati. Kad je htio isprati lice, moradoše mu podići ruku. Jer svi ovi dijelovi, što sastavljahu nekad cjelinu, čovjeka, biće, bijahu sad svoji, rastavljeni, atomizirani. Zato je Nikšić zadrhtao. Zato se je zgrozio. Zgrozio se pred prevratom počela, analizom sinteze, smrću života. (Polić Kamov, 2004: 102; isticanje naše) 
Njegovo fragmentirano tijelo nije samo prikaz razrušenoga organizma nego implicira i osjećaj duševne razjedinjenosti. A za Lacana svaki takav osjećaj ugrožava iluziju o jedinstvenosti koja konstituira sebstvo (prema Evans, 1996: 67). Ta slika fizičkoga raspadanja organizma, njegova rastakanja na sastavne dijelove, svoju kulminaciju doseže nakon jednoga alkoholnog delirija, kad se oko Arsena na postelji, gotovo kao na odru, okuplja obitelj:

Arsen zaudaraše. Bijaše sav zapackan nečim skrutnutim, bezbojnim. Ko krv, ali se ne pokaza rana; ko bljuvotina, ali sve bijaše probavljeno; ko žutilo, ali se ne pokaza oteklina. Zaudaraše ko strvina, ali ne bijaše još mrtav; kretaše se ponešto, ali prestajaše biti živ. (Polić Kamov, 2004: 102)

Pa i u njegovu eksplicitnom osvrtu na proces pisanja i umjetničkoga stvaranja, u kojem svjedoči o njegovoj tegobnosti i mukotrpnosti, ali i nedostatnosti tradicionalnoga jezičnog izražavanja koji ga tjera da pomisli kako je bolje služiti se brojkama, prepoznajemo upravo boržeovsku i ničeovsku definiciju dekadencije s početka rada. Dezintegracija se tjelesnosti i duhovnosti prenosi i na umjetnički plan u kojem se bolest nastoji nadvladati kreacijom. Jer, „Arsen Toplak nije samo plućni bolesnik, on je i bolesnik pisanja“ (Milanja, 1981: 463). „Pogledah na svoj rukopis. I tu bijahu slova i riječi, slova ne bijahu povezana organski, čvrsto; bijahu naherena, neravna, razbacana, i rečenice bijahu isto tako nepotpune: manjkahu tu i tamo riječi, prelaz, stilistika.“ (Polić Kamov, 2004: 308; isticanje naše)

Onemoćaloga i iscrpljenoga, najočiglednije sjetne i tjeskobne preokupacije preuzimaju ga prema kraju romana, u njegovu trećem dijelu, dok se ekstatično izvija „u vis“ ne bi li napustio vlastito ,ja“. Polagano prelazeći u stanje trajnosti dok besciljno luta Italijom, Arsen u potpunosti preuzima senzibilitet bezvoljnoga dekadentnog junaka. Dramatično proživljava modernistički taedium vitae, odustaje od svake odluke, a to znači i od svake akcije. Impresionistički nepokretan, „tako trošan, suh i star“ (ibid.: 317). Eskapistički tragajući za vlastitim mjestom pod suncem, što je, kako smo demonstrirali, tipično dekadentan doživljaj svijeta i stvar najdublje intime, abulično konstatira:

Nenadano me uhvati uzrujanost, neduh i srsenje (...). I ovo me ležanje umori kao hodanje. Ja sam odsele često znao sjediti komotno i umarati se, zapuhavati i znojiti kao od žurbe, trčanja i uzbrdice. (...) Opet se pokušah dići, ali sam znao, da se pridići neću moći, da je moj organizam razrezan na komade, komadiće komada, atome, i da je sve to povezano koncem, a ne živom energijom i da je zato nemoguće uspraviti se, krenuti i htjeti. „Što mi ostaje? “ Preda mnom 
izmicahu u neodređenim potezima i bojama ljudi, životi i fakta... I ovi bijahu zapuhani u bijegu kao ja u mirovanju. Gledah se sâm, ostavljen, odbjegnut, i pomislih na trešnju, propadanje, ništavilo. „Nijesam li bacio bombu u hram ljudski, koji bijaše već prazan i ja ostah jedini posut ruševinama? Što mi ostaje?"“ (ibid.: 307-308; isticanje naše)

Odnosno, kao što je sažeo Gašparović, „od početne točke jakog energetskog polja odlučnosti egzistencije da se brani od ugroženosti neegzistencijom (bolest, impotencija), u središnjem dijelu prelazi na autoanalizu, te u konačnici spušta/uspinje (padanje $u$ vis) u ironijsko semantičko polje pojmovnog sustava“ (2005: 223). Naposljetku radikalna entropija. Prema svemu tome možemo sumirati da Arsen uistinu najbolje pokazuje da ništa od onoga što smo u radu tematizirali nije bio izdvojen slučaj. Osvrnemo li se na druge proze s likovima dekadenata koje su nam bile u fokusu, malo je reći da je znakovito da je u Isušenoj kaljuži napokon jasno prezentirano da su introspekcija i bolest posve izjednačene. Bacil, uzrok bolesti, već se nalazi u autoanalitičaru. Dekadencija, ako ćemo je izjednačiti s izostankom zdravlja u onom najrigidnijem smislu, već čuči u svima njima. Jer, vidjeli smo, upravo je individualnost uvjet „bolesti“. I zato je prigodno s Toplakom zaokružiti našu priču o ovoj temi potkrepom teze da je dekadencija privilegij koji uvijek i iznova prisiljava na propitivanje sebe i svijeta:

Slabost je dakle moja snaga i bezvoljnost moja volja. (Polić Kamov, 2004: 346) 


\section{ZAKLJUČAK}

Zaokružiti problematiku dekadencije, jednoga od najistaknutijih fenomena $\mathrm{u}$ intelektualnoj povijesti fin de sièclea, i srodnih tema koje se uz nju vežu, odnosno iz njezinih tumačenja iskrsavaju, pa i dekadenciju čije smo manifestacije promatrali na reprezentativnim muškim likovima u hrvatskoj findesiècleovskoj prozi, pomalo je nezahvalan zadatak. Posebno zbog toga što je, kako smo utvrdili na početku, sam pojam vrlo teško precizno i cjelovito odrediti. U nastojanju da iščitamo ideju i koncept dekadencije te izdvojimo modele i paradigme prema kojima se dekadentni senzibilitet, posredno i neposredno, otkrivao u izabranim djelima, posegnuli smo za odgovarajućim momentima tadašnje duhovne atmosfere, za koje smo procijenili da su s njom nerazmrsivo prepleteni, kako bismo u interpretativnom dijelu rada što kvalitetnije pokazali da su svi likovi dekadenata zapravo fikcionalizacija dominantnih duševnih dispozicija i misaonih preokupacija. Polazeći od pretpostavke da je razmatrati dekadenciju kao nezaobilaznu činjenicu europskoga prijeloma stoljeća nemoguće bez poznavanja konteksta, u prvim smo dvama poglavljima opsežno predstavili duhovnu i kulturnu klimu u kojoj se razvijala te je povezali i s nekim (pseudo)medicinskim konceptima, čime smo nastojali upotpuniti naše čitanje toga osnovnog pojma. Pokazalo se kako ona, čak i dan-danas, ostaje termin koji lako prelazi disciplinarne granice te se uspješno može skrasiti u različitim diskursima. I ovaj je rad nastao na stjecištu različitih perspektiva, s namjerom da u njegovu središnjem poglavlju što cjelovitije razmotrimo i interpretiramo modele njezine književne reprezentacije. Budući da smo prepoznali kako je lik dekadenta jedno od stalnih mjesta naše proze na kraju XIX. i početku XX. stoljeća, cilj nam je bio detektirati ključne topose koji su s dekadencijom izravno korespondirali te presudno utjecali na hrvatsku kulturnu i književnu atmosferu.

S obzirom na to da je izrastala iz kompleksnoga duha vremena te da se uvijek odnosila i na ono što joj je prethodilo, ispostavilo se kako je dekadencija najsloženiji pojam rada. Mnogobrojne nijanse njezina značenja te dugotrajna upotreba u različitim područjima (od filozofije, sociologije, povijesti i teologije do književnosti i umjetnosti uopće), u kojima je označavala urušavanje ili slom društvenoga ili političkoga sustava, propadanje vrijednosti te opadanje stvaralačkih snaga, simptomatične su za njezino opiranje ikakvoj sistematizaciji. No unatoč tomu dekadencija se potvrdila kao izvrstan aparat za opisivanje književnih slabića, iscrpljenih, abuličnih, hipersenzibilnih, malodušnih likova koji nastanjuju sve europske književnosti fin de sièclea. Pritom se njome nismo koristili kao moralnom diskvalifikacijom ili vrijednosnom procjenom, što je u povijesti njezine primjene, kako smo vidjeli, bio čest slučaj. 
Moderno, devetnaestostoljetno razumijevanje dekadencije nepotpuno je bez poznavanja opće ideje propasti u povijesti zapadne misli. Princip rasapa kao nezaobilaznoga elementa svake dekadencije bio je prisutan u gotovo svim starim civilizacijama i kulturama, koje su vjerovale da žive u nepovoljnijim vremenima u odnosu na zlatnu prošlost, a osobito je snažno iskrsnuo u judeo-kršćanskoj tradiciji u kojoj se, uz grozničav dojam urgentnosti, dekadencija doživljavala kao moralna izopačenost, što će joj zadugo ostati karakteristikom. U naracijama o propastima pojedinih povijesnih razdoblja i kultura kao dominantna se paradigma izdvojila priča o padu Rimskoga Carstva, u kojoj se inzistiralo na njegovoj političkoj i društvenoj regresiji, koja se odrazila i na estetsku inferiornost. Prema tome zaključili smo da se različite varijante kulturnoga pesimizma mogu pronaći u svim zapadnoeuropskim epohama. Znakovito je da se upravo od XIX. stoljeća prvi put sustavno javlja vizija konačnoga kraha čovječanstva, a uvjerenje da se stoji na kraju civilizacije, koje je vrlo uspješno korespondiralo s fin de siècleom kao temporalnom oznakom, nikad nije bilo izraženije. Posve generalno gledajući, nakon razdoblja „velikoga optimizma“, koje se povezuje s Francuskom revolucijom, prevladavalo je stanje općega razočaranja i skepticizma, a posljednja dva desetljeća zahvatila je prava plima pesimizma, melankolije i tjeskobe. Dekadencija dakle krajem XIX. i na početku XX. stoljeća doživljava svoj vrhunac te se u svojim raznovrsnim pojavnim oblicima prepoznaje kao conditio humana modernističkoga razdoblja.

Kulturnopovijesno gledano, modernu je dekadenciju, kako smo objasnili, prijelomno odredio aktualni duhovni horizont, kultura krize u kojoj smo kao temeljnu oznaku epohe prepoznali, Brochovim riječima rečeno, raspad vrijednosti. Raspad vrijednosti bio je nerazdvojivo povezan $\mathrm{s}$ konačnim ishodom jedinstvenoga civilizacijskog procesa: sa slabljenjem ili potpunim nestankom autoriteta kao središtem i konstitutivnim načelom svakoga duha. Onoga trenutka kad je čovjek shvatio da mu ni idejni ni materijalni svijet ne mogu ponuditi odgovore na njegove teorijske i praktične dvojbe, na pitanja o smislu života, kristalizirala se posve nova pozicija, pozicija onoga koji odbacuje svaki autoritet da bi potpunim poništenjem dospio do ništavila koje će postati početnom točkom novoga postajanja. Pojedinac koji intenzivno promišlja svijet shvaća da povijesno mišljenje opterećeno metafizikom i transcendentnim istinama onemogućuje nužno identitetsko razdvajanje subjekta od objekta te preuzima pesimizam i nihilizam kao svoje glavne životne filozofije. Zato se može reći kako iščezava uvjerenje o nepromjenjivosti i stabilnosti tradicionalnih vrednota zapadnoga svijeta, vječnih istina koje se sad naočigled prepuštaju propasti.

Te vječne istine, vrlo je zanimljivo, nestaju upravo u vremenu punoga civilizacijskog zamaha, industrijskoga, znanstvenoga i tehnološkoga napretka koji generira tjeskobu i otuđenje, 
postajući okidačem za najraznovrsnije individualne i kolektivne patologije. Modernitet, koji neizbježno dopunjava smisao findesiècleovske dekadencije, razumijeva se kroz međuodnos tih dviju komponenti: brze industrijalizacije, optimistične vizije napretka čovječanstva i vjere u dolazak novoga vijeka te osjećaja nesigurnosti, bespomoćnosti i beznačajnosti dok se živi na kraju civilizacije. Napredak i dekadencija, regeneracija i degeneracija, život i smrt išli su ruku pod ruku. Modernizacijski procesi u svim područjima ljudske djelatnosti nevjerojatnom su snagom proizvodili začudnu onemoćalost tijela i duha. Dekadencija se, kao što smo višekratno upozorili, nije razvijala u kontekstualnom vakuumu, nego je nastala kao reakcija na supostojanje staroga i novoga svijeta, smjestivši se u središte progresa i utopijske ideje o novom vremenu. Stoga je bila usko vezana s učincima „histeričnoga“ civilizacijskog razvoja na čovjekovu svijest. Progres i neuroza jedna su te ista stvar, zaključak je koji nam je omogućio da se složimo s autorima koji su govorili o imploziji moderniteta, odnosno njegovu urušavanju u samoga sebe. Specifični izrazi te implozije bile su degeneracija i neurastenija, koncepti koje smo doveli u blisku vezu s dekadencijom jer su kao jedinstveno uvjerenje o biološkom urušavanju čovječanstva najbolje prezentirali na koje se načine društvo nastoji nositi s neprilagođenim pojedincima, s onima koji na bilo koji način iskaču iz cjeline poretka i njegova utvrđenoga reda. Opsesija fizičkom i mentalnom degeneracijom izravan je odraz raspada vrijednosti, nestajanja jedinstvenoga autoriteta i propitivanja tradicionalnih obrazaca ponašanja i djelovanja. Dekadencija je profilaksa suočavanja s modernitetom.

Ne čudi stoga što joj je pesimizam, dok se očajava zbog povijesne prepuštenosti čovjeka samomu sebi i grozničavo traga za svrhom njegova postojanja, unaprijed upisana vrijednost. Kulturni pesimizam na kraju XIX. stoljeća, kao odgovor na političke događaje, nezadovoljstvo pozitivističkom perspektivom svijeta i dosadnim buržoaskim moralom, bio je zapravo konačan izraz „bolesti stoljeća“, kulminacija disharmonije pojedinca i svijeta karakteristične za romantizam, što nas je i motiviralo da prikažemo neku vrstu evolucije lika romantičara u lik dekadenta. Maladie du siècle izravno se pak nadovezuje na mal de vivre, fenomen „životne boli“ čiji je temelj negativno stajalište o prirodi ljudskoga postojanja, odnosno ideja da je čovjek u svojoj biti nesretan, a njegov život prepun patnje. Pojedinac, preuzimajući objeručke taj životni pesimizam, tegobno osvještava raskorak između idealiteta i realiteta te zaključuje kako je nepostojanje na takvom svijetu prihvatljivije od postojanja.

Nedvojbeno je da se takva negativna percepcija stvarnosti i definiranje ovoga svijeta kao najgorega od svih mogućih, kako smo nastojali elaborirati u drugom poglavlju, fundirala na filozofijama Schopenhauera, von Hartmanna i Kierkegaarda, koje su proizvele karakterističan beznadan i zloslutan ,štimung“ te pesimizam pretvorile u kolektivno viđenje 
života i ,svjetsku moć“, što se potom odrazilo na svim poljima ljudske djelatnosti. Najpotpuniji izraz uvjerenja da život gubi smisao te da se neprestano odvija između boli i dosade bio je Schopenhauerov sustav, u kojem je volja predstavljena kao unutarnja bit svega što jest: život pod njezinim diktatom očitovanje je najgore moguće patnje. Sličan je filozofsko-životni model razvijao von Hartmann, koji je sumorno poimanje ljudske sreće kombinirao s optimizmom o kulturnom napretku čovječanstva, dok se Kierkegaard, kao duhovni otac filozofije egzistencijalizma, među prvima posve konkretno okrenuo čovjekovu mikrokozmosu, njegovim unutarnjim stanjima, uspostavivši tjeskobu i očajanje kao vezivno tkivo svake egzistencije.

U takvom se odnosu snaga dekadencija kao misaona konstrukcija i estetska kategorija pojavljuje i u književnosti, u kojoj smo je, na tragu njezina prvoga reinterpretatora Baudelairea, promatrali kao zajednički nazivnik tema propadanja i urušavanja u svim područjima života. Nerazmrsivo je prepletena s činjenicom da za fin de sièclea umjetnost zaokreće prema čovjekovim psihičkim proživljavanjima, prema subjektivnome i intuitivnome te u središte svoga zanimanja postavlja krhke, slabe, problematične subjekte, postajući jedinstvenim izrazom besmisla pojedinačne egzistencije i simbolom atemporalnosti ljudske patnje. $\mathrm{Na}$ književni tron zasjedaju estetika imanencije te psihologizam i subjektivizam kao glavni ideologemi toga razdoblja u kojem nervoza prerasta u paradigmatski moderni poremećaj. Ne iznenađuje stoga što su različiti autori u različitim zemljama na slične načine gradili svoje dekadentne karaktere: bili su inspirirani istim narativima i sličnim kulturnim kontekstom.

Dekadencija je i u hrvatskoj književnosti postala jednom od ključnih misaonih struktura vremena te smo o njoj u ovom radu raspravljali na pozadini specifičnoga tematsko-motivskog repertoara koji je funkcionirao u toj osebujnoj duhovnoj atmosferi. Kao i u drugim zemljama, i kod nas je, kako smo nastojali protumačiti u trećem poglavlju, izrasla na stabilnim temeljima nacionalne ,psihologije“, kao jedinstven odgovor na političko-društvene krize koje su se snažno širile iz Austro-Ugarske Monarhije. Iz njezine podvojenosti između tradicionalizma i liberalizma, što smo joj prepoznali kao jedno od osnovnih obilježja, emanirali su različiti problemi koji su svoje svjedočanstvo pronalazili i u hrvatskoj književnoj stvarnosti te pritom podupirali uvjerenje kako rastrganost među aktualnim prilikama odražava i rastrganost ljudi kao integralnoga dijela njihova konteksta. Nemogućnost pronalaženja smisla života i čuvstvo bezizlaznosti u nas su bili osobito poduprti kuenovštinom, što nas je ponukalo da zaključimo kako je naša reprezentacija dekadencije, najčešće krajnje indirektno, zrcalila frustriranost književnika neslobodom i svakom mogućom vrstom inferiornosti. Prema tome hrvatska se zbilja nametnula kao optimalan kontekst za prihvaćanje zapadnoeuropskih strujanja i artikulaciju dekadencije kao dominantnoga findesiècleovskog toposa, omogućivši joj da se 
razvije u jedinstven proizvod vremena kojim se napajala i prostora na kojem je nastajala. Dekadencija povezana sa stanjima glavnih likova bila je puno više od reprezentacije individualne propasti. Bila je, kako nam se čini, svjesna namjera, nenametljiv bunt protiv stanovitih civilizacijskih tendencija, odnosno neka vrsta ideološkoga fenomena. Pritom su razvoju dekadentne misli možda najviše pogodovale obvezne lektire naših pisaca, Schopenhauer i von Hartmann te neki ruski književnici (među njima posebno Turgenjev), koji su svojim figurama suvišnih ljudi neosporno inspirirali stilizaciju hrvatskih dekadenata. Pod svim tim utjecajima i nadahnućima, nakon uvida u labilnost i konačnost povijesnih pojava, tlo za književnu interpretaciju dekadencije bilo je pripremljeno.

Sve nas je navedeno vodilo do četvrtoga poglavlja, središnjega dijela disertacije, $u$ kojem smo izabrana djela čitali u okviru povijesnoga skepticizma da bismo pokazali na koji se način dekadencija veže uz glavne junake, odnosno kako su oni oblikovani u skladu s konstrukcijama glavnih findesiècleovskih duševnih poremećaja. Promatrali smo je u petnaest reprezentativnih proznih djela te smo ih, uočivši srodna svojstva na kojima su njihovi protagonisti građeni, razvrstali u osam poglavlja. U svima njima autori, materijalizirajući modernu osjećajnost i osnovne dispozicije epohe - izuzevši Šenou, zbog čega njegova Lovru i jesmo promatrali kao preteču, odnosno protodekadenta - ulaze u unutrašnjost tih hamletovskih priroda, što vodi izostanku svake konkretnije radnje, koja se zamjenjuje načelom rezignacije i izjalovljenih nada. No prije nego što sumiramo pojedinačne karakteristike svakoga od likova, istaknut ćemo zajedničke teme hrvatske dekadencije, odnosno opća mjesta na kojima se likovi fundiraju i određene konvencije u njihovu oblikovanju.

$* * *$

Za početak je bitno napomenuti, s obzirom na tumačenje dekadentne senzibilnosti kao nedostatka, kako smo dekadenciju interpretirali kao privilegij pomoću kojega pojedinac spoznaje temelje društva kojemu pripada te uočava njegovu iskvarenost i promašenost. Dekadencija, taj jedinstven osjećaj egzistencijalnoga besmisla i duševne onemoćalosti, u analiziranim se likovima postavlja kao granično stanje stanovite iznimnosti koje otkriva tajne vlastitoga bića i svijeta, što nas je uputilo na njezino povezivanje s idejom patološkoga. U smislu društvenoga prihvaćanja samo onoga što je u skladu s normom dekadencija je iščašenje, tj. narušavanje pravilnosti poretka, degeneracija „normalnoga“. Gubitak kontrole koji generira snažnu društvenu tjeskobu. A osnovna joj je definicija, zaključili smo, proizašla iz ničeovske ideje o raspadu nečega što je svojedobno bilo jedinstveno i homogeno. Nietzsche je, 
nedvosmisleno na Bourgetovu tragu, uspostavio koncept dekadencije kao rastakanja nečega što je nekad bilo cjelovito te ju je definirao kao logiku nihilizma, toga glavnog simptoma bolesti moderne civilizacije. Ta nam je definicija zapravo bila početna točka za svako daljnje razmatranje. A iz Nietzscheova smo tumačenja kao još jednu vrlo vrijednu činjenicu, koju smo uočili u gradnji svih likova, preuzeli tezu da slabost postaje primarna zadaća: dekadencija je naime kao pitanje volje prihvaćanje osiromašenja života i nazadovanja. Dekadent nije zaista bolestan, on jednostavno želi biti slab i umoran.

Ideja dekadencije kao rasapa cjelovitosti motivirala nas je da joj kao kamen temeljac postavimo problem identiteta, odnosno nemogućnost ili nesposobnost uspostave vlastitoga ,ja“, usko vezan s nestajanjem univerzalnih vrednota, koje su i identitetska uporišta. Naime identitet se svih protagonista iz proza u našem korpusu prezentira kao trajno nedovršen proces jer $u$ potrazi za osobnim i profesionalnim ispunjenjem oni ne uspijevaju nadići surovost društvenoekonomskih okolnosti, razriješiti zamršene emocionalne odnose u koje su upleteni ili okončati borbu sa samima sobom. Zato smo sve dekadente nazvali neurotičnima, ne toliko $\mathrm{u}$ medicinskom smislu živčane iscrpljenosti, koliko u društveno-psihoanalitičkome: neuroza je pokretač identitetske disocijacije jer pojedinac, ćuteći „nelagodu u kulturi“ koja ga suočava s različitim izazovima, zahtjevima i preprekama, shvaća da nije moguće zadovoljiti društvene norme te pritom održavati stabilno i zdravo ,,ja“. Od Lovre do Stanka Lukavca, kronološki, ili od Lovre do Arsena Toplaka, tematsko-motivski, svi oni egzistiraju izvan bilo kakve pripadnosti: dok žude za integracijom u društvo i mjestom pod suncem, bolno spoznaju da ono što im društvo nudi nije ono što žele.

A budući da je jedna od dominanti u stilizaciji likova mučan osjećaj samoće, odnosno otuđenosti od drugih, što se pak neposredno veže na tezu kako je razvoj pojedinca izravan rezultat suživota i interakcije s drugima, svi se dekadenti mogu odrediti i kao moderni narcisi. Time se tekstovi iz korpusa izravno upisuju u findesiècleovsku narcističku kulturu, koja se pokazala kao plodno tlo za razvoj melankoličnih stanja koja su u sudaru s modernitetom poprimila epidemijske razmjere. Naime pretjerana usmjerenost samomu sebi blokira sva druga čuvstva, jer se sve snage troše u službi vlastite ličnosti, te zaklanja predodžbu o drugome. Zato se solipsizam, referentna točka svake definicije dekadencije, prepoznaje kao destruktivna sila: sačuvati vlastitu egzistenciju za dekadente znači sačuvati individualnost, samoću, odnosno uništiti svaku mogućnost suživota. Osobna se egzistencija ulaskom u zajedništvo poništava, a ljubav se predstavlja kao tragedija koja se odvija isključivo zbog njihove emocionalne i mentalne zakočenosti. Tako se u glavnini proza životi protagonista destruiraju čim se pojavi i najmanja naznaka zajedničkoga života, dok u manjem dijelu emocionalne veze sa ženama nikad 
nisu dovoljno jake da ih se spasi od tragičnoga kraja. Prema tome njihov odnos prema drugima, pa i prema ženi, možemo odrediti kao apstraktnu osjećajnost. Individualizam se takoreći okreće protiv samoga sebe postajući moćnim oružjem u rastakanju identiteta. Naime njegujući pravu umjetnost otuđenja, oni se nalaze odvojeni od svih vrijednosti koje bi im trebale pružiti osjećaj ontološke sigurnosti. Jer, kako smo napomenuli, za samoostvarenje je nužno iskustvo odnosa s drugim. Odnosno, budući da smo sami sebi nevidljivi, identitet je moguće utvrditi samo pogledom kroz drugoga. Teško uspostavljajući odnose te gubeći iz vida smisao i svrhu vlastitoga života, svi dekadenti završavaju posve dezintegrirani jer individualno je uvijek rezultat interakcije s ,ne-ja“. I zato svi odreda živote okončavaju bijegom, ludilom ili smrću.

Dakle pod svim navedenim pretpostavkama koje razumijevanje dekadencije čine kompletni(ji)m izranjaju tipizirani individualci, dekadenti čije se osobine mogu svesti na nekoliko osnovnih stanja, koja se međusobno snažno prožimaju, utječu jedno na drugo i jedno iz drugoga nastaju. U imaginariju naše dekadencije kao temeljni se toposi artikuliraju, kako smo opazili, pretjerana osjetljivost, duševna i tjelesna slabost, sklonost intelektualizaciji te patološki manjak volje. To su fundamentalna svojstva koja se kompleksno prepleću te deriviraju još niz drugih dispozicija. Sve su to, kako jednostavno i efektno poentira Kristeva, devitalizirane egzistencije. A prototip je takvoga dekadenta intelektualac, talentiran, obrazovan, inteligentan $\mathrm{i}$ intenzivno perceptivan pojedinac. Umjesto da ga osnaže, educiranost, inteligencija i intuicija čine ga neprilagođenim na mnogim razinama, ponajprije zbog činjenice da zahvaljujući svojoj razvijenoj i sofisticiranoj svijesti vidi svijet kakav ne želi vidjeti. I zbog toga je silno nesretan. Zato je osnovni dojam koji izbija iz svih djela osjećaj beznačajnosti i bespomoćnosti tih hamletovaca pred pitanjima o smislu života, što se pak kombinira s dubokim razočaranjem zatečenim poretkom stvari i banalnošću svakidašnjice. Svijest o tome da su dio svijeta, ali da im je on istodobno potpuno stran mučno će opterećivati sve naše dekadente, zbog čega smo ih prepoznali kao autsajdere, ljude kojima pripada rubni prostor. Izmještaju se iz svijeta da bi ga vidjeli, a onda se pokazuju nesposobnima u njega se ponovo inkorporirati. Svi su u neku ruku odabrano bolećivi (pa čak i onda kad pate od organske bolesti) te slabost drže svojom ključnom zadaćom, njegujući sumorni pesimizam i abuličnu klonulost kao modus vivendi.

A zbog svega smo apostrofiranoga interpretaciju dekadentnih identiteta poduprli tumačenjem dviju središnjih dispozicija koje smo dijagnosticirali kao simptome neuroze, melankolije i tjeskobe, koje se opet mogu tijesno povezati s netom navedenim karakternim svojstvima; iz njih izviru ili ih pak uzrokuju. Klinička se slika dekadenata popunjava patološkim formama melankolije (stanja duboke sjete, neke neshvatljive tuge i čežnje za nedohvatljivim) 
te tjeskobe (bezobjektnoga paralizirajućeg straha i nespokoja), koje postaju njihovim esencijalnim afektivno-bihevioralnim stanjima što blokiraju svaku aktivnost i konkretan životni angažman. Budući da smo zaključili da medicinska tumačenja ne mogu u potpunosti osvijetliti uzroke tih stanja kao sastavnoga dijela nekoga razdoblja, dekadente smo promatrali osobito iz kulturnoantropološke perspektive: oba stanja radikalno djeluju na osiromašenje ličnosti i kidanje veze između ,ja“ i svijeta. Osjećaj izgubljenosti odraz je simboličnoga urušavanja poznatoga svijeta te u njima rađa tjeskobno čuvstvo jer percipiraju da gube nešto što drže fundamentalnim za vlastiti mir i sreću: urušavanje i/ili nestajanje poznatih sustava veže se $\mathrm{s}$ vlastitom izgubljenošću. Neovisno o tome gube li apstraktne ideale ili voljene osobe osjećaju da se suočavaju s ništavilom. Jer, kako smo višekratno elaborirali, za održavanje zdrave egzistencije čovjeku je prijeko potreban osjećaj pripadanja. Melankolične i tjeskobne dispozicije generiraju nemogućnost osmišljavanja (produktivnoga) života, što će činiti patologiju djelovanja svih protagonista. Zato smo ih, s obzirom na to da su im aktivnosti isključivo intelektualne, prepoznali kao ekstremne modele cerebralnih pojedinaca koji o životu intenzivno razmišljaju, nesposobni uistinu ga živjeti. Najsažetije rečeno, njihova je „bolest“" proizvod bolećivoga srca i kritičkoga uma: melankolični su jer spoznaju da stari ideali više ne vrijede, a tjeskobni jer su svjesni da nisu u stanju uspostaviti nove. Ne čudi stoga što se povlače u svoju ljušturu te izrastaju u prave ljude od „neakcije“. Usvajaju simptome neuroze kao neku vrstu bijega od objektiviteta svijeta te boležljivost prihvaćaju kao privilegirano utočište.

A na razvijen analitički duh, odnosno na neurotski nagon za (samo)propitivanjem izravno se nadovezuje zamor tijela i gubitak energije - patološka zakočenost volje. Zamor i energija lice su i naličje istoga fenomena. U vremenu moderniteta koji je ukupnošću svojih složenih promjena čovjeka iscrpio, učinio ga nervoznim, nesigurnim i labilnim, manjak energije, odnosno zamor, postaje uobičajena abnormalnost. On pritom u naših dekadenata nije posljedica potrošenosti tijela - jer oni, fizički gledano, nemaju od čega biti iscrpljeni - već nesklonost i nesposobnost obavljanja praktičnoga posla, radna neproduktivnost. Dekadent nije homo faber, nego, u uvjetima u kojima se prema radu kao ideologemu pojedinci polariziraju na prihvatljive i neprihvatljive, one koji rade i one koji troše, krajnje nedjelatan subjekt. Radna (ne)učinkovitost i duševni poremećaj izranjaju u uzročno-posljedičnoj vezi. U tom se smislu može poentirati kako je njihova dekadencija i na taj način subverzija moderniteta jer dekadent svojim umornim tijelom, koje je posljedica njegova umornoga duha, ni na koji način ne pridonosi društvu. Zamor smo stoga u njemu interpretirali kao patologiju bolesti volje. Slabost mu piše povijest. Volja se pak u devetnaestostoljetnim naracijama zasnivala na predodžbi 
energije kao temeljnoga kapitala tijela te se izravno vezala na ideju o važnosti živaca za pravilno funkcioniranje organizma. U takvoj se predodžbi abulija, kao bolesna bezvoljnost, tj. morbidna nemogućnost donošenja i provođenja odluke, objašnjavala kao iscrpljenost živčanoga sustava koji organizmu ne uspijeva osigurati dovoljnu količinu energije, odnosno kao nemoć da se želja pretvori u konkretan čin. Dekadent ne može djelovati čak i kad to želi. Prema tome uvidjevši sponu između oslabljenih živaca i malaksalosti duše, zaključili smo da bismo sve dekadente mogli nazvati neurastenicima, čime smo ih primarno odredili kao slabiće volje. Njihovo je umovanje simptom inhibirane volje, a inhibirana je volja simptom neuroze. Upravo su nam navedena tumačenja pomogla da opravdamo tezu da su to pasivni životi koji se odvijaju u promišljanju: vita contemplativa nasuprot vita activa. Hamletovština u kojoj se život razvodnjava misaonošću.

Možemo stoga sažeti kako je hrvatski dekadent po svojoj definiciji statičan, mekoputan, asteničan, uman karakter, zastrašujuće spriječen nekom dramatičnom povijesnom nemogućnošću djelovanja. I pritom besprijekorno materijalizira modernistički ennui. Sve su figure dekadenata postavljene u karakterističan položaj slaboga subjekta koji se, baštineći od svoje slavenske „braće“ razarajući osjećaj suvišnosti, gubi u ispraznim kontemplacijama te, nesposoban za angažiranu borbu s okolinom i samim sobom, brižno njeguje svoj status quo. Netom istaknuta činjenica posebno se potencira još jednom konvencijom u gradnji dekadentnoga lika: svaka karakterna i bihevioralna promjena glavnih junaka pokazuje se uvijek varljivom i naposljetku nemogućom. Svaka potencija sretnoga ishoda u tim centripetalnim svjetovima u kojima je sve usmjereno ništavnosti vlastitoga ,ja“ iluzorna je. To su suvišni ljudi aktivni unutar sebe, zbog čega u prozama i izostaju konkretni (izvanjski) neprijatelji; svi su sukobi smješteni u njihovoj intimi. Trpe, a ne bore se. Provode „terapijski nihilizam“ ne čineći ništa što bi moglo poremetiti ustaljen im život, apatično uvjereni kako njihovom egzistencijom ionako upravlja ono „nešto“. Indikativno je pritom da su i duhovno i tjelesno oblikovani kao mladići prerano ostarjeli, koji na svojim leđima nose upravo fascinantnu težinu života. Sve su to tipovi muškaraca u dvadesetima i tridesetima koji se ponašaju kao da su proživjeli stotinu života te su, što po svojoj psihičkoj strukturi i karakteru, što pod utjecajem surovoga društvenog okruženja, postali nepokretljivi, nepoduzetni, malaksali. Oni su čak i svojom pojavom zazorni: bljedunjavi, krhki, ispijeni. To se dogodi kad entropija svlada organizam. Usto u svih se likova iz korpusa dalo izvrsno zamijetiti kako su konstruirani većim dijelom pomoću ženskih rodnih crta, čime su se uklopili u sve jači findesiècleovski trend propitivanja uvriježene slike muškosti. Njihova je dekadencija zapravo degenerirana muškost, tj. biološki atavizam. I u tom su smislu, budući da izazivaju stabilnost velikih, apsolutnih subjekata, neprilagođeni: smješteni u sivoj 
zoni između muškosti i ženskosti, patologije i normalnosti. A ne bi li još snažnije i posve direktno naglasili njihove androgine crte, autori im redovito suprotstavljaju antipode: produktivne, energične, realne, praktične i učinkovite muške likove, koji nerijetko funkcioniraju i kao objektivni rezoneri njihova života te im odriču nepokolebljivu želju da kreiraju neke paralelne svjetove. Jer snaga njihove emotivne prenapregnutosti, koja ozbiljno može narušiti mušku poziciju moći, golema je i prijeteća.

Dakle prekomjerna tankoćutnost protagonistâ, koju smo razumijevali i u kontekstu mentalne sofisticiranosti, odnosno bavljenja umnim poslom, u svim je radovima postavljena u procjep između privilegija i abnormalnosti te je na neki način (pa i onda kad se to čita između redaka) upisana u genetski kod svakoga od njih. Svi su oni unaprijed oblikovani, kako smo prepoznali, odgojem i obrazovanjem ili pak urođenim sklonostima, odnosno degeneracijom u odnosu na „normalno“. Čak i onda kad ih uništava surova sredina, njihov život usmjeravaju crte inherentnih slabosti.

$$
* * *
$$

Osnovni specifikum hrvatske dekadencije u odnosu na onu zapadnoeuropsku jasno se kristalizirao već u Šenoinu Prijanu Lovri (1873), pripovijesti čiji glavni lik zauzima početno mjesto u liniji stilizacije dekadentnoga karaktera. To nije dekadencija zapadnjačkoga, hedonističko-vajldovskoga modusa, što se veže za pripadnike mondenoga svijeta koji se u dokolici i financijskoj slobodi prepuštaju intelektualiziranju, nego tragična sudbina koja vodi u bijeg, ludilo ili smrt. Na horizontu je naše dekadencije samo destrukcija. Pritom je svojstvena „malim“ ljudima - (polu)intelektualcima, učiteljima, (propalim) svećenicima, književnicima i malim plemićima - smještenima u jedinstven hrvatski ambijent. Naš je dekadent dakle osobit rezultat kombinacije nekih glavnih preokupacija europskoga fin de sièclea i naslijeđa ruskoga suvišnog čovjeka, pozicioniran u specifično političko i društveno ozračje u kojem se suočava i $\mathrm{s}$ frustrirajućim osjećajem neslobode i podređenosti.

Dakle Lovrina je uloga u razvoju lika dekadenta programatska: ta priča o tragičnoj sudbini mladoga nadarenog intelektualca, koji pokušava nadići društvena ograničenja te $u$ svijetu kojim vladaju okrutne materijalne ambicije svoje mjesto izboriti znanjem, jest početna pozicija svih drugih proza iz korpusa (uz, razumljivo je, manje ili veće modifikacije). Neprevladiv jaz između intelektualne superiornosti i inferiornosti njegova društvenoga položaja, koji će drugi pisci preuzeti u gotovo istom obliku, u Lovri smo prepoznali kao nemogućnost da pronađe svoje ,ja“ i uspostavi se kao subjekt, a dekadenciju smo mu označili kao simptom društveno-političke zbilje i njegove, zasad još uglavnom posve objektivne nemoći 
da tu zbilju nadiđe. Međutim iako Lovrina dekadencija nije izraz patološke neuravnoteženosti, primijetili smo i u njemu stanovite neurotske karakteristike te kao referentnu točku njegova kraja izdvojili činjenicu da i on postupno razvija tjeskobu kao strepnju pred nepostojanjem čvrstih egzistencijalnih oslonaca. Ta tjeskoba neslobode u kojoj osvještava uzaludnost znanja i apsurdnost takva života, shvaćajući da nigdje ne pripada, obilježit će njegovo književno potomstvo koje će nastaviti vegetirati suvišno i sebi i drugima. Njegova će se egzistencijalna sumnja u drugih dekadenata razviti do neslućenih razmjera.

Lovrinu razapetost između nužnosti i slobode, što smo izdvojili kao uobičajen životni put findesiècleovskoga intelektualca, iskoristio je Gjalski kao početnu točku neuroze za gradnju Janka Borislavića iz istoimenoga romana (1887), našega prvog pravog dekadenta koji pesimizam preuzima kao životnu devizu te spoznaje jalovost čovjekovih napora da vlastitoj egzistenciji osigura smisao. Borislavić, doduše, nije Lovro u sociološkom smislu, nego u neurotičnom nastojanju da obuhvati sve znanje i otkrije „svjetsku tajnu“, a to njegovo zlokobno uranjanje u spekulativno i nedokučivo preuzet će i drugi autori kako bi potencirali nesposobnost svojih protagonista da žive u ,životnoj“ svakidašnjici, da se vežu za uobičajeno i aktualno. Rastrojenih živaca, Borislavić polagano propada sam od sebe te nakraju, ne pronalazeći oslonac ni u jednom sustavu, pa čak ni u Schopenhauerovu učenju o slijepoj volji i primitivnom nagonu kao temelju svakoga ljudskog djelovanja, koje je tako nepromišljeno nastojao slijediti, baš poput Lovre diže ruku na sebe.

Šopenhauerizacijom jednoga autentičnog homo melancholicusa bavio se i Leskovar u noveli Poslije nesreće (1894), u kojoj je glavni lik Ivanović oblikovan kao dekadent koji „pravo“ življenje zamjenjuje filozofijom te u intelektualizaciji očajnički traži nadomjestak za autentično bivanje. Takav se život, osmišljen u okviru filozofije beznađa, može čitati i kao podgrizanje sadašnjosti i budućnosti sindromom prošlosti u kojoj je smještena njegova trauma gubitka, zbog čega melankolija kao neriješeno žalovanje zauvijek ostaje konstitutivnim dijelom njegova identiteta. Tu traumu izgubljenoga Leskovar je upečatljivo iskoristio i za stilizaciju Martića i Imrovića, glavnih likova Misli na vječnost (1891) i Jesenskih cvijetaka (1897). Đurom Martićem, protagonistom svoga prvog proznog rada, najavio je pesimizam šopenhauerovske provenijencije kao glavni interes, a potom je u cjelokupnom opusu stvorio možda najcjelovitiji prikaz dekadencije u hrvatskoj književnosti. Primijetivši da je i Martićeva i Imrovićeva egzistencija utemeljena u gubitku objekta, koji prerasta u gubitak stabilnoga osjećaja vlastitoga sebstva, utvrdili smo da u fatalnom osjećanju egzistencijalne iscrpljenosti oba lika funkcioniraju kao mjesta melankoličnoga beznađa, u kojima se zauvijek održava sjećanje na traumatičan događaj. Naime opterećeni smrću te izmučeni nepodnošljivim teretom prošlosti, ostaju trajno 
uronjeni u svoj gubitak te, nemoćni oduprijeti se autoanalitičkoj misli, životare razapeti između prošlosti i sadašnjosti. Ta opsjednutost prošlošću i prokletstvo misli posve će se konkretizirati i u Bušinskom, glavnom junaku Sjena ljubavi (1898), kojim Leskovar simbolično zaokružuje svoju sliku dekadencije. Posvetivši mu posebno potpoglavlje, Bušinskoga smo apostrofirali kao metafizičkoga dekadenta bez opravdanja, prototipskoga melankolika onemoćale životne energije koji se malodušno povlači pred životnim odlukama te u sebi materijalizira sve bitnije odlike modernističkoga taedium vitae. Kao ekstreman primjer intelektualnoga junaka koji o životu samo misli, on kao osnovnu vrijednost svoga bivanja postavlja umjetnost, pronalazeći u njoj zaklon od efemernosti svakidašnjice, a kao modus vivendi epikurejstvo u kojem se želi sve ili ništa. U takvom ga stanju preplavljujuće tjeskobe i jedinstvene egzistencijalne dosade zatječe i prošlost koja ga gura u još radikalniju mentalnu inertnost, sve kako bi se konačno potvrdilo da za takvoga čovjeka budućnosti jednostavno nema.

$\mathrm{U}$ korpusu proza koje su nam bile $\mathrm{u}$ fokusu zasebno smo mjesto prepustili djelima $\mathrm{u}$ kojima se dekadencija može čitati i kao suptilan bunt protiv određenih modernističkih tendencija. Nemogućnost identitetske uspostave zbog rascijepljenosti između „nekad“ i „sad“, domovine i tuđine, provincijske sredine i velegradskoga okružja, popraćena tjeskobom beznačajnosti i prazninom kao odgovorom na gubitak duhovnoga središta, posebno opterećuje Novakova Šegotu iz istoimenoga romana (1888) te Nehajevljeva Mirkovića iz Velikoga grada (1902) i Grančarića iz Zelenoga mora (1903). Pavlom Šegotom nagovijestio je Novak svoju preokupaciju dekadentnim prirodama, što će je zatim izraziti u nizu romana u kojima će u većoj ili manjoj mjeri inzistirati na pogubnoj iskorijenjenosti pojedinca iz prirodnoga okruženja i frustrirajućoj nemogućnosti ili nedoraslosti da pojedinac takvu realnost nadiđe. Budući da su njegovi likovi svodivi na nekoliko osnovnih pojavnih oblika, kao prototip nam je dakle poslužio Šegota koji, prirođeno smanjenoga élan vitala, shvaća kako nikad neće uspjeti prevladati jaz koji se otvorio njegovim odlaskom u velegrad. U pasivizirajućem strahu što onemogućuje svako djelovanje, potičući isključivo na promišljanje, on neurotično uviđa vlastitu neprilagođenost $i$ suvišnost: osjećaj dvostrukoga pripadanja u konačnici se pretvara u tragičan osjećaj nepripadanja. S tim romanom grad postaje prostor uznemirujuće desubjektivacije te se imaginira kao drugost koja dezintegrira sebstvo, zbog čega smo i uvidjeli da dekadencija ovih likova nije leskovarovska, nego taineovska, i to u kombinaciji $\mathrm{s}$ urođenim karakternim osobinama. Velegradski život generira nove kulturne fenomene i različite psihološke oblike, pa tako i neurastenične tipove. Pozitivistički predestiniranim junakom, primarno određenim miljeom, bio je posebno okupiran Nehajev, koji je i u navedenim dvjema pripovijetkama i u Bijegu oblikovao figure koje se bezuspješno nose s vlastitom hibridnošću i društvenom 
okolinom. On je, uz Leskovara i Novaka, u tom svom „dekadentnom“ korpusu jedinstveno sumirao sve osjećaje koje su razdraženi intelektualci gajili u dodiru s europskom dekadencijom i specifičnim hrvatskim prilikama. Mirković i Grančarić, kako smo prosudili, kao paradigmatski primjeri apatičnih ljudi zapalih u omamljujuću svakidašnjicu, materijaliziraju pravu urbanističku blaziranost te suspregnute volje njeguju postojan fatalistički determinizam, vjerujući da im život usmjerava neka nepoznata sila, odnosno ne prepoznajući da ključ njihova problema leži i u njima. Pritom je Mirkovićeva sudbina kudikamo tragičnija jer u nastojanju da se izdigne iznad ograničenja provincijske sredine i prilagodi metropoli završava posve dezintegriran i poražen pod svjetlima velikoga grada.

Tragične posljedice raskoraka između intelektualne superiornosti pojedinca i nedostojnosti njegova društvenoga položaja, koji se začeo u Lovri, zajednički su nazivnik Gjalskijeva Radmilovića (1894), Novakovih Dvaju svjetova (1901) i Nehajevljeva Bijega (1909), romana u kojima se model izrazito tankoćutna umjetnika stilizira s obzirom na društvene okolnosti. Kao glavna se bolest društva u svima njima naglašava nepriznavanje i uništavanje slobodnih umjetnika te su oni prema tom ključu vjerna preslika bijedna života hrvatskoga intelektualca za Khuenova banovanja. Od Radmilovića, koga mazohističko promatranje samoga sebe i svega oko sebe priječi u aktivnom bivanju, preko Zlatanića, koji mučno spoznaje da primitivna provincijska sredina potkopava sve mehanizme sublimacije, do Andrijaševića, koji u budnom promatranju vlastite propasti pokušava ponuditi i njezinu etiologiju - ilustrira se specifična dekadentna agonija generirana problemima socijalne prirode i imanentnim slabostima. Pritom se ta djela razvijaju kao pokušaj spajanja univerzalne, apstraktne problematike čovjeka uopće i konkretne problematike hrvatskoga čovjeka te se nakraju potvrđuje kako u hrvatskim prilikama svako kvalitetno jedinstvo bistra uma i naobrazbe, koje se izdvaja iz masovne prosječnosti, tragično propada te, u spletu različitih okolnosti, društvenih konvencija, sudbinskih slučajnosti, osobnih izbora i slabosti, završava luđačkom košuljom i smrću. Pojedinac iz borbe sa zajednicom nikad ne može izaći kao pobjednik.

U prikazu kulture osjetljivosti posebno smo mjesto prepustili Šimunovićevu Stanku Lukavcu iz Tuđinca (1911), radikalnomu primjeru lika dekadenta bez identiteta, tipičnomu homo duplexu koji svim silama želi biti dio društva te pritom zadržati jedinstven identitet. U pokušaju da se vrati zajednici i tako dokine svoju iskorijenjenost, njegovo je traganje za vlastitim ,ja“ onesposobljeno pogubnom sveprostornošću i apovijesnošću te naglašeno fatalnim osjećajem slabosti i pasivnošću. Preslab da bi nadjačao svoje klonuće i trajno obremenjen 
sindromom tuđinstva, tjeskoban će mu nemir koji iz njega izvire u potpunosti odrediti budućnost. Budućnost međutim ni tu ne postoji.

Priču o dekadenciji zaokružili smo poglavljem u koje smo smjestili Leskovarova Ljubića iz Katastrofe (1892) i Kamovljeva Toplaka iz Isušene kaljuže (pisana 1906-09). Prepoznavši da njihova tuberkulozna tijela u najneposrednijem smislu evociraju fragmentirano sebstvo, koje smo u radu označili kao početnu točku naše definicije dekadencije, istaknuli smo da se njihova dekadencija gradi upravo oko nedostatka zdravlja, čime smo i simbolično upotpunili razumijevanje dekadencije kao „bolesti“. Dok lik Frana Ljubića sažeto i sugestivno iznosi agoniju jednoga hrvatskog intelektualca, učitelja koji skončava kao žrtva društvenopolitičkih prilika i ekonomskoga sustava, ali i vlastitoga smrtonosnog samoanaliziranja, u Toplaku smo uočili najradikalniji primjer raspada identiteta kao temelja svake dekadencije i dekadencije kao raspada cjelovitosti. Njegovo zazorno tijelo, pokretački duh cijeloga romana, započinje proces propitivanja temelja društva i vlastitoga ,ja“ te se pritom Arsen, nastojeći nadići sferu tjelesnosti i intelektualnim naporima zatrti iskustvo organskoga, predstavlja kao negirajući solipsizam u punom sjaju. No budući da zapinje u procjepu između instinkta i kulture, psihoze i neuroze, ispostavlja se da je svaka spoznaja ubila djelovanje, odnosno da je analiza završila bez sinteze. Život završava spoznajom da pojedinac ne može uspostaviti svijet; on naime ne može uspostaviti ni vlastito sebstvo. Svaki se pokušaj intelektualizma rastače u besmislu apsurda te Arsen ostaje zauvijek zarobljen u procesu kontinuiranoga stjecanja identiteta, ideala koji se nikad ne može dosegnuti.

Prigodno nam se zato činilo upravo s Toplakom završiti ovaj doktorski rad: u njemu se posve jasno prezentira kako je individualnost uvjet bolesti (a ne obratno, kako bi se moglo pretpostaviti) te kako je ,ja“ najobičnija iluzija, što smo i na simboličnoj razini povezali s našom konstatacijom da je dekadencija u odabranim prozama neka vrsta bolesti koja pojedinca izaziva na propitivanje svijeta i samoga sebe. Ona je, vidjeli smo, oznaka nadmoći intelekta jer kako se on razvija, tako raste razina misaonosti i pronicljive percepcije svijeta. Indikativno je pritom da su svi dekadenti u većoj ili manjoj mjeri svjesni da se svijet oko njih urušava, no, onemoćala duha i oslabljene volje, oni svoju dekadenciju ne uspijevaju upotrijebiti kao spiritus movens za izdizanje iz identitetskoga rasapa. Svijest o propadanju u njima se ne može razviti u novo postajanje. I zato se dekadencija uvijek definira kroz gubitak. Beznačajnost, bezdomnost, nepripadanje, praznina, odvojenost, necjelovitost, nedovršenost, (samo)otuđenje, (samo)uništenje. Unatoč tomu ona ostaje privilegij koji pojedinca tjera da svijet gleda drugim očima. 


\section{IZVORI I LITERATURA}

\section{Izvori}

Cihlar Nehajev, Milutin. 1944a. Poloneza. U: M. Cihlar Nehajev, Pripoviesti, 5-14. Zagreb: Izdanje Hrvatskoga izdavalačkog bibliografskog zavoda.

Cihlar Nehajev, Milutin. 1944b. Zeleno more. U: M. Cihlar Nehajev, Pripoviesti, 54-85. Zagreb: Izdanje Hrvatskoga izdavalačkog bibliografskog zavoda.

Draženović, Josip. 1902. Zeleni zastor. Nada VIII, br. 22: 297-299; br. 23: 309-312; br. 24: $325-327$.

Đalski, Ksaver Šandor. 1964. Janko Borislavić. U: K. Š. Đalski, Janko Borislavić. Pripovijesti i lirske minijature. Pet stoljeća hrvatske književnosti, sv. 51/2, 5-140. Zagreb: Matica hrvatska - Zora.

Đalski, Ksaver Šandor. 1980. Na rođenoj grudi. U: K. Š. Đalski, Na rođenoj grudi. Bijedne priče, 5-145. Zagreb: Grafički zavod Hrvatske.

Gjalski, Ksaver Šandor. 1932. Radmilović. Zagreb: Knjižara St. Kugli.

Kolarić Kišur, Rudolf. 2013. Laž. Zagreb: Ognjište.

Leskovar, Janko. 1997. Izabrana djela. Zagreb: Matica hrvatska.

Nehajev, Milutin. 1963. Bijeg. U: M. Nehajev, Bijeg. Vuci. Pet stoljeća hrvatske književnosti, sv. 82, 5-149. Zagreb: Matica hrvatska - Zora.

Nehajev, Milutin. 1964. Veliki grad. U: M. Nehajev, Ogledi i članci. Pripovijesti. Pet stoljeća hrvatske književnosti, sv. 81, 281-304. Zagreb: Matica hrvatska - Zora.

Novak, Vjenceslav. 1931. Pavao Šegota. Zagreb: Minerva nakladna knjižara d. d.

Novak, Vjenceslav. 1932a. Nikola Baretić. Zagreb: Minerva Nakladna knjižara d. d.

Novak, Vjenceslav. 1932b. Zapreke. Zagreb: Minerva nakladna knjižara d. d.

Novak, Vjenceslav. 1964. Tito Dorčić. U: V. Novak, Pripovijesti. Tito Dorčić. Pet stoljeća hrvatske književnosti, sv. 58, 151-323. Zagreb: Zora - Matica hrvatska.

Novak, Vjenceslav. 2009. Dva svijeta. U: V. Novak, Otrov u duši, 225-432. Zagreb: Mozaik knjiga.

Polić Kamov, Janko. 2004. Isušena kaljuža. Zagreb: Večernji list.

Šenoa, August. 2001. Prijan Lovro. Zagreb: SysPrint. 
Šimunović, Dinko. 1952. Tuđinac. U: D. Šimunović, Djela, sv. 2, 183-308. Zagreb: Državno izdavačko poduzeće Hrvatske.

Treščec Borotha, Vladimir. 1969. Listak romana. U: V. Treščec Borotha, M. Lovinac i M. Lisičar, Izabrane proze. Pet stoljeća hrvatske književnosti, sv. 69, 197-264. Zagreb: Matica hrvatska - Zora.

\section{Literatura}

Aho, James i Kevin Aho. 2006. Body Matters: A Phenomenology of Sickness, Disease, and Illness. Lanham - Boudler - New York - Toronto - Plymouth: Lexington Books.

Badalić, Josip. 1967. Milutin Nehajev kao tvorac „,suvišnih ljudi“. Riječka revija XVI, br. 6-7: 390-397.

Badalić, Josip. 1972. I. S. Turgenjev. U: J. Badalić, Rusko-hrvatske književne studije, 289-344. Zagreb: Liber.

Bahr, Hermann. 2005. Studien zur Kritik der Moderne. Kritische Schriften, sv. 4, 24-30. Weimar: Vdg.

Barac, Antun. 1951. Vjenceslav Novak (1859-1905). Republika VII, br. 11-12: 785-797.

Bauer, Roger. 2002. Décadence und Dekadenz. Euphorion XCVI, br. 2: 117-126.

Beard, George M. 1869. Neurasthenia, or Nervous Exhaustion. The Boston Medical and Surgical Journal III, br. 13: 217-221.

Beard, George M. 1880. A Practical Treatise of Nervous Exhaustion (Neurasthenia): Its Symptoms, Nature, Sequences, Treatment. New York: William Wood \& Company.

Beard, George M. 1881. American Nervousness: Its Causes and Consequences. New York: G. P. Putnam's Son.

Beiser, Frederick C. 2016. Weltschmerz: Pessimism in German Philosophy 1860-1900. Oxford: Oxford University Press.

Bernheimer, Charles. 2002. Decadent Subjects: The Idea of Decadence in Art, Literature, Philosophy, and Culture of the Fin de Siècle in Europe. Baltimore - London: The Johns Hopkins University Press.

Binni, Walter. 1936. La poetica del decadentismo italiano. Firenze: G. S. Sansoni - Editore.

Biti, Vladimir. 2005. Uzgoj eksplozije: „Logika apsurda“ u Isušenoj kaljuži Janka Polića Kamova. U: V. Biti, Doba svjedočenja, 31-51. Zagreb: Matica hrvatska.

Blom, Philipp. 2015. Vrtoglave godine: Europa, 1900.-1914. Preveo Goran Schmidt. Zaprešić: Fraktura. 
Bobbio, Norberto. 1944. La filosofia del decadentismo. Torino: Chiantore.

Borossa, Julia. 2001. Histerija. Preveo Igor Grbić. Zagreb: Naklada Jesenski i Turk.

Boulter, Jonathan. 2011. Melancholy and the Archive: Trauma, Memory, and History in the Contemporary Novel. London - New York: Continuum.

Bourget, Paul. 1920. Essais de psychologie contemporaine, sv. 1. Paris: Librerie Plon.

Breitenberg, Mark. 1996. Anxious Masculinity in Early Modern England. Cambridge: Cambridge University Press.

Bridge, Gary i Sophie Watson. 2003. City Imaginaries. U: A Companion to the City, ur. Gary Bridge i Sophie Watson, 7-17. Oxford: Blackwell Publishing.

Breuer, Josef i Sigmund Freud. 1957. Studies on Hysteria. New York: Basic Books Publishers.

Brlek, Tomislav. 2004. „Ako je literatura“ - (pot)pisano isušivanje kaljuže identiteta. Dani hvarskoga kazališta XXX: 151-166.

Broch, Hermann. 2007. Zlo u vrijednosnom sustavu umjetnosti. U: H. Broch, Duh i duh vremena: Eseji o kulturi moderne, 25-52. Preveo Nikica Petrak. Zagreb: Antibarbarus.

Buci-Glucksmann, Christine. 1988. Melankolični cogito suvremenosti. Quorum IV, br. 4: 245247.

Burrow, John W. 2000. The Crisis of Reason: European Thought 1848-1914. New Haven London: Yale University Press.

Bynum, Helen. 2012. Spitting Blood: The History of Tuberculosis. Oxford: Oxford University Press.

Byrne, Katherine. 2013. Tuberculosis and the Victorian Literary Imagination. Cambridge New York: Cambridge University Press.

Calinescu, Matei. 1988. Lica moderniteta: Avangarda, dekadencija, kič. Prevela Gordana Slabinac. Zagreb: Stvarnost.

Carter, Afred E. 1958. The Idea of Decadence in French Literature 1830-1900. Toronto: University of Toronto Press.

Caruth, Cathy, 1995. Introduction. U: Trauma: Explorations in Memory, ur. Cathy Caruth, 312. Baltimore - London: The Johns Hopkins University Press.

Cerovac, Mirko. 1969. Janko Leskovar. Rad JAZU CCCLV: 195-401.

Chances, Ellen. 2001. Superfluous Man in Russian Literature. U: Reference Guide to Russian Literature, ur. Neil Cornwell, 111-122. London - New York: Routledge. 
Čolak, Tode. 1966. Dinko Šimunović: Čovjek i umjetnik. Rijeka: Matica hrvatska, Pododbor u Rijeci.

Čuljat, Sintija. 2012. Poetika prostora: Kovačić, Novak i Hardy. Zagreb: Hrvatsko filološko društvo.

Čuržik, Doris i Nenad Jakšić. 2012. Patološki narcizam i narcistični poremećaj ličnosti pregled suvremenih spoznaja. Klinička psihologija V, br. 1-2: 21-36.

Davis, Colin. 2007. Derrida's Haunted Subjects. U: C. Davis, Haunted Subjects: Deconstruction, Psychoanalysis and the Return of the Dead, 128-150. New York: Palgrave Macmillan.

Derrida, Jacques. 2005. Rams: The Uninterrupted Dialogue - Between Two Infinities, the Poem. U: J. Derrida, Sovereignties in Question: The Poetics of Paul Celan, 135-163. New York: Fordham University Press.

Detoni Dujmić, Dunja. 1991. Dinko Šimunović. Zagreb: Zavod za znanost o književnosti.

Dežman, Milivoj [anonimno]. 1951. „Mladost“. U: Hrvatska moderna, sv. 1, ur. Milan Marjanović, 84-85. Zagreb: Jugoslavenska akademija znanosti i umjetnosti.

Dienstag, Joshua Foa. 2006. Pessimism: Philosophy, Ethic, Spirit. Princeton - Oxford: Princeton University Press.

Dobroljubov, Nikolaj Aleksandrovič. 1966. Šta je oblomovština. U: Ruska književna kritika, ur. Aleksandar Flaker, 87-129. Zagreb: Naprijed.

Dollimore, Jonathan. 2001. Death, Desire and Loss in Western Culture. New York: Routledge.

Donskis, Leonidas. 2011. Modernity in Crisis: A Dialogue on the Culture of Belonging. New York: Palgrave Macmillan.

Downes, Stephen. 2010. Music and Decadence in European Modernism: The Case of Central and Eastern Europe. Cambridge: Cambridge University Press.

Drake, Richard. 1982. Decadence, Decadentism, and Decadent Romanticism in Italy: Toward a Theory of Décadence. Journal of Contemporary History XVII, br. 1: 69-92.

Durić, Dejan. 2009. Grad i povratak potisnutoga. Prostor u romanu „U registraturi” Ante Kovačića. Fluminensia XXI, br. 1: 83-101.

Durkheim, Émile. 1951. Suicide: A Study in Sociology. London - New York: Routledge.

Emanuel, Ricky. 2005. Tjeskoba. Prevela Tamara Slišković. Zagreb: Naklada Jesenski i Turk.

Enderwitz, Anne. 2015. Modernist Melancholia: Freud, Conrad and Freud. New York: Palgrave Macmillan.

Evans, Dylan. 1996. Dictionary of Lacanian Psychoanalysis. London - New York: Routledge. 
Feld, Alina N. 2011. Melancholy and the Otherness of God: A Study of the Hermenetics of Depression. Lanham - Boulder - New York - Toronto - Plymoth: Lexington Books.

Flaker, Aleksandar. 1968. Hrvatska novela i Turgenjev. U: A. Flaker, Književne poredbe, 83158. Zagreb: Naprijed.

Flaker, Aleksandar. 1995. Beč u hrvatskoj književnosti 19. i 20. stoljeća. U: A. Flaker, Riječ, slika, grad: Hrvatske intermedijalne studije, 65-104. Zagreb: Hrvatska akademija znanosti i umjetnosti.

Flaker, Vida. 1977. Časopisi hrvatskoga modernističkog pokreta. Zagreb: Hrvatsko filološko društvo.

Fletcher, Ian. 1979. Foreword. U: Decadence and the 1890s, ur. Ian Fletcher, 7-14. London: Edward Arnold.

Földényi, László F. 2016. Melancholy. New Haven - London: Yale University Press.

Frangeš, Ivo. 1963. Janko Leskovar. U: J. Leskovar, Propali dvori. Pripovijesti. Pet stoljeća hrvatske književnosti, sv. 59, 7-27. Zagreb: Matica hrvatska - Zora.

Frangeš, Ivo. 1970. Šenoina baština u hrvatskom realizmu. Croatica I, br. 1: 137-166.

Frangeš, Ivo. 1972a. Gjalski prema Šenoi. Forum XIV, br. 9: 345-376.

Frangeš, Ivo. 1972b. „Janko Borislavić“ i „Radmilović“ kao književna tema. Croatica III, br. 3: $17-28$.

Frangeš, Ivo. 1987. Povijest hrvatske književnosti. Zagreb - Ljubljana: Nakladni zavod Matice hrvatske - Cankarjeva založba.

Frank, Arthur W. 1995. The Wounded Storyteller: Body, Illness and Ethics. Chicago - London: The University of Chicago Press.

Freud, Sigmund. 1984. On Metapsychology: The Theory of Psychoanalysis. Harmondsworth: Penguin.

Friedeberg Seeley, Frank. 1952. The Heyday of the „Superfluous Man“ in Russia. The Slavonic and East European Review XXXI, br. 76: 92-112.

Friedländer, Saul. 1985. Themes of Decline and End in Nineteenth-Century Western Imagination. U: Visions of Apocalypse: End or Rebirth?, ur. Saul Frieländer, Gerard Holton, Leo Marx i Eugene Skolnikoff, 61-83. New York - London: Helmes \& Meyer.

Frojd [Freud], Sigmund. 1970. Nelagodnost u kulturi. U: S. Frojd, Iz kulture i umetnosti, 261357. Preveo Đorđe Bogićević. Novi Sad: Matica srpska.

Fromm, Erich. 1984. Bekstvo od slobode. Preveli Slobodan Đorđević i Aleksandar I. Spasić. Zagreb: Naprijed - Nolit - August Cesarec. 
Frosh, Stephen. 1991. Identity Crisis: Modernity, Psychoanalysis and the Self. New York: Palgrave Macmillan.

Fuko, Mišel [Foucault, Michel]. 1980. Istorija ludila u doba klasicizma. Prevela Jelena Stakić. Beograd: Nolit.

Gagnier, Regenia. 2015. Global Literatures of Decadence. U: The Fin-de-Siècle World, ur. Michael Saler, 11-28. London - New York: Routledge.

Gašparović, Darko. 2005. Kamov. Rijeka: Adamić - Filozofski fakultet.

Giddens, Anthony. 1990. The Consequences of Modernity. Cambridge: Polity Press.

Giddens, Anthony. 1991. Modernity and Self Identity: Self and Society in the Late Modern Age. Cambridge: Polity Press.

Gijswijt-Hofstra, Marijke i Roy Porter, ur. 2001. Cultures of Neurasthenia from Beard to the First World War. Amsterdam - New York: Rodopi.

Gilman, Richard. 1979. Decadence: The Strange Life of an Epithet. New York: Farrar, Strauss and Giroux.

Gilman, Sander L. 1985. Difference and Pathology: Stereotypes of Sexuality, Race and Madness. Ithaca - London: Cornell University Press.

Gioanola, Elio. 1999. Il Decadentismo. Roma: Edizioni studium.

Gjalski, Ksaver Šandor. 1997. Rukovet autobiografskih zapisaka. U: Autobiografije hrvatskih pisaca, ur. Vinko Brešić, 217-261. Zagreb: AGM.

Gjurgjan, Ljiljana Ina. 1995. Mit, nacija i književnost „kraja stoljeća“: Vladimir Nazor i W. B. Yeats. Zagreb: Nakladni zavod Matice hrvatske.

Goering, Laura. 2003. „Russian Nervousness“: Neurasthenia and National Identity in Nineteenth-Century Russia. Medical History XLVII, br. 1: 23-46.

Goldstein, Jan. 2004. Psychiatry. U: Companion Encyclopedia of the History of Medicine, ur. William F. Bynum i Roy Porter, 1350-1372. London - New York: Routledge.

Gordon, Jan B. 1979. Decadent Spaces: Notes for a Phenomenology of the Fin de Siècle. U: Decadence and the 1890s, ur. Ian Fletcher, 30-58.

Gottfried, Paul. 1973. Pessimism and the Revolution 1848. The Review of Politics XXXV, br. 2: 193-203.

Grizelj, Mario. 2016. Filip i décadence, Filip i dekadencija. U: Povratak Miroslava Krleže, ur. Tomislav Brlek, 149-163. Zagreb: Leksikografski zavod Miroslav Krleža - Kulturni centar Beograda - Hrvatsko semiotičko društvo.

Gruber, Milan. 1910. Dekadentstvo. Narodne novine LXXVI, br. 15: 1-2. 
Hamren, Kelly. 2011. The Eternal Stranger: The Superfluous Man in Nineteenth-Century Russian Literature. Lynchburg: Liberty University, School of Communication (magistarski rad).

Hanson, Ellis. 1997. Decadence and Catholicism. Cambridge - London: Harvard University Press.

Hartmann, Eduard von. 1893a. Philosophy of the Unconscious, sv. 2. London: Kegan Paul, Trench, Trübner \& Co.

Hartmann, Eduard von. 1893b. Philosophy of the Unconscious, sv. 3. London: Kegan Paul, Trench, Trübner \& Co.

Hauzer [Hauser], Arnold. 1966. Socijalna istorija umetnosti i književnosti, sv. 2. Preveo Ksenije Anastasijević. Beograd: Kultura.

Herman, Arthur. 1997. The Idea of Decline in Western History. New York: The Free Press.

Herzlich, Claudine i Janine Pierret. 1987. Illness and Self in Society. Baltimore - London: The Johns Hopkins University Press.

Hobsbawm, Eric. 1987. The Age of Empire 1875-1914. New York: Vintage Books.

Hobsbawm, Eric. 1989. Doba kapitala 1848-1875. Prevela Sanja Lovrenčić. Zagreb: Školska knjiga - Stvarnost.

Horney, Karen. 1950. Neurosis and Human Growth: The Struggle Toward Self-Realization. New York: W. W. Norton \& Company Inc.

Hranilović, Jovan. 1900. Dekadentske težnje u hrvatskoj literaturi. Vijenac XXXII, br. 33: 518519.

Hranilović, Jovan. 1902. „Dva svieta“: Pripoviest, napisao Vjenceslav Novak. Vienac XXXIV, br. 19: 297-298.

Hurley, Kelly. 2004. Entropic Bodies. U: K. Hurley, The Gothic Body: Sexuality, Materialism and Degeneration at the Fin de Siècle, 65-88. Cambridge: Cambridge University Press.

Invernizzi, Giuseppe. 1994. Il pessimismo tedesco dell'Ottocento. Firenze: La nuova Italia editrice.

Iveljić, Iskra. 2009. Modernizacija izvana i modernizacija iznutra: Hrvatske zemlje od neoapsolutizma do bana Ivana Mažuranića. U: Hrvatska i Europa: Kultura, znanost i umjetnost, IV. Moderna hrvatska kultura od preporoda do moderne (XIX. stoljeće), gl. ur. Mislav Ježić, 77-91. Zagreb: Školska knjiga.

Janet, Pierre. 1925. Principles of Psychotherapy. London: George Allen \& Unwin Ltd.

Jankélévitch, Vladimir. 2011. Smrt. Preveo Daniel Bučan. Zagreb: AGM. 
Jervis, John. 2008. Uncanny Presences. U: Uncanny Modernity: Cultural Theories, Modern Anxieties, ur. Jo Collins i John Jervis, 10-49. New York: Palgrave Macmillan.

Jervis, John. 2015. The Modernity of the Fin de Siècle. U: The Fin-de-Siècle World, ur. Michael Saler, 59-73. London - New York: Routledge.

Johnston, William M. 1993. Austrijski duh: Intelektualna i društvena povijest 1848-1938. Preveo Janko Paravić. Zagreb: Nakladni zavod Globus.

Judson, Pieter M. 2018. Povijest Habsburškog Carstva. Prevela Karmela Cindrić. Zagreb: Sandorf.

Kann, Robert A. 2002. Decline and Discord (1879-1914). U: R. A. Kann, A History of the Habsburg Empire 1526-1918, 406-521. Berkeley - Los Angeles: University of California Press.

Kearney, Richard. 2003. Strangers, Gods and Monsters: Interpreting Otherness. LondonNew York: Routledge.

Kenedy Darnoi, Dennis N. 1967. The Unconscious and Eduard von Hartmann: A HistoricoCritical Monograph. Hague: Martinus Nijhoff.

Kierkegaard, Søren. 1980a. Bolest na smrt. Preveo Milan Tabaković. Beograd: Velika edicija Ideja.

Kierkegaard, Søren. 1980b. The Concept of Anxiety. Princeton - New Jersey: Princeton University Press.

Kierkegaard, Søren. 1990. Ili-ili. Preveo Milan Tabaković. Sarajevo: Veselin Masleša.

Klibansky, Raymond, Panofsky, Erwin i Saxl, Fritz. 2009. Saturn i melankolija: Studije iz povijesti filozofije prirode, religije i umjetnosti. Prevele Marina Kralik, Martina Kolarec i Judita Uremović. Zagreb: Zadruga Eneagram.

Kopić, Mario. 2001. Nihilizam kao usud? U: M. Kopić, S Nietzscheom o Europi, 9-41 Zagreb: Naklada Jesenski i Turk.

Košutić-Brozović, Nevenka. 1970. Evropski okviri hrvatske moderne. U: Hrvatska književnost prema evropskim književnostima, ur. Aleksandar Flaker i Krunoslav Pranjić, 345-363. Zagreb: Liber.

Kowalewski, Arnold. 1904. Studien zur Psychologie des Pessimismus. Wiesnbaden: Verlag J. F. Bergmann.

Kristeva, Julia. 1989. Moći užasa: Ogledi o zazornosti. Prevela Divina Marion. Zagreb: Naprijed.

Kristeva, Julia. 2014. Crno sunce: Depresija i melankolija. Prevela Vanda Kušpilić. Zagreb: Naklada Jurčić d. o. o. 
Krnic, Ivan. 1900. Dekadentske težnje u hrvatskoj literaturi. Narodne novine LXVI, br. 178: 12.

Kuhn, Richard. 1976. The Demon of Noontide: Ennui in Western Literature. Princeton: Princeton University Press.

Laplanche, Jean i Jean-Bertrand Pontalis. 1992. Rječnik psihoanalize. Preveli Radmila Zdjelar i Boris Buden. Zagreb: August Cesarec - Naprijed.

Lasch, Christopher. 1986. Narcistička kultura: Američki život u doba smanjenih očekivanja. Prevela Višnja Špiljak. Zagreb: Naprijed.

Lasić, Stanko. 1967. Nehajev u doba moderne (1899-1905). Kolo V, br. 1-2: 50-92; br. 3: 170186.

Lawlor, Clark i Akihito Suzuki. 2000. The Disease of the Self: Representing Consumption, 1700-1830. Bulletin of the History of Medicine LXXIV, br. 3: 458-494.

Lawlor, Clark. 2007. Consumption and Literature: The Making of Romantic Disease. New York: Palgrave Macmillan.

Lehrer, Johan. 2007. Proust Was a Neuroscientist. Boston - New York: Houghton Mifflin Company.

Leskovar, Janko. 1963. Janko Leskovar o sebi. U: J. Leskovar, Propali dvori. Pripovijesti. Pet stoljeća hrvatske književnosti, sv. 59, 243-249. Zagreb: Matica hrvatska - Zora.

Lombroso, Cesare. 1891. The Man of Genius. London: Walter Scott.

López Piñero, José M. 1983. Historical Origins of the Concept of Neurosis. Cambridge: Cambridge University Press.

Lučin, Ita. 2015. Kierkegaardova koncepcija egzistencijalne dijalektike. Diacovensia XXIII, br. 2: $169-184$.

Lugarić, Danijela. 2006. „Isušivanjem kaljuže“ do antislike. U: D. Lugarić, Kulturni stereotipi: Koncepti identiteta u srednjoeuropskim književnostima, 193-212. Zagreb: FF Press.

Lyytikäinen, Pirjo. 2014. Decadent Tropologies of Sickness. U: Decadence, Degeneration, and the End: Studies in the European Fin de Siècle, ur. Marja Härmänmaa i Christopher Nissen, 85-102. New York: Palgrave Macmillan.

Machiedo, Mladen. 1986. Eksplozija poticaja (inozemni Kamov). Croatica XVII, br. 24-25: $7-45$.

Marchand, Suzanne. 2015. Central Europe. U: The Fin-de-Siècle World, ur. Michael Saler, 131-149. London - New York: Routledge.

Marjanović, Milan. 1950. Janko Leskovar. U: Hrvatska književna kritika, sv. 3, ur. Petar Lasta, 121-138. Zagreb: Matica hrvatska. 
Matijašević, Željka. 2006. Strukturiranje nesvjesnog: Freud i Lacan. Zagreb: AGM.

Matijašević, Željka. 2008. Toplakova „dobro“ strukturirana neuroza i pokušaj izlaska iz hipertrofije neurotske autoanalize. U: Komparativna povijest hrvatske književnosti, sv. 10, ur. Cvijeta Pavlović i Vinka Glunčić-Bužančić, 236-246. Split: Književni krug.

Matković, Stjepan. 2003. Ban Khuen-Héderváry - značenje i utjecaji. Povijest u nastavi I, br. 1: 37-47.

Matoš, Antun Gustav. 1973a. Dinka Šimunovića Tuđinac. U: A. G. Matoš, O hrvatskoj književnosti, sv. 2. Sabrana djela, sv. 7, 188-195. Zagreb: Jugoslavenska akademija znanosti i umjetnosti - Sveučilišna naklada Liber.

Matoš, Antun Gustav. 1973b. Odbjegle duše. U: A. G. Matoš, O hrvatskoj književnosti, sv. 2. Sabrana djela, sv. 7, 280-284. Zagreb: Jugoslavenska akademija znanosti i umjetnosti Sveučilišna naklada Liber.

Matoš, Antun Gustav. 1973c. Zagrebačka kronika. U: Theatralia. O glazbi. Sabrana djela, sv. 10, 213-217. Zagreb: Jugoslavenska akademija znanosti i umjetnosti - Sveučilišna naklada Liber.

Matutinović, Ljerka. 1973. Oblomovština. 15 dana XVI, br. 4-5: 49-51.

Maudsley, Henry. 1884. Body and Will. New York: D. Appleton and Company.

May, Rollo. 1977. The Meaning of Anxiety. New York: W. W. Norton \& Company.

Micale, Marc S. 2008. Hysterical Men: The Hidden History of Male Nervous Illness. Cambridge - London: Harvard University Press.

Mighall, Robert. 1999. Atavism: A Darwinian Nightmare. U: R. Mighall, A Geography of Victorian Gothic Fiction: Mapping History's Nightmares, 130-165. Oxford: Oxford University Press.

Milanja, Cvjetko, 1981. Roman kao autobiografija. Republika XXXVII, br. 5-6: 454-473.

Milanja, Cvjetko. 1987. Janko Leskovar. Zagreb: Zavod za znanost o književnosti - Sveučilišna naklada Liber.

Milanja, Cvjetko. 2002. Nehajevljev Bieg: kriza identiteta i forma romana. U: Riječki filološki dani, sv. 2, ur. Diana Stolac, 287-298. Rijeka: Filozofski fakultet.

Milanja, Cvjetko. 2011. Tipovi lika iseljenika u novijoj hrvatskoj književnosti. Društvena istraživanja XX, br. 3: 861-876.

Milanja, Cvjetko. 2012. Konstrukcije kulture. Zagreb: Institut društvenih znanosti Ivo Pilar.

Minois, Georges. 2005. Storia del mal di vivere: Dalla malinconia alla depressione. Bari: Edizioni Dedalo. 
Morazé, Charles i dr. 1976. Devetnaesto stoljeće: Kulturni uspon u Europi. Preveo Vladimir Brodnjak. Zagreb: Naprijed.

Moroni, Mario. 2004. Sensuous Maladies: The Construction of Italian Decadentismo. U: Italian Modernism: Italian Culture between Decadentism and Avant-Garde, ur. Luca Somigli i Mario Moroni, 65-85. Toronto - Buffalo - London: University of Toronto Press.

Mosse, George L. 1996. The Image of Men: The Creation of Modern Masculinity. New YorkOxford: Oxford University Press.

Nehajev, Milutin. 1927. Gjalski. Savremenik XX, br. 6: 241-260.

Nehajev, Milutin. 1964a. Janko Leskovar: Književna studija. U: M. Nehajev, Ogledi i članci. Pripovijesti. Pet stoljeća hrvatske književnosti, sv. 81, 65-78. Zagreb: Matica hrvatska - Zora.

Nehajev, Milutin. 1964b. O razvitku glumačke igre. U: M. Nehajev, Ogledi i članci. Pripovijesti. Pet stoljeća hrvatske književnosti, sv. 81, 57-65. Zagreb: Matica hrvatska - Zora.

Nehajev, Milutin. 1964c. Studija o Hamletu. U: M. Nehajev, Ogledi i članci. Pripovijesti. Pet stoljeća hrvatske književnosti, sv. 81, 154-188. Zagreb: Matica hrvatska - Zora.

Nemec, Krešimir. 1993. Romani K. Š. Gjalskoga. Forum XXXII, br. 1-3: 175-188.

Nemec, Krešimir. 1995. Leskovarov antijunak ili literarni portret jednog dekadenta. U: K. Nemec, Tragom tradicije, 76-87. Zagreb: Matica hrvatska.

Nemec, Krešimir i Marijan Bobinac. 1997. Bečka i hrvatska moderna. U: Fin de siècle Zagreb - Beč, ur. Damir Barbarić, 84-105. Zagreb: Školska knjiga.

Nemec, Krešimir. 1998. Povijest hrvatskog romana od 1900. do 1945. godine. Zagreb: Znanje.

Nemec, Krešimir. 1999. Povijest hrvatskog romana od početaka do kraja 19. stoljeća. Zagreb: Znanje.

Nemec, Krešimir. 2010. Urbana nelagoda. U: K. Nemec, Čitanje grada, 94-109. Zagreb: Naklada Ljevak.

Nevistić, Ivan. 1927. Ksaver Šandor Gjalski. Vijenac V, br. 23-24: 582-607.

Nietzsche, Friedrich. 1971. Frammenti postumi 1887-1888. Opere di Friedrich Nietzsche, sv. 8, br. 2. Milano: Adelphi.

Nietzsche, Friedrich. 2006. Volja za moć \& Slučaj Wagner. Nietzsche contra Wagner. Preveo Ante Stamać. Zagreb: Naklada Ljevak.

Nissen, Christopher i Marja Härmänmaa. 2014. Introduction: The Empire at the End of Decadence. U: Decadence, Degeneration, and the End: Studies in the European Fin de Siècle, ur. Marja Härmänmaa i Christopher Nissen, 1-14. New York: Palgrave Macmillan.

Nordau, Max. 1895. Degeneration. New York: D. Appleton and Company. 
Nye, Robert A. 1982. Degeneration, Neurasthenia and the Culture of Sport in Belle Epoque France. Journal of Contemporary History XVII, br. 1: 51-68.

Nye, Robert A. 1984. Crime, Madness and Politics in Modern France: The Medical Concept of National Decline. Princeton: Princeton University Press.

Oraić Tolić, Dubravka. 1996. Paradigme 20. stoljeća. Zagreb: Zavod za znanost o književnosti Filozofskoga fakulteta Sveučilišta u Zagrebu.

Oraić Tolić, Dubravka. 2006. Tipovi modernoga subjekta: Muškarci sa ženskim rodnim crtama. U: Čovjek, prostor, vrijeme: Književnoantropološke studije iz hrvatske književnosti, ur. Živa Benčić i Dunja Fališevac, 291-323. Zagreb: Disput.

Paić, Žarko. 1999. Mjesečari pred zidom: Kulturni pesimizam kao mal du siècle. Europski glasnik IV, br. 4: 522-558.

Paić, Žarko. 2007. Nakon raspada vrijednosti: Hermann Broch i vrijeme neduhovne situacije. U: H. Broch, Duh i duh vremena: Eseji o kulturi moderne, 199-213. Zagreb: Antibarbarus.

Pająk, Patrycrusz. 2005. Raspad identiteta u prozi Janka Polića Kamova. Umjetnost riječi XLIX, br. 3-4: 243-259.

Patterson, David. 1995. Exile: The Sense of Alienation in Modern Russian Letters. Lexington: University Press of Kentucky.

Pavešković, Antun. 2002. Turgenjev Asja - Leskovar Jesenski cvietci. Dani hvarskoga kazališta XXVIII: 48-59.

Pavličević, Dragutin. 2009. Ustroj hrvatskoga društva i njegove promjene u XIX. stoljeću. U: Hrvatska i Europa: Kultura, znanost i umjetnost, IV. Moderna hrvatska kultura od preporoda do moderne (XIX. stoljeće), gl. ur. Mislav Ježić, 131-150. Zagreb: Školska knjiga.

Pavlović, Jovan. 1986. Dva tuđinca izvan ljušture života. Stremljenja XXVI, br. 6: 100-105.

Pejović, Danilo. 1970. Sistem i egzistencija: Um i neum u suvremenoj filozofiji. Zagreb: Zora.

Pejović, Danilo. 1979. Suvremena filozofija Zapada i odabrani tekstovi. Zagreb: Nakladni zavod Matice hrvatske.

Pick, Daniel. 1989. Faces of Degeneration: A European Disorder, c. 1848-c. 1918. Cambridge: Cambridge University Press.

Pierrot, Jean. 1981. The Decadent Imagination 1880-1900. Chicago - London: The University of Chicago Press.

Pietikainen, Petteri. 2007. Neurosis and Modernity: The Age of Nervousness in Sweden. Leiden - Boston: Brill.

Pođoli [Poggioli], Renato. 1975. Teorija avangardne umetnosti. Prevela Jasna Janićijević. Beograd: Nolit. 
Pogačnik, Jože. 1991. Hrvatska moderna i književnosti zapadnoeuropskog kruga. Croatica XXII, br. 35-36: 39-57.

Porter, Roy. 2004. Diseases of Civilization. U: Companion Encyclopedia of the History of Medicine, sv. 1, ur. William F. Bynum i Roy Porter, 585-600. London - New York: Routledge.

Posavac, Zlatko. 1986. Hrvatska estetika u doba Moderne. U: Z. Posavac, Estetika u Hrvata, 151-197. Zagreb: Nakladni zavod Matice hrvatske.

Praz, Mario. 1974. Agonija romantizma. Prevela Cvijeta Jakšić. Beograd: Nolit.

Prohaska, Dragutin. 1917. Janko Leskovar. Hrvatska njiva I, br. 39: 695-698.

Prohaska, Dragutin. 1919. Turgenjevski realizam. Suvremenik XIV, br. 1: 1-8.

Proust, Adrien i Gilbert Ballet. 1903. The Treatment of Neurasthenia. New York: Edward R. Pelton.

Pynsent, Robert B. 1989. Conclusory Essay: Decadence, Decay and Innovation. U: Decadence and Innovation: Austro-Hungarian Life and Art at the Turn of the Century, ur. Robert B. Pynsent, 111-248. London: Weidenfeld and Nicolson.

Rabinbach, Anson. 1992. The Human Motor: Energy, Fatigue and the Origins of Modernity. Berkeley - Los Angeles: University of California Press.

Radden, Jennifer, ur. 2000. The Nature of Melancholy: From Aristotle to Kristeva. Oxford: Oxford University Press.

Radden, Jennifer. 2009. Moody Minds Distempered: Essays on Melancholy and Depression. New York: Oxford University Press.

Rasch, Wolfdietrich. 1982. Literary Decadence Artistic Representations of Decay. Journal of Contemporary History XVII, br. 1: 201-218.

Rasch, Wolfdietrich. 1986. Die literarische Décadence um 1900. München: Verlag C. H. Beck.

Ribot, Théodule. 1896. Diseases of the Will. Chicago: The Open Court Publishing Company.

Rider, Jacques Le. 1993. Modernity and Crisis of Identity: Culture and Society in the Fin-deSiècle Vienna. New York: The Continuum Publishing Company.

Ridge, George Ross. 1961. The Hero in French Decadent Literature. Athens: University of Georgia Press.

Rimmon-Kenan, Shlomith. 2002. The Story of „I“: Illness and Narrative Identity. Narrative X, br. 1: 9-27.

Rousseau, Jean-Jacques. 1979. Rasprava o znanosti i umjetnosti. Politička misao XVI, br. 1: 32-58. 
Rudan, Vlasta. 2007. Psihoanalitički koncept anksioznosti. Medix XIII, br. 71: 67-71.

Russon, John. 2003. Human Experience: Philosophy, Neurosis, and the Elements of Everyday Life. Albany: State University of New York Press.

Schaffner, Anna Katharina. 2016. Exhaustion: A History. New York: Columbia University Press.

Schiesari, Juliana. 1992. The Gendering of Melancholia. Ithaca: Cornell University Press.

Schorske, Carl E. 1997. Beč krajem stoljeća: Politika i kultura. Preveo Nikica Petrak. Zagreb: Izdanja Antibarbarus.

Scull, Andrew. 2018. Ludilo u civilizaciji: Kulturna povijest umobolnosti od Biblije do Freuda, od ludnice do moderne medicine. Preveo Dinko Telećan. Zagreb: Sandorf.

Seroni, Adriano, ur. 1970. Il decadentismo. Palermo: Palumbo.

Shiraev, Eric. 2015. Psychology and Psychiatry. U: The Fin-de-Siècle World, ur. Michael Saler, 471-486. London - New York: Routledge.

Simmel, Georg. 2001. Velegradovi i duhovni život. U: G. Simmel, Kontrapunkti kulture, 137151. Preveo Kiril Miladinov. Zagreb: Naklada Jesenski i Turk - Hrvatsko sociološko društvo.

Sirotkina, Irina. 2002. Diagnosing Literary Genius: A Cultural History of Psychiatry in Russia, 1880-1930. Baltimore - London: The Johns Hopkins University Press.

Solar, Milivoj. 1985. Mit o avangardi i mit o dekadenciji. Beograd: Nolit.

Sontag, Susan. 1978. Illness as Metaphor. New York: Farrar, Straus and Giroux.

Stančić, Mirjana. 1994. Die Rezeption Arthur Schopenhauers in der kroatischen Literatur und Philosophie. Wiesbaden: Harrassowitz Verlag.

Stone, Norman. 1999. Europe Transformed 1878-1919. Oxford: Blackwell Publishers.

Sunajko, Goran. 2016. Opasnost od normalnih: Politizacija ludila u Foucaultovu i Lützovu diskursu. Filozofska istraživanja XXXVI, br. 3: 451-472.

Sunajko, Goran. 2017. Genij nasuprot talentu - umjetnost nasuprot estetici: Bit Schopenhauerove estetike. Studia lexicographica XI, br. 21: 61-74.

Sunajko, Goran. 2018. Schopenhauerova filozofija između metafizike i filozofije religije. U: Filozofija i religija: Suvremene perspektive, ur. Danijel Tolvajčić, Nenad Malović, Iva Mršić Felbar i Alojz Ćubelić, 95-109. Zagreb: Katolički bogoslovni fakultet - Kršćanska sadašnjost.

Supek, Rudi. 1950. Egzistencijalizam i dekadencija. Zagreb: Matica hrvatska.

Swart, Koenraad W. 1964. The Sense of Decadence in Nineteenth-Century France. Haag: Martinus Nijhoff. 
Sydow, Eckart von. 1922. Die Kultur der Dekadenz. Dresden: Im Sibyllen Verlag.

Symons, Arthur. 1919. The Symbolist Movement in Literature. New York: E. P. Dutton \& Company.

Šicel, Miroslav. 1984. Gjalski. Zagreb: Globus.

Šicel, Miroslav. 2005. Povijest hrvatske književnosti. Knjiga III. Moderna. Zagreb: Naklada Ljevak.

Šopenhauer, Artur [Schopenhauer, Arthur]. 1981. Svet kao volja i predstava, sv. I/1. Preveo Božidar Zec. Beograd: Grafos.

Šopenhauer, Artur [Schopenhauer, Arthur]. 1984. Svet kao volja i predstava, sv. I/2. Preveo Božidar Zec. Beograd: Grafos.

Šoštarić, Sanja. 2016. Recepcija književnokritičkoga i romanesknoga opusa Paula Bourgeta u Francuskoj od 1881. do 1914. Zagreb: Filozofski fakultet (doktorski rad).

Tafra, Alen. 2008. Kulturni pesimizam u tradiciji povijesti filozofije. Zagreb: Hrvatsko filozofsko društvo.

Tattersall, Mason. 2014. Thermodynamics and the Heat-Death of the Universe in Victorian Science, Philosophy and Culture. U: Decadence, Degeneration, and the End: Studies in the European Fin de Siècle, ur. Marja Härmänmaa i Christopher Nissen, 17-34. New York: Palgrave Macmillan.

Taylor, Alan J. P. 1990. Habsburška Monarhija 1809-1918. Preveo Omer Lakomica. Zagreb: Znanje.

Thornton, Robert K. R. 1979. Decadence in Later Nineteenth-Century England. U: Decadence and the 1890s, ur. Ian Fletcher, 14-29. London: Edward Arnold.

Thornton, Robert K. R. 1983. The Decadent Dilemma. London: Edward Arnold.

Tillich, Paul. 2000. The Courage to Be. New Haven - London: Yale University Press.

Turgenjev, Ivan Sergejevič. 1991. Očevi i djeca. Preveo Zlatko Crnković. Zagreb: Školska knjiga.

Vercellone, Federico. 1992. Introduzione a il nichilismo. Roma - Bari: Editori Laterza.

Volpi, Franco. 2013. Nihilizam. Preveo Miroslav Fridl. Zagreb: Demetra.

Vuković, Tvrtko. 2014. Naša zazorna drugost: Čudaci u književnosti hrvatske moderne i rađanje hrvatske građanske kulture. U: Kultura, identitet, društvo - europski realiteti, ur. Miljenko Brekalo i dr., 319-328. Osijek - Zagreb: Odjel za kulturologiju Sveučilišta J. J. Strossmayer - Institut društvenih znanosti Ivo Pilar. 
Vuković, Tvrtko. 2016a. Grdoba napretka: Degeneracija, kultura normalizacije i hrvatska književnost na prijelazu iz 19. u 20. stoljeće. Romanoslavica LII, br. 2: 437-450.

Vuković, Tvrtko. 2016b. Nenormalni: Normalizacijska kultura 19. stoljeća i hrvatska književnost fin de sièclea. U: Drugi: Alteritet, identitet, kontakt u hrvatskome jeziku, književnosti i kulturi. Zagreb: FF Press - Zagrebačka slavistička škola.

Vuković, Tvrtko. 2017. Living in the Corpse: Functions of Tuberculosis and Forms of Its Representation in Croatian Literature and Culture in the Late $19^{\text {th }}$ and Early $20^{\text {th }}$ Century. Poznańskie Studia Slawistyczne XIII, br. 13: 95-108.

Weber, Eugen. 1982. Decadence on a Private Income. Journal of Contemporary History XVII, br. 1: 1-20.

Weir, David. 1995. Decadence and the Making of Modernism. Amherst: University of Massachusetts Press.

Weir, David. 2018. Decadence: A Very Short Introduction. Oxford: Oxford University Press.

Wendell, Susan. 1996. The Rejected Body: Feminist Philosophical Reflections on Disability. New York - London: Routledge.

White, Frederick H. 2014. Degeneration, Decadence and Disease in Russian Fin de Siècle: Neurasthenia in the Life and Work of Leonid Andreev. Manchester - New York: Manchester University Press.

Windelband, Wilhelm. 1988. Povijest filozofije, sv. 2. Preveli Nada Šašel, Danko Grlić i Danilo Pejović. Zagreb: Naprijed.

Zaninović, Vice. 1964. Milutin Nehajev. U: M. Nehajev, Ogledi i članci. Pripovijesti. Pet stoljeća hrvatske književnosti, sv. 81, 7-42. Zagreb: Matica hrvatska - Zora.

Zurovac, Mirko, 1980. Dijalektika egzistencije u filozofiji Sjerena Kjerkegora. U: S. Kierkegaard, Bolest na smrt, v-xxviii. Beograd: Velika edicija ideja.

Žižek, Slavoj. 1986. „Patološki narcis“ kao društveno nužni oblik subjektivnosti. U: C. Lasch, Narcistička kultura: Američki život u doba smanjenih očekivanja, 309-336. Zagreb: Naprijed.

Žižek, Slavoj. 2000. Melancholy and the Act. Critical Inquiry XXVI, br. 4: 657-681.

Žmegač, Viktor. 2001a. Anarhijska ironija u književnoj kulturi moderne. U: Književni protusvjetovi, ur. Nikola Batušić, Zoran Kravar i Viktor Žmegač, 53-59. Zagreb: Matica hrvatska.

Žmegač, Viktor. 2001b. Suvremena zbilja kao književni problem. U: Književni protusvjetovi, ur. Nikola Batušić, Zoran Kravar i Viktor Žmegač, 27-36. Zagreb: Matica hrvatska.

Žmegač, Viktor. 2012. Bečka moderna. Zagreb: Matica hrvatska. 
Žunec, Ozren. 1996. Søren Aabye Kierkegaard. U: Suvremena filozofija I, 139-191. Zagreb: Školska knjiga.

Žunjić, Slobodan. 1975. Kjerkegorova egzistencijalna dijalektika vjere. U: S. Kierkegaard, Strah i drhtanje, 5-24. Beograd: Beogradski izdavačko-grafički zavod. 


\section{ŽIVOTOPIS}

Martina Kokolari rođena je 1985. u Osijeku, gdje je završila osnovnu školu i opću gimnaziju. Diplomirala je hrvatski jezik i književnost i talijanski jezik i književnost na Filozofskom fakultetu u Zagrebu 2010. U Leksikografskom zavodu Miroslav Krleža, u redakciji Hrvatskoga biografskog leksikona, honorarna je suradnica od 2010. te zaposlena od 2012 (leksikografska suradnica od 2015, leksikografkinja od 2019). Od 2017. izvršna je urednica Hrvatskoga biografskog leksikona te urednica struke kazalište. Za matičnu je redakciju napisala i uredila više od 150 biobibliografskih članaka, ponajprije iz književnosti, kazališta i lingvistike, a autorskim je člancima surađivala i u Leksikonu Ruđera Boškovića (2011), Leksikonu Antuna Gustava Matoša (2015) i Enciklopediji Hrvatskoga zagorja (2017) te (neobjavljenom) Leksikonu kulturno-književnoga nazivlja. Također je urednica talijanske književnosti u mrežnom izdanju Hrvatske enciklopedije. Bila je članica leksikografskoga uredništva u izdanju Islamski enciklopedijski almanah (suradnja Leksikografskoga zavoda s Mešihatom Islamske zajednice u Hrvatskoj; 2019).

Znanstveni su joj interesi novija hrvatska književnost, napose findesiècleovska, te recepcija talijanske književnosti u hrvatskim okvirima.

Objavila je radove:

- Talijanske teme u Vidinu opusu. Nova Istra, 19(2014) 1/2, str. 121-132.

- Matošev autobiografski diskurs: pisma i bilježnice. Književna republika, 13(2015) 4/6, str. $134-139$.

- Vesna Parun u kontekstu socrealizma: analiza jednog »slučaja«. Studia lexicographica, 9(2015) 1, str. 37-51.

- Vladan Desnica i Split 1920.-1945. Zbornik radova s Desničinih susreta 2014. Studia lexicographica, 9(2015) 2, str. 133-138.

- Hrvatska slikovnica do 1945. Studia lexicographica, 11(2017) 21, str. 151-156.

- Hermeneutička borba phōné-logos: Rancière i kritika socrealističkog logocentrizma. Filozofska istraživanja, 37(2018) 4, str. 723-742 (u suautorstvu s G. Sunajkom) 